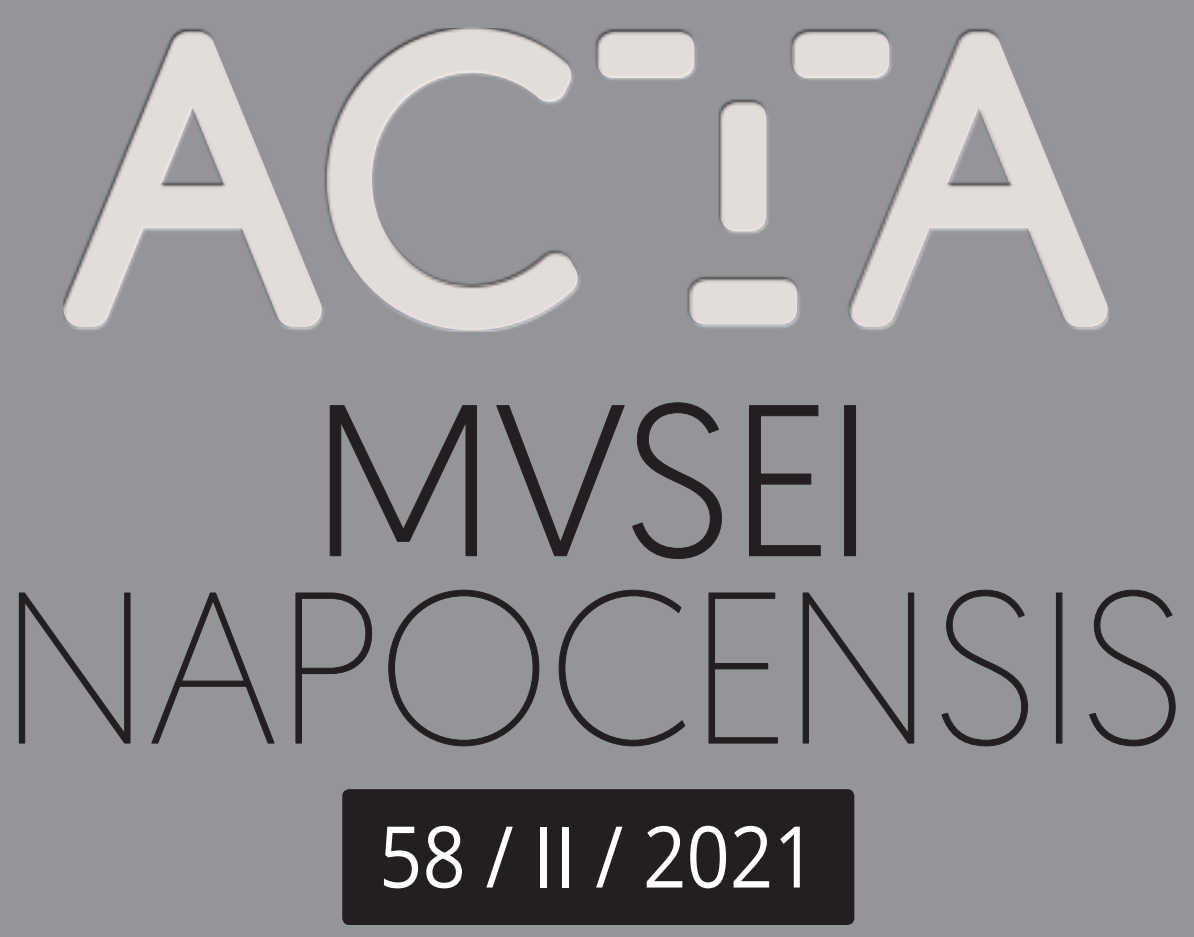




\section{ACTA MVSEI NAPOCENSIS \\ 58/II}





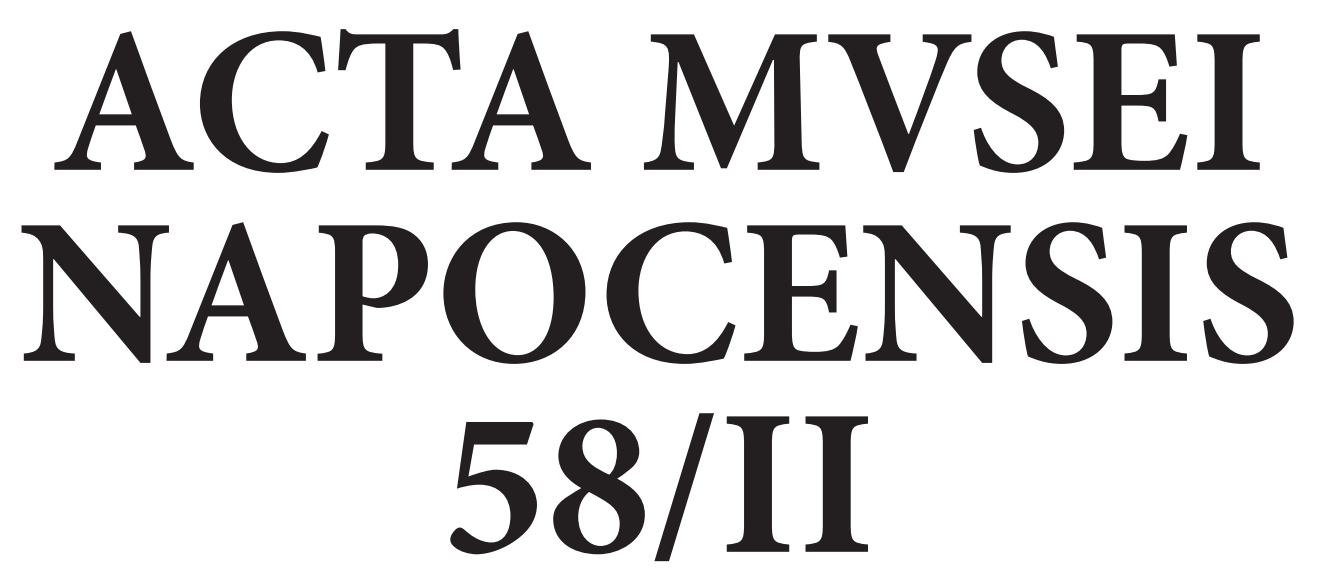

HISTORICA

2021

CLUJ-NAPOCA

2021 


\section{EDITORIAL BOARD:}

Editorial Scientific Board: Horațiu Bodale, Claudia M. Bonța, Manuela Marin, Melinda Mitu, Ovidiu Muntean, Oana Toda

Editor-in-chief: Manuela Marin

Assistant Editor: Oana Toda

Volume editors: Manuela Marin, Oana Toda

Technical editing and printing: MEGA Print SRL, Cluj-Napoca.

Cover: TD Studio

Copyright for section images: National Museum of Transylvanian History, Cluj-Napoca Image editing: Anca-Dumitrița Bâlc, Károly Török \& MEGA Print SRL, Cluj-Napoca

\section{HONORARY SCIENTIFIC BOARD:}

Konrad Gündisch (Institut für deutsche Kultur und Geschichte Südosteuropas an der Ludwig-Maximilians-Universität, München), Ioan-Aurel Pop (Romanian Academy, 'Babeș-Bolyai' University), Marius Porumb (Romanian Academy, Institute of Archaeology and Art History, Cluj-Napoca), Valentin Șerdan-Orga ('Lucian Blaga' Central University Library of Cluj-Napoca, 'Babeș-Bolyai' University), Tudor Sălăgean (The Transylvanian Museum of Ethnography, Cluj-Napoca), Rudolf-Mihai Dinu (Istituto Romeno di Cultura e Ricerca Umanistica, Venezia), Ioan Bolovan ('George Bariţ' Institute of History, 'Babeș-Bolyai' University).

FOUNDER: Constantin Daicoviciu

\begin{tabular}{|l|l|}
\hline ACTA MVSEI NAPOCENSIS & ACTA MVSEI NAPOCENSIS \\
Publicaţie a Muzeului Naţional & Publication of the National Museum of \\
de Istorie a Transilvaniei. & Transylvanian History. \\
Orice corespondenţa se va adresa: & All correspondence will be sent to the address: \\
Muzeul Naţional de Istorie & National Museum \\
a Transilvaniei, & of Transylvanian History, \\
400020, Cluj-Napoca, & 400020 Cluj-Napoca, \\
str. Constanti Daicoviciu, nr. 2, & Constantin Daicoviciu St. no. 2, \\
Tel/fax: 0040264 591718; & Tel/fax: $0040264591718 ;$ \\
Tel: 0040264595677. & Tel: 0040264595677. \\
email: secretariat@mnit.ro & email: secretariat@mnit.ro \\
\hline
\end{tabular}

ISSN 1454-1521 (PRINT) și 2783-9710 (ONLINE)

DOI: $10.54145 /$ ActaMN.58

Copyright@ National Museum of Transylvanian History 


\section{CONTENTS}

\section{ARTICLES AND STUDIES}

\section{LIVIU CÎMPEANU}

The Transylvanian-Saxon University at War: Trabanten in John Sigismund Szapolyai's Campaigns at the North-Western Borders of Transylvania (1561-1567).....

\section{MÁRIA LUPESCU MaKó}

Clothing - A Mark of Noble Identity in Early Modern Transylvania (I).

\section{Dragoș IANC}

The Conduct Lists of Habsburg Officers and Non-commissioned Officers. Sources for the Biographical Reconstruction.

\section{EDUÁRD SEBöK}

From birth to death. Aspects of Population Dynamics in Dămăcușeni Village (1765-1918). .73

\section{Alexandru-Augustin Haiduc}

The Use of Some Digital Instruments in the Study of the Greek Catholic High School in Beiuș.

\section{Claudia M. Bonţa - Melinda Mitu}

Female Portraits from Long Ago. Graphic Artworks in the Collection of the National Museum of Transylvanian History.

\section{Ovidiu Muntean}

An Unpublished Visual Document: The Photo Album of Lawyer Augustin Raţiu.

\section{Péter Sas}

Lajos Kelemen of Nagyernye: A Historian-Archivist (1877-1963). 


\section{MeTIN OMER}

The Role of Associations in the Organization of the Muslim Community. The Case of the Association of Graduates of the Muslim Seminary in Dobrudja

\section{IOANA GRUIȚ̆ Ă-SAVU}

Atenție, Picasso! Beware, Picasso! The Story of an Artifact in the Collection of the National Museum of Transylvanian History

\section{ANDREI DĂLĂLĂU}

Cultural Surveillance in Communist Romania in the 1950s and 1960s. Repression, Re-Education, and Reinsertion. The Case of Constantin Noica

\section{Mihai Chiș}

Nihon No Sensou - The Japanese War Experience Illustrated through the Lens of Ningen No Joken (The Human Condition)

\section{Vlad ONACIU}

Unwilling or Incapable? Understanding How People Remember Informal Exchanges during

Communism

\section{GABRIEL ZVÎNCĂ}

The Metamorphoses of the UN Peacekeeping Principles: How the End of the Cold War Reshaped Them (1988-1992)

\section{LiLiana-Maria TIVAdar}

The Gaza Strip and the Israel-Hamas Conflict: From 2008 until Nowadays

\section{REVIEWS}

Peter BURKE, Polimatul: o istorie culturală de la Leonardo da Vinci la Susan Sontag [The Polymath: a Cultural History from Leonardo da Vinci to Susan Sontag], Litera Press, Bucharest, 2021, pp. 384 (Tudor Turian)

Stefano BOTTONI, Lungul drum spre Occident. O istorie postbelică a Europei de Est [Long Awaited West. Eastern Europe since 1944], Mega Publishing, Cluj-Napoca, 2021, pp. 360 (Alexandra Cojocaru) 
Vlad PAȘCA-OPRIȘIU, Cincinalu-n patru ani și jumătate (1971-1975).Nicolae Ceaușescu și economia României socialiste, de la tentații tehnocratice la primatul politicului [The Five-Year Plan in Four and a Half Years (1971-1975). Nicolae Ceaușescu and the Economy of Socialist Romania, from Technocratic Temptations to the Primacy of Politics], Mega Publishing, Cluj-Napoca, 2020, pp. 263 (Gabriel Zvîncă)

Zoltán GYÖRKE, Napoca, o istorie recentă a Clujului. Obsesia romanizării sub două regimuri politice 1974-2014 [Napoca, a Recent History of Cluj. The Obsession of Romanization under Two Political Regimes], Mega Publishing, 2017, pp. 334 (Mihai Chiș).

Vlad ONACIU, Societatea penuriei. Carențele din construcția regimului comunist în România. Studiu de caz: Cluj în anii '60 și '70 [Society of Shortage. Deficiencies in the Construction of the Communist Regime in Romania. Case Study: Cluj in the '60s and '70s], Cluj-Napoca, Argonaut Publishing, pp. 377 (Andrei-Dumitru Olteanu).

\section{PROJECT PRESENTATIONS}

PHARMATRANS. All Things Apothecary in Sixteenth-Twentieth-Century Transylvania. The History of Pharmacy Collection in Cluj-Napoca (Ana-Maria Gruia)

Towards Inclusive Mnemonic Communities: Re-Visiting Violent Pasts through the Lens of Artistic Memory in Eastern Europe (Maria Alina Asavei) 


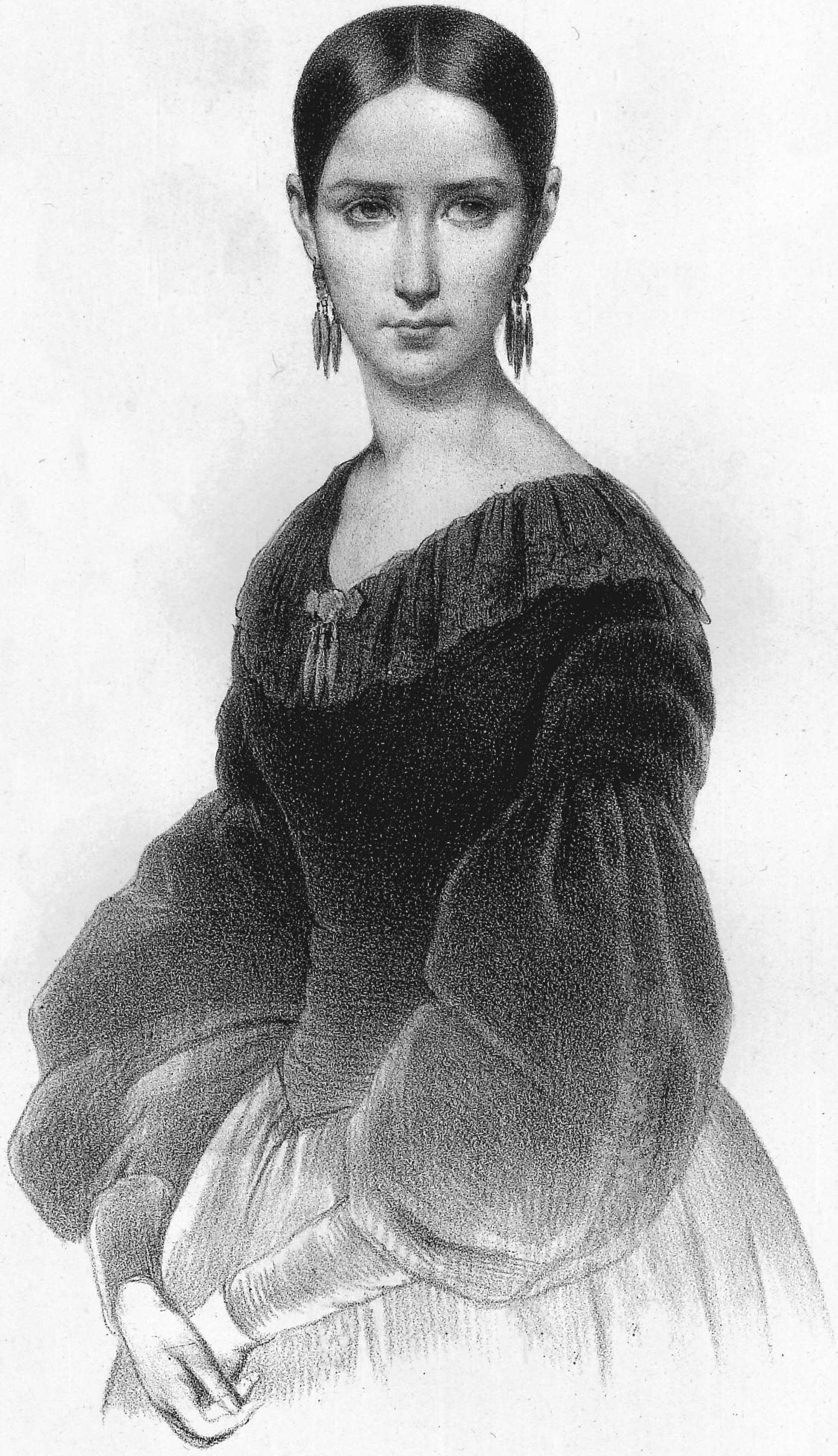

MIlle RACHEL .

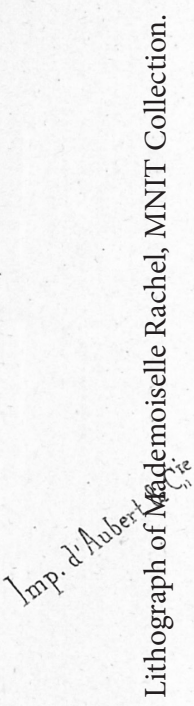


ARTICLES AND STUDIES 



\title{
THE TRANSYLVANIAN-SAXON UNIVERSITY AT WAR: TRABANTEN IN JOHN SIGISMUND SZAPOLYAI'S CAMPAIGNS AT THE NORTH-WESTERN BORDERS OF TRANSYLVANIA (1561-1567)*
}

\author{
LIVIU CÎMPEANU*
}

\begin{abstract}
Throughout the seventh decade of the sixteenth century, the border regions located in north-western Transylvania were disputed between Ferdinand of Habsburg and John Sigismund Szapolyai. The actual stake of this conflict was, in fact, the Crown of St. Stephen, claimed by both dynasties, as 'true heirs' of the medieval kings of Hungary. Despite being already treated by the Hungarian and Romanian historiographies, there is also a lesser-known aspect of these conflicts: the involvement of the Transylvanian Saxons in John Sigismund Szapolyai's war efforts in the Partes Hungariae. The unpublished and underused account books of the Transylvanian-Saxon University and those of Sibiu and the Seven Seats dating from the mentioned period reveal exciting data on the topic, which I aim to analyze in the present paper. According to these sources, the Transylvanian-Saxon University hired infantry handgunners, also known as trabanten, who participated in the north-western campaigns of John Sigismund Szapolyai between 1561 and 1568. This analysis is also an excellent opportunity to emphasize the transformations that the military organization of the Transylvanian Saxons went through by the mid-sixteenth century.
\end{abstract}

Keywords: Habsburgs, John Sigismund Szapolyai, The Transylvanian-Saxon University, account book(s), trabanten.

Rezumat: De-a lungul celei de-a şaptea decade a secolului al XVI-lea, regiunile de frontieră situate în nord-vestul Transilvaniei au fost disputate între Ferdinand de Habsburg şi Ioan Sigismund Szapolyai. Miza reală a conflictului a fost, de fapt, Coroana Sfântului Ştefan, asupra căreia au ridicat pretenţii ambele dinastii, ca „adevăraţi urmaşi” ai regilor medievali ai Ungariei. Deşi au fost deja tratate de istoriografiile maghiară şi română, aceste conflicte prezintă şi unele aspecte mai puţin cunoscute: implicarea saşilor transilvăneni în eforturile militare ale lui Ioan Sigismund Szaplyai în aşa-numitele Partes Hungariae. Nepublicate şi prea puţin folosite de istorici, registrele de socoteli ale Universităţii Săseşti din Transilvania, precum şi cele ale Sibiului şi ale Celor Şapte Scaune, elaborate în răstimpul menţionat, relevă informaţii interesante privind acest subiect, pe care intenţionăm să le analizăm critic în prezenta lucrare. Potrivit acestor surse, Universitatea Săsească a angajat puşcaşi pedeştri, cunoscuţi şi sub numele de trabanţi, care au participat la campaniile nord-vestice ale lui Ioan Sigismund Szapolyai, între 1561 şi 1568. Această analiză reprezintă şi o ocazie excelentă pentru a releva transformările survenite în organizarea militară a saşilor transilvăneni, până la mijlocul secolului al XVI-lea.

Cuvinte cheie: Habsburgi, Ioan Sigismund Szapolyai, Universitatea Săsească, register de cheltuieli, dorobanți

\footnotetext{
* This work was supported by a grant of the Romanian Ministry of Education and Research, CNCS UEFISCDI, project number PN-III-P1-1.1-TE-2019-0457, within PNCDI III.

** Ph.D., Researcher III, Liviu Cîmpeanu, Institute of Social Sciences and Humanities, Romanian Academy, Sibiu, email: liviucimpeanu@yahoo.com.
} 
After de death of Queen Isabella Jagiellon in 1559, the reign of young John Sigismund Szapolyai, the elected king of Hungary, was utterly contested by Ferdinand of Habsburg, who also claimed the Crown of St. Stephen. The latter tried by every available means, diplomacy, politics, and military campaigns, to occupy Upper Hungary and recover Transylvania (briefly held by the Habsburgs between 1551-1556) to become the sole king of Hungary. Ferdinand's ambitions led to a prolonged war with John Sigismund Szapolyai for the regions located at the north-western borders of Transylvania. The political context and the outline of campaigns during the Transylvanian-Habsburg war of 1561-1567 are well-known. ${ }^{1}$ Lesser known is the contribution of the Transylvanian Saxons to these war efforts of the elected king of Hungary. Almost ignored by the former historiography, the account books of the Transylvanian-Saxon University and those of Sibiu and the Seven Seats reveal essential data on this matter, which complete the already edited narrative and documentary sources. The present paper aims to capitalize this unpublished information in the historical context of John Sigismund Szapolyai's campaigns at the north-western border of Transylvania, which is also an excellent opportunity to reveal the transformations and improvements of the military organization of the Transylvanian-Saxons, from the late Middle Ages to the Early Modern Period. In order to avoid off-topic digressions, in this paper, I will not refer to the mercenary trabanten hired as guardsmen by the Transylvanian-Saxon towns of Bistriţa, Braşov, and Sibiu, in the latter case, especially after the citizen's riot of $1556 .^{2}$ This topic will be covered in a separate study.

\section{From medieval militiamen to early modern mercenaries (trabanten)}

By the late Middle Ages, the Transylvanian-Saxon University was the supreme authority of the German-speaking inhabitants of Sibiu and the Seven Seats, the Two Seats (Mediaş and Şeica), the district of Braşov, and the district of Bistriţa. ${ }^{3}$ According to their age-old privilege charters, the Transylvanian Saxons of the four local autonomies had to take up arms per singula capita, together or separately, in order to join the royal host in both offensive and defensive campaigns. ${ }^{4}$ Albeit the Transylvanian Saxons ensured for the Hungarian kingship a firm foothold at the south-eastern border of the realm, especially after building their fortified towns and churches from the second half of the fourteenth century on, their militias had several shortcomings. In a separate study, I already stated that, thanks to their privileges and their actual military might, the Transylvanian Saxons enjoyed a special status that allowed them to ignore the mobilization orders issued by different royal captains, including the voivode of the province, fulfilling only the written orders of the king, whom they owed military service. Thus, according to the preserved sources, during the fifteenth century, the Transylvanian-Saxon militiamen armed themselves only for a few offensive and defensive campaigns: 1426 and 1427 - in Wallachia, 1442 - in Transylvania, 1467 and 1476 - in Moldavia, 1479 - in Transylvania, 1526 - at the southern and western borders of Transylvania. ${ }^{5}$ Further conclusions would be that their refusal to gather under

\footnotetext{
${ }^{1}$ Fodor, Oborni 2020, 149-153; Ardelean 2019, 248-254.

2 Kramer 1887, 57-58; Seraphin 1898, 320-324; Pakucs 2018, 86.

3 Cîmpeanu 2014, passim.

4 Cîmpeanu 2019, 123-144.

5 Cîmpeanu 2019, 139-143.
} 
the banner of different royal captains without a mobilization order issued by the king reveals their weak moral: the Transylvanian Saxons took up arms only to fulfill their military obligations towards the Hungarian kingship. Furthermore, the rare occasions of their mobilization reveal the lack of military experience. After all, the militiamen were townsfolk and villagers at arms. Finally, there were no regulations about their weapons and equipment: the military obligations of the province of Sibiu are mentioning only the expected number of men, while the military obligations of the Two Seats and the county later district - of Braşov state that the inhabitants should join the royal host, on horseback or foot, according to their possibilities. ${ }^{6}$ Thus on 13 February 1469, Voivode John Pongracz of Dengeleg urged the inhabitants of Sibiu and the Seven Seats to hold their arms, horses, lances, bows, and other war machines (sic!) ready, in order to repel an Ottoman attack. ${ }^{7}$ The authorities of the town and district of Braşov received a similar order on 20 December 1478, from Peter Gereb, the voivode of Transylvania, who requested 200 footmen, well-armed with crossbows, handguns, and pavises, as well as artillery, for the siege of two rebel fortresses. ${ }^{8}$ It seems that the Transylvanian-Saxon militiamen were quite well armed and equipped, but they were no match for the ever-growing Ottoman threat. A good example is revealed by the chronicler Antonio Bonfini, who writes about their participation at the Battle of Câmpul Pâinii, where Voivode Stephan Báthory of Ecsed engaged the Ottoman raiders of Ali Beg. The Transylvanian-Saxons held the right wing of the voivode's army, but, despite the high morale they showed on this occasion, the militiamen were routed by the gâai warriors at the first encounter because of their small numbers. ${ }^{9}$

Thus, immediately after the appearance of the Ottoman forces at the southern border of Transylvania, in the early fifteenth century, the Hungarian kingship was forced to take extraordinary measures to defend the realm. On 24 February 1433, King Sigismund of Luxembourg ordered the towns of Braşov, Bistriţa, and Cluj to financially support the town of Sibiu to pay the wages of 2,000 mercenaries, hired to defend the southern border of Transylvania, between the district of Făgăraş in the east and the district of Haţeg in the west. ${ }^{10}$ During the fifteenth century, the town of Sibiu hired only occasional mercenaries, like in 1467, when its stipendiarii Theutonici joined King Matthias' army in Moldavia. ${ }^{11}$ In the context of the Ottoman invasion of 1479, which culminated with the Battle of Câmpul Pânii, Voivode Stephan Báthory ordered the authorities of the town and district of Braşov to hire several hundred Wallachian mercenary horsemen, repeating it in 1480 and $1481 .^{12}$ By early spring 1481, the voivode ordered all Transylvanian-Saxon towns, seats, and districts to hire mercenaries for the anti-Ottoman defense permanently. At least, this emerges from a charter issued by Stephen Báthory on 9 March 1481, in which he orders the authorities of Braşov to hire mercenaries, like the other towns and market towns of Transylvania ('quatenus omni et qualibet hora vestros stipendarios per vos instar aliarum civitatum et opidorum tenere debentes, prout et aliae civitates et opida promptos

\footnotetext{
${ }^{6}$ Cîmpeanu 2019, 125-130.

7 Gündisch et alii 1981, 375.

${ }^{8}$ Gündisch et alii 1991, 201-202.

9 Bonfini 1941, 111-112.

${ }^{10}$ Gündisch 1937, 493-394.

11 Cîmpeanu 2019, 140.

12 Cîmpeanu 2017, 350.
} 
et paratos tenere debeatis'). ${ }^{13}$ This statement is confirmed by a charter issued by the same voivode on 30 April 1481, through which he ordered the authorities of Sibiu to send all its mercenaries to his camp at Rupea. ${ }^{14}$ It seems that by the early 1490s, the military might of the Transylvanian-Saxon towns, seats, and districts consisted mainly of mercenaries. At least, this might be the conclusion of two charters issued by the Vicevoivode Stephen of Tileagd on 8 January 1493, through which he urged the town of Sibiu and, separately, Sighişoara, as one of the Seven Seats, to send their stipendiarii to the district of Haţeg, at the south-western border of Transylvania. ${ }^{15}$ However, the Transylvanian-Saxon authorities did not keep mercenary units permanently in service but hired them when requested for a certain period. Thus, on the eve of the Battle of Mohács (29 August 1526), the Voivode John Szapolyai requested the Transylvanian-Saxon University to hire 1,000 cavalrymen to defend the country. During the Diet of 27 July 1526, the Transylvanian Estates decided that the Transylvanian-Saxon University should hire 5,000 cavalrymen for four months. On 15 August, the authorities of Sibiu urged those of Bistriţa to conscript 1,000 of the 5,000 horsemen and send them to the host of John Szapolyai. ${ }^{16}$ This document shows that each town, seat, and district contributed separately with mercenary units and that the Transylvanian-Saxon University indeed sent the requested troops to the camp of the voivode.

After the fall of the medieval Kingdom of Hungary in 1526, especially during the Civil War between John Szapolyai and Ferdinand of Habsburg (1526-1538), the heavy burden of defense fell on the local elites. Thus, in 1536 the Transylvanian Estates, allied in the fraterna unio since 1437 (renewed on 1438, 1459, 1506, and 1542), gathered on a Diet in Târgu-Mureş, where they established the military obligations of the nobles, Szeklers, and Transylvanian-Saxons. For the present paper, I will focus only on the regulations regarding the Transylvanian-Saxons: according to the decisions of the Estates, their leaders and officials should go to war on horseback, armed with lances, javelins, and shields, and equipped with suits of armor, or at least helmet and breastplate. The Transylvanian-Saxons with an income higher than 12 florins should go to war armed with a javelin, a handgun, and they should be given sufficient gunpowder and bullets, as well as maces and battle-axes. As defensive equipment, they were expected to wear breastplates or mail hauberks. Those with an income under 6 florins were expected to go to war armed with lances or javelins, bows and arrows, and shields for defense. ${ }^{17}$ Indeed, when the authorities of Sibiu issued regulations for the conscription of the inhabitants of the homonymous seat, on 17 March 1564, there are listed three categories of soldiers and their daily wages: horsemen - 6 denars ('einem czu ross den. 6'), pikemen on foot - 4 denars ('einem fusgenger mit einen spiess den. 4 '), and handgunners on foot -5 denars ('einem trabanden oder pyxenschücz den. $\left.5^{\prime}\right) .^{18}$

The decision of the Diet held in Târgu Mureş in 1536 does not specify any number of troops that the Transylvanian Estates should send for the defense of the province. It is only

\footnotetext{
13 Gündisch et alii 1991, 260.

14 Gündisch et alii 1991, 273.

15 Regest: UB online VIII, 5302; full text (original medieval charter): MNL DF 245164.

Regest: UB online VIII, 5304; full text (original medieval charter): MNL DF 245166.

16 Berger 1986, 234, 240, 241.

17 Müller 1911, 408-409.

18 Pakucs 2016, 255.
} 
speculated that all of them or as many as necessary should take up arms. ${ }^{19}$ Four years later, on 29 August 1540, the same Estates gathered at the Diet of Sighişoara established that each should provide a contingent of 3000 men, while those of the Transylvanian-Saxons should receive monthly wages. ${ }^{20}$ In 1548 , the three Estates established that each should send to war a contingent of 2,000 men..$^{21}$ Thus, the Estates assembly of Cluj, loyal to Queen Isabella Jagiellon, requested the Transylvanian Saxons to send to their camp 2,000 men and artillery, juxta veterem consuetudinem, in order to besiege the fortress of Gherla, at the time loyal to the Habsburgs. ${ }^{22}$ During the Diet of Alba Iulia held between 5-21 June 1558, the Estates requested again from the Transylvanian-Saxon University the regular 2,000 footmen, their captains, standard-bearers, and drummers, who were expected in the Queen's camp at Oprişani (Keresztes), on 16 July. ${ }^{23}$ All in all, in the second half of the sixteenth century, especially during the reign of the Szapolyai family (1541-1571), the Transylvanian Saxons used to send in the royal army 2,000-3,000 infantry handgunners, also called in German trabanten (trabanden oder pyxenschücz) and in Hungarian darabontok. ${ }^{24}$

In the regulations issued on 17 March 1564 by the authorities of Sibiu regarding the military conscription of the homonymous Transylvanian-Saxon seat, it is stipulated that in the event of mobilization, the inhabitants of all communities of the Seat should take up arms and each neighborhood of every community should provide an equal number of men..$^{25}$ The example of the Seat of Sibiu offers an insight into the social background of the trabanten-units, which came from urban centers, market towns, and villages of all seats and districts of the Transylvanian Saxons. Even the domain villages of Sibiu had to contribute: according to the account records of the mayor from 1565, there were no handgunners (püxenschüczen). Thus, they had to be hired from the town and paid with money gathered via a special tax imposed on the domain. ${ }^{26}$ When describing the mobilization ordered by John Sigismund Szapolyai in 1561, the Transylvanian historian Wolfgang/Farkas Bethlen wrote in the mid-seventeenth century that, at the king's orders, Sibiu and the other (Transylvanian-Saxon) towns conscripted soldiers, and every third villager took up arms. ${ }^{27}$ Regarding the mobilization of the Transylvanian forces in 1562, the historian Matthias Miles, from the second half of the seventeenth century, mentioned the Transylvanian-Saxon contingents of Sighişoara and Braşov, ${ }^{28}$ which demonstrates that all Transylvanian-Saxon towns, seats, and districts contributed to the war efforts of King John Sigismund Szapolyai. However, there were not enough available mercenaries. Thus, the Transylvanian-Saxon authorities often lured away footmen from the princely court by offering them high wages. To avoid this situation, the Diet of 1566 decided that soldiers could be no longer hired exclusively from among the burghers ${ }^{29}$.

\footnotetext{
${ }^{19}$ Müller 1911, 409.

${ }^{20}$ Seiwert 1870, 29.

${ }^{21}$ Müller 1911, 409.

22 Szilágyi $1875,575$.

${ }^{23}$ Szilágyi 1876, 96; SJS AN, MOS SB, SC, Reg. No.72 [1558], f. 79 f.-80 f.

24 Szabó 2020, 227-228; Pakucs 2016, 255.

${ }^{25}$ Pakucs 2016, 254-255.

${ }^{26}$ SJS AN, MOS SB, SC, Reg. No. 82 [1565], f. 74 f.

${ }^{27}$ Bethlen 1782, 10.

${ }^{28}$ Miles 1670, p. 83.

${ }^{29}$ Szabó 2020, 227.
} 
As we shall see below, the contingents sent by the Transylvanian-Saxon University in the army of John Sigismund Szapolyai between 1561-1567, whose numbers varied between 500 and 3,000 men, consisted of mercenary infantry, armed with handguns (drabanten, püxenschüczen, pedites pixidarios). Every ten men were headed by decurions (Zehndleuten, decuriones), and every 100 men were headed by centurions or captains (Hauptleuten, centuriones). They were also accompanied by drummers (drummelschläger, tympanatores) and standard-bearers (fendrich, vexilliferos). Each handgunner received a wage of 3 florins/ month, while the decurion, drummer, and standard-bearer received 4 florins/months. The captain received a monthly wage of 8 florins/month. ${ }^{30}$

The accounts of the Transylvanian-Saxon University and those of Sibiu and the Seven Seats do not give any details about the firearms of the trabanten-infantrymen, calling them only in general terms 'handgunners' (pixidarios, püxenschüczen). Their handguns seem to be harquebuses since this was the most common firearm by the mid-sixteenth century. Some of the few sources on the actual use of weapons are the inventories of the towers of Sibiu, maintained and defended by the town guilds. From the many preserved inventories, dating from the late fifteenth century to the early eighteenth century, four were compiled in the second half of the sixteenth century: 1560,1567, 1575, and one at an unknown date. The most common firearms registered in these inventories were the harquebuses (Hocken puxen) of different sizes and calibers. ${ }^{31}$ It is also noteworthy that in the Habsburg arsenal estated in Sibiu at the orders of General Castaldo, in 1552, which was taken over by the town in 1568, the most common manual firearms were also the harquebuses (around 1,500 pieces). ${ }^{32}$ Thus, one can state with great probability that the handgunners hired by the Transylvanian-Saxon University to join the army of King John Sigismund Szapolyai were harquebusiers. By the 1560s, their second weapon was no longer the javelin, previously established by the Diet of Târgu-Mureş in 1536, but the saber, since John Sigismund Szapolyai expressly requested in 1566, that the trabanten-infantrymen should be skilled in shooting their handguns and wielding their sabers. ${ }^{33}$ The preserved sources do not reveal any details about the uniforms and defensive equipment of the trabanten-infantrymen. Though, considering the inventories of the towers defended by the guilds of Sibiu in the second half of the sixteenth century, one can assume that at least part of them wore helmets (Schyschack/Schyschak), breastplates (Harnisch), mail hauberks (Panczer, Panzer, Pantzer), mail collars (Pantzer Kregen) and pavises (paysch). ${ }^{34}$

\section{Transylvanian-Saxon trabanten in King John Sigismund's campaigns at the north-western border of Transylvania}

After the fall of Buda in 1541, the Ottoman Empire and the Habsburg Monarchy came to a stalemate, entering a long phase of static warfare, up to the fall of Szigetvár, in 1566. For further territorial gains, both powers needed human and material resources,

${ }^{30}$ SJS AN, MOS SB, SC, Reg. No. 77 [1561], f. 51 v.; SJS AN, MOS SB, SC, Reg. No. 82 [1565], f. 42 f.; SJS AN, MOS SB, SC, Reg. No. 87 [1567], f. 2 f.-v.

31 Reissenberger 1900, 363-372.

32 Cîmpeanu 2020, 261, 272.

33 Szilágyi 1876, 299-303.

${ }^{34}$ Reissenberger 1900, 363-372. 
which they did not have for almost two decades. Thus, the warring effort concentrated mainly around the forts at the Habsburg-Ottoman border in central Hungary. ${ }^{35}$ Despite a brief period of Habsburg occupation, between 1551-1556, Transylvania remained under Ottoman suzerainty during the whole period. Its rulers, Isabella Jagiellon and John Sigismund Szapolyai, were still monarchs of Hungary (although the latter was just elected king, electus rex), contesting Ferdinand of Habsburg's rights to the Crown of St. Stephen. After losing the Transylvanian foothold in 1556, the Habsburg monarch tried by every means to unite the realm: on the one hand, he led negotiations with the Szapolyais and their supporters, and on the other hand, he sent his armies to occupy bit by bit the regions located at the north-western border of Transylvania, known as the Partes Hungariae. Despite the agreements concluded between Ferdinand of Habsburg and John Sigismund Szapolyai in 1560 and 1562, the former's captains continued to attack the north-western border regions of his rival. ${ }^{36}$

In these circumstances, the elected king of Hungary, residing now at Alba Iulia, sent military aid to the threatened fortresses. Thus, in the late summer of 1561, King John Sigismund Szapolyai demanded 500 footmen (pedites) from the Transylvanian-Saxon University. The account book of Sibiu and the Seven Seats for the year 1561 records that the Transylvanian-Saxon University paid the wages of the 500 footmen for three months: August, September, and October. ${ }^{37}$ The records also reveal (only once!) that the target of the campaign was the fortress of Sătmar: on 12 October 1561, the Transylvanian-Saxon University sent a certain Servatius Pathay to Zakmar, in order to bring the wages for the third month of military service to the footmen there ${ }^{38}$. Thus, the source reveals that the elected king of Hungary sent (at least) 500 foot soldiers, paid by the Transylvanian-Saxon University for three months, to support his garrison in Sătmar. This was an important strategic point at the Transylvanian-Habsburg border, in the Partes Hungariae, which was donated in 1559 by Queen Isabella Jagiellon to her Captain-General Melchior Balassa in order to reward his loyal services towards the Szapolyai Dynasty. ${ }^{39}$

As governor of Sătmar, Melchior Balassa built, in 1560, a strong fortress, well-supplied with artillery, ammunition, and provisions, at the expense of the Transylvanian Estates. ${ }^{40}$ As stated above, King John Sigismund Szapolyai sent military support for this fortress in August 1561. However, in the late autumn of the same year, encouraged by the advance of the Habsburgs, Melchior Balassa switched sides, submitting the fortresses of Sătmar and Baia Mare, along with other market towns, to the latter. Shortly afterward, Nicholas Báthory, another local baron, followed suit and pledged allegiance to the Habsburgs. ${ }^{41}$ Thus, John Sigismund Szapolyai lost important positions in the Partium Hungariae, which had to be recovered at any cost.

In the second half of the seventeenth century, the historian Matthias Miles stated that Melchior Balassa betrayed John Sigismund Szapolyai and brought him public offense by

\footnotetext{
35 Rúzsás 1982, 252-254.

${ }^{36}$ Fodor, Oborni 2020, 145-150.

37 SJS AN, MOS SB, SC, Reg. No. 77 [1561], f. 51 f. -52 v., 61 f., 62 f., 63 f.

38 SJS AN, MOS SB, SC, Reg. No. 77 [1561], f. 51 v.

39 Ardelean 2021, 19.

40 Miles 1670, 76, 81.

${ }^{41}$ Bethlen 1782, 9.
} 
naming him a circumcised Turk bastard of Sultan Suleyman..$^{42}$ When the news of Melchior Balassa's rebellion reached the Court at Alba Iulia, the elected king of Hungary immediately called the Estates to arms, sending Michael Gyeröffy and Jacob Pokay to Sibiu, in order to deliver the bad news and to summon the Transylvanian-Saxons under the royal banner. Sibiu and the other towns conscripted soldiers, while from the Transylvanian-Saxon villages, every third man was recruited. ${ }^{43}$

John Sigismund Szapolyai may have learned about Melchior Balassa’s rebellion prior to 8 November 1561, a date on which the account book of Sibiu and the Seven Seats records that the king requested 2,000 mercenary footmen from the Transylvanian-Saxon University. The mentioned source reveals that on the one hand, Sibiu and the Seven Seats contributed with 848 footmen, and on the other hand that the central authorities of the Transylvanian Saxons only supplemented the numbers that were already in the royal army, from 500 to 2,000 men because the account book records in November the payment of the wages for the fourth month of military service. ${ }^{44}$ The 2,000 footmen joined the Transylvanian army in the camp at Sebeș. ${ }^{45}$ Unfortunately, the preserved account books do not contain further information about the infantry units paid by the Transylvanian-Saxon University up to February 1562, when they briefly record: 'reuersis nostris ex bello, venditis est equus vexilliferum R. 15. d.. ${ }^{46}$ Thus, between November 1561-February 1562, the Transylvanian-Saxon footmen took part in the winter campaign of the Transylvanian army under the command of the Royal Captains Nicholas Orbay and Stephen Keserü, during which Melchior Balassa’s Transylvanian castles Geoagiu and Litenii de Sus were conquered and razed to the ground (the latter by the explosion of its underground arsenal). ${ }^{47}$

Despite the mobilization of some infantrymen and (at least) a standard-bearer in February, the Transylvanian-Saxon University kept in service the 2,000 mercenaries for the first three months of the year 1562. The account book of Sibiu and the Seven Seats for the year 1562 records the wages that the 2000 footmen received monthly in January, February, and March (although, for some unknown reason, the payment of the first wages, in January, is not recorded).$^{48}$ During this period, the military operations were resumed: encouraged by the conquest of Geoagiu and Litenii de Sus, John Sigismund Szapolyai sent his army against Melchior Balassa's estates and castles at the north-western border of Transylvania. On 3 February, the Transylvanian army camped at $\mathrm{Cluj}^{49}$ and, in early March, it laid siege to Hodod, a castle of the pro-Habsbug Jaksić family. Melchior Balassa and Francis Zay rushed to help the threatened fortress, coming face to face with the enemies on 4 March. The 8,000-strong Transylvanian army was led by Royal Captains Stephen Báthory of Somlyo and Francisc Németh, who adopted the following battle formation: they placed at the center the Transylvanian-Saxon pedestrian handgunners and on the two flanks cavalry units from the ranks of the nobles, each led by one of the captains. Despite having decent

\footnotetext{
${ }^{42}$ Miles 1670, 81-82.

${ }^{43}$ Bethlen 1782, 9-10.

${ }^{44}$ SJS AN, MOS SB, SC, Reg. No. 77 [1561], f. 52 f., 65 f., 77v.

${ }^{45}$ Bethlen 1782, 10.

${ }^{46}$ SJS AN, MOS SB, SC, Reg. No. 79 [1562], 18.

${ }^{47}$ Bethlen 1782, 10-11; Miles 1670, 81.

${ }^{48}$ SJS AN, MOS SB, SC, Reg. No. 79 [1562], 18, 21, 101-102, 110.

${ }^{49}$ SJS AN, MOS SB, SC, Reg. No. 79 [1562], 18.
} 
numbers and being well-armed, the Transylvanians, including the Transylvanian-Saxon infantrymen, were routed at the first encounter with the enemy cavalry. Stephen Báthory and Francisc Németh fled the battlefield, along with most of the troops. ${ }^{50}$

After the defeat of his army, John Sigismund Szapolyai requested the support of the Ottoman pashas of Buda and Timişoara, who immediately entered Bihor County. The elected king of Hungary lost most of the Partes Hungariae, but he needed a break to regroup his forces. Thus, on 12 April 1562, he signed a one-year truce with the Habsburgs that was renewed in 1563 for another year. ${ }^{51}$ The authorities of Sibiu and the Seven Seats heard about the lost Battle of Hodod no later than 18 March, when they recorded it in their account book..$^{52}$ The Saxon authorities might have asked the king to release them, at least partially, from the heavy financial burden of paying the wages for 2,000 mercenaries, as they did later, as we shall see below. Some of the 2,000 infantrymen might also have fallen in the Battle of Hodod. The fact is that the Transylvanian-Saxon University paid in April and May of the year 1562 the wages for only 1,000 handgunners on foot, for the fourth and the fifth month of military service at the Court of John Sigismund Szapolyai. ${ }^{53}$

On 12 May, a contingent from Braşov was sent to the king, who returned on 4 June $^{54}$ and it seems that during the same month, all 1,000 mercenaries were disbanded since the accounts of the Transylvanian-Saxon University and those of Sibiu and the Seven Seats no longer record the payment of their wages. Only in the Diet of Alba Iulia, between 4-9 November 1562, the king and the Estates requested 500 Szekely cavalrymen and 500 Transylvanian-Saxon handgunners on foot, 'vt igitur defensioni patrie'. Both cavalry and infantry were to be ready in 25 days, and they were to march where the king would request. ${ }^{55}$ Thus, the Transylvanian-Saxon mercenaries reported for duty at the latest on 3 December 1562 , and they remained in the royal service for the next three months: December, January, and February. On 2 March 1563, the Transylvanian-Saxon University sent to the king in Alba Iulia the unpaid wages for the 500 men, including handgunners, decurions, centurions, standard-bearers, and drummers, in a total amount of 2,250 florins. ${ }^{56}$

Already on 7 March 1563, King John Sigismund Szapolyai held a Diet in Mediaş, in which he imposed the Transylvanian-Saxon University to hire 500 trabanten again to serve at the royal court. On 4 March and 15 April, the central authorities of Sibiu sent twice the sum of 2,292 florins and 50 denars, representing the wages of the 500 infantrymen in the service of the king, who was holding now Court at Braşov. ${ }^{57}$ During the first half of the year, several trabanten-units accompanied John Sigismund Szapolyai in his tour from Sibiu to Braşov and back, ${ }^{58}$ since the military activity at the north-western border of Transylvania ceased due to the prolonged truce with the Habsburgs.

Despite the peaceful times, the king insisted on having almost permanently at his service units of Transylvanian-Saxon handgunners. Thus, during the Diet of Turda, held

\footnotetext{
50 Ardelean 2019, 248-249; Veress 1933, 32-33; Bethlen 1782, 13-14; Miles 1670, 82-85.

51 Fodor, Oborni 2020, 150.

52 SJS AN, MOS SB, SC, Reg. No. 79 [1562], 102.

53 SJS AN, MOS SB, SC, Reg. No. 79 [1562], 109, 116.

${ }^{54}$ Seraphin 1909, 138.

55 Szilágyi 1876, 213.

56 SJS AN, MOS SB, SC, Reg. No. 80 [1563], f. 57 v.

57 SJS AN, MOS SB, SC, Reg. No. 80 [1563], f. 58 f., 59 f.

58 Seraphin 1909, 139.
} 
between 6-13 June, John Sigismund Szapolyai and the Transylvanian Estates decided that 'domini Saxones, in integram angariam conseruabunt quingentos pedites cum eorum capitaneis et decurionibus, quos medio jam anno coseruauerunt. ${ }^{59}$ On 18 July, the Transylvanian-Saxon University paid the wages of the 500 mercenaries imposed by the Diet of Turda. Another payment of the outstanding wages followed on 25 August, when 2,555 florins were sent to John Sigismund Szapolyai in Braşov. ${ }^{60}$ Since this is the last recorded payment of the wages for the mercenaries, one can infer that the latter were disbanded in the late summer of 1563.

The diplomatic negotiations of the same year between John Sigismund Szapolyai and Ferdinand of Habsburg failed because the former refused to hand over the Partes Hungariae to his rival. ${ }^{61}$ By 1564 , the truce between the two rival monarchs had expired, and the military activity at the north-western borders of Transylvania resumed. John Sigismund Szapolyai wanted to bring the Partes Hungariae back under his rule by establishing a firm foothold in the region. As a consequence, in October and November of the same year, a great Transylvanian army of 12,000 men, led by Stephen Báthory of Somlyo, royal captain of Oradea, managed to conquer the Habsburg fortresses Sătmar, Ardud, Atea, Hodod, and Baia Mare, as well as other smaller forts in the counties Bereg and Ugocsa, in a real military show off. ${ }^{62}$ The Transylvanian-Saxon towns, seats, and districts also contributed to this campaign with 3,000 trabanten. On 24 October, the Transylvanian-Saxon University paid the wages for their second month of military service, ${ }^{63}$ which means that the king required this infantry unit at the latest in September, in unknown circumstances. For some reason, the account book of the Transylvanian-Saxon University from 1564 records only once the payment of the 3,000 footmen who were in royal service in late autumn. They were likely disbanded in mid-November when the Transylvanian army returned home. ${ }^{64}$

King John Sigismund Szapolyai summoned the Transylvanian Estates at a new Diet in Cluj on 18 January 1565. On that occasion, he requested another 500 infantry handgunners (pedites pixidarios) for three months, at the expense of the Transylvanian-Saxon University, whose wages for the whole period of military service (January-March) amounted to 4,755 florins. ${ }^{65}$ On 16 March, the Transylvanian-Saxon University sent the whole amount to Cluj to pay the wages for all three months of military service of the drabanten. ${ }^{66}$

In the meantime, by late March, the 7,000-men strong Habsburg forces led by the talented general of Swiss origin Lazarus Schwendi managed to recover most of the fortresses conquered by the Transylvanian army in the previous year: Tokaj, Szerencs, Sătmat, Baia Mare, Ardud and Chioar. ${ }^{67}$ During the enemy's military operations, on 26 February, King John Sigismund Szapolyai urged all Transylvanian-Saxon towns, domains, seats, and districts to prepare 3,000 trabanten, each fiscal unit being obliged to sustain 46

\footnotetext{
${ }^{59}$ Szilágyi 1876, 217.

${ }^{60}$ SJS AN, MOS SB, SC, Reg. No. 80 [1563], f. 62 v., 64 f.

${ }^{61}$ Fodor, Oborni 2020, 150-152.

${ }^{62}$ Ardelean 2019, 250-251.

${ }^{63}$ SJS AN, MOS SB, SC, Reg. No. 81 [1564], f. 70 v.

${ }^{64}$ Ardelean 2019, 251.

${ }^{65}$ SJS AN, MOS SB, SC, Reg. No. 82 [1565], f. 5 f.

${ }^{66}$ SJS AN, MOS SB, SC, Reg. No. 83 [1565], f. 38 f.

${ }^{67}$ Ardelean 2019, 251.
} 
of them. Since there were no handgunners in domain villages of Sibiu, they had to pay a special tax in order to hire the required mercenaries from the town. ${ }^{68}$ Yet, the king issued the mobilization order only after another round of failed diplomatic negotiations with the Habsburgs. ${ }^{69}$

On 2 June, John Sigismund Szapolyai decreed the general mobilization of the Transylvanian army to recover the fortresses of Ardud and Sătmar. All the nobles were expected to take up arms, along with every sixteenth serf of their domains, while the Transylvanian-Saxon University had to hire 3,000 infantry handgunners (3000. peditum pixidariorum), whose monthly wages amounted to 9,510 florins. ${ }^{70}$ On 6 June, the contingent left Sibiu for the royal camp, which was already under the fortress of Sătmar. The trabanten-infantrymen were under the command of Antonius Jungk, whose expenses during the campaign are recorded separately in the account books of Sibiu and the Seven Seats for the year $1565 .^{71}$

The 3,000 mercenary handgunners on foot remained in the royal service for the next three months, at the expense of the Transylvanian-Saxon University. The latter sent the amounts for the payment of their wages to the royal chancellor in Cluj, as follows: on 13 June, for the first month of military service - 9,510 florins; on 9 July, for the second month of military service - 9,510 florins; and, on 20 August, for the third month of military service $-9,510$ florins. ${ }^{72}$ In addition to the regular wages, several deliveries of provisions were sent to the operative troops, like the one sent by Sibiu and the Seven Seats on 30 June, worth 258 florins and 6 denars. ${ }^{73}$

During this period, John Sigismund Szapolyai's army, joined by Ottoman forces, targeted the fortress of Sătmar again, effectively defended by Lazarus Schwendi. ${ }^{74}$ On 9 July, the Transylvanian army was still beneath the ramparts of Sătmar, ${ }^{75}$ but the protraction of the siege determined John Sigismund Szapolyai to move his forces beneath the fortress of Ardud, whose Habsburg garrison surrendered on 2 August. After conquering this fortress, the elected king of Hungary moved his army again towards Lazarus Schwendi's camp, pitched by the River Someş. A fierce fight broke up between the two enemies, after which the Transylvanians and Ottomans had to flee the battlefield. Schwendi sent Habsburg forces to Baia Mare, which immediately surrendered, and some contingents even tried to recapture the Ottoman stronghold of Ineu. In the meantime, Habsburg-Ottoman peace negotiations were ongoing, during which Maximilian II, the heir of Ferdinand of Habsburg, complained to Sultan Suleyman about the attacks of John Sigismund Szapolyai. The Ottoman sovereign immediately ordered his vassal in Transylvania to cease any military operations, which he did without delay. ${ }^{76}$

\footnotetext{
${ }^{68}$ SJS AN, MOS SB, SC, Reg. No. 82 [1565], f. 74 f.

${ }^{69}$ Bethlen 1782, 46-71.

70 SJS AN, MOS SB, SC, Reg. No. 82 [1565], f. 11 f.-12 v., 94 v.; SJS AN, MOS SB, SC, Reg. Nr. 83 [1565], f. 7 f.

71 SJS AN, MOS SB, SC, Reg. No. 82 [1565], f. 42 v. -45 f.

72 SIS AN, MOS SB, SC, Reg. No. 83 [1565], f. 42 v., 43 f., 44 f.

73 SJS AN, MOS SB, SC, Reg. No. 82 [1565], f. 43 f.

${ }^{74}$ Bethlen 1782, 71-72.

75 SIS AN, MOS SB, SC, Reg. No. 83 [1565], f. 8 f.

${ }^{76}$ Bethlen 1782, 72-75, 76-79.
} 
By 12 September, the royal army was in Cluj, where some Transylvanian-Saxon mercenary handgunners were disbanded. ${ }^{77}$ Even more, the 'German lords' (Deutschen Herrn) asked the king to release the Transylvanian-Saxon University from the heavy financial burden of the wages for 2,000 drabanten. John Sigismund Szapolyai agreed only partially, keeping however 1,000 infantry handgunners in his service, at the expense of the Transylvanian-Saxon University. ${ }^{78}$ The latter paid their wages in a total amount of 3,170 florins on 22 September. ${ }^{79}$ The 1,000 mercenaries remained in service the following month, too.

During the Diet of Cluj-Mănăştur, on 8 October, King John Sigismund Szapolyai urged the Transylvanian-Saxon University again to pay the wages of the 1,000 drabanten ${ }^{80}$ The first wage (after the latest Diet), of 3,000 florins, was sent by the central authorities in Sibiu to Alba Iulia on 3 November. The wages for the second and third month of military service of the 1,000 trabanten, each worth 3,000 florins, were sent by the Transylvanian-Saxon University to the king in Alba Iulia on 27 November and 21 January $1566 .{ }^{81}$ The mercenaries seem to have been disbanded only at the beginning of next year since the accounts of the Transylvanian-Saxon University and those of Sibiu no longer record wage payments.

1566 was the year of the great Ottoman-Habsburg showdown: the aging Sultan Suleyman himself led his formidable army against what seemed to be the most important footholds of his sworn enemy: the border forts Gyula and Szigetvár. According to the ahd-nâme received from the Sublime Porte, John Sigismund Szapolyai had to join the Ottoman campaign at the head of the Transylvanian army. The military preparations were thoroughly discussed during the Diets of Turda in March and April of 1566 to fulfill the military obligations towards the sultan. ${ }^{82}$

During the first Diet in Turda, on 10-17 March 1566, King John Sigismund Szapolyai ordered the general levy of the nobles and Szeklers and requested from the Transylvanian-Saxons 1,000 selected footmen, skilled in firing their handguns and wielding their sabers. The expected trabanten should also be bold in order not to run away at the first battle cry of the enemy, as they have done in the previous campaigns. ${ }^{83}$ The Transylvanian-Saxon University sent the requested handgunners to the royal camp at Oprişani (Keresztes) before 30 May, when, during another Diet in Turda, the king imposed the hiring of another thousand (bis mille) footmen, to join the others already in his service. Their wages of the 2,000 Transylvanian-Saxon infantry handgunners mounted up to a total of 6,000 florins. ${ }^{84}$

On 12 June, the newly conscripted troops left Sibiu for the royal camp, which had already joined the army of the 'Turkish emperor' at Belgrade (Kriechisch Weissenburg). The Transylvanian-Saxon contingent was led by Simon Miles, mayor of Sibiu, Matthias

\footnotetext{
77 SJS AN, MOS SB, SC, Reg. No. 82 [1565], f. 95 v.

${ }^{78}$ SJS AN, MOS SB, SC, Reg. No. 82 [1565], f. 80 f., 117 f.; SJS AN, MOS SB, SC, Reg. Nr. 83 [1565], f. 10 f.-v.

${ }^{79}$ SJS AN, MOS SB, SC, Reg. No. 83 [1565], f. 45 v.

${ }^{80}$ Szilágyi 1876, 295.

${ }^{81}$ SJS AN, MOS SB, SC, Reg. No. 83 [1565], f. 50 f., 50 v.; SJS AN, MOS SB, SC, Reg. Nr. 85 [1566], f. 32 f.

${ }^{82}$ Ardelean 2019, 251-252.

${ }^{83}$ Szilágyi 1876, 299-303.

${ }^{84}$ SJS AN, MOS SB, SC, Reg. No. 85 [1566], f. 4 f.
} 
Panczler, judge of the homonymous seat, and Captain Simon Beer, whose expenses for the campaign are recorded separately in the account book of the University. ${ }^{85}$

Despite the record in this source regarding the initial destination, the Transylvanian-Saxon contingent received orders to join the main army that headed for Bihor County and, later, to the fortress of Tokaj. The 2,000 handgunners on foot (pedites pixidarios), under the command of the high officials of Sibiu, remained in 'bellicem in Hungaria (sic!) expeditionis' for five months, receiving their wages from the Transylvanian-Saxon University as follows: on 15 June, for the first month (June) of military service - 6,000 florins; on 1 August, for the second month (July) of military service $-6,000$ florins; on 11 September, for the third month (August) of military service - 6,340 florins; on 30 September, for the fourth month (September) of military service - 6,340 florins; and on 24 October, for the fifth month (October) of military service $-6,340$ florins. ${ }^{86}$

During this period, John Sigismund Szapolyai's army managed to recapture the fortresses Ardud, Cehu Silvaniei, Satu Mare, and Baia Mare, ${ }^{87}$ albeit nothing is known about the actions of the Transylvanian-Saxon contingent, save the fact that Captain Simon 'Pauer' (i.e., Beer) seems to have been captured in a skirmish with some Hungarian horsemen but was released by Melchior Balassa himself. Even though the author of late Chronicon Fuchsio-Lupino-Oltardinum dates this event on 1564, or even before the Battle of Hodod (1562), ${ }^{88}$ Simon Beer was peditum Saxonicorum ductor during the campaign of 1566 !

By mid-November, the contingent under the command of the high officials of Sibiu returned home. This statement is proved by the fact that the account book of the Transylvanian-Saxon University records from 14 November on the 'Expensa Domini Magistri Civium post reditum suum factae. ${ }^{89}$

Despite de death of Sultan Suleyman after the conquest of Gyula and Szigetvár on 6 September 1566, the Habsburg-Ottoman struggles went on. In the first month of the year 1567, the forces of Lazarus Schwendi managed to recover the fortresses at the north-western border of Transylvania, threatening even John Sigismund Szapolyai's fortresses at Mukachevo and Khust. ${ }^{90}$

Thus, during a Diet in Turda, on 4 March 1567, the elected king of Hungary requested again the general levy of the nobles and Szekler, as well as 3,000 handgunners on foot, whose wages, amounting to 9,510 florins, were to be supported by the Transylvanian-Saxon University. ${ }^{91}$ This time, the mercenaries remained in royal service for only three months. However, the constant war efforts had terrible consequences on the economy of the Transylvanian-Saxon University: its treasury was empty, as it appears from the fact that it paid the monthly wages of the hired handgunners in several installments. For the first month of military service, on 10 March, the University and the district of Braşov paid together 4,760 florins, while the Seat of Mediaş paid separately 2,149 florins. On 22 March,

\footnotetext{
85 SJS AN, MOS SB, SC, Reg. No. 85 [1566], f. 38 f.-40 f.

${ }^{86}$ SJS AN, MOS SB, SC, Reg. No. 85 [1566], f. 7 f., 40 v., 43 v., 46 f., 46 v.

87 Ardelean 2019, 252.

88 Trausch 1847, 64.

89 SJS AN, MOS SB, SC, Reg. No. 85 [1566], f. 47 f.

90 Ardelean 2019, 253.

${ }^{91}$ SJS AN, MOS SB, SC, Reg. No. 87 [1567], f. 2. f.
} 
the University paid a debt of 710 florins, while the district of Bistrița paid its contribution of 1,521 florins and 60 denars, separately. Finally, the last debt of 369 florins was paid on 9 April..$^{92}$ The wages for the second month of military service of the 3,000 mercenaries were also paid in several installments: after receiving a stern order from the king, the Transylvanian-Saxon University paid on 11 April 3,000 florins, and on 16 April another 4,000 florins. On 27 April, the debt of 988 was paid, while the district of Bistriţa paid its contribution of 1,521 florins and 60 denars separately. ${ }^{93}$ Regarding the wages for the third month of military service, the Transylvanian-Saxon University also paid in installments, but only partially: on 11 May it paid 3,000 florins and on 14 May another 2,702 florins and 34 denars, but only for 1,000 trabanten, who remained in the royal camp at Gherla (Newen Schloss). ${ }^{94}$

During this campaign, the forces of John Sigismund Szapolyai managed to conquer the pro-Habsburg fortresses of Chioar and Baia Mare. ${ }^{95}$ Thus, on 28 May, 'Serenissima Regiae Majestas expugnationis castris Köwar et Riuulis Dominarum in oppidum Zomosfalwa ex bellica expeditione regressa esset'. After disbanding 2,000 mercenaries, only 1,000 Transylvanian-Saxon infantry handgunners in his service, whose wages amounted to 5,705 florins, were imposed to the Transylvanian-Saxon University. ${ }^{96}$ Since the account books of the Transylvanian-Saxon University and those of Sibiu and the Seven Seats do not record other payments, one can presume that the last 1,000 footmen were also disbanded in June. It seems that no further conscriptions were imposed on the Transylvanian Saxons that year. Only one brief record, in the account register of the town domain of Sibiu, mentions that during a Diet in Albia Iulia, on 8 September, the king imposed the conscription of an unspecified number of mercenaries, but this might be an erroneous note or a decision that was never put into practice since the same document does not record any payments for this matter. ${ }^{97}$

On 17 February 1568, Emperor Maximilian II and Sultan Selim II concluded the Treaty of Adrianople, which established peace between the Habsburgs and the Ottomans for the next 25 years. Besides the political and territorial status quo between the two great powers, John Sigismund Szapolyai also had to cease the war and cede most of the fortresses and territories at Transylvania's north-western border, also known as Partium Hungariae, to the Habsburgs. The new political circumstances opened the gateway for the Treaty of Speyer (1 December 1570/10 March 1571). Through it, Maximilian II acknowledged the reign of John Sigismund Szapolyai over Transylvania and some of the Partes Hungariae, but not as electus rex, only as a prince. The same document established that the Habsburgs should inherit all territories of the Transylvanian prince if the latter died without an heir. ${ }^{98}$

The ceasing of the military activity at the north-western borders is also reflected in the account book of Sibiu and the Seven Seats for the year 1568, which does not record any military expenditures, but only ordinary and extraordinary taxes requested by the king,

\footnotetext{
${ }^{92}$ SJS AN, MOS SB, SC, Reg. No. 87 [1567], f. 27 v., 28 f., 29 f.

${ }^{93}$ SJS AN, MOS SB, SC, Reg. No. 87 [1567], f. 29 f.-v.

${ }^{94}$ SJS AN, MOS SB, SC, Reg. No. 87 [1567], f. 31 f.

${ }_{95}$ Bethlen 1782, 169-174.

${ }^{96}$ SJS AN, MOS SB, SC, Reg. No. 87 [1567], f. 4 f.

97 SJS AN, MOS SB, SC, Reg. No. 86 [1567], f. 53 f.

${ }^{98}$ Fodor, Oborni 2020, 152-153; Ardelean 2019, 253-254.
} 
like the one imposed during the Diet of Turda, on 1 May, amounting to the sum of 30,000 florins. ${ }^{99}$ The account books of the Transylvanian-Saxon University are not preserved for 1568 and 1569, and neither is the book of Sibiu and the Seven Seats from 1569.

Despite the peace at the north-western borders of Transylvania, John Sigismund Szapolyai aimed to strengthen the fortress of Oradea. Thus, during the Diet in Mediaş, on 1 January 1570, he imposed a capitation of 99 plus 20 denars for each noble and an extraordinary tax for the Transylvanian-Saxon University, in a total amount of 20,000 florins. The raised sums were for the 'edificatione arcis Waradinensis'. The account book of the Transylvanian-Saxon University for the year 1570 is not preserved, but the fact that Sibiu and the Seven Seats delivered their contribution of 8,480 florins on $20 \mathrm{March}^{100}$ is clear proof that the whole sum was paid, as requested by the king.

During the Diet of Târgu-Mureş, held between 6-14 January 1571, John Sigismund Szapolyai imposed new extraordinary taxes 'ad structuram Waradiensis. While each fiscal unit of the nobles had to pay 30 denars, the Transylvanian-Saxon University was taxed with an extraordinary amount of 26,000 florins. The sum has been paid only partially: on 13 March were delivered 13,900 florins, and on 26 March another 3,200 florins, due to the partial shortening for the sent craftsmen at the building site ('der handwercker limitation halben'). ${ }^{101}$ Thus, the Transylvanian-Saxon University paid only 17,100 florins from the whole sum of 26,000 florins. The account book does not record any other military expenditure, especially after the death of John Sigismund Szapolyai, on 14 March 1571.

Finally, one can conclude that the Transylvanian-Saxon University was an active supporter of King John Sigismund Szapolyais's military efforts at the north-western borders of Transylvania between 1561-1568. During this period, contingents of handgunners on foot, paid by the central authorities of the Transylvanian Saxons in Sibiu, were almost continuously in royal service: in 1561 for five months ( 500 footmen between August-October, 2,000 footmen in November-December), in 1562 for six months (2,000 footmen between January-March, 1,000 footmen in April-May, 500 footmen in December), in 1563 for six months (500 footmen between January-April and another 500 footmen in July-August), in 1564 for around three months (3,000 footmen between September?-November), in 1565 for ten months (500 footmen between January-March, 3,000 footmen between JuneAugust, 1,000 footmen between September-December), in 1566 for 6 or 7 months (1000 footmen in April?-May and 2,000 footmen between June-October) and in 1567 for three months (3,000 footmen in March-April and 1,000 footmen in May). The payment of the wages for hundreds, even thousands of mercenaries for so many months and years was a tremendous financial burden for the Transylvanian-Saxon University, whose treasury was empty by 1567, as it appears from the irregular payment of the wages that year. Despite the great effort, the troops hired by the Transylvanian-Saxon University were of mediocre value. It is significant that in 1566, King John Sigismund Szapolyai requested that the trabanten-infantrymen be skilled in shooting their handguns and wielding their sabers and especially required that they should be bold in order not to flee anymore at the first battle cry of the enemy. Nonetheless, most of the trabanten-infantrymen were still townsfolk

\footnotetext{
99 SJS AN, MOS SB, SC, Reg. No. 88 [1568], f. 6 f.

100 SJS AN, MOS SB, SC, Reg. No. 90 [1570], f. 4 f.- 5 f., 25 v.

101 SJS AN, MOS SB, SC, Reg. No. 91 [1571], f. 2 f.-v., 19 v., 20 v.
} 
and peasants at arms. However, their units have undergone significant improvements over the hosts of medieval militiamen. First and foremost, the trabanten-infantrymen received wages, campaigning thus as mercenaries, unlike the militiamen, who went to war at their own expense just to fulfill their military duties towards the king. Second, during the first half of the sixteenth century, the central authorities of Transylvania established regular numbers of armed men that the Transylvanian-Saxon University had to send in the army of the principality. In contrast, the troops of the medieval militiamen were rarely sufficient to withstand foreign invasions because the military obligations themselves were ambiguous, the Transylvanian-Saxons being expected to join the royal army according to their (material) possibilities. Third, the weapons and equipment of the trabanten-infantrymen were standardized, all of them being armed with harquebuses and sabers. As opposed, the medieval militiamen, despite being reasonably well-armed, their weapons varied according to the wealth of each individual, some of them fighting even as horsemen. Fourthly, the trabanten-infantrymen were organized in decimal units, headed by decurions and centurions, marching in the rhythm of drums and pipes, while the bands of medieval militiamen were organized by the Transylvanian-Saxon seats and districts of origin. The central authorities of Sibiu regulated even the process of mobilization. Finally, the Early Modern infantrymen of the Transylvanian-Saxon University joined the campaigns of the royal/princely army outside the borders of the realm, unlike the medieval militiamen of the towns, seats, and districts. The latter were reluctant even to join the host of the province if they did not receive the mobilization order directly from the king. One major political transformation might have caused this development: after the disaster at Mohács (1526) and, especially after the loss of Buda (1541), the Szapolyai dynasty moved to Transylvania, being thus in the proximity of the Transylvanian-Saxon towns, seats, and districts. The physical presence of the sovereign automatically increased his authority over his subjects. Thus, the Transylvanian-Saxon University had no choice but to fulfill the mobilization orders and join his army in internal and external campaigns alike. Despite all the shortcomings, the Transylvanian-Saxon infantrymen, armed with modern harquebuses, represented a steady military force, which was almost constantly in royal service, thus forming the core of the standing army that the princes of Transylvania tried to organize, as a firm step towards the Early Modern state.

\section{Bibliography}

\section{Unpublished sources}

SJS AN, MOS SB, SC

MNL DF
Serviciul Județean Sibiu al Arhivelor Naționale, Primăria (Magistratul) oraşului şi scaunului Sibiu Fonds, Socoteli consulare, Register Numbers. 72 [1558], 77 [1561], 78 [1561], 79 [1562], 80 [1563], 81 [1564], 82 [1565], 83 [1565], 84 [1566], 85 [1566], 86 [1567], 87 [1567], 88 [1568], 90 [1570], 91 [1571].

Magyar Nemzeti Levéltár, Diplomatikai Fényképgyüjtemény, https://archives.hungaricana.hu/hu/charters, accessed 12 May 2021. 


\section{Edited primary sources and studies}

Ardelean 2019

Ardelean 2021

Berger 1986

Bethlen 1782

Bonfini 1941

Cîmpeanu 2014

Cîmpeanu 2017

Cîmpeanu 2019

Cîmpeanu 2020

Fodor, Oborni 2020

Gündisch 1937

Gündisch et alii 1981

Gündisch et alii 1991

Kramer 1887

Miles 1670
F. N. Ardelean, Organizarea militară în Principatul Transilvaniei (1541-1691), Cluj-Napoca 2019.

F. N. Ardelean, War and Social Conflicts in Early Modern Border Areas: Colonel Ludovicus de La Borde and Satu Mare (Szatmár) Fortress (1673-77), Hiperboreea 8/1 (2021), 16-37.

A. Berger (ed.), Urkunden-Regesten aus dem Archiv der Stadt Bistriz in Siebenbürgen 1203-1570, vol. I, posthumous ed. by E. Wagner, Köln-Wien 1986.

W. de Bethlen, Historia de rebus Transsylvanicis, vol. II, 2nd edn., Cibinii 1782.

A. de Bonfinis, Rerum Ungaricarum Decades, vol. IV/1, ed. by I. Fógel, B. Iványi, L. Juhász, Budapest 1941.

L. Cîmpeanu, Universitatea Saxonă şi districtele româneşti aflate sub jurisdicţia ei în Evul Mediu şi Epoca Modernă, Târgu-Mureş 2014.

L. Cîmpeanu, Organizarea militară a Braşovului până la sfârşitul secolului al XV-lea. In: V. Ciobanu, D. D. Iacob (eds.), Studii de istorie a oraşelor. In honorem Paul Niedermaier, Bucureşti-Brăila 2017, 336-359.

L. Cîmpeanu, Obligaţii militare şi ordine de mobilizare a oraşelor săseşti din Transilvania la sfârşitul Evului Mediu, HU, XXVII (2019), 123-144.

L. Cîmpeanu, The Royal Habsburg Arsenal of Sibiu (Hermannstadt, Nagyszeben) under the Rule of Queen Isabella. In: A. Máté, T. Oborni (eds.), Isabella Jagiellon, Queen of Hungary (15391559), Budapest 2020, 257-273.

P. Fodor, T. Oborni, Between Two Great Powers: The Hungarian Kingdom of the Szapolyai Family. In: P. Fodor, Sz. Varga (eds.), A Forgotten Hungarian Dynasty: the Szapolyais, Budapest 2020, 127-161.

G. Gündisch (ed.), Urkundenbuch zur Geschichte der Deutschen in Siebenbürgen, vol. IV (1416-1437), Hermannstadt 1937.

G. Gündisch, H. Gündisch, G. Nussbächer, K. G. Gündisch (eds.), Urkundenbuch zur Geschichte der Deutschen in Siebenbürgen, vol. VI (1458-1473), Bucureşti 1981.

G. Gündisch, H. Gündisch, K. G. Gündisch, G. Nussbächer (eds.), Urkundenbuch zur Geschichte der Deutschen in Siebenbürgen, vol. VII (1474-1486), Bucureşti 1991.

F. Kramer, Bistritz um die Mitte des 16. Jahrhunderts. Auf Grund eines Rechnungbuches für die Jahre 1547 bis 1553, Archiv, XXI/1 (1887), 28-86.

M. Miles, Siebenbürgischer Wuerg-Engel oder Chronicalischer Anhang des 15. (sic!) Seculi nach Christi Geburt, aller theils in Sibenbürgen, theils in Vngern und Sibenbürgen angraentzenden Ländern fürgelauffener Geschichten, Herman-Stadt 1670. 
Müller 1911

Pakucs 2016

Pakucs 2018

Reissenberger 1900

Rúzsás 1982

Seiwert 1870

Seraphin 1898

Seraphin 1909

Szabó 2020

Szilágyi 1875

Szilágyi 1876

Trausch 1847

UB online VIII

Veress 1933
H. Müller, Zur Geschichte des Repser Stuhles (Fortsetzung), Archiv, 37/2 (1911), 271-472.

M. Pakucs, „zu urkundt in das Stadtbuch lassen einschreiben”. Die ältesten Protokolle von Hermannstadt und der Sächsischen Nationsuniversität (1522-1565), Hermannstadt-Bonn 2016.

M. Pakucs, Sibiul veacului al XVI-lea. Rânduirea unui oraş transilvănean, București 2018.

L. Reissenberger, Über die ehemaligen Befestigungen von Hermannstadt, Archiv, XXIX/2 (1900), 315-417.

L. Rúzsás, The Siege of Szigetvár of 1566: Its Significance in Hungarian Social Development. In: J. M. Bak, B. K. Király (eds.), From Hunyadi to Rákóczi. War and Society in Late Medieval and Early Modern Hungary, Brooklyn NY 1982, 251-259.

G. Seiwert, Akten und Daten über die gesetzliche Stellung und den Wiekungskreis derSächsischen Nations-Universität, Hermannstadt 1870.

F. W. Seraphin, Kronstadt zur Zeit des Honterus. In: Aus der Zeit der Reformation. Vorträge, gehalten im Auditorium des ev. Gymnasiums A. B. in Kronstadt in den Jahren 1897 und 1898, Kronstadt 1898, 295-379.

W. Seraphin (ed.), Fortsetzung der Historien des Hieronymus Ostermayer [1562-1570]. In: Quellen zur Geschichte der Stadt Brassó, Brassó 1909, 138-140.

J. B. Szabó, The Army of the Szapolyai Family During the Rule of John Szapolyai and John Sigismund. In: P. Fodor, Sz. Varga (eds.), A Forgotten Hungarian Dynasty: the Szapolyais, Budapest 2020, 207-238.

S. Szilágyi (ed.), Monumenta Comitialia Regni Transylvaniae, vol. I, Budapest 1875.

S. Szilágyi (ed.), Monumenta Comitialia Regni Transylvaniae, vol. II, Budapest 1876.

J. Trausch (ed.), Chronicon Fuchsio-Lupino-Oltardinum sive annales Hungarici et Transsilvanici, pars I. Complectens annales ann. 990.-1630, Coronae MDCCCXLVII.

Urkundenbuch zur Geschichte der Deutschen in Siebenbürgen Online, vol. VIII (online volume), http://siebenbuergenurkundenbuch.uni-trier.de, accessed 10 May 2021.

A. Veress, A történetíró Báthory István király, Cluj-Kolozsvár 1933. 


\title{
CLOTHING - A MARK OF NOBLE IDENTITY IN EARLY MODERN TRANSYLVANIA (I)*
}

\author{
MÁRIA LUPESCU MAKÓ**
}

\begin{abstract}
It is not the coat that makes the man', the proverb says nowadays. However, for a long time, it was the garment that gave the person individuality. Once the costume was lost, the identity was lost. Clothing is, therefore, one of the essential markers of social convention, with each part of the population being assigned a specific role and place, easily recognizable by shape and color. For several generations, the merchant has been recognized by his attire, the priest and the monk by the color of their tunic, the nobleman by his cut and color. Hence, clothing was the most prominent instrument of external representation. The symbolism of clothing articles, with a very different cut and color range, could immediately be interpreted by the contemporaries. For modern research, the knowledge of the specific characteristics of garments and their wear can be possible - to a considerable extent - only with the help of written sources and images. Therefore, the study aims to examine the role of status indicator, or the social role of clothing from the end of the sixteenth century and the first half of the seventeenth century, based on the documents of last will of the Transylvanian nobility. The first part is dedicated to the feminine costume.
\end{abstract}

Keywords: clothing, last wills and testaments, noblewomen, Transylvania, sixteenthseventeenth centuries

Rezumat: „Nu haina îl face pe om” - spune în zilele noastre proverbul. Mult timp însă veșmântul era cel care oferea individualitate persoanei. Odată pierdut costumul, se pierdea și identitatea. Vestimentația este prin urmare unul din semnele esențiale ale convenției sociale, fiecărei părți din populație atribuindu-se un rol și un loc anume, ușor de recunoscut prin formă și culoare. De mai multe generații se recunoaște negustorul după ținuta lui, preotul și călugărul după culoarea tunicii, nobilul după croială și culoare. Îmbrăcămintea constituia deci instrumentul cel mai evident, vădit al reprezentării externe. Sistemul simbolistic al articolelor de îmbrăcăminte, cu o croială și gamă de culori foarte diferită, de îndată putea fi interpretat de contemporani. Pentru cercetarea modernă, cunoașterea caracteristicilor specifice ale pieselor de îmbrăcăminte și ale purtării lor poate fi posibilă - într-o măsură considerabilă - doar cu ajutorul izvoarelor scrise și ale imaginilor. Prin urmare, studiul își propune să examineze rolul de indicator de statut, ori rolul social al îmbrăcăminții de la sfârșitul secolului al XVI-lea și din prima jumătate a secolului al XVII-lea, pe baza actelor de ultimă voință ale nobilimii transilvane. Prima sa parte este dedicată costumului feminin.

Cuvinte cheie: îmbrăcăminte, testamente, femei nobile, Transilvania, secolele XVI-XVII

\footnotetext{
* This study, with minor modifications, initially appeared - alongside a second part, dedicated to analyzing men's noble clothing - in Lupescu Makó 2015.

** Ph.D., Associate Professor, 'Babeș-Bolyai' University, Faculty of History and Philosophy, Department of HistoryinHungarian,Cluj-Napoca,e-mail:maria.lupescu@ubbcluj.ro, iD https://orcid.org/0000-0003-1683-5654.
} 


\section{Introduction}

At the fifth edition of the Marc Bloch Conference in 1983, at the beginning of his speech on the relationship between history and ethnology, Claude Lévi-Strauss, the keynote speaker, recalled a discussion he had had with the historian Lucien Febvre thirty years before. He wished historians would also be interested in the 'origin and distribution of buttons,' since the presence or absence of this humble haberdashery item encapsulated a significant dividing line between draped (drapé) and sewn (cousu) clothes, in fact, two different clothing styles. The former emphasized the human body, while the second highlighted the fabric. Both styles, however, paid attention to body conduct, the art of living, and the ways of self-insertion into the world that were typical of different civilizations. ${ }^{1}$ There is some truth in the perception of buttons as milestones in human behavior if we consider that their appearance and, later, their variety of shapes and materials coincided, to a large extent, with the onset of new periods in human history. From this point of view, the end of the sixteenth century and the first half of the subsequent one opened a new chapter in the history of clothing, as evidenced by the string of buttons made of precious metals and applied to various garments, buttons clad in a wide range of textiles and the establishment of the button makers' guilds. Although this period was still primarily inspired by the sartorial culture of the late Middle Ages, the emergence of new forms of clothing or the transformation or accentuation of some older ones betrayed, nonetheless, the start of a new period, from both a qualitative and a quantitative point of view.

If we were to specify which aspects best convey information about a person's appearance, then facial expressions, body posture, clothing, and accessories would certainly rank foremost among them. ${ }^{2}$ Clothing not only signals but also reinforces individual and social identity, for instance, through the daily act of dressing. ${ }^{3}$ The style, fabric, and color of clothing can betray the wearer's sex, age (Fig. 1), social status (Fig. 2-3), and, why not, one's belonging to a subculture. Interpretation requires the viewer's attention and takes place, first of all, in a public space.

In medieval and early modern Europe, knowledge related to writing and reading was much less widespread than in modern times. Therefore, a 'visual tool' that could provide the viewer with necessary explanations about unwritten information had to be discovered. It seems that clothing was this decoding tool for the people of medieval and early modern times. They easily identified the value of textiles and clothing shapes as well-established signs for the wearers' occupation, social status, material condition, ethnic, and regional affiliation. Of all these, the most relevant were social status ${ }^{4}$ and sex. Men's wear and women's attire were quite clearly distinguished from one another. The difference between trousers and dresses, as well as the indispensable corset or rigid waistline, had a tremendous visual impact. In addition to all these aspects, clothing could signal the wearer's age and marital status, and it also had to match the occasion on which it was worn (Fig. 4-5).

Clothing still has an essential function of social differentiation. In the public space, it is one of the defining elements of the elite and the richness. Throughout history, it has

\footnotetext{
${ }^{1}$ The speech also appeared in an article: Lévi-Strauss 1983, 1217.

${ }^{2}$ Weatherill 1991, 308; Finkelstein 1991, 2.

${ }^{3}$ Jones, Stallybrass 2003; Vincent 2003, 108.

${ }^{4}$ On the link between clothing and social status, see: Belfanti, Giusberti 2000, 359-365; Blockmans 1999, 1-18; Jütte, Bulst 1993, 2-7; Dinges 1992, 49-76.
} 
been one of the most important elements that allow individual status to be clearly seen: it can express the social status and the wearers' ambitions or their desire to climb the social ladder. Differences in taste were also manifested in clothing and fashion, so fine differences made visible and supported social inequality. ${ }^{5}$ According to the norm, clothing had to intimate social status as accurately as possible, to signal out existing social boundaries and, moreover, to express the internal stratification of a group. Since eliminating the elements that indicated the social status of the upper classes was considered illegal, the authorities tried to prevent people from dressing above their social rank, so they issued laws, provisions, and statutes directed against luxury. ${ }^{6}$

Clothing was, therefore, the most obvious instrument of external representation, betraying, at first sight, the wearer's social and material status, ambitions, and aspirations. With its range of very different cuts and colors, the symbolic system of apparel could be instantly decoded by a contemporary. For modern research, knowledge of specific garments and their wearing may be acquired, except for the few remaining clothing items, ${ }^{7}$ only with the help of written sources and images. Rarely, these treasures housed by museums can be admired by the general public in exhibitions. One of the most beautiful and spectacular exhibitions of this kind was the Horn of Abundance. Luxury in the Transylvanian Noble World, organized by the National Museum of Transylvanian History in Cluj (Kolozsvár, Klausenburg) in 2019. ${ }^{8}$ Fine embroidered garments, made of gold and silver thread and adornments (belts, brooches, pendants, earrings, bracelets, weapons, harnesses, and other objects) meant to reflect the splendor of the noble world of Transylvania in the seventeenthnineteenth centuries offered a foray into the luxury that society enjoyed.

The most important and often used sources for the history of clothing in the Transylvanian space of the first half of the seventeenth century are letters, travelogues, legal provisions, measures, and sartorial regulations. ${ }^{9}$ The latter belong to the category of normative-didactic sources in which the situation that is described reflects the aims or aspirations of the authors of these texts (be they princes or city councils) and not reality. However, we have few sources of this kind from the Principality of Transylvania. An example could be the sartorial regulations in force in Cluj during the sixteenth-seventeenth centuries, edited by Gyöngy Kovács Kiss. ${ }^{10}$ Figurative representations of garments, whether

${ }^{5}$ Bourdieu 1984; Bourdieu 1984/2002, 196-206.

${ }^{6}$ On the European history of anti-luxury legal provisions, see: Bulst 1993, 32-46; Hunt 1996; Kovesy Killerby 2002. For Hungary and Transylvania: Endrei 1989, 110-116; Szende 1997, 13-24; Zimányi 1994, 7-18. Most recently: Pakucs-Willcocks 2018.

${ }^{7}$ In Transylvania, for example, the garments discovered during the excavations carried out in the Roman Catholic Cathedral of Alba Iulia at the beginning of the 20th century, more precisely between 1907-1914, presented and published in a bilingual Hungarian-French edition (1918) by archaeologist Béla Pósta, are particularly important. Children's clothing, men's suits, and women's dresses from the sixteenth-seventeenth centuries, along with accessories and other artifacts, came to light. After the publication of the excavation results, the clothing remains (and, in general, the vestiges of the objects unearthed from the 33 discovered tombs) were lost until 2009, when they were 'rediscovered' in a forgotten chest at the Batthyaneum Library in Alba Iulia. After the restoration, in 2014, the objects were presented in an impressive exhibition, which led to the publication of a volume (Hendre Biro 2013).

${ }^{8}$ Subsequently, the temporary exhibition became itinerant and was presented in Oradea, Carei, Făgăraș, etc.

${ }^{9}$ For an overview - albeit not an exhaustive one - of sources on the clothing of the Transylvanian aristocracy, see Papp 2002-2003.

10 Kovács Kiss 2001, 74-77. 
they are colored costume books, ${ }^{11}$ painted portraits (Fig. 6.) or catafalque paintings, undoubtedly had their reasons at the time. These images could be idealized, biased - in a positive or negative sense (and could thus be likened especially to sermons), or they could be descriptive, used for illustrative purposes, like in chronicles or other, generically close narrative sources. Finally, the most realistic and unbiased types of sources consist of price regulations, inventories of wealth and dowries, and last wills and testaments. These I will examine in this paper. Archaeological finds and other artifacts from the respective period may be added to these. Researchers are facing a problem concerning the identification of the pieces (described in texts, painted, or discovered in excavations). The correlation of the names with the represented forms often raises problems because specific terms were not always consistent or explicit in the past. However, given their frequent mention in noble wills, the description of the garments is an important objective of the present investigation, in full awareness that the abundance of data must also be accompanied by appropriate criticism. Only by taking into account the testator's intention can we correctly appreciate the actual value of the garments and the sometimes-deliberate distortion of that value. The present study aims to examine the role of clothing as a status indicator and its social function in the late sixteenth century and the first half of the seventeenth century, based on the last wills and testaments of the Transylvanian nobility. From a structural point of view, the study comprises two parts: the first part is dedicated to themes and issues revolving around white clothes and the women's costume, while the second part will include similar aspects necessary for understanding men's costumes.

\section{White clothes}

A notable observation is the overwhelming presence of apparel in the noblemen's wills in Transylvania. While, according to such testaments, underwear items were not at all rare in the material culture of Transylvanian townspeople in the first half of the seventeenth century, in the noblemen's wills, they appear in a very small number and, even then, in the form of the collective term 'white clothes', i.e., white linen underwear. It seems that there was a specific value limit below which particular objects were no longer included in wills. Perhaps Márta Gerendi, the widow of Miklós Erdélyi of Somkerék, wanted to contribute to the dowry of her nieces, Judith and Zsófia, when she stipulated in her 1583 will that the white clothes in the Sărmașu (Nagysármás, Sarmen) chest should be left to them. ${ }^{12} \mathrm{~A}$ natural gesture was also displayed by Dorottya Bánffy, the widow of János Szalánczi. In 1586 she decided, by her last will and testament, written 'in the agony of death', that the third part of the white clothes should belong to Mrs. Farkas (Bánffy?), and the other two parts should be divided between her orphans. ${ }^{13}$ Family members were again beneficiaries of white clothes in three other wills from the investigated period. One belonged to János Kovacsóczy, who was already by himself, 'deprived of relatives and his beloved wife' in 1599, when he completed his will, written in Alba Iulia (Gyulafehérvár) a year before. Among the movable goods listed were white clothes, which were to be given to his younger

${ }^{11}$ Born 2011, 52-81. Based on the same type of sources, namely costume books, the issue of costumes and identity was also approached by Deák 2014, 150-168.

12 SJC AN, WFF, fasc. 18, no. 34, published in Tüdős S. 2006, 124-125, here 125.

13 MNL OL, F 3, Centuria Z, 521-522; Tüdős S. 2006, 135. 
sister. ${ }^{14}$ In 1608, princely councilor Boldizsár Bornemisza of Kápolna considered it necessary to specify that his men's clothes would belong to his son, while women's clothes and 'white clothes', otherwise called mundus mulieris, were to be divided equally between his three children (two daughters and a son). ${ }^{15}$ Erzsébet Bornemisza, the widow of János Gyerőfi of Kiskapus, also did not detail the pieces of underwear that were to be distributed following the execution of her will. Ms. Erzsébet expressed her wish that her white clothes ('fejernemü ruhak, feier nemü ruha') should be divided (probably between her two children), adding that her daughter, Mrs. Pál Vadászi, had already received some white clothes as part of her dowry, 'as many and just as it was proper', on the occasion of her marriage. ${ }^{16}$ Kata Szécsi, the wife of Zsigmond Prépostvári, wrote her will in 1639. The reason (more or less invoked) was to protect her three children from her first marriage. It seems that Mrs. Kata had had a happy marriage with her first husband, László Gyulafi of Rátót, when they were 'one body and soul. ${ }^{17}$ Therefore, it is not surprising that the children resulting from this marriage, Zsuzsanna, Borbála, and Sámuel Gyulafi, were the main beneficiaries of Mrs. Kata's last will and testament. Among the many garments she bequeathed was her underwear: some of her white clothes and the dress with pearls were to be given to Borbála Gyulafi, while the rest were to be entrusted to Mrs. Kapi's daughter. ${ }^{18}$

The only pieces of lingerie that appear nominally in wills, namely shirts, are the most representative type of white clothes. Usually, both women and men wore two types: a longer shirt, made of thin, simple cloth, without ornaments, worn directly on the body, and a shorter one, made of shroud, hemp cloth, or silk, worn on top of the first. The young György Kornis, who went to university in Heidelberg, asked his mother, in a letter he sent her in 1588, to make him some shirts, 'both inferior and superior, because I'd much rather wear Hungarian or Transylvanian shirts than German ones.' ${ }^{19}$ Sometimes, it was specified whether they were made for women or men. Usually, the shirt worn on top was decorated in various ways, most often with embroidery. Embroidered with silk threads and metallic threads of gold, silver, or gilded silver and hemmed with various embroideries, shirts could also be adorned with pearls, embroidered with lace or braids. Such shirts (ingváll) were those of Anna Sálfi, the wife of György Melith of Briber, ${ }^{20}$ listed in her first will in 1574.

${ }^{14}$ SJC AN, BFF, no. 181, published in Tüdős S. 2006, 172-174, here 173.

${ }^{15}$ MNL OL, F Prot. 126. D; Tüdős S. 2008, 56. For the specialized terms referring to the history of textiles, costume, and colors, see the historical dictionary of the Hungarian lexicon from Transylvania, which can also be used as an excellent Hungarian-Romanian-German trilingual dictionary: Szabó T. et alii 1975-2014, vol. I-XIV and the glossary compiled by Endrei 1989, 215-239.

${ }_{16}$ MNL OL, F. 23, 1642; Tüdős S. 2008, 141.

17 Stephen Báthory of Șumuleu intervened with the magistrates of Bistrița (Beszterce, Bistritz), asking them to lend some bowls and plates for the marriage that took place in 1591. Horn, Kreutzer, Szabó 2005, 181. László Gyulafi wrote his will in 1604, the primary beneficiaries of his inheritance being his wife Kata Szécsi, and their children, but the testament did not provide details about his real estate and movable property (MNL OL, Lib. Reg. Sig. Rak. 1607-1608, 28-29).

${ }_{18}$ MNL OL, Végrendeletek [Testaments] 1571-1830, fasc. 9, no. 23; Tüdős S. 2008, 134, 136.

19 Vass 1898, 278.

20 Anna Sálfi proved to be very conscientious when organizing the assets that belonged to her. She wrote her will three times. The first and the last times $(1574,1575)$ the reason was that she had come down with a disease, while the second time (1575), she actually extended her first will, adding some provisions that she had left out earlier (SJC AN, JFF, no. 167; Petrichevich Horváth 1943, 159-160; Tüdős S. 2006, 101-108, here 101-105). 
The one kept in her chest, which had a Turkish seam, was 'worn', in the sense that it was old, and was embroidered with gold threads, was to be given to Sára. Two others, described in detail, were to be inherited by her daughter, Borka: one old, slightly more worn but whole, embroidered with purple silk, and the other, not so valuable, made of thin linen (patyolat), and wrinkled. Another shirt mentioned before, which was to be given to Kata, was entirely embroidered with red silk, 'in Italian style'. It was not forgotten a close friend of Anna's, Mrs. Pernaman too, who was to receive, shortly after the testator's death, a short, wrinkled shirt, along with the deceased woman's long-worn dress and fur coat. A particular item was the women's shirt that Mrs. Anna had kept in the big yellow chest next to two hats, one of them richly decorated with pearls. The shirt was embroidered with lace and gold threads, adorned with pearls and sequins (islóg). The high value of these underwear probably motivated Anna Sálfi to be so rigorous in their description. She did not forget a shirt with Turkish stitching, richly woven with silver and gold threads, the new, purple shirt, sewn with (threads of) silk, or the one with regular Persian stitching $(\mathrm{kazul})^{21}$ and the gilded one, that is, the one embroidered with gold threads. Fine, expensive shirts were sometimes a reward even for faithful servants, for the years they had spent in the service of their masters. Mrs. Anna thought it appropriate to leave her maid a women's shirt with thick red silk embroidery. The Italian silver linen shirt certainly did not go unnoticed either, sewn with iskófia, mentioned in the will of Kata Máttyus, the wife of György Nagy of Bodókőúffalu, in December 1604. This shirt was destined for György Király, the son of her late husband. ${ }^{22}$ Anna Sálfi's will is illustrative of the large number of shirts that some noble testators could own, as evidenced by the dowry records, which mention many such pieces in possession of a person, from two to 40 pieces. ${ }^{23}$ Since, as a rule, two were worn at a time, we would expect them to appear in even numbers in the written sources, but the cited examples suggest that this custom was not very rigorously respected. ${ }^{24}$

\section{Women's attire}

While underwear was not given particular importance in the testamentary mentions, the situation of other garments, privileged in such sources, was completely different. Meant for everyday wear or use on holidays or special occasions, the noble costume immediately betrayed the fact that the wearer belonged to the higher classes. For starters, I will focus on women's clothing. Women's fashion prevailed over men's in creative fantasy and various shapes. For centuries, the dress was the central piece of women's clothing that was also most different from men's wear. In this era, it was called szoknya (today skirt) in most cases. In the sense it bore at that time, the term 'dress' indicated two elements: a skirt and a bodice. The main piece of women's clothing, the dress, had the gift of shaping the female body according to the ideal of beauty of the time and the wearer. While, in the beginning,

${ }^{21}$ Usually, the ladies of the mansions and castles made the shirts and dresses, with the noble girls raised at their court and local maids. Embroidery was often coordinated, supervised by Turkish seamstresses called bulyák. The Hungarian ladies learned from them, among other things, the so-called kazul embroidery or Persian embroidery, using gold and silver or gilded silver metallic threads. Hungarian noblewomen sometimes exchanged embroidery patterns with Turkish ladies. Mojzsis 1988, 30-31.

${ }^{22}$ MNL OL, Lib. Reg. Sig. Rak. 1607-1608, 156-185b.

${ }^{23}$ Radvánszky 1879-1896, vol. I, 40.

${ }^{24}$ Five times 23 shirts appear in some documents. Radvánszky 1879-1896, vol. I, 40. 
according to an unwritten but accepted rule, the skirt and the bodice were made of the same material and in a single piece, the turn of the seventeenth century brought about a very successful change. Dresses were now made of two pieces: the bodice adjusted to the body and the wide skirt, pleated at the waist, with folds formed by overlapping the material at a certain distance, each from a different fabric. The separate cutting of the bodice (also) had practical reasons, as the two pieces could be exchanged. The skirt, which extended from the waist down, had to cover the legs as well. At the beginning of the seventeenth century, the uniform shape of dresses began to be abandoned. Therefore, some dresses were 'long,' others rounded at the base. Some had a short train, others a long train, called 'long tail' dresses. The materials (fabrics or silks) and the colors for the bodices and skirts also varied. The bodice, finished with buttons or laces, began to have a neckline, which the pleated chest of the shirt could cover. The sleeves were, more or less, puffy. As a rule, the pieces of dresses are not specified in wills, so the one made by Erzsébet Borsvai, the wife of Farkas Petki, in 1647 can be considered a rarity because it mentions the two distinctive parts of dresses. Erzsébet left her relative, Klára Váradi, a dress consisting of a green satin skirt with floral motifs and a bodice with gold fur, made of golden, 'carnation-colored' cloth tercenella hemmed with braid. ${ }^{25}$ Another dress was made of blue satin, embroidered with flowers, hemmed with braid; the skirt was of black velvet and also featured floral motifs, while the top, the bodice, was made of golden fur. She also mentioned a dress whose skirt was made of purple cloth tercenella, with flowers 'the color of hair, i.e., hazel brown, hemmed with a braid of silk, without a bodice. ${ }^{26}$ Usually, however, dresses were described in wills according to efficient considerations: their color, the textile material from which they were made, their cut, style, decorative elements, possibly their condition (worn, old, etc.), and other information related to them (inherited, bought, etc.). Therefore, we do not find a detailed description of them, as in the case of inventories, which the very nature of the document can explain. Wills are not inventories: clothing items are described only so that the executors can identify them. The latter had the task, which was sometimes not so easy, to choose from the lined clothes precisely that piece of clothing that belonged by right to the heirs, as stipulated in the will. Indeed, the executors appointed by Zsuzsanna Kendi in 1602 had no such problems. The beaded and hemmed dress, ${ }^{27}$ along with the small blue velvet coat (suba) and the Spanish black velvet robe with gold rosette (boglár), could hardly be confused with other pieces, especially since they were accompanied by a warm message from the testator, in which she wished her brother, István Kendi, good luck in his upcoming marriage. The vermillion velvet dress, matched with the small, purple, velvet coat (suba) worn 'on the chest' (probably a cape-type short coat) was to belong to Zsuzsanna Kendi, the orphaned relative she had raised. A dress made of purple taffeta and a small velvet cherry-colored coat (suba) was intended for her relative, Borka, and the black velvet dress was left to Mrs. Szécsi. The simpler dresses donated to the servants were, in turn, difficult to confuse. These included the purple damask dress left to Szilágyi,

\footnotetext{
${ }^{25}$ A kind of ornamental braid, gallon in Hungarian, embroidered with strings and sometimes with gold or silver threads (Endrei 1989, 224).

${ }^{26}$ Deák 1878, 949-955; Tüdős S. 2008, 170-175, here 172.

${ }^{27}$ The statement that the dress is hemmed (peremes) usually refers to a fabric or fur hem. Szabó T. et alii 1975-2014, vol. X, 673.
} 
and the purple cloth dress given to Ilkó. As the maid Nyaxa did not receive any clothes, the mistress left her enough red cloth for a dress. ${ }^{28}$ Anna Sálfi did the same. The money obtained from the sale of two large and 'old' pieces of bacon was to be used to buy Kata Bergamo cloth (purgamál) ${ }^{29}$ and velvet for a dress. As a reward for the long time she served, Mrs. Anna's wish was for her dress to be sewn as well. His stepdaughter, Borka, was also to have a robe made of Bergamo red cloth, although Mrs. Anna had originally bought it intending to make her a dress. Borka also received, after the sale of eight pieces of bacon, mohair (muhar) for a dress and two scarves (fedél), one bigger, the other smaller. ${ }^{30} \mathrm{~A}$ year later, when Mrs. Anna rewrote her will, the red Bergamo cloth needed for a dress was still in the black closet, but the mohair had 'turned' into a new red dress made of Italian cloth. It seems that the bacon had also found its buyer in the meantime because the two scarves for Borka, one big and golden and the other smaller, were to be paid for with the 8-10 florins in her yellow chest. ${ }^{31}$ The maid Somogyi was also rewarded with a coat by Margit Balassa, the wife of Gábor Kendi, in 1572. She would receive a yellow taffeta dress if her mother decided to take her home. ${ }^{32}$ Sometimes, testators also thought about the potential life partners of their spouses, in case one of them died and the surviving partner remarried. Krisztina Bethlen, widow of György Horváth of Széplak, later married to István Herczeg of Póka, ordered in her first will, written in 1648, that the black velvet dress, a gift from her husband, should be given to his future wife if he remarried after her death. Otherwise, it was to be left to her stepdaughter Bagi, along with her 'white clothes' (i.e., underwear) and rings. The caftan dress (Turkish silk material) was left to her two sons from the current marriage. ${ }^{33}$ It seems that Mrs. Krisztina worried in vain about her death because her second will, drafted in 1652, reveals that she was the one who became a widow for the second time. It is not surprising that when she mentioned the funeral, she stated very curtly: not much should be spent, the priest should be adequately paid, and she should be buried in the usual way, at her own expense. ${ }^{34}$

In addition to the variety of textiles, the broad color palette is the essential feature of dresses. Only Europe's elites could afford and were entitled to wear colorful clothing in the early modern period. It is also clear from the will of János Várfalvi, written in 1603, that the color of apparel was, indeed, a distinctive social marker. He left brightly colored dresses to the closest women in his family: his wife, Kata Fodor, received a red damask

${ }^{28}$ MNL OL, F 15, Protoc. B, vol. 15; Tüdős S. 2008, 39.

${ }^{29}$ Endrei 1989, 127.

${ }^{30}$ SJC AN, JFF, no. 167; Tüdős S. 2006, 103.

${ }^{31}$ SJC AN, JFF, no. 167; Tüdős S. 2006, 106-107.

${ }^{32}$ MNL OL, F. 3, Centuria Z, 113-114; Tüdős S. 2006, 89.

${ }^{33}$ MNL OL, P 658, Teleki család lvt. [Teleki Family Archive] 54. R. e., fasc. 15; Tüdős S. 2008, 175-176.

${ }^{34}$ MNL OL, P 1912. Herczegh család végrendeletei [Testaments of Herczegh Family] 1645-1660; Tüdős S. 2008, 197. Krisztina Bethlen drafted her will four times, on the following dates, in chronological order: 1648 (MNL OL, P 658, Teleki család lvt. 54 R. e., fasc. 15; Tüdős S. 2008, 175-177), 1652 (MNL OL, P 1912. Herczegh család végrendeletei 1645-1660; Tüdős S. 2008, 196-199); 1656 (MNL OL, P 1912. Herczegh család végrendeletei1645-1660; Tüdős S. 2008, 204-208), and 1660 (MNL OL, P 1912. Herczegh család végrendeletei 1645-1660); Tüdös S. 2008, 229-230). Whereas in the first two cases custom and the changes in her social status (the fact that she became a widow) led her to draft her last will and testament, disease was the main reason in the last two. 
dress and a taffeta green one, while his pampered niece Erzsók (from Erzsébet) was given a red satin dress. ${ }^{35}$ Certainly, the 'sky-colored' (light blue) satin dress that Kata Máttyus left to her husband, along with a red velvet dress and a tecin (satin?) dress, also made of velvet, was also noteworthy. ${ }^{36}$ Expressing the color shades of the dresses by analogy with the different parts of the human body provides a warmer tone to the testamentary evidence. In the middle of the seventeenth century Anna Mária Barkóczi (Fig. 7), ${ }^{37}$ the widow of István Haller (Fig. 2), arranged for two dresses, one 'skin-colored' (pale pink), the other 'hair-colored' (brown), made of satin, both hemmed at the bottom, to be given to her sister-in-law, Kata Barkóczi. Her stepchildren were to have equally intensely colored and precious dresses because of the applied ornaments. Her son inherited the black skirt and the black cloak, both adorned with pearls, and her daughter Judit received an embroidered cherry-colored skirt, another embroidered black velvet skirt, and a cloak. ${ }^{38}$

Rarely do we find in wills information that specifies the wearing of a specific piece of clothing next to another. Last wills and testaments are not normative sources, which is why data of this kind are all the more valuable, betraying, in a way, the testators' fashion knowledge, but also their compliance with the behavioral patterns of their time. In 1574, Anna Sálfi mentioned a shirt whose breastplate was made of taffeta, ${ }^{39}$ and when Margit Balassa, the wife of Gábor Kendi, drafted her will in 1572, she states that she was leaving her daughter, Zsófia Bornemisza, a gilded red dress made of silk atlas and, for that, a Spanish red velvet robe, along with a red satin coat (suba), arranging for the weasel's fur to be replaced with a marten's fur. She also left her daughter another black Spanish velvet robe woven with silver threads, another red satin dress, and a gilded white dress. The other daughter from her first marriage was not forgotten either. Anna Bornemisza was to receive a dress woven with gold thread and adorned with cords, a black velvet dress woven with three rows of gold threads, a white damask dress, green damask for a dress, and a red velvet coat (suba), with forest marten fur. ${ }^{40}$ The opulence of these dresses is evident. Expensive fabrics, embroidered with gold and silver threads, dresses in bright colors, accompanied by other garments (Spanish robes), all these indicated the social status of the wearers, but not only. Obviously, they were members of the upper classes, but the sophisticated, refined details betrayed much more, namely the fact that the Bornemisza women belonged to the high nobility, which 'forced' them to spend larger sums on attire.$^{41}$ However, we must note that this 'obligation' was closely followed by a more or less obvious desire to, somehow, stand apart from the rest of the noble class. We could say that the place one occupied in the noble hierarchy was directly proportional to their desire to stand apart: the further one advanced in the noble hierarchy, the more they felt the need to distance themselves from

\footnotetext{
${ }^{35}$ MNL OL, F 15, Protoc. B, vol. 15; Tüdős S. 2008, 39.

${ }^{36}$ MNL OL, Lib. Reg. Sig. Rak. 1607-1608, 156-185b.

${ }^{37}$ At the dawn of the early modern age, we can rarely associate the will with the person who formulated it. Anna Mária Barkóczi is an exception. Her portrait betrays not only the fact that she was an aristocrat but also, to some extent, the richness of her will in terms of the items of clothing it included.

${ }^{38}$ MNL OL, P 21, Barkóczy család lvt. [Barkóczy Family Archive], Fasc. 6, no. 859; Tüdős S. $2008,210$.

39 SJC AN, JFF, no. 167; Tüdős S. 2006, 105.

${ }^{40}$ MNL OL, F 3, Centuria Z, 113-114; Tüdős S. 2006, 89.

${ }^{41}$ Vintilă-Ghițulescu 2013, 35-40.
} 
those they had left behind. ${ }^{42}$ And one of the most effective 'weapons' of asserting a newly acquired social status was the costume, for both women and men.

In the $1630 \mathrm{~s}$, there was a new change, ${ }^{43}$ resting on the prestige acquired by Italian fashion: the sleeve was detachable, separate, independent of the dress or bodice and made of a different fabric, as valuable as possible, of silk velvet or brocade woven with gold or silver threads; the color of the detachable sleeve had to harmonize with that of the dress. ${ }^{44}$ With the help of these sleeves, the ladies could keep up with the new fashion trends without buying new dresses. ${ }^{45}$ Sometimes the documents stated whether or not a dress had sleeves. Even in the latter case, the dress had sleeves, only they were not sewn to the bodice but detachable. A red dress with satin flowers, without sleeves, alongside a small taffeta robe lined with marten fur, appears in Anna Sálfi's first will, and she left it to her stepson, Pál Melith. Her last will mentions a dress of silk fabric (tabit) with long sleeves, which was to be inherited by her niece, Anna Baranyai, along with a taffeta dress (a particular assortment of taffeta, called dupla-tafota), a blackberry-colored, light mantle (hacuka) made of taffeta and another double taffeta, embroidered dress. ${ }^{46}$ In the case of long sleeves, we can add a second adjective: wide. Nevertheless, the seamstress's fantasy did not stop there: she enhanced the overall image with another element of opulence, inserting a delicate silk lining of a different color than the sleeve so that the simple gesture of raising the hand offered the viewer a charming set of shapes and colors, like a colored harp (not coincidentally also called harp sleeves). ${ }^{47}$ Usually, these sleeves (both or only one) were loaded with different ornaments, sometimes of considerable value. It should be noted that the detachable sleeves did not take the place of the fixed ones, just as the dresses cut into two distinctive parts did not acquire a monopoly over those in one piece. They coexisted, offering a multitude of forms of feminine dresses. All this had, among other things, the purpose of quenching the thirst of the beautiful sex for dresses as varied as possible in shapes and colors, and fashion allowed for different cuts and shapes, which survived in parallel for a certain period. While in the first decades of the seventeenth century, most dresses were long, with a small train, by the middle of the century, they had begun to change their shape and became rounded at the base. Whatever its shape, however, the dress sought to highlight the beauty of the body, the new ideal of female beauty promoted by the Renaissance. The tricks that were

${ }^{42}$ In Herbert Spencer's view, this endeavor of the lower classes is a 'persecution, the upper classes becoming the 'persecuted.' As aspirants reach their goal after a while, the 'persecuted' are forced to create new distinctive signs. Therefore, this infinite process is 'a persecution aspiring to equality' (apud Zsolt 2007, 14-18). However, there were also cases when the upper classes took over clothing items from those inferior to them from a social point of view (Neumann 1922, but especially Gáborján 1991, 345-351).

43 'Guest sleeves' (vendég ujjak), i.e., detachable ones, were also present in the Middle Ages, but, similar to the early modern period, they did not become a widely used piece of clothing. It seems that, due to new fashion trends, they were 'sacrificed' quite quickly, ending up being transformed (sometimes into the cloth for the altar table). Szende 2004, 148.

${ }^{44}$ Radvánszky 1879-1896, vol. I, 91.

${ }^{45}$ It is no coincidence that these extravagant sleeves are the attribute of Mary Magdalene on painted panels from the late Middle Ages as a symbol of barely acceptable indecency. Kühnel 1992, 279-280; Rath 1995, 489-503.

${ }^{46}$ SJC AN, JFF, no. 167; Tüdős S. 2006, 103. Double taffeta, a variant of taffeta, did not refer to the width of the fabric but the density of the material (Endrei 1989, 163).

47 Radvánszky 1879-1896, vol. I, 91; Tompos 2008. 
used included small cushions sewn to the shirt to accentuate the roundness of the hips, the bandages with which the bust was wrapped to lift the breasts, or a kind of corset made of metal strips that made up a piece with small hinges, in such a way as to give the bust an ideal shape. Such stratagems applied to dresses foreshadowed the grand fashion of the crinoline or malacof in the second half of the seventeenth century (which appeared in the West already in the sixteenth century). The tight fabric or cloth of the dress was supported inside by a circle fixed around the hips, forming a casing that folded the dress into a cone or bell shape.

Most of the dresses were tightened around the waist with laces/belts (pártaöv, öv) made of various materials and techniques, with embroidery and silver buckles, possibly with applications of precious stones. A variety of belts, in terms of technique and ornament, is mentioned in the will of György Melith of Briber's wife. Of the four belts adorned with precious stones, two were to belong to Anna Baranyai, her niece, and the third, considered 'old,' meaning large, woven with silver threads and (with silver buckle) weighing seven gíra ${ }^{48}$ was inherited by Anna's two brothers. In the event of their death, this cordon would also reach Anna Baranyai's wardrobe. The fourth belt made of cord (korda öv) was to belong to György Utyekevith. ${ }^{49}$ Gold or silver cord belts, as their name suggests, were probably made by weaving several gold or silver cords. These cord cords were wrapped around the waist several times to make a stronger impression. In 1603 János Várfalvi stated, without giving further details, that his niece Erzsók was the beneficiary of a belt adorned with precious stones, and his wife, of another, 'wider' one. ${ }^{50}$ It is difficult to say what the nobleman from Moldovenești (Várfalva) meant by this phrase. Maybe he thought of richer ornamentation or the size/length of the cord. What is certain is that the belt offered to his wife was superior to the one given to his niece, that it was a 'more' valuable belt. An unusual piece had to be the belt adorned with pagan coins (pogánypénzes) that Borbála Kemendi, the wife of Farkas Kendi, left in 1580 to her son from her first marriage, Péter Décsei, together with the purple satin dress. ${ }^{51}$ During the Renaissance, it was discovered that ancient coins could be offered a different destination than that of museum collections. As Transylvania was rich in such vestiges and interest in the material culture of antiquity, especially the Roman, flourished, the making of belts from ancient gold and silver coins also became fashionable among members of the nobility. ${ }^{52}$ In some cases, reference was made to the origin of the artifact. In Erzsébet Bornemisza's will of 1642, the delicate, glazed German silver belt was to belong to her daughter. The belt was, in this case, most likely, adorned with precious stones in enameled mounts. ${ }^{53}$ This type of accessory, almost indispensable to women's and men's costumes (in certain forms and those of children), had been present in noble fashion since the end of the Middle Ages. Since it was a ready-made piece, it could be purchased

\footnotetext{
${ }^{48}$ Unit for measuring weight, a subdivision of the ounce.

49 SJC AN, JFF, no. 167; Tüdős S. 2006, 102.

${ }^{50}$ MNL OL, F 15, Protoc. B, vol. 15; Tüdős S. 2008, 44

${ }^{51}$ MNL OL, F 3, Centuria Z, 130-131; Tüdős S. 2006, 121.

52 In the absence of ancient coins, there are reported cases in which goldsmiths minted new coins, following their model, combining ancient coins with more modern copies to manufacture belts (Radvánszky 1879-1896, vol. I, 129).

${ }^{53}$ MNL OL, F 23, 1642; Tüdős S. 2008, 143.
} 
anywhere in Paris, Spain, Italy or Germany ${ }^{54}$ In addition to their excellent quality, these belts satisfied the desire of buyers to keep up with fashion. We must note that these cords or belts were unisex, like the coats called suba, and could be worn by women and men. However, some were confined exclusively to women's wear (those made of pearls or beads). Therefore, their transmission from female testators to male beneficiaries, and vice versa, was not uncommon. However, it can be seen that they were left as a legacy to family members due to their high value. Zsófia Kendi, the wife of Menyhárt Bogáti, made explicit reference to this in her will of 1598, when she left to her dearest relative, Anna Báthory, a Spanish velvet robe with rosette, lined with motley velvet, which she had received from her husband, next to the golden cord, inherited from her father. ${ }^{55}$ At the same time, their more significant number (two, three, four, etc.) can be correlated with fashion trends and the different shapes and colors of the costumes: some matched the clothes worn, others did not. Therefore, it was advisable to have several belts to match the dresses worn. Kata Máttyus did not give more details about the belts she owned in her will of December 1604, and she only showed that the beneficiary of the three belts adorned with precious stones was to be György Király, her stepson. ${ }^{56}$

If we were to appreciate the fashion of the seventeenth century only after the dresses kept in museum collections, we would be tempted to believe that the noble ladies of Transylvania wore silk clothes every day, the finest fabrics, adorned with floral motifs, embroidered with gold and silver threads, shining in vivid colors. Therefore, it is easy to understand the reason for their survival, even after a few centuries. Being of superior quality, often adorned with pearls and other jewels, their preservation was given greater attention. It is no coincidence that such clothing is among museums' most precious and best-preserved treasures. However, the reality was different. In the wardrobe of any noblewoman, there were three types of garments: all day/every day, holiday, and occasion clothes. The clothes preserved in today's public or private collections or those that we can admire due to the skill of the painters, in portraits and catafalque representations, usually come from the last two categories of clothing. Then again, it is easy to understand why everyday dresses or 'house dresses', so named after the custom of the time, did not survive. Being intensely used, they did not withstand the passage of time and, since they were not valuable, their wearers did not pay special attention to them. In the case of dresses in the last two categories, however, an essential feature was the material from which they were made: usually fabrics of silk, cotton, or high-quality linen (brocade and silk velvet), with floral motifs, sewn and/or embroidered with threads of silk and metal threads of gold, of silver or gilded silver, whether or not passed over the warp and weft threads, and adorned with pearls, precious and semi-precious stones or fur. The general image is that of very rich decorations, with nuances, tone contrasts, finesse, and refinement. Therefore, due to their value and the caution to be worn daily, these garments were much more likely to be preserved for generations.

In some wills, when the number of heirs was small and the beneficiaries of movable property were few, garments were designated in general terms. Thus, in 1593 Ferenc Geszti,

\footnotetext{
${ }^{54}$ Radvánszky 1879-1896, vol. I, 129.

${ }^{55}$ MNL OL, E 149, Acta Transylvanica, batch 2, fasc. 2; Tüdős S. 2006, 177.

${ }^{56}$ MNL OL, Lib. Reg. Sig. Rak. 1607-1608, 156-185b.
} 
princely counselor and captain of Deva (Déva) fortress, married twice, but having no other children from any marriage than one stepson, arranged in his will that the entire manor in Dobra, with all its outbuildings, as well as the precious objects and all the clothes, both the important ones, i.e., for feasts and special occasions (forruhák), as well as the everyday, usual (közruhák) outfits, everything, to the last footcloth (kapca), should be bequeathed to his valet, Balaskó Gyulai, who had served him since childhood. ${ }^{57}$ It was rare for personal servants, or valets, to be rewarded in this way. However, it seems that for Balaskó Gyulai, the years spent with his master had not been in vain. Thanks to the devotion with which he had cared for him during many years of illness as if he was his son, Gyulai had gained the trust of his master, who, in turn, rewarded him far beyond what was customary at the time. ${ }^{58}$ At other times, different types of dresses were mentioned indirectly. When the noblewoman Kata Szécsi drafted her will, she drew the attention of her daughter Borbála Gyulafi that she had been well-endowed at the wedding, receiving both silver and gold goods along with jewels, as well as 'beautiful, princely clothes and garments', i.e., garments for special occasions and celebrations. ${ }^{59}$

Wedding dresses can also be in the category of clothes worn on special occasions. These dresses, of high material value, also had a strong emotional charge. Therefore, it is not surprising that the daughters or granddaughters usually inherited these garments. Krisztina Bethlen's wedding dress was mentioned in her first and third wills and was to be inherited by her daughter Kató, married to András Herczeg. However, the misunderstandings between the children prompted Mrs. Krisztina to reconsider her attitude towards her heirs, conditioning the reception of the wedding dress by Mrs. András Herczeg on her reconciliation with her brother Zsigmond; otherwise, the dress would belong to Zsigmond. ${ }^{60}$ The value of such a garment transpires from the will made by the Cluj comes, Gergely Frátai, in 1572. Even if the document was drafted in a hurry, due to an unexpected illness, the testator did not forget the wedding dress of his wife, Ilona Bartakovith, to whom he left the pledged possession from Iuriu de Câmpie (Ör) ${ }^{61}$ It seems that, for some reason, Mrs. Ilona had been forced to give up her wedding dress, and her husband thought it appropriate to make up for her loss.

In the description of the dresses, besides the color, the most frequently mentioned feature was the textile material, and sometimes allusion was made to the cut. Almost all types of materials were used to make dresses: velvet, tabit (silk fabric), satin, taffeta, as well as other fine fabrics (garnet, damask, scarlatto). From the 1612 will of Sára Szinnyei, Márton Cserényi's wife, we find out the value of a dress: she hoped to recover her gilded satin dress, pledged to Péter Oszvald for two florins, before she died, as she was to donate it to János Füzi. ${ }^{62}$ But we also have examples of much more expensive dresses. The two dresses

${ }^{57}$ Radvánszky 1879-1896, vol. II, 145-152; Tüdős S. 2006, 151-157, here 153.

58 Tüdős S. 2006. On Geszti’s will, see Lupescu Makó 2020, 194-195.

59 MNL OL, Végrendeletek 1571-1830, batch 9, item 23; Tüdős S. 2008, 131-136.

60 Tüdős S. 2008, 206, 229-230. Mrs. Krisztina wanted to specify why she was partial to her sons from her two marriages in the property division. They were good children, she confessed, they were loyal, and she was confident that they would treat her like that in the future. However, one of the daughters, Mrs. András Herczegh, had caused her much trouble, so she was to receive less; some goods from her share were to be divided among the other three brothers.

${ }^{61}$ Petrichevich Horváth 1943, 100-102; Tüdős S. 2006, 90-93, here 92.

62 Tüdős S. 2008, 68. 
left by Krisztina Bethlen in her first will of 1648 to her daughter Kató must have been extraordinary if their value was set at 100 florins ${ }^{63}$ The 1639 will of Kata Szécsi, formerly the wife of László Gyulafi of Rátót, remarried to Zsigmond Prépostvári, the supreme comes of the Middle Solnoc (Közép-Szolnok) and Crasna (Kraszna), was somewhat out of the ordinary, as she also included a public rebuke against her husband. The testator stated that she had never benefited from her husband's money, a well-known fact, she said. Moreover, he had not spent as much as 10 florins for her children (from her first marriage) or her household and had not even bought her a set of clothes. For many years since she had been his wife, it was only thanks to her resources that she had managed to purchase a velvet cherry dress, a mottled taffeta dress, a purple satin dress, and a damask green one, while her husband had only bought her black velvet for two or three small coats (suba) and purple satin for a small coat (suba). He once gave her ten cubits of shroud, seven ells of flax, and 100 florins, when they wanted to go to the octaves of Prešov (Eperjes, Preschau) ${ }^{64}$ Therefore, she had dressed herself and dressed those in the house (family, servants) from the income of her estate in Cehu Silvaniei (Szilágycseh). She did not forget about the other pieces of clothing, drawing Zsigmond Prépostvári's attention to the marten fur coat (suba), which he was still wearing, and to a pelisse (mente) crimson made of scarlatto without a collar, which matched the coat, but that she had been looking for in vain. She also mentioned the new pelisse (mente) lined with marten fur and an old, worn ('old'), crimson scarlatto, with blue buttons, lined with velvet. Other clothes left by her first husband were exquisite, marten-lined pelisses (mente), which the second husband also wore. With special affection, she referred to the fur made from a part of a lynx's leg, which her poor husband had worn before he died underneath the old pelisse (mente) - the fur was still at Prépostvári. With a disguised reproach, she reminds her current husband of the lynx fur, made from the hind part of the animal, which was worn under a short pelisse (mente) and which he had sold to an unknown person in Prague. ${ }^{65}$ Because all these pieces of clothing were masculine, they were to belong to her son from her first marriage, Sámuel Gyulafi. They had belonged to his father anyway. The reason invoked by Mrs. Kata was full of emotion but also took into account social conventions. Her son had no clothes left from his deceased father, so it was time to 'have something to remind him of his father'. She also tried not to be accused (by the world) of not taking care of her husband's clothes, of inheriting the clothes that belonged to her son, the rightful heir. ${ }^{66}$ Therefore, it is not surprising that Mrs. Kata left nothing to her current spouse, insisting that the inheritance of her three children from her first marriage should be theirs. ${ }^{67}$ The children and the various pieces of clothing were again the center of attention in the testament of Erzsébet Bornemisza, drafted in 1642.

\footnotetext{
${ }^{63}$ Tüdős S. 2008, 175.

${ }^{64}$ The deadline of the periodic jurisdiction was related to the last day, the eighth of the most important religious holidays.

${ }^{65}$ The posterior part of the lynx skin, the skin of the foot and abdomen, was used as fur and lining. However, the price was extremely high. In 1643 István Réthy bought for George Rákóczi I two lynx skins for 415 thalers. He added that he had had the opportunity to buy two stunning pieces of lynx skins from the abdomen, which would have ended up on the collar of the tunic, but they were costly: one was valued at 1800, the other at 1200 thalers. Szilády, Szilágyi 1868-1878, vol. III, 190.

${ }^{66}$ MNL OL, Végrendeletek 1571-1830, batch 9, item 23; Tüdős S. 2008, 133.

${ }^{67}$ MNL OL, Lib. Reg. Sig. Rak. 1607-1608, 28-29; Tüdős S. 2008, 133.
} 
In this case, the primary beneficiary was the testator's son, Pál, because her daughter had already been richly rewarded at the time of her marriage. Thus, Mrs. Erzsébet reminded her daughter, Pál Vadászi's wife, that at her wedding she had received eight dresses that were 'all the fashion,' of which six had gilded fur, and two had silky fur, four small 'decent' coats (suba), a black velvet (mente) with floral motifs, as well as white clothes. ${ }^{68}$ As can be seen from these examples, dresses usually appear in greater numbers in wills.

We rarely have information about the transformation of clothing. If in the Middle Ages it was not at all unusual for the testator's glass to be transformed into a chalice, or the tunic to become a priest's cassock, in the early modern period, this practice diminished due to the change of the message associated with it. In the Middle Ages, these transformations usually followed the transition of the artifact from the secular to the ecclesiastical sphere, with the motivation that, through them, the testator would continue to be present in the lives of loved ones and those who had received donations. The testator's memory would be revived, albeit indirectly, whenever a chalice or tunic was used during the service. With the Reformation, this need to cultivate the memory of the deceased dropped sharply and took other forms, having moved into the sphere of the laity. Margit Balassa could be sure that whenever her daughters, Anna and Zsófia, sat on the bed adorned with pillowcases sewn from her red gilded velvet dress, her spirit would come to life and, for a few moments, she was with her loved ones again. ${ }^{69}$ Anna Sálfi left Sára a garnet robe, which the testator had been wearing, and arranged for a dress to be made from Sára's new felt/broadcloth robe (purgamal); thus, she could have three. ${ }^{70}$

The fate of dresses was not always that intended by the testator. Sometimes they were accidentally destroyed. Other times, due to their high value, they received another destination, being pledged. Less frequently, dresses were confiscated by the authorities due to disputes, as happened in the case of János Várfalvi in the early seventeenth century. The local nobleman showed with much indignation and anger that most of his movable property had been taken illegally by the authorities. Of the three chests full of goods (money, jewelry, silverware), the third deserves special attention. The chest contained beautifully arranged, special garments, dresses, fine tablecloths, bed linen, carpets, and 'other beauties' that Mr. János did not mention, with a certain resignation and sadness. ${ }^{71}$ At other times, human nature, subjected to mistakes and vices, intervened in the natural process of children inheriting clothes from parents. When László Brinyi, the praefectus of Gherla (Szamosújvár, Neuschloss) castle, decided to dictate his will on his deathbed, he had good reason to do so cautiously. Sick and without descendants, he was aware, as he put it, that the drafting of his last will and testament was the only way he could decide the fate of his property so as not to let it fall into the hands of greedy strangers. Having no direct heirs, his brothers and cousins were next in the line of inheritance. ${ }^{72} \mathrm{He}$, therefore, mentioned the nieces of his brother, Gáspár Brinyi. He showed that a daughter of Gáspár was married to István Márton, an infamous, unworthy man, widowed with two daughters.

\footnotetext{
${ }^{68}$ MNL OL, F. 23, 1642; Tüdős S. 2008, 141.

${ }^{69}$ MNL OL, F 3, Centuria Z, 113-114; Tüdős S. 2006, 89.

70 SJC AN, JFF, no. 167; Tüdős S. 2006, 104-105.

${ }^{71}$ MNL OL, F 15, Protoc. B, vol. 15; Tüdős S. 2008, 42.

${ }^{72}$ Lupescu Makó 2012, 84-105; Lupescu Makó 2002-2003, 115-138.
} 
Although he owed nothing to the two orphans, László Brinyi nonetheless considered his kinship with their grandfather and decided that if they reached the age of marriage, they would each receive 100 florins. However, he wanted to emphasize that the money should not be given to Márton, the girls' father, because he would spend all of it on drinks, as he had done before with all the dresses, cloaks, and coats that had belonged to his wife, the girls' mother. 'He drank them,' that is, he sold them, and he spent the money on drinks. ${ }^{73}$ So a little life story emerges from this will. The two noble girls in this relatively wealthy family had every chance to grow up, be educated, and marry according to their rank. With the death of their mother, however, there was a break in the natural evolution of their lives. The father had sought refuge in alcohol and not taken care of them. Moreover, he had also ruined their dowry, which had been wasted away.

Robes or overcoats were usually worn over dresses. Because they are types of clothing that both women and men could wear, I will treat them when I present men's costumes. ${ }^{74}$

A winter garment that enjoyed great success in the world of nobleladies in Transylvania was the coat made entirely of fur (gerezna). It was left as a legacy both to kin and the house staff. The will of György Melith of Briber's wife mentions a coat of grey Siberian squirrel fur (pegymet gerezna), new, which was to be given to Mrs. János Melith. ${ }^{75}$ The 'older' fur coat (gerezna) and the cloak of Márta Gerendi were to belong to her daughter Kata, and the fur coat she was wearing was to be given to Mrs. Balázs Wass. ${ }^{76}$ Dorottya Bánffy's will refers to several fur coats, differentiated by their size. Maid Sos was to get a smaller fur coat (gerezna), Mrs. Farkas Kendi a larger coat of Siberian gray squirrel fur (pegmet), Mrs. György Nagy a larger fur coat, and Vince's daughter a dress made of a special fabric (igler). ${ }^{77}$ János Várfalvi's will of September 1603 is also interesting because he mentions a piece of clothing rarely referenced in such documents. Along with a coat made of grey Siberian squirrel fur (pegymet mal gerezna), his wife was to receive a women's cloak made of a fabric called hernác, usually worn over one shoulder, to the back (hernacz palast). Similarly, among the nobles, especially those with military functions, wearing animal skins, called kacagány, thrown over the shoulder enjoyed success. Those of lower rank wore such a piece of wolf skin, while those of higher rank, tiger or panther skin. Probably Gáspár Menyhárt referred to such an accessory when he pointed out, in his will of 1589, that Lukács Bihari had borrowed a breastplate of his and a panther skin for a military inspection (mustra). ${ }^{78}$

\section{Preliminary conclusions}

Closing the analysis of the female costume, we can formulate some summary ideas before the conclusions attached to the second part of the study. Thus, without a doubt, clothing had a fundamental role as an identity indicator. Among the critical information provided by the documents is social status, gender, ethnicity, or fashion change, seasons and occasions when specific garments were worn. Wills, therefore, can be significant sources not only for social history but also for art history and costume history.

\footnotetext{
${ }^{73}$ MNL OL, F. Prot A. i.; Tüdős S. 2006, 141.

${ }^{74}$ See the second part of this paper.

75 SJC AN, JFF, no. 167; Tüdős S. 2006, 103.

${ }^{76}$ MNL OL, R. 224, fasc. 24; Tüdős S. 2006, 125.

77 MNL OL, F. 3, Centuria Z, 521-522; Tüdős S. 2006, 136.

${ }^{78}$ MNL OL, F. 25, batch 1; Tüdős S. 2006, 138.
} 
In terms of fashion, the women of the early modern era in Transylvania turned to the Western one but did not fully adopt it. The pieces taken from the West were given a local, Hungarian touch; the most prominent contribution to women's costumes was the long, embroidered aprons, usually lighter in color, to contrast with the darker color of the skirt material. Anna Sálfi's will mentions several aprons (előkötők): a wide, black, embroidered, new one, another distinguished by the Persian stitch ( $k a z u l)$ and three other gilded aprons, two of which were embroidered and the third adorned with braids (kötéses). ${ }^{79}$ Due to the very fine material from which they were made, too few aprons have been revealed by archaeological investigations. Therefore, in the case of these garments, visual images can make up for the near absence of artifacts. They have not entirely disappeared from the costume landscape and are still present in aprons in folk costumes. ${ }^{80}$

Regarding the colors of the clothing ensemble, we cannot notice radically new tastes compared to the previous medieval period. The differences between the colors also help a lot in classifying the costume wearer in the social hierarchy. In early modern Europe, the elite had the opportunity to dress in colorful garments. In the first half of the seventeenth century, the preference for a varied color palette persisted (bright red, crimson, cherry, green, purple, black, yellow, blue, white), though red had predominated since previous centuries. ${ }^{81}$

As materials, woolen fabrics, or textiles made of cotton, linen, or hemp and those of different silks were varied in terms of quality, provenance, and color. Elegant clothing very often featured embroidery elements, such as floral motifs. Embroidery, reserved in the Middle Ages for liturgical vestments, now adorned hoods, shirts, handkerchiefs, berets, or even textile shoes.

Reflecting on the paper's title, we can see that clothing was undoubtedly one of the essential markers of social convention; its shape and color indicated the role and place of each population segment. Today we accept the explanation, validated by the popular wisdom, according to which it is internal, spiritual values that give integrity to a person and realize that clothes do not make the man. However, in the past, especially in the Middle Ages and then in the early modern period, clothes conferred individuality to people.

\section{Bibliography}

\section{Primary sources}

Horn, Kreutzer, Szabó 2005

MNL OL

SJC AN, BFF
I. Horn, A. Kreutzer, A. P. Szabó (eds.), Politika és házasság. Menyegzöre hívogató levelek a 16. századi Erdélyből, Budapest 2005.

Magyar Nemzeti Levéltár Országos Levéltára, Budapest.

Serviciul Județean Cluj al Arhivelor Naționale, Cluj-Napoca, Bálintitt Family Fonds, Series 1 - Medieval documents, no. 181, CJ-F-00318-1-181, www.arhivamedievala.ro, accessed 22 May 2021.

\footnotetext{
79 SJC AN, JFF, no. 167; Petrichevich Horváth 1943, 159-160; Tüdős S. 2006, 104-105.

${ }^{80}$ Mojzsis 1988, 31.

${ }^{81}$ A comparison with the color of the clothes from the Romanian Principalities shows that red and its shades ranked foremost in preferences in Moldova and Wallachia, but compared to Transylvania, the following 'places' were occupied by yellow, white, green, blue, and black (Székely 2011, 13).
} 
SJC AN, JFF

SJC AN, WFF

Tüdős S. 2006

Tüdős S. 2008

Vass 1898

\section{Secondary sources}

Belfanti, Giusberti 2000

Blockmans 1999

Born 2011

Bourdieu 1984

Bourdieu 1984/2002

Bulst 1993

Deák 2014

Deák 1878

Dinges 1992

Endrei 1989

Finkelstein 1991

Gáborján 1991
Serviciul Județean Cluj al Arhivelor Naționale, Cluj-Napoca, Jósika Family Fonds, Series 1 - Medieval documents, no. 167, CJ-F00255-1-167, www.arhivamedievala.ro, accessed 22 May 2021.

Serviciul Județean Cluj al Arhivelor Naționale, Cluj-Napoca, Wass Family Fonds, Series 2 - Filed documents, fasc. 18, no. 34, CJ-F-00457-2-18-34, www.arhivamedievala.ro, accessed 22 May 2021.

K. Tüdős S., Erdélyi Testamentumok II. Erdélyi nemesek és föemberek végrendeletei, Marosvásárhely 2006.

K. Tüdös S., Erdélyi Testamentumok III. Erdélyi nemesek és föemberek végrendeletei 1600-1660, Marosvásárhely 2006.

M. Vass (ed.), Egyháztörténelmi adatok CXXXVI. Kornis György levelei anyjához, Bethlen Krisztinához, Keresztény Magvető, 33/5 (1898), 278-280.

C. M. Belfanti, F. Giusberti, Clothing and Social Inequality in Early Modern Europe: Introductory Remarks, Continuity and Change, 15/3 (2000), 359-365.

W. Blockmans, The Feeling of Being Oneself. In: W. Blockmans, A. Janse (eds.), Showing Status. Representation of Social Positions in the Late Middle Ages, Turnhout 1999, 1-18.

R. Born, Mapping Transylvania as a Multiethnic and Multiconfessional Region in Costume Books $17^{\text {th }}-19^{\text {th }}$ centuries. In: C. Vintilă-Ghițulescu (ed.), From Traditional Attire to Modern Dress: Modes of Identification, Modes of Recognition in the Balkans (XVI ${ }^{\text {th }}-X X^{\text {th }}$ Centuries), Cambridge 2011, 52-81.

P. Bourdieu, Distinction: A Social Critique of the Judgment of Taste, Cambridge 1984.

P. Bourdieu, Haute couture et haute culture. In: P. Bourdieu, Questions de Sociologie, Paris 1984/2002, 196-206.

N. Bulst, Kleidung als sozialer Konfliktstoff. Probleme kleidergesetzlicher Normierung im sozialen Gefüge, Saeculum, 44 (1993), 32-46.

É. Deák, Öltözködés és identitás a 17-18. századi Erdélyben a viseletsorozatok tükrében, Korall, 55 (2014), 150-168.

F. Deák, Két végrendelet a XVII. és XVIII. századból, Magyar Történelmi Tár, 1 (1878), 949-960.

M. Dinges, Der "feine Unterschied". Die soziale Funktion der Kleidung in der höfischen Gesellschaft, Zeitschrift für Historische Forschung, 19 (1992), 49-76.

W. Endrei, Patyolat és posztó, Budapest 1989.

J. Finkelstein, The Fashioned Self, Philadelphia 1991.

A. Gáborján, Emelkedő elemek. In: P. Halász (ed.), A Duna menti népek hagyományos müveltsége. Tanulmányok Andrásfalvy Bertalan tiszteletére, Budapest 1991, 345-351. 
Galavics, Várkonyi 1990

Hendre Biro 2013

Jones, Stallybrass 2003

Jütte, Bulst 1993

Kovács Kiss 2001

Kovesy Killerby 2002

Kühnel 1992

Lévi-Strauss 1983

Lupescu Makó 2002-2003

Lupescu Makó 2012

Lupescu Makó 2015

Lupescu Makó 2020

Mojzsis 1988

Neumann 1922

Oborni et alii 2009

Pakucs-Willcocks 2018

Papp 2002-2003
G. Galavics, Á. R. Várkonyi (eds.), Régi erdélyi viseletek. Viseletkódex a 17. századból, Budapest 1990.

D. Hendre Biro (ed.), Batthyaneum. Descoperirile arheologice din Catedrala Romano-Catolică din Alba Iulia (1907-1914) publicate in 1918 de Pósta Béla. Valorificarea unui inventar uitat, București 2013.

A. R. Jones, P. Stallybrass, Renaissance Clothing and the Materials of Memory, Cambridge 2003.

R. Jütte, N. Bulst, Einleitung. Zwischen Sein und Schein. Kleidung und Identität in der ständischen Gesellschaft, Saeculum, 44/1 (1993), 2-7.

Gy. Kovács Kiss, Adatok a viselet szabályozásáról a XVIXVII. századi Kolozsváron. In: T. K. Dáné, Á. Egyed, G. Sipos, W. Rudolf (eds.), Kolozsvár 1000 éve, Kolozsvár 2001, 74-77.

C. Kovesy Killerby, Sumptuary Law in Italy 1200-1500, Oxford 2002.

H. Kühnel (ed.), Bildwörterbuch der Kleidung und Rüstung: Vom Alten Orient bis zum ausgehenden Mittelalter, Stuttgart 1992.

C. Lévi-Strauss, Histoire et ethnologie, Annales ÉSC, 38/6 (1983), 1217-1231.

M. Lupescu Makó, Consideraţii privind testamentele nobiliare din Transilvania la sfârşitul evului mediu, ActaMN, 39-40/II (20022003), 115-138.

M. Lupescu Makó, Késö-középkori erdélyi végrendeletek joggyakorlata. In: R. Nagy, E. Rüsz-Fogarasi (eds.), Ablakok a múltra, Kolozsvár 2012, 84-105.

M. Lupescu Makó, (Nu) haina îl face pe om. Îmbrăcămintea și purtătorii ei în Transilvania (secolele XVI-XVII). In: D. D. Iacob (ed.), Avere, prestigiu și cultură materială în surse patrimoniale, Iași 2015, 35-69.

M. Lupescu Makó, Nobilimea și practica scrisului în Transilvania premodernă. In: M. Dejan (ed.), Scris, scriitură, text în Țările Române (secolele XV-XVIII), Suceava 2020, 181-218.

D. Mojzsis (ed.), Régi magyar öltözködés. Viseletek dokumentumok és források tükrében, Budapest 1988.

H. Neumann, Theorie vom gesunkenen Kulturgut, Leipzig 1922.

T. Oborni, L. Tompos, G. Bencsik, A régi Erdély népeinek képeskönyve. Kéziratos viseletkódex az Apafiak korából, Budapest 2009.

M. Pakucs-Willcocks, Transylvanian civic sumptuary laws in the early modern period: Preliminary observations, Revista istorică, 29/1-2 (2018), 55-73.

A. Papp, Izvoare privind vestimentația aristocrației transilvănene in secolele XVII-XVIII, ActaMN, 39-40 (2002-2003), 273-280. 
Petrichevich Horváth 1943

Pósta 1918

Radvánszky 1879-1896

Rath 1995

Szabó T. et alii 1975-2014

Szende 1997

Szende 2004

Székely 2011

Szilády, Szilágyi 1868-1878

Tompos 2008

Vincent 2003

Vintilă-Ghițulescu 2013

Weatherill 1991

Zimányi 1994

Zsolt 2007
E. Petrichevich Horváth, Régi magyar végrendeletek, Magyar Családtörténeti Szemle, 9/5-12 (1943), 99-102, 136-137, 159161, 186-188, 240-241, 281-283.

B. Pósta, A gyulafehérvári székesegyház sírleletei. Les trouvailles de la cathédrale de Gyulafehérvár, Kolozsvár 1918.

B. Radvánszky, Magyar családélet és háztartás a XVI. és XVII. században, vol. I-III, Budapest 1879-1896.

B. Rath, Der Ärmel und das Haar. Darstellungsweisen von Maria Magdalena in der Kunst des Spätmittelalters. In: J. Bernard (hrsg.), Zeichen/Manipulation. Akten des 5. Symposiums der Österreichischen Gesellschaft für Semiotik, Wien 1995, 489-503.

A. Szabó T., M. Vámszer, Á. Daly, F. Kósa Ferenc, E. Fazakas, J. Zsemlyei, A. Zselyke et alii (eds.), Erdélyi magyar szótörténeti tár, vol. I-XIV, Budapest-Kolozsvár 1975-2014.

K. Szende, A luxus fogalma és a luxusigények kielégitése a középkorban. In: S. Horváth, J. Szulovszky (eds.), Luxusiparok. Válogatás a IX. Kézmüvesipartörténeti Szimpózium előadásaiból, Budapest-Veszprém 1997, 13-24.

K. Szende, Otthon a városban. Társadalom és anyagi kultúra a középkori Sopronban, Pozsonyban és Eperjesen, Budapest 2004.

M. M. Székely, Colour Garments: Tradition, Fashion or Social Mark? The Romanian Principalities in the $16^{\text {th }}-17^{\text {th }}$ Centuries. In: C. Vintilă-Ghițulescu (ed.), From Traditional Attire to Modern Dress: Modes of Identification, Modes of Recognition in the Balkans (XVI ${ }^{\text {th }}-X X^{\text {th }}$ Centuries), Cambridge 2011, 12-28.

Á. Szilády, S. Szilágyi (eds.), Török-magyarkori állam-okmánytár, vol. I-VII, Pest 1868-1872.

L. Tompos, Magyar és spanyol női viselet Magyarországon a 16. században, Korunk, 19/7 (July 2008), https://epa.oszk. hu/00400/00458/00139/tomposl.html, accessed 24 May 2021.

S. Vincent, Dressing the Elite: Clothes in Early Modern England, Oxford-New York 2003.

C. Vintilă-Ghițulescu, De la ișlic la joben. Modă și lux la Porțile Orientului, București 2013.

L. Weatherill, Consumer Behaviour, Textiles and Dress in the Late 17th and Early Eighteenth Centuries, Textile History, 22/1 (1991), 297-310.

V. Zimányi, Néhány szempont az életszínvonal változásához a 17. századi Magyarországon. In: V. Zimányi (ed.), Óra, szablya, nyoszolya (Életmód és anyagi kultúra Magyarországon a 1718. században), Budapest 1994, 7-18.

P. Zsolt, Divatszociológia, Budapest 2007. 


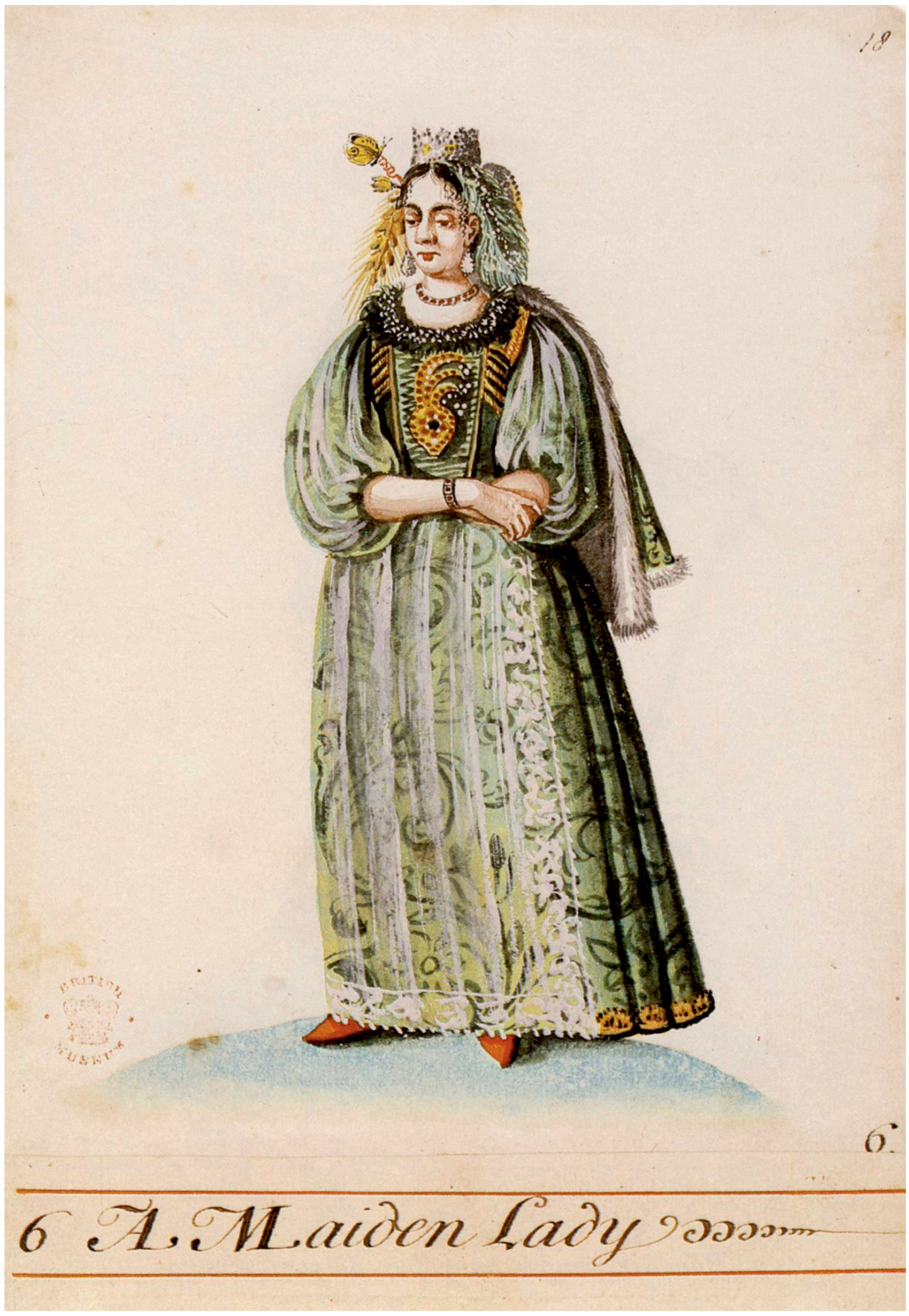

Fig. 1. Unmarried female aristocrat (Galavics, Várkonyi 1990, img. 6). 


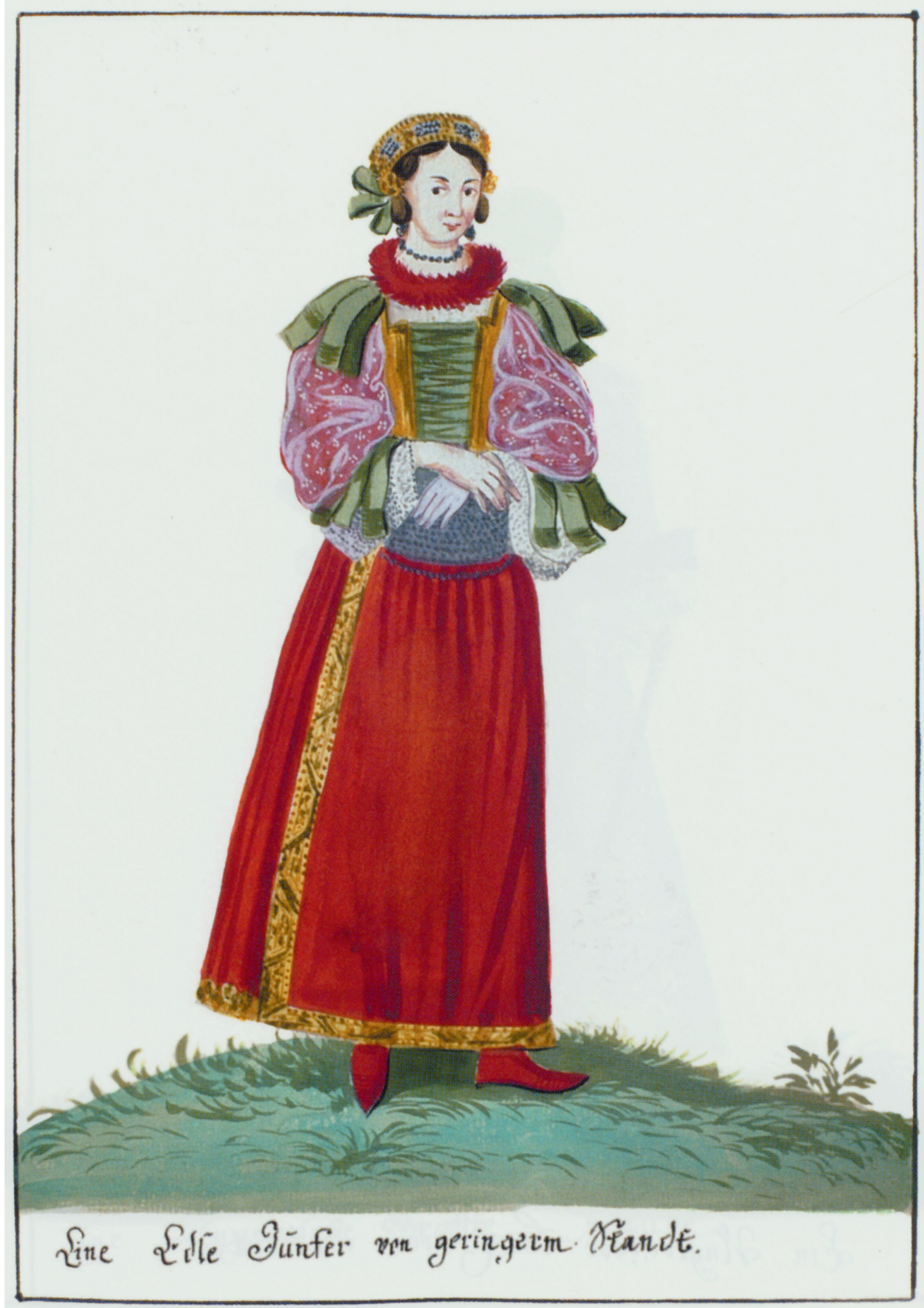

Fig. 2. Eine Edle Junfer von geringerm Stande - Hungarian noblewoman of lower rank (Oborni et alii 2009, img. III). 


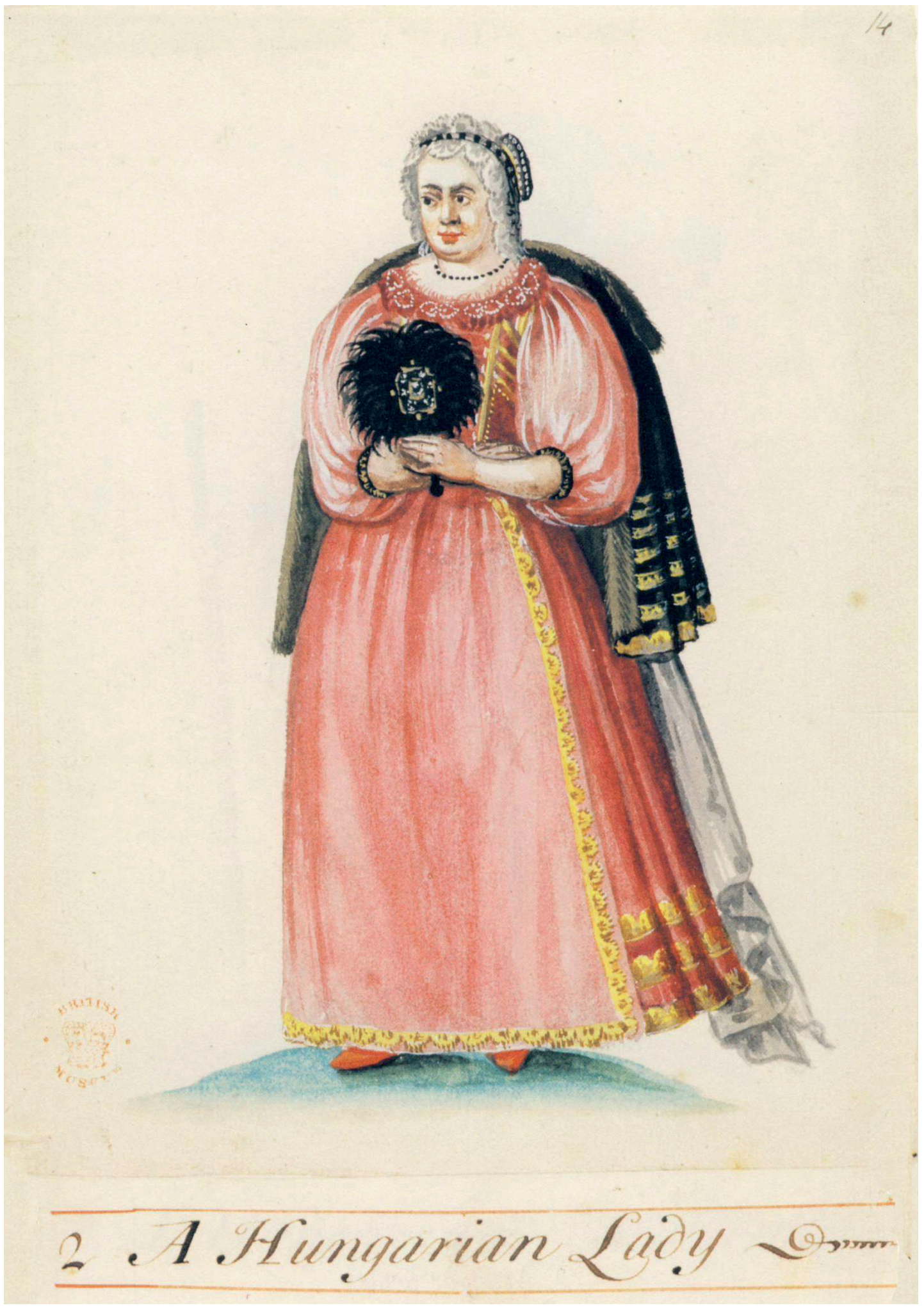

Fig. 3. Hungarian female aristocrat (Galavics, Várkonyi 1990, img. 1). 


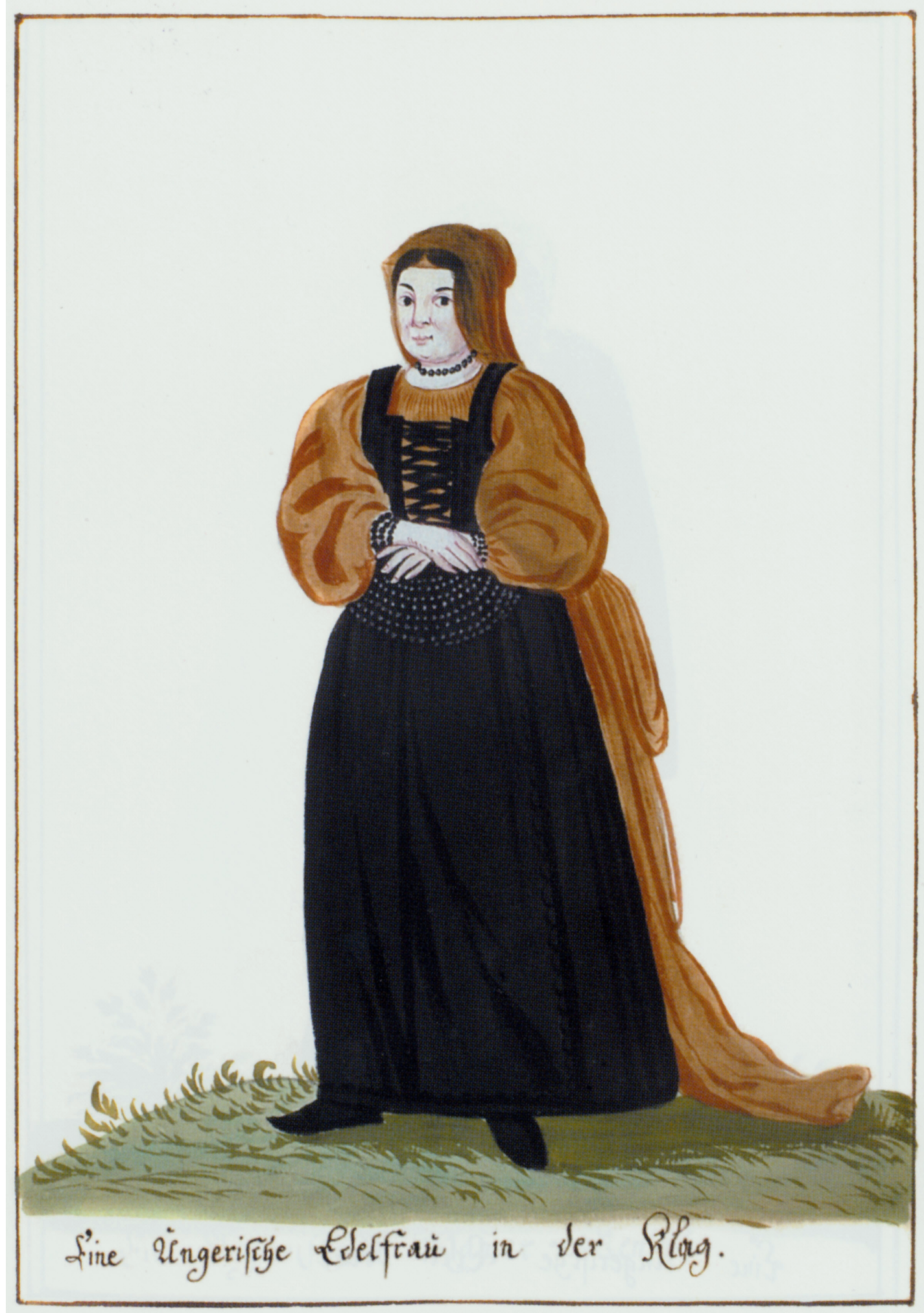

Fig. 4. Eine Ungerische Edelfrau in der Klag - Hungarian noblewoman in mourning (Oborni et alii 2009, img. VII). 

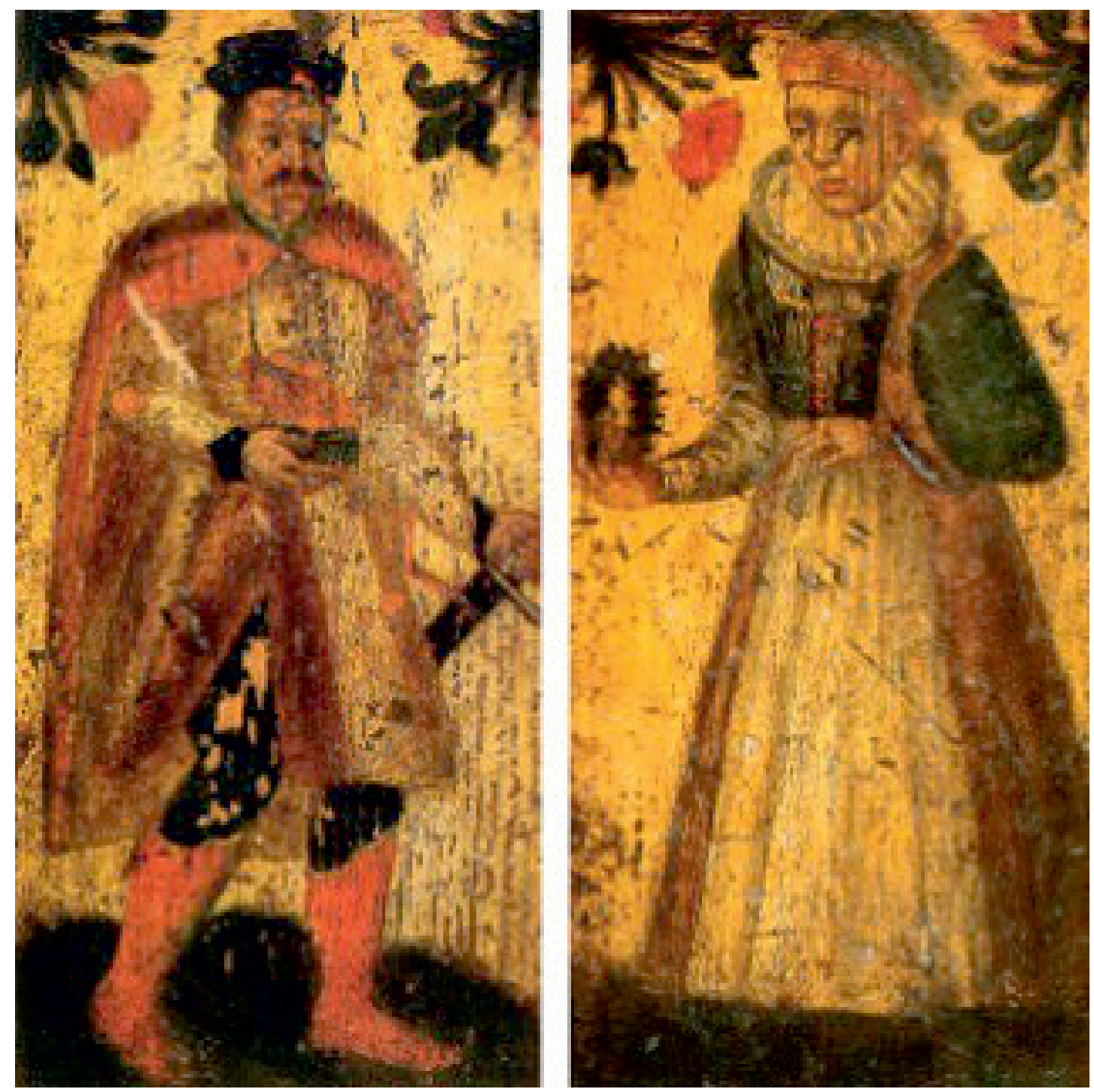

Fig. 5. Pair of bride and groom (Dowry chest, early seventeenth century, detail, Museum of Applied Arts, Budapest, Furniture Collection, Inventory no. 5363, http://gyujtemeny.imm.hu/gyujtemeny/kelengyelada-lucretia-es-cornelia-alakjaval/9699?ds=eyJxIjoia2VsZW5neWVsw6FkYSAifQ\%3D\%3D\&i=9, accessed 21 May 2021). 


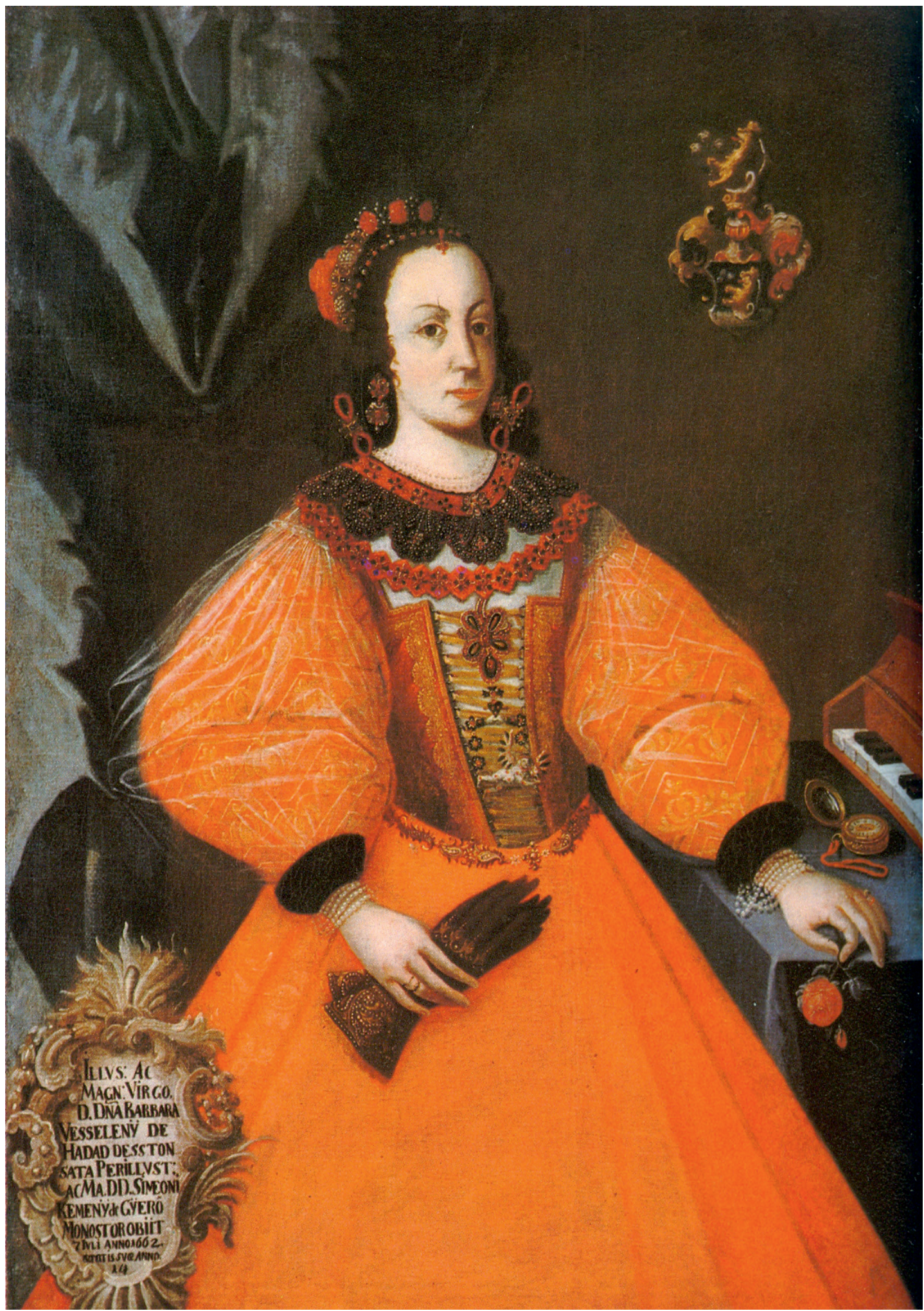

Fig. 6. Borbála Wesselényi, 1648-1662 (Historical Gallery of the Hungarian National Museum, Budapest, http://npg.hu/component/jcollection/item/757, accessed 21 May 2021). 


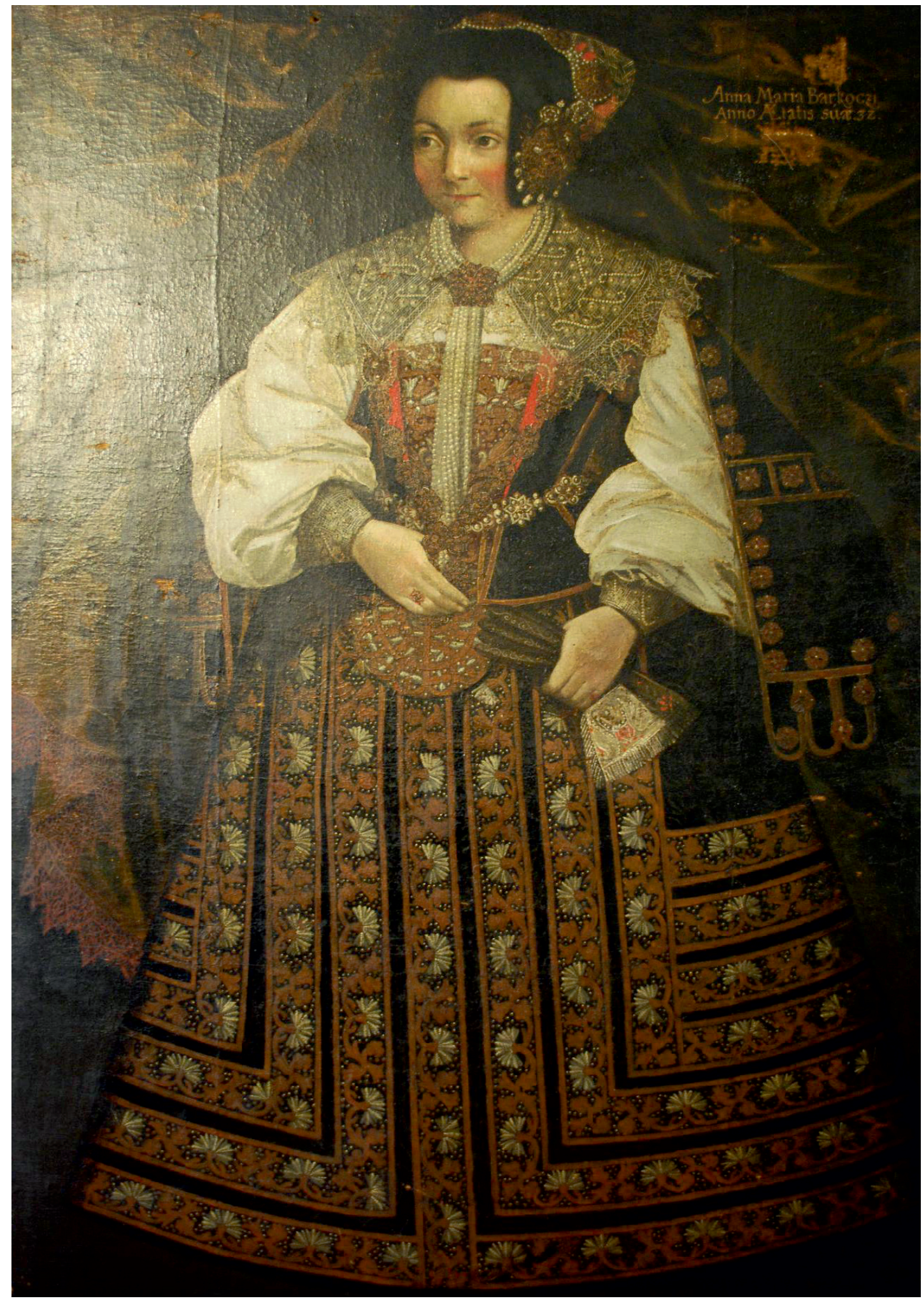

Fig. 7. Anna Mária Barkóczi, ?-1658, wife of István Haller (Private collection, on display in Haller Castle in Ogra/Marosugra/Ugern, www.npg.hu/component/jcollection/item/274, accessed 21 May 2021). 



\title{
THE CONDUCT LISTS OF HABSBURG OFFICERS AND NON-COMMISSIONED OFFICERS. SOURCES FOR THE BIOGRAPHICAL RECONSTRUCTION
}

\author{
DRAGOȘ IANC*
}

\begin{abstract}
The article explores the lists of conduct (Conduitelisten) of 25 officers and non-commissioned officers of the two Romanian border guard regiments from Transylvania to assess the potential of these documents as sources in the process of biographical and historical reconstruction. To this end, the diverse information recorded in the Conduitelisten was divided into eight categories: social background and education, military career, family, financial situation, health, temperament and behavior, knowledge, and dexterities, respectively. Given the nature of the hosted information, the Conduitelisten could open new research directions towards a social history of the military border, an aspect neglected so far by the Romanian historiography.
\end{abstract}

Keywords: Conduitelisten, Austrian militaryborder, Transylvania, officers, non-commissioned officers

Rezumat: Articolul explorează listele de conduită ale 25 de ofițeri și subofițeri ai celor două regimente de graniță din Transilvania, cu scopul de a evalua potențialul acestor documente ca surse în procesul de reconstituire istorică și biografică. În acest scop, informația înregistrată de listele de conduită a fost împărțită în opt categorii diferite: background social și educație, cariera militară, familie, situație financiară, sănătate, temperament și comportament, cunoștințe și dexterităţi. Având în vedere caracterul informațiilor, considerăm că listele de conduită pot deschide noi direcții de cercetare orientate spre o istorie socială a graniței militare din Transilvania, un aspect neglijat până acum in istoriografia românească.

Cuvinte-cheie: Conduitelisten, granița militară austriacă, Transilvania, ofițeri, subofițeri

\section{Argument}

The Romanian historical discourse regarding the officers of the border guard regiments of Transylvania has primarily focused on military events, such as acts of bravery, decorations, and periods of conflict, at the expense of the social aspect of the military service. ${ }^{1}$ A particular historiographic approach does not necessarily determine this development. It can rather be attributed to the neglect of primary sources containing valuable information for social history. Based on this observation, the following study aims to reduce the disparities between the social and the military components of the history of the border guard regiments. For this purpose, I will address the potential of the Habsburg officers' and non-commissioned officers' (NCOs') lists of conduct (i.e. die Conduitelisten) as sources in the process of historical and biographical reconstruction.

\footnotetext{
* M.A. Student, 'BabeșBolyai' University, Cluj-Napoca, email: dragosianc@gmail.com, (D) https://orcid. org/0000-0002-5375-1380.

${ }^{1}$ See, for example, Bucur, Lupea 2001.
} 
Firstly, the study offers an extensive presentation of these primary sources, including the rubrication, the information collected, and how the data itself was collected. The information recorded in the conduct lists was divided in eight categories: social background and education, military career, family, financial situation, health, temperament and behavior, knowledge, and dexterities, respectively. Simultaneously, the study follows the lists of conduct of a small cohort of 25 officers and non-commissioned officers of the two Romanian border guard regiments from Transylvania (i.e., $16^{\text {th }}$ and $17^{\text {th }}$ Border Guard Regiments), between 1824 and 1849, in order to illustrate how these sources can serve in the process of biographical reconstruction. ${ }^{2}$ Lastly, given the standardized nature of the data recording process and the numerous transcriptions encompassed in the text, the study can act, to some extent, as a glossary of terms that might prove helpful to those using this type of source in the future.

\section{The lists of conduct as biographical sources}

Through a resolution passed on the 24 December 1761, the empress Maria Theresa introduced within the Habsburg Army die Conduitelisten, emulating a Prussian model. ${ }^{3}$ Their introduction represented one of the numerous actions undertaken by the empress during the modernization process of the Habsburg army. Later, Joseph II adopted a similar evaluation form among the state's civil servants. ${ }^{4}$ The emperor valued the civil and military Conduitelisten and considered them a means to check whether the state's officials were justly serving the state. ${ }^{5}$

The military lists of conduct were compiled by the field officers of each regiment annually or biennially in October, at the end of the military year. These documents contain detailed descriptions and conduct evaluations of NCOs and officers up to the rank of captain (Hauptmann), thus without including field officers. The data was recorded in German, using Kurrentschrift. Even though they were introduced theoretically in 1761, the collection kept at Kriegsarchiv in Vienna starts from 1823. Following the military reforms of 1868, the lists of conduct were abandoned, being replaced with the more detailed Qualifications-Listen. ${ }^{6}$

The military Conduitelisten served more than one purpose. Firstly, just as the civil servants' ones, ${ }^{7}$ the officers' lists of conduct played an essential role in their promotion. ${ }^{8}$ To this end, these documents contained a separate section in which the field officers assessed whether the serviceman was fit for promotion or not. Secondly, with the help of the Conduitelisten, the military authorities were able to supervise the servicemen's conduct and observe its evolution and improvement. ${ }^{9}$ In an article published in 1845, Pannasch, then a lieutenant colonel (Oberstleutnant) in the Habsburg army, argued that the intention behind these documents was not to inflict punishment on the wrongdoer but to encourage

\footnotetext{
${ }^{2}$ AT-OeStA/KA Pers CL Grenze 498. The documents found in this box are not numbered. Thus, referencing the conduct lists will be done by mentioning the box identification code and the creation year.

${ }^{3}$ Ganser 2001, 109; Hochedlinger 2006, 19.

4 Beales 2007, 259.

${ }^{5}$ Deak 2015, 60-61; Roeder 2018, 90.

${ }^{6}$ Ganser 2001, 111.

7 Deak 2015, p. 61.

8 Fenner von Fenneberg 1847, 169-170.

${ }^{9}$ Roeder 2018, 90.
} 
him in revising his behavior. ${ }^{10}$ Finally, the lists of conduct were consulted in the event of servicemen's investigations. For instance, in September 1849, the command of the Năsăud Grenzer regiment received a letter from the military authorities in Vienna, who asked, among other documents, for the Conduitelisten of several officers, whose activity during the war was being questioned. ${ }^{11}$

Given their subjective nature, the Conduitelisten's efficiency was soon questioned. At the beginning of the nineteenth century, both army officials and senior civil servants warned about the potentially distorted information recorded by these sources. In his article, Pannasch advised his fellow field officers not to leave any room for interpretation and gave examples of how easily the data recorded could be misunderstood. ${ }^{12}$ Commenting on the civilian Conduitelisten, Ignaz Beidtel, a former civil servant, argued that a promotion system based on superiors' evaluations was arbitrary and 'made superiors into despots.'13 Historians that later made use of these sources also warned about their shortcomings. István Deák, who in his social and political history of the Habsburg officer corps used them extensively, argued that one must read the Conduitelisten critically, as superiors were sometimes inclined to excessively praise their subordinates' abilities. ${ }^{14}$ Uta Krottenthaler, who studied similar Conduitelisten, introduced in the Bavarian army in 1789, doubted their efficiency in developing an objective promotion system. ${ }^{15}$ Similarly, assessing the potential of die Conduitelisten as sources in identifying a Habsburg military mentality (i.e., habitus), Helmut Kuzmics claimed that superiors' evaluations of conduct and personality 'generate ... data ... according to multiple filters that distort the 'objective' picture of the ... person in action. ${ }^{16}$ However, despite their drawbacks, the lists of conduct have great potential in the process of biographical reconstruction, which I intend to demonstrate by taking a closer look at their content.

\section{Content of the source \\ Introductory section}

First of all, the officers' and NCOs' lists of conduct indicated their current rank (Charge) and the date of promotion. The rank is followed by the name and surname of the serviceman, written with Latin handwriting, and by the noble predicate, if applicable. If the serviceman was decorated, the decoration was usually recorded above his name. Moreover, if an officer was the commander of the regiment's Military Institute (i.e., Instituts Kommandant), this was generally registered below his name. In some cases, the military authorities signaled the promotion of officers and NCOs through a pencil mention (e.g., 'Av.', 'Avan.', 'Avanciert'), recorded at a later date. Occasionally, the retirement or the death of officers were recorded identically. For instance, the retirement of Basilius Stephany, described as incapable of doing his duty ('dienstuntauglich') in 1828, was underlined with

\footnotetext{
10 Pannasch 1845, 300.

11 Sotropa 1931a, 412.

12 Pannasch 1845, 300-301.

13 Deak 2015, 60.

14 Deak 1990, 19-21.

15 Krottenthaler 2010, 106.

${ }^{16}$ Kuzmics 2009, 287.
} 
a pencil mention (i.e., 'pensioniert') written below his name at a later date. ${ }^{17}$ Similarly, the 1832 list of conduct belonging to Johann Dodie, first lieutenant (Oberleutnant) in the Năsăud Grenzer regiment, contains a pencil note attesting to his death (i.e., 'gestorben'). Most probably, the mention dates from 1833, the year of his death. ${ }^{18}$

\section{Social background and education}

The lists of conduct recorded the year and the place of birth of the servicemen. Further information regarding the officer's previous activity or details about his father's occupation were registered under the heading 'What he was?' (i.e., Was er war?). Unfortunately, up to at least 1840 these recordings were highly standardized, meaning that most officers fell into one of the following categories: son of an officer ('Offiziers Sohn'), son of a townsman ('Bürgers Sohn'), son of a clerk ('Beamtes Sohn'), or son of a nobleman ('Edelmanns Sohn'). Only rarely, the superiors nuanced the information. An example is Anton Ittul of Felsö-Szálláspataka, an officer of the Orlat regiment listed as the son of a staff officer ('Staubsoffiziers Sohn'). ${ }^{19}$ Occasionally, in addition to the father's profession or social standing, the lists of conduct also mentioned brief information about the officers' studies. For instance, Ludwig Klokocsan of Also Venecze, officer of the two Romanian border guard regiments in Transylvania, was listed both as the son of an officer and graduate of the Wiener Neustadt Military Academy ('Offiziers Sohn und Zögling der Neustädter Akademie'). ${ }^{20}$ In contrast, Franz Aron von Bistra, was registered solely as a former student ('Student'), without any information regarding his studies or his father's social milieu. ${ }^{21}$ We learn, thanks to a secondary source, that he had studied in Blaj. ${ }^{22}$ In the case of former border guards who became officers through promotion and for whom the father's profession or condition did not fall within the categories mentioned above, they were solely listed as former border guards ('Grenzer des Regiments' or 'Conscribirter Grenzer').

Over time, the nature of the information recorded under this heading (i.e. Was er war?) evolved. From 1840 onwards, die Conduitelisten no longer recorded information about the father's occupation and social milieu but on the officers' studies or other activities carried out before entering into service. Superiors' notes include observations regarding the level of education achieved and, sometimes, the place where the officer studied. Thus, we learn that Anton Ittul de Felsö-Szálláspataka graduated the mathematics school in Caransebeș ('hat die mathematische Schule zu Caransebes absolviert'). ${ }^{23}$ The shift of focus in the data recording process is evident in the lists of conduct of Johann Runkan, an officer of both Romanian Grenzer regiments from Transylvania. While listed as the son of an officer ('Offiziers Sohn') in his 1838 Conduiteliste, the list of 1842 exclusively recorded his studies, namely his graduation from the regular school ('hat die Normalschule absolviert').$^{24}$ One also witnessed this change in the case of Johann Czerbes, an officer born in Braşov. In 1838 , he was listed as the son of a townsman ('Bürgers Sohn'). However, in 1840, the same

\footnotetext{
17 AT-OeStA/KA Pers CL Grenze 498, year 1828.

18 AT-OeStA/KA Pers CL Grenze 498, year 1832; Bichigean 1925, 65.

19 AT-OeStA/KA Pers CL Grenze 498, year 1838.

${ }^{20}$ AT-OeStA/KA Pers CL Grenze 498, year 1836.

${ }^{21}$ AT-OeStA/KA Pers CL Grenze 498, year 1836.

${ }^{22}$ Bucur 2001, 21.

23 AT-OeStA/KA Pers CL Grenze 498, year 1847.

${ }^{24}$ AT-OeStA/KA Pers CL Grenze 498, year 1838 and 1842.
} 
rubric only recorded the trade apprenticeship he completed before becoming an officer ('Handlungs Praktikant'), no longer mentioning his father's condition. ${ }^{25}$

This rubric (i.e. Was er war?) was characteristic of only the officers' Conduitelisten and, in comparison, the ones belonging to the NCOs recorded only whether they were the sons of noblemen or officers ('Edelmann oder Offiziers Sohn').

\section{Reconstruction of the military career}

In a separate section, the lists of conduct recorded all the units in which the serviceman had served, all the ranks obtained and the time - expressed in years, months, and days spent in each of them. Thus, the lists of conduct offer a high degree of accuracy in the reconstruction of a military career. Consequently, the length ('in allen') of the serviceman's career up to that moment was then calculated. If the officer or NCO had served in another state's army, this was mentioned in a different section - 'bei anderen Puisancen.' Unlike the officer's Conduiteliste, the NCO's list of conduct contains an additional heading, under which the exact date of enlisting into military service, the initial rank and the military unit in which he had initially served were registered (Wann, wo und wie assentiert). The NCOs' Conduitelisten also mentioned whether the individual had ever deserted ('Ob jemals desertierte') or if he had ever been placed under military investigation ('ob, wie und warum kriegsrechtlich behandelt'). Thus, we learn that Athanasius Motz Dimbul, ${ }^{26}$ who in 1826 was serving as a sergeant (Feldwebel) in the Năsăud border guard regiment, was placed under military investigation at one point in his career, but was found innocent ('einmal ..., ist aber unschuldig erklärt worden'). ${ }^{27}$

The military career of officers and NCOs can be further reconstructed using the information recorded under the heading Was für Kampagnen mitgemacht hat, which contains a list of all the campaigns in which the officer or NCO participated. Unfortunately, no geographical mentions were made, die Conduitelisten recording only the years in which the campaign took place.

A separate section considers the battle performance - 'in front of the enemy' (i.e., Vor dem Feind). Most entries merely mentioned the fulfillment of duty, using the same expressions repetitively (e.g. 'leistete seine Schuldigkeit, hat seine Pflicht vollkommen erfüllt'), or praised the courage shown in the face of the enemy (e.g. 'brav', 'tapfer,' 'unternehmend,' 'standhaft'). Unfortunately, given their repetitiveness and briefness, these descriptions lack any relevance to the process of historical reconstruction. However, this section's importance stems from the fact that superiors mentioned the wounds servicemen sustained as proof of their commitment. The field officers registered the number, severity, and location of the injuries suffered by their subordinates and the battles during which they occurred. For instance, one learns that Basilius Stephany, who participated in the 1813 and 1814 campaigns against France, fulfilled his duty and was wounded in the mouth in 1813 ('leistete seine Schuldigkeit vollkommen und ist 1813 durch den Mund stark blasirt worden'), ${ }^{28}$ most likely during the battle of Passo Tonale in northern Italy. ${ }^{29}$ Similarly, the

\footnotetext{
${ }^{25}$ AT-OeStA/KA Pers CL Grenze 498, year 1838 and 1840.

${ }^{26}$ Athanasius Motz Dimbul's activity was addressed in several studies: Tutula 2004; Tutula 2012; Vaida

27 AT-OeStA/KA Pers CL Grenze 498, year 1826.

28 AT-OeStA/KA Pers CL Grenze 498, year 1824.

${ }^{29}$ Klein 1867, 128.
} 2006. 
1824 list of conduct of Andreas Wartholomey, sergeant (Feldwebel) of the Năsăud Grenzer regiment, contains a detailed description of the wounds he suffered during the 1809 campaign. The NCO was wounded twice: once in his right leg and once on the left side of his chest ('hat in der Campagnie 18092 blasuren, eine in der rechten Fuß, und die 2te in der linken Brustseite erhalten').$^{30}$ Georg Szekulich's Conduitelisten also indicate the two battles during which he was wounded: at Mantua in 1797 and at Eckmühl in 1809 ('ist 1797 bei Mantua und 1809 bei Eckmühl blasirt worden'). ${ }^{31}$ The Conduitelisten of Captain Lieutenant (Capitän-Leutnant) Paul Reou attests that he sustained a severe wound through the tongue and jaw in 1796 during the battle of Arcole ('ist 1796 bei Arcole durch Zunge und Kinnladen schwer blasirt worden'). ${ }^{32}$ Moreover, Reou's presence at Arcole proves that the Năsăud Grenzer regiment participated in the famous battle, a fact recently contested. ${ }^{33}$

\section{Family}

A separate section contains information about the serviceman's family (i.e. Ledig oder verheiratet mit oder ohne Kinder). The superior officer registered the marital status of the officer or NCO (i.e., married, unmarried, or widower) and the number of children, including their gender. It was also mentioned whether the serviceman had to provide for them or not (i.e. 'versorgt' or 'unversorgt') and if any of them followed military studies. Thus, one learns that one of the sons of Georg Szekulich, captain lieutenant (Capitän-Leutnant) of the Năsăud Grenzer regiment, was attending in 1824 the courses of the renowned Military Academy in Wiener-Neustadt. ${ }^{34}$ This section also recorded whether any of the serviceman's sons were serving in the army. From the list of conduct of the Captain (Hauptmann) Basil Wellikan von Boldogmezö, one discovers that his eldest son, Wilhelm, was serving as a cadet in the same regiment ('der ältere Sohn, Wilhelm, dient als K. K. Kadet'). ${ }^{35}$ Similarly, the list of conduct of Daniel Borcocsel, an officer of the Năsăud Grenzer regiment as well, records that one of his sons was serving as Fähnrich in the line regiment no. 41 Baron Watlet ('verheiratet hat 2 Söhne und 1 Tochter, ... 1 Sohn als Fähnrich bei Baron Watlet Infanterie ...). ${ }^{36}$ In comparison, mentions regarding the serviceman's daughters are relatively scarce, and most of them concern their marriage. For instance, the 1840 list of conduct of Theodor Arsenti, first lieutenant (Oberleutnant) of the Năsăud Grenzer regiment, mentions that one of his four daughters was married. This meant that he still had to provide for the rest of them ('... nur eine Tochter durch Heirat versorgt ist'). ${ }^{37}$

The field officers also assessed whether the serviceman could take good care of his family and household (i.e., 'guter Wirth'). With rare exceptions, almost all members of our cohort were evaluated as good household heads. Sergeant (Feldwebel) Wartholomey, an exception, received a negative assessment ('Guter Wirth - nein'), most probably due to his alcohol issues. ${ }^{38}$

\footnotetext{
30 AT-OeStA/KA Pers CL Grenze 498, year 1824.

31 AT-OeStA/KA Pers CL Grenze 498, year 1824 and 1826.

32 AT-OeStA/KA Pers CL Grenze 498, year 1824.

33 Șerbănescu 2013.

${ }^{34}$ AT-OeStA/KA Pers CL Grenze 498, year 1824.

35 AT-OeStA/KA Pers CL Grenze 498, year 1834.

${ }_{36}$ AT-OeStA/KA Pers CL Grenze 498, year 1834.

37 AT-OeStA/KA Pers CL Grenze 498, year 1840.

38 AT-OeStA/KA Pers CL Grenze 498, year 1824.
} 


\section{Financial situation}

The financial situation of the officers and NCOs was an issue of concern for the military authorities as well. The lists of conduct contain a separate section (i.e., 'hat beihilfe') in which the superiors registered whether the serviceman received any allowances or had other additional income. Although most mentions are brief (e.g., 'yes' - 'ja,' 'etwas') or 'no' - 'nein, keine'), in some cases, such as that of Daniel Runkan, more details were provided. In 1828, Runkan, then a cadet of the Năsăud Grenzer regiment, was described as being provided for by his father, a retired second lieutenant ('wird von seinem Vater pensionierter Unterlieutenant unterhalten und gekleidet'). 12 years later, in 1840, his list of conduct indicates another source of income: a 'Heiratskaution' ${ }^{39}$ Most often taking the shape of a bank deposit, the marriage bond (i.e., 'die Heiratskaution') was generally a condition imposed on officers to marry. The income received from the deposit's interest represented financial support for the new family and in the case of the officer's death, it ensured a safe source of income for the widow. ${ }^{40}$ Regarding Johann Czerbes, whose earlier commercial activity was mentioned above, one discovers that in 1841 he was receiving interest from a deposit of 400 florins in Viennese currency ('Kautions Interessen 400 f. W.W.). ${ }^{41}$

The superiors were also supposed to record whether the officer was indebted (i.e., 'Schuldenmacher'). These observations are, however, rarely encountered. Among the servicemen of our cohort, I came across such mentions in the cases of Andreas von Illiesy and Georg Peicsich, both of them officers of the Năsăud Grenzer regiment. Illiesy's 1840 list of conduct recorded that he was still dealing with the debts he had accumulated ('ist noch mit Schulden belastet') ${ }^{42}$ In comparison, in the case of Peicsich, the superiors mentioned that he had been able to pay off part of his debts ('hat zum Teil seine Schulden berichtigt').43

\section{State of health}

Information on the health of officers and NCOs was recorded in a separate section entitled: Gesundheitsumstände. The superiors recorded various information, such as diseases the officers went through, physical characteristics, the injuries suffered in battle or as a result of accidents, or even the treatments some of them undertook. In 1836, the list of conduct of Gabriel Leo, an officer of the Năsăud Grenzer regiment, recorded severe health problems, which brought him close to disability ('nähert sich der Invalidität'). Leo was suffering from a form of foot ulcer ('leidet an veralteten Fußgeschwüren'). ${ }^{44}$ His illness proved most likely fatal, as he died the same year. ${ }^{45}$ Gabriel Wararan was suffering in 1838 from an ulcer as well, located, in his case, in the rectum. Interestingly, his list of conduct recorded that he underwent a surgery ('war in diesem Jahr jedoch an einem Mastdarm Geschwür operiert'), thanks to which he recovered completely ('dermalen vollkommen geheilt'). Moreover, his 1840 list of conduct no longer recorded any health issues, mentioning that he was in good health ('gute Gesundheit'). ${ }^{46}$ In other cases, the superiors drafting the

\footnotetext{
${ }^{39}$ AT-OeStA/KA Pers CL Grenze 498, year 1828 and 1840.

40 Berger 2010, 22.

41 AT-OeStA/KA Pers CL Grenze 498, year 1841.

42 AT-OeStA/KA Pers CL Grenze 498, year 1840.

43 AT-OeStA/KA Pers CL Grenze 498, year 1838.

${ }^{44}$ AT-OeStA/KA Pers CL Grenze 498, year 1836.

45 Barițiu 1874, 108.

${ }^{46}$ AT-OeStA/KA Pers CL Grenze 498, year 1838 and 1840.
} 
lists of conduct did not name the illnesses servicemen had. For instance, about Anton Ittul of Felsö-Szálláspataka, an officer of the Orlat Grenzer regiment, one only learns that in the course of 1847 he was often ill ('war im Laufe dieses Jahres viel krank'). ${ }^{47}$

In August 1836, the territory of the Năsăud border guard regiment experienced an outbreak of cholera. ${ }^{48}$ From the lists of conduct drafted in October 1836, one can observe the epidemic's impact on the regiment's officer corps. Die Conduitelisten of Theodor Arsente and Theodor Constantin Piorasch, drafted in October, recorded that they had fallen ill with the disease six weeks before ('seit sechs Wochen an der Brechruhr krank'). ${ }^{49}$

In addition to information about servicemen's health conditions, the conduct lists also recorded descriptions of their physiques. For instance, Athanasius Motz Dimbul was described as having a robust constitution ('von großen robusten Körperbau'), ${ }^{50}$ while Daniel Runkan was depicted as having a strong physique ('von kräftigem Körperbau'). ${ }^{51}$ On the other hand, superiors also drew attention to servicemen's weight problems. For example, Johann Czerbes' lists of conduct from 1840 and 1841 repeatedly highlighted the fact that he was overweight ('Gesundheitsumstände - gute, jedoch corpulent'). ${ }^{52}$ Similarly, Andreas von Illiesy's weight issues were first reported in his 1828 list of conduct ('Gesundheit - gute, wird aber zu dick') ${ }^{53} 12$ years later, however, they seem to have worsened. The superior officer reported in 1840 that Illiesy had been ill for a year and a half, suffering from obesity and a disease of the urethra ('seit anderthalb Jahren krank, mit Fettleibigkeit, und Krankheit der Harnröhre behaftet') ${ }^{54}$ For other servicemen, the lists of conduct mentioned even the cause of their health problems. For instance, Georg Markusch's shaking hands were thought to be caused by his drinking habits ('starkes Zittern der Hände, folgen des Trunkes'). ${ }^{55}$

Occasionally, the field officers drafting the lists of conduct made references to servicemen's past wounds. For example, the health status of Reou Paul, whose mouth wound suffered at Arcole was mentioned earlier, was assessed as good, despite his severe injury ('gute, ungeachtet seiner schweren Blasur') ${ }^{56}$ Carl Justy was another officer whose wounds were mentioned by his superior officer. In 1836, the field officer indicated the presence of a sword cut ('Säbelhieb'). However, in contrast to Reou, Justy was wounded during peacetime after taking part in a duel ('Rencontre'). ${ }^{57}$

These examples confirm the high potential of the lists of conduct as sources in the process of biographical reconstruction and, especially, in monitoring health evolution - an aspect that most sources of the era fail to capture. Their regularity allows us to observe the subject's health evolution over a more extended time (in some cases, even decades). Thus, the lists of conduct should not only be considered as sources of military or social history, but also as sources of medical history.

\footnotetext{
47 AT-OeStA/KA Pers CL Grenze 498, year 1847.

48 Ziarul 1936, 244.

49 AT-OeStA/KA Pers CL Grenze 498, year 1836.

${ }^{50}$ AT-OeStA/KA Pers CL Grenze 498, year 1840.

${ }^{51}$ AT-OeStA/KA Pers CL Grenze 498, year 1840.

52 AT-OeStA/KA Pers CL Grenze 498, year 1840 and 1841.

53 AT-OeStA/KA Pers CL Grenze 498, year 1828.

${ }^{54}$ AT-OeStA/KA Pers CL Grenze 498, year 1840.

55 AT-OeStA/KA Pers CL Grenze 498, year 1826.

${ }_{56}$ AT-OeStA/KA Pers CL Grenze 498, year 1824.

57 AT-OeStA/KA Pers CL Grenze 498, year 1836.
} 


\section{Temperament and behavior}

The superiors drafting the lists of conduct assessed the temperament and behavior of the officers and NCOs. A separate section titled state of mind (Gemütsbeschaffenheit) contained brief observations concerning their character. In 1834, two years before engaging in the duel mentioned above, Carl Justy's superior officer described him as cheerful ('heiter'), but lacking maturity of judgment ('aber nicht mit reifer Überlegung'). ${ }^{58}$ This observation was later maintained as Justy's 1836 Conduiteliste portrayed him as imprudent ('unüberlegt'). ${ }^{59}$ Paul Reou was generally silent but also irascible ('stille, aber jähzornig'). ${ }^{60}$ Another officer of the Năsăud Grenzer regiment, Leo Popp, was described in 1824 as ambitious, but also irascible ('ehrgeizig und auffahrend') ${ }^{61}$ His superior officer's assessment proved correct, as 24 years later, in 1848, Popp was promoted to the rank of field officer. ${ }^{62}$ In most cases, the conduct lists recorded positive attributes of the servicemen and very rarely negative ones. Theodor Piorasch, first lieutenant (Oberleutnant) of the Năsăud regiment, was described in 1838 as serious and modest ('ernst und bescheiden') and Franz Aron von Bistra, officer of the Orlat regiment, as quiet and calm ('still und gelassen'). ${ }^{63}$ Without additional sources, these very concise descriptions cannot tell as much about the officers' personalities and, as Lieutenant Colonel (Oberstleutnant) Pannasch ironically suggested in 1845, they do not differ much from the descriptions of horses' temperament. ${ }^{64}$

The superior officer also assessed the behavior of his subordinates concerning civilians ('mit den Zivilen'), subordinates ('mit Untergebenen'), and in the regiment ('im Regiment'). The vast majority of entries acknowledge a positive conduct. However, one comes across a few exceptions. Carl Justy's superior noted that the officer revised his behavior towards civilians, becoming decent ('dermalen anständig') ${ }^{65}$ In relation to his subordinates, however, Justy still behaved sometimes discretionarily and arbitrarily ('manchmal eigenmächtig und willkürlich'). ${ }^{66}$ Georg Markusch's bad attitude towards his subordinates was also pointed out, his list of conduct revealing that the NCO was mean to them ('mit Untergebenen gemein'). ${ }^{67}$ On the other hand, some servicemen were believed to be too lenient. This was the case of Andreas von Illiesy, whose behavior towards his subordinates was considered humane but sometimes too lenient ('human aber manchmal zu nachsichtig'). ${ }^{68}$

The superior drafting the lists of conduct was also supposed to report servicemen's behavioral misconducts and vices. While in the case of NCOs' lists of behaviors, these were included in a single section (i.e., Fehlern unterworfen), the officers' Conduitelisten were much more detailed, containing no less than five different sections: alcoholism

\footnotetext{
${ }_{58}$ AT-OeStA/KA Pers CL Grenze 498, year 1834.

59 AT-OeStA/KA Pers CL Grenze 498, year 1836.

60 AT-OeStA/KA Pers CL Grenze 498, year 1824.

${ }^{61}$ AT-OeStA/KA Pers CL Grenze 498, year 1824.

62 Șotropa 1931b, 457.

63 AT-OeStA/KA Pers CL Grenze 498, year 1838.

${ }^{64}$ Pannasch 1845, 299.

65 AT-OeStA/KA Pers CL Grenze 498, year 1836.

${ }_{66}$ AT-OeStA/KA Pers CL Grenze 498, year 1836.

${ }^{67}$ AT-OeStA/KA Pers CL Grenze 498, year 1828.

68 AT-OeStA/KA Pers CL Grenze 498, year 1838.
} 
('dem Trunk ergeben'), gambling ('Spieler'), debtor ('Schuldenmacher'), quarrelsome ('Zünder'), and selfishness ('Eigennützig'). As opposed to the other vices, mentions about alcohol consumption are much more often encountered. For instance, Sergeant (Feldwebel) Georg Markusch's conduct lists repeatedly recorded that he was a drinker ('Fehlern unterworfen - dem Trunk). ${ }^{69}$ Similarly, Andreas Wartholomey's superior officer indicated that he was quarrelsome and had a problem with alcohol consumption ('Fehlern unterworfen - zänkisch und dem Trunk ergeben'). ${ }^{70}$ Concerning Johann Raglan, an Orlat border guard regiment officer, one learns that he drank only occasionally ('Trinkt bisweilen'). ${ }^{71}$ As already mentioned in the introduction, one of the intentions behind the Conduitelisten was to monitor the serviceman's behavior and encourage its improvement. A relevant example is that of Sergeant (Feldwebel) Peter Dragomir, whose superior officer acknowledged in 1841 that he stopped drinking ('hat vom Trinken nachgelassen'). ${ }^{72}$ As I have noticed above, comments regarding servicemen's vices or faults in their behavior are relatively scarce. Helmut Kuzmics hypothesized that the field officers refrained from negative mentions in the Conduitelisten, not to negatively influence their subordinates' career prospects. ${ }^{73}$ This hypothesis is, however, challenging to demonstrate. Moreover, an example presented by Tobias Roeder, proves the contrary. In 1781, Anton Hessen, an officer of the Wallachia-Illyria Grenzer regiment, was classified as drinker, gambler, and quarreler. However, the superior officers who drafted his list of conduct also decided to send a supplication to the Hofkriegsrat, praising Hessen's activity during the last war and asking the military authorities not to sanction him. ${ }^{74}$

The field officers also judged whether the servicemen demonstrated zeal or fervor while serving (Eifer und Application). Given their brief and highly standardized nature (e.g., 'Ja,' 'Nein,' 'wenig'), these entries fail to provide the readers with clues about how eagerly the officers were accomplishing their tasks.

The heading Sonst im Dienst included further information concerning the serviceman's overall service. In most cases, superiors briefly noted general aspects of the conduct of officers or NCOs. For instance, Ludwig Klokocsan was described as punctual and reliable ('pünktlich und verlässlich'), while Andreas von Illiesy was listed as zealous and fit for service ('eifrig und brauchbar'). Two years later, however, Illiesy fell ill and his superior recorded that, due to his illness, he was no longer fit for service ('war bis zu seiner Krankheit brauchbar'). ${ }^{75}$

In the final part of the Conduiteliste, under the heading Verdient das Avancement, the field officer assessed whether the officer or the NCO deserved a promotion (e.g. 'Ja,' 'Allerdings') or not (e.g., 'nein'). Occasionally, the entries also contained suggestions regarding the order in which the officers should be promoted. For instance, Second Lieutenant (Unterleutnant) Leo Popp's superior believed that Popp deserved a promotion before his older fellow officer Basilius Stephany due to his impeccable performance

\footnotetext{
${ }_{69}$ AT-OeStA/KA Pers CL Grenze 498, year 1826 and 1828.

70 AT-OeStA/KA Pers CL Grenze 498, year 1824.

${ }^{71}$ AT-OeStA/KA Pers CL Grenze 498, year 1832.

${ }^{72}$ AT-OeStA/KA Pers CL Grenze 498, year 1841.

${ }^{73}$ Kuzmics 2009, 284.

${ }^{74}$ Roeder 2018, 90-91.

${ }^{75}$ AT-OeStA/KA Pers CL Grenze 498, year 1840.
} 
('Verdient das Avancement - vor seinem Vordermann Basilius Stephany'). ${ }^{76}$ Less than a year later, Popp was promoted to first lieutenant (Oberleutnant), while Stephany was still a second lieutenant (Unterleutnant), a rank he held until his death in $1829 .{ }^{77}$ Over the following years, Popp continued to enjoy positive assessments. In 1840, then a captain (Hauptmann), Popp was characterized as having all the qualities necessary for being promoted to the rank of field officer. However, he would have to wait eight more years before being named a major of the Năsăud Grenzer regiment. ${ }^{78}$

\section{Knowledge}

First of all, the field officers recorded in the Conduitelisten their subordinates' knowledge of languages. Under the heading Redet Sprachen, all languages spoken by the officers and NCOs, including their level of expertise, were recorded. Unfortunately, the standardized way of registering information makes it difficult to assess the actual knowledge of the language. In most cases, the superiors assessed either a 'good' level of language (e.g. 'Deutsch und Walachisch gut'), or a lower one, attested by the term 'some' ('etwas'), both terms having a high degree of ambiguity. An intermediate level of language (i.e. 'mittelmässig') was very rarely recorded.

Not surprisingly, all the officers of the two border regiments spoke good German. In addition to German, servicemen's language skills reflect, to some extent, their social and educational background. Ludwig Klokocsán of Also Venece studied, as I have already mentioned, at Wiener Neustadt, where he was accepted as a result of his father's sacrifice at the Battle of Arcole. ${ }^{79}$ The fact that he benefited from higher education is confirmed by his Conduitelisten, which in 1834 mentioned no less than six spoken languages. A real polyglot, Klokocsán spoke good German and Romanian and had knowledge of Latin, Hungarian, Polish and French ('Deutsch und Walachisch gut, Latein, Ungarisch, Polnisch und Franzözisch etwas'). ${ }^{80}$ Over time, however, his language skills diminished. Thus, six years later, in 1840, his superior registered only his command of German, Romanian and French ('Deutsch und Walachisch gut, Franzözisch etwas'). ${ }^{81}$ One encounters such transformation in the case of other officers as well. For instance, Von Illiesy's 1836 and 1838 Conduitelisten recorded that he spoke an intermediate level of Latin ('Latein mittelmässig'). Two years later, however, his 1840 list of conduct no longer mentioned any knowledge of Latin. ${ }^{82}$ On the other hand, some officers managed to improve their language capabilities. In 1830, after serving for more than 23 years in the Năsăud Grenzer regiment, Carl Justy's Romanian was assessed only as intermediate ('Walachisch mittelmässig'). From 1832 onwards, however, he appears to have improved his Romanian language skills ('Walachisch gut'). ${ }^{83}$ Unlike officers' Conduitelisten, which focused solely on the conversational skills (i.e. 'redet sprachen'), the NCOs' lists of conduct contained an additional section in which field officers assessed their reading and writing skills (i.e. 'kann lesen und schreiben'). Thus, one

\footnotetext{
76 AT-OeStA/KA Pers CL Grenze 498, year 1824.

77 Şotropa 1936, 15.

78 Șotropa 1931b, 457.

79 Klein 1867, 107.

80 AT-OeStA/KA Pers CL Grenze 498, year 1834.

${ }^{81}$ AT-OeStA/KA Pers CL Grenze 498, year 1840.

82 AT-OeStA/KA Pers CL Grenze 498, year 1836, 1838, and 1840.

${ }^{83}$ AT-OeStA/KA Pers CL Grenze 498, year 1830 and 1832.
} 
learns that Andreas Wartholomey, who spoke German and Romanian well ('Redet Sprachen - Deutsch und Walachisch gut'), could also read and write clearly and orthographically in both languages ('Kann lesen und schreiben - In beiden Sprachen geläufig, deutlich und ziemlich orthographisch'). ${ }^{84}$ The trembling of Sergeant (Feldwebel) Georg Markusch undoubtedly affected his ability to write. This did not go unnoticed by his superiors, who in 1828 noted that due to the tremor, he was writing very slowly (Kann lesen und schreiben - Deutsch und Walachisch gut, jedoch des zitternwegen sehr langsam) ${ }^{85}$

In addition to the linguistic competencies, the Conduitelisten also mention servicemen's other knowledge and interests. The most important one was engineering expertise, which was registered under a separate heading (Kenntniße - im Geniewesen). For instance, Ludwig Klokocsán of Also Venece knew to build fortifications ('Feldfortification'), knowledge he probably acquired during his studies. ${ }^{86}$ Another officer whose engineering knowledge was mentioned was Carl Justy, his superior attesting his knowledge of geometry ${ }^{87}$ The knowledge of other sciences, arts, and trades was recorded in a separate section (i.e. Kenntniße - in anderen Wissenschaften, Künsten und Professionen). In addition to the engineering expertise mentioned above, Klokocsan also knew mathematics, military drawing, and cartography ('Mathematik, militär Zeichnung, ... Mappeur'). Moreover, his 1828 Conduiteliste also listed knowledge of history and geography ('Geographie und Geschichte'). By 1840, however, the list shortened, the Conduiteliste only listing his knowledge of drawing, history, and geography ('Zeichnen, Geographie und Geschichte'). ${ }^{88}$ About Franz Aron von Bistra, the officer who studied at Blaj, one learns that he had knowledge of history and geography and that he was interested in military literature ('Geschichte, Geographie und militär Literatur'). ${ }^{89}$

\section{Dexterities}

The field officers assessed the dexterities (Geschicklichkeit) of the officers and NCOs in carrying out military-specific activities: during exercises ('im Exerzieren'), in wearing of the uniform ('im Adjustieren'), and regarding their drilling skills ('im Dressieren'). Most of the entries are brief, rating the officers' dexterities either as 'good' ('gut') or 'average' ('mittelmäßig'). There are, however, few exceptions. The superior abilities of some servicemen, such as Leo Popp, were constantly evaluated as excellent (e.g., 'vorzüglich, geschickt, vollkommen').$^{90}$ On the other hand, some officers' bad health hindered their abilities to exercise. In 1834, after a career of over 38 years, Mathias Motz von Thurnthal's health was in a bad state due to his age and long career ('durch lange Dienstzeit und Alter geschwächt'). Although he could not exercise anymore, his superior officer acknowledged that he was still mastering the theoretical aspect of the exercises ('im Exerzieren theoretisch gut, im praktischen etwas verlegen'). ${ }^{91}$

\footnotetext{
${ }^{84}$ AT-OeStA/KA Pers CL Grenze 498, year 1824.

${ }^{85}$ AT-OeStA/KA Pers CL Grenze 498, year 1828.

86 AT-OeStA/KA Pers CL Grenze 498, year 1838.

87 AT-OeStA/KA Pers CL Grenze 498, year 1832.

${ }^{88}$ AT-OeStA/KA Pers CL Grenze 498, year 1828 and 1840.

${ }^{89}$ AT-OeStA/KA Pers CL Grenze 498, year 1830.

${ }^{90}$ AT-OeStA/KA Pers CL Grenze 498, year 1824 and 1838.

${ }^{91}$ AT-OeStA/KA Pers CL Grenze 498, year 1834.
} 
The officers' Conduitelisten also recorded, under the heading 'Rider' (Reiter), whether the officers were able to ride a horse. Most of them, except those suffering from health problems, were judged as fit to ride. For instance, Gabriel Leo's 1836 Conduiteliste attested that he could no longer ride due to his illness ('dermalen nicht mehr') ${ }^{92}$ Under a separate heading (Pferdkenner) the field officers drafting the lists of conduct were supposed to record whether the officers had any knowledge of hippology. Since our cohort comprises only infantry officers, mentions attesting this type of knowledge are very rare. Franz Aron von Bistra is, however, an exception. His superior officer recorded that he had expertise with horses, most probably acquired during the time he served as an officer of a cavalry regiment (i.e. $3^{\text {rd }}$ Uhlanen). ${ }^{93}$

\section{Conclusions}

The Conduiteliste is only one of the relatively numerous categories of sources developed since the second half of the eighteenth century, during the modernization process of the Habsburg army and, consequently, of the Habsburg state. ${ }^{94}$ Our study aimed at demonstrating their high potential in the reconstruction of the biographies and careers of the servicemen and, therefore, in the prosopographic analysis of the Habsburg officer corps. Covering numerous aspects such as social background, education, military career, family, financial situation, health, temperament, behavior, knowledge, and dexterities they allow the reconstruction of a much more comprehensive biographical profile than most sources of the period. Moreover, their regularity allows us to identify the changes and transformations the officers went through throughout their lives, a feature rarely encountered in the case of other categories of sources, excepting situations (mostly in the case of aristocratic elites) in which massive corpora of private correspondence or other ego-documents were kept. Finally, at least in the case of Romanian historiography, the Conduitelisten allow the completion or revision of existing officers' biographies.

Thus, the Conduitelisten open new research directions towards a history at the intersection between the military history and the social one. Reaching their full potential would, therefore, require more in-depth research, both through an analysis focusing exclusively on them and through the lens of the broader documentary and historical context of the military archives concerning Transylvania in the early modern period.

\footnotetext{
${ }_{92}$ AT-OeStA/KA Pers CL Grenze 498, year 1836.

93 AT-OeStA/KA Pers CL Grenze 498, year 1830.

${ }^{94}$ A synthetic presentation of these sources and an attempt to organize them in a database, Hirsch et alii 2019.
} 


\section{Bibliography}

\section{Primary sources}

AT-OeStA/KA Pers CL Grenze 498 Österreichisches Staatsarchiv. Kriegsarchiv, Vienna, Personalunterlagen, Conduitelisten, Individualbeschreibungen, Grenze 498, Grenzinfanterieregiment Nr. 16 (1824-1849), Grenzinfanterieregiment Nr. 17 (1824-1840).

Ziarul 1936

Ziarul grănicerului Vasile Crăciun din Nepos, Arhiva Someșană, 20 (1936), 233-254.

\section{Secondary sources}

Barițiu 1874

Beales 2007

G. Barițiu, Istoria Regimentului alu II Romanescu Granițiariu Transilvanu, Brașov 1874.

D. Beales, Joseph II, petitions and the public sphere. In: H. Scott, B. Simms (eds.), Cultures of Power in Europe during the Long Eighteenth, New York 2007, 249-268.

Berger 2010

E. Berger, Die Versorgung der Offizierswitwen der k.(u.)k. Armee und ihre Darlegung in militärischen Zeitschriften (1867-1914), Diplomarbeit, Universität Wien, Wien 2010.

Bichigean 1925

Bucur, Lupea 2001

V. Bichigean, Poëmation de secunda legione Valachica, Arhiva Someșană, 3 (1925), 39-65.

A. Bucur, C. Lupea, Ofițerii români din regimentul 1 grăniceresc român de la Orlat, Sibiu 2001.

Deak 1990

I. Deak, Beyond Nationalism: A Social and Political History of the Habsburg Officer Corps, 1848-1918, New York 1990.

Deak 2015

J. Deak, Forging a Multinational State: State Making in Imperial Austria from the Enlightenment to the First World War, Stanford 2015.

Fenner von Fenneberg 1847

F. D. Fenner von Fenneberg, Oesterreich und seine Armee, Leipzig 1847.

Ganser 2001

R. Ganser, Qualifikationslisten für Offiziere im Kriegsarchiv Wien 1823-1918, MÖStA, 49 (2001), 109-115.

Hirsch et alii 2019

S. Hirsch, C. Horváth, A. Lumezeanu, V. Popovici, Digital Framework for the History of the Austrian Military Border in Transylvania, SUBB Digitalia, 64/2 (Dec. 2019), http://www. studia.ubbcluj.ro/download/pdf/1327.pdf, accessed 27 July 2021.

Hochedlinger 2006

M. Hochedlinger, Des Kaisers Generale: Bibliographische und quellenkundliche Anmerkungen zur Erforschung militärischer Eliten in der frühneuzeitlichen Habsburgermonarchie, Wien 2006.

Klein 1867

K. Klein, Istoria de arme a Regimentului cezaro-crăiesc grăniceresc de infanterie nr. 17 național român transilvănean. In: A. Onofreiu, I. Bolovan (eds.), Contribuții documentare privind istoria regimentului grăniceresc năsăudean, Cluj-Napoca 2012, 47-251. 
Krottenthaler

Kuzmics 2009

Pannasch 1845

Roeder 2018

Șerbănescu 2013

Șotropa 1931a

Șotropa 1931 b

Șotropa 1936

Tutula 2004

Tutula 2012

Vaida 2006
U. Krottenthaler, Eine militärische Elite zwischen Stagnation und Wandel: Die bayerische Generalität im Übergang von der Frühen Neuzeit zur Moderne am Beispiel ihres Karriereverlaufs, Militär und Gesellschaft in der frühen Neuzeit, 14/1 (2010), 85-126.

H. Kuzmics, Concept for validating the theoretical potential of historical sources: the case of analyzing long-term changes in the Habsburg military habitus, HSR, 34/1 (2009), 270-304.

A. Pannasch, Über Verfassung de Conduitelisten im Allgemeinen, Allgemeine Militär-Zeitung, 38 (1845), 298-302.

T. Roeder, Professionalism and Training of Army Officers in Britain and the Habsburg Monarchy, 1740-90, MCU Journal, 9/1 (Spring 2018), 74-96.

H. Șerbănescu, Au luptat grănicerii năsăudeni împotriva trupelor franceze conduse de Napoleon Bonaparte, în faimoasa bătălie la Arcole, din 15-17 noiembrie 1796, In: O. M. Glodarenco (ed.), Muzeul Militar Național "Regele Ferdinand I" - 90 De Ani în Slujba Istoriografiei și Muzeografiei Militare. 1923-2013, București 2013, 76-95.

V. Șotropa, Păţaniile Batalionului I năsăudean în 1848-49, Arhiva Someșană, 14 (1931), 379-416.

V. Șotropa, Soarta Maiorului Leon Pop, Arhiva Someșană, 14 (1931), 457-486.

V. Șotropa, Năsăudul de altă dată, Arhiva Someșană, 19 (1936), $1-39$.

V. Tutula, Eroul de la 1848/1849: Atanasie Moț Dâmbul, Virtus Romana Rediviva, 8 (2004), 118-121.

V. Tutula, Atanasie Moț Dâmbu - apărător ferm al Revoluției de la 1848-1849 din nord-vestul Transilvaniei, Arhiva Someșană. Seria III, 11 (2012), 21-31.

A. Vaida, Atanasie Başotă Moț Dâmbul. Tribunul de la Zagra, Baia-Mare 2006. 



\title{
FROM BIRTH TO DEATH. ASPECTS OF POPULATION DYNAMICS IN DĂMĂCUȘENI VILLAGE (1765-1918)
}

\author{
EDUÁRD SEBÖK
}

\begin{abstract}
This study attempts to provide a demographic perspective on the population of Dămăcușeni village between 1765 and 1918. It concerns an insular community, entirely Hungarian, of Reformed (Calvinist) confession, located near Târgu Lăpuș, which has preserved its ethnic and confessional profile in time.

The main studied demographic phenomena are natality, nuptiality, divortiality, and mortality. Research relies on two main sources, namely the archive documents and the censuses carried out by the Habsburg Empire (that had become the Austro-Hungarian Empire) between 1850 and 1910. Based on them, we analyzed the evolution of that population during the specified period, thus revealing the demographic analogies and particularities of that community. The data were displayed in a series of charts and tables meant to draw the readers' attention and facilitate their understanding.
\end{abstract}

Keywords: Transylvania, population, natality, mortality, epidemic waves.

Rezumat: Acest studiu își propune să ofere cititorului o perspectivă demografică asupra populației din satul Dămăcușeni, în perioada 1765-1918. Este vorba despre o comunitate insulară, eminamente maghiară, de confesiune reformată (calvină), situată în proximitatea Târgu Lăpușului, care și-a păstrat profilul etnic și confesional de-a lungul secolelor.

Principalele fenomene demografice surprinse au fost natalitatea, nupțialitatea, divorțialitatea și mortalitatea. Cercetarea s-a fundamentat pe două surse principale și anume: documentele de arhivă și recensămintele realizate de Imperiul Habsburgic (devenit Austro-Ungar) în perioada 1850-1910. Pe baza acestora, am analizat evoluția populației în perioada amintită, evidențiind analogiile și particularitățile demografice ale acestei comunități. Datele au fost valorificate de o serie de grafice și tabele cu menirea de a atrage atenția cititorului și de a facilita urmărirea acestora.

Cuvinte cheie: Transilvania, populație, natalitate, mortalitate, valuri de epidemii.

\section{Introduction}

Dămăcușeni village (in Hungarian: Domokos) is located in Suciu Valley, in a hilly area approximately $3 \mathrm{~km}$ from Târgu Lăpuș town, ${ }^{1}$ in the northern part of Transylvania. Dămăcușeni village was documentary attested in the Middle Ages and took its name from its founder, Domokos, the outlaw from Chioar, who settled down in that area. ${ }^{2}$ From an ethnic point of view, the population of Dămăcușeni village was predominantly Hungarian, and there were also some Jews and Romanians. The first mentions of the parish date

\footnotetext{
M.A. Student, 'Babeș-Bolyai' University, Cluj-Napoca, email: sebok_eduard@yahoo.com, https://orcid.org/0000-0002-5421-8211.

Ștef 2016, 98.

${ }^{2}$ Kádár 1900, 357.
} 
back to $1643 .^{3}$ The church was raised before the Reformation, ${ }^{4}$ and documents refer to it throughout the Middle Ages, according to historian Géza Entz. ${ }^{5}$ The population data we have is related to the period around 1553. According to them, the community consisted of 11 serfs and 8 poor inhabitants. ${ }^{6}$

After almost a century, more precisely in 1637 , the village population visibly increased, as it numbered 101 serfs and their families living in 42 houses. ${ }^{7}$ Their number dropped drastically around 1703 when only 5 serfs and 2 other inhabitants were registered. ${ }^{8}$ This significant population reduction was probably caused by the Polish attacks on the Târgu Lăpuş region in the summer of 1657. Dămăcușeni village was also affected. ${ }^{9}$

In 1661, János Kemény, prince of Transylvania, who was pursued by the Turkish-Tatar troops of Ali Pasha, passed through Dămăcușeni, a fact that led to the complete destruction of the village and the church. ${ }^{10}$ Despite all this, according to tradition, the community members survived thanks to Jókus, the village priest at that time. He was informed of the approaching invaders and ordered the evacuation of the village. ${ }^{11}$ Thus, the priest and the villagers hid in a forest. There they had taken the parish assets and stayed alive. ${ }^{12}$

The area around Târgu Lăpuş was also affected in 1662 by a part of the army led by János Kemény, in retreat after the defeat suffered in Seleușul Mare on 23 January. ${ }^{13}$ After this, population decline followed a new gradual increase, so that in 1750, 19 serfs were mentioned. ${ }^{14}$ The first parish registers, written witnesses of population registration, date from 1765 . They contain details referring to natality, nuptiality, mortality, and beginning with 1831 , to confirmation.

During the analyzed period, Dămăcușeni village, like the other villages in Transylvania, went through a few crises. These dramatic events had a profound impact on population movement. The first crisis, leading to increased mortality, occurred in 18161817 because of the famine during those years, caused by unfavorable climate conditions and the corresponding meager harvests. ${ }^{15}$

The next historical event marking the population from a demographic point of view was the Revolution of 1848 , in which 2 persons lost their lives. ${ }^{16}$

An episodic crisis factor was the epidemics of cholera, smallpox, diphtheria, etc., affecting the community during the nineteenth century. For example, in the period before the First World War, Dămăcușeni village was haunted by various diseases and epidemics

\footnotetext{
${ }^{3}$ Nagybányai Hírlap 1910, 5.

${ }^{4}$ Kádár 1900, 360.

${ }^{5}$ Entz 1943, 4.

6 Kádár 1900, 364.

7 Kádár 1900, 364.

8 Kádár 1900, 364.

9 Kádár 1900, 357.

10 Kádár 1900, 360.

11 Kádár 1900, 360.

12 Kádár 1900, 360.

13 Kádár 1900, 358.

14 Kádár 1900, 364.

15 Bolovan 2007, 230.

${ }^{16}$ SJM AN, Matricole Confesionale, file 486, fol. 144 r.
} 
like cholera in 1873 , sore throat ${ }^{17}(1877-1878)$, pulmonary diseases (1891), smallpox, and diphtheria (1894).

A last critical moment included in this study was the Great War that enrolled many men for the front. All these aspects have marked population dynamics, rendering it with increasing or decreasing tendencies, according to the magnitude and character of the respective events.

\section{Sources and methodology}

The present study is based on two main sources. They include the parish civil status registers, kept at the Maramureș County Office of the National Archives, and the censuses performed by the Habsburg Empire and, later on, by the Austro-Hungarian Empire between 1850 and 1910. Based on them, we have considered a series of aspects influencing population movement from 1765 until the end of the Great War.

As far as the registers are concerned, they are a particularly important source for our study. They enable us to analyze from a demographic perspective a series of developments. The registers gave information about the natality, the nuptiality, the confirmation (it allows us to observe the number of young people who survived childhood diseases), and the mortality. The registers are in relatively good condition. The writing style, the handwriting, the headings, and data complexity differ from one priest to another. The first records made in this respect are rather fragmentary. However, they became richer in the second half of the nineteenth century. In 1858, a tabular system of recording data on natality, nuptiality, and mortality was introduced. Given that the community members belonged to the Reformed confession, we have records of confirmation in addition to the data mentioned above. ${ }^{18}$ In their case, the first references appear as late as 1831 . The practice of confirmation was introduced (after a long preparation process) in 1810 at the Synod of Szárazajta. ${ }^{19}$ The registers also include people from nearby communities (such as Băiut, Rogoz, Suciu de Jos, or even Târgu Lăpuș) who belonged, from a confessional point of view to the village of Dămăcușeni.

As far as censuses are concerned, the village of Dămăcușeni can be found in all records made by the Austrian and then the Austro-Hungarian state. The first census was carried out in 1850 as the Court of Vienna wished to have data on the population affected by the 1848-1849 Revolution. ${ }^{20}$ Thus, the Transylvanian Government was encharged with carrying out the census by Order no. 3491, issued on 2 April, $1850 .{ }^{21}$ The first census was a lengthy process, as in some regions, data collection lasted until the beginning of 1851, and the results were processed only later on. ${ }^{22}$ Therefore, according to some historians, such as George Barițiu, the data provided by the first census can be doubted, as the fear

17 The so-called 'sore throat' was a term designating upper respiratory tract infections, like pharynx and larynx inflammations.

${ }^{18}$ Confirmation takes place at the age of 14. It consists in attending catechesis classes and learning religious songs. In the end, there is a ceremony during which the young people confess their faith.

19 Kolumbán 2011, 648-649.

20 Bolovan 2000, 7.

21 Bolovan 2000, 7.

22 Bolovan 2000, 8. 
of taxation determined people to change the number of family members in their favor. ${ }^{23}$ This was the reason for the adoption of the Census Law on 23 March 1857. It provided several recommendations for the conduct of censuses, including a fixed interval for data collection..$^{24}$ The same law also stated that censuses were to be carried out every six years. Because of the war with Prussia and the establishment of dualism in 1867, the next census was postponed until $1869 .{ }^{25}$

At the Eighth International Congress of Statistics, held in Petersburg in August 1872 , it was proposed that censuses be scheduled every ten years. Thus, in the case of Transylvania, the censuses of 1880, 1890, 1900, and 1910 resulted. The last two introduced several significant contributions, which made them stand out from all the censuses in previous years, as there was a serious interest in data accuracy. ${ }^{26}$

The village of Dămăcușeni was included in all these censuses and the agricultural census of 1895 . This second category of sources, represented by the censuses, provides us, in addition to the parish registers, with data on the total number of the population and the denominational, ethnic, and occupational structure of the community members. In the case of the agricultural census, we also learn about the materials used in the construction of houses. The census contained information on the size of the different types of land, calculated in Hungarian acres, ${ }^{27}$ and the owned fruit trees and animals. As in the case of the registers, it can be argued that the first censuses contained fewer data. Their headings changed over time. All these data allow us to perform a more in-depth analysis of the community's population.

From a methodological point of view, we employed the comparison and quantitative analysis of data provided by parish registers and censuses. These data are presented as charts and tables for easier tracking.

\section{Population movement during 1765-1918 Natality}

As shown in the chart below (Fig. 1), the number of baptisms registered in the parish of Dămăcușeni fluctuated greatly. Increases and decreases were recorded throughout the respective period. They were marked by diseases and the First World War when natality fell sharply due to the conscription of men for the front.

Regarding the average age for births, in the nineteenth century, women living in the village of Dămăcușeni first gave birth at an average age of 23.1 years, at approximately 1.8 years after marriage, and their last births took place at an average age of 32.4 years. ${ }^{28} \mathrm{After}$ this age, we can assume the use of contraceptive methods. ${ }^{29}$

\footnotetext{
23 Bolovan 2000, 8.

24 Bolovan 2000, 9.

25 Bolovan 2000, 10.

26 Bolovan 2000, 10-12.

27 A Hungarian acre (in Hungarian hold, in Romanian iugăr) is equivalent to 1.42 acres (cf. Müllerson et alii 1998, 221, translator's note).

${ }^{28}$ Ciocotișan-Miron 2002, 131.

${ }^{29}$ Ciocotișan-Miron 2002, 133.
} 


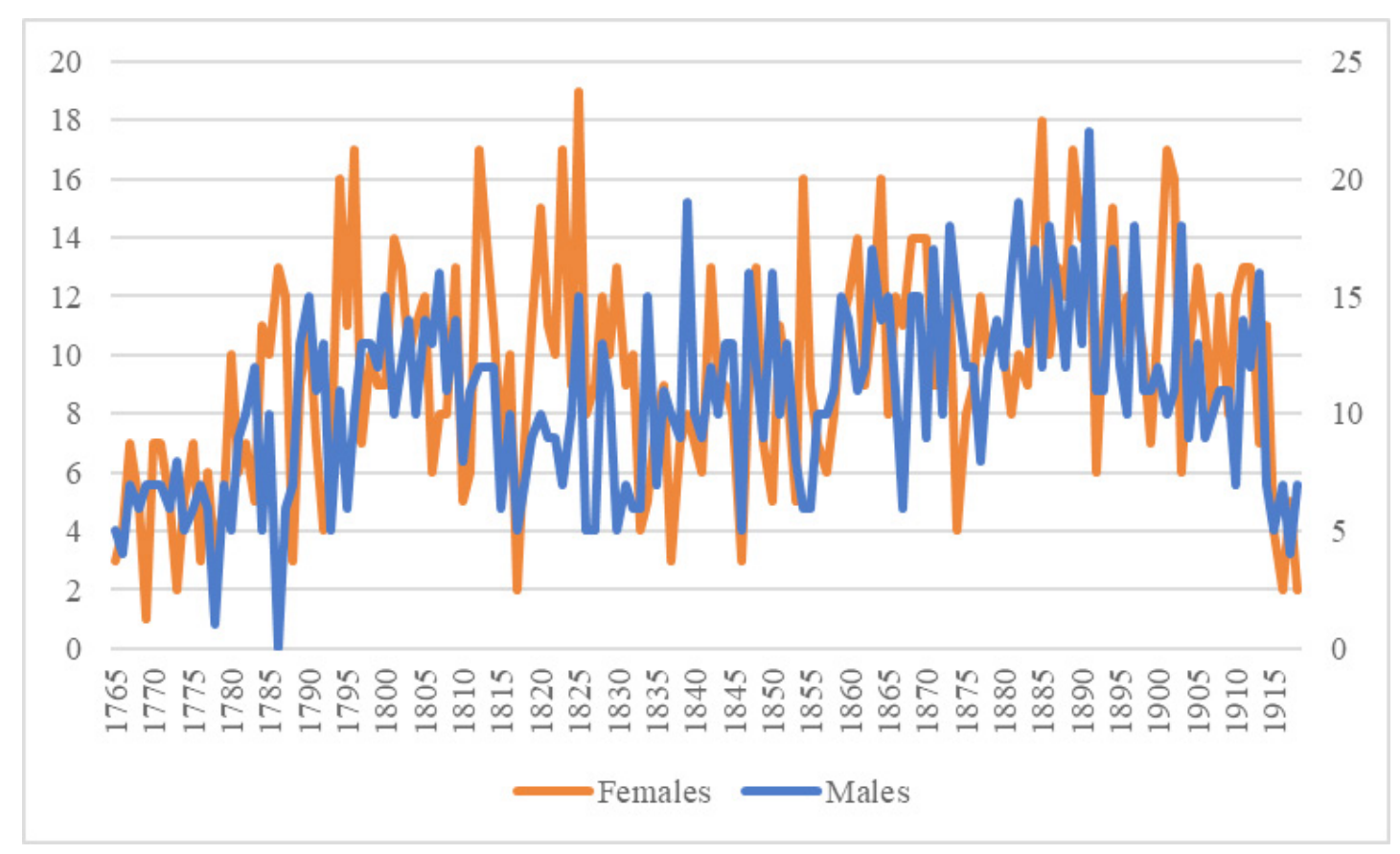

Fig. 1. Variation in the number of gender-related births between 1765 and 1918.

In modern times, children were born at home, assisted by some family members, and at some point by midwives (in Hungarian: a bába). Evidence of this can be found in the register entries, which provide us with concrete data on these midwives.

Special attention began to be paid to the medical system through the measures adopted by Empress Maria Theresa in the mid-eighteenth century. ${ }^{30}$ The impetus concerning the education of midwives also came from the state. ${ }^{31}$ In this respect, at the beginning of the twentieth century, in Transylvania, there were altogether nine schools for training midwives, in Cluj, Dej, Deva, Oradea, Sibiu, Sighetu Marmației, Sighișoara, Târgu Mures, and Turda, respectively. ${ }^{32}$ Despite all this, the number of qualified midwives in the Transylvanian area was lower than in other kingdom regions..$^{33}$ For example, in 1900, in the Solnoc-Dăbâca County, which at that time included the village of Dămăcușeni, there were 105 midwives. ${ }^{34}$ However, Solnoc-Dăbâca was among the counties with a high number of midwives, the fewest being recorded in Făgăraș and Târnava Mică. ${ }^{35}$

In the village of Dămăcușeni, during the studied period, several persons were assuming the midwife role, but we do not know anything about their training. They were most likely local midwives, and this knowledge/practice was passed on from one generation to another. The midwives working during the period in question were as follows: Juliánna Vékony who worked during the time span 1847-1861, Éva Miklós 1862-1887, Mária Gergely

\footnotetext{
30 Dumănescu 2019, 10.

31 Dumănescu 2019, 13.

32 Dumănescu 2019, 19.

33 Dumănescu 2019, 25.

34 Dumănescu 2019, 22.

35 Dumănescu 2019, 22.
} 
1862-1879, and Ágnes Szigyártó 1870-1893. These midwives can also be encountered in documents chronologically outside the intervals mentioned above, but less frequently, as they were replaced by much younger and more suitable peers for this profession.

After 1850, when the Vienna Court Decree of 1826, which forbade Jewish women to practice midwifery on Christians, was repealed ${ }^{36}$ midwives of Jewish origin appeared in the Dămăcușeni community as well. In this respect, we would like to mention the Jewish midwives Rifka Lázár $1855-1861,{ }^{37}$ and Bájla in 1904. ${ }^{38}$

The village of Dămăcușeni was not spared from unpleasant events in connection with births. For example, in 1857, a child was born dead allegedly because of the midwife, ${ }^{39}$ however, this is the only such case recorded in the confessional registers.

Baptism took place relatively soon after a child was born, within a day or two after birth. According to the canons of the Reformed Church in Transylvania, baptism had to be performed as soon as possible. If not, there were penalties for cases in which the child died unbaptized..$^{40}$ This matter was regulated at the Synod of Aiud in 1642, where it was decided to urge parents to baptize their children within three or four days after birth. ${ }^{41}$ The Calvinist Church took these decisions into account because delaying baptism was considered an offense against the sacrament. Therefore, children were baptized into the Reformed religion and confirmed at the age of 14, a religious practice by which young people professed their faith. In the case of mixed marriages, the rules of the Reformed Church required that boys be baptized in the father's and girls in the mother's confession unless otherwise agreed between the two parties to the betrothal. ${ }^{42}$

At baptisms, most of the given names were biblical ones. Other names have appeared over time. The most common names were András, Dániel, Sándor, János, József, and Sámuel for boys, and Anna, Boriska, Éva, Zsuzsa, Juliánna, and Ráchel for girls.

The data provided by the registers illustrate the fact that the number of illegitimate children (born out of wedlock) was very small, and there were periods when no such children were registered.

From the parish registers, we learn about the concerns of the Reformed Diocese of Transylvania regarding birth rates on the visit of Protopope István Pap to the village of Dămăcușeni. Thus, on 7 September 1910, the community was aware that the mortality rate was higher than the birth rate since only 19 children were born that year, but 29 people died, which was regarded as 'shocking', according to the reports. ${ }^{43}$ The reasons for the low birth rate were due to 'either a sinful reduction in births or the precarious situation of the community ${ }^{34}$ that affected 'the Hungarian Church and nation. ${ }^{45}$ Consequently, it was the duty of the presbyters to put an end to the precarious situation of the community so that

\footnotetext{
${ }^{36}$ Dumănescu 2019, 11-12.

37 SJM AN, Matricole Confesionale, file 486, fols. 15 v-29 r.

${ }^{38}$ SJM AN, Matricole Confesionale, file 487, fol. $48 \mathrm{v}$.

39 SJM AN, Matricole Confesionale, file 486, fol. 152 r.

40 Pokoly 1905, 250.

${ }^{41}$ Pokoly 1905, 250.

42 Lukács 2005, 82.

${ }^{43}$ SJM AN, Oficiul parohial reformat Dămăcușeni, file 3, fol. 27 r-v.

${ }^{44}$ SJM AN, Oficiul parohial reformat Dămăcușeni, file 3, fol. 27 r-v.

${ }^{45}$ SJM AN, Oficiul parohial reformat Dămăcușeni, file 3, fol. 27 r-v.
} 
birth rates would recover in the following period. ${ }^{46}$ This was only partly achieved because the First World War led to an even more dramatic drop in birth rates.

\section{Confirmation}

As mentioned above, the custom of confirmation was introduced in 1810 by the Synod of Szárazajta. ${ }^{47}$ However, in the case of Dămăcușeni village, the first data appear as late as 1831 (with small gaps).

Figure 2 suggests, first of all, that this ceremony was taking place every two years, as in the periods $1831-1836,1864-1872$, and 1875-1901. However, we can see that there also was a shorter interval of only one year, for example, between 1836 and 1837, due to a large number of young people, and a longer break of three years during the time spans $1837-1840$ and $1872-1875$.

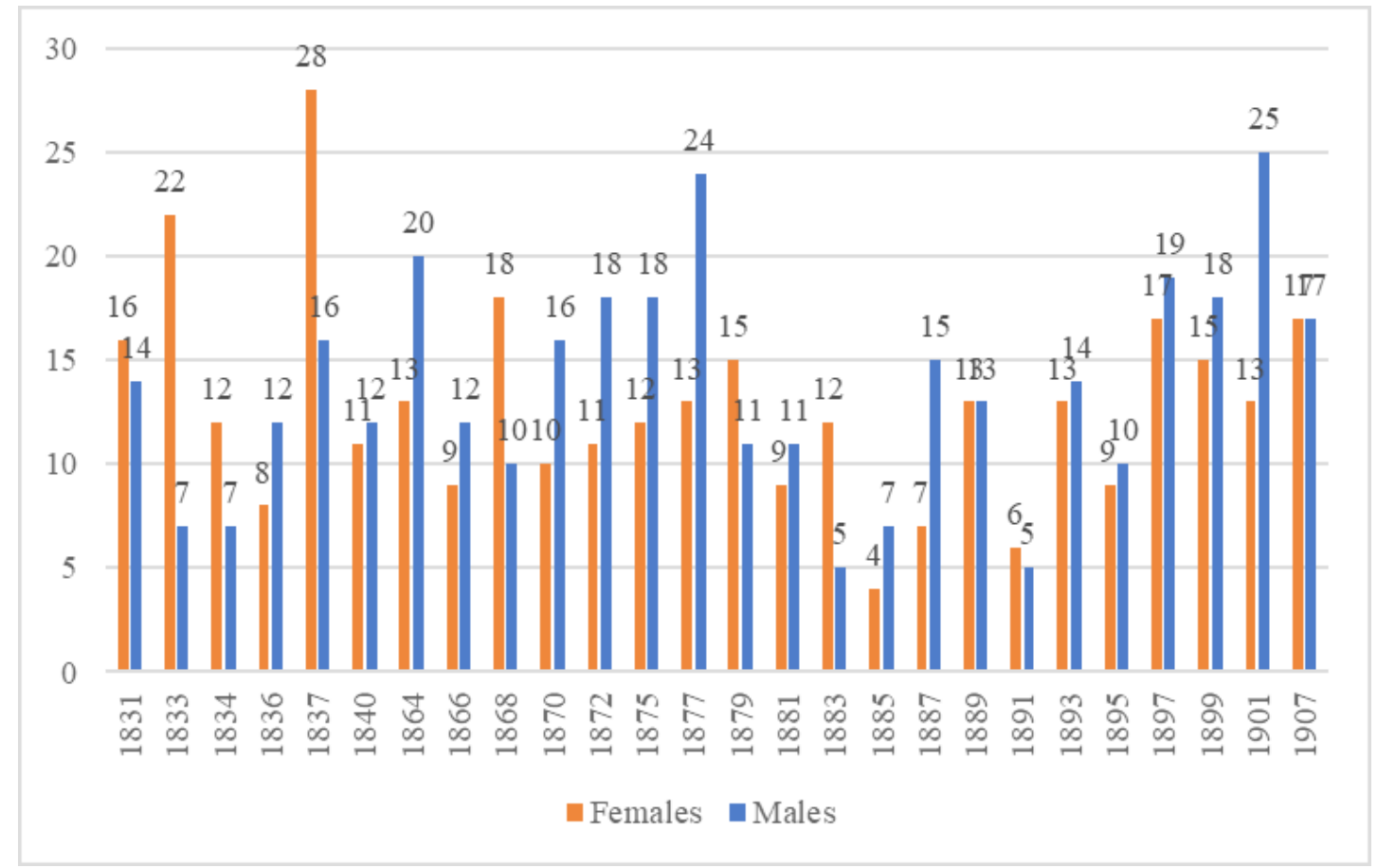

Fig. 2. Variation in the number of young men and women receiving confirmation between 1831 and 1907.

The number of young people fluctuated from one year to another. There was a significant drop between 1879 and 1885. After this year, the number started to increase until 1891, which marked the beginning of new oscillations. The chart above reveals that the highest number of young people receiving confirmation was recorded at the beginning of the studied period, more precisely in 1837 ( 44 children) and in 1901, when on 19 March, 25 boys and 13 girls were confirmed in Dămăcușeni. ${ }^{48}$ The large number of young people resulted from the fact that when this practice was introduced, the ceremony did not take place yearly but, as noted above, once every two or even three years. This very large number

46 SJM AN, Oficiul parohial reformat Dămăcușeni, file 3, fol. 27 r-v.

47 Kolumbán 2011, 648-649.

48 SJM AN, Matricole Confesionale, file 486, fol. 136 r. 
can also be explained by the high birth rate during the period in which the respective children were born.

In the studied period, the number of boys was higher than that of girls. In addition to the numerical evolution, these data are important because, as already mentioned, we can observe the number of young people who survived childhood diseases.

\section{Nuptiality}

In the case of nuptiality, the confessional registers provide us with concrete data beginning with 1767 . Thus, in the interval 1767-1918, most marriages were registered in 1867 (19), 1885 (16), and at the beginning of the twentieth century, in 1910 (14). A peak of 28 marriages (of which 2 mixed) was recorded in $1919 .{ }^{49}$ A decisive factor contributing to the high number of marriages in 1919 was that during the war years, marriages were significantly reduced as many men had been drafted to the front. The return of men from the front led to a marked increase in the number of marriages.

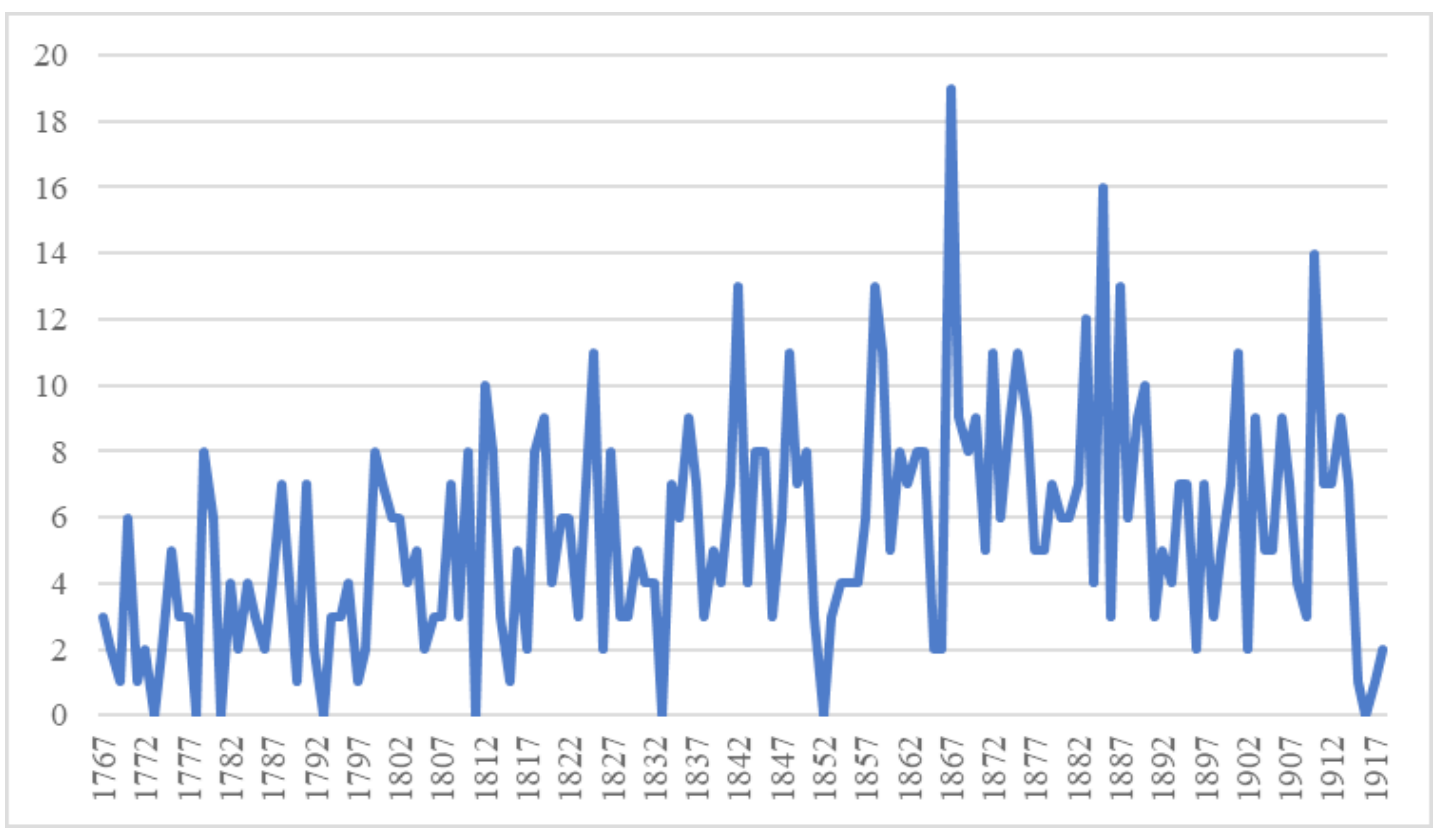

Fig. 3. Variation in the number of marriages concluded between 1767 and 1918 .

Weddings took place in spring, before the beginning of work in the fields, in autumn, and in winter (Fig. 4). Summer marriages began to appear gradually towards the end of the studied period. There are no details about the wedding ceremonies, but we can assume that they were held in people's courtyards, as there are no other records of them. The average age of marriage during 1834-1930 was 25.4 years for men and 20.3 years for women. ${ }^{50}$

It is worth mentioning that the Reformed denomination accepted mixed marriages as well. ${ }^{51}$ There was a specific procedure to be followed in such cases. Specifically, the marriage announcement had to be made three times before the wedding. It was to take

\footnotetext{
${ }^{49}$ SJM AN, Matricole Confesionale., file 487, fols. 123 r-124 r.

${ }^{50}$ Ciocotișan-Miron 2002, 129.

51 Lukács 2005, 69.
} 
place in both communities to which the bride and the groom belonged (a practice still observed today). ${ }^{52}$ The role of the public announcement was to consult the community about possible impediments to marriage, determined by age, degree of kinship, etc.

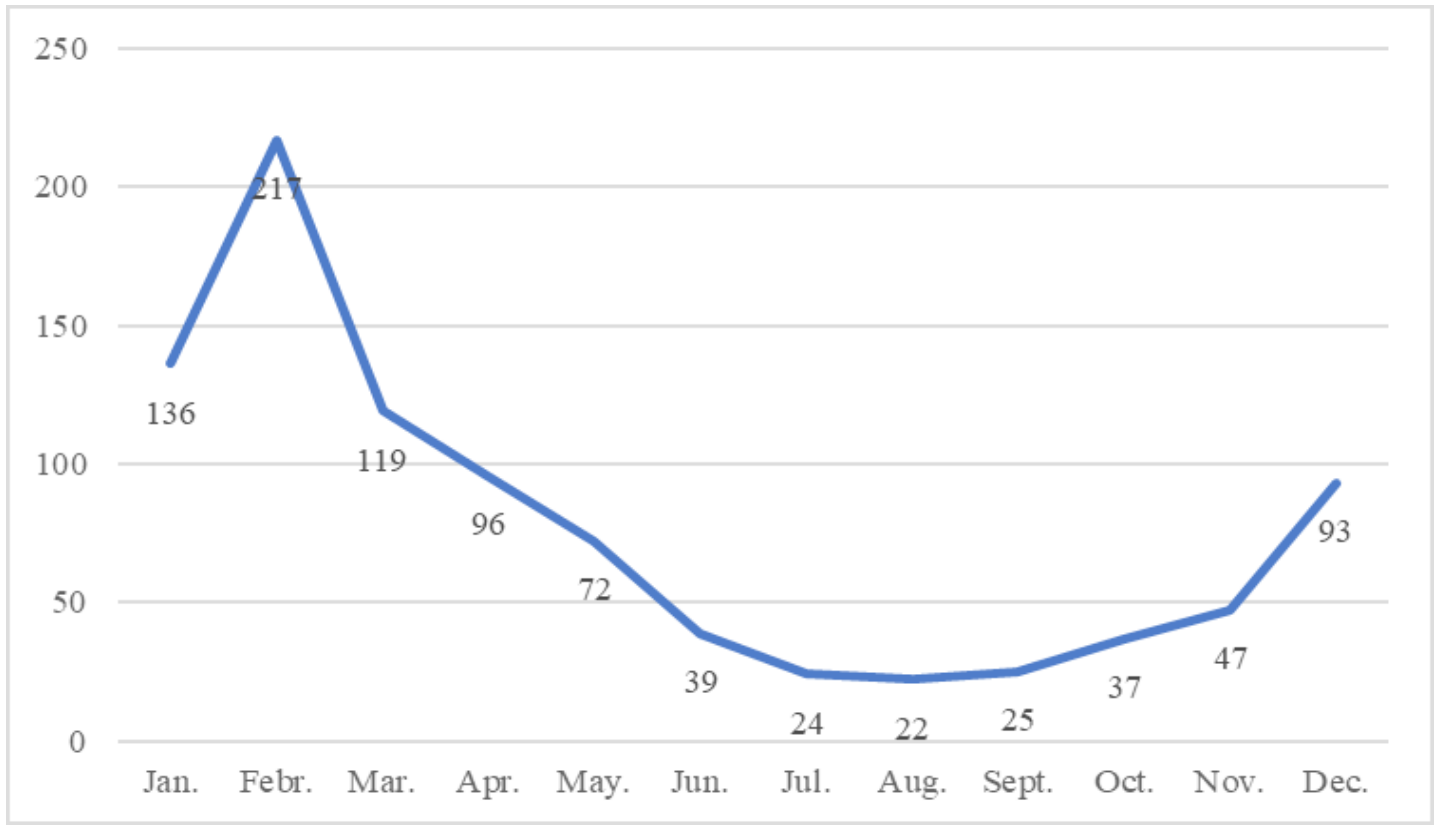

Fig. 4. The months in which marriages were concluded in the village of Dămăcușeni between 1771 and 1930 (source: Ciocotișan-Miron 2002, 128).

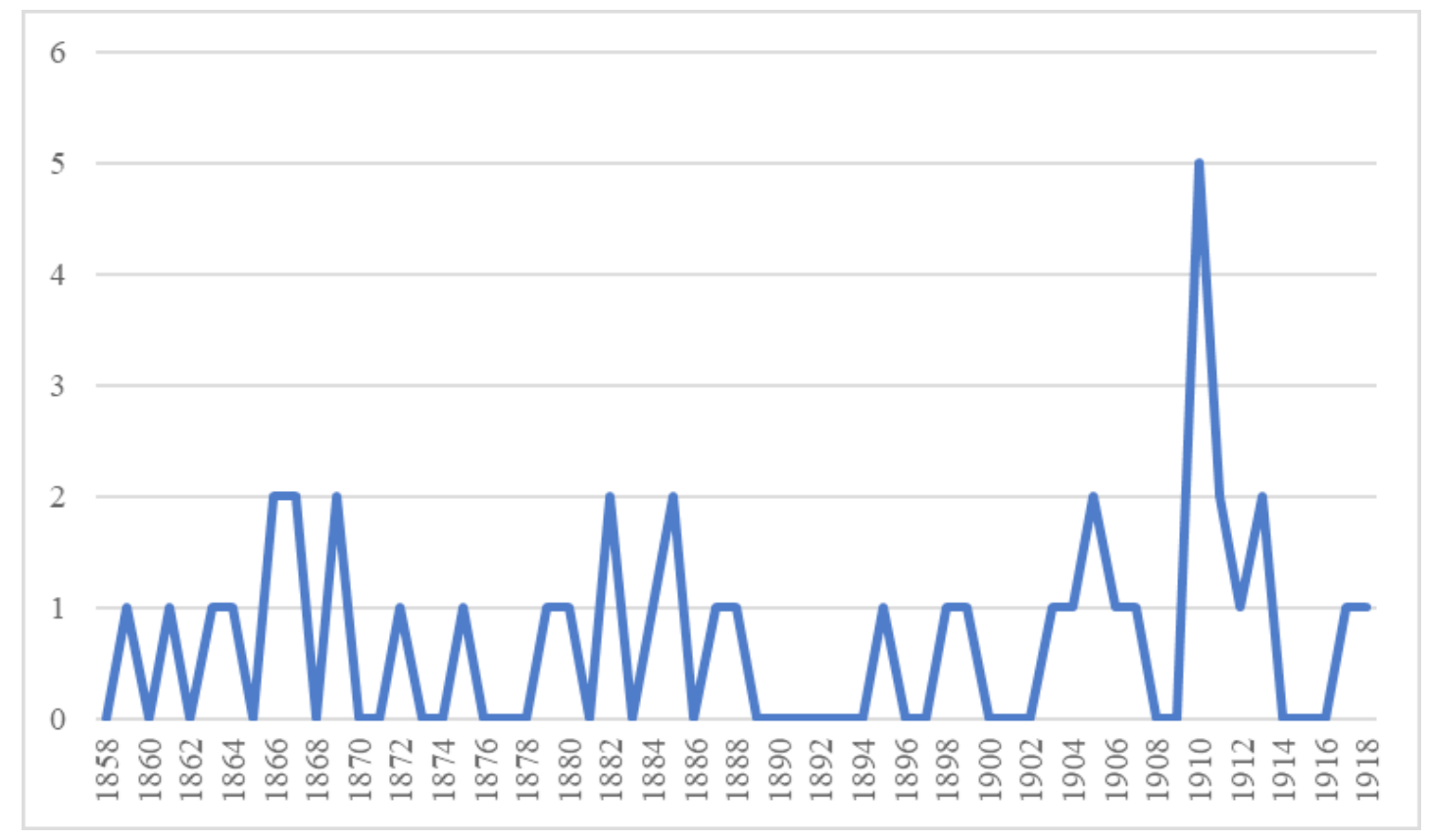

Fig. 5. Mixed marriages between 1887 and 1918.

52 Lukács 2005, 75. 
The number of mixed marriages was relatively small during the studied period (Fig. 5). However, the records show that the inhabitants of Dămăcușeni village chose their partner from the surrounding villages. Most men came from Târgu-Lăpuș, Băiuț, Strâmbu-Băiuț, but also from more distant localities, such as Baia Mare, Baia-Sprie, Dej, and Mureș. However, women came from the neighboring villages, which are situated relatively close to each other. ${ }^{53}$ The highest number of mixed marriages (5) was concluded in 1910 (Fig. 5).

As far as concubinage is concerned, the data provided by the parish registers are incomplete. However, the issue was discussed in detail at the parish assembly held during the visit of Protopope István Pap in 1910. Therefore, it was the duty of the presbyters to prevent concubinage at all costs. ${ }^{54}$ Despite all this, concubinage persisted during the subsequent period. A report drafted in 1912 by the parish priest reveals the existence of two persons living in concubinage. ${ }^{55}$

\section{Mortality}

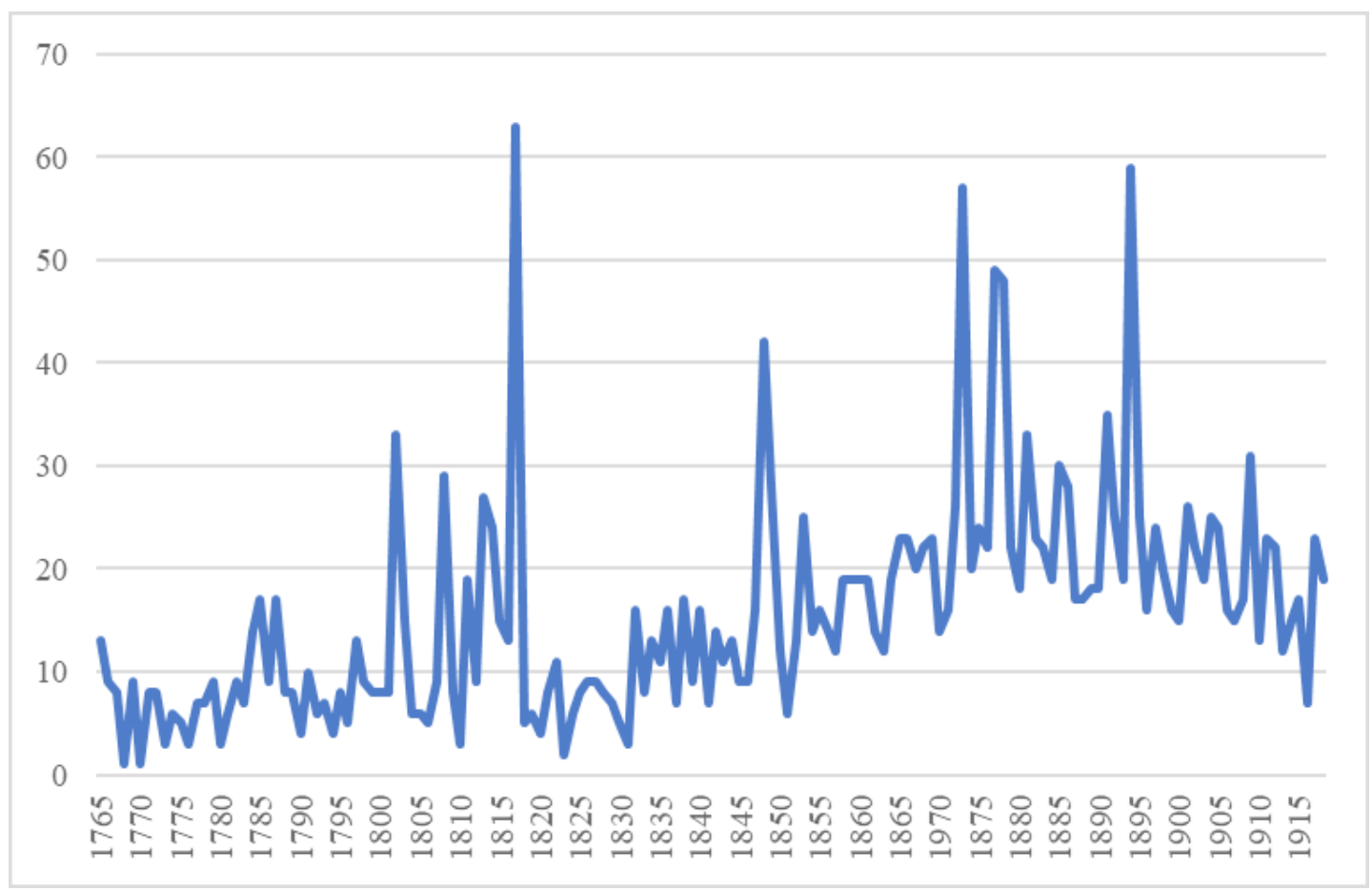

Fig. 6. Fluctuation in the number of deaths between 1765 and 1918.

Before presenting the factors that influenced mortality, it should be noted that the data provided by the registers before 1800 are not very generous because they only sometimes include the age of the persons and the causes of death. In addition, for some periods, a small number of deaths were recorded. All these aspects cast doubt on the accuracy of the early data recorded by priests in the registers. Even so, as shown in Fig. 6, mortality in the

\footnotetext{
53 Ciocotișan-Miron 2002, 131.

${ }^{54}$ SJM AN, Oficiul parohial reformat Dămăcușeni, file 3, fol. 27 r-v.

${ }^{55}$ SJM AN, Oficiul parohial reformat Dămăcușeni, file 13, fol. 8 r.
} 
village of Dămăcușeni was relatively low at the beginning of the studied period. Still, later on, the community experienced several mortality increases.

The first such increase occurred in 1784 when 13 children died in the smallpox epidemic. ${ }^{56}$ This disease reappeared in 1802 when 33 people died (mostly of smallpox ${ }^{57}$ ), in $1808,{ }^{58}$ and in $1814 . .^{59}$ The deaths in these years were primarily due to smallpox and larynx inflammation, in those days called 'sore throat', a disease that claimed a significant number of victims, especially in 1814. It affected mainly children during the latter part of that year. ${ }^{60}$

A new increase in mortality was caused by the famine that broke out in the second half of 1816, resulting in the death of 3 people. ${ }^{61}$ It persisted into 1817 , causing 60 deaths that year. ${ }^{62}$ The famine was most likely caused by the cold and rainy seasons marking Transylvania between 1813 and $1817 . .^{63}$

One of the epidemics that most affected the Transylvanian area, including the village of Dămăcușeni, was cholera. Transylvania experienced six major cholera epidemics between 1831 and $1873 .{ }^{64}$

\begin{tabular}{|c|c|c|c|c|c|c|}
\hline Period & $\mathbf{1 8 3 1 - 1 8 3 2}$ & $\mathbf{1 8 3 6}$ & $\mathbf{1 8 4 8 - 1 8 4 9}$ & $\mathbf{1 8 5 5}$ & $\mathbf{1 8 6 6}$ & $\mathbf{1 8 7 3}$ \\
\hline Men & - & 2 & 4 & 0 & 0 & 5 \\
\hline Women & - & 4 & 2 & 0 & 0 & 11 \\
\hline Children & - & 2 & 4 & 0 & 0 & 1 \\
\hline Total & - & $\mathbf{8}$ & $\mathbf{1 0}$ & $\mathbf{0}$ & $\mathbf{0}$ & $\mathbf{1 7}$ \\
\hline
\end{tabular}

Table 1. The evolution of the cholera epidemics in the village of Dămăcușeni.

In this respect, the years 1831-1832 were marked by the first great epidemic. However, it did not affect all regions. ${ }^{65}$ A possible reason why there is no mention of any case of cholera in Dămăcușeni village is most likely the fact that in the period mentioned above, the registers do not contain data on the cause of death.

In 1836, the second cholera epidemic did not spare the members of this community. Thus, as shown in Table 1, 2 men, 4 women, and 2 children died of this disease. ${ }^{66}$

The next epidemic coincided with the 1848 Revolution. ${ }^{67}$ In Dămăcușeni, in addition to the 2 people killed during the revolutionary movements, 2 men died (one of them was a guard from Satu-Mare), 1 woman, and 3 children. ${ }^{68}$ A specific feature of this epidemic

\footnotetext{
${ }^{56}$ SJM AN, Matricole Confesionale, file 484, fol. $70 \mathrm{r}-\mathrm{v}$.

57 SJM AN, Matricole Confesionale, file 484, fols. $55 \mathrm{v}-56 \mathrm{r}$.

58 SJM AN, Matricole Confesionale, file 484, fols. 77 v-83 r.

59 SJM AN, Matricole Confesionale, file 485, fol. 64 r.

${ }^{60}$ SJM AN, Matricole Confesionale, file 485, fol. 64 r.

${ }^{61}$ SJM AN, Matricole Confesionale, file 485, fol. $64 \mathrm{v}$.

62 SJM AN, Matricole Confesionale, file 485, fols. $64 \mathrm{v}-65 \mathrm{v}$.

${ }^{63}$ Bolovan 2007, 230.

${ }^{64}$ Bolovan 2007, 235.

${ }^{65}$ Bolovan 2007, 235.

${ }^{66}$ SJM AN, Matricole Confesionale, file 485, fols. 68 v-69 v.

67 Bolovan 2007, 232.

${ }^{68}$ SJM AN, Matricole Confesionale, file 486, fols. $142 \mathrm{v}-144 \mathrm{v}$.
} 
is that mortality returns relatively quickly to pre-epidemic levels. ${ }^{69}$ Thus, in 1849 , cholera continued to affect the community, but mortality decreased. As of the recorded 28 deaths, only 4 were caused by cholera. However, the majority of the population was affected by scarlet fever. ${ }^{70}$ After 1849, mortality followed a downward trend, below 20 deaths, but increased again in 1853, reaching 25 deaths. $^{71}$

Shortly after the revolutionary events, the Transylvanian area was again affected by cholera in 1855. Although the most affected regions were Banat, Crișana, and Maramureș, ${ }^{72}$ no cholera case was recorded in this community. ${ }^{73}$

As shown in Table 1, the fifth epidemic did not affect the village of Dămăcușeni, because the Dămăcușeni parish did not record any death. The situation was different in the case of the last major cholera epidemic in 1873, which had the strongest impact on the community, causing the death of 17 people, ${ }^{74}$ two more than in the Greek-Catholic parish of Beiuș. ${ }^{75}$

During these years, cholera has more affected the female population, with 17 deaths. Second came the male population, with 11 deaths, and the fewest deaths were recorded in children, with 8 victims throughout these years. Based on these data, we can claim that cholera caused fewer victims compared to other Transylvanian villages. For instance, just in 1836, the village of Vlăhița registered 32 deaths. ${ }^{76}$

In addition, mortality reached high levels in 1838, when 17 people died. The main cause was high fever, which reappeared in 1840, leading to 16 deaths, besides those caused by tuberculosis and edema. ${ }^{77}$ In 1842, 14 people died, and most of them were males. ${ }^{78}$

Other causes of death were dysentery, edema, and tuberculosis. Until 1873, mortality figures fluctuated but were never as high as in $1848\left(42\right.$ deaths $\left.{ }^{79}\right)$. In 1873, mortality reached high levels again, as 57 people died. ${ }^{80}$ This high number of deaths was caused by cholera, smallpox, and pharyngitis. Mortality was also increased in 1877-1878, the main cause for it being the sore throat. ${ }^{81}$

In the period 1881-1914, Transylvania was affected only by local epidemics. ${ }^{82}$ In this sense, in the case of Dămăcușeni village, we should mention the year 1891, marked by pulmonary diseases, ${ }^{83}$ and 1894 , when 59 community members died, primarily due to smallpox and diphtheria. ${ }^{84}$ By comparison, the transition to the twentieth century recorded a decrease in mortality, with few exceptions (such as in 1909).

\footnotetext{
${ }^{69}$ Bolovan 2007, 235.

70 SJM AN, Matricole Confesionale, file 486, fols. 145 r-146 r.

${ }^{71}$ SJM AN, Matricole Confesionale, file 486, fols. 146 v-149 r.

72 Bolovan 2007, 232.

${ }^{73}$ SJM AN, Matricole Confesionale, file 486, fol. 150 r.

74 SJM AN, Matricole Confesionale, file 486, fols. $180 \mathrm{v}-184 \mathrm{r}$.

75 Brie 2008, 8.

76 Pakot 2002, 220.

77 SJM AN, Matricole Confesionale, file 485, fols. $69 \mathrm{v}-72 \mathrm{r}$.

${ }^{78}$ SJM AN, Matricole Confesionale, file 485, fols. $72 \mathrm{v}-75 \mathrm{r}$.

79 SJM AN, Matricole Confesionale, file 486, fols. $142 \mathrm{v}-144 \mathrm{v}$.

${ }^{80}$ SJM AN, Matricole Confesionale, file 486, fols. $180 \mathrm{v}-183 \mathrm{r}$.

${ }^{81}$ SJM AN, Matricole Confesionale, file 486, fols. $189 \mathrm{v}-191 \mathrm{v}$.

${ }^{82}$ Bolovan 2000, 143.

${ }^{83}$ SJM AN, Matricole Confesionale, file 487, fols. $138 \mathrm{r}-141 \mathrm{r}$.

${ }^{84}$ SJM AN, Matricole Confesionale, file 487, fols. 144 r-148 r.
} 


\begin{tabular}{|c|c|c|c|c|}
\hline \multirow{2}{*}{ Period } & \multicolumn{2}{|c|}{$\begin{array}{c}\text { Number of deceased } \\
\text { aged 20-49 }\end{array}$} & \multicolumn{2}{c|}{$\begin{array}{c}\text { Uumber of deceased } \\
\text { aged over 50 }\end{array}$} \\
\cline { 2 - 5 } & Males & Females & Males & Females \\
\hline $\mathbf{1 8 1 3 - 1 8 1 9}$ & 19 & 10 & 21 & 24 \\
\hline $\mathbf{1 8 2 0 - 1 8 2 9}$ & 7 & 6 & 9 & 10 \\
\hline $\mathbf{1 8 3 0}-\mathbf{1 8 3 9}$ & 4 & 13 & 22 & 25 \\
\hline $\mathbf{1 8 4 0 - 1 8 4 9}$ & 17 & 19 & 33 & 31 \\
\hline $\mathbf{1 8 5 0}-\mathbf{1 8 5 9}$ & 18 & 17 & 29 & 25 \\
\hline $\mathbf{1 8 6 0}-\mathbf{1 8 6 9}$ & 15 & 9 & 45 & 39 \\
\hline $\mathbf{1 8 7 0 - 1 8 7 9}$ & 25 & 15 & 52 & 49 \\
\hline $\mathbf{1 8 8 0}-\mathbf{1 8 8 9}$ & 16 & 22 & 42 & 33 \\
\hline $\mathbf{1 8 9 0}-\mathbf{1 8 9 9}$ & 11 & 20 & 54 & 39 \\
\hline $\mathbf{1 9 0 0 - 1 9 0 9}$ & 15 & 20 & 45 & 50 \\
\hline $\mathbf{1 9 1 0}-\mathbf{1 9 1 8}$ & 8 & 13 & 51 & 34 \\
\hline
\end{tabular}

Table 2. Mortality by age group.

Concerning mortality by age group, as in the village of Vlăhița, ${ }^{85}$ the age group 20-49 years stood out with higher figures in the female population. However, in the age group over 50 years, more men than women died. In Dămăcușeni village, we can sustain as possible explanations for the high number of deaths in women's life-threatening births, the respective hygienic and sanitary conditions, and the work specific to village life.

In conclusion, throughout this entire period, mortality reached higher levels in the male population. The community was affected by various crises caused by famine, cholera, and other diseases and epidemics, but mortality quickly returned to the pre-crisis levels.

Infant mortality

\begin{tabular}{|c|c|c|c|c|}
\hline \multirow{2}{*}{ Period } & \multicolumn{2}{|c|}{ Infant mortality } & \multicolumn{2}{c|}{$\begin{array}{c}\text { Number of deceased aged } \\
\text { 1-19 }\end{array}$} \\
\cline { 2 - 5 } & Males & Females & Males & Females \\
\hline $\mathbf{1 8 3 1 - 1 8 3 9}$ & 10 & 5 & 12 & 10 \\
\hline $\mathbf{1 8 4 0 - 1 8 4 9}$ & 19 & 10 & 20 & 18 \\
\hline $\mathbf{1 8 5 0 - 1 8 5 9}$ & 17 & 15 & 17 & 13 \\
\hline $\mathbf{1 8 6 0 - 1 8 6 9}$ & 19 & 20 & 25 & 19 \\
\hline $\mathbf{1 8 7 0}-\mathbf{1 8 7 9}$ & 20 & 14 & 62 & 60 \\
\hline $\mathbf{1 8 8 0}-\mathbf{1 8 8 9}$ & 33 & 18 & 33 & 22 \\
\hline $\mathbf{1 8 9 0}-\mathbf{1 8 9 9}$ & 29 & 22 & 40 & 42 \\
\hline $\mathbf{1 9 0 0 - 1 9 0 9}$ & 24 & 19 & 20 & 15 \\
\hline $\mathbf{1 9 1 0 - 1 9 1 8}$ & 15 & 7 & 12 & 11 \\
\hline
\end{tabular}

Table 3. Infant mortality and mortality over 1 year of age.

\footnotetext{
${ }^{85}$ Pakot 2002, 220.
} 
Due to the lack of data referring to the age of the deceased children up to 1831, infant mortality can be studied only in the case of few exceptions. As shown in Table 3, the cases of infant mortality were relatively scarce at the beginning of the analyzed period. Then their number started to grow in the forties of the nineteenth century. As late as 1847, data begin to be more abundant, so we can deduce the causes of death. Among them are scarlet fever, smallpox, pulmonary diseases, and sore throat. Nevertheless, the number of deaths in the age group 1-19 years was a lot higher. We can see that there were several disease waves affecting children. Thus, scarlet affected both age groups during the period $1847-1849 .{ }^{86} \mathrm{In}$ the case of the age group 1-19 years, there was also cholera in $1848 .{ }^{87}$

The year 1873 brought the second wave affecting both age groups. This time, it was sore throat that caused the death of 7 children aged less than one year and 23 people from the age group $1-19 .{ }^{88}$

In children under one year of age, mortality was high due to smallpox in 1868, 1881, 1883, and 1891. The same disease also occurred in the population aged between 1 and 19 years but in different periods. The highest recorded values were reached in 1894 when 24 boys and 24 girls died. ${ }^{89}$ Another disease that affected this age group was diphtheria. It caused the most deaths in 1877-1878, 1880, and 1895. Other diseases were gastritis, weakness, failure to thrive in young children, edema, and whooping cough. Infant mortality in Dămăcușeni was highest in the ninth decade of the nineteenth century, but natural causes and weakness predominated.

We also find that throughout the studied period, mortality was higher for both groups in the male population.

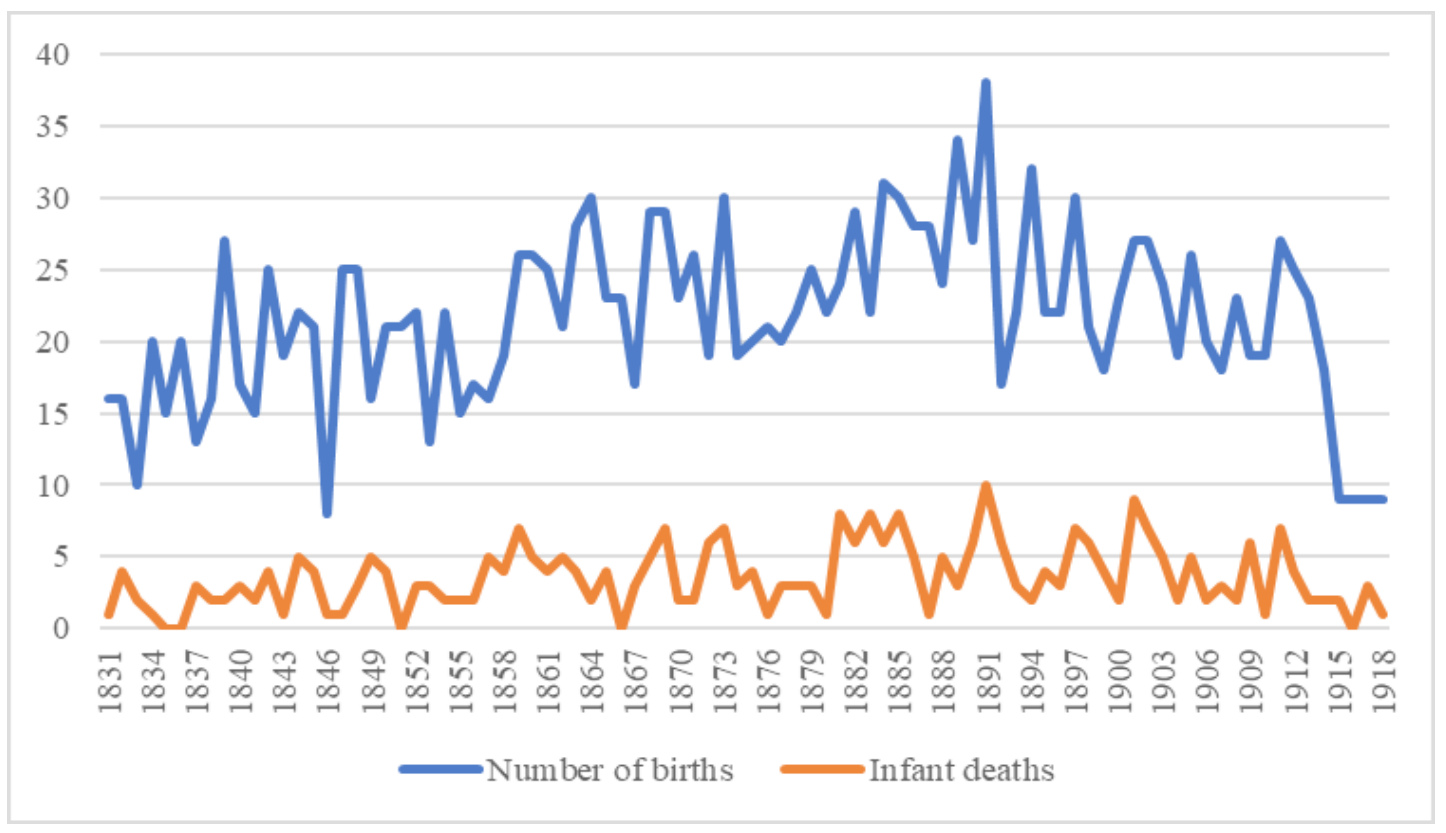

Fig. 7. Natality to infant mortality ratio.

${ }^{86}$ SJM AN, Matricole Confesionale, file 486, fols. 142 r-146 v.

${ }^{87}$ SJM AN, Matricole Confesionale, file 486, fols. $142 \mathrm{v}-144 \mathrm{v}$.

${ }^{88}$ SJM AN, Matricole Confesionale, file 486, fols. $180 \mathrm{v}-184 \mathrm{r}$.

${ }^{89}$ SJM AN, Matricole Confesionale, file 487, fols. 144 r-149 v. 
In 87 years, 316 children under the age of one have died. Compared to other communities, the village of Dămăcușeni is below the Greek-Catholic parish of Beiuș, which only in 20 years recorded the death of 144 children, but above the Greek-Catholic communities of Șuncuiuș de Beiuș and Ghenetea, which recorded the death of 46 and 63 children, respectively, between 1860 and $1910 . .^{90}$ Despite all the diseases and epidemics affecting the population, infant mortality did not exceed the birth rate in any year during the entire period under analysis.

\section{Divortiality}

The community was closely connected to the Church due to its significant influence. In this sense, the community members who faced trouble knew that one of the main places in the village they could turn to was the priest and the parish council. There are numerous examples of this kind. The most relevant is that of Éva Szabó, a woman who wished to divorce her husband because she had not seen him for ten years, and he was not committed to raising their child. ${ }^{91}$ Therefore, the woman sought the consent of the presbyters and the Church to divorce because 'she had a very sad life. ${ }^{\prime 2}$ In such cases, when a person was accused, the parties were called in front of the presbyters. In this case, the husband was called in front of the presbyteral assembly, and he brought several counter-arguments, claiming that he was forced to leave because his wife was not faithful; as for the child, it was born after he had left. ${ }^{93}$ Presbyteral assemblies played an important part because they always tried to find a good solution. In this sense, the presbyters suggested that the two should be reconciled, but they refused. As a result, the priest and the presbyters agreed that the couple should separate and begin the divorce procedure, the costs of which should be borne by both parties. ${ }^{94}$

There have been many cases where abandoned, beaten, or cast out women have found some support in the parish. However, it was not only women who came to the assembly but also men. In this regard, we would like to mention the case of a man who claimed that he was not happy because his wife did not listen to him but to others. ${ }^{95}$

As we have seen, there are numerous data on divorces in the parish registers. Moreover, the census records revealed the existence of 4 divorcees in 1900 and 3 in 1910. ${ }^{96}$

Usually, divorcees remarried. During the period 1834-1930, for men, the mean age at which they remarried was 37.9 years, and for women, 33 years. ${ }^{97}$ Therefore, we can conclude that the inhabitants of Dămăcușeni village had a relatively free matrimonial behavior, and divorce did not mean the marginalization of the previous couples by the community, as was the case of women in the predominantly Romanian localities. ${ }^{98}$

\footnotetext{
90 Brie 2008, 17-18.

${ }^{91}$ SJM AN, Oficiul parohial reformat Dămăcușeni, file 4, fol. 153 r.

92 SJM AN, Oficiul parohial reformat Dămăcușeni, file 4, fol. 153 r.

93 SJM AN, Oficiul parohial reformat Dămăcușeni, file 4, fol. 153 v.

${ }^{94}$ SJM AN, Oficiul parohial reformat Dămăcușeni, file 4, fol. 153 v.

95 SJM AN, Oficiul parohial reformat Dămăcușeni, file 4, fol. 159 r-v.

${ }_{96}$ Rotariu 1999, 393; Rotariu 1999-2006, 375.

97 Ciocotișan-Miron 2002, 129.

98 Ciocotișan-Miron 2002, 135.
} 


\section{The population as revealed by the censuses (1850-1910)}

According to the censuses, most of the inhabitants living in the village of Dămăcușeni belonged to the Reformed (Calvinist) confession. Moreover, a smaller number of people of other confessions were recorded. Thus, the census conducted in 1850 registered 24 Israelis and 8 Greek-Catholics. ${ }^{99}$ In 1857, the Orthodox (11) and the Roman-Catholics (20) were mentioned for the first time in addition to the religions referred to in the previous census. ${ }^{100}$ To these were added 6 Evangelicals and 1 Unitarian in $1890 .{ }^{101}$ Over time, the number of people belonging to these confessions varied, but the Reformed denomination has remained predominant. In 1910, before the First World War, the population consisted of 726 Calvinists, followed by 101 Israelis, 47 Orthodox, 26 Greek-Catholics, and 9 Roman-Catholics. ${ }^{102}$

In terms of ethnicity, the most numerous were the Hungarians, but members of other ethnic origins were also recorded. For example, in 1850, besides the Hungarian majority, 24 Jews and 8 Romanians were registered. ${ }^{103}$ Since 1857, the population can be traced only by religion, and since 1880 , by first language. In 1880 , the community consisted of 716 Hungarians, 45 Romanians, 21 inhabitants of unknown first language, 12 of other nationalities, and 8 Germans. ${ }^{104}$ From the records of this census, we can also learn the literacy index, which registered 75 people. ${ }^{105}$

In 1895, an agricultural census was carried out. Its data mentioned the total surface of the households and their use, calculated in Hungarian acres. The total surface of the households was 4,253 Hungarian acres, ${ }^{106}$ and they were used as follows: 1,021 Hungarian acres of arable land, 49 Hungarian acres of gardens, 795 Hungarian acres of hay fields, and 393 Hungarian acres of pastures. ${ }^{107}$ From the agricultural census records, we also learn that the total woodland area was 1,971 Hungarian acres, and the thicket covered 8 Hungarian acres. The village had 16 Hungarian acres of unproductive land. ${ }^{108}$

The 1895 census also lists fruit trees by variety and livestock. As far as fruit trees are concerned, in the village of Dămăcușeni, there were a total of 1,658 trees, of which 896 plum trees, 280 apple trees, 258 mulberry trees, 151 pear trees, 57 sour cherry trees, 12 cherry trees, 2 peach trees, and 2 chestnut trees. ${ }^{109}$ In the case of animals, birds $(1,622$, more than in the neighboring village of Rogoz), sheep (805), and cattle (714) predominated, mostly of Hungarian-Transylvanian breed. ${ }^{110}$ All these data reveal the main occupations of the inhabitants, namely agriculture, horticulture, and animal husbandry. According to the agricultural census of 1895, in Dămăcușeni village, there were 212 households, of which 8

\footnotetext{
${ }_{99}$ Rotariu 2004, 320.

100 Rotariu 1996, 144.

101 Rotariu 2009, 231.

102 Rotariu 1999-2006, 373.

103 Rotariu 2004, 320.

104 Rotariu 1997, 225.

105 Rotariu 1997, 225.

106 Rotariu 2003, 195.

107 Rotariu 2003, 195.

108 Rotariu 2003, 195.

109 Rotariu 2003, 373.

${ }^{110}$ Rotariu 2003, 374-375.
} 
buildings were fire insured, far fewer than in Târgu Lăpuș. ${ }^{111}$ They most probably belonged to the parish or other important members of the community.

The 1900 census included a number of new items enabling us to learn about the conditions in which the members of this community lived. According to it, most houses were built of wood, and stone or brick were rarely used. ${ }^{112}$ As for the materials employed for house roofing, shingles predominated, followed by reeds and straw. ${ }^{113}$ From this point of view, there have been few changes since the last census, because apart from the increase in the number of houses made of wood, stone, or brick, we find only one house with walls made of clay and straws or mud. ${ }^{114}$

Another novel element introduced by this census was the division of the population by age groups. Thus, from a numerical point of view, in the censuses carried out in 1900 and 1910, the age group 20-39 years predominated, followed by the 40-59 age group. ${ }^{115}$

Moreover, a column was included for recording the population that could speak Hungarian. In 1900, 778 speakers of Hungarian ${ }^{116}$ were registered, and in 1910, this number rose to $842 . .^{117}$

A huge leap can also be seen in the literate population because in 1900, 307 inhabitants of the village could read and write, ${ }^{118}$ which represents an improvement compared to the 1880 census. Thus, before the Great War, the village of Dămăcușeni took the second place (after Târgu-Lăpuş) among the neighboring communities, with its 493 inhabitants who could read and write. ${ }^{119}$ On the other hand, there was a decline in the married population. According to the last censuses, there were more unmarried people. ${ }^{120}$

\section{Evolution of the total population in Dămăcușeni village}

Thanks to the censuses carried out between 1850 and 1910, the population of Dămăcușeni village can be studied from other perspectives as well. Here we are taking into account the quantitative and socio-professional criteria.

The total population of the village has varied over time (Fig. 8). It increased from 643 inhabitants in 1850 to 949 inhabitants in $1910 .{ }^{121}$ During this period, the population increased from 1850 to 1869 . After 1880, there was a significant decrease of 73 people compared to the previous census. This was due to the mortality rate, influenced by diseases such as cholera, smallpox, and sore throat. This rate scored much higher values than the birth rate. The infant mortality rate was also high because 42 children died between 1869 and 1880 , primarily males. ${ }^{122}$ All these factors have led to a decrease in the total population.

\footnotetext{
111 Rotariu 2003, 194.

112 Rotariu 1999, 393.

113 Rotariu 1999, 393.

114 Rotariu 1999, 375.

115 Rotariu 1999, 392-393; Rotariu 1999-2006, 374-375.

116 Rotariu 1999, 392.

117 Rotariu 1999-2006, 374.

118 Rotariu 1999, 392.

119 Rotariu 1999-2006, 374.

120 Rotariu 1999, 392-393; Rotariu 1999-2006, 374-375.

121 Rotariu 2004, 318; Rotariu 1999-2006, 372.

122 SJM AN, Matricole Confesionale, file 486, fols. 173 v-194 r.
} 


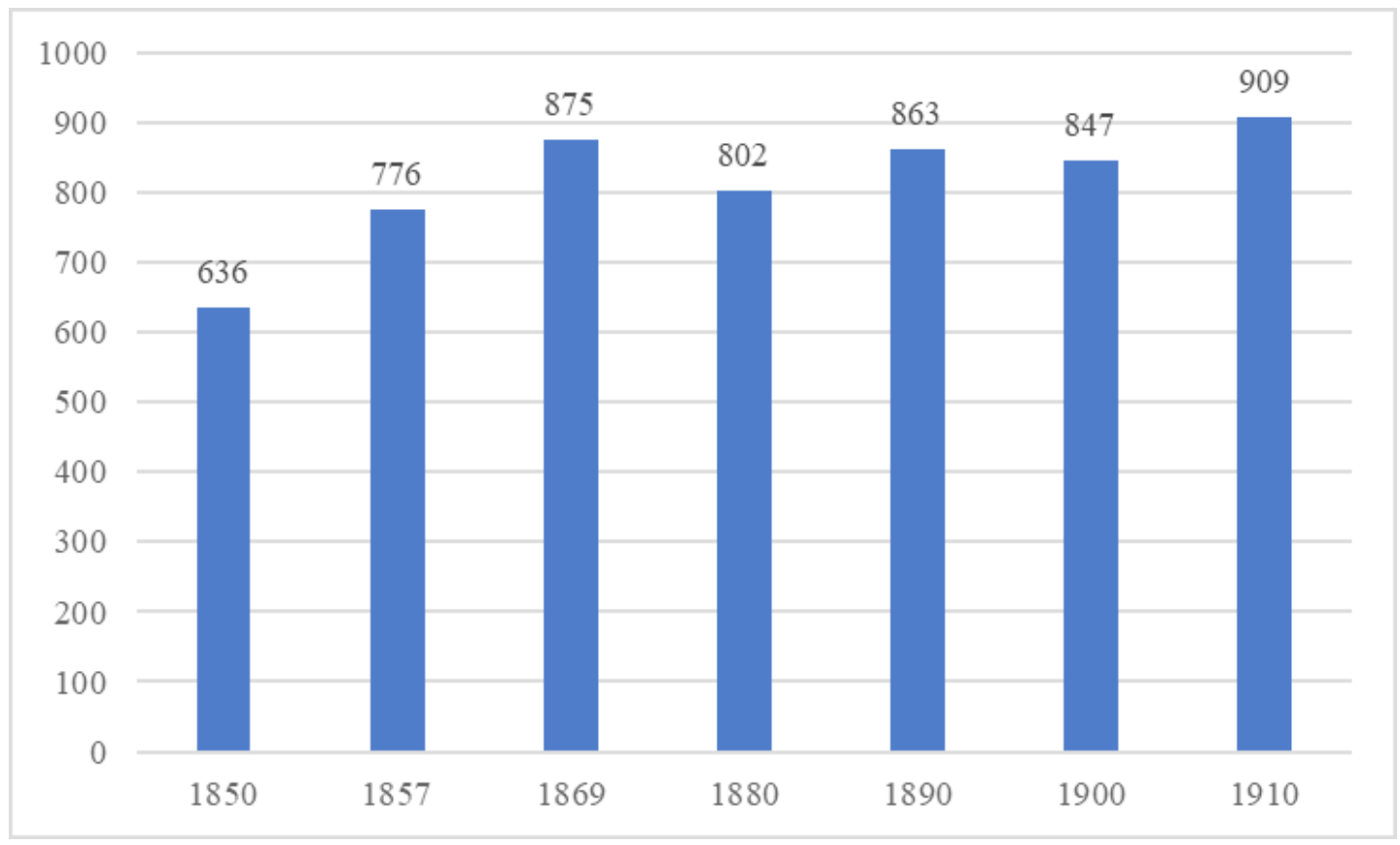

Fig. 8. Evolution of the total population according to the censuses.

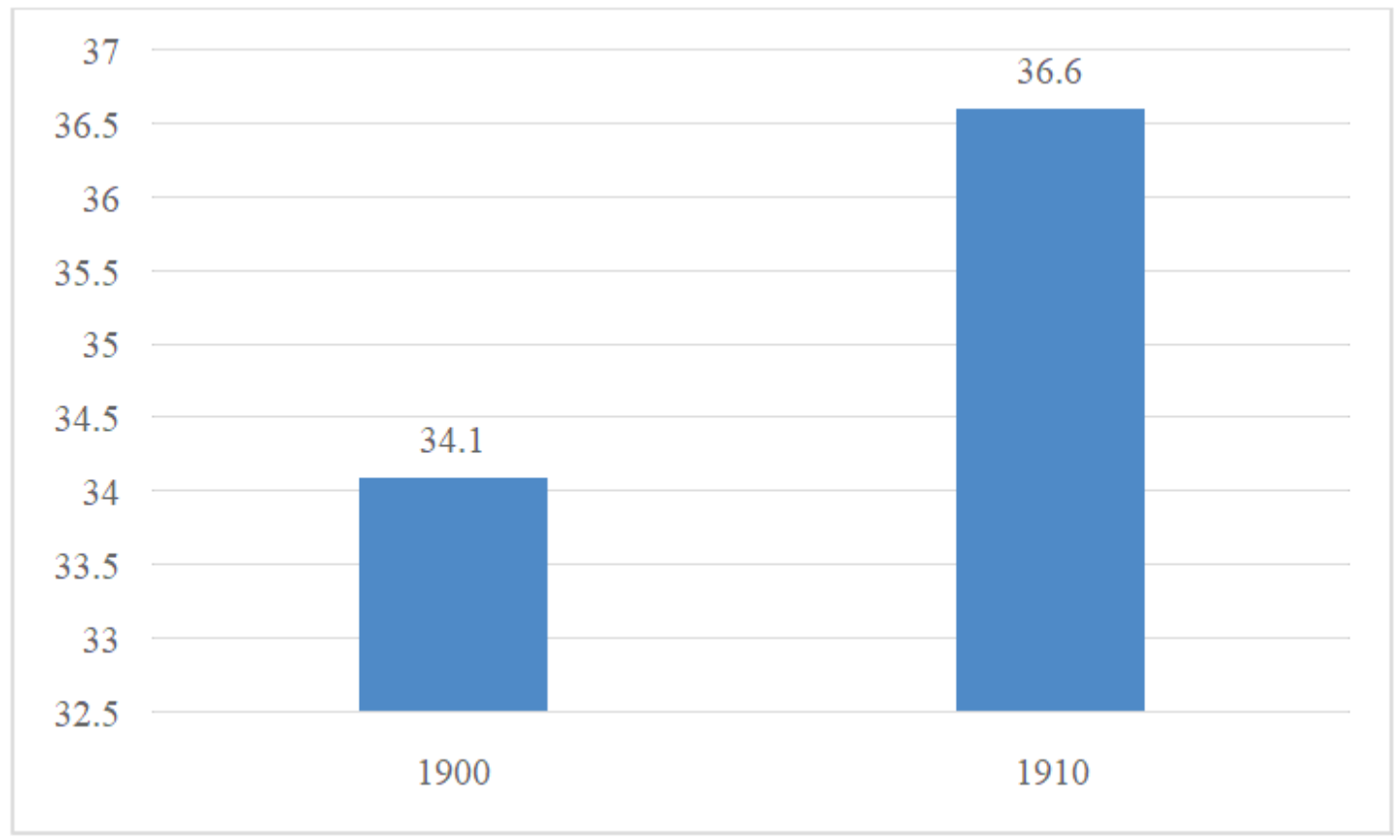

Fig. 9. Population density (inh./ $\left.\mathrm{km}^{2}\right)$.

Then followed a slight growth (between 1880 and 1890) as the number of deaths has significantly decreased. Very rarely, as in 1881 , there were more than 30 deaths, ${ }^{123}$ and

${ }^{123}$ SJM AN, Matricole Confesionale, file 486, fols. 195 v-199 r. 
natality reached more than 20 births each year. In this respect, the highest number of births was registered in 1891, with 39 children, of which 23 males and 16 females. ${ }^{124}$

As in the case of Borcut village, the years 1890-1900 marked a new decline in the population of Dămăcușeni village. This was due to the birth rate, which did not exceed the number of deaths. The infant mortality rate continued to increase, predominantly among male children.

Since 1900 there has been a spectacular increase in population. According to the 1910 census, the village of Dămăcușeni reached a peak of 909 people.

As far as population density is concerned, it can be determined only for two years due to missing data. Therefore, the population density of Dămăcușeni village increased since 1900 from 34.1 inhabitants $/ \mathrm{km}^{2}$ to 36.6 inhabitants $/ \mathrm{km}^{2}$ in 1910.

\section{The occupational structure of the Dămăcușeni village inhabitants}

Thanks to the 1900 census that provides us with data on occupations, we know that the vast majority of the inhabitants (350) were engaged in agriculture and horticulture, 27 were involved in mining and iron industry, 4 practiced commerce and credit business, and 6 inhabitants were in public service and self-employed. ${ }^{125}$ In addition to these, the census also recorded 2 -day workers, 11 domestic servants, and 1 person with an occupation different from those mentioned above. ${ }^{126}$

Agriculture and horticulture

- Mining and iron industry

- Commerce and credit

Public service and selfemployed

- Day workers

- Domestic servants

- Other occupations

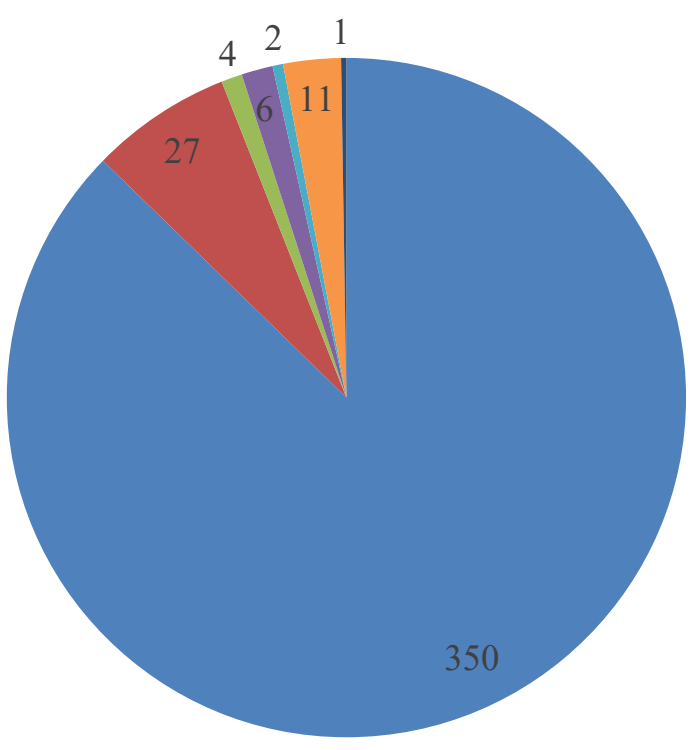

Fig. 10. Population by economic sectors.

\footnotetext{
${ }^{124}$ SJM AN, Matricole Confesionale, file 487, fols. 12 r-16 r.

125 Rotariu 2006, 406.

${ }^{126}$ Rotariu 2006, 406.
} 
We also know that there were 166 small owners or tenant farmers, 7 sharecroppers, 126 auxiliary family members, 34 servants, 1 worker under 16 years, and 16 over this age; 21 men and 6 women were industrial workers ${ }^{127}$ (Fig. 11), placing the village of Dămăcușeni after Târgu Lăpuș in terms of people involved in industry.

Moreover, in this village, there were 1 journeyman, 2 apprentices, 1 servant, 3 blacksmiths, 1 carpenter, 3 shoemakers/bootmakers, 3 millers, 1 butcher, 1 joiner, 8 people working in the hotel or catering business, and 268 people with secondary industrial activities. $^{128}$

Indeed, this diversification of occupations is one of the factors determining a total population growth by 62 people between 1900 and 1910 .

- Small owners or tenant farmers

- Sharecroppers

Auxiliary family members

- Servants

Industry

- Journeymen

- Apprentices

- Servants

- Blacksmiths

- Carpenters

- Shoemakers

— Joiners

- Hotel and catering business

- Secondary industrial activity

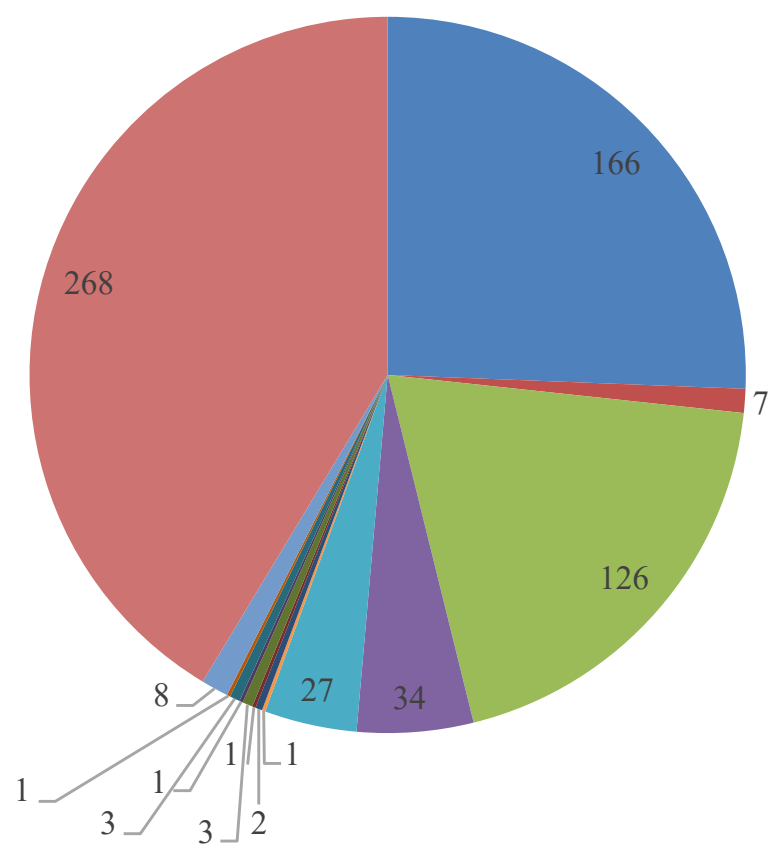

Fig. 11. The occupational structure of the Dămăcușeni village inhabitants.

In this respect, the registers are also useful, as they provide us with data on the occupations of the inhabitants. According to these documents, most of the inhabitants were farmers. A significant part of the male population was enlisted in the army. The registers also include singers, potters, bootmakers, and blacksmiths. ${ }^{129}$

To these we should add the priest, the cantor, the bell-ringer, and the community teacher. In the late nineteenth and early twentieth centuries, the Church, through the priest and his council, provided the leadership of the village. The duties of the priest were to

\footnotetext{
${ }_{127}$ Rotariu 2006, 407.

128 Rotariu 2006, 408-409.

129 SJM AN, Matricole Confesionale, file 486, fols. 151 r-168 r.
} 
hold services and carry out Bible-related work. ${ }^{130}$ The priest officiated liturgies, visited the sick, performed marriages, looked after young people about to be confirmed, and led the religious classes at the public school. ${ }^{131}$

The Council had judicial power in some cases. The Church made decisions for the modernization and beautification of the village. However, they were also interested in peace in the community and in the families, their ultimate purpose being to establish peaceful and harmonious relations between people.

The duties of the cantor throughout the period under review remained almost unchanged, as he was responsible for church and funeral songs, he had to maintain the parish registers, teach young people church songs at the public school (four hours a week), and to attend to the choir. ${ }^{132}$ At first, the cantor was also the schoolteacher, but his duties were taken over by the teacher in time. Therefore, in 1904, the cantor was teaching the pupils only church songs. ${ }^{133}$

As a result, in 1912, the hierarchy in the community's Calvinist Church was as follows: Priest Gyula Kovács, who had been in that position for 30 years, was followed by cantor and parish notary Mihály Lakatos, curator József Pál, and 20 presbyters. ${ }^{134}$

\section{The population of Dămăcușeni village during the First World War}

The First World War resulted in human losses affecting entire Europe. In Transylvania, between 1 August 1914 and 1 November 1918, a total of 926,500 men were recruited, that is, $16.5 \%$ of the total population. ${ }^{135}$ Concerning the village of Dămăcușeni, from the Golden Book of the parish, we learn that a significant number of this village's inhabitants participated in the First World War. ${ }^{136}$ More precisely, we know that in 1914, 34 men participated in the wars against Serbia and Russia, 4 of whom died on the battlefield. ${ }^{137}$ In addition to these, 92 reservists and 14 carriers were recruited. ${ }^{138}$ Of these, 10 reservists and 2 carriers died. ${ }^{139}$

The parish registers indicated the orders of the Administrative Council of the Reformed Diocese of Transylvania and the bishop (numbers 724 and 726, respectively) were brought to the attention of the community of Dămăcușeni on 9 June 1918. According to them, the presbyters had to register the men who had died 'like heroes' on the battlefields of the Great War up to that point, the number of missing, of prisoners, of those who returned wounded from the war, and, last but not least, the number of widows and orphans were also to be recorded. ${ }^{140}$ They also had to state whether there were any adoption cases. ${ }^{141}$ According to the calculations made by the presbyters, the following data are relevant for Dămăcușeni:

\footnotetext{
${ }^{130}$ SJM AN, Oficiul parohial reformat Dămăcușeni, file 4, fol. 62 v.

131 SJM AN, Oficiul parohial reformat Dămăcușeni, file 4, fol. 62 v.

132 SJM AN, Oficiul parohial reformat Dămăcușeni, file 3, fol. 51 r-v.

133 SJM AN, Oficiul parohial reformat Dămăcușeni, file 13, fol. 1 r-v.

${ }^{134}$ SJM AN, Oficiul parohial reformat Dămăcușeni, file 13, fol. 8 r.

135 Bolovan, Bolovan 2007, 165.

${ }^{136}$ Cartea de aur/Aranykönyv [The Golden Book].

137 Cartea de aur.

138 Cartea de aur.

139 Cartea de aur.

140 SJM AN, Oficiul parohial reformat Dămăcușeni, file 3, fol. 89 v.

141 SJM AN, Oficiul parohial reformat Dămăcușeni, file 3, fol. 89 v.
} 
28 deceased, 2 missings, 22 prisoners, 15 widows, 34 paternal orphans. ${ }^{142}$ According to their report, there were no maternal or tutor orphans in this village, so there were no adoption cases. Nevertheless, the Great War left 34 children fatherless. ${ }^{143}$

As is known, several demographic changes took place in Transylvania during the war. They affected natality, nuptiality, and mortality. ${ }^{144}$ In this regard, it should be noted that similarly to other communities in Transylvania, the village of Dămăcușeni underwent some changes already in the period preceding the Great War. In this sense, the birth rate began to decline steadily from 1912 onwards. ${ }^{145}$ This low birth rate trend continued during the First World War. However, our attention is drawn by the fact that the effects were not visible in the first year of the war, only beginning with 1915 . The birth rate began to rise immediately after the end of the war, reaching a new peak in 1920, when 22 children were born. ${ }^{146}$

A setback was registered in the case of nuptiality, too. The number of marriages, like the birth rate, began to fall before the war. In 1910, for example, the last record number of marriages was $14,{ }^{147}$ after which their number began to vary, showing a decreasing tendency. The effects of the war were not felt in 1914 either (when 7 marriages were concluded ${ }^{148}$ ). However, from 1915 onwards, the number of marriages fell drastically. As a result, only 11 marriages were concluded in the four years of the war. ${ }^{149}$ The end of the war meant for Dămăcușeni village, as for the rest of Transylvania and the world, a 'marriage boom,' since in 1919 , a total of 28 marriages were concluded. ${ }^{150}$

All the issues discussed so far can be explained by the fact that young men could not marry and have children due to the outbreak of the First World War, which meant they were conscripted and sent to the front for an extended period. ${ }^{151}$ The men who were already married at the outbreak of the war had the same fate, as they did not have the possibility to increase the number of family members they already had. ${ }^{152}$ However, as we have seen, immediately after the end of the Great War, both birth and marriage rates increased significantly.

As far as mortality is concerned, it should be noted that, despite the data mentioned above, the parish registers of civil status contain only 3 deaths caused by diseases acquired during the war. Of these, two men, József Miklos and János Pál, both married, were from Dămăcușeni village ${ }^{153}$ and died in 1917. The third man, József Gothárd, was a lieutenant major of Unitarian confession; he came from Kohóvölgy (today Strâmbu-Băiuț) and died in $1918 .{ }^{154}$

\footnotetext{
${ }^{142}$ SJM AN, Oficiul parohial reformat Dămăcușeni, file 3, fol. 90 r.

143 SJM AN, Oficiul parohial reformat Dămăcușeni, file 3, fol. 90 r.

144 Bolovan, Bolovan 2007, 167.

145 SJM AN, Matricole Confesionale, file 487, fol. 64 r.

146 SJM AN, Matricole Confesionale, file 487, fol. 76 r.

${ }_{147}$ SJM AN, Matricole Confesionale, file 487, fol. 118 r.

148 SJM AN, Matricole Confesionale, file 487, fol. $121 \mathrm{r}$.

149 SJM AN, Matricole Confesionale, file 487, fols. 121 r-122 r.

150 SJM AN, Matricole Confesionale, file 487, fol. 125 r.

151 Bolovan, Bolovan 2007, 170.

152 Bolovan, Bolovan 2007, 170.

153 SJM AN, Matricole Confesionale, file 487, fols. 178 r-179 v.

154 SJM AN, Matricole Confesionale, file 487, fol. 179 r.
} 
We also know that during the disturbing events taking place at the end of the war (4 December 1918), Samu Balázs, a 53-year-old man from Dămăcușeni, was shot in Târgu Lăpuș. He was buried by the village priest Gyula Kovács on 5 December 1918. ${ }^{155}$

\section{State measures and interventions concerning the population}

Regardless of ethnicity or denomination, the Church played a significant role in the community, including demographically. An example illustrating the importance of the Church is a circular letter issued by the Evangelical Reformed Consistory of Transylvania in Cluj, on 2 December 1842. It states that a smallpox epidemic affected the village of Dămăcușeni, so the Reformed parish was informed that doctors would come to vaccinate children against smallpox. ${ }^{156}$ Therefore, parents needed to take their children to be vaccinated, and priests had to witness this event and draw up some tables. ${ }^{157}$

At the beginning of the twentieth century, Gyula Kovács, the village priest in that time, corresponded with the Royal Hungarian Central Statistics Office (founded in 1867 by Károly Keleti ${ }^{158}$ ). In this regard, two questionnaires concerning the population in 1907 and 1908, respectively, remained in the parish archives. The questionnaires had to be completed in two copies: Version B (B. Minta) always remained at the parish (this explains why these documents were kept in the archive fonds). The other copy was sent to the institution mentioned above within 14 days. ${ }^{159}$ According to the excerpt from Law no. 1897, tome XXXV, we learn that all town halls and parishes had to submit the requested data $(\$ 9) .{ }^{160}$ The task of the Royal Hungarian Central Statistics Office was to keep records of the population of the Hungarian Kingdom and to point out annual changes (\$1). ${ }^{161}$ Therefore, this institution was responsible for collecting and processing data to be used for scientific and legal purposes by the Hungarian Crown $(\$ 1) .{ }^{162}$ False data provided voluntarily, incorrect or only partial completions of the questionnaires could lead, according to the law, to the fining of the persons responsible for their preparation, with amounts of up to 100 kroner $(\$ 13) .^{163}$

All these measures illustrate the state's concern and interest in controlling the health system and optimizing the population's life conditions.

\section{Conclusions}

Through this study, we tried to highlight the main demographic phenomena that marked the Hungarian community in the village of Dămăcușeni during the years 17651918. Although the first entries in the registers seem to be incomplete, they allow us to note that both the birth rate and the mortality rate reached high values during the entire period of interest. Births took place at home, with the help of local midwives, and children were

\footnotetext{
155 SJM AN, Matricole Confesionale, file 487, fol. $180 \mathrm{r}-\mathrm{v}$.

156 SJM AN, Oficiul parohial reformat Dămăcușeni, file 1, fol. 14 v.

157 SJM AN, Oficiul parohial reformat Dămăcușeni, file 1, fol. 14 v.

158 Bolovan 2000, 10.

159 SJM AN, Oficiul parohial reformat Dămăcușeni, file 4, fol. 103 r.

160 SJM AN, Oficiul parohial reformat Dămăcușeni, file 4, fol. 105 r.

161 SJM AN, Oficiul parohial reformat Dămăcușeni, file 4, fol. 105 r.

162 SJM AN, Oficiul parohial reformat Dămăcușeni, file 4, fol. 105 r.

163 SJM AN, Oficiul parohial reformat Dămăcușeni, file 4, fol. 105 r.
} 
baptized shortly after birth. The next important event in the life of a person of the Calvinist faith was confirmation. Consequently, confirmation records reveal the number of people who survived childhood diseases often circulated in Dămăcușeni.

With regard to nuptiality, we see that although sometimes community members chose their life partner from other localities, very few mixed marriages were concluded, most probably due to religious reasons. Mortality was mainly influenced by various diseases and epidemics marking the Transylvanian area in the nineteenth century, such as cholera, and to a lesser extent by the famine of 1716-1717, the First World War, and childbirth accidents. Despite all this, as shown in Figure 12, birth rates were much higher than death rates, except for the periods of crisis, after which mortality decreased relatively fast to pre-crisis levels.

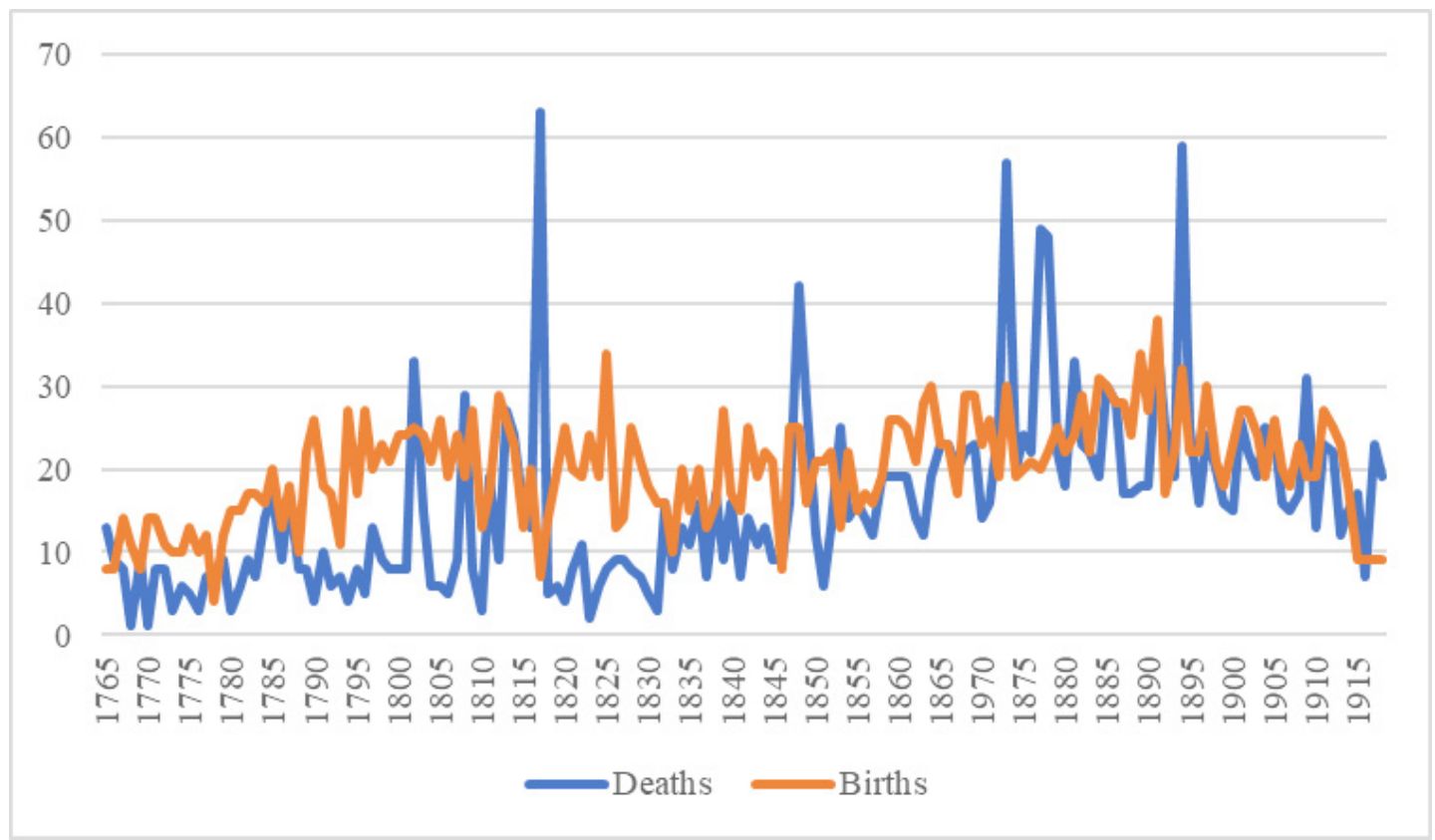

Fig. 12. The number of births correlated with the number of deaths during 1765-1918.

Thus, in the case of Dămăcușeni village, as in most of the villages in the Târgu Lăpuş area, according to the census records and the data we have, we notice population growth that is specific to the region of Transylvania.

\section{Bibliography}

\section{Primary sources}

\section{Cartea de aur}

SJM AN, Oficiul parohial reformat Dămăcușeni

SJM AN, Matricole Confesionale
Cartea de aur/Aranykönyv [The Golden Book], Arhiva Parohiei Reformate Dămăcușeni, sat Dămăcușeni, nenumerotat.

Serviciul Județean Maramureș al Arhivelor Naționale, Oficiul parohial reformat Dămăcușeni Fonds, Dosarele 1, 3, 4, 13.

Serviciul Județean Maramureș al Arhivelor Naționale, Colecția Matricole Confesionale Fonds, Dosarele 484, 485, 486, 487. 


\section{Studies and articles}

Müllerson et alii 1998

Bolovan 2007

Bolovan, Bolovan 2007

Bolovan 2000

Brie 2008

Ciocotișan-Miron 2002

Dumănescu 2019

Entz 1943

Kádár 1900

Kolumbán 2011

Lukács 2005

Nagybányai Hírlap 1910

Pakot 2002
R. A. Müllerson, M. Fitzmaurice, M. Andenas (eds.), Constitutional Reforms and International Law in Central and Eastern Europe, The Hague-Boston 1998.

I. Bolovan, Aspecte privind impactul demografic și mental al epidemiilor în spațiul ardelean în secolul al XIX-lea. In: N. Edroiu, S. Andea, Ș. Turcuș (eds.) Națiune și europenitate. Studii istorice. In honorem Magistri Camil Mureșanu, București 2007, 228-241.

S. P. Bolovan, I. Bolovan, Demographic phenomena and behaviour in Transylvania during World War I, Romanian Journal of Population Studies, I/1-2 (2007), 164-180, http://dspace.bcucluj. ro/jspui/bitstream/123456789/47835/4/Bolovan\%2bIoan-Dem ographic $\% 2$ bphenomena $\% 2$ band $\% 2$ bbehaviour-2007.pdf, accessed 6 Jul. 2021.

I. Bolovan, Transilvania între Revoluția de la 1848 și Unirea din 1918. Contribuții demografice, Cluj-Napoca 2000.

M. Brie, 'Crizele de mortalitate și vulnerabilitatea comunităților bihorene și sătmărene în fața morții (a doua jumătate a secolului XIX-începutul secolului XX), MPRA 2008 https:// mpra.ub.uni-muenchen.de/44174/1/MPRA_paper_44174.pdf, accessed 6 Jul. 2021.

A. Ciocotișan-Miron, Problema căsătoriei și a familiei în parohia reformată Dămăcușeni (jud. Maramureș) între 1771 și 1930. In: I. Bolovan (ed.), Transilvania în epocile modernă și contemporană. Studii de demografie istorică, Cluj-Napoca 2002, 125-136.

L. Dumănescu, M. Eppel, The Politics of Birth in Composite States: Midwives in Transylvania (19 $9^{\text {th }}-20^{\text {th }}$ Century), Romanian Journal of Population Studies, 13/1 (2019), 7-27.

G. Entz, Szolnok-Doboka Középkori Müvészeti Emlékei, Cluj 1943.

J. Kádár, Szolnok-Dobokavármegye Monographiája, vol. III, Dej 1900.

V. J. Kolumbán, A konfirmáció bevezetése az erdélyi református egyházakban. Káté és katekézis, Református Szemle, 104/6 (2011), https://konyvtar.proteo.hu/sites/konyvtar.proteo.hu/files/ documents/2011/1477938385.pdf, accessed 21 May 2021.

O. Lukács, Premisele juridice ale căsătoriilor mixte în Biserica Reformată din Ardeal în secolele XVII-XIX. In: C. Pădurean, I. Bolovan (eds.), Căsătorii mixte în Transilvania: secolul al XIX-lea și începutul secolului XX, Arad 2005, 67-82.

Nagybányai Hírlap, 41 (9 október 1910) https://library.hungari cana.hu/hu/view/NagybanyaiHirlap_1910/?query=domokosfalva\&pg=338\&layout=s, accessed 6 Jul. 2021.

L. Pakot, Aspecte privind fenomenul mortalității în satul Vlăhița (jud. Harghita) între 1776 și 1895. In: I. Bolovan (ed.), Transilvania în epocile modernă și contemporană. Studii de demografie istorică, Cluj-Napoca 2002, 211-228. 
Pokoly 1905

Rotariu 2003

Rotariu 2003

Rotariu 2004

Rotariu 1996

Rotariu 1997

Rotariu 2009

Rotariu 1999

Rotariu 1999-2006

Rotariu 1999-2006

Ștef 2016
J. Pokoly, Az Egyházi Intézmények Története, vol. IV, Budapest 1905.

T. Rotariu, Recensământul agricol din 1895. Transilvania, vol. I, Cluj-Napoca 2003.

T. Rotariu, Recensământul agricol din 1895. Transilvania, vol. II, Cluj-Napoca 2003.

T. Rotariu, Recensământul din 1850. Transilvania, Cluj-Napoca 2004.

T. Rotariu, Recensământul din 1857. Transilvania, București 1996.

T. Rotariu, Recensământul din 1880. Transilvania, București 1997.

T. Rotariu, Recensământul din 1890 și recensământul țiganilor din 1893. Transilvania, Cluj-Napoca 2009.

T. Rotariu, Recensământul din 1900. Transilvania, vol. I, București 1999.

T. Rotariu, Recensământul din 1900. Transilvania, vol. II București 1999-2006.

T. Rotariu, Recensământul din 1910. Transilvania, București 1999-2006.

D. Ștef, Dicționar etimologic al localităților din județul Maramureș, Baia Mare 2016. 


\title{
THE USE OF SOME DIGITAL INSTRUMENTS IN THE STUDY OF THE GREEK CATHOLIC HIGH SCHOOL IN BEIUS,
}

\author{
ALEXANDRU-AUGUSTIN HAIDUC*
}

\begin{abstract}
This study sketches some of the innovative approaches to be used in a planned monograph of the Greek Catholic High School of Beiuș during the nineteenth century and the first quarter of the twentieth century. It aims to use a sample of pupils and teachers from between 1876 and 1882. On the one hand, by employing a database of the pupils that studied at the high school and coding systems for historical occupational data, the intergenerational social mobility of the pupils is briefly analyzed. On the other hand, an online, hybrid visualization software (Nodegoat), is used to geographically project the intellectual and professional formation of the high school's teachers.
\end{abstract}

Keywords: Beiuș, education, Digital Humanities, databases, social mobility

Rezumat: Prezentul studiu schițează unele direcții novative pe care intenționăm să le aplicăm într-o viitoare monografie a Gimnaziului superior greco-catolic din Beiuș, recurgând la un eșantion cuprinzând perioada 1876-1882. Pe de o parte, făcând apel la o bază de date cuprinzând elevii Gimnaziului și la sistemele de codare a ocupațiilor istorice, analizăm mobilitatea socială intergenerațională în rândul elevilor. Pe de altă parte, recurgem la Nodegoat, un serviciu online hibrid, pentru a vizualiza geografic traseul formării intelectuale și profesionale a dascălilor beiușeni.

Cuvinte cheie: Beiuș, educație, Digital Humanities, baze de date, mobilitate socială

\section{Introduction}

There is no general agreement in the Romanian historiography regarding the stage of knowledge on the Greek Catholic High School of Beiuș/Belényes. On the one hand, Iudita Călușer and Constantin Stelaru (Mălinaș) claim that the information provided by the secondary literature, high school yearbooks, and press are rather lapidary, the exploitation of the archival materials related to the topic being opportune. ${ }^{1}$ Viorel Faur claims that the history of the education in Bihor is little known, 'cu excepția perioadei de la finele veacului al XVIII-lea și începutul celui următor' [except for the time frame at the end of the eighteenth century and the beginning of the subsequent one]. ${ }^{2}$ On the other hand, more recently, Blaga Mihoc states, in one of his many works, that the history of the high school in Beiuș was largely unearthed, yet there is still a significant number of new or little known sources. ${ }^{3}$ However, it is a fact that there is still no monograph on the Beius high school done professionally and comprehensively. The historiographical contributions referring to

\footnotetext{
* Ph.D. Student, 'BabeșBolyai' University, Cluj-Napoca, email: haiduc_alexandru1996@yahoo.ro, (D) https://orcid.org/0000-0002-6663-487X.

${ }^{1}$ Călușer, Stelaru (Mălinaș) 1982, 411.

${ }^{2}$ Faur 1972, 317.

3 Mihoc 2003, 117.
} 
the high school located in Beiuș are either old or unadjusted to the new historical analysis and interpretation methods. They are disparate and deal with minor aspects of the high school's past. Thus, a re-evaluation of the high school's existence is justified, and this study is a proposal to prefigure it, representing a sample of a planned monograph. The present article addresses two aspects that are intended to be seen in the future monograph, social mobility, respectively data visualization.

\section{Methodological aspects}

Beyond the qualitative methods of the historical writing used, such as historical reconstruction, source hermeneutics, comparison, deduction, and induction, a strong emphasis on the quantitative methods is intended, which are more and more present in the Romanian historiographical environment. Furthermore, I aim at connecting my research to the contemporary historiographical trends and to the use of the latest technological means to render more faithfully the history of the Beius, high school.

Based on the premise that the most important actors in the educational process are the students and the teachers, the main approach used is prosopographical. Approaching history in the long term, the paper examines the main trends that the high school in Beius, faced. Elements to be considered include the human component (students and teachers) and the curriculum in the nineteenth century and the first quarter of the twentieth century. At this stage, to exemplify the methodological directions used, I am resorting to a chronological cut-out (1876-1882), as the continuous series of high school yearbooks only starts with the school year 1876-1877. The yearbooks of the high school had appeared sporadically for the previous school years and did not contain enough information for an optimal prosopographical interpretation. ${ }^{4}$

Regarding the primary sources used, they are situated mainly in the archival fonds of Liceul „Samuil Vulcan” Beiuș, located within the Bihor County Service of the National Archives, organized in three parts: Matricole și registre școlare (inventory no. 1020), Corespondență fără registre (inventory no. 1021), and Registre de intrare-ieșire. Indexe (inventory no. 1022). At the same time, the development of the high school in Beius is partially approached in some files within the fond of the Greek-Catholic Episcopate of Oradea (inventory no. 1403, respectively 881 microfilm), which are kept by the above-mentioned county service. As a chronological interval, the school transcripts, the archival sources on which I focused mainly so far, cover an extended period, starting with 1851 . As mentioned above, at this research stage, I am interested only in the period starting with the school year 1876-1877.

A tool employed in the management and exploitation of the information provided by archives and yearbooks is a database, ${ }^{5}$ currently in the making. It brings together all the students who studied at the high school in the analyzed chronological interval. In addition to the information concerning the first name, last name, religion, place of birth, year of birth, fraternal ties between students, and various mentions, the database mainly assesses the intergenerational social mobility of students from Beiuş in relation to their parents. In this regard, the coding systems of occupations and social stratification, Historical Standard

\footnotetext{
${ }^{4}$ Further information in: Dudaș 2004; Mălinaș 2003.

5 The database is accessible at https://airtable.com/shrilnSNjci1BgOwz.
} 
Classification of Occupations (HISCO), Historical International Social Class Scheme (HISCLASS) and HIStorical CAMsis (HISCAM), were utilized to code occupations that the parents or the guardians of students had. Another tool from the field of Digital Humanities used is the digital geographical annotations in QGIS. Using QGIS, a digitized map of the Habsburg Empire dating to 1856 was annotated with the birthplaces of students who studied in Beius, where information was available and places could be identified. I will not get into technical details about the instruments mentioned above, as the subject has been the subject of a previous study. ${ }^{6}$ Regarding the teachers who worked at the Beiuss high school, the facilities offered by Nodegoat ${ }^{7}$ were called into play in order to geographically visualize the centers where they had studied and the schools they had taught prior to their installation in Beiuș.

\section{Social mobility}

The database mentioned above proved to be especially useful in assessing social mobility. The goal is to analyze social mobility, in its intergenerational dimension, and how it manifests itself in the case of the students of the Greek Catholic High School in Beiuș in the second half of the nineteenth century. Given the small sample of the occupational statuses held after graduation by the students, this study concerns mainly with the directions wished to be applied in the planned monograph of the high school.

According to Pitirim Sorokin, social mobility is the phenomenon of the movement of individuals in the social space. ${ }^{8}$ It is of two types. In horizontal mobility, the individual moves from one social status to another, but the statuses are at the same level. Vertical mobility requires the individual to move from one social status to another and the acquired status is on a level either higher or lower than the previous one. ${ }^{9}$ A special form of vertical social mobility is represented by intergenerational social mobility. It considers the relationship between the status of the individual and of his parents at a given time. ${ }^{10}$

Using the digital tools already mentioned and importing methodology from the international literature, especially the use of coding and social comparison systems of historical occupations, HISCO, ${ }^{11}$ HISCLASS, ${ }^{12}$ and HISCAM,,${ }^{13}$ I listed the occupations held by the students' parents and also pinpointed the occupations some students acquired after graduation. ${ }^{14}$ The purpose of this approach is to determine the extent of intergenerational social mobility in the case of the students. I believe this will be reflected better after long-term data is acquired, hoping that the after-graduation evolution of several hundred students will be known. ${ }^{15}$

Even though the social status has been dominant in determining social mobility, today, the occupation of individuals is accepted as a good indicator for intergenerational

\footnotetext{
${ }^{6}$ Haiduc 2020.

7 https://nodegoat.net.

${ }^{8}$ Sorokin 1927, cited in Roșu 2016, 27.

9 Sorokin 1927, cited in Roșu 2016, 27.

${ }_{10}$ Dearden et alii 1997, 47-48; Miles 1999, 14-15.

11 van Leeuwen et alii 2004; van Leeuwen et alii 2002.

${ }^{12}$ van Leeuwen, Maas 2011; van Leeuwen, Maas 2005.

13 Lambert et alii 2013.

14 Pavel 2009, 186-188; Mîndruț 1986.

15 Roșu 2016, 28; Treiman 1977, 1; van Leeuwen, Maas 2010, 443.
} 
social mobility. However, to be effective, the use of occupational models as an indicator for social mobility must refer to a classification of occupations. This is why the use of the coding mentioned above and comparison systems is important.

I consider a brief excursion on the above-mentioned systems of coding historical occupations necessary. The Historical Standard Classification of Occupations (HISCO) is a system used for coding historical occupations derived from ISCO-68, a system for coding contemporary occupations developed by the International Labor Organization. ${ }^{16}$ Thus, each occupation is rendered by a six-digit code and is assigned to a minor group. In turn, they are included in ten major groups. At the same time, HISCO integrates codes for status, relationship, and product, in case the historical sources used provide information that cannot be compressed in a six-digit code. ${ }^{17}$ A HISCO extension, The Historical International Social Class Scheme (HISCLASS) organizes occupation codes into ten major groups. It is done based on criteria including manual or non-manual labor or the economic sector. Last but not least, HIStorical CAMsis (HISCAM) organizes the occupations brought together by HISCO according to the intensity of the social relations between the occupations..$^{18}$ Starting from CAMSIS (Cambridge Social Interaction and Stratification), HISCAM realizes a scale of historical occupations, depending on the intensity and number of relationships such as marriage, friendship, parent-child registered between occupations. HISCAM was developed based on historical databases in seven countries (Belgium, Great Britain, Canada, France, Germany, the Netherlands, and Sweden) concerning the period between 1800 and $1938 .{ }^{19}$

As for the international scientific tendencies, the concerns about social mobility are mainly the prerogative of sociology, such scientific approaches finding precedent, as it has been seen, in the contributions of Pitirim Sorokin. ${ }^{20}$ Within sociology, two hypotheses have been developed regarding social mobility. Both of them postulate that social mobility is stable in the long run, especially after the industrial revolution. ${ }^{21}$ On the one hand, the LZ hypothesis (formulated by Lipset and Zetterberg) argues that industrial societies experience similar rates of intergenerational mobility, regardless of the degree of economic expansion. ${ }^{22}$ On the other hand, the FJH hypothesis (theorized by Featherman, Jones and Hauser) argues that intergenerational mobility is similar only in the market economy societies with nuclear families. ${ }^{23}$ Even though the LZ hypothesis ${ }^{24}$ has fallen into disuse, and the FJH hypothesis has been relatively accepted, with the adjustments made by Erikson and Goldthorpe, ${ }^{25}$ there is still no consensus on social mobility in the industrial age, and the question of whether

\footnotetext{
${ }^{16}$ van Leeuwen, Maas 2005.

17 van Leeuwen et alii 2002, 192.

18 van Leeuwen, Maas 2010, 433.

19 Lambert et alii 2013, 79.

20 Sorokin 1927, Sorokin 1957.

${ }^{21}$ van Leeuwen, Maas 2010, 435.

22 van Leeuwen, Maas 2010, 435.

${ }^{23}$ van Leeuwen, Maas 2010, 435.

${ }^{24}$ For instance, Sewell talks about the problem of the city of Marseille as early as 1976 and notes that intergenerational mobility encountered is different from the grid postulated by Lipset and Zetterberg (Sewell 1976, 218).

${ }^{25}$ Erikson, Goldthorpe 1992, cited in Ganzeboom 1989, 6.
} 
it is mostly ascending, descending, or whether it remains constant, persists ${ }^{26}$ in a series of studies. ${ }^{27}$ Complementary to the theories on social mobility, mentioning the structural theory of determining prestige, enunciated by Donald J. Treiman, is important. According to Treiman's theory, power relations determine a similar hierarchy of prestige in all societies with complex organization. ${ }^{28}$ Even if there is still no consensus on social mobility and how it manifests itself, Treiman's theory legitimizes the efforts to establish universal systems for coding occupations. Thus, the coding systems referred to above, HISCO, HISCLASS, and HISCAM, were born. In line with the information provided by historical databases, the use of such tools is promising and, in fact, allows for the resolution of the scientific dispute over social mobility in the modern era. ${ }^{29}$ The new hypothesis that seems to be emerging is that social mobility has varied from one industrial society to another and does not follow a single pattern, nor is it constant. ${ }^{30}$

As for the national scientific tendencies, concerns about social mobility are mostly present in the field sociology as well, ${ }^{31}$ and historians have, until recently, timidly used this direction of research. ${ }^{32}$ However, the situation is justified, given that the historian cannot use interviews or questionnaires as sources, his sources being designed for a purpose other than sociological. ${ }^{33}$ Moreover, such a direction of historical research requires extensive information integrated into historical databases and systems for coding historical occupations within them. Until the development of the Historical Population Database of Transylvania, ${ }^{34}$ such databases did not exist, and the coding systems of historical occupations were relatively recently used. The recent contributions brought by Raluca Botoș $^{35}$ and Elena Crinela Holom ${ }^{36}$ should be noted for the Transylvanian space.

As can be seen in the database I build, information on the parents of the students was added. Specifically, HISCO (including codes for status, relationship, and product), HISCLASS, and HISCAM codes were assigned to the occupation of each parent or guardian of the students. ${ }^{37}$ The codes were allocated based on the information provided by the school transcripts within the Fonds Liceul „Samuil Vulcan” Beiuş held by the Bihor County Service of the National Archives ${ }^{38}$ and by the Beius high school yearbooks.

Subsequently, the database was completed with a new table that provides information on the occupation that the students acquired after graduation, at some point in their lives,

\footnotetext{
${ }^{26}$ van Leeuwen et alii 2016, 585 .

27 The following contributions are listed as an example: Dearden et alii 1997; Miles 1999; Pickens 1978; Sewell 1976.

28 Treiman 1977, 2.

${ }^{29}$ van Leeuwen et alii 2016: using occupational coding systems and extensive samples provided by historical databases, the article determines the nature of social mobility in France from 1720 until 1986.

30 van Leeuwen et alii 2016, 580.

${ }^{31}$ For example, Pop 2015; Roșu 2016.

${ }^{32}$ For example, Popa-Andrei 2015.

${ }^{33}$ Miles 1999, 14-15.

${ }^{34}$ Bolovan et alii 2019.

35 Botoș 2019.

36 Holom 2016.

37 I once again mention that the database is accessible at the following address: https://airtable.com/ shri1nSNjci1BgOwz.

38 SJB AN, Liceul „Samuil Vulcan”, no. 1020, dossiers no. 26, 27, 28, 29, 30, 31, 32.
} 
based on the lists of students included in the monograph signed by Constantin Pavel ${ }^{39}$ and other works. ${ }^{40}$ In a manner similar to the occupations of the parents or guardians, the occupation acquired by each student was assigned HISCO (including codes for status, relationship and product), HISCLASS and HISCAM codes.

In contrast to the information on the parents or guardians of students, the sources used for post-graduation occupations are exclusively secondary, ${ }^{41}$ as there is no complete data set on the evolution of the graduates. The lack of such a source led to a smaller sample of the occupations acquired by the students. This comes in sharp contrast with the sample of occupations of the parents or guardians. However, I appreciate that in the future the analysis of the intergenerational mobility for a larger number of students will be enabled, mainly through their nominal identification in the multitude of digitized periodicals, provided both by the Central University Library 'Lucian Blaga' in Cluj-Napoca ${ }^{42}$ and ADT Arcanum database from Hungary. ${ }^{43}$

Ultimately, the goal of this approach is a triadic one. First of all, the intended purpose is to compare the data on the occupation of the parents or guardians with the data on the after-graduation occupations of the students. It helps determine how intergenerational mobility manifests itself in the case of the students of the high school in Beiuș. Secondly, the contextualization of the results obtained to hypotheses encountered in the national literature is desired. For example, it can be observed to what extent the phenomenon of priestly dynasties, discussed by Mirela Popa-Andrei in the case of the Greek Catholic canons of Oradea ${ }^{44}$ includes the students from Greek Catholic priestly families as well. Moreover, in general, it can be observed to what extent it can be discussed about professional dynasties or about models of intergenerational occupational changes (from a certain type of profession to others). In the case of the students from the same family, it can be observed if the position of the child in the family (the number of children born) has influenced their career path after graduation. Thirdly, the results obtained will be compared with those in other European geographical areas to determine to what extent the intergenerational mobility encountered in the case of the Beiuss students is similar to that encountered in other geographical areas.

At this level of research, limiting myself to comparing the information on parental occupation with the data on the students' subsequent careers and determining intergenerational social mobility becomes a prerequisite.

In the table below the comparison of the two codes, namely HISCLASS and HISCAM, can be observed related to the occupations that parents and students held at one time. The three types of intergenerational social mobility are descending, stagnant, and ascending. The intergenerational social mobility can be observed for a sample of 39 parent-student pairs: for 16 students, the intergenerational social mobility is upward; in the case of 13 students, the intergenerational social mobility is stagnant; in the case of a single

\footnotetext{
39 Pavel 2009, 186-188

${ }^{40}$ Mîndruț 1986.

${ }^{41}$ For example: Câmpean 2008; Câmpean 2010a; Câmpean 2010b; Dulgău, Porumbăceanu 2010; Neagu 2018; Neagu 2017; Neș 2006; Sigmirean 2000.

${ }^{42}$ See http://dspace.bcucluj.ro/ și http://documente.bcucluj.ro/periodice.html.

${ }^{43}$ See https://adtplus.arcanum.hu/en/.

${ }^{44}$ Popa-Andrei 2015.
} 


\begin{tabular}{|c|c|c|c|c|c|c|}
\hline ID & $\begin{array}{c}\text { Last name } \\
\text { student }\end{array}$ & $\begin{array}{c}\text { First name } \\
\text { student }\end{array}$ & $\begin{array}{c}\text { HISCLASS } \\
\text { student }\end{array}$ & $\begin{array}{c}\text { HISCAM } \\
\text { student }\end{array}$ & $\begin{array}{l}\text { HISCLASS } \\
\text { father }\end{array}$ & $\begin{array}{c}\text { HISCAM } \\
\text { father }\end{array}$ \\
\hline 67 & Pârvu & Mihailu & 3 & 99 & 12 & 51 \\
\hline 74 & Antal & Augustinu & 3 & 99 & $3 / 2$ & 99/99 \\
\hline 95 & Budó & Nicolau & 3 & 99 & 4 & 54 \\
\hline 97 & Marga & Demetriu & 3 & 99 & 12 & 51 \\
\hline 108 & Bulcu & Teodoru & 2 & 67 & - & - \\
\hline 111 & Buder & Franciscu & 2 & 99 & 5 & 64 \\
\hline 114 & Gavra & Alesandru & 3 & 99 & 12 & 51 \\
\hline 123 & Papp & Iustinu & 2 & 99 & 3 & 99 \\
\hline 128 & Szilágyi & Gavrielu & - & - & 12 & 51 \\
\hline 140 & Dudulescu & Ioanu & 3 & 99 & - & - \\
\hline 142 & Flonta & Gratianu & 2 & 99 & 12 & 51 \\
\hline 147 & Marianu & Emanuilu & - & - & - & - \\
\hline 163 & Dumbrava & Basiliu & 2 & 67 & 4 & 67 \\
\hline 167 & Iancu & Iustinu & 3 & 99 & 3 & 99 \\
\hline 170 & Ossianu & Augustinu & 2 & 99 & 3 & 99 \\
\hline 172 & Popoviciu & Terentiu & 3 & 99 & 3 & 99 \\
\hline 174 & Selagianu & Florianu & 3 & 99 & 12 & 51 \\
\hline 175 & Teaha & Filipu & 3 & 99 & - & - \\
\hline 181 & Baba & Jacobu & 3 & 99 & 12 & 51 \\
\hline 184 & Cosma & Georgiu & 3 & 99 & 12 & 51 \\
\hline 185 & Dredeanu & Vasiliu & 3 & 99 & 3 & 99 \\
\hline 187 & Filimonu & Iuliu & 2 & 99 & 12 & 51 \\
\hline 191 & Papfalvai & Andreiu & 3 & 99 & - & - \\
\hline 198 & Serbu & Gerasimu & 2 & 99 & 3 & 99 \\
\hline 267 & Ghitta & Corneliu & 3 & 99 & 3 & 99 \\
\hline 273 & Lupanu & Nicolau & 3 & 99 & 12 & 51 \\
\hline 274 & Nyisztor & Iuliu & 3 & 99 & - & - \\
\hline 275 & Ossianu & Pamfilu & 2 & 99 & 3 & 99 \\
\hline 276 & Péter & Franciscu & 3 & 99 & - & - \\
\hline 282 & Tardiu & Augustin & 2 & 99 & 4 & 67 \\
\hline 336 & Bohotielu & Ioanu & 3 & 99 & 12 & 51 \\
\hline 338 & Hoblea & Vasiliu & 3 & 99 & 12 & 51 \\
\hline 348 & Ternovanu & Coriolanu & 3 & 99 & 3 & 99 \\
\hline 402 & Anca & Vasiliu & 3 & 99 & 12 & 51 \\
\hline 406 & Borlanu & Victoru & 2 & 67 & 3 & 99 \\
\hline 409 & Popoviciu & Aureliu & 3 & 99 & 3 & 99 \\
\hline 453 & Paulu & Augustin & 1 & 93 & 3 & 99 \\
\hline 518 & Dascalu & I. Iacobu & 3 & 99 & - & - \\
\hline 519 & Germanu & Petru & 3 & 99 & 12 & 51 \\
\hline
\end{tabular}

Table 1. The HISCLASS and HISCAM codes of the students and parents' occupation for whom we have information, as they appear in the database (https://airtable.com/shrilnSNjcilBgOwz). 
student, the intergenerational social mobility is downward, and for nine students the intergenerational social mobility cannot be determined, as the data on the student, or the data on the father, or the data on both are missing. Thus, descending intergenerational social mobility is an exception, students usually obtaining similar or ascending occupations compared to those of the fathers. However, the data obtained are problematic, as, obviously, the secondary literature only preserves occupations situated at a higher level.

At the same time, the intragenerational social mobility can be evaluated in terms of the occupations that the students' parents had or, rather, in terms of the occupational changes they made. Thus, out of the 492 fathers entered in the database, 11 fathers registered occupational changes, which can also be included in the classification systems of historical occupations. There were noticed occupational changes for mothers and guardians, but one or both occupations cannot be included in the classification systems of historical occupations.

In the case of the 11 fathers who made the transition from one occupational status to another, the changes were made as follows: a butcher (mészáros) becomes an artisan (iparos); a shoemaker (czipész mester) becomes an artisan (iparos); a peasant (földmivelö) becomes an artisan (iparos); a priest (lelkész) becomes archpriest (esperes); a peasant (földmivelö) becomes a singer-teacher (kántor-tánitó); an artisan (mesterember) becomes a potter (fazekasmester); a chaplain (okendész) becomes a forester (erdész); a miller (molnár) becomes an artisan (iparos); an artisan (iparos) becomes a gold miner (aranymüves); an artisan (iparos) becomes a peasant (földmivelö); a singer-teacher (kántor-tánitó) becomes a priest (lelkész). In the case of occupations such as butcher, shoemaker, miller, etc. who make the transition to/from the occupation of artisan, it is believed to be the same category, the teachers registering the same occupation with different terms. Thus, real intragenerational social mobility can be found in the case of six parents, and it is either ascending or descending. In cases of transition from peasant (HISCLASS code 12, HISCAM code 51) to artisan (HISCLASS 11, HISCAM 61), priest (HISCLASS 3, HISCAM 99) to archpriest (HISCLASS 2, HISCAM 99), peasant (HISCLASS 12, HISCAM 51) to singer-teacher (HISCLASS 4, HISCAM 59-67), chaplain (HISCLASS 3, HISCAM 99) to forester (HISCLASS 4, HISCAM 54); singer-teacher (HISCLASS 4, HISCAM 59-67) to the priest (HISCLASS 3, HISCAM 99), intragenerational social mobility is ascending. In only one case, that of the transition from artisan (HISCLASS 11, HISCAM 61) to peasant (HISCLASS 12, HISCAM 51), intragenerational social mobility is descending. Therefore, except for one case, intragenerational social mobility in the case of the parents is vertical and ascending.

\section{Data visualization}

If in the case of the students, Airtable was used for better exploitation of the information. In the case of the teachers, Nodegoat, an online service that offers the possibility to insert information in databases and view it geographically, socially, and chronologically, was used. At this stage of research, I chose to use Nodegoat to perform an analysis of the teachers at a fixed point in time and not in continuous duration. Thus, I introduced the teachers who taught at the high school in Beius at the time of the school year 1878-1879, because for this school year, compared to the rest of the school years analyzed, there was sufficient 
information regarding the biography of the teachers. I appreciate that the degree of use of Nodegoat at this level of research is sufficient. However, in the future, with the deepening of the research topic, it will be necessary to extend the use of this tool to the entire period for which there is information about teachers.

As can be seen below, different columns were used for the name, surname, and status of teachers, school year, subjects taught, and the number of hours taught per week. In the future, the An literar column will become Ani literari, including the number of years spent by the teachers in this capacity in Beiuș. The Obiecte predate column will be removed, and the Număr de ore pe săptămână column will become the Media orelor predate pe săptămână.

\begin{tabular}{|c|c|c|c|c|c|c|c|}
\hline Fekete Dumitru & Fekete & Dumitru & profesor al obiectelor extraordinare & 7 & Cantul eclesiastic & 2 & edit del $\square$ \\
\hline Șipoș Emeric & Șipoș & Emeric & profesor de religiunea altor confesiuni & [1] & Religiunea helvetică & & edit del $\square$ \\
\hline Sárkány losif & Sárkány & Iosif & profesor de religiunea altor confesiuni & [1] & Religiunea romano-catolică & & edit del $\square$ \\
\hline Groszberg losif & Groszberg & losif & profesor de religiunea altor confesiuni & [1] & Religiunea ebraică & & edit del $\square$ \\
\hline Tamaș Vasile & Tamaș & Vasile & profesor al studililor obligatorii & 5 & Limba latină, Limba română, Limba ma... & 20 & edit del $\square$ \\
\hline Bălașiu Augustin Paul & Bălașiu & Augustin Paul & profesor al studililor obligatorii & 2 & Limba latină, Limba maghiară, Istoria & 19 & edit del $\square$ \\
\hline Roșiu Teodor & Roșiu & Teodor & profesor al studililor obligatorii & 12 & Limba Iatină, Fizica, Matematica & 18 & edit del $\square$ \\
\hline Papfalvai Iuliu & Papfalvai & Iuliu & profesor al studililor obligatorii & 7 & Religiunea, Limba latină, Limba român... & 19 & edit del $\square$ \\
\hline Creșniacu Ștefan & Creșniacu & Ștefan & profesor al studililor obligatorii & 5 & Limba latină, Limba română, Limba ger... & 19 & edit del $\square$ \\
\hline Clintoc Ioan & Clintoc & loan & profesor al studililor obligatorii & 3 & Religiunea, Limba germană, Istoria nat... & 19 & edit del $\square$ \\
\hline Buteanu loan & Buteanu & Ioan & profesor al studililor obligatorii & 8 & Limba maghiară, Fizica, Matematica, D... & 20 & edit del $\square$ \\
\hline Ardeleanu loan & Ardeleanu & Ioan & profesor al studililor obligatorii & 4 & Limba latină, Limba greacă, Limba rom.... & 18 & edit del $\square$ \\
\hline Minuțiu Petru & Mihuțiu & Petru & director & 11 & Limba latină, Limba germană & $\begin{array}{l}\text { Activate Win } \\
\text { Go to Settings to }\end{array}$ & edit \\
\hline
\end{tabular}

Fig. 1. Screenshot of the database made in Nodegoat, showing the teachers who taught at the high school in Beiuș during the school year 1878-1879.

As the data entered is limited, given the small sample, it is beneficial to view the data geographically, in the case of the places where the teachers were born, lived, and studied. Chronological visualization proves helpful only where there are sufficient and clear data from a chronological point of view, such as the date of birth of teachers or the date of their appointment as teachers. However, regarding their secondary or superior education, for which there is mostly no information on the date of their enrollment or the date of their graduation, chronological visualization proves to be problematic. On the other hand, social visualization does not prove useful, because teachers appear as unrelated nodes.

Of the 18 teachers introduced in Nodegoat, there is information on the birthplace of five teachers, namely Ioan Ardelean, born in Oradea, on 15 November 1850; Petru Mihuțiu, born in Leta-Mare (today Létavértes, Hungary) on 6 July 1830; Ioan Buteanu, born in Carei, Satu-Mare county, on 25 March 1848; Vasile Leșianu, born in Vezendiu, Satu-Mare county, in 1845, and Ștefan Cresineacu, born in Hirep, in $1846 .{ }^{45}$

${ }^{45}$ Câmpean 2008, 110-113; Câmpean 2010a, 183; Câmpean 2010b, 288, 294, 296, 301. 


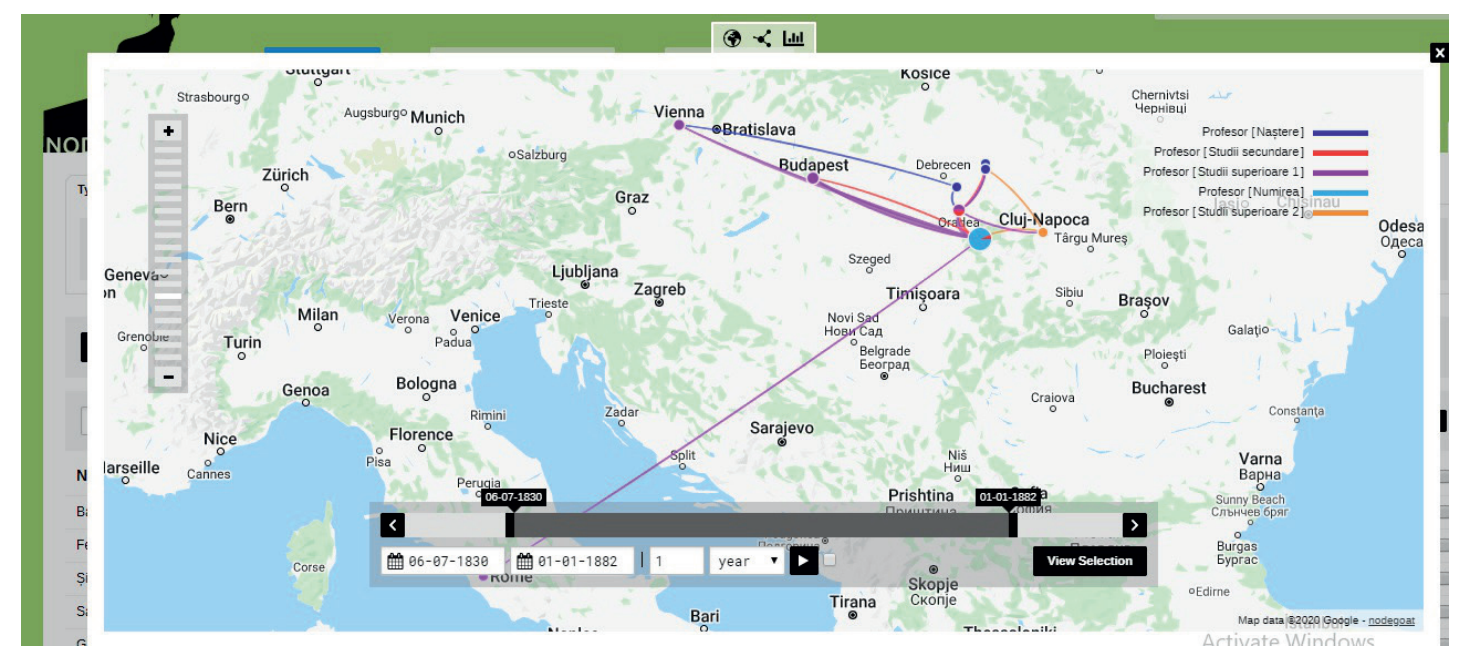

Fig. 2. Screenshot of the geographical visualization facilitated by Nodegoat, rendering the teachers who taught at the high school in Beiuș during the school year 1878-1879.

The information is rather abundant in the case of the education of the teachers. Thus, it is known that Ioan Buteanu and Petru Mihuțiu completed their secondary education in Oradea, and Gheorghe M. Marinescu and Sever A. Mărcuşiu completed theirs in Beiuș. The teachers were graduates of various university centers: Vasile Leșianu, Sever A. Mărcușiu and Ioan Buteanu graduated in Oradea; Dumitru Fekete, Teodor Roșiu and Gheorghe M. Marinescu in Budapest; Petru Mihuțiu and Iuliu Papfalvai in Vienna; Ioan Ardelean in Rome. ${ }^{46}$ In fact, Vasile Leșianu also studied at the University of Cluj.

As for the date of the beginning of their careers as teachers, it can be deduced by decreasing the years of service mentioned for each teacher in the yearbooks. Thus, Petru Mihuțiu has been teaching since 1867, Ioan Ardelean since 1874, Ioan Buteanu since 1870, Ioan Clintoc since 1875, Ștefan Cresineacu since 1873, Vasile Leșianu since 1871, Gheorghe M. Marinescu since 1860, Iuliu Papfalvai since 1871, Teodor Roșiu since 1866, Augustin Paul Bălașiu from 1876, Iosif Sárkány for one year, Emeric Șipoș for one year, Dumitru Fekete from 1871, and Paul Balász from 1870. The average length of service of the teachers was six years, so the staff had to be relatively young. However, this situation can be translated either by a lack of experience or by the teachers' preference to teach in Beiuș only for a certain period, later transferring to more important positions. It remains to be seen in the future of the research to what extent the second hypothesis is valid by evaluating their careers after leaving Beiuș.

\section{Conclusions}

Drawing on traditional sources of historiography, such as archival documents, secondary literature, and school yearbooks, as well as on innovative auxiliary tools, which include databases and data structured in various forms, several innovative methodological elements used in the case of the evolution of the Beiuș high school during 1876-1881 were highlighted. This evaluation grid was predominantly quantitative, especially in the case of

${ }^{46}$ Pavel 2009, 166-178; Mihuțiu 1882, 49-51. 
students, to the detriment of a qualitative approach, option more and more present in the Romanian historiography.

The statement made in the introductory chapter, according to which this study is only a sample from a future monograph of the Beius, high school in the modern era, must be reiterated. Thus, in the future, a professional monograph and importer of innovative methodology regarding the destiny of the high school from Beiuss in the modern era will complete the Romanian historiography.

\section{Bibliography}

\section{Primary sources}

SJB AN, Liceul „Samuil Vulcan” Serviciul Județean Bihor al Arhivelor Naționale, Oradea, Liceul „Samuil Vulcan” Beiuș. Matricole și registre școlare Fonds, inventory no. 1020, dossiers no. 26, 27, 28, 29, 30, 31, 32.

\section{Yearbooks}

Mihuțiu 1882

\section{Secondary sources}

Bolovan et alii 2020

P. Mihuțiu, Reportu despre gimnasiulu sup. gr. cat. de Beiusiu pentru anulu scol. 1881-1882, Gherla 1882.

Botoș 2019

I. Bolovan, B. Crăciun, D. Covaci et alii, Historical Population Database of Transylvania. A Database Manual, SUBB Digitalia, 64/1 (2020), 10-85. doi: 10.24193/subbdigitalia.2019.1.1.

R. Botoș, Education as a Vehicle for Social Mobility in the 19th Century in Transylvania. A Comparative View on Romanians and Hungarians in the Gurghiu Valley, Romanian Journal of Population Studies, 13/1 (2019), 29-46. doi: 10.24193/RJPS.2019.1.02.

Câmpean 2008

V. Câmpean, Oameni și locuri din Sătmar, vol. I, Satu Mare 2008.

Câmpean 2010a

Câmpean 2010b

Călușer, Stelaru 1982

V. Câmpean, Oameni și locuri din Sătmar, vol. II, Satu Mare 2010.

V. Câmpean, Oameni și locuri din Sătmar, vol. IV, Satu Mare 2010.

I. Călușer, C. Stelaru (Mălinaș), Biblioteca liceului din Beiuș între anii 1835-1845, Crisia, 12 (1982), 411-418.

Dearden et alii 1997

L. Dearden, S. Machin, H. Reed, Intergenerational Mobility in Britain, The Economic Journal, 107/440 (1997), 47-66. doi: 10.1920/wp.ifs.1995.9520.

Dudaș 2004

F. Dudaș, În legătură cu cel mai vechi anuar al gimnaziului din Beiuş, Crisia, 34 (2004), 171-179.

Dulgău, Porumbăceanu 2000

P. B. Dulgău, C. Porumbăceanu, Oameni din Sătmar, Satu Mare 2000.

Erikson, Goldthorpe 1992

Faur 1972

R. Erikson, J. H. Goldthorpe, The Constant Flux. A Study of Class Mobility in Industrial Societies, Oxford 1992.

V. Faur, Contribuții documentare la istoria învățământului românesc din Bihor în ultimele două decenii ale veacului al XIX. In: Centenar muzeal orădean, Oradea 1972, 317-345. 
Ganzeboom et alii 1989

Haiduc 2020

Holom 2016

Lambert et alii 2013

Mihoc 2003

Miles 1999

Mîndruț 1986

Neagu 2018

Neagu 2017

Neș 2006

Pavel 2009

Pickens 1978

Pop 2015

Popa-Andrei 2015

Roșu 2016
H. B. G. Ganzeboom, R. Luijkx, D. J. Treiman, Intergenerational class mobility in comparative perspective, Research in Social Stratification and Mobility, 8 (1989), 3-84.

A. A. Haiduc, The construction of a database with the pupils of the Beiuș High School and the geographic visualization of their birthplace (1876-1877 school year), SUBB Digitalia, 2 (2020), 7-20. doi: 10.24193/subbdigitalia.2020.2.01.

E. C. Holom, Transformări în structura ocupaţională şi mobilitate socială în Transilvania (1850-1918). În: I. M. Balog, R. Gräf, I. Lumperdean (eds.), Fenomene economice şi financiare în spaţiul românesc în secolele $X I X-X X$ : studii de economie regională, Cluj-Napoca 2016, 89-112.

P. S. Lambert, R. L. Zijdeman, M. H. D. van Leeuwen et alii, The Construction of HISCAM: A Stratification Scale Based on Social Interactions for Historical Comparative Research, Historical Methods, 46/2 (2013),77-89. doi: 10.1080/01615440.2012.715569.

B. Mihoc, Biserică și societate în nord-versul României. Contribuții monografice, Oradea 2003.

A. Miles, Social Mobility in Nineteenth- and Early TwentiethCentury England, London 1999.

S. Mîndruț, Augustin Paul (1866-1921), Întregiri biografice, ActaMP, 10 (1986), 629-641.

R. M. Neagu, Formarea elitei ortodoxe din Transilvania, Banat şi Crişana la sfârşitul secolului al XIX-lea şi începutul secolului al XX-lea. Studenţi români din Transilvania, Banat şi Crişana la Facultatea de Teologie a Universităţii din Cernăuţi (1875-1918), Cluj-Napoca 2018.

R. M. Neagu, Studenți din comitatul Bihor la Facultatea de Teologie a Universității din Cernăuți (1875-1918), Crisia, 47 (2017), 127-140.

T. Neș, Oameni din Bihor (2nd edn.), Oradea 2006.

C. Pavel, Școalele din Beiuș. 1828-1928 (2nd edn.), Cluj-Napoca 2009.

K.A. Pickens, Occupational Mobility in a Nineteenth-Century British Colony, JSH, 11/3 (1978), 404-412.

C. Pop, Social Mobility Patterns in Romania, AIIC Humanistica, 13 (2015), 29-58.

M. Popa-Andrei, Dinastiile preoțești: sursă de recrutare a elitei ecleziastice greco-catolice. Studiu de caz: episcopiile Oradea și Gherla (1853-1918), Țara Bârsei, 14/14 (2015), 167-177.

M. Roșu, Mobilitatea intergenerațională ocupațională și educațională în România. O analiză a cohortelor 1955-1966 și 1977-1985, AIIC Humanistica, 14 (2016), 25-52. 
Sigmirean 2000

Sewell 1976

Sorokin 1927

Sorokin 1957

Treiman 1977

van Leeuwen, Maas 2005

van Leeuwen, Maas 2011

van Leeuwen et alii 2004

van Leeuwen et alii 2002

van Leeuwen, Maas 2010

van Leeuwen et alii 2016
C. Sigmirean, Istoria formării intelectualităţii româneşti din Transilvania şi Banat în epoca modernă. Studenţi români la universităţi din Europa Centrală şi de Vest, Cluj-Napoca 2000.

W. H., Jr. Sewell, Social Mobility in a Nineteenth-Century European City: Some Findings and Implications, JIH, 7/2 (1976), 217-233.

P. Sorokin, Social Mobility - A Pioneer Study of the Historical and Contemporary Dynamics of Inequality, New York 1927.

P. Sorokin, Social and Cultural Mobility, New York 1957.

D. J. Treiman, Occupational Prestige in Comparative Perspective, New York 1977.

M. H. D. van Leeuwen, I. Maas, 'A Short Note on HISCLASS', History Of Work Information System (2005), https://historyof work.iisg.nl/list_pub.php?categories=hisclass, accessed 29 Jul. 2021.

M. H. D. van Leeuwen, I. Maas, HISCLASS. A Historical International Social Class Scheme, Leuven 2011.

M. H. D. van Leeuwen, I. Maas, A. Miles, Creating a Historical Standard Classification of Occupations. An Exercise in Multinational Interdisciplinary Cooperation, Historical Methods, 37/4 (2004), 186-197. doi: 10.3200/HMTS.37.4.186-197.

M. H. D. van Leeuwen, I. Maas, A. Miles, HISCO. Historical International Standard Classification of Occupations, Leuven 2002.

M. H. D. van Leeuwen, I. Maas, Historical Studies of Social Mobility and Stratification, Annu.Rev.Sociol., 36 (2010), 429-451. doi: 10.1146/annurev.soc.012809.102635.

M. H. D. van Leeuwen, I. Maas, D. Rébaudo, J. P. Pélissier, Social Mobility in France 1720-1986: Effects of Wars, Revolution and Economic Change, JSH, 49/3 (2016), 585-616. doi: 10.1093/jsh/ shv054. 



\title{
FEMALE PORTRAITS FROM LONG AGO. GRAPHIC ARTWORKS IN THE COLLECTION OF THE NATIONAL MUSEUM OF TRANSYLVANIAN HISTORY
}

\author{
CLAUDIA M. BONȚA ${ }^{*}-$ MELINDA MITU*b
}

\begin{abstract}
Among the multitude of (prevalently male) portraits from the graphic art collections housed by the National Museum of Transylvanian History, there is a small number of nineteenth-century female portraits, most of which belong to the artistic world of those times. These creations often depict figures from social and aristocratic circles or heroines brought to the public's attention by special events. The precise artistic investigation of the portraits accomplished in romantic or Biedermeier style is completed by the presence of some compositional portraits in the collections, which bring a note of delicacy and romanticism in an austere environment.
\end{abstract}

Keywords: portrait, graphic art, nineteenth century, romantic style, Biedermeier

Rezumat: În multitudinea de portrete din colecțiile grafice ale Muzeului Naţional de Istorie a Transilvaniei, cu o pondere covârșitor masculină, se remarcă un număr mic de portrete feminine de secol XIX, majoritatea aparținând lumii artistice a epocii. De multe ori aceste creații redau figuri din cercurile mondene și aristocrate ori eroine aduse în atenția publicului de evenimente deosebite. Investigația artistică precisă a portretelor realizate în stil romantic sau Biedermeier este completată de prezența în colecții a unor portrete compoziționale, care aduc o notă de delicatețe și romantism într-un mediu auster.

Cuvinte cheie: portret, grafică, secolul al XIX-lea, stil romantic, Biedermeier

The female portrait has been a source of inspiration in the field of artistic creation over the centuries. Female representations have existed since ancient times. However, how the woman has been perceived and portrayed is uneven. It oscillated between extremes that either conveyed idealized, charming visions of female nature, materialized in perfect goddesses, muses, and heroines, or pushed representations to the other extreme, mystifying the idea of femininity to the point of demonizing women and incriminating them for all existing evils. After female statuettes depicting deities in the Paleolithic or antiquity, and after medieval depictions of woman as righteous Madonna or as an evil character, guilty of expulsion from paradise, the modern era brought about a more temperate note, presenting feminine nature in a way that was closer to reality. The unprecedented proliferation of the female portraits in the eighteenth century, with a whole procession of elegant characters described in the intimacy of the house or more or less idyllic landscapes, in images involving beauty, grace, and spirit, changed the tone of artistic representations

\footnotetext{
${ }^{*}$ Ph.D., Museum curator, National Museum of Transylvanian History, Cluj-Napoca, email: claudiamol@yahoo.com, (D) https://orcid.org/0000-0003-4067-335X; ${ }^{b}$ Ph.D., Museum curator, National Museum of Transylvanian History, Cluj-Napoca, email: mitu_meli@yahoo.com, (D) https://orcid.org/00000001-6629-7773.
} 
of femininity. This turn in portraiture made possible a serene approach to the feminine universe of the nineteenth century. The concept of femininity became more palpable and was more realistically expressed through simple portraits that evoked authentic characters with actual qualities and flaws. Departing from the archetypal symbols of beauty, the nineteenth-century imposed the rigor of simplicity and produced a series of galleries of female portraits in iconic or everyday poses. Ladies from the society of the time posed observing the aesthetic codes of the period, in ceremonial outfits, against neutral backgrounds, or in an essentialized setting.

The portrait genre was dominant in Transylvanian art in the nineteenth century. Long series of portraits, individual or collective, depicted mainly historical figures from long ago or political personalities of the moment, in an unprecedented effort to reawaken national pride or record past or contemporary human values.

Among the multitude of portraits from the graphic art collections of the National Museum of Transylvanian History in Cluj-Napoca (hereafter MNIT), depicting mostly masculine characters (the majority of the portraits in the MNIT collections are of statesmen or political or cultural personalities from the medieval, pre-modern and modern eras), ${ }^{1}$ there are a small number of female portraits, most of which belong to the artistic world of the nineteenth century and convey a note of delicacy and romance in an austere environment. The portraits invite us to a journey through time, enabling us to meet outstanding female characters of that period. They were immortalized for their unique activity or extraordinary life. The works are painted in romantic or Biedermeier style, and there are also a few compositional portraits.

Among the first female portraits included in the MNIT's graphic heritage and analyzed in this study, mention should be those representing respectable ladies of Hungarian aristocratic society from the first half of the nineteenth century.

Thus, Mária Majthényi of Kesselökö (1769-1851) impresses with her status as a lady of honor at the Habsburg Court and as a holder of the prestigious Ordo Stellatae Crucis [Order of the Starry Cross]. She was immortalized in this pose in a lithograph executed by Miklós Barabás, the most prolific Hungarian portraitist of the Biedermeier era. ${ }^{3}$ In his long career, Barabás created 'an invaluable portrait gallery'4 depicting numerous political, ecclesiastical, and cultural personalities of the era in which he lived. Barabás also displayed his talent through portraits of bourgeois sponsors, exceptional genre scenes or landscapes, and magazine illustrator. ${ }^{5}$ Between 1831 and 1833, the Hungarian artist lived in Bucharest, where he distinguished himself by making 'an impressive number of portraits of boyar families and Russian officers and works depicting local, picturesque subjects, including a View of Bucharest from the Metropolitan Church.'

\footnotetext{
${ }^{1}$ On the MNIT’s engraving collection, see also Mitu 2000; Bonţa 2019.

2 'Maria Anna Brunswick'/Family Tree \& Family History.

${ }^{3}$ On the multitude of bibliographical references about the life and activity of the painter Miklós Barabás (1810-1898), see: Barabás 1998a; Genthon 1936; Hoffmann, 1950; Florea 1982, 46, 49, 51; Murádin 1998; Ciortea 1999. A recent presentation at the Apostol 2021, entry: Barabás Miklós (Nikolaus), 48-50.

4 See Murádin 1998, 6.

${ }^{5}$ See, for instance, Éber s.a. (1926), 55, entry: Barabás Miklós.

${ }^{6}$ Apostol 2021, 48-50.
} 
Returning to the lithograph dedicated to Mária Majthényi of Kesselökő (Fig.1), ${ }^{7}$ the character is portrayed by Barabás in a ceremonial outfit, in a Hungarian gala dress, ${ }^{8}$ consisting of a blouse with puffy sleeves made of overlapping layers of lace, a corset with crossed threads, a lace apron on top of the crinoline skirt, and a veil attached to the tiara. The countess is smiling, with three-quarters of her face turned to the viewer. Her wavy hair hangs loose on her shoulders. She has a triple string of pearls around her neck, and her long earrings frame her face. Her vivid eyes complete a successful, elegant, vibrant portrait. Below the side portrait is the author's signature, 'Barabás,' '1844,' printing house 'Nyomt[atta] Walzel A. F. and the location, 'Pesten' [in Pest]. The character's civil status and name are recorded next (in the Hungarian spelling of the era): Korompai Gróf Brunsvick József Országbíró Özvegye [Widow of the Royal Judge József Brunsvick, Earl of Korompa] / KESSELEÖKEÖI MAJTHÉNYI MÁRIA, and her title: 'Csillagkeresztes és palotadáma ő excellentiája' [Her Excellency the Lady of Honor - at the Habsburg Court -, holder of the Order of the Starry Cross].

Regarding the order bestowed upon Mária Majthényi de Kesselőkő, it is known that from 1668 on, this distinction was granted by the Austrian Imperial Court to ladies from old aristocratic families of the Catholic faith. This was an acknowledgment of their exemplary religious life, virtuous conduct, and exceptional charitable activities, materialized through cash donations, visits to hospitals, and other activities that involved the care of the sick and the suffering. ${ }^{9}$

The lithograph was edited by Adolf Frankenburg in Életképek ('Az Életképekhez kiadja Frankenburg Adolf'), a literary magazine from Pest. It also served as a fashion journal, offering readers, especially women, models worth following in life. This was in tune with the feminine ideal of the Hungarian ruling elites on the cusp of the eighteenth and nineteenth centuries. According to this ideal, women were to have 'a noble and lofty soul' and to 'respect the principles of loyalty, love of family, charity, and meekness. ${ }^{10}$ During this period, the cultivation of national feelings among women became important. They had the duty to 'develop and deepen in their children the appreciation of their mother tongue, as well as their love of the homeland.'11

Within the gallery of female portraits from the MNIT's patrimony, there are also two watercolors (in a leather folder) made by the Transylvanian painter Ferenc Simó Kissolymossy, ${ }^{12}$ another important representative of the formal simplicity that was characteristic of Biedermeier classicism.

\footnotetext{
7 Colecția MNIT, no. M 5571, size $35 \times 27.5 \mathrm{~cm}$.

${ }^{8}$ On the Hungarian ball gown (díszmagyar) and its representative role, see Tompos 2005, 9, 25-54. On the components of the Hungarian ball gown, also see: Tompos 2005, 97-112.

9 Diós, Viczián 1996, entry Csillagkereszt-rend (ném. Hochadeliger-Sternkreuzorden) [Order of the Starry Cross].

${ }^{10}$ Papp 2014, 143.

11 Papp 2014, 142.

${ }^{12}$ Ferencz Simó Kissolymossy (1801-1869), Transylvanian painter born in Odorheiu Secuiesc. He studied at the Akademie der Bildenden Künste in Vienna, and was active in Buda and Cluj, ÖBLonline, entry Simó, Ferenc. On the life and activity of Ferenc Simó, see also Bayer 1915; Éber, Gombosi 1935, 446, entry Simó Ferenc; Biró Béla 1942.
} 
The first watercolor (Fig. 2) ${ }^{13}$ is a portrait depicting the bust of a middle-aged lady holding - like Mária Majthényi of Kesselőkő - the prestigious Order of the Starry Cross. The character is gazing seriously at the spectator from a three-quarter angle. Her pale face, dark hair, grey eyes, and tight lips give her a stern expression specific to bourgeois portraiture. She is wearing a sober outfit, a simple black dress with a lace collar, and a shawl covering her shoulders. The lace bonnet, the triple string of pearls around the neck, the carefully combed hair with curls brought on to the temples according to the time's fashion, with a dividing line in the middle, without bangs, reinforce the austerity of the image. The Biedermeier portrait depicts the bourgeois aesthetic ideal in a realistic way, marked by simplicity and sobriety. A decorative medallion that seems to be the Order of the Starry Cross is fastened to the dress with a black ribbon on the lady's chest.

From the second half of the eighteenth century, the order was featured as a golden cross with light-blue enamel. In the center of this larger cross was a smaller, russet-colored one. The crosses were superimposed over a two-headed, imperial black eagle without a crown. This decorative motif was contained within an oval border, with dark-blue enamel with golden edges. In its upper part, there is a white-enameled serpentine band with golden edges in three sections. On the band, one can distinguish (inscribed in black letters) the motto of the order, namely 'Salus et Gloria' [Salvation and Glory]. The decoration had the shape of a pendant on a black silk ribbon bow. It was worn on the dress, above the heart. ${ }^{14}$ In this portrait, the artist was not concerned with faithfully rendering the medallion. However, it has several elements that help identify it: a larger, light-blue cross, with a smaller, dark-blue cross inside, both superimposed on a black two-headed eagle, within gold edges and surrounded by a white band. All of these are enclosed in a blue-bordered rectangle with gold edges. One can even distinguish the black ribbon with which the medallion is attached to the dress. In the corners of the image appear details related to location, author and date, 'Kolosvárt' [in Cluj], respectively 'Simó 1840.' We could not ascertain the character's identity, but the words scribbled on the back of the watercolor probably indicate the name: Toldalaki [probably Toldalagi] Anna.

The second watercolor (Fig. 3) ${ }^{15}$ presents the portrait of a young woman in an indigo blue dress with wide sleeves, in a studied pose, with her head supported by her right arm. Her curly hair is adorned with a simple braid, over which she is wearing a green veil, in obvious color contrast with the red ring on her hand. The long earrings, the green veil, the ring, and a long, crossed cord enliven the image dominated by the character's thoughtful, almost worried attitude. Her right arm is leaning against a stand, and her left hand is reaching into her deep pocket. According to the taste of the time, the portrait exudes a romantic air, a sentimental vision transposed with great finesse by the painter. This is also a case where we have no information on the identity of the character. Nevertheless, on the back of the watercolor, we can see a note written in pencil, which suggests that the work comes 'Báró Horváth családtól' [from the family of Baron Horváth]. The painting does not bear the artist's signature. Only a rather blurry note appears next to the young woman's image: 'Döbrenteyhez' (?) [To/for Döbrentey], and a date: '[1]857'. The two elements also

\footnotetext{
${ }^{13}$ Colecția MNIT, no. M 4100, size $24.2 \times 19 \mathrm{~cm}$.

14 See: Ortner, Ludwigstorff 2017, 381; Diós, Viczián 1996, entry Csillagkereszt-rend.

${ }^{15}$ Colecția MNIT, no. M 4100a, size $24.2 \times 19 \mathrm{~cm}$.
} 
serve to attribute the work to Ferenc Simó. It seems to have been given to Gábor Döbrentei, one of the great Hungarian writers of the early nineteenth century, who supported Simó's artistic career. ${ }^{16}$

Actresses or dancers of the time are other categories of women who stood out in the public life of those times. In Transylvania, famous artists of the nineteenth century, such as Carol Popp de Szathmári or Miklós Barabás, immortalized some Hungarian actresses or ballerinas. They performed on the lyrical or dramatic stages of Transylvania, usually in tours, some reaching Cluj. Such portraits are included today in the patrimony of the Cluj history museum.

The first plate dedicated to the actresses of the time depicts DÉRINÉ (Fig. 4). ${ }^{17}$ This is Róza Széppataki (1793-1872), often referred to by her marriage name ('Dériné', meaning Mrs. Déry), who was one of the most famous and beloved actresses and singers of her time. She was a true symbol of the Hungarian traveling theatre in the first half of the nineteenth century. She began her artistic career in Pest in 1810. Between 1815 and 1847 she played on all the major stages in Hungary and Transylvania. She performed in cities Miskolc (18151819), Cluj (1823-1827), Kassa (1828-1837), and Pest (at the German Theatre, in 1822, at the Hungarian Theatre, between 1837 and 1838, and at the National Theatre (between 1846 and 1847). Róza Széppataki 'was a complex prima donna, with ingénue roles in dramatic performances and soprano roles in opera shows. Her repertoire included over a hundred roles. Her success allowed her to promote Hungarian dramatic art and to organize actions in support of it.' Mrs. Déry also distinguished herself as a translator of plays, and her Memoirs (written between 1869 and 1872 and published in 1879, 1900, and 1955) are valuable examples of Hungarian Biedermeier prose. ${ }^{18}$

In Cluj, the Hungarian actress had numerous shows. Like a member of the Cluj theatre troupe for four years (in 1823-1827), and then (until 1845, on nearly annual tours), she acted on the stage of the Stone Theatre on Farkas St. (today Mihail Kogălniceanu St.). This was the first building on the territory of Transylvania and former historical Hungary built specifically for theatrical life, an institution that opened its doors on 12 March $1821 .{ }^{19}$ In Cluj, Mrs. Déry starred in a whole series of memorable roles in plays written by Castelli, Grillparzer, Kotzebue, Scribe, Victor Hugo, and Hungarian playwrights (Károly Kisfaludy, József Katona, Ede Szigligeti), as well as in operas. She was Rosina in Rossini's Barber of Seville, Donna Anna in Mozart's Don Giovanni, and Agathe in Freischütz by Karl Maria

16 See Bayer 1915. It is also mentioned that Simó had a predilection for painting solitary young women (Éber, Gombosi 1935, 446). For identifying the author of the M 4100a portrait, we must thank to Professor Jenő Murádin, art historian from Cluj.

17 Colecția MNIT, no. M 5393, size $46.7 \times 33 \mathrm{~cm}$.

18 Székely 1994, entry Déryné Széppataki Róza; Schenbach-Schekenbach.

${ }^{19}$ On the Stone Theatre in Cluj, see, for example, Herepei 2005a, 53; Vincze 2013, 44-52. On the presence of the actress Déryné Széppataki Róza in Transylvania and Cluj, see, for example, Herepei 2005c, 94-97; Herepei 2005d, 103-104; Enyedi 1975; Egyed 2021, 6. The founding of the Stone Theatre 200 years ago was commemorated on 20 and 21 March 2021 by the Faculties of Theatre and Film, the Faculty of Letters, the Faculty of History-Philosophy and the Faculty of Protestant Religion and Museum Education within UBB, Babeș Bolyai University, through a series of conferences and a round table entitled Theatre as a Community Space. 
von Weber. ${ }^{20}$ During the tours she undertook in the 1840s, Mrs. Déry rented a house in the vicinity of the former theatre, in the Pataki-Tollas House on Farkas St. (today: Mihail Kogălniceanu St. no.5). The actress was extremely loved by the Cluj audience, being rewarded with 'showers of flowers', with praiseworthy poems written for her and disseminated on printed leaflets, with decorative objects for the home or with silver jewelry. ${ }^{21}$

The special popularity Mrs. Déry enjoyed among the Cluj public can explain the need to keep her in memory through a portrait. This materialized as a lithograph made in 1834 by Carol Popp de Szathmáry, the famous Hungarian painter and graphic artist from Cluj, who was then at the beginning of his career, shortly before leaving on his study trips to the Academy of Arts in Vienna and then in Italy. ${ }^{22}$ The lithograph was multiplied in 76 copies at the Printing House of the Reformed College, which was run by Gábor Barra at that time. ${ }^{23}$

A copy of this typographically multiplied lithograph is kept today in the MNIT collections. It portrays the image of the famous actress in a pathetic pose, with her hands crossed on her chest, with a melancholy, thoughtful look, in the posture required by the role of Lisli, from the play The Rose of the Alps. She has large eyes, arched eyebrows, full cheeks, tight lips, a finely contoured nose, a face beautifully framed by her neat hairstyle, with her straight hair arranged in elaborate curls that run from the temples to the neckline. There is a great deal of attention in rendering her physiognomy. It focuses on the face to the detriment of the body that seems to be drawn from memory. Consequently, there is a clear disproportion between head and body. The dramatic dress, with bare shoulders but with oversized sleeves, with ruffles that cover the arm to the elbow, and the transparent veils that surround the artist contribute to the romantic atmosphere imagined by the artist, as does the vague outline of nature as a background: a patch of sky, mountains on the horizon and flowers alongside the artist. Below, under the portrait, to the side, appears the author's signature, 'Szathmári,' and the date, '1834,' respectively the place and the printing house: 'Kolozsvárt Ref[ormátus] Coll[égium] Lithographiajaban' [at the Lithographic Institute of the Reformed College in Cluj]. In the center of the image, there is an inscription containing: the name after and before the actress's marriage and the role in which she was immortalized: DÉRINÉ / Széppataki Róza / mint Lisli, az Alpesi rózsában [DÉRINÉ Széppataki Róza in the role Lisli, from The Rose of the Alps].

Other famous Hungarian actresses of the nineteenth century whose portraits are in the MNIT's collection of engravings are Flóra Munkácsy, Lina Bodenburg (Mrs. Hegedüs), and Prielle Kornélia. Their images are preserved in lithographs by Miklós Barabás, which are also published in Hungarian illustrated magazines.

Flóra Munkácsy lived between 1836 and 1906. She started her career in her childhood, at the age of 5, by acting on the dramatic stages in Györ, Bratislava, Oradea,

${ }^{20}$ List of roles played by actress Déryné Széppataki Róza on the Transylvanian theatre stages, at Enyedi $1975,121-150$.

${ }^{21}$ On all this, see: Herepei 2005c, 98-105.

${ }^{22}$ On Szathmári Pap Károly or Carol Popp de Szathmáry (Szathmári) (1812-1887), see: Oprescu 1945, II, 182-183; Florea 1982, 73-74; Murádin 2003. A recent presentation in Andrei 2021, 231-236, entry Szathmári (Szathmáry) Carol Popp de.

${ }^{23}$ Herepei, 2005c, 94-97. Herepei shows that one of the typographic multiplications from Cluj, from 1834, was taken over, engraved in brass, and then multiplied in the magazine Honmüvész from Pest. In that engraving, executed by Anton Chladek, the image of the actress underwent some unfavorable changes. 
Cluj (in 1843), or Subotica, between 1841 and 1846. Later, between 1847 and 1853, she participated in shows in Arad, Szeged, and Timișoara. In 1855 she became an actress at the National Theatre in Pest. She worked there until 1901, enchanting the public with her candor and beauty, and was, for a long time, the prima donna of the national theatre in Pest in the second half of the nineteenth century. ${ }^{24}$

The three-quarter view portrait (Fig. 5) ${ }^{25}$ of the young lady shows her standing, with her right hand supported by a short pedestal and with her left holding a lacy handkerchief. The dress with ruffles and velvet ribbons is adorned with velvet bows on the sleeves, and, at the waist, it has a white lace collar that matches the lace sleeves coming out from under the dress and the cap that adorns her hairstyle at the back. She is wearing a long chain brooch with a watch, a locket bracelet, and large earrings. Lace, bows, and jewelry make up a rather overladen image. However, they are counterbalanced by the serene attitude, the smiling face, and the elegant posture that makes up a balanced, serene portrait. The floral wreath on the low wall behind it and a vaguely contoured landscape in the distance provide the background against which the silhouette is outlined. However, the upper part of the portrait, in the head area, is designed with a white background, making sure no element distracts from her face. The excellent portrait exudes naturalness, elegance, and grace. The author's signature appears to one side, 'Barabás', the year '[1]856,' respectively 'Nyom [tatta] Reiffenstein és Rösch Bécsben' [Printed by Reiffenstein and Rösch in Vienna]. The title, 'Munkácsy Flóra', appears below the image.

Another actress portrait signed by Miklós Barabás depicts Lina Bodenburg, married to Hegedüs (Fig. 6). ${ }^{26}$ She was also the first Hungarian professional singer of musical tunes dedicated to the general public. Lina Bodenburg lived between 1837 and 1859 and acted on the stages of Arad (between 1854 and 1855) and Pest (from 1858). The National Pest Theatre 'has never had an actress so popular, so well received by the public, as well as by the press. Her soft face, beautiful posture, serene nature, and femininity conquered the spectators. Her acting was characterized by originality and finesse. When needed, she knew how to be impetuous, even dramatic. Her whole being and her slightly German-sounding pronunciation radiated simplicity and kindness. ${ }^{27}$

However, the actress's personal life was unhappy. Bodenburg suffered a lot due to the jealousy fits of her husband, actor and playwright Lajos Hegedüs. The Hegedüs couple lived together for three years, from 1855 to 1859, when the actress died of a cold. Within a year, her grieving husband and their three-year-old son died. The tragedy of the Hegedüs family moved an entire country. A particularly noteworthy mourner was the novelist Jókai Mór, who knew the family personally. He felt the need to dedicate a work to the sad events, entitled Egy család drámája [The Drama of a Family]. ${ }^{28}$

In Barabás's lithograph, the young actress is depicted with a gentle face, big eyes, and curly hair, gazing dreamily, somewhere far away, beyond the spectator, and holding a book in her hands. Her high forehead, long nose, and thin lips compose a melancholic

\footnotetext{
${ }^{24}$ Székely 1994, entry Munkácsy Flóra; Gaidler Emilia; Egyed 2021, 6.

${ }^{25}$ Colecția MNIT, no. M 5572, size $62 \times 44 \mathrm{~cm}$.

${ }^{26}$ Colecția MNIT, no. M 5575, size $62 \times 44 \mathrm{~cm}$.

27 Székely 1994, entry Bodenburg Lina; Egyed 2021, 6.

28 See, for example: 'Hegedüsné Bodenburg Lina'/Kéthelyért Egyesület; 'Egy család drámája'/Kepeslap Muzeum.
} 
figure, turned three-quarters towards the spectator. She has an elegant, Hungarian-inspired dress, with fine lace at the neckline, crossed strands that adorn the bodice, and puffy white sleeves with ribbons at the elbow. The jewelry is discreet: she wears bracelets on both hands and has earrings matched with the locket around her neck. It is a toned-down image that preserves the emotional charge of the subject, painted in a three-quarter view. Next to the image, below, are the signature and the year: 'Barabás, [1] 858', respectively the information 'Nyomt[atta] Rohn / Pest 1858' [Printed by Rohn, at Pest, in 1858]. To the center is the title HEGEDÜSNÉ-BODENBURG LINA. Under it is stated: '18dik mümelléklet a Hölgyfutárhoz 1858' [artistic supplement no. 18. to The Ladies' Courier, 1858] and 'Szerk[esztő] Kiadó: Tóth Kálmán’ [Editor].

The third lithograph Barabás dedicated to a theatre star, depicts Kornélia Prielle (Fig. 7) ${ }^{29}$ She lived between 1826 and 1906. Her first appearance in a performance took place in Satu Mare, in 1841. Then, between 1841 and 1859, she played on all the dramatic stages in the great cities of Transylvania and Hungary, such as Sibiu, Pest, Debrecen, Cluj, Bratislava, Székesfehérvár, Kassa, Miskolc or Győr. In 1859 she returned to the National Theatre in Pest, where she acted until the end of her life. ${ }^{30}$ She performed remarkable roles in dramatic works of the French repertoire, ${ }^{31}$ much loved, especially in bourgeois salons. ${ }^{32}$ She was, for example, Marguerite Gautier (in The Lady with the Camellias by Alexandre Dumas fils) countless times. In this role, she also impressed Empress Elizabeth of Austria-Hungary at Pest in $1865 .^{33}$

Kornélia Prielle was the first actress to receive the honorary title of 'permanent member' of the Hungarian National Theatre in Pest in 1881. She was married several times - to the actor Kálmán Szerdahelyi, then to Elek Hidassy, and again to Szerdahelyi. She also partnered with Kálmán Szerdahelyi on stage, being especially appreciated as the first true master of stage conversation in Hungarian dramatic art. ${ }^{34}$ Prielle is also well known for her courageous and generous actions in favor of suffering people. Throughout her life, she cared for her disabled father or other relatives and colleagues, elderly or young alike, who lacked the necessary subsistence means. ${ }^{35}$

In Barabás's lithograph, the actress is serene, sitting on a chair, with her hands clasped together. Earrings with precious stones and a bracelet are the only jewelry she is wearing discreetly, probably to compensate for the loaded dress, with overlapping ruffles and edges marked with scotch ribbons. The lace collar around the neck, the border of the lace sleeves, the thin string of buttons that end the dress at the top decorate the image. The middle-parted hair is braided in twisted tails arranged in a circle that covers the ears in the form of wasp nests. A careful look and a quick smile paint a superior attitude, calm but alert, aware of her value. Below the image are the technical data, 'Nyom[tatta] Reiffenstein

\footnotetext{
${ }^{29}$ Colecția MNIT, no. M 5576, size $44.5 \times 30.9 \mathrm{~cm}$.

${ }^{30}$ See Székely 1994, entry Prielle Kornélia; Priel Antónia; Herepei 2005e; Egyed 2021, 6.

${ }^{31}$ Probably also due to her origin, as her father's grandfather was a French emigrant settled in Hungary. At the time, it was appreciated that her French heritage gave the artist the aura of spirituality and natural conversation skills, through which she stood out on stage from an early age (Csetriné 2006, 28).

32 See in Székely 1994; Herepei 2005e; Egyed 2021, 6.

33 See Csetriné 2006, 31.

${ }^{34}$ Csetriné 2006, 30.

${ }^{35}$ Csetriné 2006, 30. See also Enyedi 1975, 116.
} 
és Rösch Bécsben' [Printed by Reiffenstein and Rösch in Vienna], signature and year, 'Barabás [1]858.' At the center, the title is written like a signature Prielle Cornélia, and the following information appears below: 'Melléklet a Délibáb 1858-diki 1ső számához / Kiadta Friebeisz István.' [Supplement to issue no. 1 per 1858 of - the magazine - Délibáb / Edited by Friebeisz István].

One last portrait of an actress from the nineteenth century that we will present in this study comes from the French world. This is the lithograph of Mademoiselle RACHEL (Fig. 8), ${ }^{36}$ which depicts Élisabeth-Rachel Félix (1821-1858), the most famous French actress of her time. Born in Switzerland into a modest family of Jewish descent, she arrived in Paris around 1830, where she took singing and acting lessons. She began her career in 1837 with great success. Despite an early death due to tuberculosis, the impression left by the famous actress has lasted for centuries. Beyond her remarkable talent and intelligence, her impeccable diction and preference for the classical repertoire (Racine, Corneille, Molière), ${ }^{37}$ a not negligible role was played by the tumultuous love life she had. Élisabeth Rachel was loved by famous men, such as Emperor Napoleon III of France, Prince Napoléon Joseph Charles Paul Bonaparte, and Alexandre Colonna-Walewski, the natural son of Emperor Napoleon I. ${ }^{38}$ Her notoriety was enhanced by tours in London, Brussels, Berlin, St. Petersburg, as well as in America. She was a great tragedian and became a model for the famous Sarah Bernhardt. ${ }^{39}$

The image shows her torso twisted in a three-quarter view position, with her head turned towards the spectator, staring blankly into the distance. She has her hair parted in the middle, gathered in a back bun. Long, large earrings and a matching brooch are her only adornments. She is wearing a dark dress with puffy sleeves and a ruffle around her neck. Her hands are clasped. Her magnetic, penetrating gaze captures all attention, confirming the fascination she exerted on her contemporaries. At the top of the page, on the broadsheet, is marked the origin and date of 'Publication de la France Littéraire' and 'SALON DE 1840.' Below the image are the technical data, the engraver, and the publishing house, 'Alophe Dèl'to / 'Challamel \& $C^{\text {ie }}$ Editeurs', the title and author of the portrait: $M^{\text {lle }}$. RACHEL. / 'Par Auguste Charpentier,' ${ }^{41}$ respectively the name of the printing house, the address and even the price of the plate, 'Imp. d'Aubert \& C ${ }^{\text {ie }} / 4$, Rue de l'Abbaye, F.S.$G^{\mathrm{n}}$. (Prix 1 F.)'

The series of portraits dedicated to celebrities of the time, owned by the Cluj history museum, also includes two portraits of ballerinas, namely Franziska (or Fanny) Elssler and Emília Aranyváry.

The plate dedicated to the famous Austrian ballerina Fanny Elssler (Fig. 9 ${ }^{42}$ presents a romantic image that incites the imagination. It depicts the graceful protagonist floating

\footnotetext{
${ }^{36}$ Colecția MNIT, no. M 5975, size $32 \times 24.5 \mathrm{~cm}$.

37 'Mademoiselle Rachel'/Encyclopaedia Britannica https://www.britannica.com/biography/MademoiselleRachel, accessed 12 May 2021. See also the chapter Francia szinészóriások Budapesten, in Gajdó 2001.

38 'Elisabeth-Rachel Félix'/The British Museum.

39 'Sarah Bernhardt'/The British Museum.

${ }^{40}$ Marie Alexandre Alophe (1812-1883), French painter, draftsman, engraver, author of lithographs, a disciple of Camille Roqueplan and Paul Delaroche, see 'Elisabeth-Rachel Félix'/The British Museum.

${ }^{41}$ Auguste Charpentier (1813/15-1880), French painter, disciple of Ingres and Francois Gérard, see: 'Auguste Charpentier'/The British Museum.

${ }^{42}$ Colecția MNIT, no. M 5573, size $43 \times 32 \mathrm{~cm}$. An identical copy can be seen on the website 'Fanny Elßler'/ Europeana.
} 
above a landscape with lofty mountains and flower carpets. The poetic approach to the subject is aligned with the romantic vision of the time. In a stage costume, wearing a dress with strands and a white apron, the beautiful woman looks seriously at the viewer. In one hand, she is holding the hat with ribbons, while in the other she is touching the carpet of flowers. The personal magnetism of the ballerina grants the portrait a special charm, depicting a very attractive feminine pose.

Fanny Elssler (1810-1884) studied ballet as a child, training in Vienna and then in Naples with Gaetano Gioja. Elssler was a first ballerina at the Kaiserliches und Königliches HofTheater in Vienna. According to Marie Taglioni (1804-1884), Fanny Elssler is considered 'the second greatest star of romantic ballet ${ }^{23}$. She appeared on the great stages of the world, in Naples, Berlin, Paris, Moscow, and in 1840 she reached the New World. ${ }^{44}$ Here she was received by the President of the United States, Martin van Buren. ${ }^{45}$ Elssler was appreciated both for her lively dance and her choreographic technique. She introduced elements of traditional folk dances into classical ballet. Her most famous dance was 'cachucha,' a Spanish solo dance similar to the bolero, accompanied by castanets. The popularity of the Austrian ballerina is also proved by the multiple porcelain figurines in the bourgeois interiors of the time, which represented her dancing 'cachucha. ${ }^{46}$

Returning to the lithograph, the authors (the painter and the lithographer) are listed laterally, at the base of the image, on both sides: 'C. Agricola ${ }^{47}$ peint.', respectively' R. Theer ${ }^{48}$ lith..' The title, Fanny Elssler, is followed by the explanation of the role she immortalized: 'Als Schweizermilchmädchen' [as the Swiss Milkmaid], and her quality as 'erste Tänzerin am k.k. HofTheater nächst dem Kärntnerthor' [first ballerina of the Imperial and Royal Theatre of the Vienna Court].

The second plate shows Emília Aranyváry (Fig. 10) ${ }^{49}$ (born around 1830 - died after $1868)^{50}$, the first ballerina and choreographer in Hungary. She took dance lessons from François Crombé, a ballet teacher at the German Theatre in Pest. In 1848 she danced at the National Theatre in Pest, then, in 1850, at the Théatre Lyrique in Paris and the theatres in London and Vienna. Between 1854 and 1859, she returned to the National Theatre in Pest, where she stood out as a ballerina and choreographer. After 1859 she played in Szeged, Arad, and Cluj, and in 1860 she toured in Bucharest, Fiume, Milan, Bologna, and Turin. The latest news about Aranyváry comes from Parma, from 1868. 'With her fine personality, with her pretentious dance and high artistic level, she gained recognition everywhere, and through her activity in her native country, she forged the first important era of Hungarian ballet. ${ }^{51}$

\footnotetext{
${ }^{43}$ Major, Gara 2014, 99-100.

${ }^{44}$ Major, Gara 2014, 99-100.

${ }^{45}$ On Fanny Elssler's visit to the White House, see: 'Fanny Elssler'/WHHA; 'Andrew Jackson'/WHHA.

${ }^{46}$ Major, Gara 2014, 100. See also Egyed 2021, 6.

${ }^{47}$ Karl Joseph Aloys Agricola (1779-1852), German painter, best known for his miniature portraits. See: ÖBLonline, entry Agricola, Karl.

${ }^{48}$ Robert Theer (1808/1863), an Austrian painter and lithographer, also known, like Agricola, especially as a miniaturist. See: ÖBLonline, entry Theer, Robert.

${ }^{49}$ Colecția MNIT, no. M 5574, size $51.8 \times 35.5 \mathrm{~cm}$.

${ }^{50}$ According to Egyed 2021, the ballerina Emília Aranyváry lived between 1838 and 1871.

${ }^{51}$ Székely 1994, entry: Aranyváry Emília; 'Aranyváry Emília'/Wien Museum; Egyed 2021, 6.
} 
In the present image, Aranyváry is Autumn in Friedrich Campilli's The Four Seasons. ${ }^{52}$ The famous ballerina is portrayed in a gorgeous ballet costume, on tiptoes, with her legs crossed. There is a contrast between, on the one hand, the upper part of the body, posing in a studied, dreamy, romantic attitude, with the tilted head supported by the bent right arm and the elbow supported by the left hand and, on the other hand, the dynamism in which the lower body is rendered. The elaborate dress, with delicate embroidery, which leaves the hands free for dancing, has a short and wide skirt, with rich layers of tulle embellished by the presence of small bouquets of flowers that delicately fix the upper layer of the dress in an elegant draping effect. The feet in fine ballet shoes tied with crossed ribbons rest on the toes, apparently without effort. The hair arranged in braided tails raised on top of the head forms a real crown that ennobles the serene face. The flowers caught in the hair increase the delicacy of the character, with her long eyes and discreet smile. The ballerina was, apparently, a lover of jewelry. She is wearing two simple necklaces: one with a cross medallion at the base of the neck; the other long, simple, has two discreet bracelets on each wrist and a ring on each ring finger. The entire portrait contained in an oval medallion emits a feeling of delicacy, tenderness, and elegance specific to the world of ballet. The background is deliberately blackened to highlight the immaculate white of the outfit. In the lower-left corner of the image is the artist's signature, 'rajzolta Canzi Ákost' (actually, Ágost Elek Canzi, whose real name was Martin Kanz, 1808-1866, an Austrian photographer and painter). The name of the printing house appears in the lower-right corner: 'Walzel A. F' as does the place and year of publication: 'Pesten 1856' (in Pest, 1856). At the center of the lithograph appears the title and name ARANYVÁRI EMILIA. On the side, under the name, the following details are provided: 'Mümelléklet a Hölgyfutár hoz' [artistic supplement to The Ladies' Courier], the date, '1856' and the editor ('Szerkesztő-Kiadó: Tóth Kálmán').

In what follows, we leave behind the great ladies of the stage and head to Marie-Fortunée Lafarge, born Capelle, a young woman from Parisian society, who came to the public's attention in 1840 following tragic and mysterious events. The drawing of Marie Lafarge (Fig. 11) ${ }^{53}$ can be considered a physiognomic study, focused on the character's face, shown in the profile. The silhouette is vaguely sketched, as is her clothing. The exception is the straight-edged cap on the head, fastened with ribbons under the chin and covered by the black embroidered veil at the base. The simple features emanate a deep calm, in total contradiction with the turmoil created around this controversial character at the center of the so-called L'Affaire Lafarge [The Lafarge business].

Marie Lafarge (1816-1852) caused one of the biggest press scandals of the nineteenth century. It was the first publicized trial in France, in which she was accused of killing her husband, Charles Pouch-Lafarge, by poisoning him with arsenic in 1840 . Her sentence to forced labor for life was issued based on a dubious toxicological report, compromised by the incompetence of the 'specialists' called to take evidence of uncertain validity. ${ }^{54}$ There was much speculation in the French society of the time. She was dubbed everything, from a cold-blooded murderer to an innocent victim of justice. Her case inspired debates on

\footnotetext{
${ }^{52}$ Egyed 2021, 6.

${ }^{53}$ Colecția MNIT, no. M 6039, size $27 \times 20.9 \mathrm{~cm}$.

${ }^{54}$ On Marie-Fortunée Lafarge, born Capelle (15 Jan. 1816-7 Nov. 1852), see: 'Marie Lafarge'/Wikipedia; 'Marie Lafarge'/The British Museum; 'Lafarge, Marie'/WorldCat; 'L'Affaire Marie Lafarge'/Musée Paris.
} 
the condition of women in nineteenth-century society, and there were reconstructions of the death of Charles Pouch-Lafarge in theatre plays. King Louis-Philippe commuted her sentence from forced labor to life imprisonment, and in 1851 Marie Lafarge published her memoirs, again asserting her innocence. Sick with tuberculosis, she was pardoned by Napoleon III in June 1852 but died shortly after that in November 1852. The lithograph is one of the most widespread images of the nineteenth century. It depicts Marie Lafarge in a portrait that accentuates the head area, which enjoys the drawing artist's full attention. At the bottom of the drawing appears a signature, 'Meist', and below it are listed the place of printing: 'Lith[ographische] Anst[alt] d. L[udwig] Mohn'55 [Ludwig Mohn Lithographic Institute] and the title MARIE CAPELLE verehlichte [married] LAFARGE.

The compositional portraits from the MNIT collection bring a note of romanticism, softness, and elegance.

The lithograph Girl by the Fountain (Fig. 12) (56 $^{56}$ depicts a compositional portrait. With her apron fastened to her waist, a barefoot young woman is thoughtfully leaning against a tree with a flower in her hand. There is a jug next to her, and there is a circular stone fountain in front of it. In the background, we see the towers of a building, probably a church. Greenery is used as a contrasting background on which the character's silhouette stands out brightly. It is a romantic portrait, which captures a moment of daydreaming in an atmosphere enriched by natural and architectural elements. Below the image is the information about the authors, the painter and the engraver, and the title ' $\mathrm{H}$. Corbould ${ }^{57}$ $\mathrm{pinx}^{\mathrm{t}} /$ DAS MÄDCHEN AM BRUNNEN / W. H. Egleton sculps" while below are listed the publishing houses, in 'Darmstadt / Druck \& Verlag von G. G. Lange', and in 'New York / Lange \& Kronfeld 201 William Street'.

The next drawing, entitled SZERET - NEM SZERET [He Loves Me - He Loves Me Not] (Fig. 13), ${ }^{58}$ presents a romantic moment captured in nature. A young woman depicted in profile is picking the petals of a flower, playing the universal game 'he loves me - he loves me not.' She is completely absorbed in the moment, and nothing else seems to matter. The beautifully contoured features of her face and her delicate silhouette amplify the poetry of the moment. Dressed in a tournelle gown made of a fabric with stripes that shine like silk, the young woman with a flower pinned to her chest has stopped next to the source of the game, and a wreath of flowers is seemingly stretching towards her. Below is the statement 'Köre metsz[ette] és nyomt[atta] Rohn, Pest, 1858' [Lithographed and printed by Rohn, ${ }^{59}$ at Pest, in 1858], followed by the title, SZERET-NEM SZERET and the following verses: 'SZERET-NEM SZERET/ ... Egyszerre azonban megáll, és elméláz, / Galyat tör azután, s tépi a levelet / Olvasva magában / Szeret vagy nem szeret' [He loves me - He loves me not / Suddenly she stops and thinks, / Then she breaks a twig and tears off the leaves / Reading to herself / He loves me or He doesn't love me]. Below, the following information is written,

${ }^{55}$ This was Ludwig Mohn (1797-1857), a draftsman and engraver in the German world, ÖBLonline, entry Mohn, Ludwig.

${ }^{56}$ Colecția MNIT, no. M 5864, size $76 \times 56.5 \mathrm{~cm}$.

${ }^{57}$ Edward Henry Corbould (1815-1905), an acclaimed painter, sculptor, and illustrator who held the position of drawing master for the British royal family between 1852 and 1872, see 'Corbould'/Art of the Print.

${ }^{58}$ Colecția MNIT, no. M 5870, size $61 \times 44.5 \mathrm{~cm}$.

${ }^{59}$ Alajos Rohn (early nineteenth century-1870), active in Pest between 1851 and 1865. See: 'Alajos Rohn'/ Wikidata; 'Alajos Rohn'/Digitális Képarchívum. 
on both sides: 'Mülap a Hölgyfutárhoz' [Artistic supplement to 'The Ladies' Courier'], respectively the date: '1858' and the name of the editor ('Szerkesztő-Kiadó Tóth Kálmán').

The lithograph VICTORINE (Fig. 14) ${ }^{60}$, signed by F. Wolf ${ }^{61}$, presents a very young girl who is smiling, putting aside the veil covering her head and shoulders. We notice the youth and vivacity of the girl, expressed by the predominantly pink chromatics and by the decorative richness of her clothes and ornaments: the flowered dress with ruffles and bows on the sleeves, the double headband made from a string of pearls, the rose in her hair. Her blond hair with large curls, her wide forehead, long eyes, arched eyebrows, red cheeks, small mouth, and generous cleavage paint an image that exudes youth and vitality. Below is the title VICTORINE and the technical details: 'Gemalt V. Bruschart', respectively 'Gedr[uckt] bei J. RAUH', and 'Verlag V. A. Paterno's We \& Sohn in Wien' [painted by Bruschart, printed by J. Rauh, the publishing press V. A. Paterno \& Sons, Vienna].

The lithograph entitled Flora (Fig. 15) ${ }^{62}$ presents a compositional portrait projected against a theatrical background, with nature as a frame and architectural elements as accessories. In front of a window that is wide open to a landscape showing the banks of a river, a young woman is sitting supported by an armchair; next to her is a curtain with large tassels and the spindle of a column and she is holding a wreath of flowers in her hands. She is looking serene straight ahead, her head tilted to the right. Her delicate features, big eyes, and straight hair parted in the middle, attached to the ears and raised in a bun at the back, according to the fashion of the time, all these features outline the portrait of a young woman with a good, calm, and elegant appearance. Her dark dress is completely covered by the long lace shawl fastened with a brooch at the neckline. The image relies on the contrast between the different textures of the rendered materials: the transparent lace's supple elegance versus the curtain's heavy brocade. Below the image are the technical data, the designer, 'Court del., the title, Flora ${ }^{63}$ the engraver, 'A. H. Payne ${ }^{64}$ sc.', as well as the publishing house and the location 'Verlag der Englischen Kunstanstalt von A.H. Payne in Leipzig.'

At the end of this paper, we will highlight some aspects about the social-historical context in which the female portraits presented above were painted.

We have described fifteen female portraits: two are watercolors, while the others are typographically multiplied lithographs. Most were made in the first half of the nineteenth century (before 1858). Therefore, stylistically they evince the romantic and Biedermeier styles of the time.

Except for the two watercolors made by Ferenc Simó, ${ }^{65}$ the portraits come from the old collections of the museum. The Transylvanian Museum Society obtained them from

${ }^{60}$ Colecția MNIT, no. M 5871, size $61.5 \times 46 \mathrm{~cm}$.

${ }^{61}$ Franz Wolf, 1795-1859, Vienna, was an Austrian painter and draftsman, an engraver specializing in lithographs, who studied at the Academy of Arts in Vienna and was the apprentice of the Austrian painter Hubert Maurer. He made many graphic drawings for the Friederich Kunike Lithographic Institute, and his work can be admired in various museums in Vienna; see: 'Franz Wolf'/AskART.

${ }^{62}$ Colecția MNIT, no. V 8092, size $25.5 \times 17.5 \mathrm{~cm}$.

${ }^{63}$ Flora, from Payne's Universum, steel engraving, around 1840.

${ }^{64}$ Albert Henry Payne was born in London on 14 Dec. 1812 and died in Leipzig on 7 May 1902; he learned the craft of engraving in London and settled in Leipzig in 1839. There he worked as a painter, engraver, and illustrator. He was the author of the volume Payne's Universum, which grouped an eclectic series of engravings, see Vollmer 1932, 325.

65 Their provenance is unknown. 
donations or acquisitions, ${ }^{66}$ or were 'officially sent' to it by the University Library of Cluj in 1903 and $1908 .^{67}$

Among the protagonists of the works, we can encounter not only ladies of impeccable moral standing (like Mária Majthényi de Kesselökő in the lithograph of Miklós Barabás) but also controversial characters, such as the Frenchwoman Marie Lafarge, who had a unique and unusual destiny. However, most of the portraits are dedicated to characters of great notoriety or to beloved artists of the time. The works were created when Europe was shaken by the Napoleonic Wars and then by the revolutions of 1848-1849. The inhabitants of the old continent aspired - after both dramatic conflicts - to peace, tranquility, and progress. Furthermore, because this desideratum was more difficult to achieve in everyday life, the educated elite (especially the progressive bourgeoisie) took refuge in the world of literature and art. $^{68}$ Besides external 'renewal' (in the sense that, in the first decades of the nineteenth century, people modernized their clothes and domestic interiors), the educated population of the time valued reading and music, frequented the theatre, or attended opera and ballet performances. This explains that actresses, singers, or ballerinas enjoyed a special appreciation from the public throughout the nineteenth century. They had admirers who displayed 'the enthusiasm of some troubadours. ${ }^{69}$ The audience offered them flowers, praiseworthy poems, and various gifts. Some artists impressed so much with their beauty and talent that they were coveted by famous men of the time. As we have seen, in the lines above, the case of Élisabeth-Rachel Félix, but also of the ballerina Fanny Elssler, who was rumored to have been loved by Napoleon II, the legitimate son of Emperor Napoleon Bonaparte ${ }^{70}$ ).

However, based on their biographical data, we can say that the artists of the nineteenth century were modern heroines and that they were unconventional for their time. They often lived a nonconformist life, with unofficial relationships, and those with unhappy marriages had the courage to divorce, remarry, or live alone and independently, often ignoring the rigid moral patterns imposed on women by the society of that time. ${ }^{71}$

In fact, at the beginning of the nineteenth century, young people in Transylvania were closely supervised by their teachers attending theatre performances. The historian János Herepei shows, for example, that both the Unitarian and the Reformed College in Cluj had internal regulations dating from 1806 and, respectively, 1814, which forbade young students to go to balls or shows without the rector's consent. They were allowed to attend only those performances which 'perfected knowledge, ennobled the heart, and contained no scandalous appearance or expression. ${ }^{\text {'2 }}$ Failure to comply with these provisions would

\footnotetext{
${ }^{66}$ The lithograph depicting Dériné Széppataki Róza, signed by Szathmári, comes from the collection of the Cluj professor Sámuel Szabó (1829-1905), included in the records of the Transylvanian Museum Society on 20 May, 1905. The lithograph entitled Flora was purchased from István Elekes in 1944.

67 See the old inventory registers of the Transylvanian Museum Society, volumes II and VIII.

${ }^{68}$ See, for instance, Major, Gara 2014, 95

${ }^{69}$ See, for example, the stories of Count Sándor Vay, in Vay 1909, who also evokes the actresses Flóra Munkácsy and Lina Bodenburg.

${ }^{70}$ Major, Gara 2014, 100.

${ }^{71}$ On various aspects of the status and rights of women in the modern age, see Bock 2002, Chapters II (French Revolution: The Conflict Is Reopened) and III (Ruptures and Outbursts: A Third Gender Controversy).

72 Herepei 2005b, 77, 80-81.
} 
result in substantial penalties from college leaders, fines or deprivation of liberty for several days, and even cane beatings. ${ }^{73}$ However, beyond the fears of some respectable members of society towards the frivolous world of theatre, due to the nonconformism of actresses, the dominant attitude of theatre lovers towards the heroines of the stage was one of admiration and recognition of their value.

Artists were appreciated not only because they brought beauty and fantasy to everyday life but especially because they spread culture, music, and literature of great aesthetic value through their play-acting. They popularized masterpieces of the classical, Enlightenment or romantic currents, written by famous playwrights, such as William Shakespeare, the French Racine, Corneille, Molière, Voltaire, Eugène Scribe, Alexandre Dumas-father and son, or Victor Hugo, the Germans Friedrich Schiller, August von Kotzebue, the Austrians Castelli, Franz Grillparzer and the Hungarians József Katona, Károly Kisfaludy, Ede Szigligeti, and Imre Vahot. Mozart, Bellini, Weber, Rossini, and Verdi were the preferred composers.

In the case of the Hungarian actresses presented above - Mrs. Déry (in the lithograph of Carol Popp de Szathmári), as well as Flóra Munkácsy, Lina Bodenburg and Kornélia Prielle (in the lithographs of Miklós Barabás) - they also made an important contribution to the dissemination of Hungarian culture and the cultivation of the Hungarian national language, which were important desiderata of romantic nationalism at that time. In the years immediately following the defeat of the Hungarian revolution, performances in Hungarian (or with Hungarian subjects) were also a symbol of national resistance against Habsburg neo-absolutism. These were the reasons why 'not only Cluj but - as we can see from Mrs. Déry's diary - the entire Hungarian population of Transylvania, led by the aristocracy, held their actors in high regard. ${ }^{74}$

One last aspect that deserves to be emphasized is that all these portraits are genuine period documents because of the feminine faces and attitudes they evoke and because they illustrate the Biedermeier fashion of the nineteenth century. Most of the protagonists are presented in dresses with a highlighted waist, corsets, and crinolines, with puffy sleeves. All garments are adorned with laces, ribbons, and bows or jewelry. The ladies' hairstyles are also interesting, as they display various braids, buns, and curls.

The conviction that the beautiful female portraits and the stories behind them still bring a touch of light to the souls of art and culture lovers has guided us in our efforts to present them in a temporary exhibition ${ }^{75}$ and in the present study. We hope that thanks to these efforts, the images of the ladies of the nineteenth century will remain pleasantly imprinted in the memory of contemporary visitors and readers.

${ }^{73}$ Herepei 2005b, 81.

${ }^{74}$ See Herepei 2005d, 107-108.

75 The exhibition was open at the Taylors' Tower - the Urban Culture Centre in Cluj-Napoca from 23 February to 9 March 2021. We wish to thank Anamaria Pop and Ancuța Lăcrimioara Chiș from the Public Service for the Management of Cultural Objectives in Cluj-Napoca, for the support they gave us in organizing the exhibition. 


\section{Bibliography}

\section{Primary sources}

The inventory registers of the Transylvanian Museum Society, volumes II and VIII, Archival Fonds of The National Museum of Transylvanian History, Cluj-Napoca.

Colecția MNIT + no.

Colecţia Muzeului Naţional de Istoriea Transilvaniei, Cluj-Napoca, nos. M 4100, M 4100a, M 5393, M 5571, M 5572, M 5573, M 5574, M 5575, M 5576, M 5864, M 5870, M 5871, M 5975, M 6039, V 8092.

\section{Secondary sources}

Andrei 2021

E. Andrei, Szathmári (Szathmáry) Carol Popp de. In: A. Silvan Ionescu (ed.), Dicționarul pictorilor din România. Secolul al XIX-lea, București 2021, 231-236.

Apostol 2021

I. Apostol, Barabás Miklós (Nikolaus). In: A. Silvan Ionescu (ed.), Dicționarul pictorilor din România. Secolul al XIX-lea, București 2021, 48-50.

Barabás 1998a

M. Barabás, Márkosfalvi Barabás Miklós önéletrajza, foreword by B. Biró (1944) and J. Murádin, Sepsiszentgyörgy 1998.

Bayer 1915

J. Bayer, Kissolymosi Simó Ferenc festő, Erdélyi Múzeum, 32/1-3 (1915), 80-83, http://www.epa.hu/00900/00979/00221/ pdf/1915_32_01_145-159.pdf, accessed 15 May 2021.

Biró 1942

B. Biró, Régi erdélyi müvészek. Kissolymosi Simó Ferenc 18011869, Erdélyi Helikon 15 (1942), 522-527.

Bock 2002

G. Bock, Femeia în istoria Europei. Din Evul Mediu până în zilele noastre, Iași 2002.

Bonța 2019 (2020)

C. Bonța, Militant Portraits. The Promotion of Hungarian National History through Nineteenth-Century Graphics. Case Study, ActaMN, 56/II (2019/2020), 73-89.

Ciortea 1998-1999 (1999) C. Ciortea, Litografii de Barabás Miklós în colecția Muzeului Național de Istorie, ActaMN, 35-36/II (1998-1999/1999), 343-346.

Csetriné 2006

K. Csetriné Lingvay, Prielle Kornélia életpályája (1826-1906), Müvelődés, LIX (February 2006), 27-31, http://www.muvelodes. ro/pdfs/2006-02.pdf, accessed 25 May 2021.

Diós, Viczián 1996

I. Diós, J. Viczián (eds.), Magyar katolikus lexicon, vol. II, Budapest 1996, http://lexikon.katolikus.hu/C/Csillagkereszt-rend.html, accessed 15 May 2021.

Éber s.a.

L. Éber (ed.), Müvészeti Lexikon, Budapest 1926; repr. as Müvészeti Lexikon A-tól Z-ig, s.a.

Éber, Gombosi 1935

L. Éber, Gy. Gombosi (eds.), Müvészeti Lexikon, vol. I (A_K), Budapest 1935, https://adt.arcanum.com/hu/view/Lexikon_ MuveszetiLexikon_2/?pg=445\&layout=s, accessed 1 May 2021.

Egyed 2021

E.Egyed,Aszínpadidealizálthösnői, képeken-aBethlen-bástyában, Szabadság, 44 (23 Febr. 2021), 6. 
Enyedi 1975

Florea 1982

Gajdó 2001

Genthon 1936

Herepei 2005a

Herepei 2005b

Herepei 2005c

Herepei 2005d

Herepei 2005e

Hoffmann, 1950

Major, Gara 2014

Mitu 2000

Murádin 1998

Murádin 2003

Oprescu 1945

Ortner, Ludwigstorff 2017

Papp 2014

Székely 1994

Tompos 2005
S. Enyedi, Déryné erdélyi színpadokon, Bukarest 1975.

V. Florea, Arta românească, vol. II, Modernă și contemporană, București 1982.

T. Gajdó (ed.), Magyar színháztörténet, vol. II, 1873-1920. Francia és olasz vendégjátékok, Budapest 2001, https://mek.oszk. hu/02000/02065/html/2kotet/82.html, accessed 25 May 2021.

I. Genthon, Erdély müvészete, Budapest 1936, http://adatbank. transindex.ro/html/alcim_pdf9314.pdf, accessed 8 May 2021.

J. Herepei, Lengyel Dániel önéletrajzának szinészettörténeti vonatkozásai. In: P. Sas (ed.), A kolozsvári színház és szinészet történetéböl (1941?), Kolozsvár 2005, 50-68.

J. Herepei, Diákok színházba járása. In: P. Sas (ed.), A kolozsvári szinház és szinészet történetéből (1941?), Kolozsvár 2005, 77-81.

J. Herepei, Déryné arcképe. In: P. Sas (ed.), A kolozsvári színház és szinészet történetéből (1941?), Kolozsvár 2005, 94-97.

J. Herepei, Adatok Déryné naplóinak kolozsvári vonatkozásaihoz. In: P. Sas (ed.), A kolozsvári szinház és szinészet történetéböl (1941?), Kolozsvár 2005, 98-105.

J. Herepei, Néhány adat Prielle Kornélia és Szerdahelyi Kálmán életéhez. In: P. Sas (ed.), A kolozsvári színház és szinészet történetéből (1941?), Kolozsvár 2005, 106-122.

E. Hoffmann, Barabás Miklós, Budapest 1950.

R. Major, M. Gara, Az európai színpadi tánc története az elözményektöl a 19. század végéig, Budapest 2014.

M. Mitu, Colecția de gravuri din patrimoniul Muzeului Național de Istorie a Transilvaniei, ActaMN, 37-38/II (2000-2001), 367-372.

J. Murádin, Barabás Miklós. În memoria locurilor natale. In: Barabás Miklós (1810-1898), National Museum of Art of Romania, București 1998, 6-12.

J. Murádin, Szathmári Pap Károly, Kolozsvár 2003.

Gh. Oprescu, Grafica românească în secolul al XIX-lea, vol. I-II, București 1942-1945.

M. C. Ortner, G. Ludwigstorff, Austrian Orders and Decorations, vol. II, Vienna 2017, 381, https://sancrucensis.wordpress. com/2010/09/18/sternkreuzorden, accessed 24 Mar. 2021.

J. Papp, 'Ti vagytok a' polgári erény 's nemzetiség védangyali...' Női olvasás a felvilágosodás és a kora reformkor időszakában. In: J. Papp (ed.), A zsoltártól a rózsaszín regényig. Fejezetek a magyar női müvelődés történetéból, Budapest 2014, 141-161.

Gy. Székely (ed.), Magyar színházmüvészeti lexikon, Budapest 1994, https://mek.oszk.hu/02100/02139/html/, accessed 15 May 2021.

L. Tompos, A díszmagyar - A magyar díszöltözet története, Budapest, 2005. 
Vay 1909

Vincze 2013

Vollmer 1932
S. Vay, Gróf Vay Sándor munkái, vol. VIII, Erzsébet királynéról és más krónikás följegyzések, Budapest 1909, https://mek.oszk. hu/10300/10345/10345.htm, accessed 5 May 2021.

Z. Vincze, Farkas utca 3. szám - Collegium Academicum - Az első köszinház. În: A kolozsvári Farkas utca. Müvelödéstörténeti barangolás, Kolozsvár 2013, 44-52.

H. Vollmer (ed.), Allgemeines Lexikon der bildenden Künstler von der Antike bis zur Gegenwart, established by U. Thieme, F. Becker, vol. XXVI, Olivier-Pieris, Leipzig 1932.

\section{Online biographical resources}

'Alajos Rohn'/Wikidata

'Alajos Rohn'/Digitális

Képarchívum

'Andrew Jackson'/WHHA

'Auguste Charpentier'/The

British Museum,

'Aranyváry Emília'/Wien

Museum

'Corbould'/Art of the Print

'Egy család drámája'/Kepeslap

Muzeum

'Elisabeth-Rachel Félix'/The

British Museum

'Fanny Elßler'/Europeana

'Fanny Elssler'/WHHA

'Franz Wolf'/AskART

'Hegedüsné Bodenburg Lina'/

Kéthelyért Egyesület
'Alajos Rohn'/Wikidata, https://www.wikidata.org/wiki/ Q26202759, accessed 22 May 2021.

'Alajos Rohn'/Digitális Képarchívum, http://dka.oszk.hu/kereses/ keres_cedulaelem.php?alkoto=Rohn_Alajos, accessed 22 May 2021.

'Andrew Jackson and Music at the White House'/The White House Historical Association, https://www.whitehousehistory. org/andrew-jackson-and-music-at-the-white-house, accessed 15 May 2021.

'Auguste Charpentier'/The British Museum, https://www.britishmuseum.org/collection/term/BIOG186778/, accessed 12 Febr. 2021.

'Aranyváry Emília'/Wien Museum. Online Sammlung, https:// sammlung.wienmuseum.at/objekt/235031-aranyvari-emilia, accessed 25 Mar. 2021.

'Edward Henry Corbould'/Art of the Print, http://www. artoftheprint.com/artistpages/corbould_edward_henry_theballroomateglintoncastle.htm, accessed 9 Febr. 2021.

'Egy család drámája'/Kepeslap Muzeum, http://kepeslapmuzeum. hobbipark.hu/buda/egy-csalad-dramaja/, accessed 15 May 2021.

'Elisabeth-Rachel Félix, known as Mademoiselle Rachel'/The British Museum, https://www.britishmuseum.org/collection/ term/BIOG203902/, accessed 12 Febr. 2021.

'Fanny Elßler'/Europeana, https://www.europeana.eu/en/ item/15503/GS_GPS460, accessed 12 Febr. 2021.

'Ballerina Fanny Elssler'/ The White House Historical Association, https://www.whitehousehistory.org/photos/ballerina-fanny-elssler, accessed 15 May 2021.

'Franz Wolf'/AskART, https://www.askart.com/artist/Franz Wolf/11081440/Franz_Wolf.aspx, accessed 11 Febr. 2021.

'Hegedüsné Bodenburg Lina'/Kéthelyért Egyesület, http://www. kethelyert.hu/?q=node/224; accessed 15 May 2021. 
'Lafarge, Marie'/WorldCat

'L'Affaire Marie Lafarge'/

Musée Paris

'Maria Anna Brunswick'/

Family Tree \& Family History

'Marie Lafarge'/Wikipedia

'Marie Lafarge'/The British

Museum

'Sarah Bernhardt'/The British

Museum

OBLonline + entry

\section{Exhibition Catalogues:}

Barabás 1998b
'Lafarge, Marie (1816-1852)'/WorldCat Identities, http://www. worldcat.org/identities/lccn-n85-183090/, accessed 15 Febr. 2021.

'Zoomsurl'AffaireMarieLafarge'/MuséedeBarreaudeParis,https:// www.museedubarreaudeparis.com/zoom-sur-laffaire-marielafarge, accessed 15 Febr. 2021.

'Maria Anna Brunswick of Korompa (Majthényi of Kesselökö)'/Family Tree \& Family History, https://www.geni. com/people/M\%C3\%A 1 ria-Anna-Brunswick-de-Korompa/6000000016278166021, accessed 25 May 2021.

'Marie Lafarge'/Wikipedia. The Free Encyclopedia, https:// en.wikipedia.org/wiki/Marie_Lafarge, accessed 15 Febr. 2021.

'Marie Lafarge'/The British Museum, https://www.britishmuseum.org/collection/term/BIOG228917, accessed 15 Febr. 2021.

'Sarah Bernhardt'/The British Museum, https://www.britishmuseum.org/collection/term/BIOG19383, accessed 12 Febr. 2021.

Österreichisches Biographisches Lexikon 1815-1950, Austrian Centre for Digital Humanities and Cultural Heritage (online version), https://biographien.ac.at/oebl, accessed 24 Mar. 2021.

Barabás Miklós (1810-1898), introduction by J. Murádin, National Museum of Art of Romania, București 1998. 


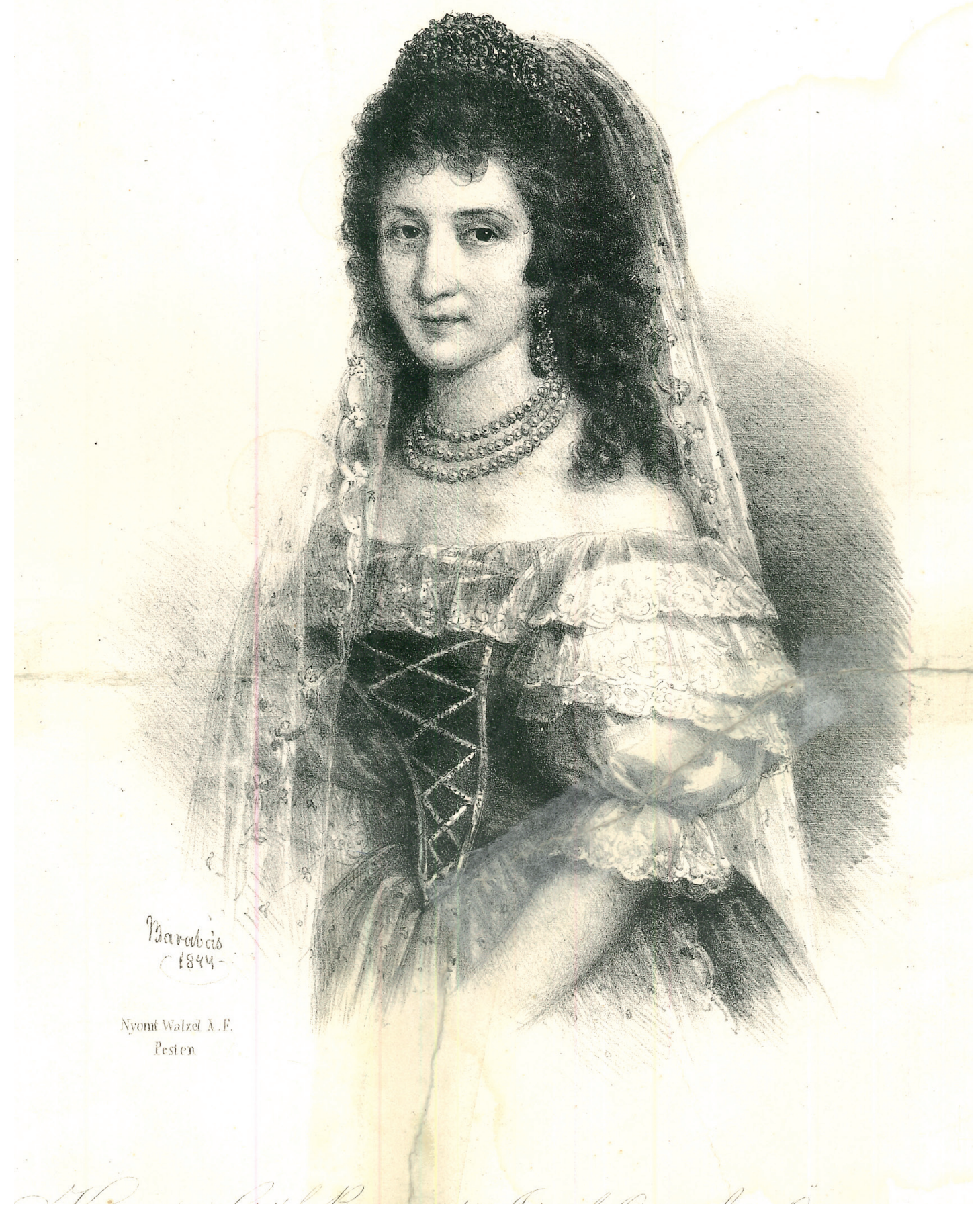

Fig. 1. Mária Majthényi de Kesselőkő (image from the MNIT Archive). 


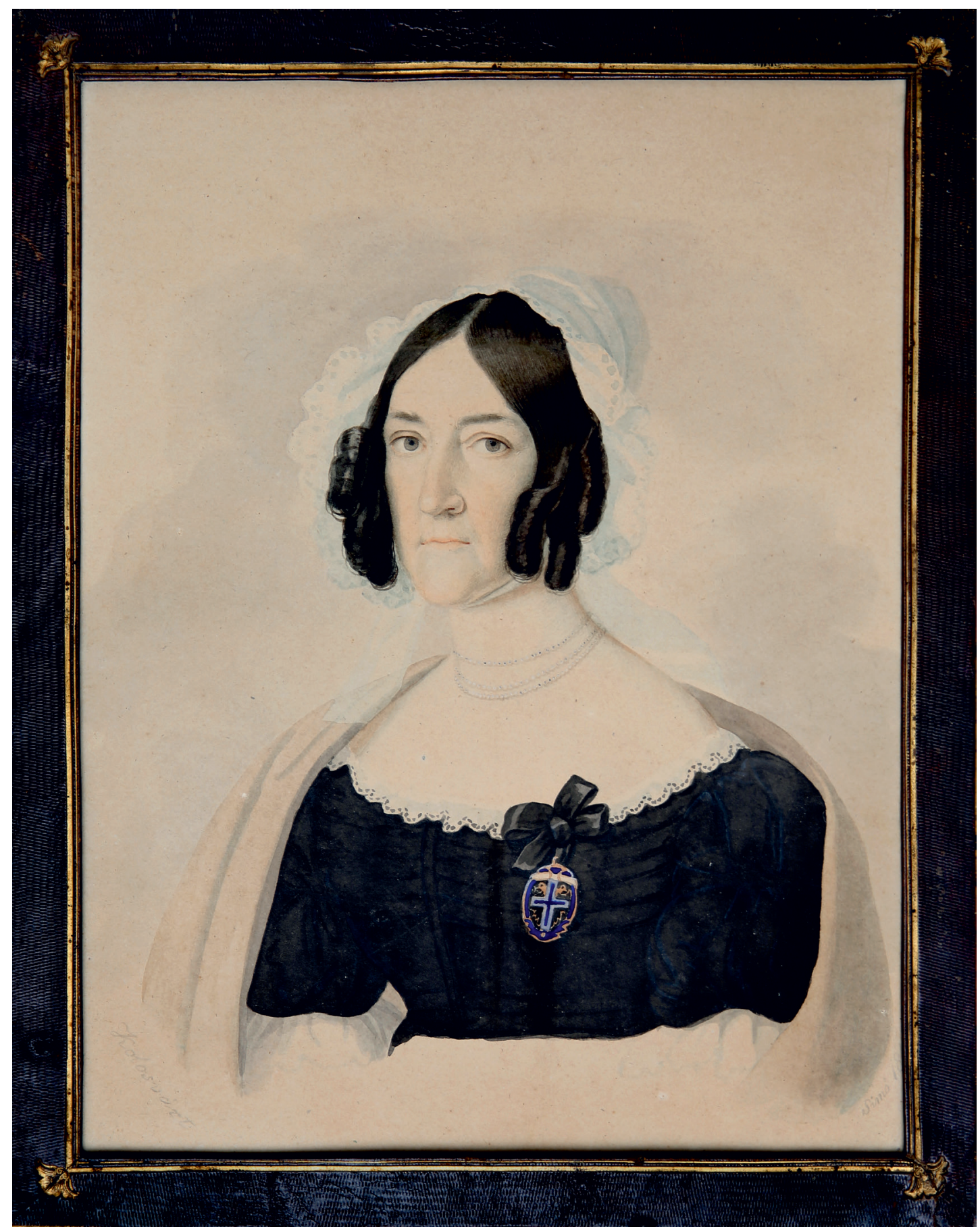

Fig. 2. Ferenc Simó watercolor (image from the MNIT Archive). 


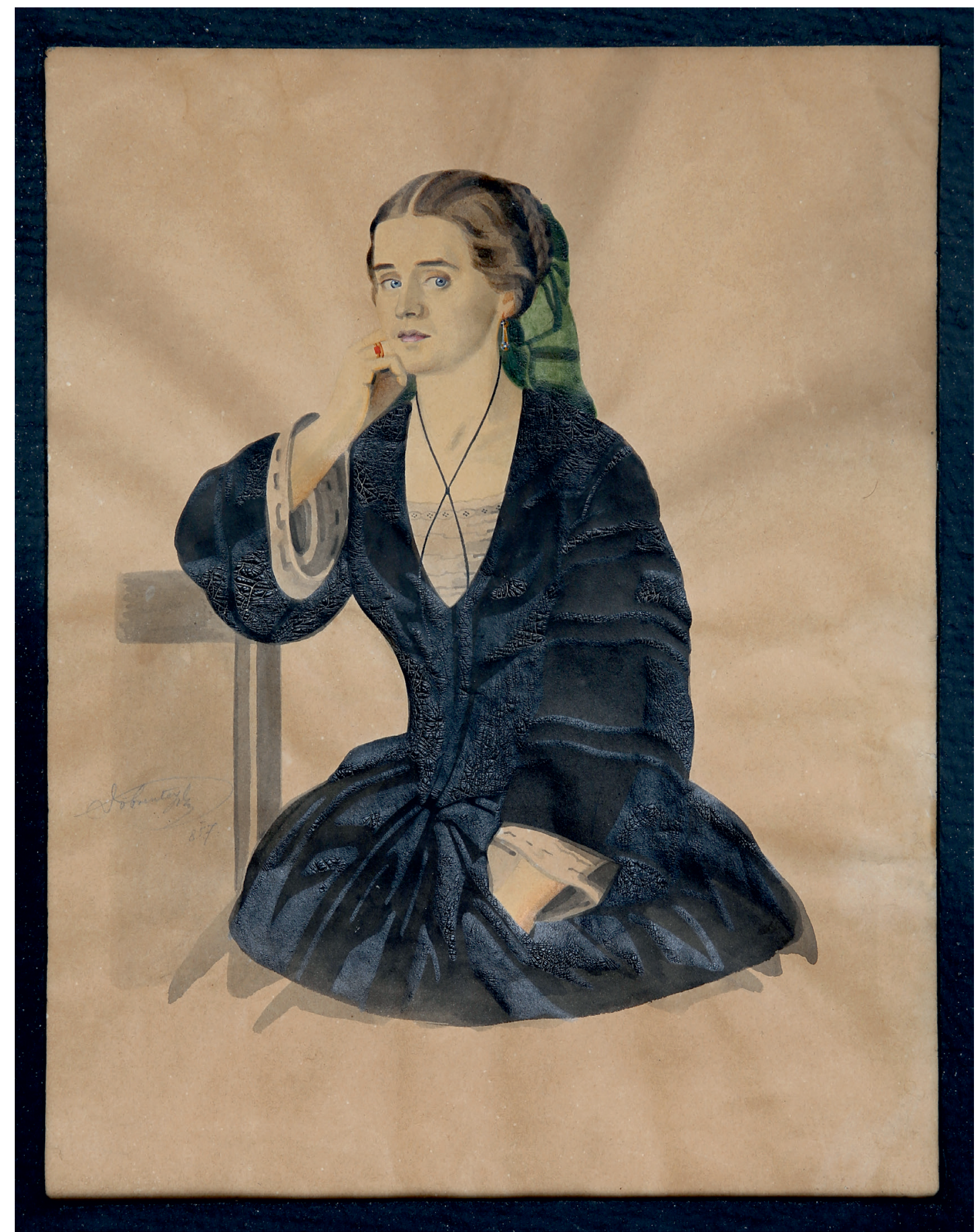

Fig. 3. Ferenc Simó watercolor (image from the MNIT Archive). 


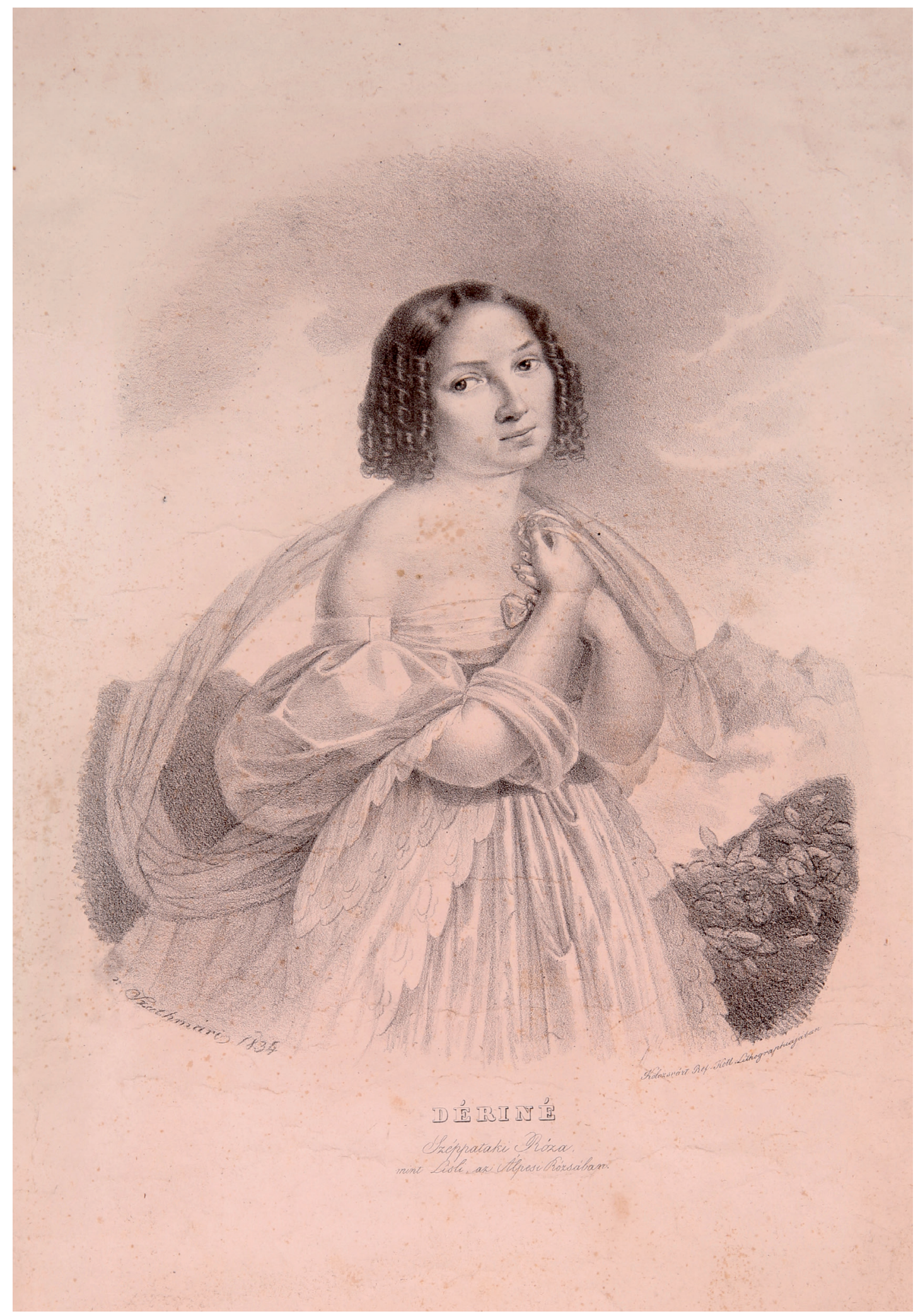

Fig. 4. DÉRINÉ Róza Széppataki (image from the MNIT Archive). 


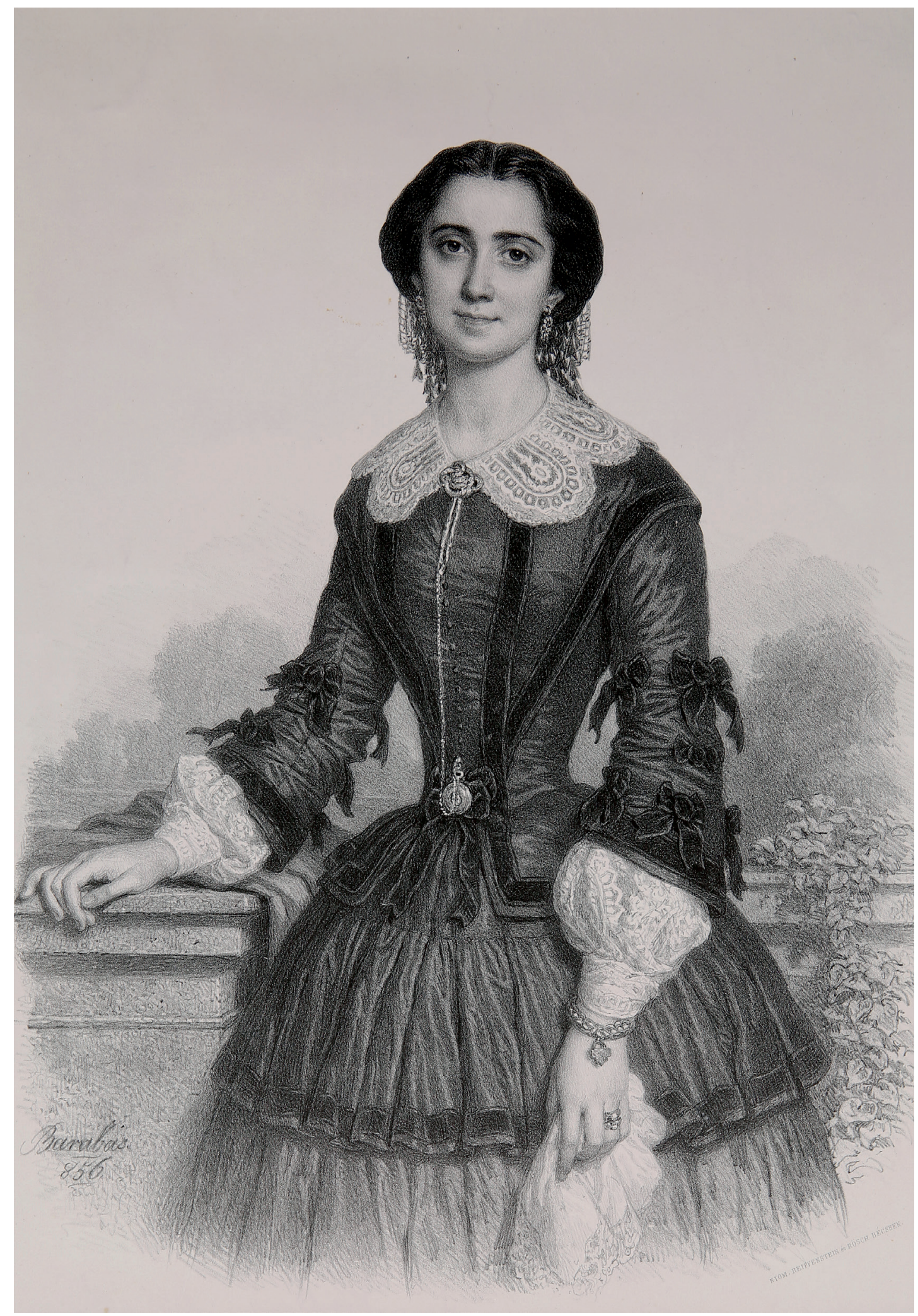

Fig. 5. Flóra Munkácsy (image from the MNIT Archive). 


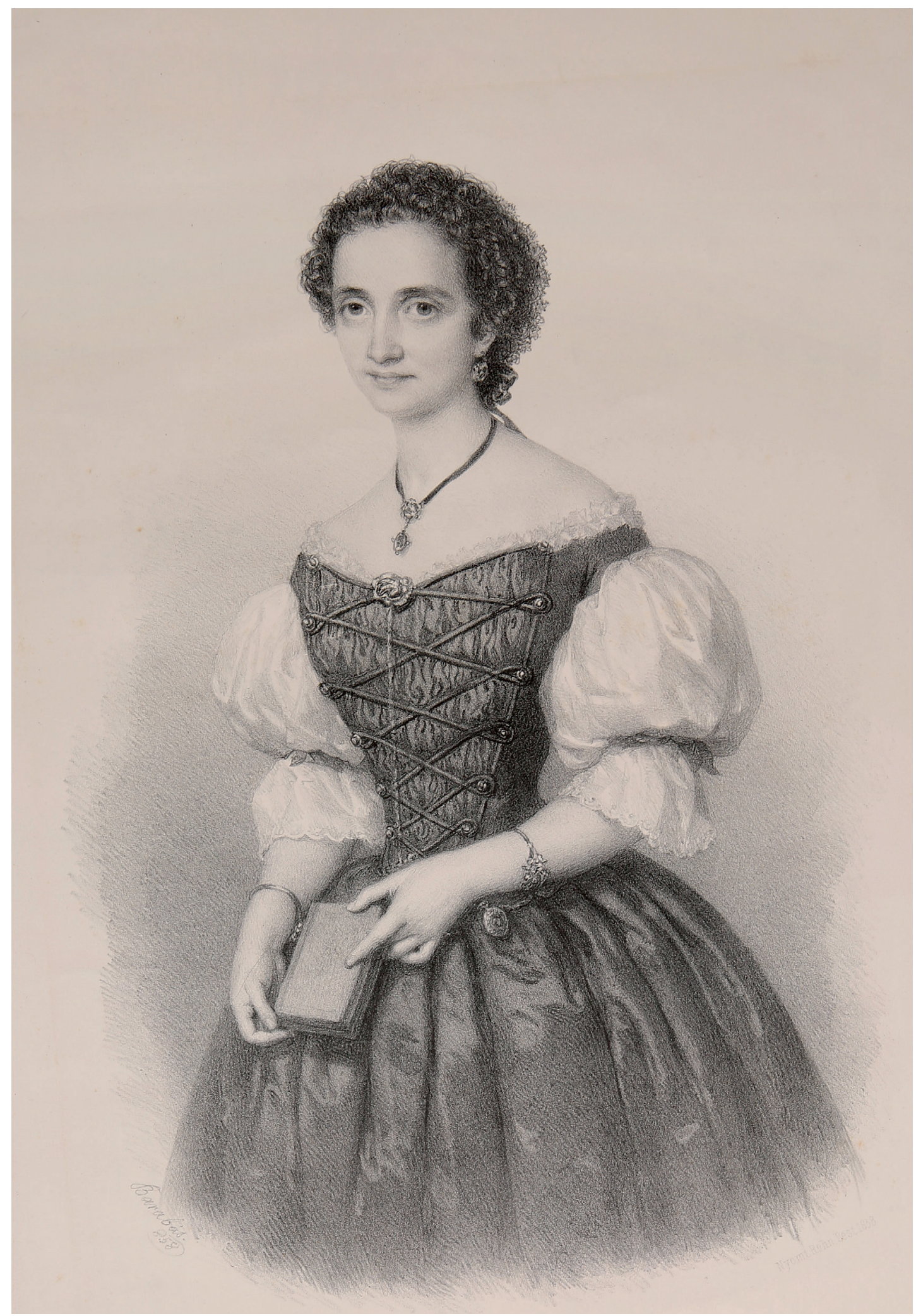

Fig. 6. Lina Bodenburg-Hegedüs (image from the MNIT Archive). 


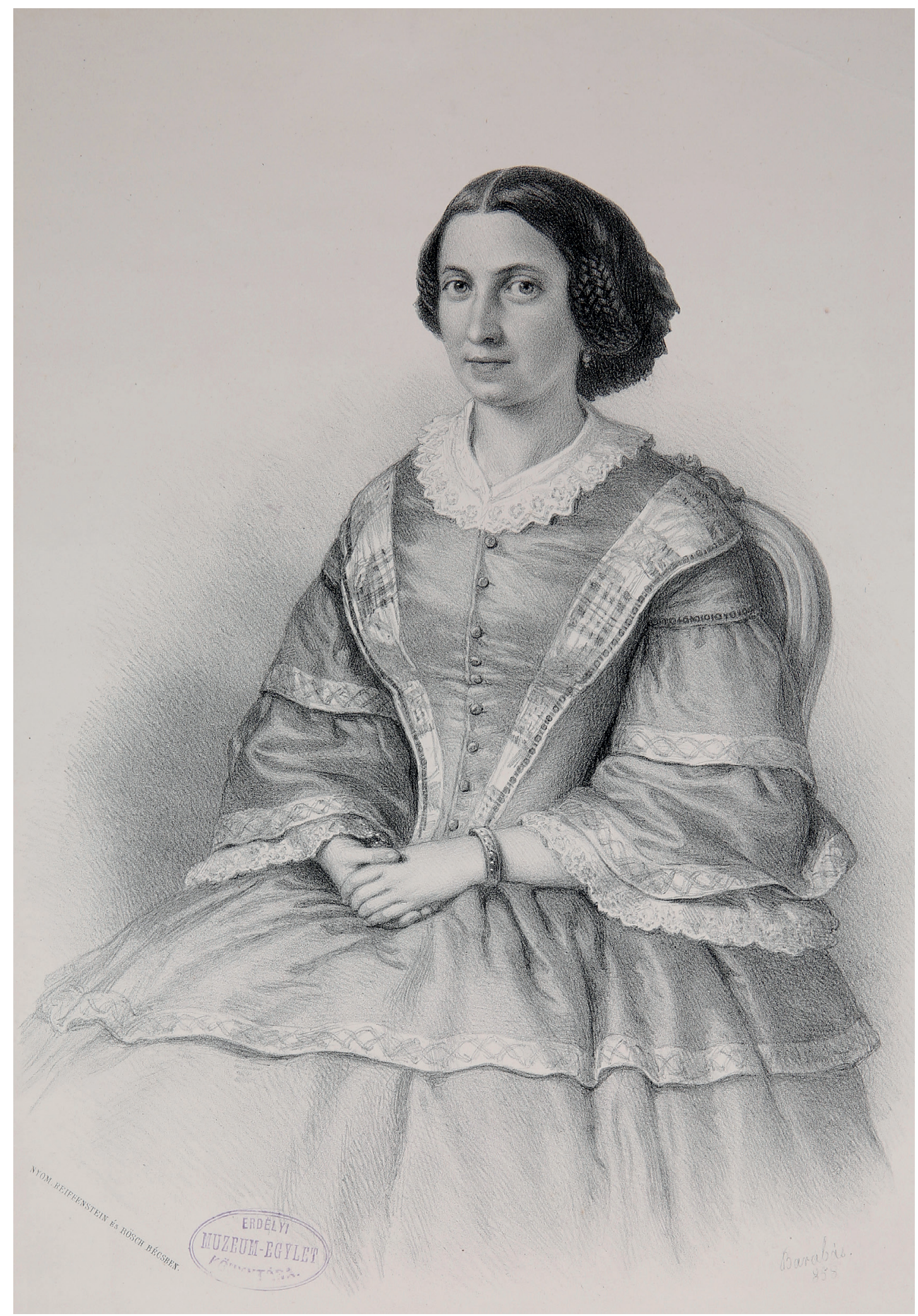

Fig. 7. Kornélia Prielle (image from the MNIT Archive). 


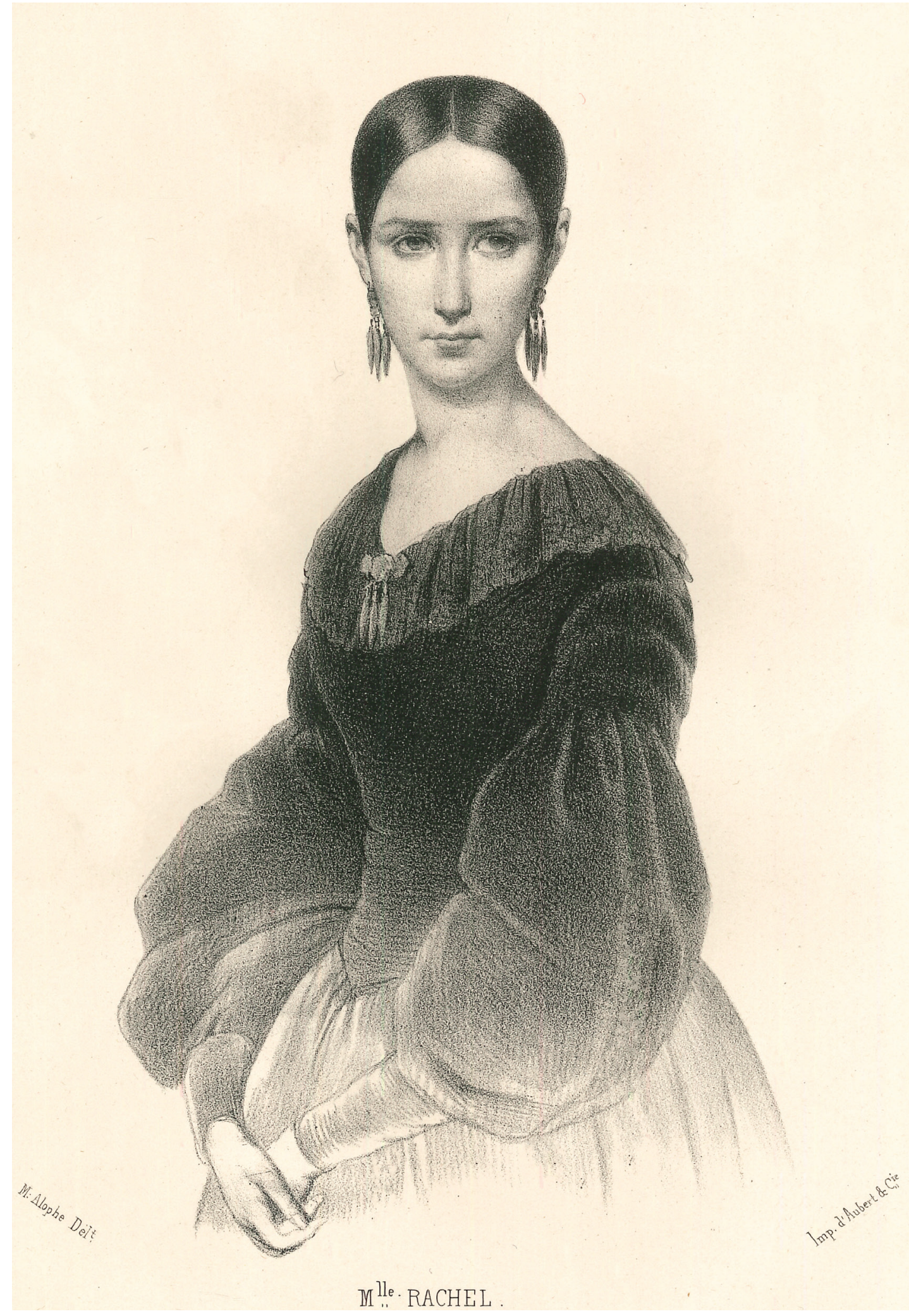

Fig. 8. Mlle Rachel (image from the MNIT Archive). 


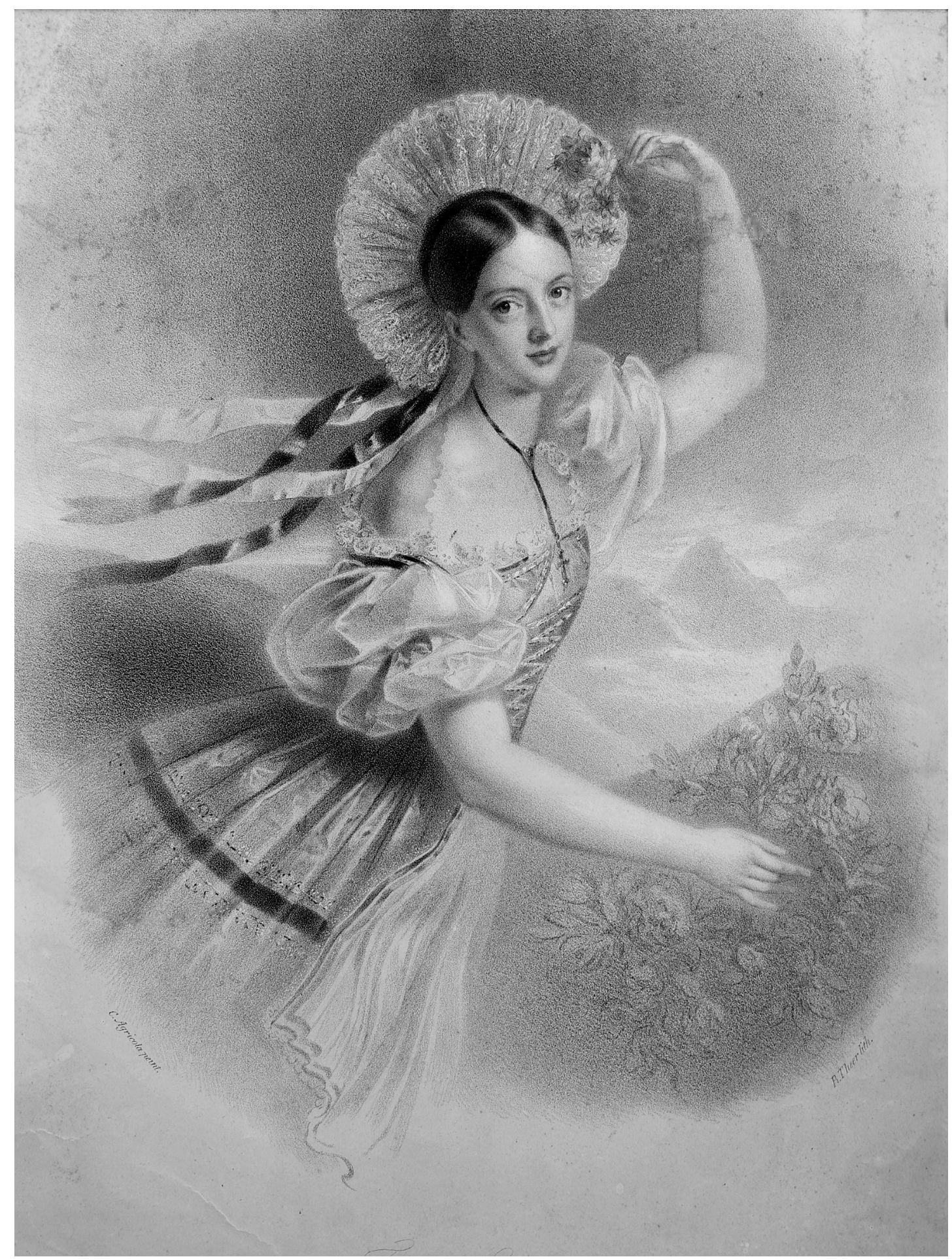

Fig. 9. Fanny Elssler (image from the MNIT Archive). 


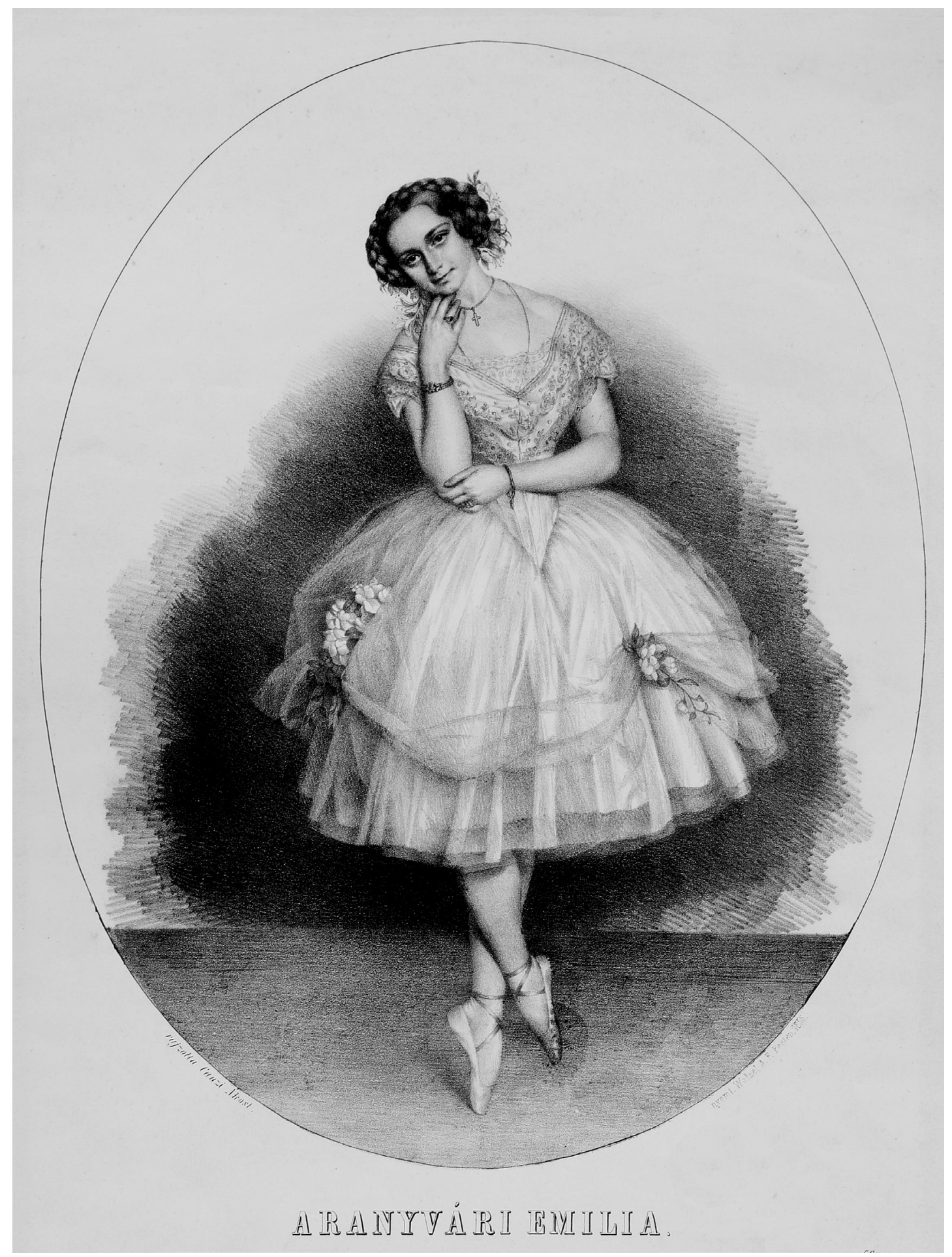

Fig. 10. Emília Aranyváry (image from the MNIT Archive). 


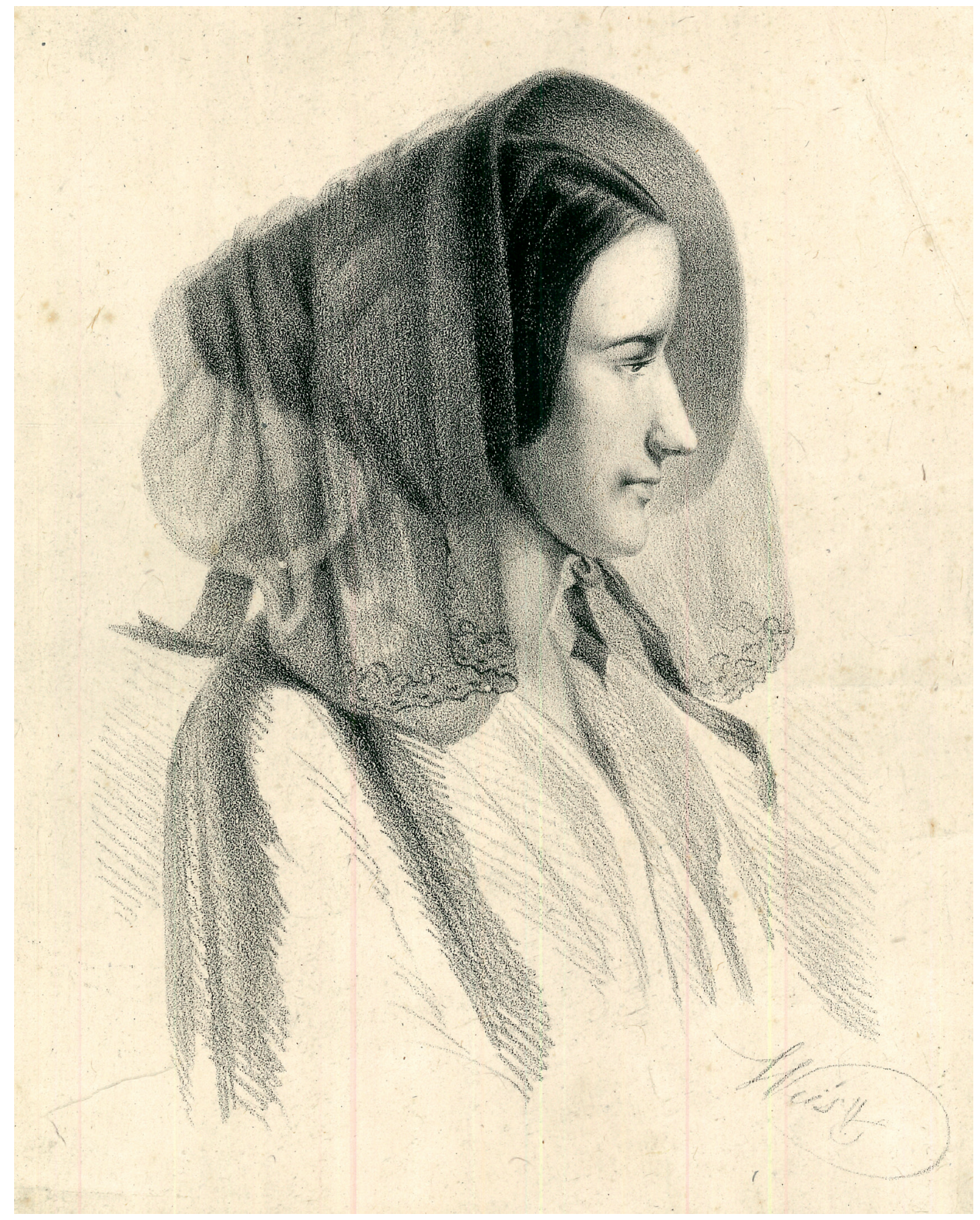

Fig. 11. Marie-Fortunée Lafarge (image from the MNIT Archive). 


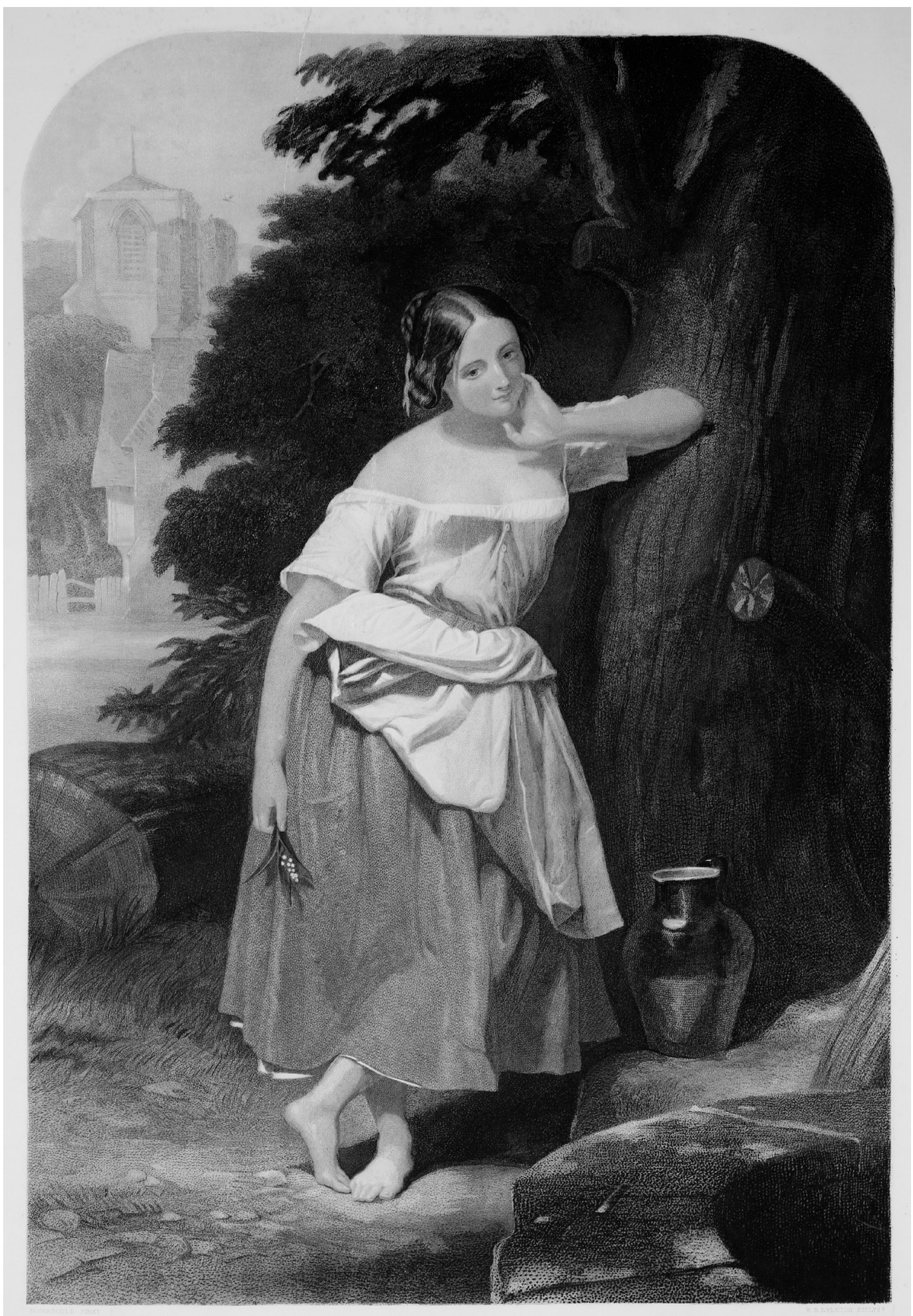

Fig. 12. Girl by the Fountain (image from the MNIT Archive). 


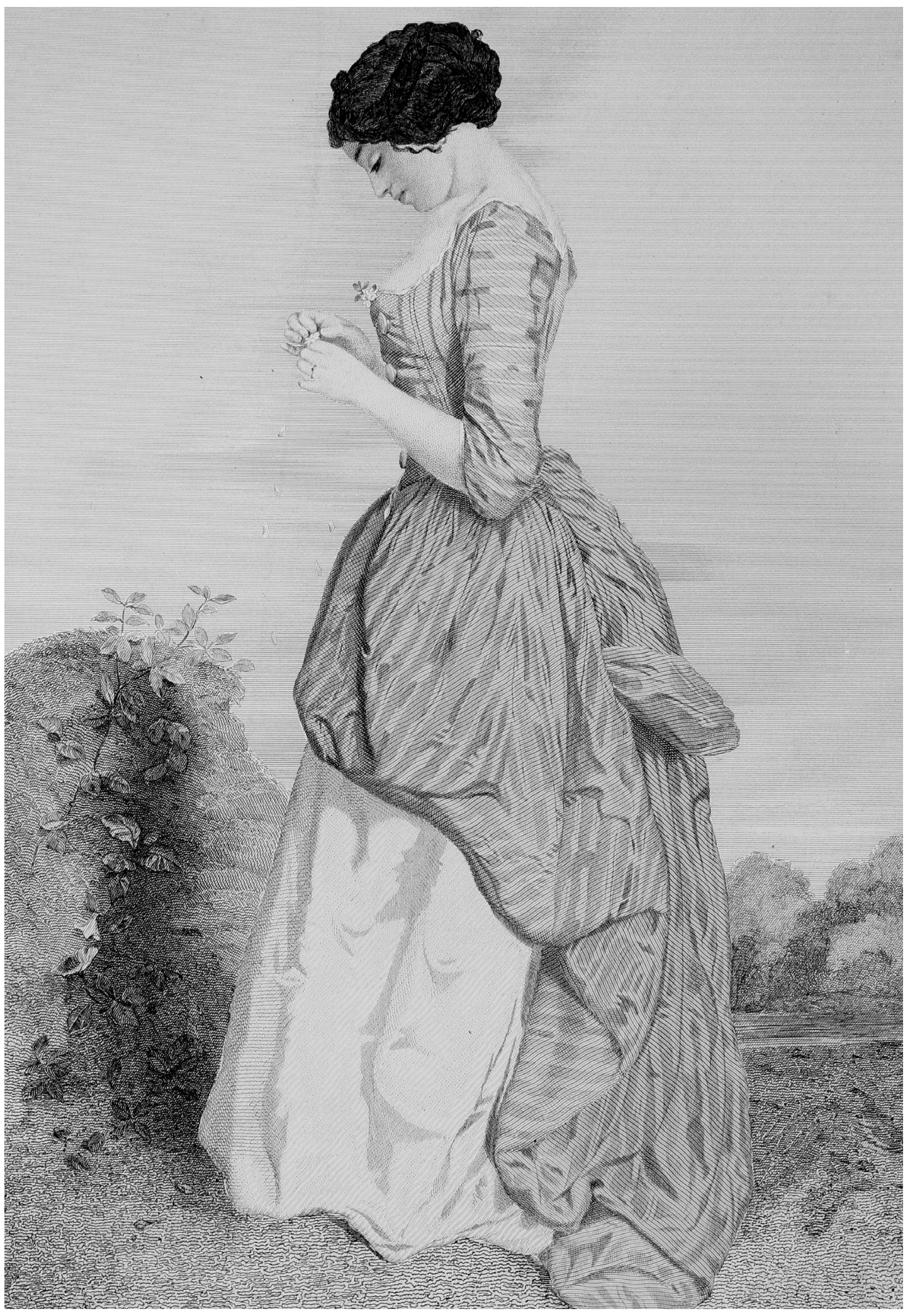

Fig. 13. Szeret - nem szeret (image from the MNIT Archive). 


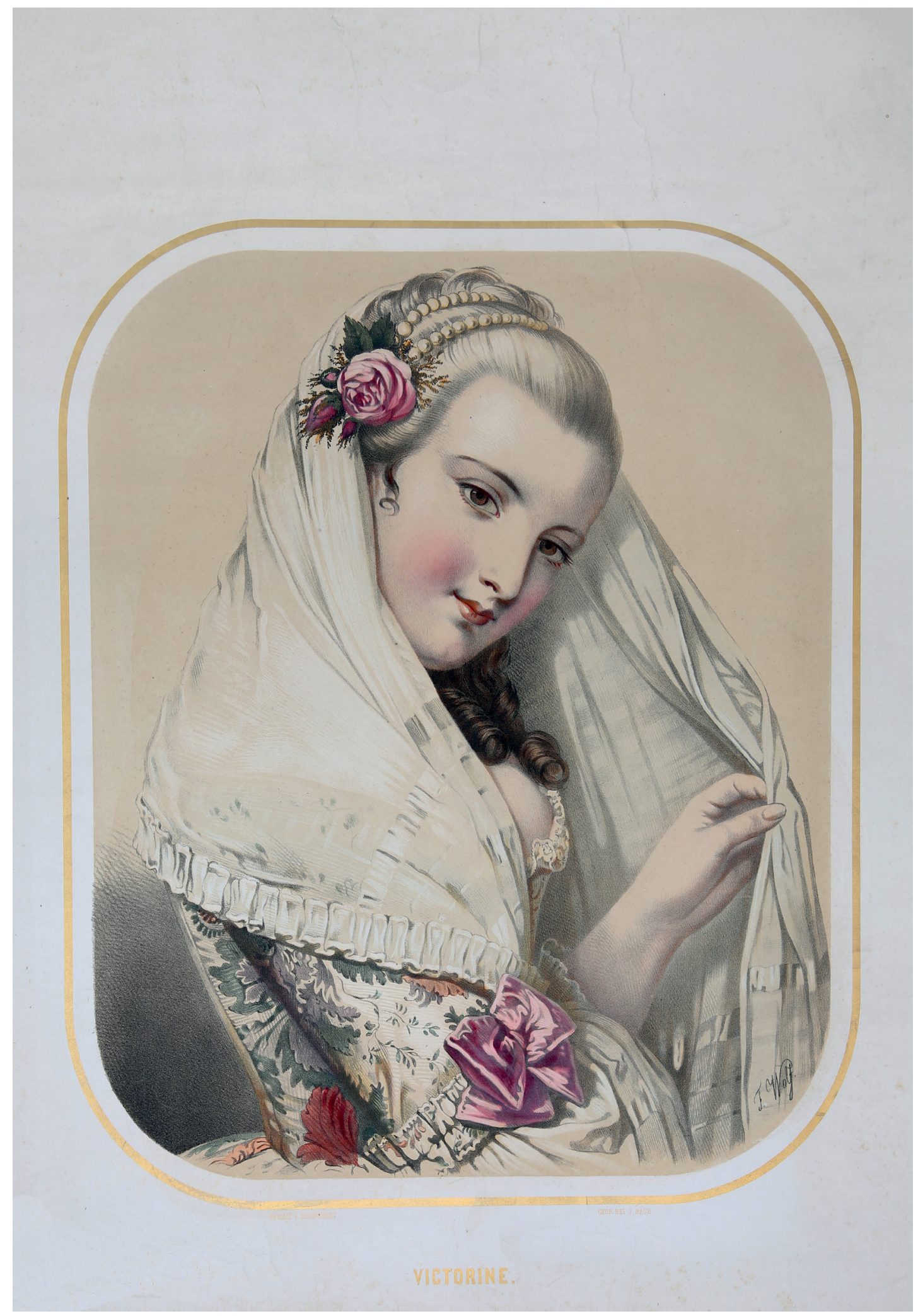

Fig. 14. Victorine (image from the MNIT Archive). 


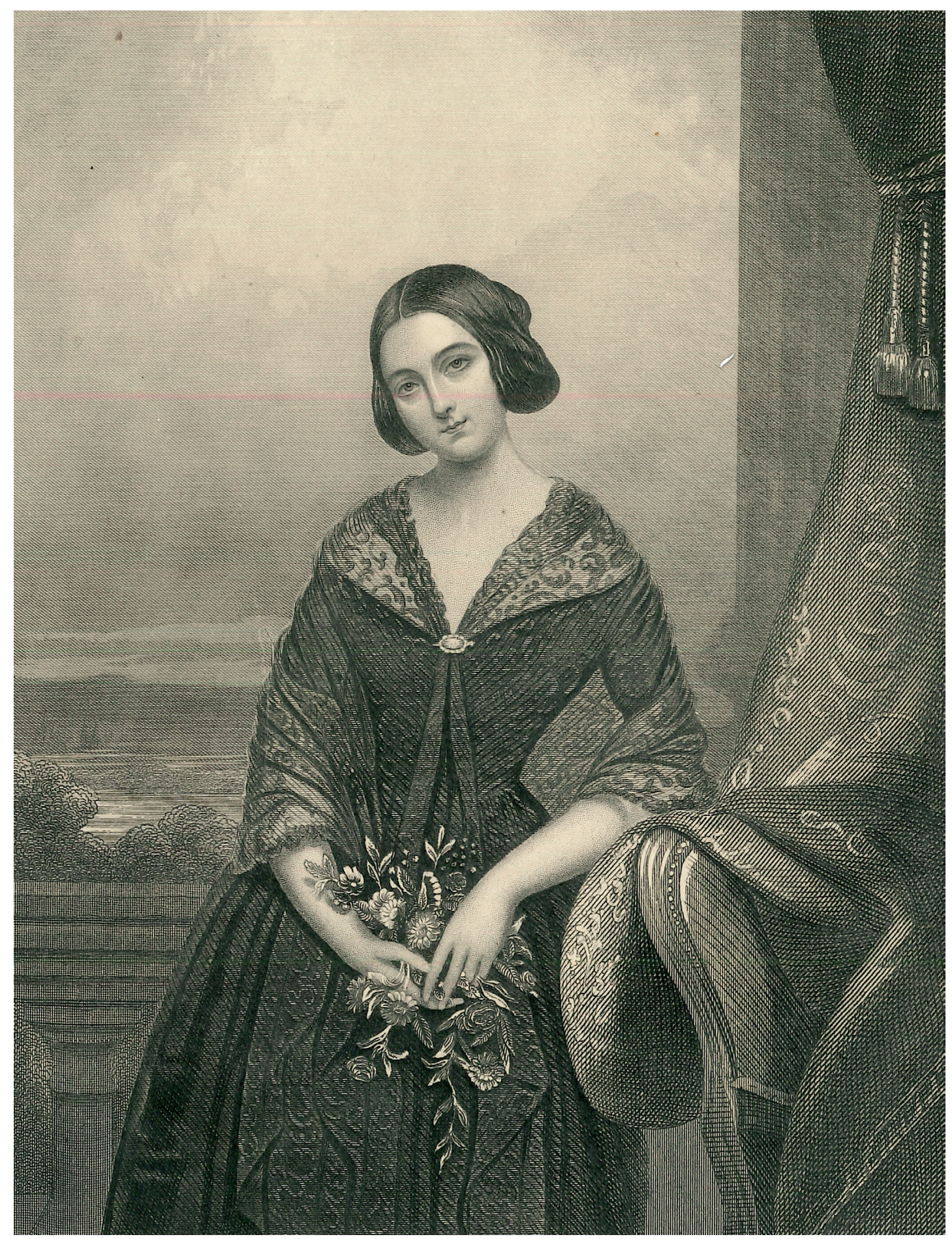

Fig. 15. Flora (image from the MNIT Archive). 


\title{
AN UNPUBLISHED VISUAL DOCUMENT: THE PHOTO ALBUM OF LAWYER AUGUSTIN RAŢIU
}

\author{
OVIDIU MUNTEAN*
}

\begin{abstract}
Dr. Augustin Rațiu (1884-1970) was a distinguished member of the intellectual elite in the town of Turda. He participated in the National Assembly held in Alba Iulia on 1 December 1918 as the official delegate of the local electoral circle. After the Great Union, he had a series of administrative positions within the Turda-Arieș County Prefecture, and between 1932 and 1933, he was mayor of Turda. Through his entire activity, he zealously promoted the memory of his uncle, the great leader of the Memorandum movement Dr. Ioan Raţiu (1828-1902), both on the occasion of the centenary of his birth (1928) but, especially, two years later, when a statue was unveiled in Turda on 9 June 1930. To that end, Augustin Rațiu also composed an impressive Album containing over a hundred vintage photographs, many of them unique, which he grouped in chronological order. The visual documents included in the Album complete the conventional sources and enrich the knowledge of some historical events that marked the family's destiny of the illustrious representative of the Memorandum movement, Dr. Ioan Raţiu. They directly capture moments and sequences of public or private life, carried out in succession, over almost eight decades, from the second half of the nineteenth century to the interwar period.
\end{abstract}

Keywords: Memorandum movement, Dr. Ioan Rațiu, photos, Dr. Augustin Raţiu, Turda

Rezumat. Avocatul Dr. Augustin Raţiu (1884-1970) a fost un distins membru al elitei intelectuale din orașul Turda. A participat la Adunarea Națională de la Alba Iulia din 1 Decembrie 1918 în calitate de delegat oficial al Cercului electoral din localitate. După Marea Unire a ocupat o serie de funcții administrative în cadrul Prefecturii județului Turda-Arieș, iar între anii 1932-1933 a fost primar al orașului Turda. Prin întreaga lui activitate a promovat cu stăruință memoria unchiului său, marele memorandist Dr. Ioan Rațiu (1828-1902), atât cu ocazia aniversării centenarului nașterii acestuia (1928) dar, mai ales, doi ani mai târziu, o dată cu dezvelirea statuii din Turda la 9 iunie 1930. În acest scop, Augustin Rațiu a alcătuit și un impresionant Album ce conține peste o sută de fotografii de epocă, multe din ele inedite, pe care le-a grupat în ordine cronologică. Documentele vizuale cuprinse în Album completează sursele convenționale și îmbogățesc cunoașterea unor evenimente istorice care au marcat destinul familiei ilustrului memorandist Dr. Ioan Rațiu. Ele surprind în mod direct momente și secvențe de viață publică sau privată, desfășurate în succesiune, într-o perioadă de aproape opt decenii, începând din cea de-a doua jumătate a secolului al XIX-lea și până în perioada interbelică.

Cuvinte cheie: mișcarea memorandistă, Dr. Ioan Rațiu, fotografii, Dr. Augustin Rațiu, Turda

An outstanding personality among the Romanians in Transylvania, Dr. Ioan Rațiu (1828-1902) was a remarkable politician, a talented jurist, and a promoter of the Romanians' national culture in the second half of the nineteenth century. His tireless activity for the

\footnotetext{
*Ph.D., Museum curator, National Museum of Transylvanian History, Cluj-Napoca, email: ovidiu2505@ yahoo.com, (iD https://orcid.org/0000-0002-5552-9943.
} 
assertion of the Romanian nation in Transylvania, in his dual capacity as leader of the Memorandum movement and president of the Romanian National Party (1892-1902), was revered both during his lifetime and after his death. ${ }^{1}$ After the Great Union of 1918, his memory was honored by the homage events organized in Sibiu for the centenary of his birth (1928) and in Turda. Here, a memorial plaque was unveiled on his former house. Two years later, the culmination of these homage events was the unveiling of his statue in Turda, a symbolic monument perpetuating his memory in bronze. ${ }^{2}$ The sculptor Cornel Medrea, the imposing statue of Dr. Ioan Raţiu is erected in the former Queen Maria Square in front of the former Palace of the County Prefecture. ${ }^{3}$

An important contribution to the realization of this emblematic monument of the city is attributed to the lawyer Dr. Augustin Rațiu (7 July 1884-2 December 1970). He was a distinguished member of the Turda intellectual elite, ${ }^{4}$ the nephew of Ioan Rațiu and the dean of the Bar Association of Turda. Together with Dr. Valeriu Moldovan and Dr. Emil Chețianu, he was on the Committee in charge of the erection of this monument. ${ }^{5}$ There is no doubt that Augustin Rațiu's Photo Album, which is the subject of this study, was completed during this period. Its final pages contain five vintage photographs taken when the statue was unveiled on 9 June 1930. Moreover, inside the last cover of the Album, there are pasted three documents printed at the printing house 'Arieșul.' They are all related to these events: The Invitation and Program for the Inauguration of the Statue, signed on behalf of the Bar by its dean, Dr. Augustin Rațiu, and by the counselor Dr. Emil Chețianu, a Ticket to Attend the Festive Banquet, as well as a flyer with the printed text of Raţiu's Doina, written by Miss Vioara Magdu from Ecica Română - Arad (Fig. 1-2).

The Album is kept in the Modern History Collection of the National Museum of Transylvanian History (hereafter MNIT), and it was donated by Dr. Augustin Rațiu on 29 April 1967. Compiled to honor the memory and deeds of its illustrious forerunner, the Album brings together an impressive collection of vintage photographs. Many of them are unique, and they reconstruct sequences from the history of the Rațiu family in the second half of the nineteenth century and the first three decades of the twentieth century. ${ }^{6}$ The author grouped the visual documents chronologically and referred to a series of public or private events of the family of the great Memorandum movement leader. The purpose of our approach is to present the most important photographs directly related to the historical context in which they were taken while highlighting, at the same time, the original ones. The covers of the Album were wrapped in red cloth and tied with a green woven cord, and the first cover had the words $A L B U M$ and initials of the author-Dr. A. $R$ imprinted with gold leaf. Inside, on cardboard, ${ }^{7} 109$ black-and-white or sepia photos were pasted-most of them with captions written in blue ink by the lawyer Augustin Rațiu.

\footnotetext{
${ }^{1}$ Polverejan, Cordoș 1973, 9-94; Josan 1992, 75-83; Teodor et alii 1994, 75-110.

${ }^{2}$ Groza 1997, 395-405.

${ }^{3}$ The famous phrase was inscribed on the statue's pedestal: The existence of a people is not discussed, it is asserted! - spoken by Dr. Ioan Rațiu, who was indicted during the Trial of the Memorandum movement leaders from Cluj (23 May 1894). See Cordoș 1980, 245-251.

${ }^{4}$ Neagu, Groza 2019, 117-199; Comșa, Glodariu, Jude 1998, 75-76; Comșa, Jude 1997, 325-339.

${ }^{5}$ Groza 1997, 404.

${ }^{6}$ Colecția MNIT, no. M 344.

7 On some of these cardboard sheets, the mark of a famous Sibiu photo studio is applied in a small oval stamp: Emil Fischer Hermannstadt.
} 
The Album opens with color reproduction, on the inside cover, of the family coat of arms, entitled COAT OF ARMS OF THE RATZ FAMILY OF NAGYLAK 1625 (Fig. 3). Next, some youth photos were added, and others taken after the portraits of the Memorandum movement leader Dr. Ioan Rațiu and his wife, Emilia Rațiu (1846-1929). Still, the most consistent chronological series of images is related to the development and echoes of the Memorandum movement of 1892-1895. In this regard, the photograph on the title page of the brochure containing the text of the Memorandum was inserted first. ${ }^{8}$ This is the official document that Dr. Ioan Rațiu, as head of the Romanian delegation to Vienna, presented to the chancellery of Emperor Francis Joseph at the end of May 1892 (Fig. 4).

In essence, it can be said that the Memorandum was a vindictive political gesture that subjected the policy promoted by the Hungarian governments after 1867 to a virulent indictment. The document considered that the rulers in Budapest had seriously subverted the enforcement of the electoral laws in Transylvania, of the law for the equal rights of nationalities, the law of education, the municipal and agrarian laws, and, last but not least, of the press law. Dr. Ioan Rațiu and the other signatories of the act denied, in the spirit of the entire Romanian national movement, the right of Hungary to annex Transylvania, seeking, through the petition they submitted to the emperor, to draw attention to the inevitable consequences in case of perpetuating dualism. ${ }^{9}$ In this document, the Memorandum movement leaders reminded Emperor Francis Joseph that only the belief that dualism was perceived by the Romanians as a passing political experiment had made them so patient in the face of the trials they had been subjected to in the last quarter of a century (18671892). ${ }^{10}$ In the authors' opinion, the solution to the severe crisis afflicting the Hungarian part of the empire was the renunciation of dualism through an energetic intervention of the monarch, in the sense of restoring equality and the 'internal association peoples.' ${ }^{11}$ This meant, consequently, the return to the politico-territorial individuality of Transylvania lost because of the compromise concluded in 1867.

After the Viennese episode of the Memorandum movement, Ioan Rațiu's return home took place in dramatic circumstances, in the sense that, in retaliation for his daring feat, his house in Turda was devastated by the Hungarians. Together with his family, he had to take refuge in Sibiu (14 June 1892). Bearing the title The Devastations Perpetrated by the Hungarians upon the Houses of the President, Dr. Ioan Rațiu in Turda in 1892, a group of photos in the Album witnessed this sad event in the family's life. This event had profound implications for its members' destiny (Fig. 5).

The punitive action of the Hungarian judiciary against the Memorandum movement leaders began on 21 September 1892 with the criminal complaint filed against Eugen Brote. As the owner of the Printing Institute in Sibiu, he was accused that he had written and printed a leaflet with the text of the Memorandum in the country and abroad. Following Eugen Brote's statement that the decision to draft, print, and disseminate the Memorandum petition had belonged to the entire Central Committee of the Romanian National Party, on

${ }^{8}$ Memorandul 1892, 1-23. The brochure entered the Modern History Collection of the MNIT (no. M 2391) in 1970. It was purchased from Camila Tilea, the wife of Ionel Tilea, the nephew of Ioan Rațiu, and has several notes on the text made in black ink.

${ }^{9}$ Maior 1992, 272.

${ }_{10}$ Memorandul 1892, 18.

${ }^{11}$ Memorandul 1892, 22. 
13 May 1893, the Prosecutor General of Cluj, Vita Sándor, extended the criminal complaint against all members of the committee. The events related to the trial in Cluj were illustrated in the Album through a series of group photos of the petitioners, with their defense lawyers (Defenders of the 'Memorandum' Trial) and with journalists of the Press Office (Fig. 6a-b, $7-8$ ). It should be noted here that the group photo with the petitioners represents the most famous vintage image of those who were sentenced to prison at the end of the trial. The notoriety of this photograph was given because it was widely spread in the form of a lithograph printed in Rome at the Luigi Salomone printing house. Titled The Convicts Sentenced for the Romanian Memorandum Petition Presented to His Majesty the Monarch, 189228 May - 189425 May, the lithograph had the image of the 15 convicted petitioners in the center and their names at the bottom (Fig. 6b).

Next, an original photo was added, entitled The Wives of the Petitioners. On it, Augustin Rațiu wrote down the name of each woman in the image. The two distinguished ladies sitting on the chairs are Clara Maniu, the sister of the lawyer Iuliu Coroianu and Emilia Raţiu. Behind them, standing, worried about the fate of their husbands on the indictment in the Cluj trial, are Viorica Mihali, Elena Pop Hossu-Longin (wife of the defense lawyer, Francisc Pop Hossu-Longin), Mrs. Barcianu, Paulina Lucaciu, and Elena Veliciu (Fig. 9).

The memorandum trial was held in Cluj between 7 and 25 May 1894. The Hungarian judiciary sentenced 15 of the 29 defendants to prison terms ranging from two months to five years and the payment of a large sum of money representing legal costs. At the end of June 1894, after the rejection of the appeal to the Court of Cassation in Budapest, the petitioners were arrested and imprisoned. Ioan Rațiu (sentenced to 2 years), Iuliu Coroianu (sentenced to 2 years and 8 months), and Vasile Lucaciu (sentenced to 5 years) were imprisoned in the Szeged gaol, while the other petitioners were in prison in Vaț. In this sense, the Album contains an original photo entitled - The Dungeon of Szeged. On it are marked the cells where Ioan Rațiu, Iuliu Coroianu and Vasile Lucaciu were held in detention (Fig. 10).

But the love and appreciation of the Romanians on both sides of the Carpathians followed the three petitioners incarcerated in Szeged and those imprisoned in Vat?. At the same time, there emerged a strong sense of national solidarity with the signatories of the Memorandum petition. Some of them carried extensive correspondence or received gifts, albums, telegrams, support missives, messages, and congratulatory letters with thousands of signatures on the occasion of the Christmas holidays, New Year, or on their name day. ${ }^{12}$

The memory of these events was preserved in the Album through photographs with the texts written by the petitioners in prison (for example, Vasile Lucaciu wrote to Felicia Rațiu on 12 September 1894). These texts containing the thoughts of the detainees were gathered in an album by Felicia Rațiu, the middle child of Ioan Rațiu, who became the head of the Committee of Romanian Young Ladies ${ }^{13}$ (Fig. 11). Also, a photo of the manifesto

\footnotetext{
${ }^{12}$ In this sense, an impressive testimony of national solidarity is a letter with a tricolored ribbon kept in the museum's collection, under inv. no. M 2469. The letter was sent from Bucharest to Ioan Rațiu on his name day on 7 January 1895. The letter was classified by us in the legal category Fund of the National Cultural Heritage by Order of the Minister of Culture no. 2471/9.08.2007.

${ }^{13}$ Rațiu 1935, 17-18. The Committee's activity consisted of raising funds for the propaganda of the Memorandum movement abroad. The money was obtained from the sale of commemorative medals, and the Call addressed to Romanian women in Transylvania by the historian V. A. Urechia, which contained
} 
newspaper 'Golgotha' was inserted, published by the Cultural League of Bucharest in a unique issue (24 April/6 May 1894). A publication that expressed the pain of the Romanian people featured crosses on which the Memorandum movement leaders were crucified on its frontispiece. On the front page, the newspaper published the poem Heroes-Martyrs written by Alexandru Vlahuță, through which the poet showed solidarity with the Memorandum movement leaders and expressed confidence in the triumph of the Romanian people (Fig. 12a-b).

The epilogue of the Memorandum movement was the release of all the convicts after 14 months in prison due to the act of pardon signed by Emperor Francis Joseph on 15 September 1895. For more than a year, numerous requests for the pardon of the Memorandum movement leaders were made at the official level by the Romanian government, by the Greek Catholic Metropolitan Church of Blaj, by the Orthodox Episcopate of Arad, by political personalities of European notoriety, etc. The intervention of the King of Romania, Carol I, produced during his visit to Vienna (August 1895) was decisive, as he insistently pleaded with the emperor to release the convicts. ${ }^{14}$

After the years documenting the Memorandum movement, the Album contains a consistent series of family photos. These are first of all images of the three daughters of Ioan Rațiu and Emilia Rațiu: Emilia-Nina (Mimi) Rațiu (1864-1940), Felicia Rațiu (18681938) and Dorina Rațiu (1872-1904). The eldest daughter, Emilia, was married first to the engineer Onoriu Tilea in Sibiu, and this marriage resulted in four children: Eugen, Mărioara, Ionel, and Viorel Virgil ${ }^{15}$. Two of them, Mărioara (married Perția) and the future career diplomat Viorel Virgil Tilea (1896-1972), have some photos taken at an early age in the Album. Along with these, there are some unique snapshots of moments captured during a vacation spent by the Rațiu sisters and other close relatives at the residence of the spouses Emilia and Onoriu Tilea in Șmig (Sibiu county) (Fig. 13).

Another favorite holiday destination of the Rațiu sisters was the Bădăcin, a village where Mrs. Clara Maniu was a welcoming host for her brother, Iuliu Coroianu, who married Dorina Rațiu ${ }^{16}$ in 1897 (Fig. 14). In the summer of 1901, Felicia and Dorina Rațiu arrived at the Maniu family home in Dealul T,arinei, where they met Cornelia and Sabina Maniu, Iuliu Maniu's sisters. Several unique photos show us the good mood of the girls. In one of the pictures, this text was recorded: Feliz, Olympia, Sabina, Cornelia, Bădăcin 1901, August (Fig. 15). About this summer stay in Bădăcin, we are given details in a letter that Felicia Rațiu sent to her father on 1 August 1901. Here, she informed him about the turmoil within the Romanian National Party and about Vasile Lucaciu's attitude towards the convening of the National Committee. She also expressed her joy to see Bădăcin again:

My dear Father. I arrived in peace and without much heat in the well-praised Bădăcin ... I left yesterday morning by carriage and traversing places of outstanding beauty in splendid weather, without dust - I arrived at 12 o'clock. It is beautiful here, a quaint

17 medallions with portraits of the leaders of the Romanian National Party. In the museum's collection, there is a copy of this Call (Colecția MNIT, no. M 12132) which comes from the personal archive of Augustin Rațiu.

14 Maior 1992, 246.

${ }_{15}$ Georgescu 1928, 21; Ciucă, Ciucă 1994, IX.

${ }^{16}$ Cordoș, Neamțu 2006, 199. 
and comfortable house. For that matter, you've been here before, and you know the place ... Tonight is the concert, we're attending it as well; the party is tomorrow. Iuliu is leaving for Toplița tomorrow, but we'll stay until 13 August ... I am laughing and partying, so I can barely write anything. Felicia. ${ }^{17}$

The pages of the Album also contain an original series of ten vintage images that show us details inside the new home of the Rațiu family in Sibiu. Forced to leave his native Turda, after the events of 13 June 1892, Ioan Rațiu moved to Sibiu with his family into a one-story house located today at the intersection of Victoria Boulevard and the street that bears his name. With the help of these unique photos, you can discover the rooms where the family received the many guests who crossed its threshold. Felicia Rațiu's Guest Room, office, and bedroom were beautifully decorated with antique furniture, decorative objects, souvenirs, fabrics, curtains, paintings, and framed photographs that created an intimate and pleasant atmosphere.

In the Guest Room (Fig. 16) we are particularly impressed by the two paintings hung on either side of the curtain. These are the portraits of Ioan Rațiu and Emilia Rațiu, painted in oil on cardboard, with a carved Secession-style wooden frame. It is significant to remember that the two paintings in the salon in Sibiu passed the test of time and entered the MNIT History collection in 1986, through a donation made by the descendants of Augustin, Eugenia, and Mircea Rațiu. The paintings of the Rațiu spouses were exposed to the public for the first time in the exhibition The Memorandum Movement of the Romanians in Transylvania - 125 Years. This anniversary exhibition was opened on 18 May 2017, being organized as part of the series of cultural-educational events preceding the Centenary of the Great Union of 1918 (Fig. 17-18).

In the early years of the twentieth century, two tragic events aggrieved the family. On 4 December 1902, Dr. Ioan Rațiu passed away and was buried in the cemetery of the Church 'among the fir trees' in Sibiu. Only two years later, on 7 June 1904, the youngest member of the family, Dorina Rațiu, also died at 32. These sad events deeply marked Felicia and Emilia Rațiu, as seen in a vintage photo with the description: Emilia Dr. Ioan Rațiu and her daughter, Felicia, under the crown received from the Bucharest League (Fig. 19). In the following years, through her entire activity, Emilia Rațiu sought to keep alive the memory of her husband in the souls of Romanians on both sides of the Carpathians. Thus, she turned her attention to patronage and charity actions supporting Romanian churches, schools, and boarding schools for children. Together with Maria Baiulescu, she organized the meetings of Romanian women, schools for orphaned children and offered support to Romanian craftsmen. ${ }^{18}$

On the centenary of the birth of Dr. Ioan Rațiu (19 August 1928), a series of commemorative events took place in both Sibiu and Turda, and they were illustrated in the Album through photographs reminiscent of these moments of pious homage where a large audience took part. Thus, in Sibiu, at the tomb of the great petitioner, the canonical Victor Macavei from Blaj officiated a memorial service. Emilia Rațiu participated together with her two daughters, Felicia and Emilia, and her husband Octavian Russu, Viorel Virgil

\footnotetext{
17 Ciucă, Ciucă 2002, 248-249.

18 Bodea 1975, 1895; Glodariu, Rațiu 1980, 253-258.
} 
Tilea, and Iuliu Maniu, who laid a wreath here (Fig. 20). Six photos of the Album capture this commemorative moment.

At the same time, a memorial service was held in Turda, and then the participants organized a large procession to the former house of Dr. Ioan Rațiu. Here, after the divine service, Dr. Valer Moldovan unveiled the commemorative plaque placed on the façade of the house during a ceremony. The following text was inscribed in golden letters on the marble plaque: Dr. Ioan Rațiu lived in this house until 14 June 1892. The archpriests Nicolae Rațiu and Ioan Tempeleanu gave speeches on this occasion. The festivity was concluded by Ștefan Cicio-Pop, the president of the Assembly of Deputies, who gave an impressive political speech. ${ }^{19}$ The moment of this speech and participants was also captured in a series of photos from the Album. Next, Augustin Rațiu also added an image where he appears alone in front of his uncle's former house (Fig. 21-22).

In chronological order, the next major event in the family, illustrated by eight photos, was the funeral of Emilia Rațiu, who, after a life lived with a sense of duty to the family, to her peers, and to achieving the ideal of Greater Romania, ${ }^{20}$ died on 1 February 1929. In Sibiu, an impressive crowd accompanied her in a funeral procession. Among the personalities who participated, we can recognize in a photo Nicolae Bălan, Metropolitan of Transylvania, along with Iuliu Maniu, Alexandru Vaida-Voevod, and others (Fig. 23).

An eyewitness to this event was Ion Rațiu (1917-2000), the son of the lawyer Augustin Rațiu, future politician and prominent personality of the Romanian exile, who remembered the moment as follows years afterward:

I was in Sibiu at 'Mother's' funeral, as Emilia Rațiu was known in the family. I was with my father, the lawyer Augustin Rațiu, who married Eugenia Turcu in 1913. He had come to Sibiu from the family's hometown, Turda, living in 'Mother's' house. I was 12 years old. The funeral service was performed in the Greek Catholic church, 'among the fir trees.' Mother was buried in the churchyard, in the same grave where the bones of her beloved husband lay. She had simply adored him her whole life and supported him with boundless devotion in the difficult task he had taken on in the service of the national cause. The crowd was huge. It was as if the whole of Sibiu was present for her last journey. After the funeral, the family members gathered in Mother's house. I remember how all the objects, all the souvenirs, all the photographs, framed in silver, many of them, were kept sacred, untouched, as they were when 'Father' was still alive. ${ }^{21}$

The event that would honor the memory of Dr. Ioan Rațiu for eternity was the unveiling of the statue in his native Turda on 9 June 1930. The five photos taken at the unveiling of the statue occupy the last pages of the Album and capture the crowd of participants who came to take part in the festive moments of this event. The ceremony organized on this occasion by Augustin Rațiu was an important cultural landmark for interwar Turda, given its size and the important personalities of Romanian culture who attended it: the Greek

\footnotetext{
19 Groza 1997, 400.

20 Bodea 1975, 1911.

21 Ciucă, Ciucă 1994, V-VI.
} 
Catholic Bishop Iuliu Hossu, the writer Ion Agârbiceanu, the scientist Emil Racoviță, the diplomat Viorel Virgil Tilea, the Memorandum petitioners Teodor Mihali and Dimitrie Comșa among others ${ }^{22}$ (Fig. 24).

The Album ends with some photos added by Augustin Rațiu after the inauguration of the statue. They refer to the personality of Felicia Rațiu, who, together with her mother, campaigned to raise the cultural and professional level of Romanian girls in Transylvania. On the other hand, she was also the author of a memoir entitled The Vandalism of Turda. ${ }^{23}$ Prefaced by the poet Ioachim C. Drăgescu, the pamphlet contained Felicia Rațiu's notes on the devastation of her family's house in Turda (1/13 June 1892), after her father's return from Vienna. For her entire activity carried out to defend the rights and freedoms of Romanians in Transylvania and the role she played in achieving the Great Union of 1918, Felicia Rațiu was decorated with the 'Ferdinand' Medal by King Carol II himself. The official ceremony took place at the 'Astra' Museum in Sibiu, and an original photo, with a note on the back, captured this event in 1932 (Fig. 25).

Felicia Raţiu passed away on 31 October 1938 and was buried in the family grave in Sibiu, together with her parents and sister. This year, on the last page of the Album, the lawyer Augustin Rațiu added the obituary with the death of his cousin, thus ending the chronological series of family events (Fig. 26).

The visual documents contained in the Album complete the conventional sources and thus enrich the knowledge of some historical events that marked the family's destiny of the illustrious petitioner Dr. Ioan Rațiu. They directly capture moments and sequences of their public or private life, carried out in succession, over almost eight decades, from the second half of the nineteenth century to the interwar period. The Memorandum movement in Transylvania was the moment that decisively marked the history of the family, which is why the photographs taken in the context of the events that occurred between 1892 and 1895 occupy a central place in the Album. The merit of the Turda lawyer Augustin Ratiiu should be highlighted here. Through his entire activity he zealously promoted the memory of his uncle, both on the occasion of the centenary of his birth in 1928 but, especially, two years later, when the statue was unveiled in Turda. In fact, both events were noted by Nicolae Iorga, who, in two articles written in 1928 and 1930, masterfully summarized the political career of Ioan Ratiu, highlighting 'his significance' as president of the Romanian National Party and leader of the memorandum delegation. In 1928, on the centenary of Ioan Rațiu's birth, the great Romanian historian thus evoked the role he played on the Romanian political scene at the end of the nineteenth century:

In Transylvania, Dr. (doctor of law) Ioan Rațiu was commemorated and, on this occasion, the figure of the strong leader of the Romanians there in the fight for national rights came to light again. That figure deserves not to be forgotten, not because Rațiu was at the head of the Romanian National Party across the mountains for so many years, nor for extraordinary talents, but for two other reasons. The first

${ }^{22}$ Groza 1997, 404; Neagu, Groza 2019, 144.

${ }^{23}$ Rațiu 1893. A rare typed copy of this brochure written by Felicia Rațiu, which came from Augustin Rațiu's personal library, was donated to the museum by his descendants and was inventoried under no. M 9903. 
was the historical moment he represented. Until then, the Romanians there had been led by the church: 'Priests with the cross in their hands...' Șaguna had given a special, princely brilliance to this hegemony of the crosier. But his descendants being only what they were, and the times being more and more secular, the search for a helmsman was in vain. Leaving aside the teachers, the choice fell on a lawyer. And since then, the policy of our brothers there has been conducted with lawyers and lawyer-like. But Rațiu was much more than a lawyer. He had a downright manner, he was stubborn, frank, of a sincerity and courage that make even interactions with a politician pleasant and give a sure line to the political life itself. Here lies his significance. ${ }^{24}$

\section{Bibliography}

\section{Primary sources}

Colecția MNIT + no.

Memorandul 1892

Rațiu 1893

\section{Secondary sources}

Bodea 1975

Ciucă, Ciucă 1994

Ciucă, Ciucă 2002

Comșa, Jude 1997

Comșa, Glodariu, Jude 1998

Cordoș 1980

Cordoș, Neamțu 2006
Colecția Muzeului Național de Istorie a Transilvaniei, Cluj-Napoca, nos. M 344/1-110, M 2391, M 2469, M 8796, M 8797, M 9903, M 12126, M 12131, M 12132, C1 5296.

Memorandul românilor din Transilvania și Ungaria cătră Maiestatea Sa Imperială și Regală Apostolică, Împăratul Francisc Iosif I, Impărat al Austriei, Rege apostolic al Ungariei, Rege al Boemiei, Dalmației, Croației, Slavoniei, Galiției, Lodomeriei și Iliriei, Archiduce al Austriei, Mare Duce al Cracoviei, Duce al Lorenei, Duce al Salisburgului, Stiriei, Carneolei, Bucovinei, Silesiei-Superioare și Inferioare, Mare Principe al Transilvaniei, Margrav al Moraviei, Comite Princiar al Habsburgului și Tirolului, etc. etc. etc., Sibiu 1892.

F. Rațiu, Vandalismul de la Turda. Memoriile domnişoarei Felicia Rațiu, București 1893.

C. Bodea, Emilia Dr. I. Rațiu, soția memorandistului, Revista de istorie, 28/12 (1975), 1893-1912.

M.-D. Ciucă, E.-T. Ciucă, Dr. Ioan Rațiu și Emilia Rațiu, Corespondență I. Scrisori primite 1866-1895, București 1994.

M.-D. Ciucă, E.-T. Ciucă, Dr. Ioan Rațiu și Emilia Rațiu, Corespondență II. Scrisori primite 1896-1919, București 2002.

D. Comșa, M. M. Jude, Nicolae P. Rațiu și Augustin Rațiu promotori ai idealului național, ActaMN, 34/II (1997), 325-339.

D. Comșa, E. Glodariu, M. M. Jude, Clujenii și Marea Unire, Cluj-Napoca 1998.

N. Cordoș, Declarația lui Ioan Rațiu din 23 mai 1894, Potaissa, 2 (1980), 245-251.

N. Cordoș, G. Neamțu, Iuliu Coroianu. În vâltoarea vremurilor.1847-1927, Cluj-Napoca 2006.

\footnotetext{
${ }^{24}$ Iorga 1967, 242. With some modifications, the article was resumed by the historian Nicolae Iorga and published on the occasion of the unveiling of the statue in Turda (1930). See Iorga 1967, 254-255.
} 
Georgescu 1928

Glodariu, Rațiu 1980

Groza 1997

Iorga 1967

Josan 1992

Maior 1992

Neagu, Groza 2019

Polverejan, Cordoș 1973

Rațiu 1935

Teodor et alii 1994
I. Georgescu, Dr. Ioan Rațiu (1828-1902). 50 de ani din luptele naționale ale românilor ardeleni, Sibiu 1928.

E. Glodariu, M. Rațiu, Emilia Rațiu, reprezentantă de seamă a mișcării femeilor din Transilvania, Potaissa, 2 (1980), 253-258.

H. Groza, Despre ridicarea și dezvelirea statuii doctorului Ioan Rațiu din Turda, ActaMN, 34/II (1997), 395-405.

N. Iorga, Oameni care au fost, vol. II, București 1967.

N. Josan, Un bărbat pentru istorie. Dr. Ioan Rațiu (1828-1902), București 1992.

L. Maior, Memorandul. Filosofiapolitico-istoricăapetiționalismului românesc, Cluj-Napoca 1992.

R. M. Neagu, H. Groza, George Mărie, Valer Moldovan și Augustin Rațiu. Reprezentanți ai orașului Turda la Marea Unire persecutați in perioada dictaturii comuniste, Cluj-Napoca 2019.

Ș. Polverejan, N. Cordoș, Mișcarea memorandistă în documente (1885-1897), Cluj 1973.

A. Rațiu, Din trecutul orașului Cluj, Cluj 1935.

P. Teodor, L. Maior, N. Bocșan, Ș. Polverejan, D. Radosav, T. Nicoară, Memorandul 1892-1894. Ideologie și acțiune politică românească, București 1994. 


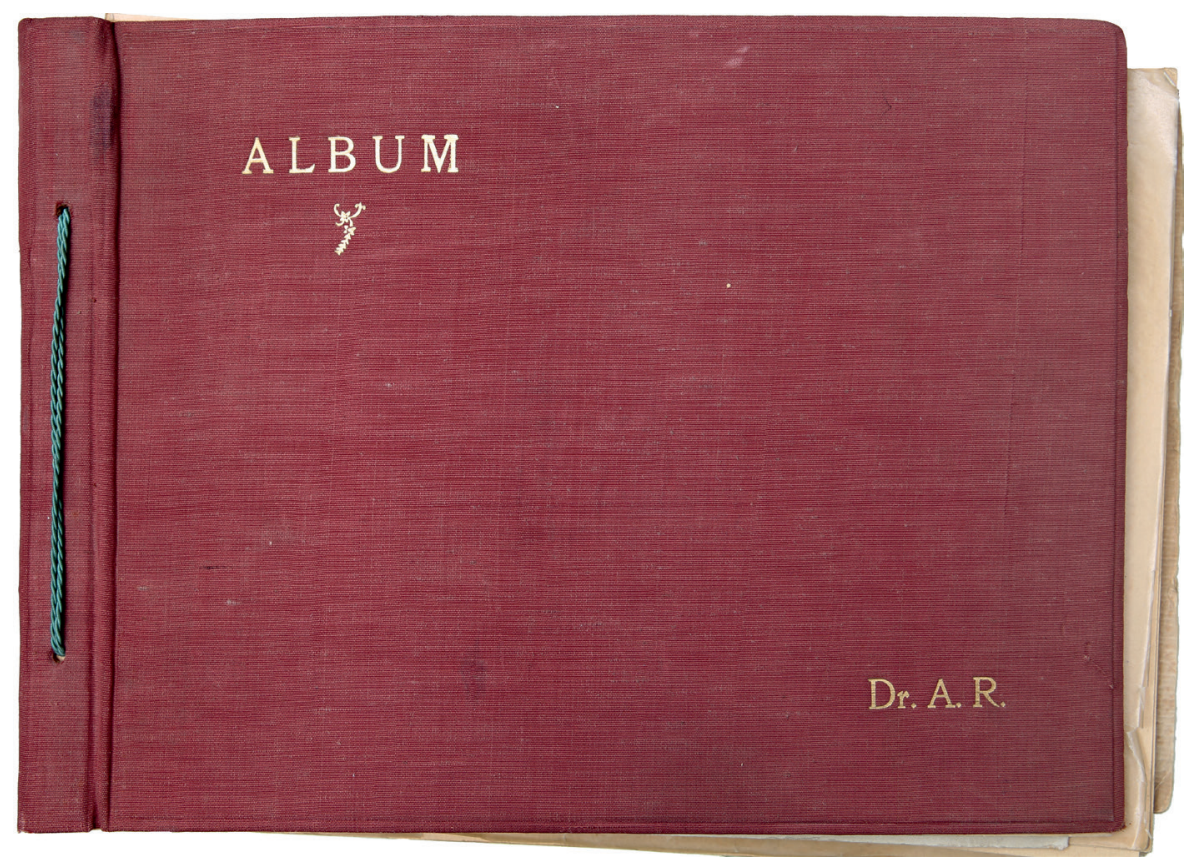

Fig. 1. Dr. A[ugustin] R[ațiu], Album (Colecția MNIT, no. M 344).

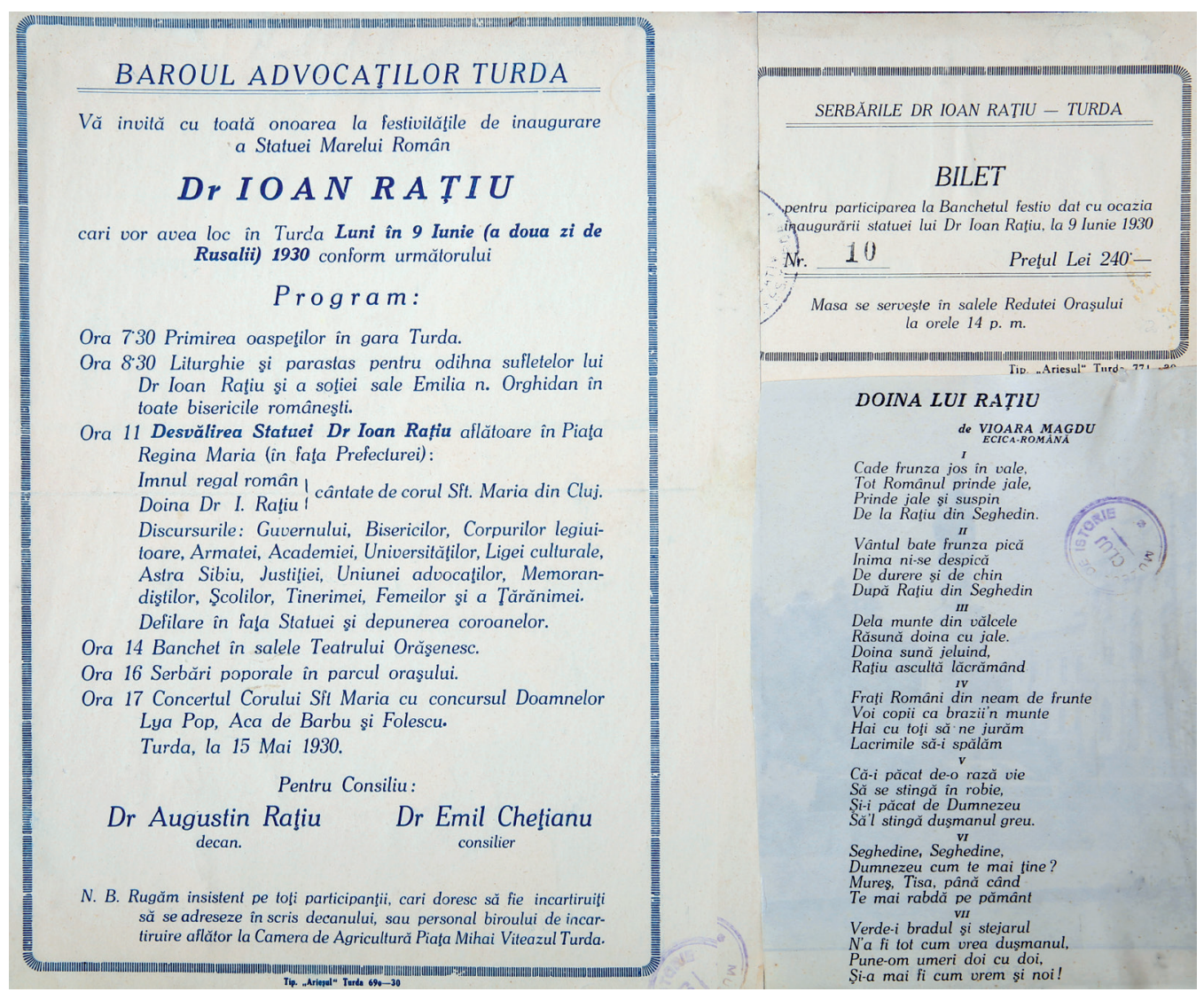

Fig. 2. The Invitation and Program for the Inauguration of the Statue (Colecția MNIT, no. M 344/110). 


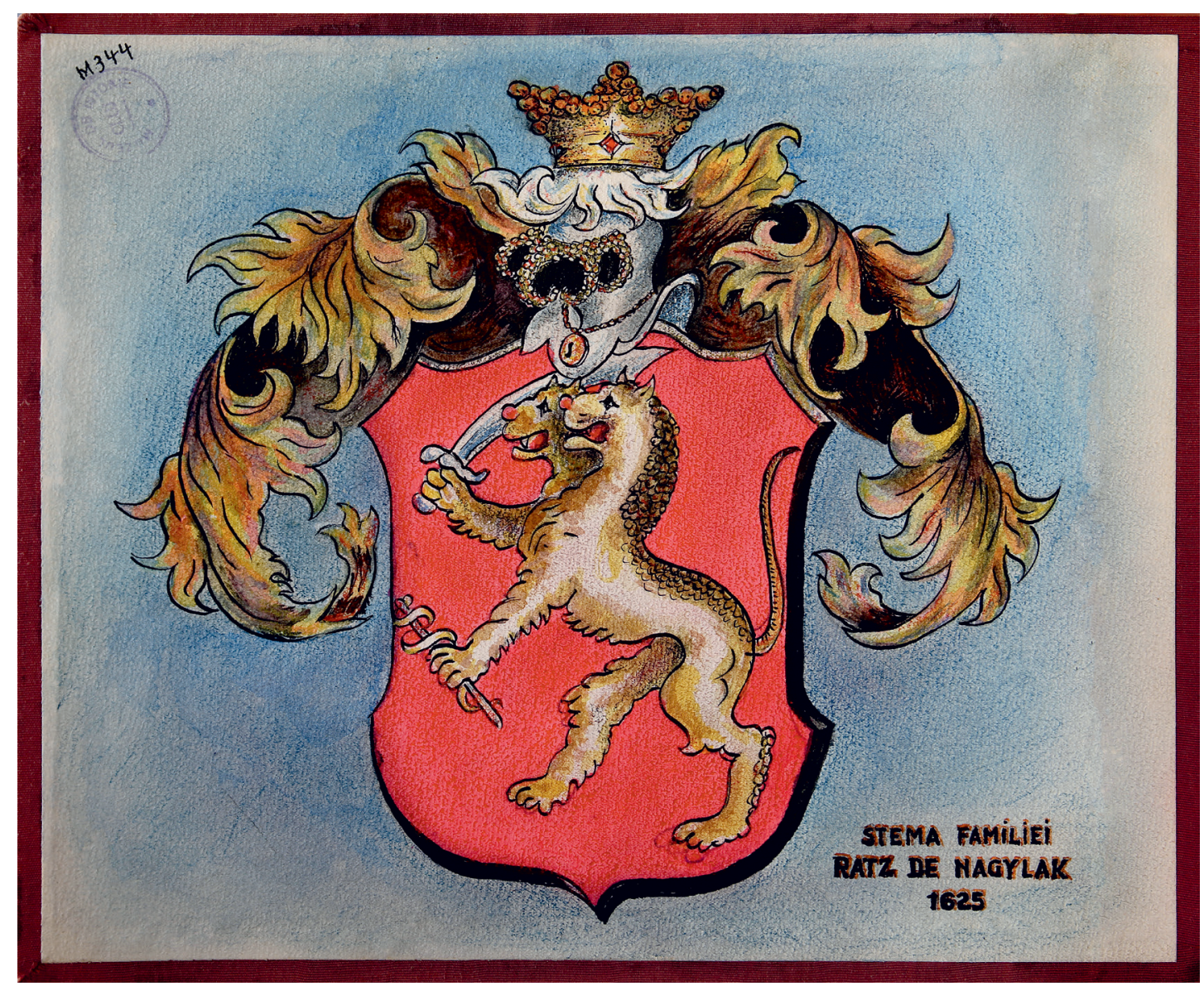

Fig. 3. Coat of Arms of the Ratz Family of Nagylak (Colecția MNIT, no. M 344/0). 


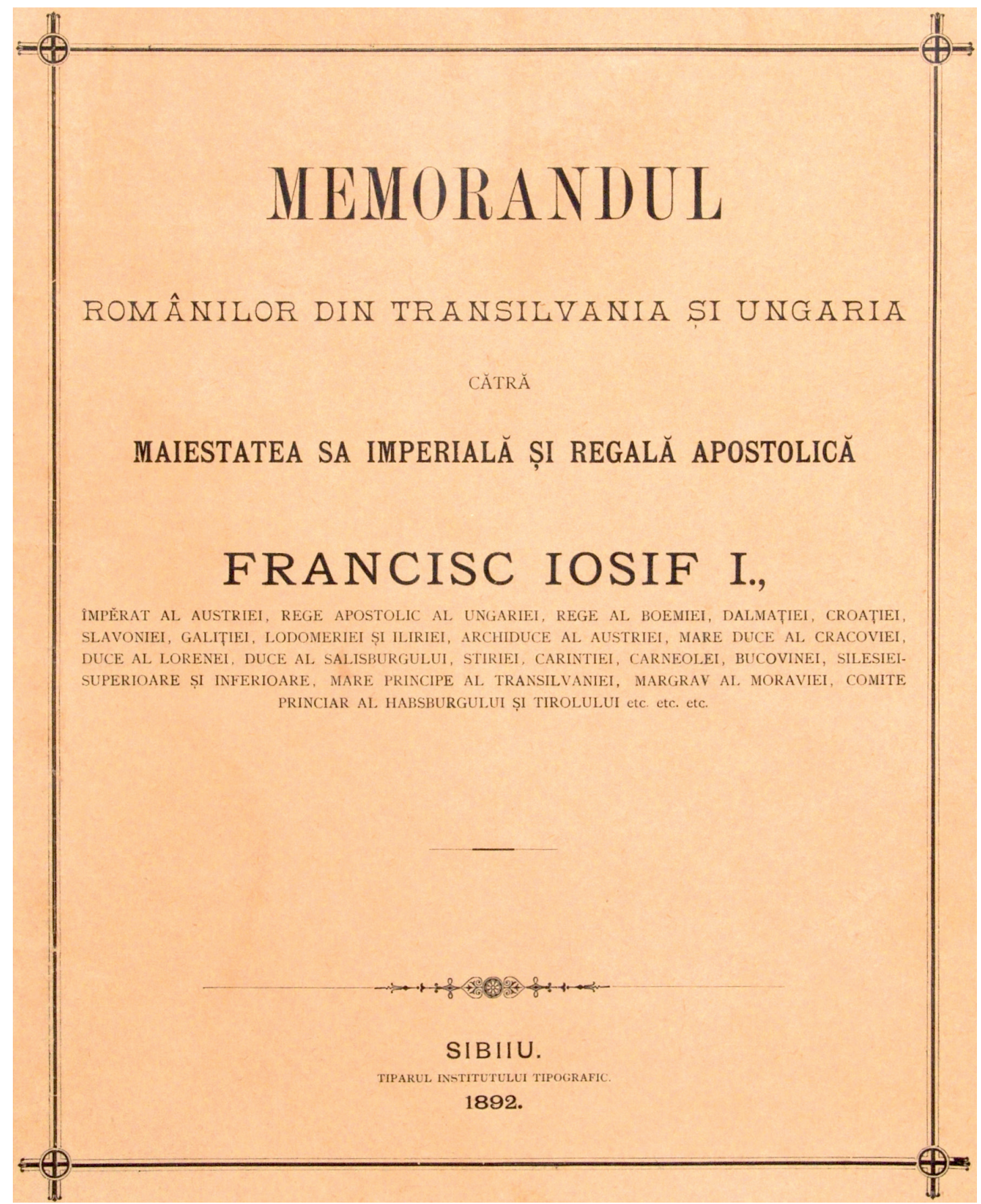

Fig. 4. Leaflet with the text of the Memorandum (Colecția MNIT, no. M 2391). 


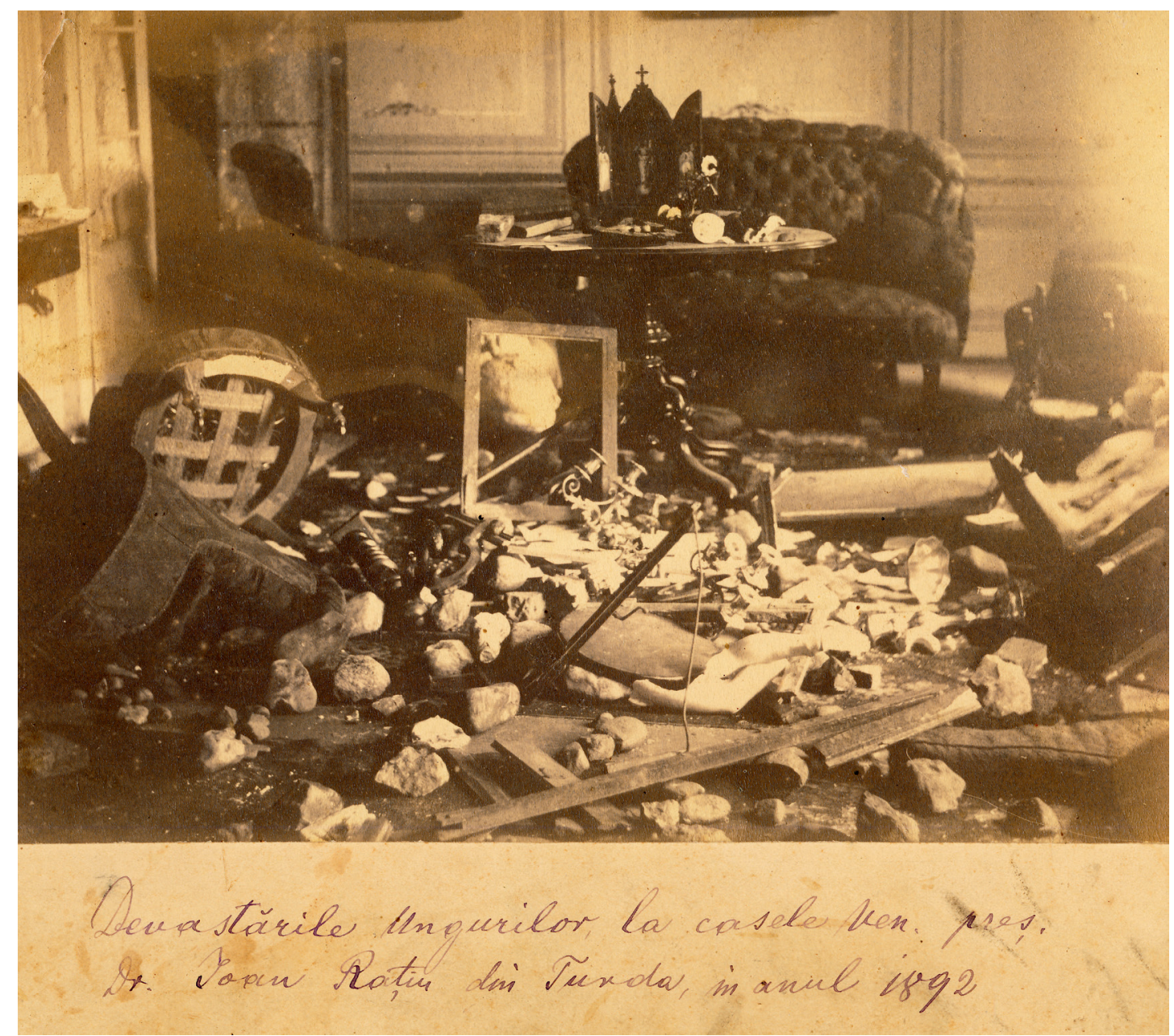

Fig. 5. The Devastations Perpetrated by the Hungarians upon the Houses of the President, Dr. Ioan Rațiu from Turda in 1892 (Colecția MNIT, no. M 344/13). 

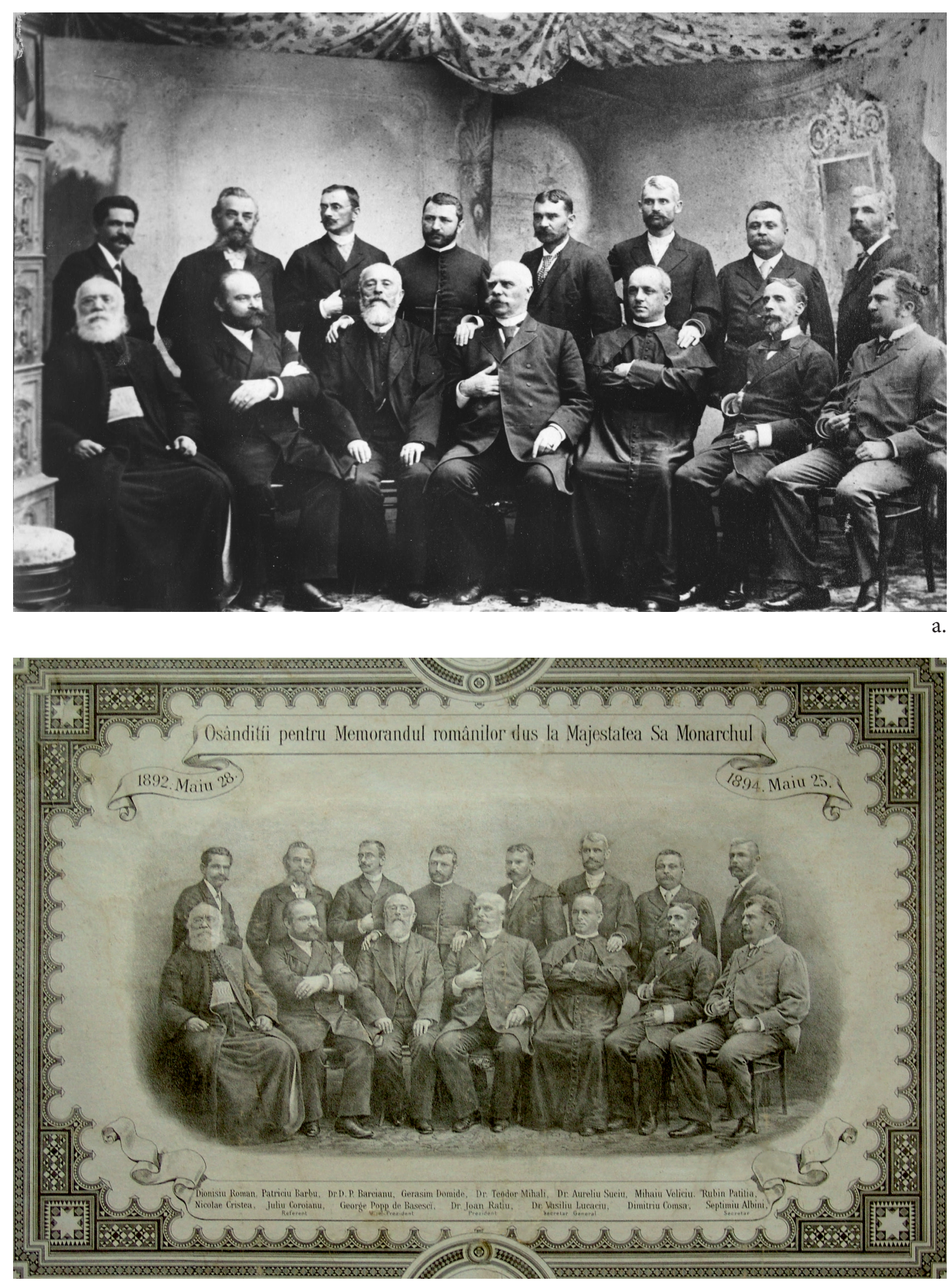

Fig. 6. a. The Memorandum movement leaders (Colecția MNIT, no. M 344/14); b. Lithograph entitled The Convicts Sentenced for the Romanian Memorandum Petition Presented to His Majesty the Monarch (Colecția MNIT, no. M 12131). 


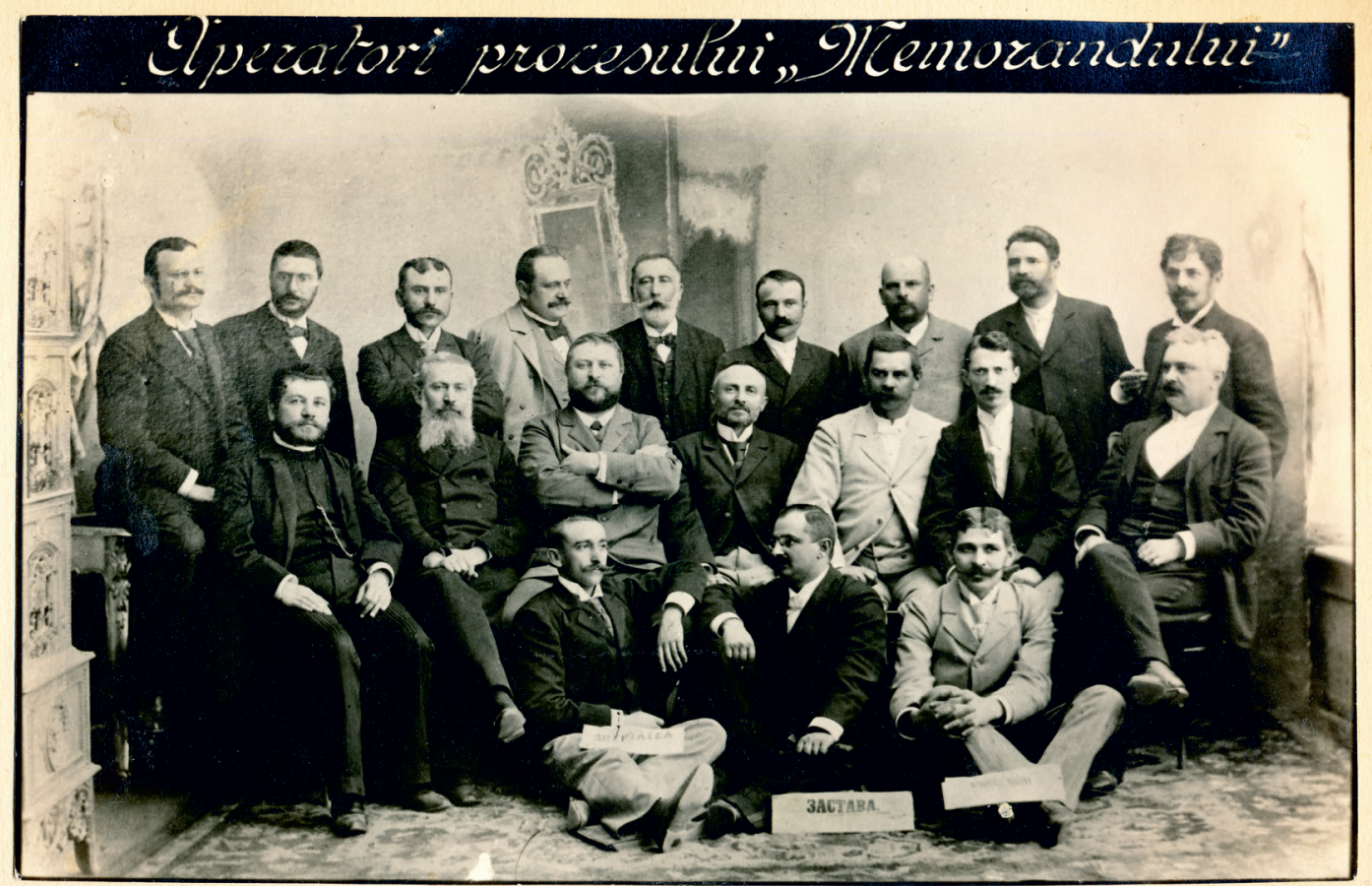

Fig. 7. Defenders of the 'Memorandum' Trial (Colecția MNIT, no. M 344/18).
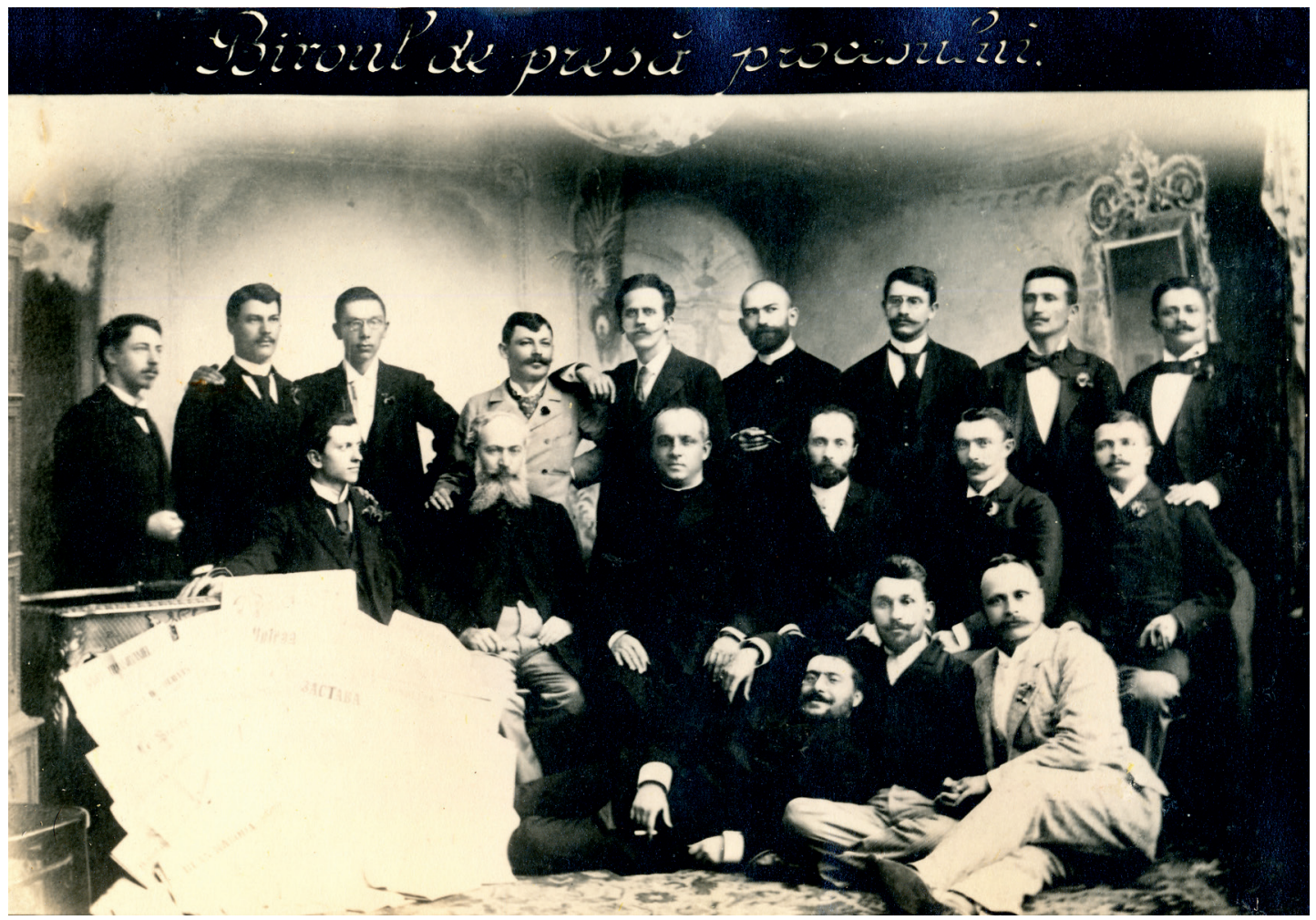

Fig. 8. Press Office of the Trial (Colecția MNIT, no. M 344/19). 


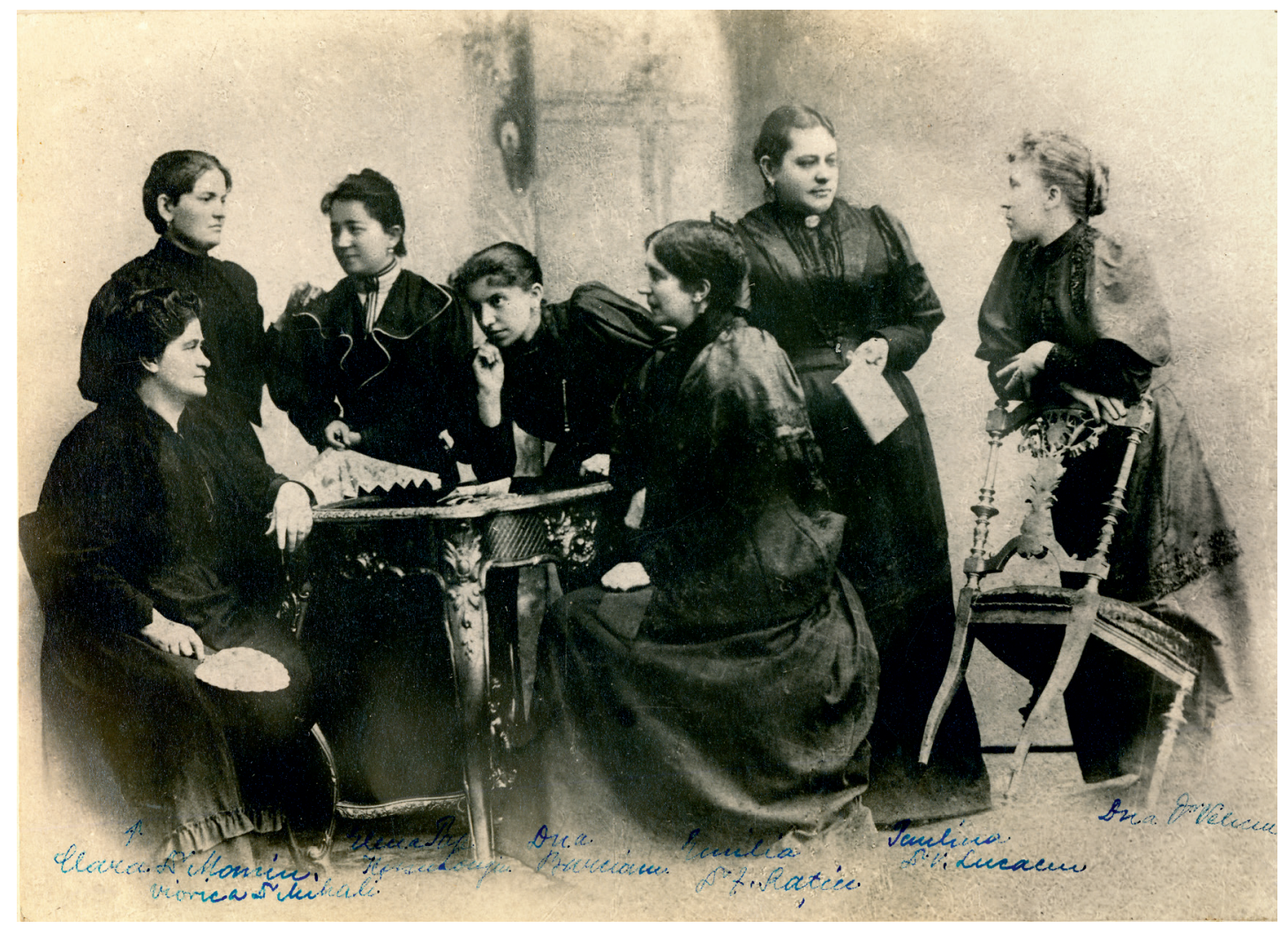

Fig. 9. The Wives of the Petitioners (Colecția MNIT, no. M 344/15).

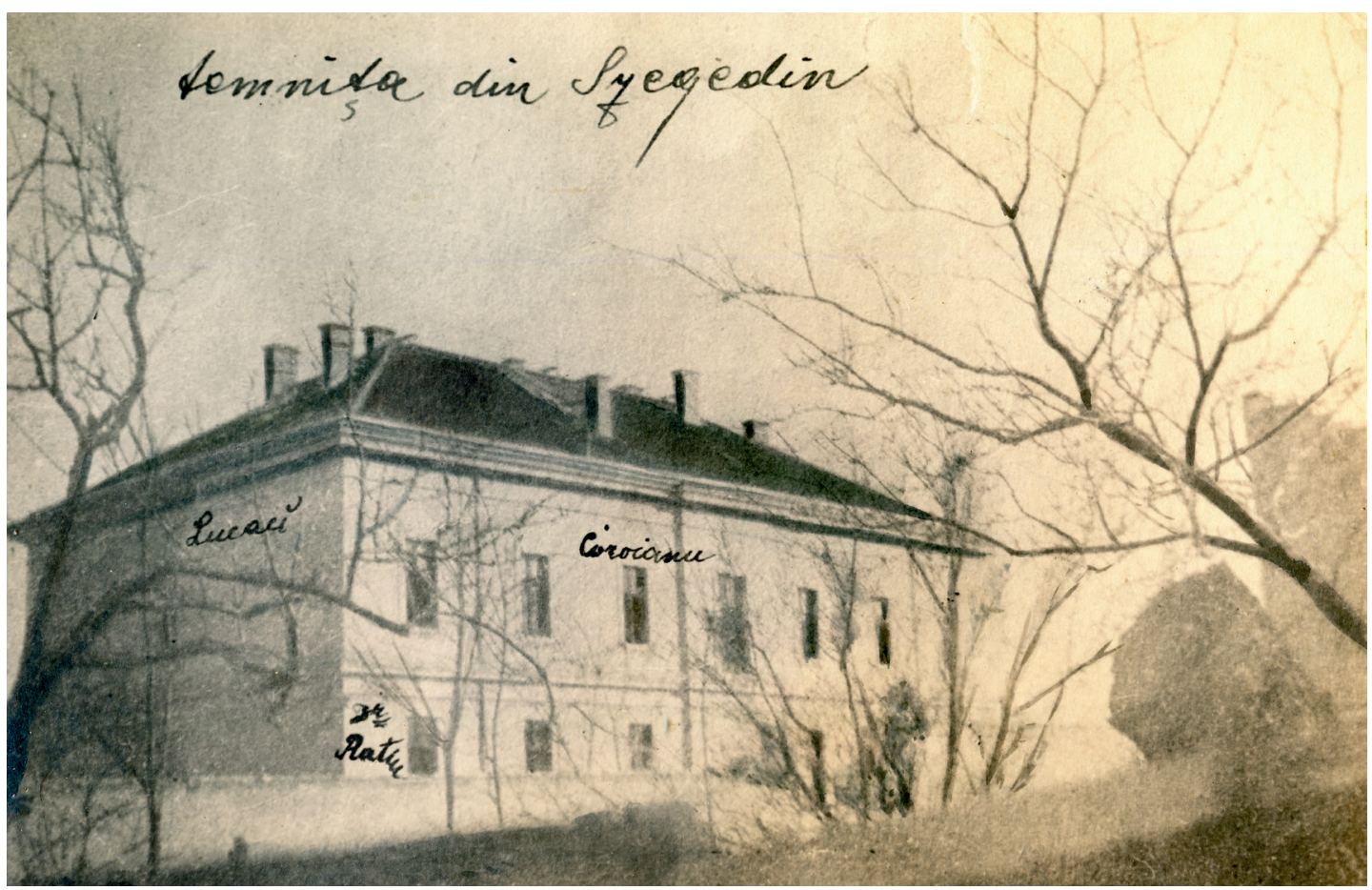

Fig. 10. The Dungeon of Szeged (Colecția MNIT, no. M 344/20). 


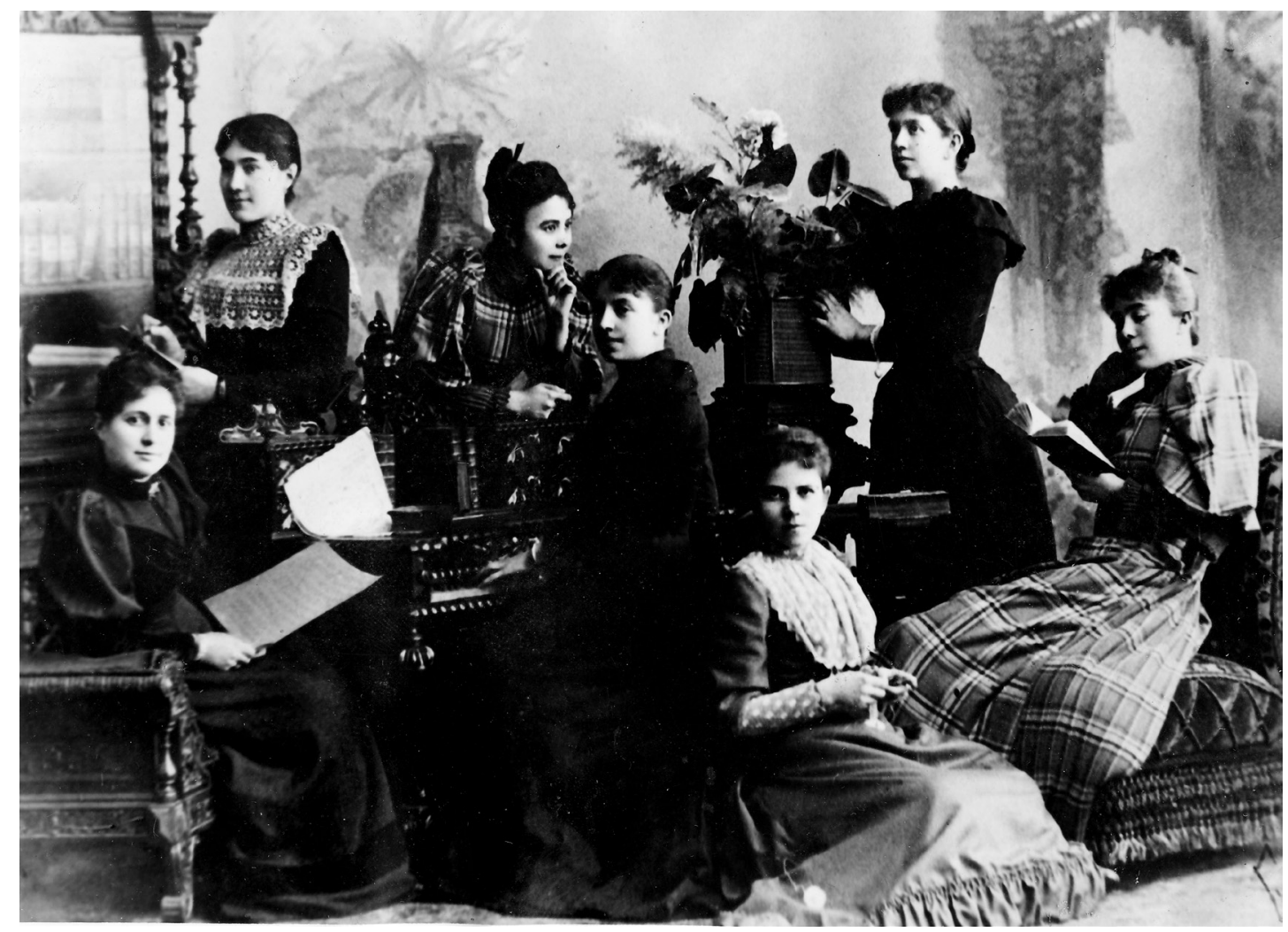

Fig. 11. The Committee of Romanian Young Ladies (Colecția MNIT, no. M 344/16).

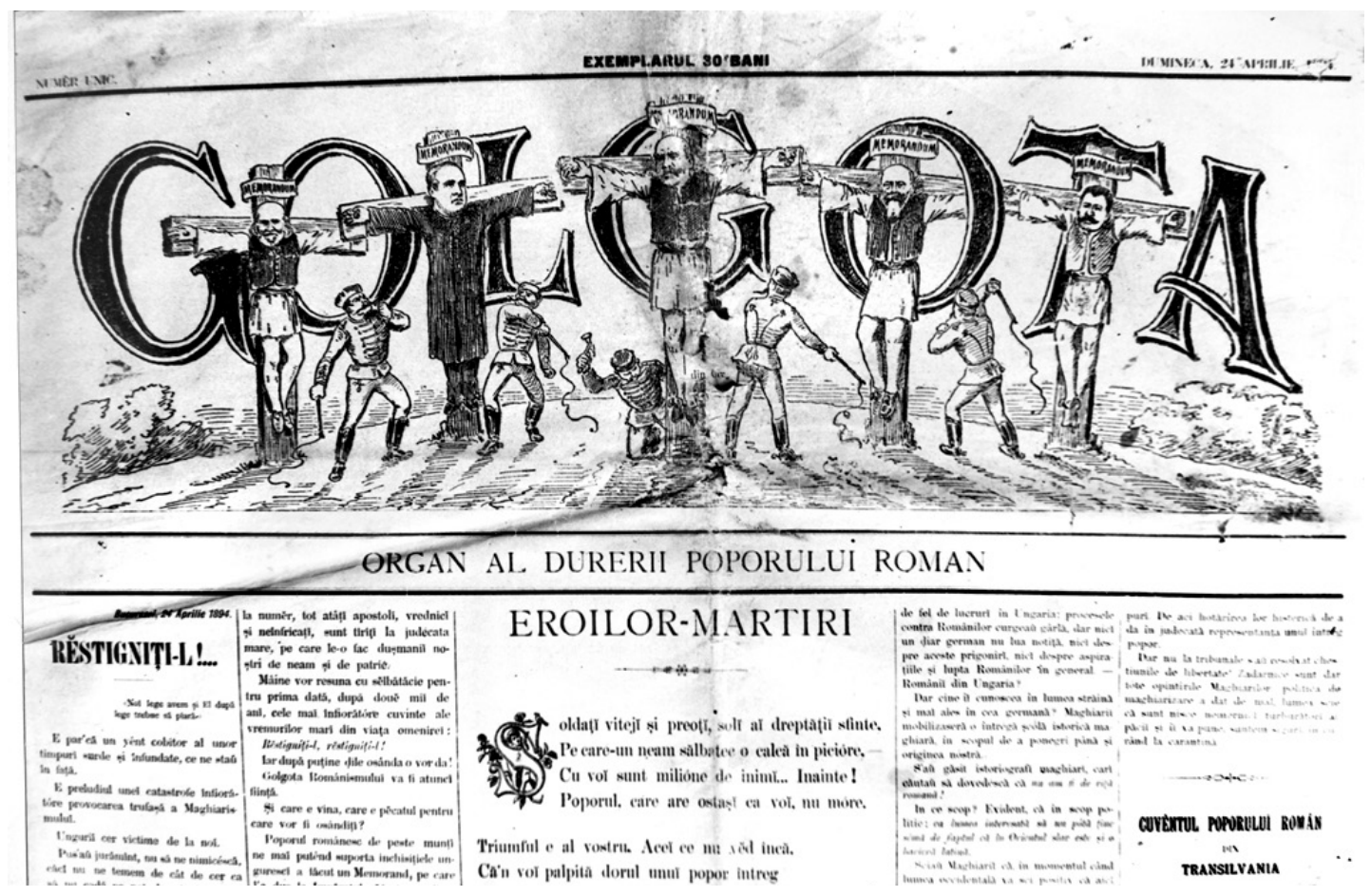

Fig. 12. a. Photo of the Golgota newspaper by lawyer Augustin Rațiu (Colecția MNIT, no. M 344/12). 


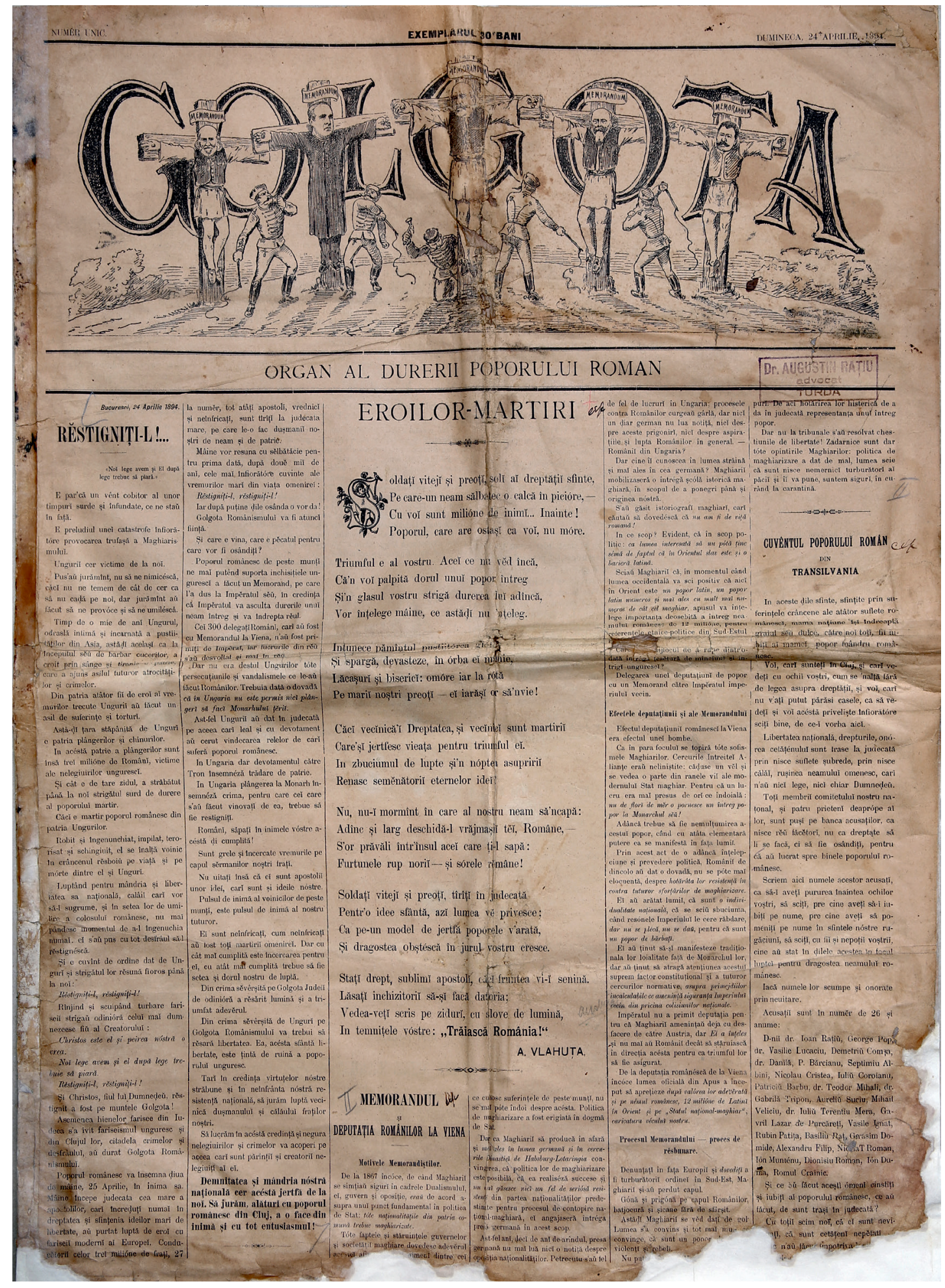

Fig. 12. b. The Golgota newspaper with the stamp of lawyer Augustin Rațiu (Colecția MNIT, no. M 12126). 


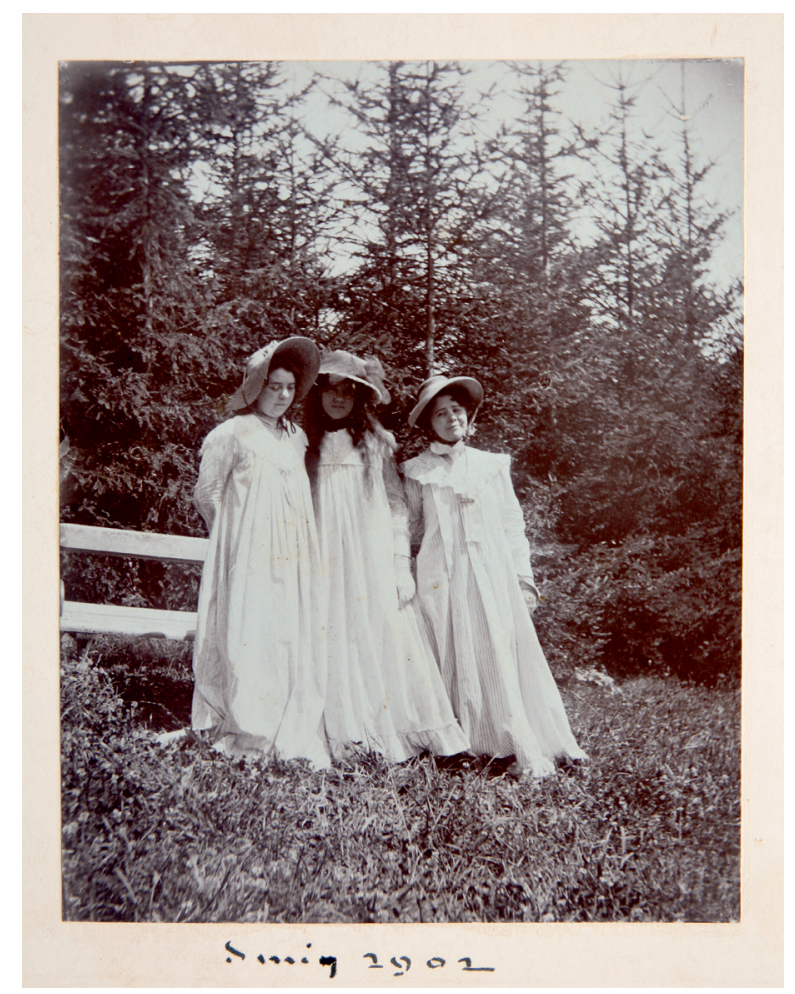

Fig. 13. Photo of the Rațiu sisters, Șmig, 1902 (Colecția MNIT, no. M 344/55).

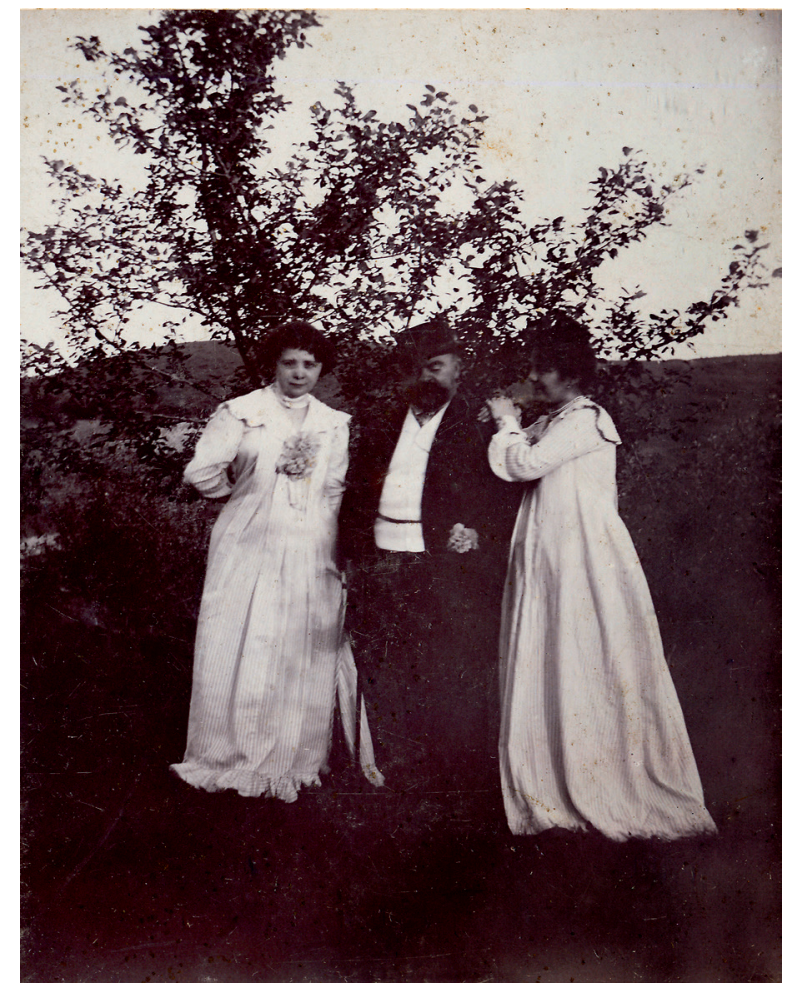

Fig. 14. Iuliu Coroianu (Colecția MNIT, no. M 344/58). 


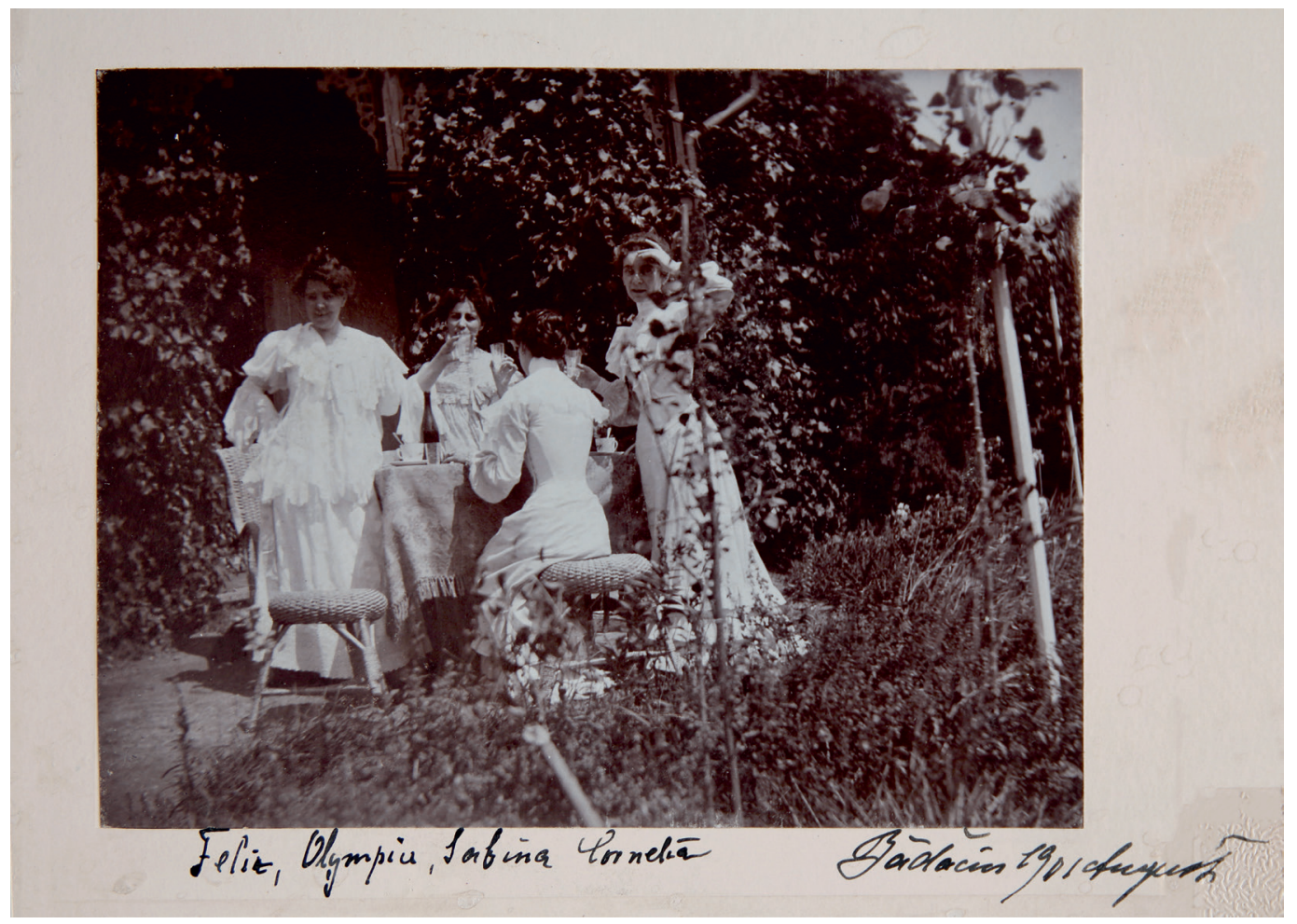

Fig. 15. Feliz, Olympia, Sabina, Cornelia, Bădăcin - 1901, August (Colecția MNIT, no. M 344/45).

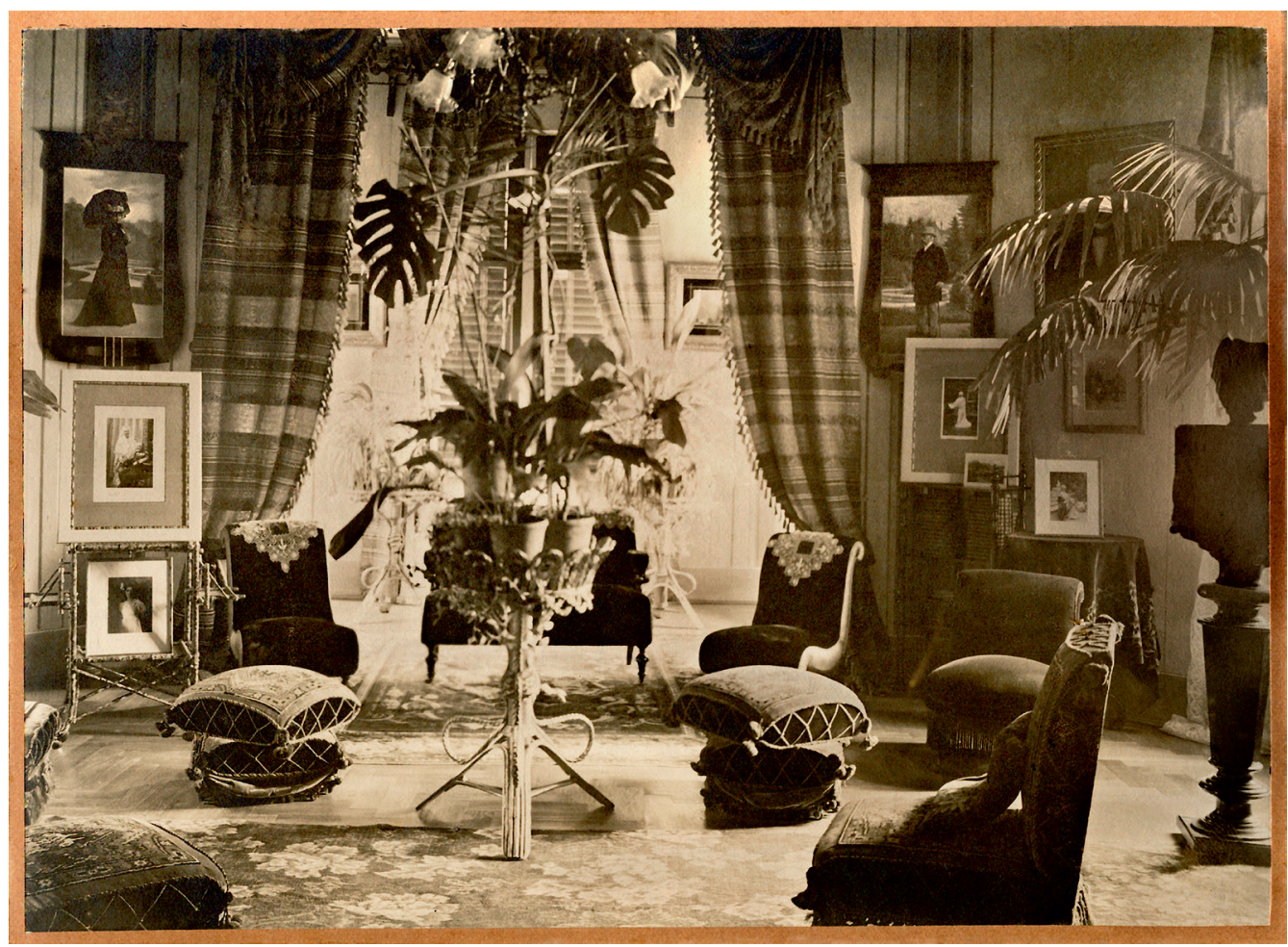

Fig. 16. The Dr. I. Rațiu Salon - Sibiu (Colecția MNIT, no. M 344/70). 


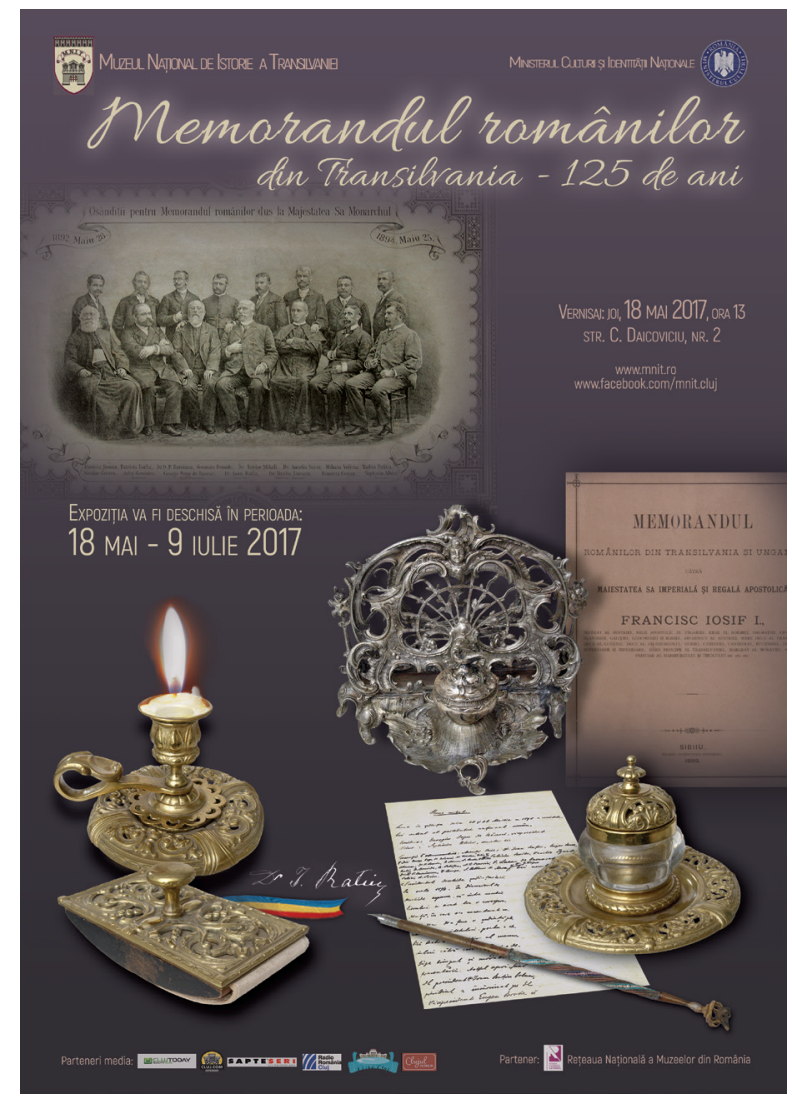

Fig. 17. Poster of the anniversary exhibition The Memorandum Movement of the Romanians in Transylvania - 125 Years (Colecția MNIT, no. C1 5296).

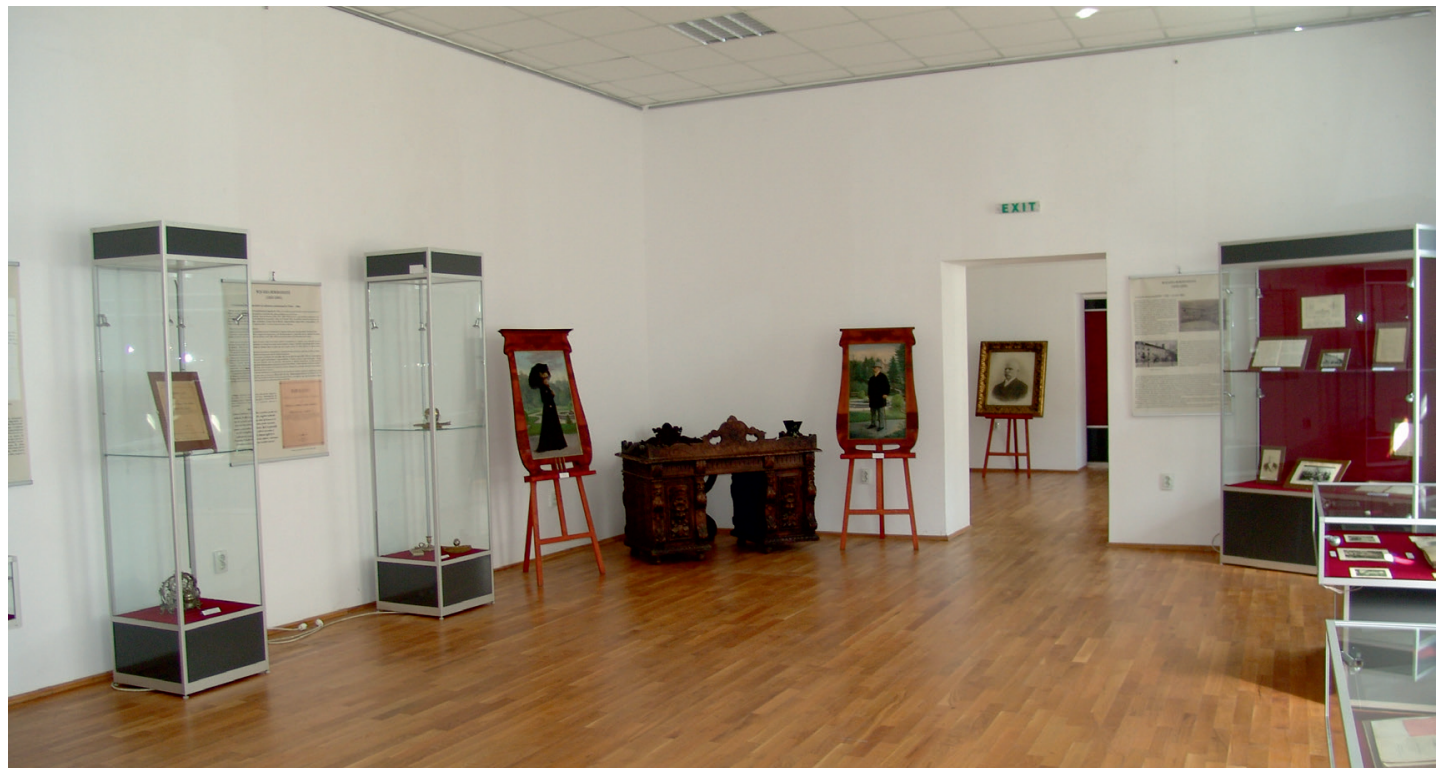

Fig. 18. Pictures of Emilia and Ioan Rațiu in the exhibition entitled The Memorandum Movement of the Romanians in Transylvania - 125 Years (Colecția MNIT, no. M 8796 and M 8797, image from the Archive of the MNIT, History Department). 


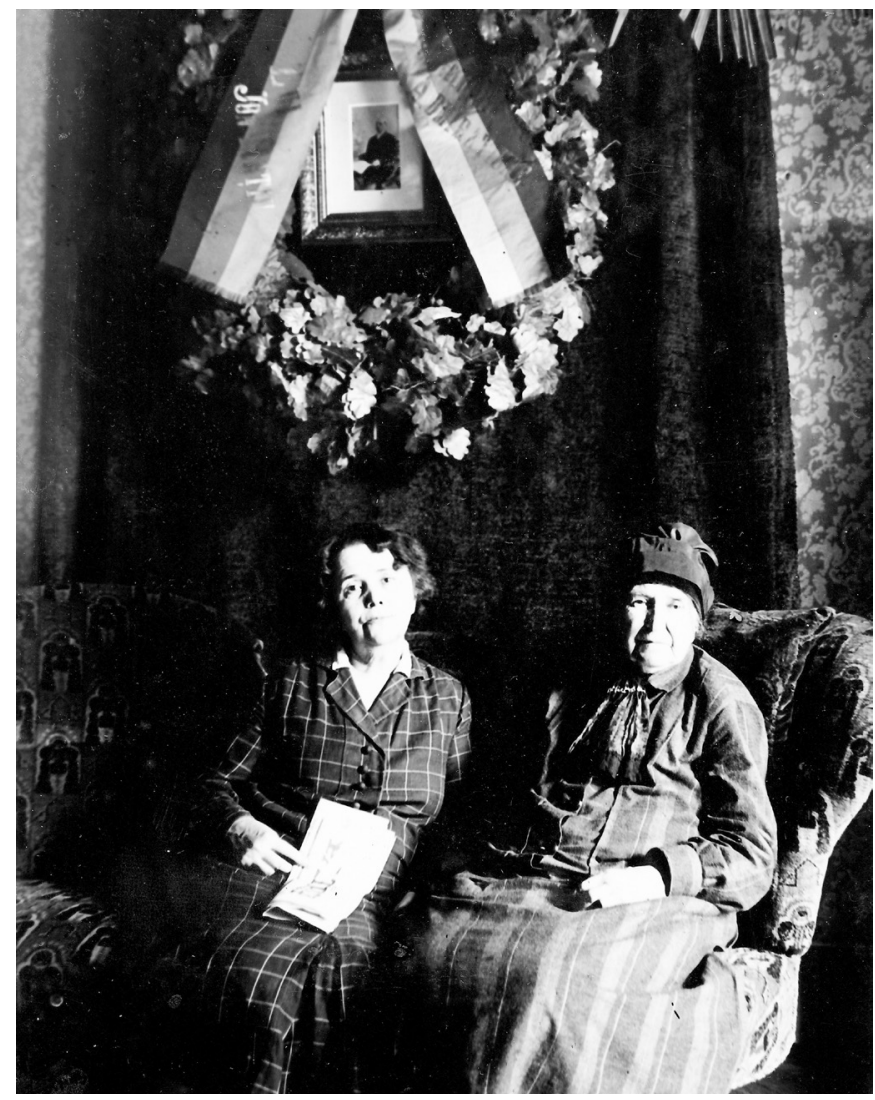

Fig. 19. Emilia Dr. Ioan Rațiu and her daughter, Felicia, under the crown received from the Bucharest League (Colecția MNIT, no. M 344/27).

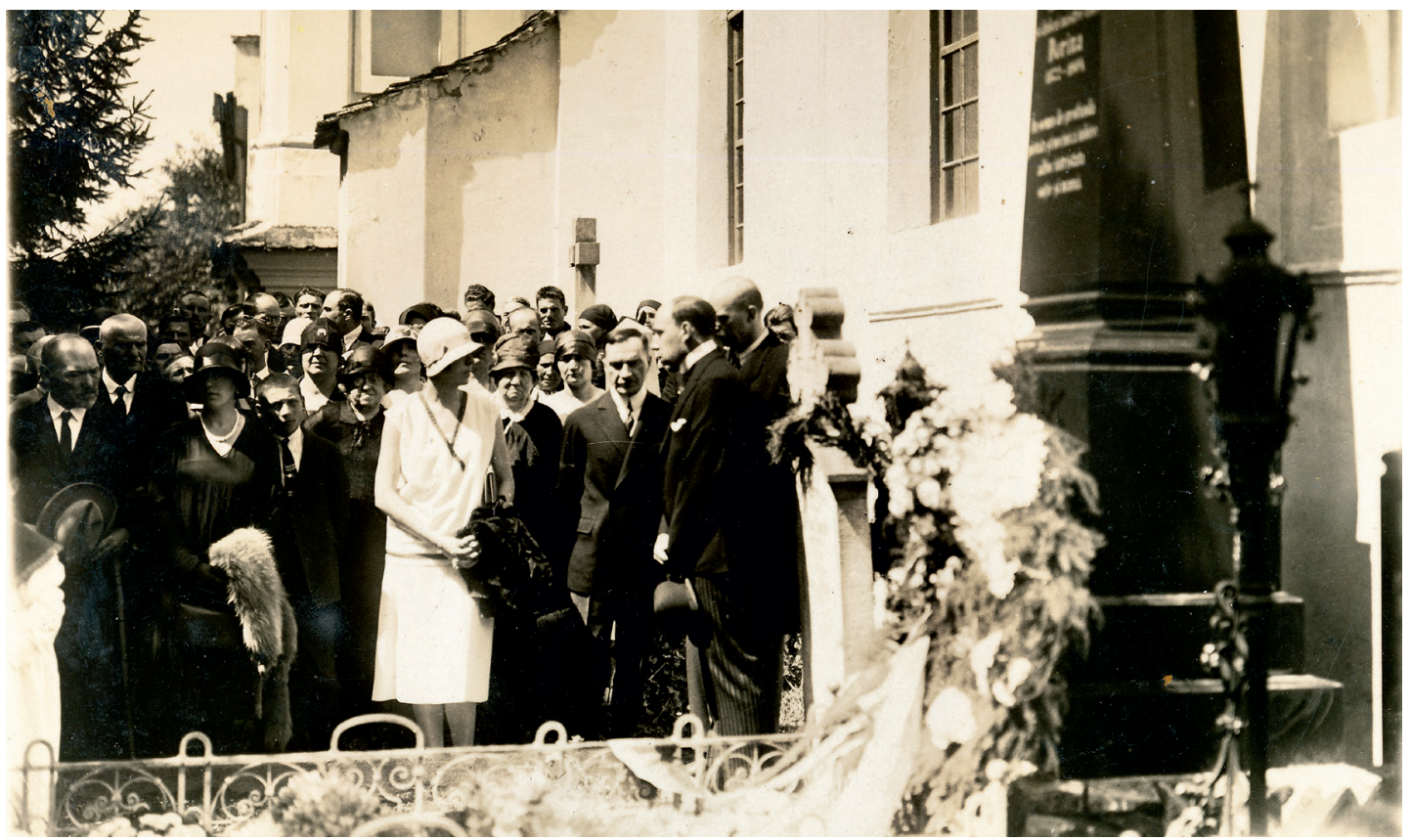

Fig. 20. Before the grave on 19 August 1928 (Colecția MNIT, no. M 344/83). 


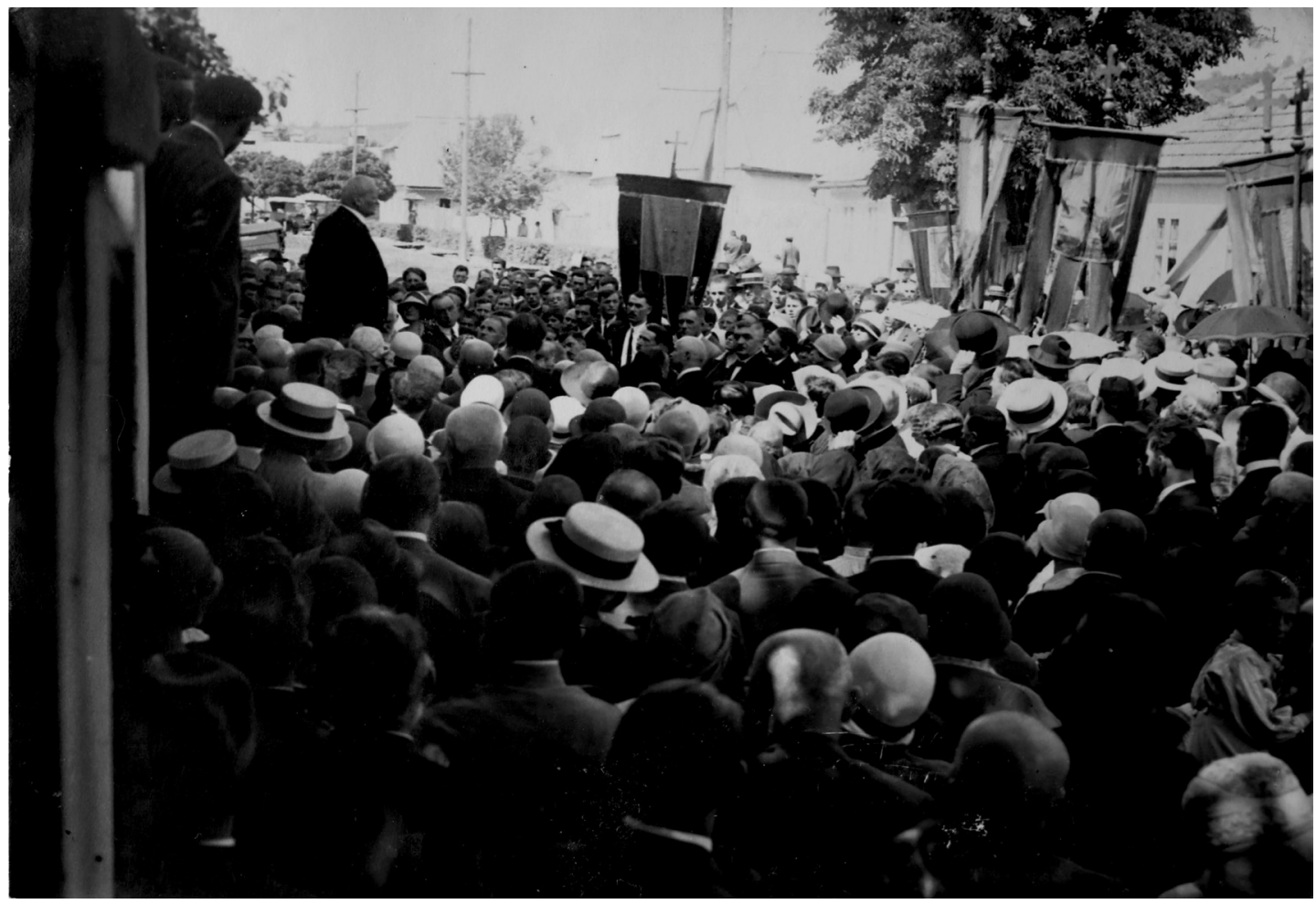

Fig. 21. Ștefan Cicio-Pop upon the unveiling of the commemorative plaque (Colecția MNIT, no. M 344/87).

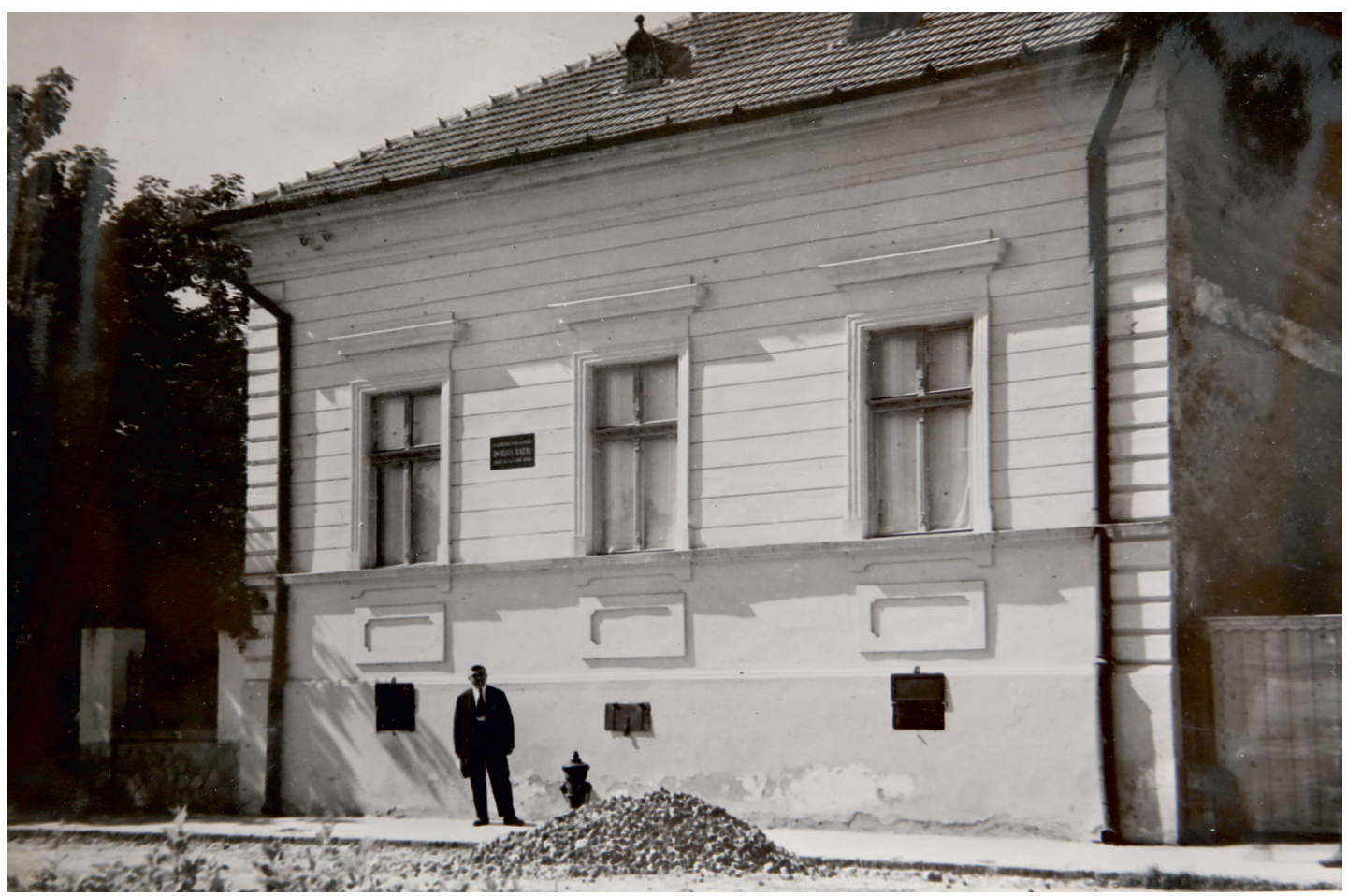

Fig. 22. The renovated house of Dr. Ioan Rațiu in Turda, with the commemorative plaque (Colecția MNIT, no. M 344/85). 


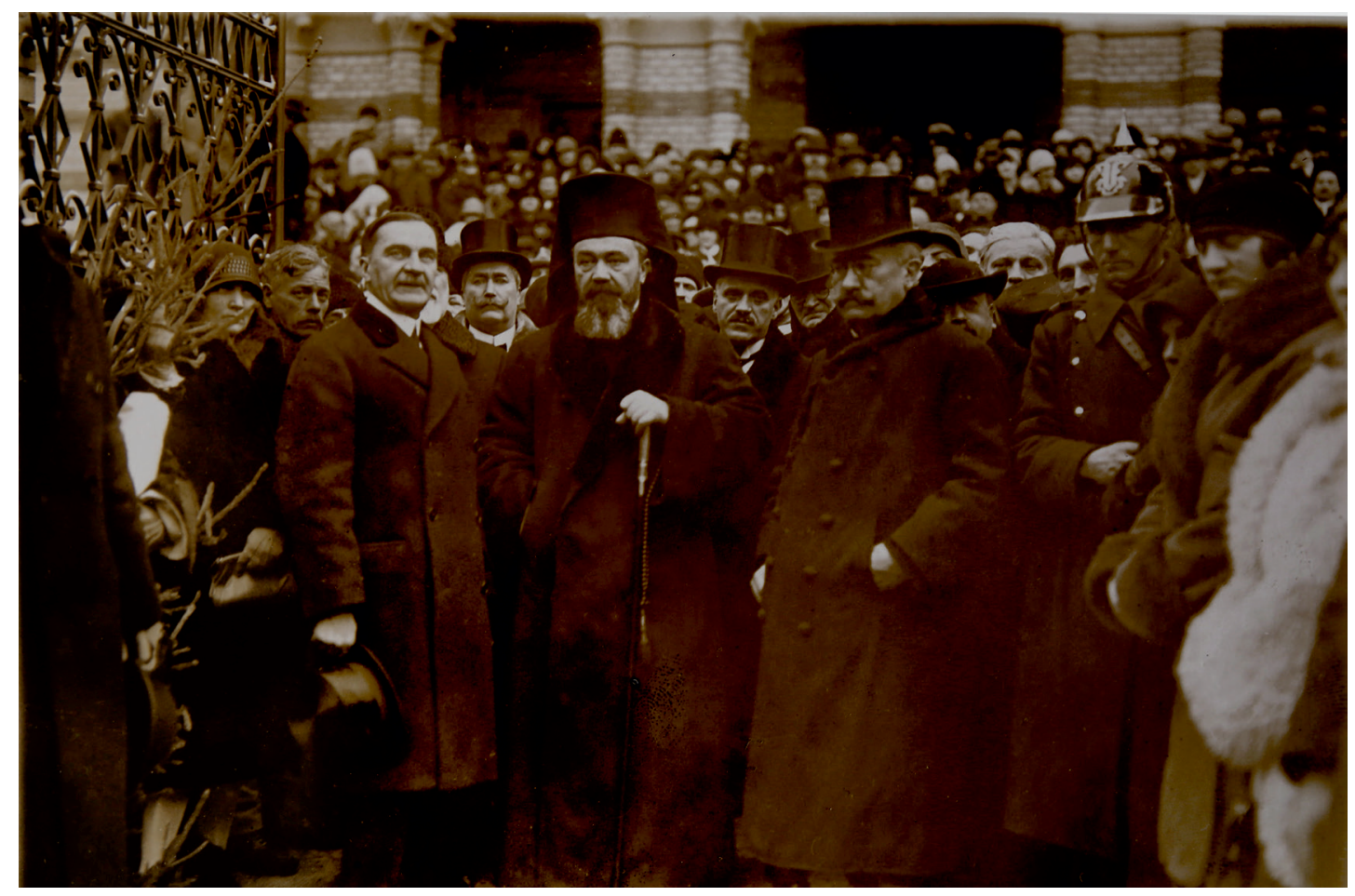

Fig. 23. The national funeral of Emilia Rațiu - the crowds in front of the cathedral (Colecția MNIT, no. M 344/101).

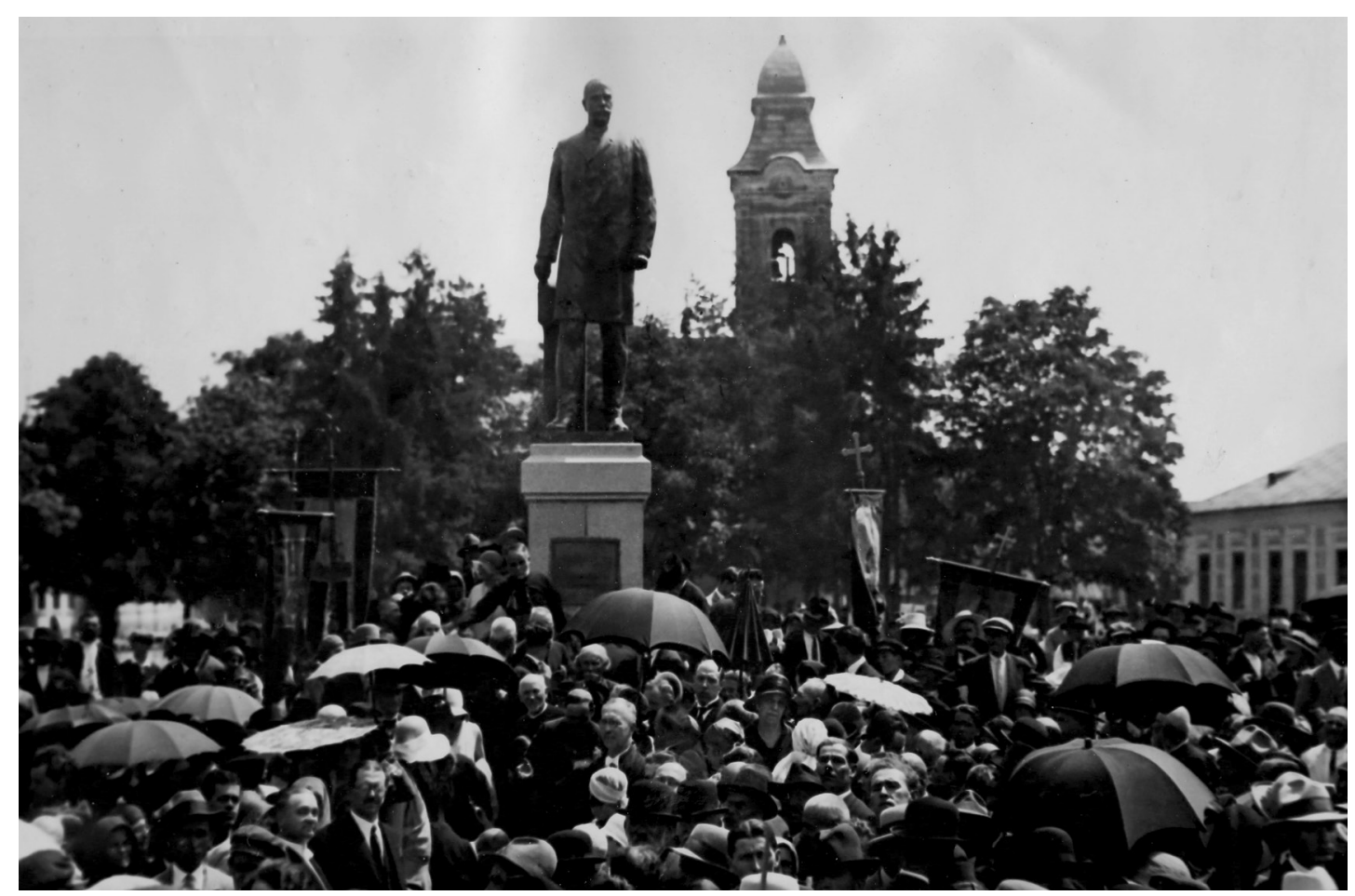

Fig. 24. Upon the unveiling of the statue in Turda (Colecția MNIT, no. M 344/90). 


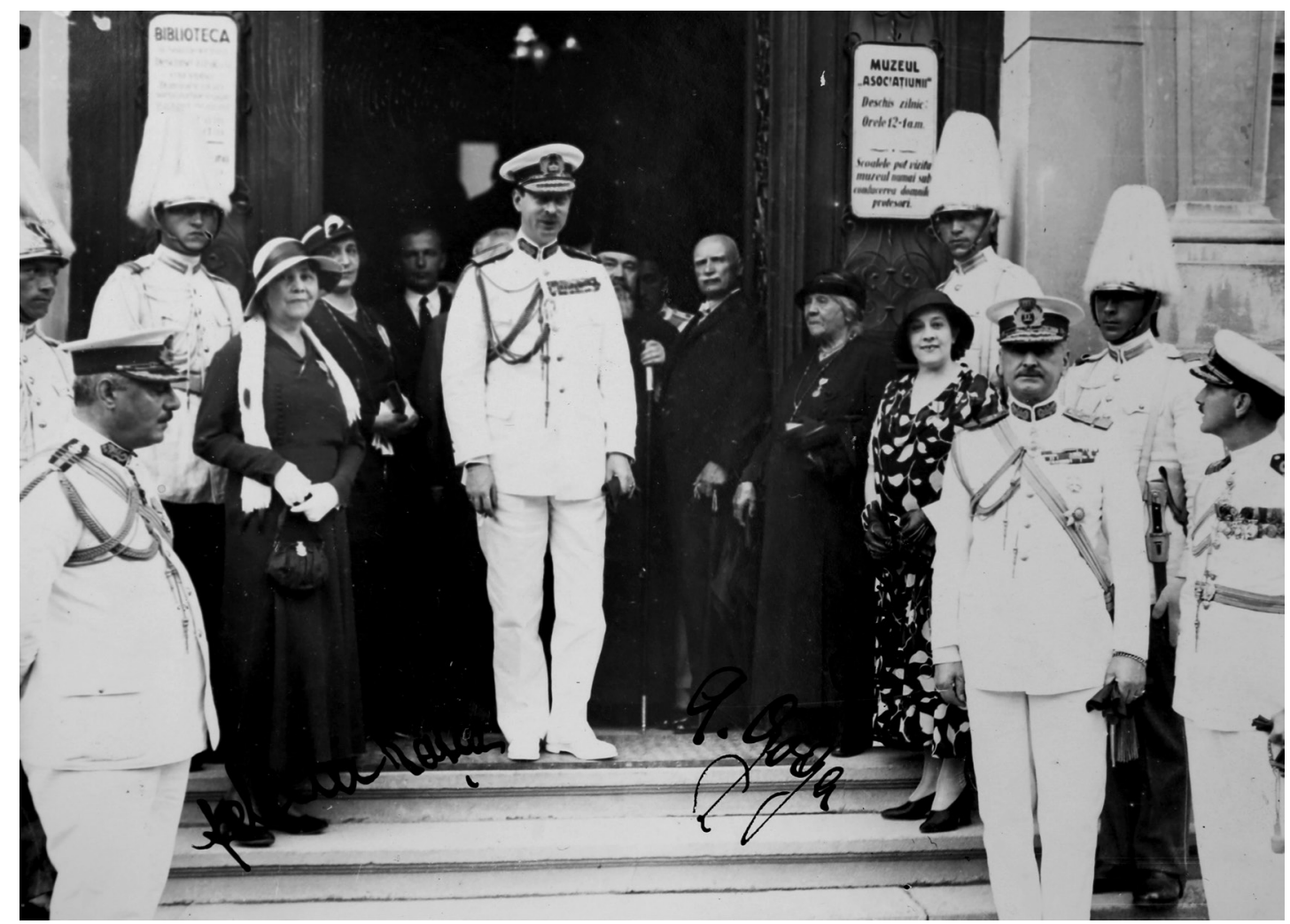

Fig. 25. Felicia Rațiu next to King Carol II, Sibiu, 1932 (Colecția MNIT, no. M 344/106).

Emilia Dr. Russu soră cu sołul Dr. Octavian Russu, Eugen Tilea, Marloapa Dr. Perţa n. Tilea, lonel Tilea cu soța Camilla, Vlorel V. Tilea cu sotla Eugenia, nepoţl ş nepoate. Marloara cu sotul lonel uillăean, Any cu sotul Dr. Remus Doctor, Radu, lleana, Miriam, loana şł Stanca Tilea strănepoft. Augusta Opghidan văd. Tăbuş ş Olimpia Opghidan mătuşı, Dr. Augustin Rafíu cu sof̧ia, verı, au nemărgı́nlta durere să anunte incetarea din olafă - dupa lungt st grele suferinte - a scumpel st in vect neutfatel lor

\section{FELICIA RATIU}

Intamplotă la 31 Octomurle 1938.

Ceremonta funebra va avea loc jol in 3 Noemurle 1938, la ora $3 \mathrm{~d}$. a., in cate-

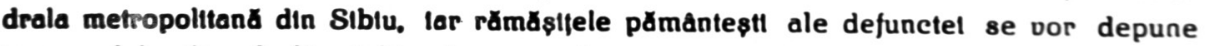
in cavoul familiar de langă blsertca gr. cat.

\section{Dormi in pace suflek nobil.}

8 Ib Iu, 1 Noemorle 1938.

Fig. 26. Obituary - Felicia Rațiu (Colecția MNIT, no. M 344/109). 


\title{
LAJOS KELEMEN OF NAGYERNYE: A HISTORIAN-ARCHIVIST
}

(1877-1963)

\author{
PÉTER SAS
}

\begin{abstract}
This paper presents the essential stages in the life of the archivist-historian Lajos Kelemen. As a mentor, he contributed significantly to innovating Hungarian scholarship from Transylvania after 1920, initiated by a new historical paradigm. In all his duties - teacher at the Unitarian College in Cluj, archivist at the Archive of Transylvanian National Museum, General Director of the Transylvanian National Museum and its Archive in Cluj, or Unitarian chief-caretaker - he put his interests in the service of his community. At the beginning of the twentieth century, the Archive of the Transylvanian Museum Society consisted of only forty thousand items, but thanks to his activity, they turned into a vast collection comprising one million documents. By personal example, Lajos Kelemen contributed to the education of many scholars, including Zsigmond Jakó and Attila T. Szabó. In recognition of his work, Lajos Kelemen was bestowed the Hungarian Corvin Chain in 1940 and the Hungarian Heritage Prize in 2011.
\end{abstract}

Keywords: Lajos Kelemen, Cluj, Unitarian College, Archive of the Transylvanian National Museum, Transylvanian Museum Society, Hungarian Academy of Sciences

Rezumat: Studiul prezintă cele mai importante etape din viața arhivistului și istoricului Lajos Kelemen. Ca mentor a contribuit cu succes la înnoirea vieții științifice maghiare din Transilvania inițiată de noua paradigmă istorică de după 1920. În toate responsabilităţile sale, fie ca profesor la liceul unitarian din Cluj, ca arhivar la arhiva Muzeului Național Ardelean, ca director general al Muzeului Național Ardelean și al arhivei acestuia din Cluj, sau ca și administrator-șef al bisericii unitariene - el a subordonat întotdeauna interesele individuale intereselor comunității. La începutul secolului al XX-lea Arhiva Societăţii Muzeului Ardelean constau doar din patruzeci de mii de piese, care sub activitatea sa s-au transformat într-o colecție uriașă de un milion de exemplare de documente. Prin exemplul său personal Lajos Kelemen a educat generaţii de cercetători, printre care și pe Zsigmond Jakó sau Attila T. Szabó. Munca sa științifică a fost recunoscută prin ordinul ungar Lanțul Corvin, în 1940 și cu Premiul Patrimoniului Ungar în 2011.

Cuvinte cheie: Lajos Kelemen, Cluj, Colegiul Unitarian, Arhiva Muzeului Naţional Ardelean, Societatea Muzeului Ardelean, Academia Maghiară de Științe

The name and work of the historian-archivist Lajos Kelemen have merged, in collective memory, with the names of the former Transylvanian National Museum and the Transylvanian Museum Society. This cultural institution, which has been operating since 1859 , houses scientifically validated records on the entire history of twentieth-century Transylvanian culture. ${ }^{1}$

Lajos Kelemen, the famous archivist of Transylvania, was born on 30 September 1877, in Marosvásárhely (present-day Târgu-Mureș), known as the Székely capital and city of the

\footnotetext{
* Ph.D., literature and cultural historian, Budapest, email: saspeter33@gmail.com.

${ }^{1}$ For details, see: Sas 2009a; Csetri 2012.
} 
two Bolyai mathematicians. ${ }^{2}$ However, his life and work tied him so much to Kolozsvár (present-day Cluj-Napoca) that he was considered a native of the 'treasure city'.

Kelemen came from a Székely noble family. His father, Miklós Kelemen, was a clerk of the royal court in Târgu-Mureș. ${ }^{3}$ Kelemen grew up hearing from his father about the nobility, coats of arms, and the Gothic style. His religious self-consciousness was also shaped by his father, who had proudly confessed that 'all our ancestors were Unitarian.' His mother, Johanna Csomoss, from whom he inherited his excellent memory, gave birth to three sons and three daughters.

Throughout his life and career, Lajos Kelemen was influenced by his time in the famous Reformed College of his hometown. His beloved teacher of Latin, József Koncz, had also deepened his interest in history.

In addition to his reading experiences, his mother's grandfather, Miklós Csomoss, encouraged him to learn about the past, familiarizing him to recollections of his former military experience in the 1848 Revolution. Kelemen wrote about his grandfather: 'He is an enthusiastic, kind-hearted, warm Hungarian man. I see a trait I have inherited. Enthusiasm, imagination, quick temper, repentance, forgiveness, and a smattering of good mood, I inherited all this from him through my mother.'

His whole life and interests were influenced by Balázs Orbán's homeland 'bible', $A$ Székelyföld leírása I-VI. [A Description of Székely Land] Pest-Budapest, 1868-1873, and by one of László Kövári’s basic works, Erdély régiségei [The Antiquities of Transylvania], Cluj, 1852. The desire to research the memories of bygone ages stemmed from the example of Balázs Orbán, 'the greatest Székely, who had visited the villages of Transylvania on foot and came across undiscovered antiques. In 1894, in the Unitarian church of Adămuş, he and his classmate, Ödön Nemes Jr., discovered the oldest coffered ceiling painting in Hungary, from $1526 .^{6}$

He soon realized the importance of archival materials, and his first research experiences were about getting to know the family heritage. In his classmate, István Biás Jr., archivist of the Teleki family's private archive, later employee of Mureș-Turda County's archive, Kelemen found a knowledgeable professional partner. They studied together old charters and account books of the tailor and furrier guilds in Târgu-Mureș. Lajos Kelemen copied and sent the 1608 charter of furrier's guild to Lajos Szádeczky, a university professor in Cluj, who published the document in a major source edition for seventeenth-century Transylvania, Székely Oklevéltár. ${ }^{7}$

Professor Szádeczky, chair of Lajos Kelemen's graduation exam board, recalled the student who had researched the archives with such commitment and competence and

\footnotetext{
${ }^{2}$ Because of his hometown and beloved teacher, József Koncz (1829-1906), who was in charge of the Bolyai estate, Kelemen may have considered it essential to make a note on the Üdvtan [Salvation] of János Bolyai. Sas 2002, 21-22.

${ }^{3}$ Benedek 1909, 84.

${ }^{4}$ Sas 2013b, 324.

${ }^{5}$ Entry dated 23 September 1904 (Kelemen 2017, 240).

${ }^{6}$ See Kelemen 1906.

${ }^{7}$ Gabriel Báthory, Prince of Transylvania, confirmed the charter issued for the furriers of Marosvásárhely. The guild charter was renewed by the city council that same year, in Cluj, on 25 September 1608 (Szabó 1895, 177-185).
} 
encouraged him to study further and enhance his lexical knowledge. As a result of his encouragement, Kelemen enrolled in the history of geography classes at the 'Ferenc József' University of Cluj in the autumn of 1896. Transylvania's intellectual and cultural capital brought a decisive change to his worldview. The scientific milieu of the modern metropolis was very impressed with his knowledge and intellect. Cluj was the city of a higher education institution, the university founded in 1872, and of a scientific society, the Transylvanian Museum Society.

On the recommendation of Lajos Szádeczky, Kelemen was employed as a private teacher by the royal notary Dr. István Gidófalvy to educate his son, a student of the local Reformed College. Through his work, he supported himself and graduated from university. According to the Newsletter of the National Secondary School Teacher Examination Committee of Cluj, he took the basic examination for secondary school teachers on 26 May 1900 and passed the professional examination for secondary school teachers on 19 October 1903. ${ }^{8}$

In the meantime, the social changes that took place in Cluj made him aware that the old dream world, rooted in the spirit of 1848 , could well become a thing of the past. Gidófalvy, the notary public, a member of the 'Unio' Masonic Lodge in Cluj, founded in 1887, played a crucial role in Kelemen's recognition. Gidófalvy sought to promote the possibility of civic transformation available to all. Because of his work, Gidófalvy was referred to as the 'apostle of the cooperative movement.' The well-being experienced in the Gidófalvy-house did not interfere with Lajos Kelemen's puritanical conception of home.

From 15 January to 31 December 1902, on the recommendation of István Gidófalvy, he was employed on a daily subsistence allowance at the library of the Transylvanian National Museum and the 'Ferenc József' University. ${ }^{9}$ From 1 January 1903, he was transferred to the University Library for public service under the direction of Pál Erdélyi. ${ }^{10}$ There were no vacant archival positions, so he got a job in the Newspaper Library and then in the Old Hungarian Library (RMK) for a year.

In May 1907, for subsistence reasons, he accepted the invitation of the Unitarian College of Cluj-Napoca, and for a decade, until May 1918, he worked as a teacher of history and geography there. In its session from 25-27 October 1908, the General Council of the Unitarian Church commissioned him to fill the position of ecclesiastical archivist.

During his teaching at the college, he forged closer ties with the Transylvanian Museum Society. On 7 October 1908, he became a temporary secretary, and on 21 March 1909, he was appointed regular secretary. He held this job until the end of 1921, when he had to leave his position as a public servant. He formally resigned but continued to work as a substitute until July 1927. At a general meeting held on 25 January 1911, he was elected board member of the Department of Humanities, Linguistics, and History of the Transylvanian Museum Society. ${ }^{11}$

\footnotetext{
${ }^{8}$ SJC AN, Fonds 593.

9 SJC AN, Fonds 593.

${ }^{10}$ SJC AN, Fonds 593.

${ }^{11}$ Lajos Schilling's and János Seprődi’s letter to Lajos Kelemen, Kolozsvár, 15 February 1911. See: MUELt, Lajos Kelemen legacy, no. 9.
} 
He got married to Erzsébet Mikó of Bölöni on 31 July 1910. He lost his wife on the tenth anniversary of their happy marriage after a severe illness. ${ }^{12}$ His daughter also died on 23 March 1939, at the age of 28, and he lived alone afterward.

The Great War, as the First World War was known, created a new situation in the life of the University Library, the Transylvanian National Museum, and the Archive of the Transylvanian Museum Society. The young Hungarian scholars were forced to fight on distant foreign battlefronts. The Romanian invasion of 1916 - aptly formulated by Károly Molter as 'the main rehearsal of the change of authority' ${ }^{13}$ - caused confusion and aimless attempts at escape. The World War opened the eyes of Lajos Kelemen, who, living in his inner world, had no idea what people or society at large could become.

According to a decree of the Ministry of Religion and Public Education dated on 12 July 1918, he was assigned to serve as a public high school teacher in the archives department of the library of the 'Ferenc József' University and the Transylvanian Museum Society. ${ }^{14}$

The Hungarians in Transylvania found out about the latest events in Hungary (The Aster Revolution of Mihály Károlyi and the Hungarian Soviet Republic of Béla Kun) from smuggled newspapers and street rumors. Then a day came when they could face reality: in December 1918, at the Christmas Vigil, the Romanian troops marched into Cluj.

On 12 May 1919, on behalf of the Romanian Governing Council, the 'Ferenc József' University was taken over by Secretary of State, Onisifor Ghibu, and Prefect of Cluj, Valeriu Poruţiu. ${ }^{15}$ Unlike the 'Ferenc József' University, the new Romanian academic institution issued a demand to continue using the collections of the Transylvanian Museum Society without any obligation to pay. In that historical situation, Hungarian public confidence in the institution ceased. The owners of the family archives realized that only Lajos Kelemen could safeguard their legacies. In the words of Zsigmond Jakó: he became the 'one-person standing in for an authentication place.' ${ }^{16}$

From September 1920 until his retirement, ${ }^{17}$ on 1 January 1938, Lajos Kelemen worked as a librarian and archivist at 'King Ferdinand I' University.

He was recalled after the Second Vienna Award, and from the autumn of 1940, he continued his work as General Director of the Transylvanian National Museum and its archive. He was formally retired on 1 July 1942 due to age restrictions, but he was recalled as General Director on 20 August because of his irreplaceability.

In addition to his duties as a scientific organizer, he taught at the Teacher Training Institute of the Faculty of Theology of the Transylvanian Reformed Diocese, one or two courses a week. His course subject was the period of Transylvanian history between 1540 and 1613. He taught diplomacy under the titles Introduction to diplomatics, Seminar practice on seventeenth-century sources, and Seminar practice on sixteenth-seventeenth-century

\footnotetext{
${ }^{12}$ Mrs. Kelemen Lajos Erzsébet Mikó’s obituary. MUELt, X/e, István Zsakó legacy.

13 Molter 1937, 37.

14 The job description of Ludovic Kelemen, archiver at the University Library (26 April 1930): SJC AN, Fonds 593.

15 Gyalui 2013, 313-314; 318-319.

16 Jakó 1990, 63.

17 The job description of Ludovic Kelemen, archiver at the University Library (26 April 1930) SJC AN, Fonds 593.
} 
diplomatics. ${ }^{18} \mathrm{He}$ also taught diplomatics at the Reformed and Unitarian Academies of Theology and the history of goldsmithing at the Seminary of the 'St. Joseph' Roman Catholic Institute for Boys. ${ }^{19}$ In addition to this, he gave dozens of scientific and educational lectures at open universities, took part in functions and itinerant meetings of the Transylvanian Museum Society, and joined the field trips of the Roman-Catholic 'Marianum' School for Girls. He significantly contributed to forming and strengthening Hungarian public thinking and historical consciousness in Transylvania based on authentic sources through his activities. In 1943, at the Summer University of Kolozsvár, he undertook a city tour on Sunday under the title Walking Tour in the Historic Districts of Cluj, ${ }^{20}$ and on Monday and Tuesday under the name Monuments of Cluj. ${ }^{21}$ According to Imre Mikó, Kelemen genuinely loved his job, comparing him to his predecessors Apáczai Csere and Tótfalusi. ${ }^{22}$

Lajos Kelemen excelled in his writing and editorial skills from a young age. In 1908 he was elected member of the Transylvanian Literary Society of Cluj and in 1910 of the 'Zsigmond Kemény' Society of Târgu-Mureș. Scientific recognition also came before long. In 1927 he was accepted as a member of the Board of Directors of the Transylvanian Museum Society. On 4 May 1938, at the suggestion of Jenö Balogh and Albin Gombos, he was elected one of the external members of the Hungarian Academy of Sciences. ${ }^{23}$ His high scientific title was removed after 1947 - 'I was thrown out too by Andics Erzsébet et comp. ${ }^{\prime 4}$ - and then returned in 1962.

In Cluj, on 24 October 1940, Lajos Kelemen received the Corvin Chain Award for outstanding contributions to Hungarian culture and intellectual life, which he shared with lawyer Arthur Balogh and poet Sándor Reményik. All the recognition encouraged him to work further, so he took on numerous social tasks in the Transylvanian Folk Culture Committee, the Association of Librarians and Archivists, the National Scout Council, the Unitarian Literary Society, and as a member of the Hungarian Unitarian Church's General and Representative Council. He served as superintendent of the ward and as head of the Unitarian Church for the last three years of his life.

${ }^{18}$ Felekezetközi tanárképző prospektusa [Interfaith teacher professional formation brochure] (Cluj-Napoca, 25 September 1920), see: GyFLtKGylt, Cluj-Napoca, Szent Mihály Plébánia iratai, no. 290/d-I.

19 According to the hand notes in his testament, he gave lectures on the Theory and Practice of Diplomacy, History of Goldsmithing (with a Focus on Transylvania), History of Chalices (with a Focus on Transylvania), and Ceiling Paintings in Transylvania (SJC AN, Fonds 593).

20 According to his sidenotes on the printed program, 'Approx. with 150 people. Continuation from 6 to 8: Old Castle, about 80 people.' The day before, on Saturday, 'Sightseeing with letters A-E (about 60) Farkas Street 12-3/4 265-70 people, second group 6-1/4 9 Farkas Street approx. 80 people. On Monday, 5 July, Bank of Transylvania, Bánffy House, Main Square, interior of St. Michael's Church, about 80 people, Cemetery about 60 [people]. On Tuesday, Main Square Church, Old Castle 60, on Wednesday, Cemetery 17 [people]. The schedule of the Summer University of Cluj is 1-7 July 1943' (SJC AN, Fonds 593).

${ }_{21}$ The schedule of the Summer University of Cluj is 8-14 July 1943 (SJC AN, Fonds 593).

${ }^{22}$ Mikó 1977, 257.

${ }^{23}$ Voinovics 1938, 10.

${ }^{24}$ Lajos Kelemen’s letter to Incze Gábor - Cluj, 25-27 October 1958 (Sárospataki Református Kollégium Levéltára, Kt. D. 2050, Incze Gábor legacy). The decision was not announced to those involved, and after hearing rumors in the mid-1950s, Kelemen asked Pál Gergely, his former student working in the Academic Library, to write 'the sheer reality.' Referring to his age, he no longer attached much importance to the matter. 'Whatever: he neither lifts me up nor humiliates me.' (Lajos Kelemen's letter to Pál Gergely - Cluj, 13 June 1954 - SJC AN, Fonds 593). 
He understood that his friends and disciples would pay tribute to his work with a homage volume. It was initially intended to be published in 1947 by way of celebrating his 70th birthday but could not come out because of a political ban. Attila T. Szabó bound together five complete copies from the offprints. Kelemen wrote on the last page of his copy: 'Gábor Gaál, the last director of the Transylvanian Institute of Science - prevented the publishing of the homage book "for reasons unknown to me." '25 Only as many copies of the cover page were made as there were authors. From the completed studies of the planned homage volume, I have bound four other volumes, similar to this one. Although, the other authors have also received all the studies published as offprints and the cover page, none of them has all the book-bound the studies. ${ }^{26}$ Thus, such a volume is a bibliophilic rarity.'

Sándor Tavaszy created a new epithet: Historicus Transsylvanicus. ${ }^{27}$

The 'official' homage book dedicated to Lajos Kelemen may have become a public treasure in 1957. In addition to articles by different Hungarian scholars, honorable studies by Romanian and Saxon historians were also published in the attractive volume. The recognition that Samu Benkö gave him may have been ailment for Kelemen: '[Just Like] József Benkő, the immortal representative of Transylvanian historiography, was a sage, 150 years ago, such is Lajos Kelemen [nowadays]. ${ }^{28}$

Even in his old age, he lived in a courtyard apartment at 16 Monostor (today Memorandumului) Street. He shared his monastic Puritan lifestyle with his cats, which breathed a little joy into his bleak life.

In the last active phase of Lajos Kelemen's life, acting as a tour guide for the mayor's walk was important. He showed countless people around the center of Cluj and the Házsongárd public cemetery. According to his memoir, 'I introduced the sights of Cluj to at least 15,000 people. ... They suspect me an eyewitness of the rebuilding of the Bethlen Bastion,'29 Kelemen added with a laugh.

His painful foot disease banned him not only from city leadership but also from walking. From January 1961 to mid-February 1963, with the help of Director János Fazakas, he spent more than two years at the Orthopedic Hospital. In his last months, his nephew, János Csomoss, and his wife looked after him in their home on Attila Street. He died on 29 July 1963. According to his last will, he was 'to be placed in the grave of my late dear good wife and unfortunate daughter. ${ }^{30} \mathrm{He}$ rests next to the great Unitarians of the Házsongárd cemetery.

\footnotetext{
${ }^{25}$ In addition to the memorial book planned for the $70^{\text {th }}$ anniversary of Lajos Kelemen, Gábor Gaál, who was probably acting on behalf of the Communist Party, also banned other scientific publications. 'Gábor Gál [!] Otherwise also prevented Lajos György from entering the sixteenth century. The study of András Valkai on the nineteenth century was also published in Scientific Institute's Yearbook. This is one of the persecution phenomena, but it characterizes the scientific standard, the perception of honor, and the domination of the party dictatorship in every sense; but in doing so, it also reveals its meanness', (Lajos Kelemen's letter to Domokos Gyallay Pap - Cluj, September 25 1947: László Gyula’s private collection).

26 Benkő 1996, 229.

27 Tavaszy 1947, 1-4.

${ }^{28}$ Benkő 1957b, 1223.

${ }^{29}$ Mikó 1977, 250.

30 Sas 2009b, 64.
} 
Despite not having a doctoral degree and a university affiliation Kelemen educated a famous team of professionals. Among them were primarily Attila T. Szabó, a linguist, and Zsigmond Jakó, a historian, considered his successor.

In the classical sense of the word, his sole-author volume did not appear in his life. Nevertheless, his writings comprise more than 400 items, covering the topics of place, politics, culture, art, church, and economic history, archeology, ethnography, museum, library, and archival history. ${ }^{31}$ His sixteen major works are still in manuscript form.

Here are some examples from his dissertations and source publications: On the History of the Bethlen-Bastion in Cluj (A kolozsvári Bethlen-bástya történetéhez, in Erdélyi Múzeum, 1905); The Siege of Cluj and Its Release from the Siege of the Kuruc in 1704 (Kolozsvár ostroma és fölmentése a kuruc ostromzár alól 1704-ben, in A kolozsvári Unitárius Kollégium értesitöje az 1907-908. iskolai évről); The Death and Burial of Mihály Teleki (Teleki Mihály halála és temetkezése, in Erdélyi Múzeum, 1913); Data on the History of Five Unitarian Church Castles in Székely Land (Adatok öt székelyföldi unitárius templomkastély történetéhez, in Dolgozatok az Erdélyi Nemzeti Múzeum Érem-és Régiségtárából, 1916); The Towers of St. Michael's Church in Cluj (A kolozsvári Szent Mihály-templom tornyai, in A kolozsvári Szent Mihály egyház, ed. by Lajos György, Cluj 1924); The Oldest Hungarian Engraved Columns in Transylvania (A legrégibb erdélyi magyar hímes oszlopok, in Erdélyi Almanach, ed. by Lajos György, Budapest 1925); Colțești and its memoirs (Torockószentgörgy és emlékei, in: Jókai Erdélyben, compiled by Géza Tabéry, Ernő Incze, Oradea 1925); The Toldalagi and Korda House from Cluj (A kolozsvári gróf Toldalagi- és Korda-ház, in Müvészeti Szalon, 1927); The baron Jósika Castle from Magyarfenes (A magyarfenesi báró Jósika-kastély, in Müvészeti Szalon, 1927); The Creator of the Ceiling Painting in Gogan-Varolea and His Time (A gogánváraljai mennyezetfestmény készítöje és kora, in Erdélyi Irodalmi Szemle, 1928); The Historian Balázs Orbán (A történetíró Orbán Balázs, in Ki volt Orbán Balázs?, Odorheiu Secuiesc 1929); The Church of St. Michael in Cluj (Biserica Sf. Mihail din Cluj, tran. by David Prodan, in Boabe de Grâu, 1933); The Cemetery in Hazsongard (A házsongárdi temetö, in Ellenzék, 1940); The History of the Batiz Stoneware Factory ( $A$ batizi köedénygyár története, in Közlemények az Erdélyi Nemzeti Múzeum Érem- és Régiségtárából, 1942); Ceiling Paintings of the Reformed Church in Filpeş (A magyarfülpösi (Filpeş) református templom mennyezetfestményei, in Közlemények az Erdélyi Nemzeti Múzeum Érem-és Régiségtárából, 1944); A Walk on Petőfis Side in Cluj before the Turn of the Century (Körséta Petőfi oldalán a százév előtti Kolozsváron, in Világosság, 1946).

As he himself admitted, Kelemen worked like a robot, as work was the utmost reward for him. His accomplishments include discoveries such as the Adămuș painted ceiling of the 1520s, the fragment of the church gallery in Petreni, the medieval frescoes in Sâncraiu de Mureș and Sănvăsii; he was fascinated by the Koncz Codex and its annotations known as Marosvásárhelyi Sorok és Glosszák [Marosvásárhely Rows and Glosses], dated around 1400, and also looked into Székely runic script and the gyepü system of the early Árpád border. ${ }^{32}$

${ }^{31}$ Collection volumes of Lajos Kelemen's writings published in print, see Kelemen 1977; Kelemen 1984 and, as a result of independent research, Kelemen 2006; Kelemen 2009.

32 See Sas 2010. 
In the service of his community-this could be a summary of Lajos Kelemen's life and work. In the words of István Imreh: 'Ultimately, what was Lajos Kelemen in this world? The whole of his oeuvre provides an answer to this question, he was of service. ${ }^{33}$ Attila T. Szabó, his closest student, remembered and recalled his main characteristic as teaching in 1977, on the centenary of his birth. 'Physical death implies the end only for a selfish human life, whilst an existence spent in selfless service, with its rich achievements and exemplary actions, is forever integrated into the moral, social, cultural, and scientific life of the community.' ${ }^{34}$ His conclusion was confirmed by his other close professional disciple, Zsigmond Jakó. 'In terms of community responsibility and the humility of selfless service, Lajos Kelemen remains an unsurpassed role model for Hungarian servants of Klió in Transylvania.'35 His motto was based on his own experience: 'He educated by the power of his example and actions.'36

'The literary legacy of Lajos Kelemen cannot be measured in kilograms or ells', said András Kiss. ${ }^{37}$ The artistic epithet emphasized by Ákos Egyed - 'I would also mention erudition for the sake of conciseness if a kind of concept of avidity were not attached to this word as a certain disturbing connotation ${ }^{38}$ - is still highly relevant. Rather, art or erudition evoke in our thoughts the figure of a very thorough guild master familiar with his craft. For him, the archives became a genuine school, a peculiar free university of Kelemen. The image of the all-knowing teacher Kelemen was immortalized by Zsigmond Móricz in his novel A nagy fejedelem [The Great Prince]. Sándor Reményik paid homage to him in his letter: 'Deeply respected Professor! Please allow me to call you that - You are a true Professor for us all. ${ }^{39}$

Although the list of his results speaks for itself, Lajos Kelemen found it quite difficult to start the career track of his choice. Today, it is clear that his main oeuvre rests on the completion of the archives of the Transylvanian Museum Society. The once 40,000-item collection amounted to half a million artifacts in 1918 and 600,000 in 1944. When it was renamed the Historical Archives of the Academy of the Socialist Republic of Romania, the collection included around one million items.

Many people turned to him for information and data. At least half of Lajos Kelemen's life was spent giving verbal and written answers to such inquiries. Presenting his work would not be complete without publishing thousands of mail exchanges, including letters of ten to twenty pages. From one of his letters, we can fathom the magnitude of his written discourse. 'My remaining 70-year-old correspondence, at least 7,000 missives, 95\% answered, is the ample witness to how I spent many of my afternoons and nights. ${ }^{40}$

His manuscript works include his diaries, which can be considered memoirs. ${ }^{41}$ His earliest chronological notes were made in October 1894, referring to fellow high school

\footnotetext{
${ }^{33}$ Imreh 1977, 1.

34 Szabó 1977, 31.

35 Jakó 1978, 374.

36 Jakó 1978, 367.

37 Kiss 1978, 2.

38 Egyed 1978, 199.

39 Sándor Reményik’s letter to Lajos Kelemen (Cluj, 21 January 1941): SJC AN, Fonds 593.

${ }^{40}$ Lajos Kelemen's letter to József Ferencz (Cluj, 30 January 1956): MUELt, VII/k, box no. 8.

${ }^{41}$ See, in print, Kelemen 2017 and Kelemen 2018.
} 
students. He recorded the confidential names and thoughts of his classmates and his young girl acquaintances in Székely runic script. His way of thinking and the most important problems of his age at that time might make contemporary readers smile. However, some of his sentences evoke the mature, thoughtful Lajos Kelemen:

Behave modestly. I should not play a role, only in serious matters. Let others do smaller things, I should just address bigger ones. ... I get antiques but do not brag about them. Control my temper. ... I am aware of the purpose of my life. With God's help, I will be a teacher, and I will write a description of the Mezőség [Transylvanian Plain], but if I cannot: I will be a clerk, I will exert myself, behave modestly, I will buy books, and I will live alone. If I can be a teacher, I will keep a lot of flowers for myself and books because flowers can turn a whole room into heaven. ... If my hopes deceive me, I will never marry but will make money and support my family. ${ }^{42}$

This logically simple, unusually serious, and committed way of thinking for a young man was reflected in the next seven decades of his life.

His diaries recorded the important events and atmosphere of the period with historical accuracy, from the late nineteenth century until almost the middle of the twentieth century. They shed light on the cultural and scientific life of the Reformed College in Târgu-Mureș and then in Cluj, known as the capital of Transylvania. We can get a glimpse of the world of the university, the professors, and the inner life of the University Library and its archives (led by Pál Erdélyi and Farkas Gyalui), the Transylvanian Museum Society, the Unitarian Church, and its dormitory. Moreover, just as importantly, society comes to life in his diary entries, shedding light on rich details of everyday life.

An exciting and captivating part is the follow-up of the history of the First World War and the subsequent change of political power - in modern terms, the 'change of empires'. Scientific activity, work on the collections, the efforts to save archival materials, and the desperate struggle to save the identity-relevant source material accumulated in the Archive of the Transylvanian Museum Society intensified. Kelemen's diary entries faithfully reflect the highly volatile, changing mood, the emotional fluctuations that those who lived there had to go through until they could reach some degree of certainty. One of his sentences poetically depicts the state of mind at the time: 'Given the nightmarish pressure on our souls, hysterical imagination projects orgies. ${ }^{33}$ In situations like this, he was annoyed by his limits of comprehension and, to use his own expression, by his 'reckless ignorance.'

It will be possible to get to know the whole life and work of Lajos Kelemen if his entire correspondence can be published ${ }^{44}$ and if his material and intellectual legacy can become a public treasure. His scientific and cultural heritage belongs to the entire Hungarian/Transylvanian/Székely community. All of these will be essential keys to writing a monograph on the history of twentieth century Hungarian culture in Transylvania.

His efforts in service of his community were unsurpassable. He was a Hungarian Heritage Prize winner, an intellectual treasure of his national community, and an

\footnotetext{
${ }^{42}$ Entry dated 13 October 1895. See Kelemen 2017, 122.

${ }^{43}$ Entry dated 3 June 1919. See Kelemen 2017, 702.

${ }^{44}$ So far, just one of the planned six volumes has been published. Kelemen 2017.
} 
inalienable part of Transylvanian cultural history. The memorial book, published upon the $80^{\text {th }}$ anniversary of his birth ${ }^{45}$ also featured tributes to the works of the Romanian and Saxon historians.

\section{Bibliography}

\section{Primary sources}

Gyalui 2013

GyFLtKGylt

Kelemen 2016

F. Gyalui, Emlékirataim 1914-1921, ed., introd. and explanatory notes by P. Sas, Kolozsvár 2013.

Gyulafehérvári Főegyházmegyei Levéltár Kolozsvári Gyüjtölevéltára [Alba Iulia Archdiocesan Archives, Cluj Collection Archives], Cluj-Napoca, Szent Mihály Plébánia iratai [Documents of the St. Michael Parish].

Kelemen 2017

Lajos Kelemen levelezése, I., ed., introd. and explanatory notes by P. Sas, Budapest 2016.

Kelemen 2017

L. Kelemen, Napló I. (1890-1920), ed., introd. and explanatory notes by P. Sas, Kolozsvár 2017.

Kelemen 2018

L. Kelemen, Napló II. (1921-1938), ed., introd. and explanatory notes by P. Sas, Kolozsvár 2018.

MUELt

Magyarországi Unitárius Egyház Levéltára [Archives of the Unitarian Church of Hungary], Cluj-Napoca.

Sárospataki Református Kollégium Levéltára [Archives of the Reformed College of Sárospatak], Sárospatak, Hungary.

SJC AN, Fonds 593

Serviciul Județean Cluj al Arhivelor Naționale, Cluj-Napoca, Fonds 593.

\section{Secondary sources}

Benedek 1909

E. Benedek, Székely név- és címkönyv. In: E. Benedek (ed.), Székely-egyesületi képes naptár és évkönyv az 1910. közönséges évre, Budapest 1909.

Benkő 1957b

S. Benkő, Köszöntjük Kelemen Lajost, Korunk, 9 (1957), 1223-1224.

Benkő 1996

S. Benkő, AzErdélyi TudományosIntézet.In:S. Benkő, Újrakezdések, Tanulmányok, előadások, beszélgetések, búcsúztatások 1990-1995, Csíkszereda, 1996, 228-238.

Bodor et alii 1957

A. Bodor, B. Cselényi, E. Jancsó, Zs. Jakó, A. T. Szabó (eds.), Emlékkönyv Kelemen Lajos születésének nyolcvanadik évfordulójára, Bukarest 1957.

Csetri 2012

E. Csetri, Kelemen Lajos élete és munkássága, ed. by M. Jánó, Kolozsvár 2012.

Egyed 1978

Á. Egyed, Müvelödéstörténet-írásunk útjai, Korunk, 3 (1978), 196-204.

Imreh 1977

I. Imreh, Emlékeztető Kelemen Lajosra, Utunk, 39 (1977), 1-2.

${ }^{45}$ See Bodor et alii 1957. 
Jakó 1978

Jakó 1990

Kelemen 1906

Kelemen 1977

Kelemen 1984

Kelemen 2006

Kelemen 2009

Kiss 1978

Mikó 1977

Molter 1937

Sas 2002

Sas 2009a

Sas 2009b

Sas 2010

Sas 2013a

Sas 2013b

Szabó 1895

Szabó 1977

Tavaszy 1947

Voinovics 1938
Zs. Jakó, Kelemen Lajos üzenete, Korunk, 5 (1978), 365-375.

Zs. Jakó, Kelemen Lajos (1877-1963). In: L. Kántor (ed.), Erdélyi csillagok, Budapest 1990, 51-74.

L. Kelemen, $A z$ ádámosi templom és mümlékeink, Unitárius Közlöny, 19/7 (Jul. 1906), 142-143.

L. Kelemen, Müvészettörténeti tanulmányok, ed. by A. Szabó T. Attila, M. Nagy B., G. Dávid, Bukarest 1977.

L. Kelemen, Müvészettörténeti tanulmányok, ed. by M. Nagy B., Bukarest 1984.

L. Kelemen, Müvelödéstörténeti tanulmányok, ed., introd. and explanatory notes by P. Sas, Kolozsvár 2006.

L. Kelemen, Müvelódéstörténeti tanulmányok II., ed., introd. and explanatory notes by P. Sas, Kolozsvár 2009.

A. Kiss, Rész az életmüből, Utunk 43 (1978), 1-3.

I. Mikó, Kelemen Lajos közöttünk. In: I. Mikó, Akik elöttem jártak, Bukarest 1977, 249-257.

K. Molter, Erdély történelmi hangulata 1916-tól Trianonig. In:

S. Kacsó (ed.), Erdélyi Magyar Évkönyv, A kisebbségi magyar polgár kézikönyve, Brassó, 1937.

P. Sas, Kelemen Lajos visszaemlékezése Bolyairól, Müvelődés 55/12 (Dec. 2002), 21-22.

P. Sas, Erdély legendás levéltárosa, Kelemen Lajos és az erdélyi magyar tudományosság, Budapest 2009.

P. Sas, Kelemen Lajos végrendelete, Korunk, 2009, 7, 62-67.

P. Sas, A mezöségi tórendszer, mint az egykori határvédelmi rendszer, a gyepü része. In: V. Keszeg, Zs. Szabó (eds.), Mezőség, történelem, örökség, társadalom, Kolozsvár 2010, 398-407.

P. Sas, Kelemen Lajos élete képekben, Kolozsvár 2013.

P. Sas, Kelemen Miklós önéletrajza, Keresztény Magvető 3 (2013), 311-324.

K. Szabó (ed.), Székely Oklevéltár IV. 1264-1707, arranged for the press by L. Szádeczky, Kolozsvár 1895.

A. Szabó T., Kelemen Lajos élete és munkássága. In: L. Kelemen, Müvészettörténeti tanulmányok, ed. by A. Szabó T. Attila, M. Nagy B., G. Dávid, Bukarest 1977, 7-32.

S. Tavaszy, Kelemen Lajos, Erdélyi Múzeum, 52/1-4 (1947), 1-4.

G. Voinovics, A Magyar Tudományos Akadémia 98. nagygyülése, Akadémiai Értesítő, 48 (1938), 5-31. 


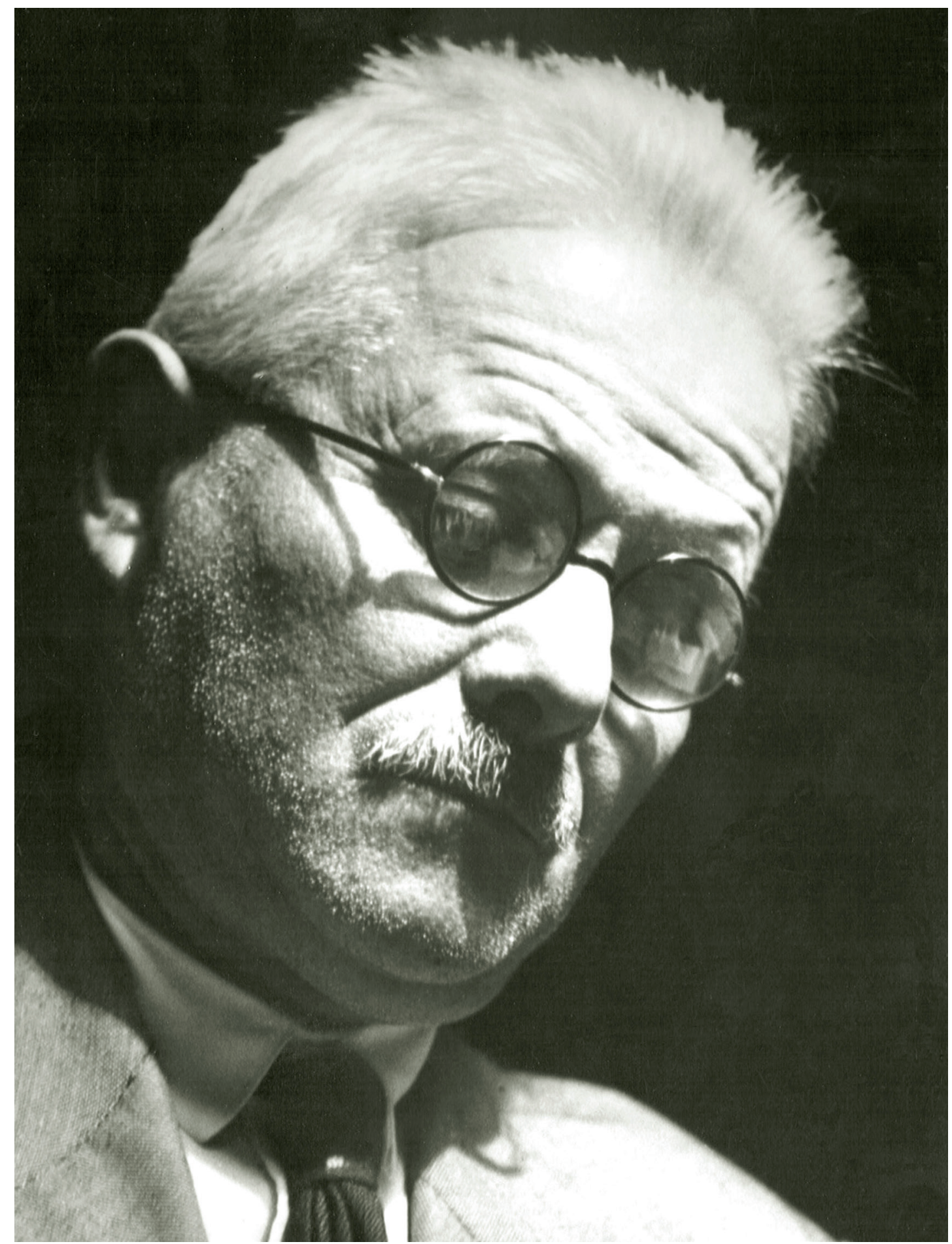

Fig. 1. Lajos Kelemen (1877-1963) historian-archivist (photo by Gyuláné Tóth Etelka Gidófalvy). 


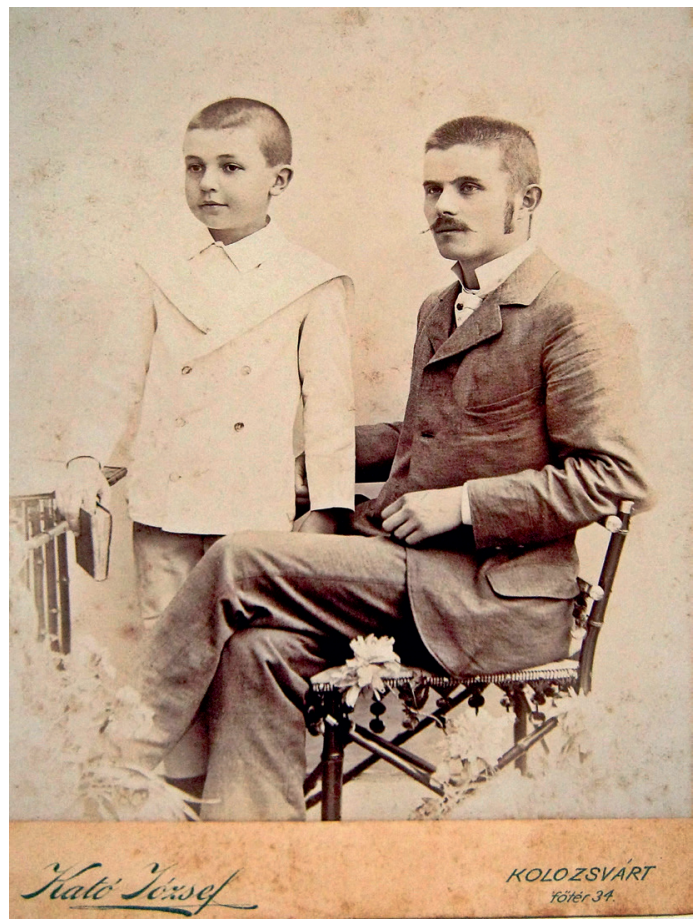

Fig. 2. Lajos Kelemen and his student, junior István Gidófalvy (private collection of Péter Sas).

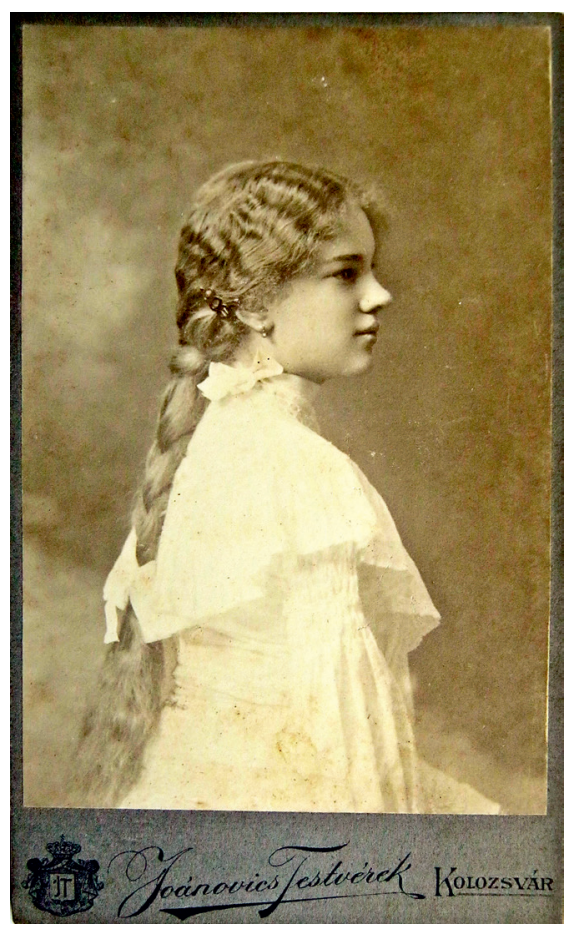

Fig. 4. His wife Erzsébet Mikó (photo by Joánovics Brothers; courtesy of SJC AN, Fonds 593).

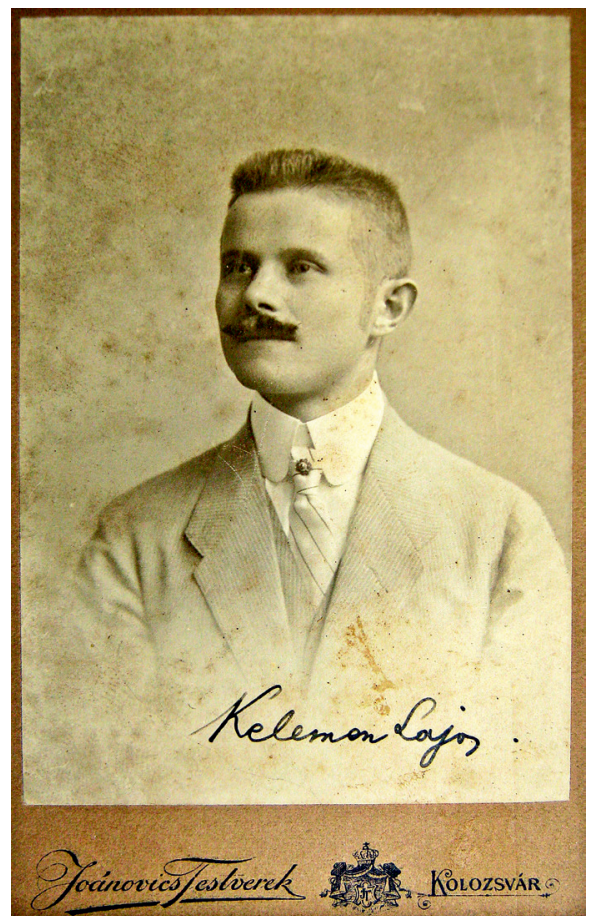

Fig. 3. Teacher at the Unitarian College (photo by Joánovics Brothers; courtesy of SJC AN, Fonds 593).

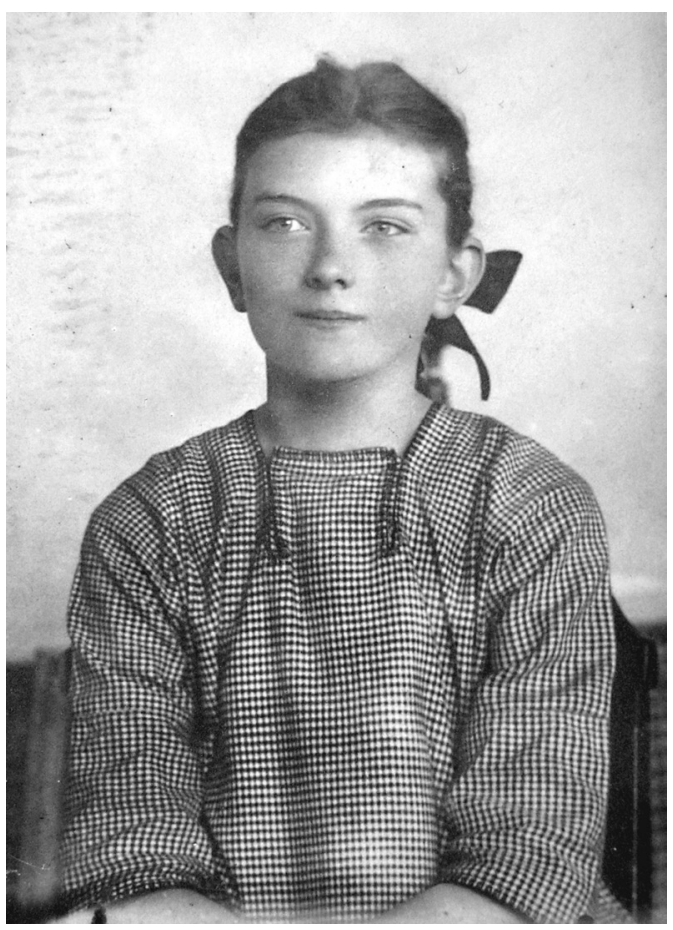

Fig. 5. His daughter, Erzsébet Kelemen (courtesy of SJC AN, Fonds 593). 


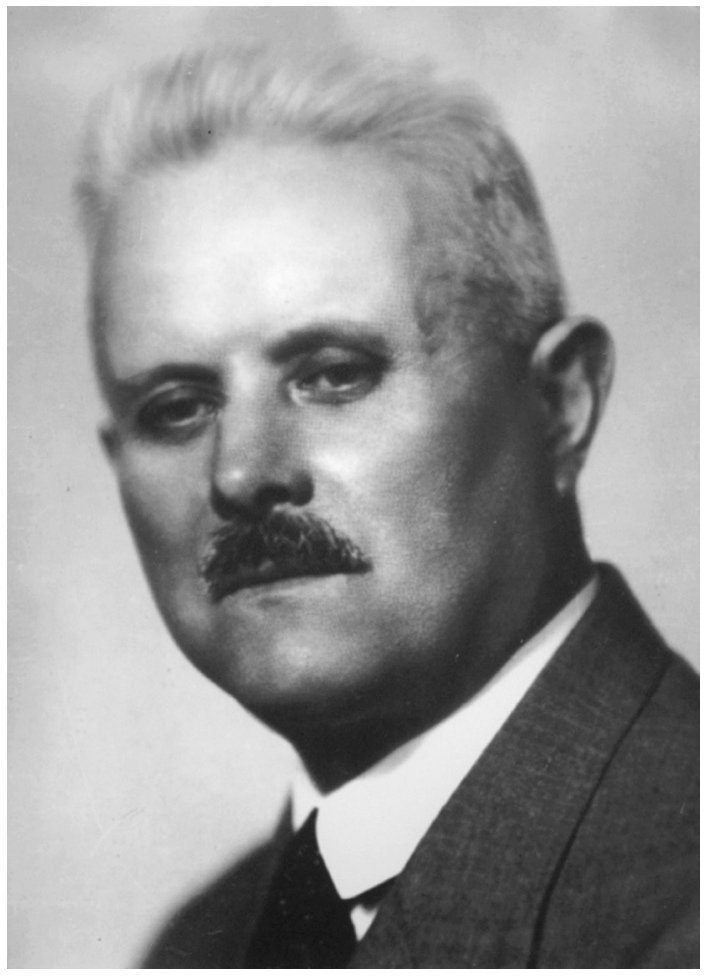

Fig. 6. Member of the Hungarian Academy of Sciences (courtesy of SJC AN, Fonds 593).

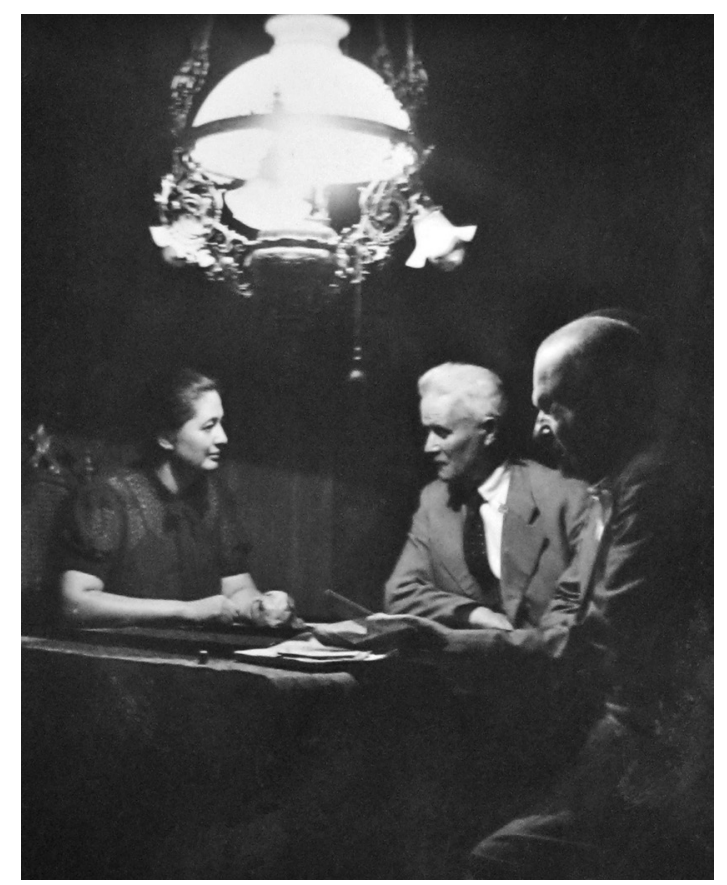

Fig. 8. With his former student, Jr. István Gidófalvy, landowner in Dăbâca and his wife, painter Etelka Pataky (photo by Gyuláné Tóth Etelka Gidófalvy).

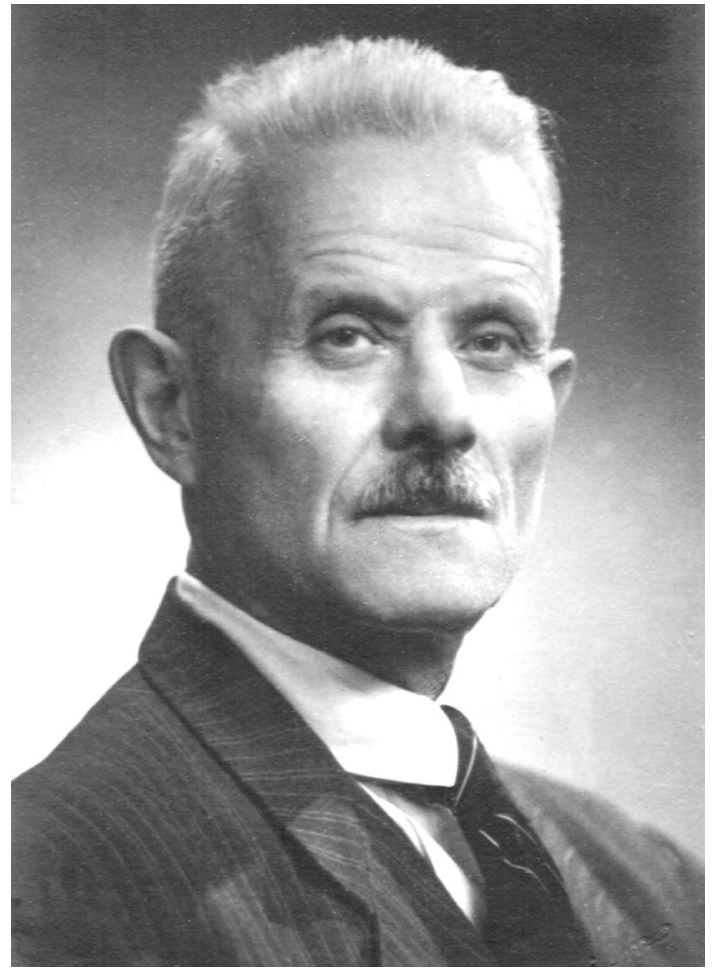

Fig. 7. General Director of the University Library and Archives (courtesy of SJC AN, Fonds 593).

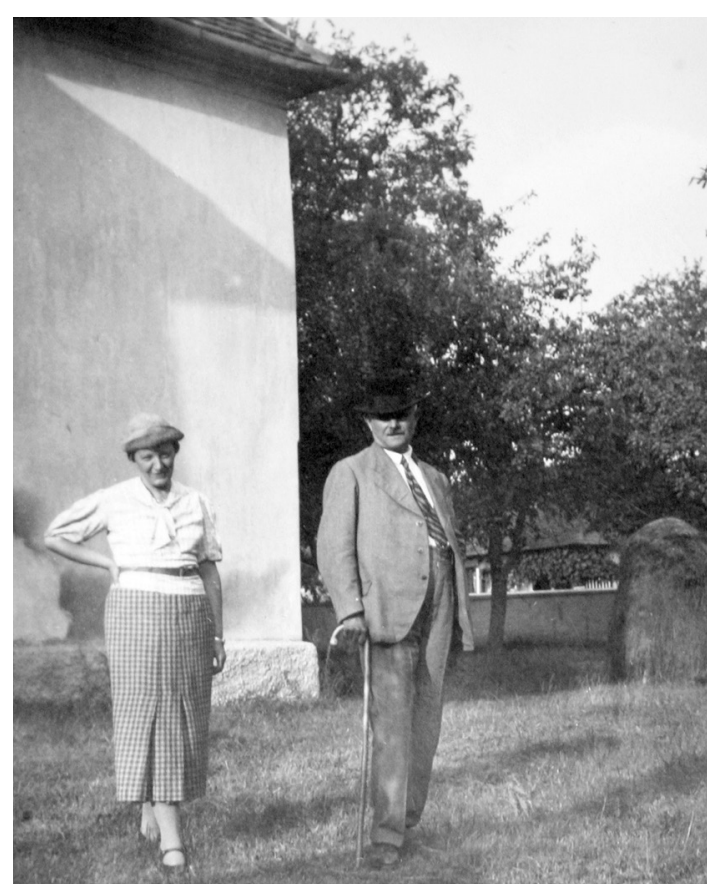

Fig. 9. With art historian Jolán Balogh (courtesy of SJC AN, Fonds 593). 


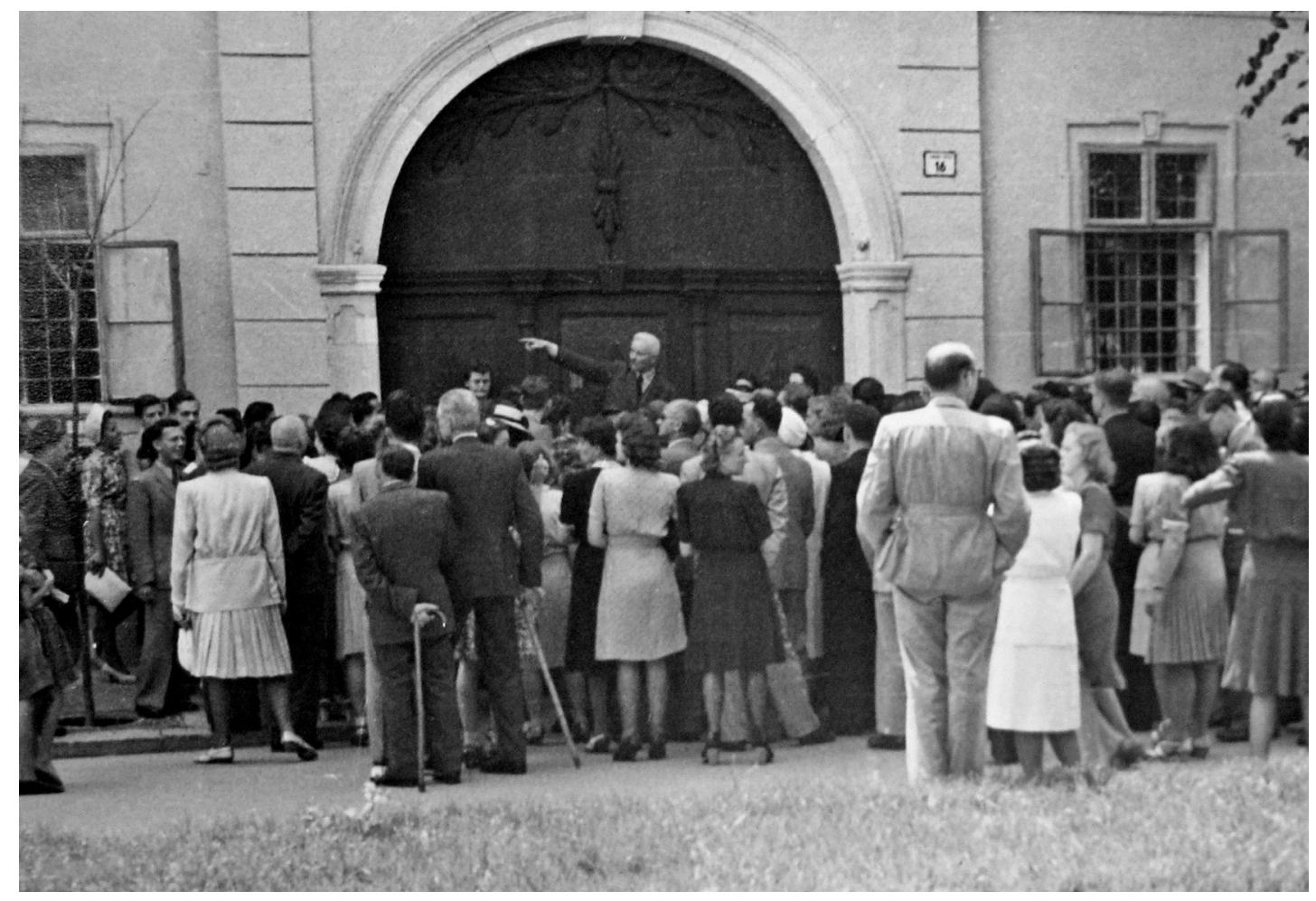

Fig. 10. One of the mayor's walks (courtesy of SJC AN, Fonds 593).

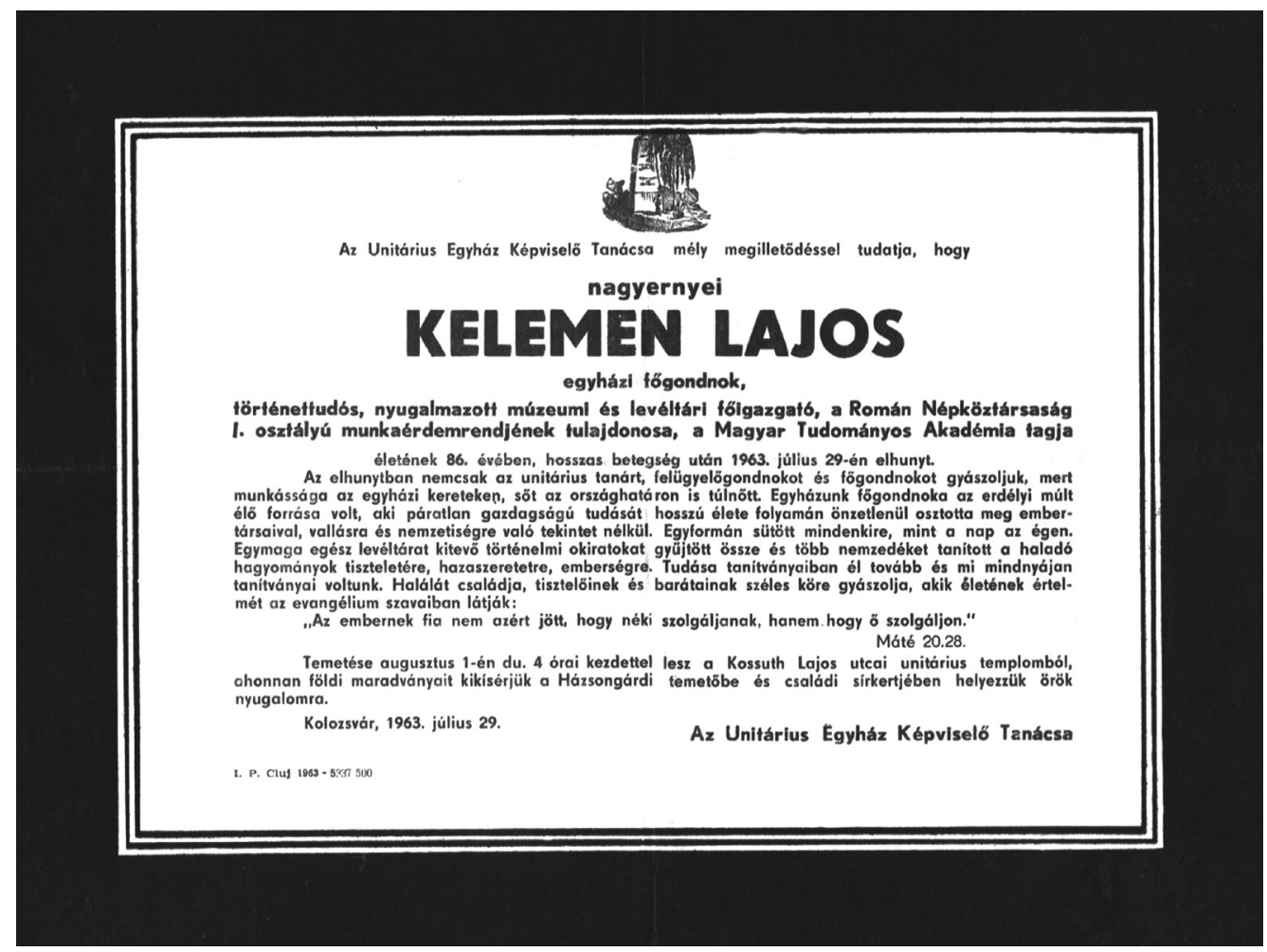

Fig. 11. Obituary of Lajos Kelemen (private collection of Péter Sas). 

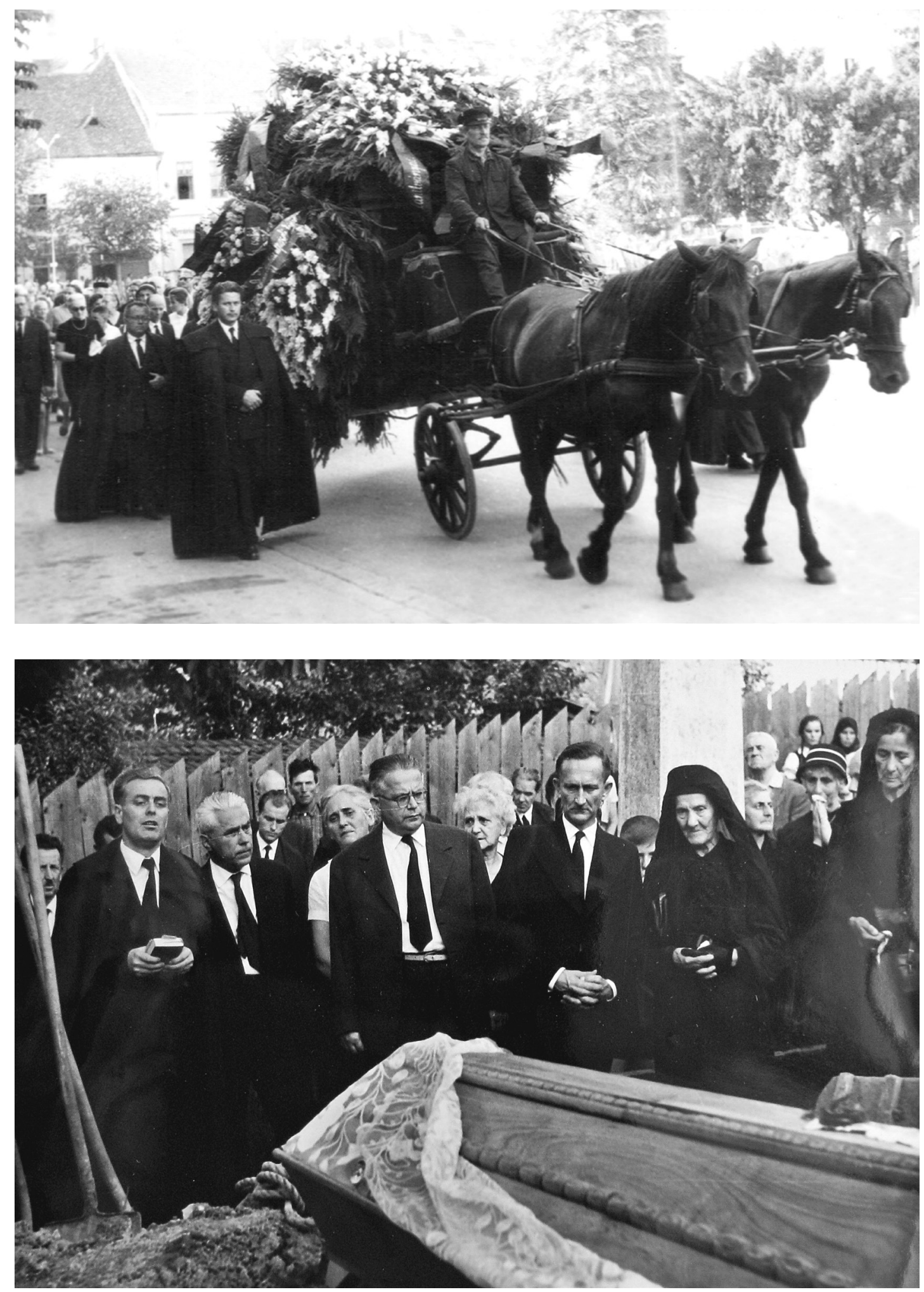

Fig. 12-13. Excerpt from his funeral procession (12. private collection of Péter Sas; 13. courtesy of the Transylvanian Unitarian Church Archive, Cluj-Napoca). 


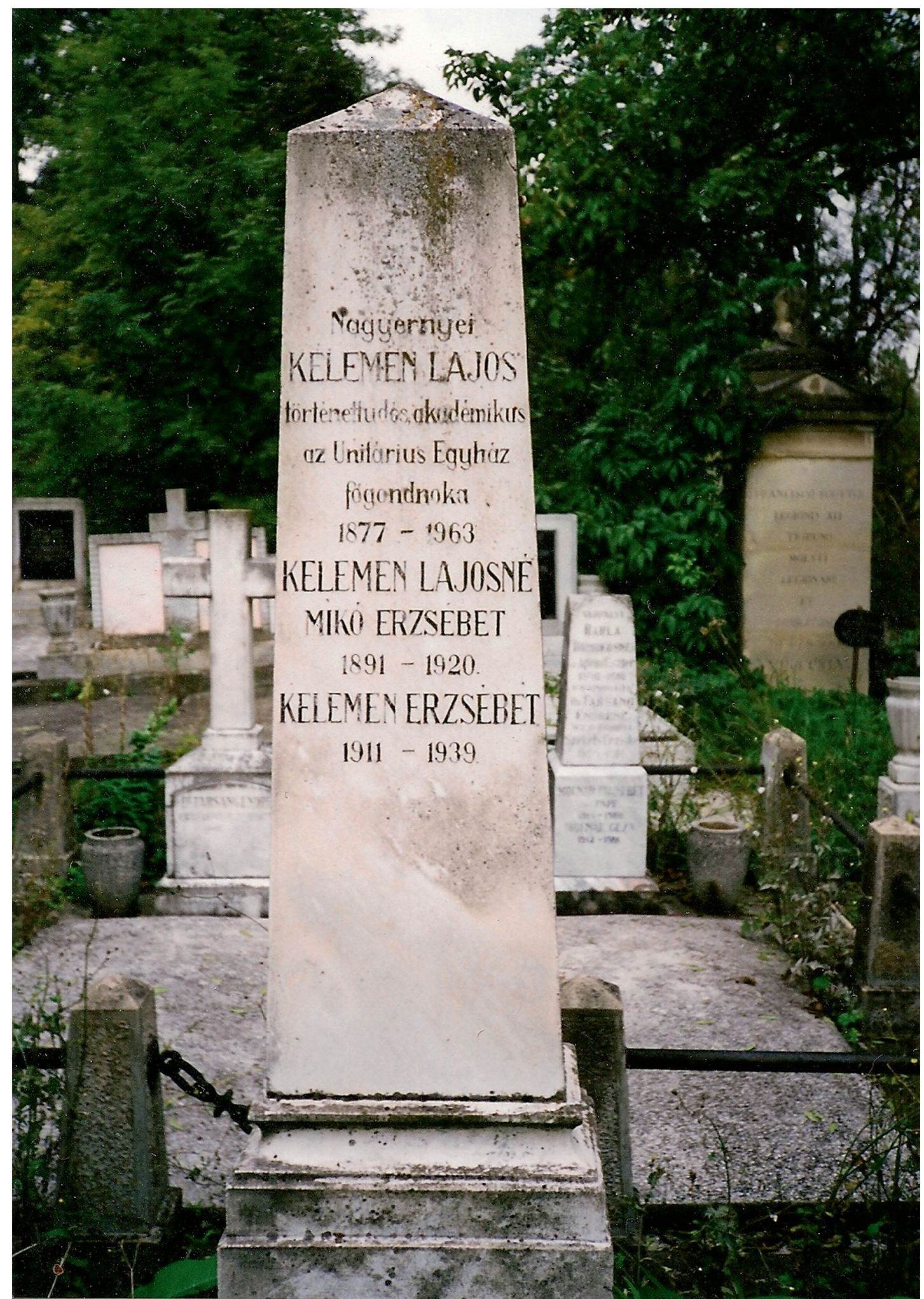

Fig. 14. Family grave in the Házsongárd cemetery in Cluj-Napoca (private collection of Péter Sas). 


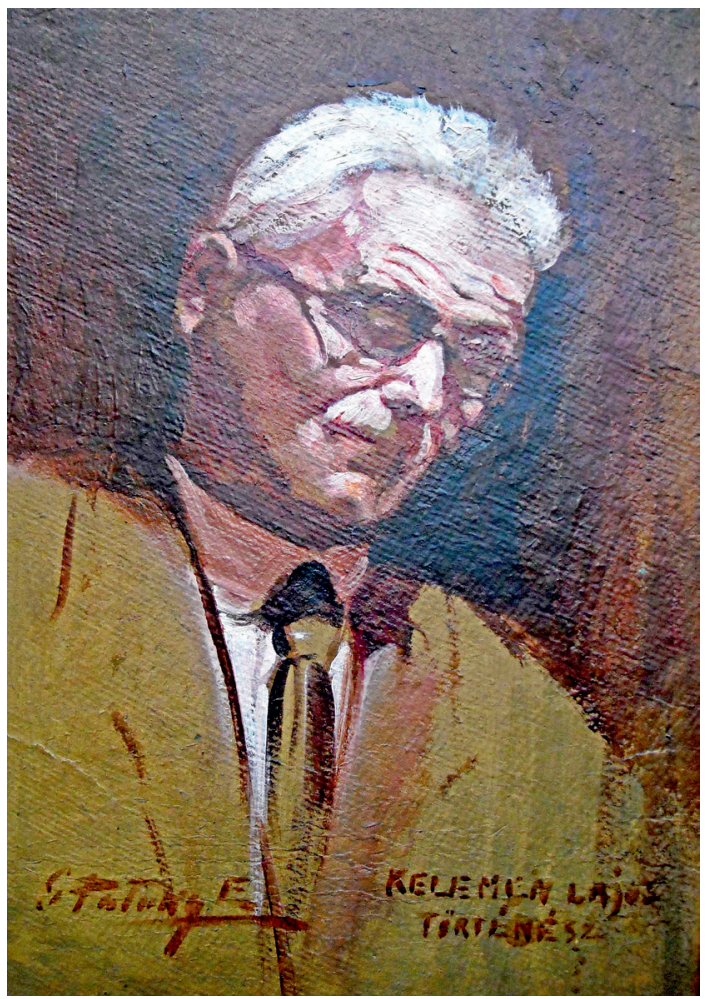

Fig. 15. Gidófalvyné Pataky Etelka, Lajos Kelemen, oil painting (Sas 2013a, front cover).

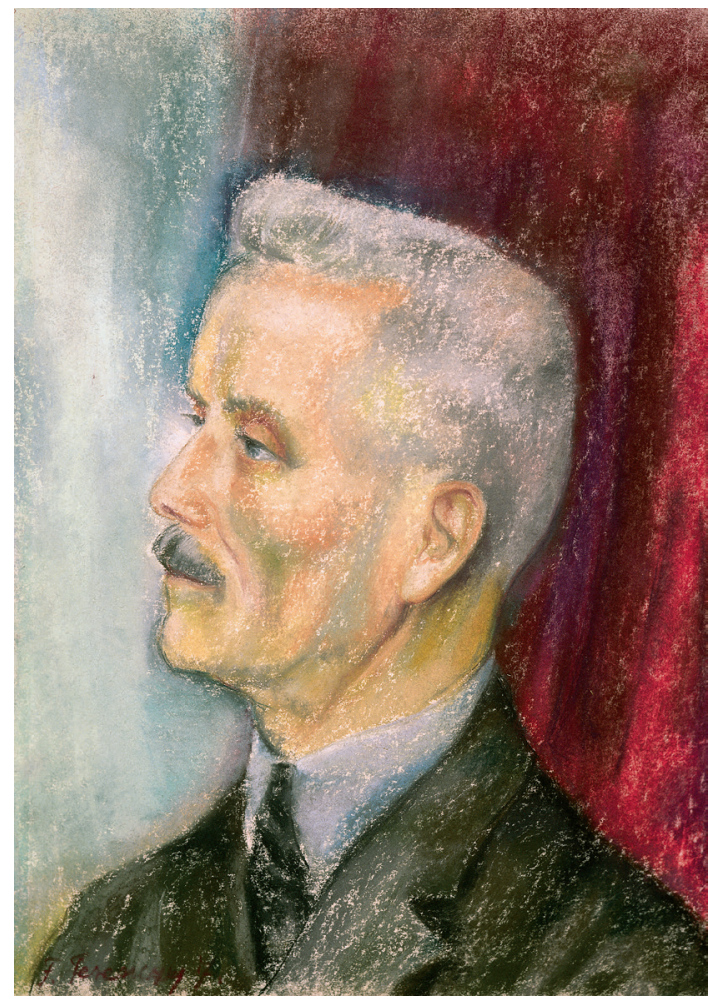

Fig. 16. Júlia Ferenczy, Lajos Kelemen, oil painting (Sas 2013a, 93).

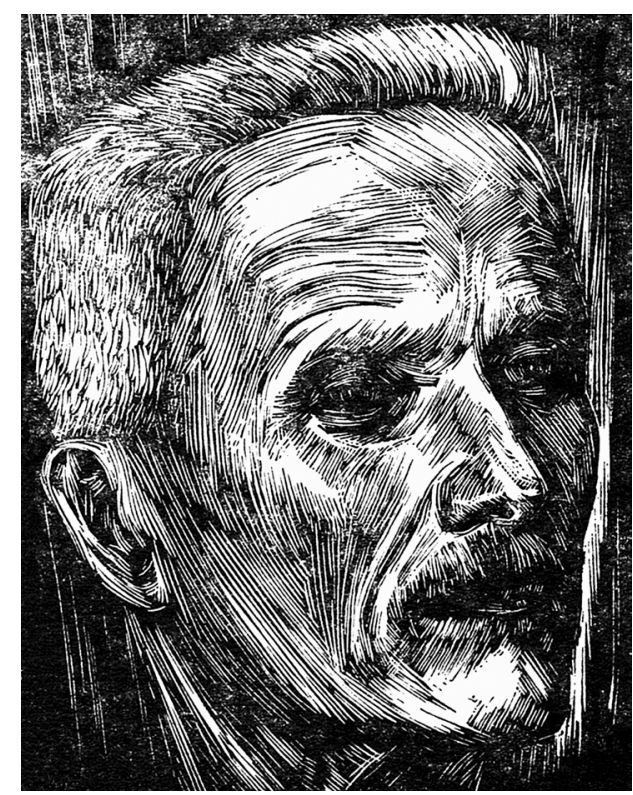

Fig. 17. Béla Szabó Gy., Lajos Kelemen, woodcut (private collection of Péter Sas).

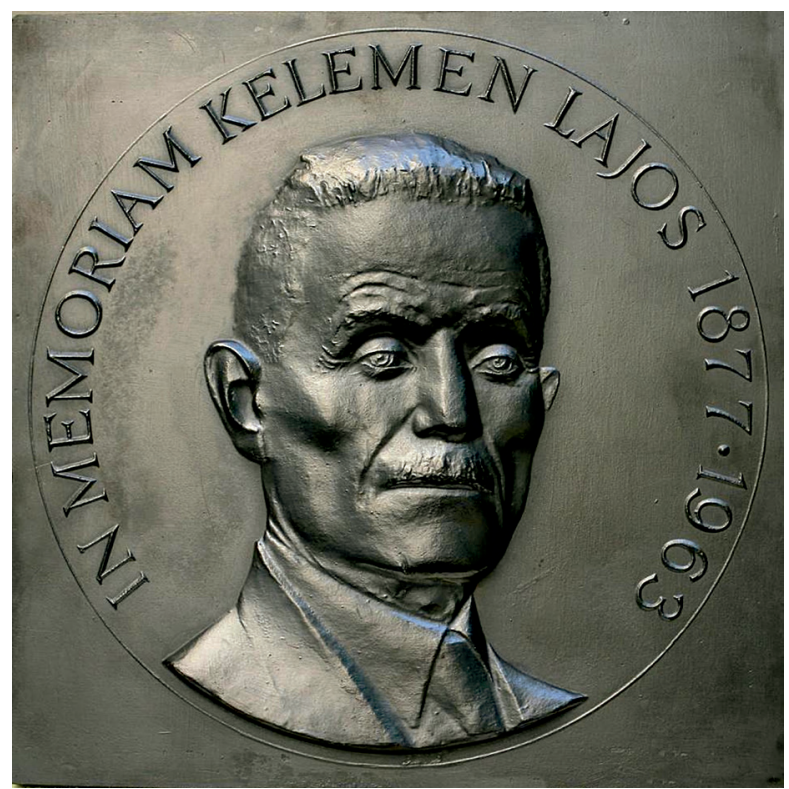

Fig. 18. István Gergely, Lajos Kelemen, plaque (private collection of Péter Sas). 


\title{
THE ROLE OF ASSOCIATIONS IN THE ORGANIZATION OF THE MUSLIM COMMUNITY. THE CASE OF THE ASSOCIATION OF GRADUATES OF THE MUSLIM SEMINARY IN DOBRUDJA
}

\author{
METIN OMER*
}

\begin{abstract}
This paper addresses an aspect of the institutional history of the Muslim community in Romania. It aims to present how the Association of Graduates of the Muslim Seminary in Dobrudja was established and analyze its purpose and activities. The role of the Association is considered from two perspectives. The establishment of the Association was linked to Emel magazine and the group that published it. This group supported the creation of a Crimean Tatar state in Crimea. However, some of its members tried to solve the problems the Turks and the Tatars in Romania faced.

In my paper, I explained the role of the Association in the organization system of Islam in Romania. The organization of the Muslim community was established in the first years after the Russo-Ottoman War of 1877-1878, after which Dobrudja became part of the Romanian state. Thus, an organizational system similar to the Ottoman one continued after this year. Its central institution was the Muftiate, under whose subordination were the Muslim Communities and the Kadiates. The Muslim Seminary held a special place in this system. It was the only educational institution whose role was to train imams and Turkish language teachers of the Turkish and Tatar community in Romania, recognized and supported by local and central authorities. In this sense, the establishment of the Association of Graduates of the Muslim Seminary in Dobrudja was also a response of the Muslim community members to the new political, demographic, and cultural realities.
\end{abstract}

Keywords: the Muslim Seminary from Medgidia, Turks, Tatars, Dobrudja, Muslim cult

Rezumat: Lucrarea de față abordează un aspect din istoria instituțională a comunității musulmane din România. El își propune să prezintă felul în care a fost înființată Asociația Absolvenților Seminarului Musulman din Dobrogea și să analizeze scopul și activitățile acesteia. Sunt propuse două perspective din care poate fi înțeles rolul asociației. Astfel, înființarea asociației poate fi pusă în legătură cu activitatea revistei Emel și a grupului din jurul acesteia care susținea crearea unui stat tătăresc în Crimeea, dar poate fi privită și ca un demers al unor lideri ai comunității musulmane de a contribui la rezolvarea problemelor cu care se confruntau turcii și tătarii din România.

În analiza făcută s-a încercat încadrarea asociației în sistemul de organizare al cultului musulman din România. Principiile de organizare ale acestuia au fost stabilite în primii ani de după Războiul ruso-otoman din 1877-1878 în urma căruia Dobrogea a intrat între granițele românești. Astfel, a luat naștere un sistem similar cu cel din perioada otomană în care instituția centrală era Muftiatul, în subordinea căruia se aflau Comunitățile Musulmane și Cadiatele. Un loc aparte în acest sistem 1-a avut Seminarul Musulman, singura instituție de învăţământ al cărei rol era de a pregăti imamii și învățătorii de limba turcă ai comunității turce și tătare din România, recunoscută

` Ph.D., Researcher, ‘Ovidius’ University of Constanța, email: metin.omer@365.univ-ovidius.ro, D https://orcid.org/0000-0003-3898-6920. 
și susţinută de autorităţile locale și centrale. În acest sens, înființarea Asociației Absolvenților Seminarului Musulman din Dobrogea a fost și un răspuns al membrilor comunităţii musulmane la noile realități politice, demografice și culturale.

Cuvinte cheie: Seminarul Musulman din Medgidia, turci, tătari, Dobrogea, cultul musulman

\section{Introduction}

A lesser-known aspect regarding the organization of the Muslim community in interwar Romania is that of the role of the associations established as initiatives independently of the official institutions. Only a few studies have addressed the associations and organizations of Turks and Tatars in Romania, which formed most Muslims in this period. The primary source is Müstecip Ülküsal's book, Dobruca ve Türkler. Despite not respecting academic standards, it is one of the most important works on Turks and Tatars in Romania until the Second World War. ${ }^{1}$ This is because Ülküsal was born in Romania in 1899 (named Mustegep Hagi Fazâl) and lived here until the outbreak of World War II when he emigrated to Turkey, becoming a Turkish citizen until the end of his life, in 1996. Coming from a wealthy family of emigrants from Crimea, he graduated from the Faculty of Law of the University of Bucharest and was actively involved in community life. Thus, his book is based on primary and secondary sources (which he often does not cite) and on his memories. Regarding ethnic and religious associations, Ülküsal summarizes some of them without a detailed analysis. Another study, which addresses a single association, is that of Ekrem Gafar on the 'Selim Abdulakim' Muslim Cultural Association (in Romanian, Asociația Culturală Musulmană „Selim Abdulachim”). ${ }^{2}$ Although Gafar presents valuable information about the establishment of the Association, it fails to explain its role and activities. Recently, Filiz Tutku Aydin published an essential book on the national movement of Crimean Tatars, dedicating a chapter to the Tatars in Dobrudja. Here it refers to the role that The Turkish Cultural Association of Dobrudja (in Turkish, Dobruca Türk Hars Birliği) played in the political and cultural life of the Tatars from Dobrudja. ${ }^{3}$ This paper follows the path started by Alexandre Popović, who, in his book Lislam balkanique: Les musulmans du sud-est européen dans la période post-ottomane addresses for the first time, distinctly, the evolution of the Muslim communities in the Balkans, focusing on the transformations suffered in the post-Ottoman period. Popović examines how Muslim communities in the nation-states that succeeded the Ottoman Empire adapted to the new conditions by referring to their institutions, involvement in political life, and the publications they had. ${ }^{4}$

In this sense, the study dedicated to the Association of Graduates of the Muslim Seminary in Dobrudja contributes to the institutional history of the Muslim community in Romania. It completes the information on one of the most important associations established by the representatives of the Muslim community in Romania in the interwar period, explains its role, and shows the extent to which it managed to achieve its objectives. In this study, two interpretations are considered about the objectives of the Association. On

\footnotetext{
${ }^{1}$ Ülküsal 1987, 178-184.

${ }^{2}$ Gafar 2005, 175-184.

${ }^{3}$ Aydin 2021.

${ }^{4}$ Popović 1986.
} 
the one hand, it was founded due to the efforts made by a group of people who sought to promote their political interests and ideas on community development. On the other hand, there was dissatisfaction with the shortcomings of the legislative framework created by the Romanian state, the Association trying to complete the efforts of representative institutions to improve the situation of the Muslims and their institutions.

The article has two main parts. After describing the organization of Islam and its central institutions, the study presents the establishment of the Association of Graduates of the Muslim Seminary in Dobrudja. In the second part, I analyze the activities of the Association. In this way, one could easily understand the purpose and the role of the Association in the organizational system of the Muslim community.

\section{Institutional organization of the Muslim cult and the foundation of the Association of Graduates of the Muslim Seminary from Dobrudja}

The institutional organization of Islam was a challenge for Romanian officials immediately after 1878 when Dobrudja became part of the Romanian state. After this moment, the functioning mechanisms of the representative institutions of the Muslims in Romania were established. Their regulation was all the more urgent and of interest to Romanian officials as the Muslim population was large and concentrated in one region of the country, Dobrudja. At the end of the Russo-Ottoman War of 1877-1878, 71,146 (31.5\%) Tatars, 48,783 (21.6\%) Turks, 46,504 (21\%) Romanians out of 225,692 inhabitants lived in Northern Dobrudja. ${ }^{5}$ After the Treaty of Bucharest (1913), Southern Dobrudja with the counties of Durostor and Caliacra was ceded to Romania. As a result, the Turkish and Tatar populations almost doubled. Thus, in 1930, 154,772 Turks and 22,141 Tatars were counted in Romania. ${ }^{6}$ It must be borne in mind that this result was possible due to a strong current of emigration to the Ottoman Empire and then the Republic of Turkey.

The authorities in Bucharest supported the creation of a system in which, on the one hand, the traditions of the Muslim population should be respected. On the other hand, its institutions should operate within the limits of Romanian laws, in a relationship of subordination to central bodies. Thus, the leading institution of Islam in Romania became the Muftiat (in Turkish, Müftülük) which was headed by a mufti who had the role of religious leader and to whom the imams (hodjas), i.e., the religious staff, were subordinated. Initially, a Muftiat was established in each county residence in Dobrudja, first Tulcea and Constanța, and after 1913, in Bazargic (Caliacra) and Silistra (Durostor). There was no relationship of subordination between them, each having authority in its county. In 1937 there was an attempt to rank the Mufties by establishing a Baș-Muftiat (tr. Başmüftülük). The Baș-Muftiat was supposed to coordinate the other four Mufties, but it was a failed attempt due to opposition from the other Mufties who did not want to relinquish their authority. As the result of the Treaty of Craiova in 1940, Romania ceded Southern Dobrudja to Bulgaria. In addition, the number of Turks and Tatars decreased as they emigrated to Turkey. Thus, since 1943 only one Muftiat based in Constanța remained to represent the entire Muslim community in Romania. ${ }^{7}$

\footnotetext{
${ }^{5}$ Karpat 2010, 413-414.

${ }^{6}$ Manuilă 1938, X-XVII.

${ }^{7}$ State Secretariat for Religious Affairs 2019, 156.
} 
The other two institutions of the Muslim community, the Muslim Communities (in Turkish, Müslüman Cemaatleri) ${ }^{8}$ and the Kadiates (in Turkish, Kadılıklar) subordinated to the Muftiate. Muslim Communities were established in all localities with Muslim populations. Their role was to manage waqf ${ }^{9}$ properties, maintain the schools and mosques, and ensure the community's salary of teachers and imams of the community. The Kadiates (Islamic courts) dealt with the civil legal issues of Muslims. There was a Kadiate in each county residence in Dobrogea. Islamic courts were abolished in 1935, at the request of the Muslim community, because of the influence of Kemalist reforms. ${ }^{10}$ The system based on Muftiate as a central institution and Muslim Communities (also called mosques committees) as institutions that deal with the administration of the Muslim community properties still works today. ${ }^{11}$

The Muslim Seminary played a key role in this structure. This educational institution opened in 1889 to train the Islamic clergy and the Turkish language teachers. It was supposed to continue the Ottoman education tradition, but, at the same time, it represented an attempt to integrate it into the Romanian education system. Thus, founded by Gazi Ali Pasha, an Ottoman military commander, ${ }^{12}$ the Muslim Seminary began its activity in Babadag, to continue the madrasa. ${ }^{13}$ Although several madrasas opened in Dobrudja in the Ottoman period, and they continued to function in the first years after 1878, the madrasa founded by Gazi Ali Pasha was the only one that the Romanian state chose to recognize as an educational institution and to finance it. ${ }^{14}$ The Muslim Seminary functioned in Babadag until 1901 when it was moved to Medgidia. Here it was opened until 1967 when it was closed by the communist authorities. ${ }^{15}$ The Muslim Seminary reopened in 1995 as the 'Kemal Atatürk' National College based on a protocol signed by the Turkish and Romanian states, with special classes for imams and Turkish language teachers training. ${ }^{16}$ Until its closure in 1967, the Muslim Seminary was the representative educational institution for Turks and Tatars in Romania. Most of the mufties and kadies of the Muslim community and its political and cultural elite graduated from this Seminary. ${ }^{17}$

Regarding the functioning of this system, the institutions through which the Muslim community should have defended and promoted its interests were the Muftiate, Kadiate, and the Muslim Communities. The staff provider to carry out their activity was the Muslim Seminary, and there were shortcomings in the functioning of the religious system. The main grievances reported by members of the Muslim community were the lack of funding for the maintenance of places of worship and educational institutions, poor pay of religious

\footnotetext{
${ }^{8}$ Here one should make the difference between the Muslim community as umma or the whole community of believers and Muslim Communities as an institution in the organizational structure of Islam in Romania.

${ }^{9}$ In the Ottoman Empire, waqf (in Turkish, vakıf) were properties whose income was to be used for the maintenance of places of worship, cemeteries, schools, or the payment of staff. They consisted of farmland, shops, or buildings.

${ }_{10}$ Hamangiu 1935, 247-248.

${ }^{11}$ For the regulation of Islam and Muslim community in Romania, see Monitorul Oficial 2008.

12 Karpat 2018, 54-55.

${ }_{13}$ Madrasa is a higher education institution in the Islamic world.

14 Omer 2016, 153-154.

15 Marin 2016, 175-210.

16 Cupcea 2016, 211-247.

17 Omer 2016, 153.
} 
and educational staff, insufficient training of clergy and teachers. Not only the Romanian institutions but also the bodies of the Muslim community were considered guilty of these deficiencies. One of the preferred solutions for solving these problems was the creation of associations. They either acted as advocacy groups for its members, or they were the initiators of actions aimed at improving the situation of the Turks and Tatars. ${ }^{18}$

One such Association was the one set up by the Muslim Seminary graduates. The memorandum of the Association of Graduates of the Muslim Seminary in Dobrudja ${ }^{19}$ was voted unanimously in the general assembly in the meeting of 22 May 1929, with 62 members out of 92 registered..$^{20}$ The Constanța County Court accepted the application for the establishment of the Association on 10 December 1929. ${ }^{21}$ What made this Association more influential was that it was the only professional Association of Muslim clergy. ${ }^{22}$ Thus, at least on a theoretical level, it represents almost the entire Muslim clergy in Romania. This was due to a legislative provision according to which imams in Romania were graduates of the Muslim Seminary in Medgidia. This rule was not put into practice for two reasons. First, there were not enough Muslim Seminary graduates, and second, not all graduates chose a religious career. However, the cases of clerics with studies elsewhere than the Muslim Seminary in Medgidia were exceptions. ${ }^{23}$

Even though the legislative provision advantaged them, the founding members aimed to consolidate graduates of the Muslim Seminary's presence in the Association. Thus, its initial statute mentioned that all graduates of the Seminary were to become members. The judge rejected this provision as it was considered against the law. ${ }^{24}$ Finally, it was decided that all members of the Muslim Seminary could volunteer as members of the Association. The only obligation was to pay their registration fee and dues, which are also some of the main sources of income. ${ }^{25}$

According to its memorandum, the Association was to 'fight in all legal ways, to raise the moral and intellectual level of the Muslim population. ${ }^{26}$ Thus, the activities of the Association were to focus on several main directions: to support the activities of Muslim Seminary graduates, to contribute to their cultural and Muslim communities development, to be a mediator in cases of misunderstandings between members, to help those in financial difficulties or disagreement with central and local authorities. ${ }^{27}$

The purpose and activities that the Association proposed were, in fact, the same as the role that the Muftiate had. ${ }^{28}$ One may raise the question regarding the need to create a new body as long as there was an official institution whose purpose was to deal with the Muslim

\footnotetext{
${ }^{18}$ For the situation of the Muslim community concerning its institutions in the interwar period, see Omer 2020, 117-146.

19 This was the official name of the Association. In the documents, the name of the educational institution appears as the Muslim Seminary of Medgidia, it is also known as the Muslim Seminary.

${ }^{20}$ ANIC, MCA Fonds, File 125/1941, f. 73.

${ }^{21}$ ANIC, MCA Fonds, File 125/1941, f. 75.

22 ANIC, MCA Fonds, File 125/1941, f. 76.

${ }^{23}$ For such an example, see ANIC, MCA Fonds, File 115/1935, f. 80.

${ }^{24}$ ANIC, MCA Fonds, File 125/1941, ff. 74-75.

25 ANIC, MCA Fonds, File 125/1941, ff. 70-71.

${ }^{26}$ ANIC, MCA Fonds, File 125/1941, f. 69.

27 ANIC, MCA Fonds, File 125/1941, f. 70.

${ }^{28}$ For the role and the organization of the Muftiate, see Omer 2020, 120-134.
} 
cult in all its aspects. The situation is all the more interesting as, among the founders, there is also the only baş-mufti in Romania, Etem Curt Mola, and the first president was Nuri Resul, the mufti of Constanța County between 1929 and $1933 .{ }^{29}$ Considering the activities carried out by the Association of Graduates of the Muslim Seminary in Dobrudja, its purpose and role can be more easily understood.

\section{The Activities of the Association of Graduates of the Muslim Seminary in Dobrudja}

Emel was one of the most influential magazines in the Muslim community, especially among ethnic Tatars in interwar Romania. It appeared between 1930 and 1940, first in Bazargic, then in Constanta. After the emigration to Turkey of one of its founders, Müstecip Ülküsal, the magazine was published in Ankara in 1960 and in 1962 in Istanbul. A group of personalities from the Tatar community also concentrated around it and came to be known as Emelciler. ${ }^{30}$ The group aimed to recreate the People's Republic of Crimea, which had a short existence in late 1917 and early 1918, and is considered the first modern state of the Crimean Tatars. Until the Second World War, the group's activities focused on creating a national consciousness among the Tatars in Dobrudja, in which ties with Crimea occupied a central place. During this period, their efforts were limited to addressing as many people as possible through Emel magazine and the organizations they created. They also promoted people with similar ideals to important positions in the leadership of the Muslim community institutions. The nature of these activities changed after the outbreak of World War II. During this period, the members of the Emel group initiated unsuccessful attempts to create military detachments to participate in the liberation of Crimea from Soviet occupation and sent aid materials to Crimea. With the withdrawal of the Romanian and German armies from the Soviet Union, the Emelciler activity focused on receiving and sheltering Crimean Tatar refugees. With the establishment of the communist regime in Bucharest, at the end of the Second World War, the group's activity was no longer possible, most of them being imprisoned, some even killed during the investigations. ${ }^{31}$

There is no document to directly link the Association of Graduates of the Muslim Seminary in Dobrudja and the Emel group. A few elements, however, suggest a connection between the two initiatives. First of all, the founding members of the Association were involved in Emel magazine's publication and the group's activities formed around it. Among the founding members, Șuaib Abduraman, Negib Hagi Fazâl, Feuzi Ismail, Etem Curt Mola, Enan C. Mola, Mustafa Amet, ${ }^{32}$ were convicted by the communist courts for their activities. Negib Hagi Fazâl, who for a time was also the president of the Association, ${ }^{33}$ died during the interrogation to which he was subjected by the Romanian political police, the Securitate in $1948 .^{34}$

Also, the leader of the Emel group, Müstecip Ülküsal, shows that $90 \%$ of the students and graduates of the Muslim Seminary, implicitly members of the Association of Graduates

\footnotetext{
${ }^{29}$ ANIC, MCA Fonds, File 125/1941, f. 69.

${ }^{30}$ Emel in Turkish and Tatar means 'ideal,' and thus, emelciler were 'idealists.'

${ }^{31}$ Omer 2021, 193-215.

${ }^{32}$ ANIC, MCA Fonds, File 125/1941, f. 69.

${ }^{33}$ Ülküsal 1999, 215.

${ }^{34}$ Cupcea 2015, 127.
} 
of the Muslim Seminary in Dobrudja, were members of Dobruca Türk Hars Birliği (Turkish Cultural Association). ${ }^{35}$ This information is essential because the role of Dobruca Türk Hars Birliği in the activities of the Emel group is well known. This was the Association through which an attempt was made to popularize the Emel magazine and coordinate the activities of those affiliated with the ideas promoted by it. ${ }^{36}$ Regarding the role of Muslim Seminary graduates in this organization, its founder, Müstecip Ülküsal, describes it as follows:

Both in the founding and the development and functioning of Türk Hars Birliği the most significant help was given to us by those who had graduated from the Muslim Seminary and were imams, hatipi or teachers in villages... Our young seminarians, teachers and clergy, both in terms of age and training, they had the greatest ease in interacting with those of our people, regardless of social category or age... We considered our young seminarians the fundamental pillars and foundation of our organization, we asked and received their help and support. ${ }^{37}$

A coincidence also strengthens the connection between the Association of Graduates of the Muslim Seminary in Dobrudja and the Emel group. The Association was founded at the end of 1929. At the same time the publication of Emel magazine, which started to appear the following year, was planned. Moreover, the first vice-president of the Association of Graduates of the Muslim Seminary in Dobrudja, Rifat Midhat, was one of the founders of the Emel magazine. ${ }^{38}$ The first president, the mufti Nuri Resul, also supported the activities of the Emel group. He is mentioned on several occasions as a participant in events dedicated to the commemoration of the personalities of the Crimean Tatars. ${ }^{39}$ Thus, we could say that the establishment of the Association of Graduates of the Muslim Seminary in Dobrudja was a first step in concretizing the approaches of the Emel group. The Association laid the intellectual foundations of the movement that Emel magazine tried to promote. Later, an elite capable of coordinating the group's activities consisted of members of the Association of Graduates of the Muslim Seminary in Dobrudja. Between 1933 and 1934, with the creation of Dobruca Türk Hars Birliği, an attempt was made to reach a large part of the population.

The affinity between the Association of Graduates of the Muslim Seminary in Dobrudja and the Emel group materialized in lobbying activities. They aimed to support certain people in the leadership positions of the representative institutions of the Muslim community. As the most important position in the organization of Islam in Romania was that of the mufti, the Association tried to control this position. An example of its influence was the 1938 crisis surrounding the election of the Mufti of Constanța. There were two main candidates: Mustafa Amet and Regep Begali. Both were graduates of the Muslim Seminary, thus having the right to run. Amet was, however, a member of the Association of Graduates of the Muslim Seminary in Dobrudja, being its first secretary, ${ }^{40}$

\footnotetext{
35 Ülküsal 1999, 240.

36 Ülküsal 1999, 181-184.

37 Ülküsal 1999, 147-148.

38 Ülküsal 1999, 240.

39 For an example, see Ülküsal 1999, 179.

${ }^{40}$ ANIC, MCA Fonds, File 125/1941, f. 69.
} 
and a member of the Emel group, publishing articles and poems in the Emel magazine. ${ }^{41}$ In order to support its candidate, the Association initiated an intense lobbying campaign with the central authorities. The president of the Association, Negip Hagi Fazâl, traveled to Bucharest to present a memorandum to the Prime Minister and the Minister of Cults and Arts. The memorandum stated that the appointed mufti should be 'neutral, who had won the sympathy and trust of Muslims,' and the election of the right person as a Mufti was a matter of respect, honor, and interest of Romania. ${ }^{42}$ Finally, Mustafa Amet was named Mufti of the Constanța County. ${ }^{43}$

Lobbying activities were significant in the context of no clear rules for electing/ appointing the mufti. The Minister of Cults and Arts appointed the mufties. One of the main grievances of the Muslim community was the lack of a law regulating the way its representative institutions should have functioned. Several congresses of Muslims in Romania were held, and various forms of regulatory acts were proposed. The Romanian authorities accepted none of them even though the Law for the General Regime of Cults of 1928 stipulated that regulation of Islam had to be established. ${ }^{44}$ Thus, the appointment of the Muslim religious leader depended on the political will: the naming of the mufties depended on the Government's political orientation. Because of this, associations that had a great influence on both the population and the authorities were significant. As the imams and Turkish language teachers were the most important opinion leaders of the Turkish and Tatar community, their Association could play a decisive role in choosing the mufti.

The Association of Graduates of the Muslim Seminary in Dobrudja was also involved in election community representatives at the central level. The opportunity in this regard arose in the context of the regime of King Carol II. The promulgation of a new Constitution in 1938 and the creation of the National Renaissance Front as the single party blocked the possibilities of the other parties to run in the parliamentary elections. Thus, the Turks and Tatars in Romania, who had representatives in all the legislatures after 1918, faced the perspective of not having a representative in the Romanian Parliament. ${ }^{45}$ The Association of Graduates of the Muslim Seminary in Dobrudja decided to promote their nominee to avoid this. Thus, they initiated a series of actions to obtain the support of Nicolae Ottescu, the royal governor (in Romanian, rezident regal) of Ținutul Mării, for a candidate of the Turkish and Tatar community. ${ }^{46}$ The initiative was successful, as Selim Abdulachim was elected to the Superior Council of the National Renaissance Front. ${ }^{47}$ Selim Abdulachim was not a random choice. He was a well-known personality both among the Muslim community and in Romanian society. He distinguished himself as the first Tatar lawyer in Romania. He was a veteran of the Romanian army in the First World War and an experienced politician being elected as deputy mayor of Constanța and parliamentarian. Ülküsal shows that 'he was the most suitable and deserving... Selim Bey knew Romanian very well. He had many

\footnotetext{
${ }^{41}$ Ülküsal 1999, 216.

42 Ülküsal 1999, 215.

43 Ülküsal 1999, 240-241.

44 Omer 2020, 129.

45 Omer 2020, 110-115.

46 Ülküsal 1999, 246-247.

47 Halk 1939, 1-3.
} 
Romanian friends. ${ }^{38}$ Also, as it appears from his activity, Selim Abdulachim supported the ideas promoted by the Association of Graduates of the Muslim Seminary in Dobrudja and the Emel group.

To ensure the success of their action, Abdulachim's supporters needed to secure the support of the royal governor and the votes of the community. For this, first of all, they carried out a work of persuasion with the Muslim community leaders. Thus, they met with the Baș-mufti Etem Curt Mola, teachers of the Muslim Seminary, lawyers, and doctors. ${ }^{49}$ Secondly, to persuade the Muslim voters to go to the polls and vote for their candidate, they organized an event to which they invited both Turkish and Tatar community personalities and prominent members of Dobrudjas political and cultural life. The participants' speeches, all full of appreciation for Abdulachim's work, were published in a bilingual, Romanian-Turkish newspaper (published in the Ottoman Turkish alphabet), of the community, on June 1 , the election day. ${ }^{50}$ All these efforts were successful, Selim Abdulachim being elected deputy in the third category of candidates 'Intellectual Occupations' with 3,225 votes. ${ }^{51}$

The Association of Graduates of the Muslim Seminary in Dobrudja's roles were not only of political nature. The Association also played a role in solving problems related to the Muslim community in general, especially to clergy's situation. The founders initially wanted to give the Association more power. Thus, in the first version of the statute, they wanted the Association to have the possibility of creating a bank..$^{52}$ The explanation lies in the fact that the Muslim Seminary constantly had financial problems. Its management tried to obtain the support of the authorities and donations from the community to preserve the Seminary's building or to grant scholarships to the students. ${ }^{53}$ In this sense, the attempt to set up a bank can be interpreted to help solve these financial problems. The Ministry of Cults and Arts objected to this provision from the statute of the Association. Consequently, the final version of the memorandum did not include it. ${ }^{54}$

There were also other attempts to create a bank to solve the financial problems facing the Muslim community in Romania. For example, a bank opened in Bazargic aimed to help those who emigrated by taking over their properties. ${ }^{55}$

Another concern of the Association was the improvement of the education provided to the students of the Muslim Seminary. In this sense, the Association was interested in the good training of the teachers who taught at this institution. The problem also concerned the Romanian authorities. Given the fact that the Muslim Seminary was a unique institution in Romania, providing staff that could teach specific subjects (interpretation of the Quran, history of Islam, Islamic jurisprudence, etc.), their endeavor posed a real challenge. Therefore, either capable students could become teachers or scholarships to prestigious universities in the Islamic world were to be awarded to those interested in

\footnotetext{
48 Ülküsal 1999, 243-244.

49 Ülküsal 1999, 245.

${ }^{50}$ Halk 1939.

${ }^{51}$ Monitorul Oficial 1939, 20-22.

${ }^{52}$ ANIC, MCA Fonds, File 125/1941, f. 74.

${ }^{53}$ Omer 2016, 158-159.

${ }^{54}$ ANIC, MCA Fonds, File 125/1941, f. 74.

55 SJI AN, BPL Fonds, File 31/1934.
} 
following a teaching career. ${ }^{56}$ Also, moral attitude of the teachers interested the members of the Association of Graduates of the Muslim Seminary in Dobrudja. For example, they demanded the dismissal of a teacher because he clives in concubinage with a Romanian woman, eats pork, things forbidden by Islam. ${ }^{57}$

The Association of Graduates of the Muslim Seminary in Dobrudja also solved some problems faced by the Islamic clergy. Before the Second World War outbreak, the president of the Association of Graduates of the Muslim Seminary in Dobrudja, Mehmet Vani, sent an address to Bishop Nicolae Colan, Minister of Cults and Arts of Romania, on 5 January 1939. In this document, he asked the Ministry to take into consideration the diplomas issued by the Muslim Seminary so that the religious personnel (imans) could enjoy the status as reservist clergy in the same way as the Orthodox priests: 'As graduates of a state seminary where we were educated under the influence of the Romanian culture and civilization and as some of us understood our mission to instill a sense of closeness and trust in the Muslim population towards the Romanian majority, we believe that we are entitled to demand our equality with the Orthodox priests on military obligations. ${ }^{58}$

This request did not receive a favorable response. Thus, at the general meeting of the Association held on 3 September 1939, the issue was re-discussed. ${ }^{59}$ This time, following the request of the members of the Association, on 16 September 1939, Etem Curt Mola, Baș-Mufti of the Muslims in Romania, also addressed Nicolae Zigre, the Minister of Cults and Arts in Romania. Curt Mola requested that the provision about the transfer of the graduates of the Muslim Seminary in Medgidia into the category of reservist clergy after reaching the age of 27 was to be made known to Recruitment Offices in Tulcea, Constanța, Caliacra, and Durostor counties. Curt Mola's intervention aimed to prevent the graduates from entering the recruitment centers to clarify their military status. He pointed out that, 'Muslim Seminary graduates, in most cases, lacked ways and means to travel; in addition, these trips forced these servants, many of whom are hatips and imams, to be absent for many days and weeks from the religious service. ${ }^{60}$ Since there were no other initiatives on this issue, most likely, the problem was solved.

\section{Conclusions}

The activity of the Association ceased due to the political changes in Romania. The logic of the new regime did not allow the functioning of associations that did not promote the official policy. Moreover, after the establishment of the communist regime in 1948, most of the members of the Association were arrested.

The Association of Graduates of the Muslim Seminary in Dobrudja was important due to the status of its members. They were the imams and Turkish language teachers of the Turkish and Tatar community, graduates of the only Islamic higher education institution recognized by the Romanian state. In other words, its members were people with influence in the community, but who, at the same time, knew the Romanian society. This position

\footnotetext{
56 ANIC, MCA Fonds, File 2372/1911, f. 5.

57 Ülküsal 1999, 255.

${ }^{58}$ ANIC, MCA Fonds, File 125/1941, f. 9.

59 ANIC, MCA Fonds, File 125/1941, f. 80.

${ }^{60}$ ANIC, MCA Fonds, File 125/1941, f. 79.
} 
allowed them to identify the problems facing the Muslim community and find ways to solve them.

Following its performed activities, this study proposes two keys to understand the role and the purpose of the Association of Graduates of the Muslim Seminary in Dobrudja. Firstly, one can notice a connection between the members of this Association and those gathered around the Emel magazine that also supported creating a Crimean Tatar state in Crimea. Most of the founders of the magazine were at the same time the ones who established the Association. They also had identical options in promoting people in positions within the Muslim community or central state apparatus.

Secondly, the Association of Graduates of the Muslim Seminary in Dobrudja aimed to address two issues: problems faced by imams and teachers of the Muslim community and the improvement of their education. In this sense, the Association strove to convince the Muslim leaders and central authorities to solve some bureaucratic issues and tried to form a teaching staff appropriate for the role of the Muslim Seminary.

\section{Bibliography}

\section{Primary Sources}

ANIC, MCA Fonds

SJI AN BPL Fonds

\section{Periodicals}

Halk 1939

Monitorul Oficial 1939

Monitorul Oficial 2008
Arhivele Naționale Istorice Centrale, Bucharest, Ministerul Cultelor și Artelor Fonds.

Serviciul Județean Ilfov al Arhivelor Naţionale, Bucharest, Banca Populară 'Lamura' - Bazargic Fonds.

Halk, 1 iunie 1939, nr. 4, Constanța.

Monitorul Oficial, Partea I-a, 6 June 1939, no 128 bis, Bucharest.

Monitorul Oficial, Partea I-a, 25 June 2008, no. 469, Bucharest.

\section{Encyclopedias, Censuses, and Reports}

Hamangiu 1935

Manuilă 1938

State Secretariat for Religious Affairs 2019

\section{Secondary Sources}

Aydin 2021

Cupcea 2015
C. Hamangiu, Codul General al României, vol. XXIII, București 1935.

S. Manuilă, Recensământul general al populației României din 29 decemvrie 1930, vol. VII (Profesiuni. Populația pe clase și grupe de profesiuni după sexe, vârstă, instrucție și neam; situația în profesie a activilor), București 1938.

State Secretariat for Religious Affairs, State and Religion in Romania, Litera, București, 2019.

F. T. Aydın, Émigré, Exile, Diaspora, and Transnational Movements of the Crimean Tatars. Preserving the Eternal Flame of Crimea, Palgrave Macmillan: Cham, CH 2021.

A. Cupcea, Tatar Nationalism and Communism: The Fate of the Fazıl Family (1948-1989). In: S. Preda, A. Cupcea, M. Dincă, M. Manuela (eds.), Cultural Heritage and Identity Dynamics in the Turkish-Tatar Community from Dobruja, Timișoara 2015, 120-137. 
Cupcea 2016

Gafar 2005

Karpat 2010

Karpat 2018

Marin 2016

Omer 2016

Omer 2020

Omer 2021

Popović 1986

Ülküsal 1987

\section{Memoires}

Ülküsal 1999
A. Cupcea, Dobruja's Muslim Community: From the Medgidia Muslim Seminary to the 'Kemal Atatürk' National College. In: A. Cupcea, M. Marin, M. Omer (eds.), Seminarul Musulman din Medgidia. Documente și Memorie/ The Muslim Seminary of Medgidia: Documents and Memory, Cluj-Napoca 2016, 211-247.

E. Gafar, Asociația Culturală Musulmană 'Selim Abdulachim.' In: M. Cojoc (ed.), Tătarii în istoria românilor, vol. 2, Constanța 2005, 175-184.

K. H. Karpat, Osmanlidan Günümüze Etnik Yapılanma ve Göçler, İstanbul 2010.

K. H. Karpat, Sarı Saltuk Diyarı Babadağ. Anıt Bir Türk Müslüman Kasabası Tarihi, İstanbul 2018.

M. Marin, The Muslim Seminary of Medgidia During Communism (1948-1967). In: A. Cupcea, M. Marin, M. Omer (eds.), Seminarul Musulman din Medgidia. Documente și Memorie/ The Muslim Seminary of Medgidia: Documents and Memory, Cluj-Napoca 2016, 175-210.

M. Omer, The History of the Medgidia Muslim Seminary (18891948). In: A. Cupcea, M. Marin, M. Omer (eds.), Seminarul Musulman din Medgidia. Documente și Memorie/ The Muslim Seminary of Medgidia: Documents and Memory, Cluj-Napoca 2016, 153-173.

M. Omer, Emigrarea turcilor și tătarilor din România în Turcia între cele două Războaie Mondiale, Târgoviște 2020.

M. Omer, From Allies to the Undesirable: The Refuge of the Crimean Tatars to Romania During World War Two. In: E. Plopeanu, G. Stelian Manea, M. Omer (eds.), The Empire. Between Dispute and Nostalgia, Berlin-Bern-Bruxelles 2021, 193-215.

A. Popović, Lislam balkanique: Les musulmans du sud-est européen dans la période post-ottomane, Wiesbaden 1986.

M. Ülküsal, Dobruca ve Türkler, Ankara 1987.

M. Ülküsal, Kırım Yolunda Bir Ömür. Hatıralar, Ankara 1999. 


\title{
ATENT,IE, PICASSO! BEWARE, PICASSO! THE STORY OF AN ARTIFACT IN THE COLLECTION OF THE NATIONAL MUSEUM OF TRANSYLVANIAN HISTORY
}

\author{
IOANA GRUIȚĂ-SAVU*
}

\begin{abstract}
The National Museum of Transylvanian History owns a graphic work signed by Pablo Picasso. The image represents a blue pigeon holding an olive branch in its beak. Iconographically, the Blue Dove is part of the series of graphic works made by the artist to promote the Peace Movement, born immediately after the Second World War. The purpose of this study is to reconstruct the history of this artifact. By contextualizing it, I aim to decipher the symbolism behind this image. Following its circulation, and establishing its provenance in the museum's collection, I aim to confirm its authenticity.
\end{abstract}

Keywords: Pablo Picasso, Blue Dove, graphic, museum collection, Cluj

Rezumat: Muzeul Naţional de Istorie a Transilvaniei deține în colecția sa o lucrare grafică semnată Pablo Picasso. Aceasta reprezintă un porumbel albastru care ține în cioc o ramură de măslin. Iconografic, Porumbelul albastru se încadrează în seria de lucrări realizată de artist pentru promovarea Mișcării pentru Pace, născută imediat după cel de Al Doilea Război Mondial. Scopul acestui studiu este acela de a reconstitui istoria acestui artefact. Prin contextualizarea sa, urmăresc să descifrez simbolismul din spatele acestei imagini. Urmărind circulația sa și stabilind proveniența sa în colecția muzeului doresc să-i confirm autenticitatea.

Cuvinte cheie: Pablo Picasso, Porumbelul Albastru, grafică, colecție muzeală, Cluj.

\section{Introduction}

Art can be dangerous, or at least not innocent. Artists have always been a subjective barometer of society. Their creations mirrored it aesthetically or in critical notes, they questioned it, being free to take sides, to change their minds, to play with notions, symbols, and ideologies. From a historical perspective, the analysis of artistic productions often reflects the subtle social, political, and even mentality changes. Concerning history, from the interrogations of art, new perspectives on the phenomena studied and researched by specialists in the historical field can be born. ${ }^{1}$

If one would ask you to name the most iconic image that comes to your mind when you hear the word PEACE, what would that image be? A dove with an olive branch in its beak would probably be amongst the first choices, and Pablo Picasso might be responsible, because after the Second World War he transformed this image into a symbol of the peace movement.

\footnotetext{
* Ph.D., Museum curator, National Museum of Transylvanian History, Cluj-Napoca, email: transylvania_is@yahoo.com; (D) https://orcid.org/0000-0002-2813-7231.

${ }^{1}$ Gruiță 2020.
} 
His doves carrying a peace message circulated all over the world but also stirred a lot of controversies. One of these doves flew to Cluj in MNIT collections and determined me to search for its story.

Without being a specialist in the subject of the Cold War, nor in the art of Pablo Picasso, in the following article, I aim at recovering the story of the museum artifact. By contextualizing the graphic artwork, I want to reveal the symbolism behind the image. By following its circulation and establishing its provenience in the National Museum of Transylvanian History collection, I aim at confirming its authenticity.

My inquiry about the history of this object began in 2016, while I was preparing a contemporary art exhibition in the context of the International Ceramic Biennial in Cluj-Napoca. The National Museum of Transylvanian History hosted several artistic events during the Biennale and wanted to use the opportunity to exhibit some of the rare objects in our collection. Some of these objects were not frequently on display; their narrative did not fit in any temporary exhibition organized by the museum in the last decade. It was also the case of the Picasso lithographic print or the mortuary mask of Lucian Blaga. We started a collaborative conceptual art project named Between Black and White in partnership with the visual artist Eva Andrea Szőcs, from Budapest and we built the exhibition concept based on the artistic communication between these interesting patrimonial objects and the contemporary artist that agreed to create new works inspired by our artifacts. She constructed her artworks as a dialog between old and new and reconverted the patrimonial objects and their artistic potential, shape, and significance from a contemporary perspective. Having in mind Fred Wilson's Mining the Museum ${ }^{2}$ project and how the context and the significance of each artifact are of great importance in the economy of an exhibition, I considered that at least minor research over the museum's artifacts was necessary.

The MNIT Collection, rich and eclectic, hosts different types of historical and artistic patrimonial objects: documents, photographs, textiles, ceramic, jewelry, rare books, maps, and also art. Most of the collected artifacts are relevant to Romanian, and to be more specific, to Transylvania's history, or they belonged to personalities of Cluj-Napoca. Every museum artifact comes with a personal narrative. In many cases, the story behind the object remains a matter of internal knowledge amongst museum specialists. When the objects are exhibited in temporary exhibitions or published in specialized catalogs, their story becomes accessible to the public.

I chose every exhibited artifact carefully, each dated from different historical periods: seventeenth century rococo painting representing a woman reading, nineteenth century photography representing a Transylvanian baroness posing as an angel, a twentieth century funerary mask of Lucian Blaga, a famous Romanian poet and diplomat, and, of course, the Picasso's Blue Dove lithography.

The artwork was always packed and well protected in the museum's storage rooms, and an extremely noticeable label attached to it: Atenţie, Picasso! Beware, Picasso! Many of our colleagues, working in the medieval or modern departments and not familiar with

${ }^{2}$ In the early 1990s, Fred Wilson worked with apparently innocent historical artifacts hosted by the Maryland Historical Society, re-contextualizing and changing their narrative. By accessing individual and collective memory, he changed the perspective of these artifacts and raised questions about the social and racial differences in American culture. For more about the subject, see Corrin 1993, 302-313. 
the contemporary collection, took it as a joke and always doubted that we have in our patrimony an original Picasso. As expected, the artifact generated numerous questions. Is it original? How does a Picasso work become part of a Transylvanian history collection? Was it purchased or donated? Who was the former owner? In one word: what is the story behind this work?

As far as I knew, the work hosted by the museum was never part of a scientific catalog and did not benefit from any analysis by a specialist in art history. To find the story behind the image and the context in which Picasso produced this artifact, I discovered several books and catalogs dedicated to his lithographic works in general. Amongst a series of posters dedicated to the Peace Movement, I found the image of the Blue Dove, as the upper part of a poster promoting the Congrès National du Mouvement de la Paix, held in Issy-Les-Moulineaux.

Fortunately, this quick investigation revealed that Picasso produced series of posters for numerous after-war Peace Congresses, starting with 1949, where he used the dove as a symbol for peace. One of the aims of this research is to trace a cultural and historical context for the Blue Dove, to understand the symbolic connotations of the work and the evolution of the image in the economy of Picasso's graphic. The most revealing volumes were the retrospective catalogs dedicated to his graphic works, both of them written by Miguel Orozco: Picasso lithographer and activist, Picasso Foundation, 2018, and Catalog raisonné of Picasso Posters, 2019. In these catalogs raisonné the author discusses each of the posters created for the Peace Movement, mentioning the technique, the print run, and the specific event promoted by these posters. Orozco identified cases when Picasso's drawings were printed separately and used for other purposes, and so I found the mention of the Blue Dove as an independent print run.

Picasso's doves, including the Blue Dove poster, were then analyzed by Hans-Martin Kaulbach in his complex art history paper: Picasso und die Friedenstaube, Georges Bloch - Jahrbuch der Kunstgeschichtlichen Seminars der Universität, Zürich, published in 1997, where he contextualized the works and revealed the symbolism behind the dove. The art history analysis is complex, presenting the evolution of the olive branch in association with the dove as symbols for peace. The study also investigates the impact of Picasso's works had on future posters dedicated to peace.

I built my research relying on other general studies written on the Peace Movement, on the border of history and history of art, analyzing the relation between Picasso, the communist party, and the peace movement in the context of the Cold War. There are several studies on the subject: Andrea Feeser's Ph.D. thesis, The Recuperated Radical: Pablo Picasso and the Debate on Art and Politics in France, 1942-1962, where the author discusses Picasso's relation with the communist party, Katarzyna Murawska-Muthesius, Modernism between Peace and Freedom: Picasso and Others at the Congress of Intellectuals in Wroclaw, 1948, Jonathan Harris, The Utopian Globalists, Artists of Worldwide Revolution 1919-2009, or Piotr Bernatowicz, Picasso behind the Iron Curtain: From the History of the Postwar Reception of Pablo Picasso in East-Central Europe, to mention a few.

Because the work in the museum collection was not a poster but the upper part of a poster, after finding out the context and the symbolism behind the image, I tried to find more about the technique and the print run, and how the work became part of our museum's 
collection. The inventory was not specific about who donated the artifact. Subsequently, I consulted the museum's archives for the donation act, and following the footsteps of former owners, I discovered how much of the legend about the work was accurate. To back up my suppositions and establish the originality of the work and its provenance, I consulted Constantin Daicoviciu and Raluca Ripan's biographies to match the information discovered in the archives.

The last part of my article deals with Picasso's Blue Dove as a museum artifact and follows its afterlife as part of the project Between Black and White. I end my research with the conclusions of this inquiry.

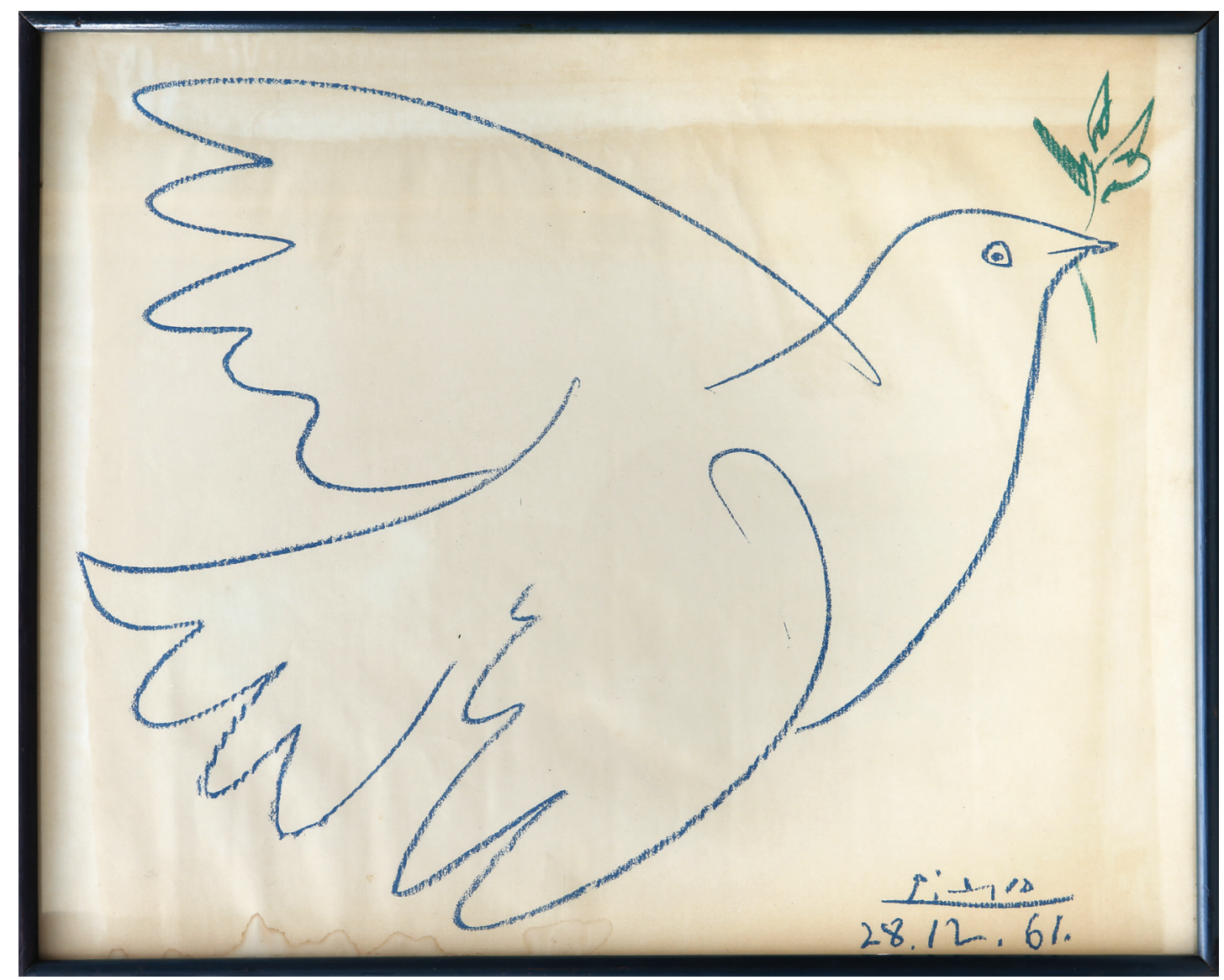

Fig. 1. Pablo Picasso, Blue Dove, lithography on paper, $63 \times 48 \mathrm{~cm}$ (Colecția MNIT, no. C 6502, photo by Alexandru Rădulescu).

\section{The Blue Dove - a dove of peace}

As Hans-Martin Kaulbach stated in his article Picasso und die Friedenstaube, there is hardly a symbol that can be recognized more quickly and generally understood worldwide than the dove of peace. ${ }^{3}$

To better understand the history of this work and decipher its meaning, it was necessary to find out the context in which it was created. After World War II, the world entered a new

\footnotetext{
${ }^{3}$ Kaulbach 1997, 165.
} 
conflict, the Cold War, and split into two blocks: the East and the West, Communism, and Democracy, two different ideologies. Preserving peace at all costs and protecting the world from a new (nuclear) war was the only common ground for worldwide nations to meet. They all agreed upon the necessity of working together for a world without mass destruction weaponries. At the same time, the general concept of peace received different interpretations depending on which side of the Cold War approached it:

Institutionalized by the two opposed bodies, the World Peace Movement, set up in the Silesian city of Wroclaw and controlled by Moscow, and the Congress for Cultural Freedom, established in Berlin and financed by Washington, the peace versus freedom opposition divided the world between the camps of Communism and Capitalism, accusing each other of 'decadent formalism and 'Socialist Realism kitsch' respectively. ${ }^{4}$

Maintaining peace and disarmament was a perfect propaganda territory for USSR, especially when western countries rejected the idea of renouncing their advantageous position, granted by their ownership of nuclear weapons. Socialism conflicted with capitalism, East against West, the Cold War was about to become the background for Picasso's works, and in this particular context, empowering his famous doves with a special symbolism.

The Blue Dove is part of an extensive series of lithographs created to promote the World Peace Congress, organized by the World Peace Council. The first campaign for peace started as the World Congress of Intellectuals in Defense of Peace, held in Wroclaw, Poland, in August 1948, and attended by hundreds of writers, artists, and scientists, representing 46 countries, a total of 600 participants. This major event created the context for the first attempt of the USSR 'to gather intellectuals and cultural figures from all over the world and forcing upon them a Soviet definition of peace after the war.'

Officially, the Polish communist Jerzy Borejsza initiated the Peace Congress; unofficially, the event happened with the approval of the USSR, whose aim was to influence the public opinion to see the communist powers as supporters of peace, and the Western countries, as a possible threat: 'The Congress was part of the Stalin-supported peace movement aimed at slowing down the development of the nuclear weaponry by the West at that time, USSR did not have nuclear weapons of its own.'

Even from the beginning, USSR intentions became transparent, especially after the anti-American opening speech by the Soviet delegation leader. A part of the invited personalities left the meetings as a sign of disapproval. ${ }^{7}$ The Peace Movement in Europe during the 1950s became a propagandistic machine, financially supported and manipulated by the USSR, and working on their behalf. ${ }^{8}$ Scientists and artists were caught between these political and ideological fights-some lured by the idea of a 'utopian globalist organization.'

\footnotetext{
${ }^{4}$ Murawska-Muthesius 2008, 34.

${ }^{5}$ Dobrenko 2016, 64.

${ }^{6}$ Dobrenko 2016, 65

${ }^{7}$ Dobrenko 2016, 65.

${ }^{8}$ Harris 2013, 120-121; Dobrenko 2016, 66.

9 Murawska-Muthesius 2008, 33.
} 
Picasso, and his friends Paul Eluard and Louis Aragon, joined the French Communist Party (PCF) in 1944. Picasso made public declarations explaining the reason for his joining the PCF: 'I became a communist because the communists are the bravest people in the Soviet Union and France and my own country,' ${ }^{10}$ 'I have become a Communist because our party strives more than any other to know and build a better world, to make men clearer thinkers, freer and happier.' ${ }^{\prime 1}$ After living with the menace of Nazism, communism seemed the best option for the ones wanting to rebuild a peaceful world. ${ }^{12} \mathrm{He}$ stayed a member until 1973, the year of his death, and his case was not singular. ${ }^{13}$

Picasso did not always agree with the communist policy, disapproving of some of the USSR's aggressive actions, and a good example was the invasion of Hungary in $1956 .{ }^{14}$ In an interview taken in 1957, when asked about communism, Picasso said that things looked bad in Hungary, and he recognized that he was wrong in the past, believing in Stalin's good intentions. Nonetheless, he remained a member of the PCF. ${ }^{15}$ On the other hand, he had numerous disputes with the communist party on esthetic grounds, seldom criticized by his PCF fellows for his works, which did not follow the Socialist Realism. ${ }^{16}$ Numerous studies discuss the ideological differences on the artistic field between Picasso's vision over art, his works representing 'Modern Art' by excellence, and the Communist Party's the imposed canon of Socialist Realism. ${ }^{17}$

The Communist Party tolerated Picasso's art because he was a famous artist but sometimes criticized it for being too modern, bourgeois, nonconformist, and individualist. ${ }^{18}$ Picasso did not generally fit in the communist paradigm, he represented the Western culture, and his creations contrasted with the campaign against formalism and modernism led by the communist countries. At the same time, Picasso made compromises and adapted his art to meet some of their requirements, and most of the works he did for the party were rendered in a naturalistic manner, with detailed feathering and creating the illusion of effortless flight.

In the Fifties, Picasso also made lithographs for illustrating the communist newspaper Le patriote (The Patriot) and other propaganda artworks, and portraits of several communist leaders. ${ }^{19}$ The non-idealized 1953 portrait of young Stalin, commissioned to Picasso by Les Lettres françaises for their commemorative number dedicated to Stalin's death, generated one of the most significant conflicts. Instead of representing Stalin in a manner close to his official photographic portraits, Picasso chose to render the Soviet leader in a naive style, triggering the most vehement critics on behalf of his comrades, and proving once more that 'he would not strictly adhere to the party's requirements for art.' ${ }^{20}$

\footnotetext{
${ }^{10}$ Bernatowicz 2016, 152.

11 Gaillard 1944, 1-2.

12 Patersen 2010, 749.

13 Keene 2017, 87.

${ }^{14}$ Harris 2013, 51.

15 Lake 1957, 9.

16 Orozco 2018, 8.

17 Reid 2015, 1-2.

18 Harris 2013, 63.

19 Freeser 1996, 47, 84.

${ }^{20}$ Freeser 1996, 94-99.
} 
When convenient, the French Communist Party transformed Picasso into an emblem for the Peace Movement and promoted his works when fitted the propaganda in their interest. His graphic works were printed in large editions, next to other allegorical peace images, and sold. A. Freeser noted that 'once the party determined that it could market itself through Picasso, it exploited this relationship in concrete, pecuniary terms...'21

As Bernatowicz observed, his works were not exhibited often behind the Iron Curtain, except the doves that were omnipresent, becoming a trademark for the peace movement controlled by the communists. ${ }^{22}$

Although he had episodes of creative loneliness, Pablo Picasso was a peace activist. He considered that his art could serve a greater purpose, so his creations frequently echoed his political allegiances or attitudes towards worldwide conflicts. ${ }^{23}$ During the Spanish Civil War, he conveyed his opinions in the famous painting Guernica, created for the Spanish Pavilion in 1937, fully reflecting his anti-fascist orientations and preoccupations for preserving democratic freedoms. ${ }^{24}$ In other paintings, he attacked sensitive subjects, taking a stand on behalf of the North Korean civilian victims, in his artwork Massacre in Korea, dating from 1951. It was a protest against American and UN armed intervention in Korea, but he never declared that his artwork was communist propaganda, neither that he considered himself as an anti-American. ${ }^{25}$ His composition was tributary to Goya's Third of May and Manet's At the Barricades, ${ }^{26}$ and the way he chose to express his attitude was to modernist for the communists. Still, the artwork became part of the communist propaganda, ${ }^{27}$ but it was not so appreciated by the party's publication. His panels War and Peace, created for Peace Temple in Vallauris dating from 1952, received the same treatment.

Returning to his attachment to the International Peace Movement, one can observe that Picasso was very active from the start. He created several graphic artworks for the promoting materials from 1949 to 1952, and starting from 1952 to 1962, designed the entire poster. ${ }^{28}$ The specific context of the Cold War empowered the image of the peace dove with a political significance. He was considered an artist of peace, and not necessarily associated with the URSS, until 1950 when he received the Lenin Prize for Peace, a prestigious Russian award granted for significant contributions to the peace cause.

The result was that his peace doves became symbols associated with the Communist Party and even with USSR. Relevant recorded situations dating from that period support this statement. For example, in 1956, when the British government opposed the Sheffield Peace Congress because of the Soviet attempt to control the event, Denis Healey ${ }^{29}$ when referring to Picasso's works used the expression 'Trojan dove' designating the dove as a symbol of subversion. ${ }^{30}$ One can notice a similar attitude in the statement: 'the bird walks

\footnotetext{
${ }^{21}$ Freeser 1996, 84-85.

22 Bernatowicz 2016, 159.

${ }^{23}$ Vallentin 1968, 336.

${ }^{24}$ Vallentin 1968, 338-346; Walther 2001, 67-70.

${ }_{25}$ Galluzzi 2009, 28; Harris 2013, 51. For more information about the painting, see Keene 2017.

26 Freeser 2016, 91.

27 Bernatowicz 2016, 159; Harris 2013, 131.

${ }^{28}$ Kaulbach 1997, 166.

${ }^{29}$ Healey was secretary of the British Labor Party and member of the Foreign Office.

${ }^{30}$ Deery 2002, 461, 463.
} 
like a bear' published in 1951 by Time Magazine, regarding the dove as a symbol for peace, but also a cover for Russia's propaganda or the dove always flies from East. ${ }^{31}$

His first work from this series was The Dove of Peace or La Colombe, ${ }^{32}$ which became worldwide famous and a universal symbol for peace. The drawing was not particularly for the event. His friend Louis Aragon found the lithography in Picasso's studio while searching for an emblem of the Peace Congress. This white pigeon, on a black background, ${ }^{33}$ was amongst the few realistic works that Picasso had at that point in his studio. Picasso had a history of drawing and painting pigeons even before 1949. The dove was a companion of his childhood, the artist's father, a painter himself, had the pigeon as a favorite theme in his works. ${ }^{34}$

The image became the poster for promoting The First Congress of Partisans for Peace (Congrès Mondial des Partisans de la Paix) that happened in April 1949, in the Great Hall of Pleyel in Paris, ${ }^{35}$ and rapidly became a well-known symbol of the Peace Movement. ${ }^{36}$ Picasso attended the 1949 Congress when his daughter was born, and he named her Paloma (dove in Spanish), thus sealing his association with the dove. ${ }^{37}$

According to Tate specialists, $\mathrm{La}$ Colombe, printed in Fernand Mourlon's workshop in Paris, transferred on a zinc plate, was first published in a limited edition, on white cotton paper and printing ink, five artist proofs, and 50 prints signed and numbered. ${ }^{38}$ Subsequently, the work was printed for commercial use, reproduced in the poster promoting the Peace Exhibition (24 April-24 May 1949), and later reused for the $20^{\text {th }}$ anniversary of the Peace Movement in $1969 .{ }^{39}$ In this particular case, Picasso represented a single white dove as a symbol of purity and hope.

The image circulated and became accessible to millions; and ever since Picasso's doves were identified with the symbol of peace and became a leitmotiv for the posters promoting similar events in London (1950), Vienna (1952), Paris (1960), or Moscow (1962).

After such a brilliant public relations campaign, Picasso's Dove gained popularity, and 1950 became the moment when the French Communist Party realized that it could promote its image in association with Picasso's doves. His doves and other allegories of peace, created for various international events, were mass-produced, transferred to different objects (scarves, postcards, pottery, etc.), and promoted in communist publications as symbolic images for the peace movement. ${ }^{40}$

In 1950, for the Second World Congress of Partisans for Peace (Deuxième Congrès Mondial des Partisans de la Paix) held in London on 13-19 November, Picasso produced an image of a flying dove, which appeared on the official poster promoting the event. ${ }^{41}$

\footnotetext{
${ }^{31}$ Gregory 2010, 154.

32 For the reproduction, see Orozco 2019, 49, catalog no. 67.

33 Orozco 2019, 49, catalog no. 67 A.

${ }^{34}$ Podoksik 2010, 10.

35 Vallentin 1968, 412.

${ }^{36}$ Galluzzi 2009, 128; Orozco 201949.

37 Vallentin 1968, 412-414.

38 Botinelli 2004.

39 Orozco 2019, 50.

${ }^{40}$ Freeser 1996, 108.

${ }^{41}$ For the reproduction, see Orozco 2019, 52, catalog no.74.
} 
The artist made four models in pencil, wash drawing, and gouache on lithographic paper. After three rejected sketches, La Colombe en vol was finally transferred to a zinc plate and printed by Mourlot in a special edition, consisting of 5 proofs and 50 prints. Afterward, the poster was mass-produced printed in 5,000 more copies. ${ }^{42}$ Everyone familiar with Picasso's work can notice that the pigeons dating from 1949 and 1950 are executed in a naturalistic manner, recognizable and accessible.

In 1951 the book Le visage de la Paix, with poems by Paul Eluard, was published and illustrated with twenty-nine studies of the dove of peace made by Picasso to celebrate the $30^{\text {th }}$ anniversary of the French Communist Party. ${ }^{43}$ At this point, the connection between the dove and the olive branch appears in Picasso's works. ${ }^{44}$

La colombe volant, dated 10 October 1952 lithograph, crayon, brush, paper, gouache, transferred to stone are impressions made by Mourlot Frères Paris and used for promoting the Third World Congress of Partisans for Peace (Congrès mondial des peuples pour la paix), held in Vienna, 12-18 December $1952 .{ }^{45}$ One can notice a realistic way to represent the pigeons, but in this situation, the wings seem too small for the pigeon's body, thus obstructing the flight. ${ }^{46}$

For this event, Picasso prepared numerous composition studies. One of these is Colombe Volant (à l'Arc-en-Ciel), created in October 1952, among the other dove studies for the Viennese Congress, was rejected and reused much later, in May 1960, for the poster Paix Désarmement pour le Succès de la Conférence au Sommet Paris. ${ }^{47}$ Represented in frontal view, as Orozco observes, the dove resembles more to a heraldic eagle. ${ }^{48}$ Les mains liees I [Bound Hands I], a lithograph, crayon on zinc, printed by Mourlot Freres in 1952, was also made for the Viennese event and rejected, being considered too difficult to be understood. ${ }^{49}$ The same happened with a cubist work, a pigeon made of cropped elements, projected on a rainbow background, dated 1952, and printed only in $1960 .^{50}$

Picasso's creations didn't always fit the taste and expectations of the French Party, some of his graphic artworks were rejected and reused for other events or artistic exhibitions, but in other cases, his images were perfectly adequate to the communist propaganda. One good example is the work made in April 1961, a dove to celebrate the USSR's first manned-rocket probe, which was, in fact, a powerful symbol, used in the competition for the conquest of space, and fueled the rivalry between the two great superpowers, the United States and the USSR, during The Cold War. ${ }^{51}$

In July 1962, for the World Congress for General Disarmament and Peace held in Moscow, Picasso made a dove with an olive branch in his beak, nesting over a pile of missiles, with a gigantic yellow sun dominating the back scene. ${ }^{52}$ Several months later, in

\footnotetext{
42 Orozco 2019, 53, catalog no. 74 A.

43 Orozco 2018, 256.

44 Kaulbach 1997, p.183.

${ }^{45}$ For the reproduction, see Orozco 2019, 55, catalog no.80.

46 Orozco 2019, 55, catalog no. 80 A.

47 Orozco 2019, 165, catalog no. 333 A, 334.

48 Orozco 2018, 265.

49 Orozco 2019, 232, catalog no. 503 A.

50 Orozco 2019, 166, catalogue no. 335, 336.

51 Harris 2013, 143.

${ }^{52}$ For the reproduction, see Orozco 2019, 194, catalog no.400.
} 
October 1962, the tension between the two superpowers reached the highest pick with the Cuban Missile Crisis, when the world came close to a nuclear conflict, and, used in this context, Picasso's work was most relevant. ${ }^{53}$ In 1962, Picasso received for the second time the Lenin Prize for Peace..$^{54}$

Another peace dove, similar to the Blue Dove, is the lithograph La Colombe Bleue volant devant les bareaux [Blue Dove Flying over the Bars], ${ }^{55}$ used in the posters promoting the National Comity for Helping the Victims of Franquisme, dated $1959 .{ }^{56}$ The poster was supporting a campaign for the amnesty of political prisoners by the Franco regime. Picasso conceived a symbolic artwork showing a dove flying in front of a prisoner behind bars, later used by Picasso for several different events bearing the same message. In this case, his dove is minimalist, almost like an icon or a brand image, already canonized.

Up to this point, my purpose was to offer a background context for Blue Dove. Following a chronological approach, I selected and presented some of the works created by Picasso, illustrating the evolution of this iconic symbol. What I could conclude is that more than a decade Picasso created numerous versions of the Peace Dove, starting with a naturalistic representation of the dove, where one could see the feathers and the anatomy of the pigeon, without the olive branch, and ending with a simplified and essentialized version, merely a contour of the bird carrying the olive branch in its beak.

In my opinion, Picasso managed to capture a big idea with a simple image, and with the Blue Dove, he abstracted it to the maximum, turning it into an icon. I believe it is not a coincidence that for the exhibition Picasso: Peace and Freedom, organized by Tate Liverpool in 2010, the reproduction after the Blue Dove became the image of the event's poster, and the same image was used for all the promoting materials and the front cover of the catalog. ${ }^{57}$ I found the same conclusion in Kaulbach study about Picasso and Peace Doves, where he states that in this version of the dove, used in the poster promoting the Issy-les-Moulineaux event, he reduced the graphic means of expression to the maximum, his pigeon is no longer just a bearer of the branch but became a symbol itself. ${ }^{58}$ The message was clear to decipher: the flight was a symbol of freedom, and the olive branch a symbol of hope. ${ }^{59}$

\section{The Blue Dove's journey to Cluj}

I reach the other part of my research that concerns the story behind the provenance of the artifact. When I first discovered the Picasso work hosted by the museum's collection, I also learned the myth of its provenience. The first natural question raised was where does this artifact come from?

One of the museum legends has it that the work was hanging on the wall in the directors' office. All senior museographers claimed that it was displayed since Constantin

\footnotetext{
${ }^{53}$ Harris 2013, 143.

${ }^{54}$ Podoksik 2010, 155.

${ }_{55}$ Orozco 2019, 147, catalog no. 293.

${ }^{56}$ Orozco 2019, 55, catalog no. 80 A.

${ }^{57}$ For more information about the exhibition 'Picasso: Peace and Freedom 2010.'

${ }^{58}$ Kaulbach 1997, 188.

${ }^{59}$ Kaulbach 1997, 188.
} 
Daicoviciu's ${ }^{60}$ directorship (between 1945 and 1973) ${ }^{61}$ and the work remained there during Hadrian Daicoviciu's time in office, between 1974 and 1984. This information, merely a local story among museographers, led to several hypotheses regarding how this work became part of the museum collection and could also answer the question of its originality.

The story was that Constantin Daicoviciu, a member of the Romanian Academy and Rector of 'Babeş-Bolyai' University, attended an international congress, conference, or official meeting where Picasso was also present. ${ }^{62}$ Everyone presumed that Daicoviciu received the artwork as a gift from Picasso, the story stating that during an international congress or conference, probably held in Moscow, Picasso sketched the dove right on the spot. The excellent quality of the print and the fact that Picasso signed on the plate could easily deceive a profane in graphic techniques.

Without knowing anything about Picasso's work, this story could have been somehow plausible. Picasso was indeed a member of the French Communist Party and attended numerous events organized by communists. He was a pacifist, and by creating images for promoting these types of cultural events, he supported the peace movement, as I tried to prove in the first part of my study.

At the same time, Constantin Daicoviciu was a well-known historian and academician, and he participated in numerous international events in the archaeology research field. He could have been a representative of the Romanian state in such an international event.

I followed this path to confirm or to dismiss the story. The first thing that caught my attention was that Picasso's lithography received inventory number C 6502. The Contemporary collection in our museum has a general fund, and all the inventoried objects receive the initial C. At the same time, there are several special collections, among which a separate fund with objects belonging to the Daicoviciu family, Constantin and Hadrian, father, and son. All the artifacts part of this fund received the initial C2. For me, this was the first sign that the information circulating in the museum might not be reliable. The object should bear the initial C2 instead of C., if belonging and donated by the Daicoviciu family.

I consulted the Daicoviciu archive, and indeed the preserved correspondence supports the hypothesis that C. Daicoviciu had numerous connections with specialists, historians, and archaeologists, from all over the world: Poland, Austria, Italy, France, Germany, USSR, United States, or Hungary. ${ }^{63}$ The study dedicated to his scientific and didactic activity, a doctoral thesis written by Mihaela Goman, dedicated a subchapter to his relationship with the international scientific world. In her research, she presents chronologically the most important congresses and conferences that Daicoviciu attended during his years as a professor of Archaeology, Antiquity, and Epigraphy, since 1938, and a rector of 'Babeş-Bolyai' University in Cluj-Napoca since 1956. ${ }^{64}$ In 1962, the author mentioned that C. Daicoviciu participated in September at the Fourth International Congress of Greek and

60 C. Daicovicu was a well-known archaeologist and rector of 'Babeș-Bolyai' University. For more information, see Comşa 2010; Goman 2011.

${ }^{61}$ Comşa 2010; Goman 2011, 107.

62 Ţene 2012.

${ }^{63}$ Gorman 2011, 101.

${ }^{64}$ Goman 2011, 81-105; Comşa 2010, 5. 
Latin Epigraphy, organized in Vienna. In September 1963, he attended the eighth edition of the International Congress of Classical Archaeology, held in Paris. ${ }^{65}$

None of the above-mentioned events are connected with the Peace Movement, nor to the numerous congresses for which Picasso designed the promoting posters. The author does not mention any international event organized in Moscow that Daicoviciu attended at the time. In D. Comşa's catalog, dedicated to Constantin and Hadrian Daicoviciu, she refers to several participations at international historian's congresses, among which Moscow. ${ }^{66}$ Indeed, in August 1970, the Thirteenth International Congress of Historical Sciences was held in Moscow. According to official documents, preserved by the National Archives, Constantin Daicoviciu, Ştefan Pascu, and Miron Constantinescu attended the 1970 Congress and the third edition of the International Congress of History of Science, held in August 1971, in Moscow. ${ }^{67}$

I can't establish a direct connection between any of these congresses and Picasso's lithography.

Another detail of the story determines me to reject the hypothesis that Daicoviciu received the lithograph in Moscow. The legend says that Picasso drew the dove as a gift for the participants, right on the spot. The aspect of the work can be deceiving, but it is clear that the artwork is a print, a handmade drawing reproduced in a lithographic or offset technique, making the story of the on-spot drawing pure speculation. After reading about Picasso's graphic works, I realized that his works were reproduced in large numbers and used and reused on multiple occasions by the peace organization. Therefore, I can't exclude the hypothesis that perhaps for the conferences in 1970, a cultural event, coinciding with the celebrations of Lenin's centenary, the organizers might have reprinted the poster with the Blue Dove as a symbol of international collaboration, but I find it less probable.

On the official inventory record, there was no information about the artifact's provenience. I had to continue my research in the museum's archives, reviewing all the donations documents. I came across a record that told a different story that I find more reliable, a donation deed, dated August 1992. Signed by Adriana Topârceanu, a former employee at the Office for National Cultural Heritage Cluj (Oficiul pentru patrimoniu cultural național Cluj), it attests that Mrs. Topârceanu hands over to MNIT an engraving entitled Peace Dove signed by Pablo Picasso, and dated in 1961.

The document also mentions that in 1978 the Chemistry Institute in Cluj-Napoca, represented by Professor V. Mercea, offered this work to MNIT, represented by Professor Hadrian Daicoviciu. In addition, the donation act states that the lithograph was received by Academician Raluca Ripan in 1962 when she was representing Romania at a Conference of Peace in Paris. The document also asserts that the artifact is one of the 2,000 copies printed by the conference organizers and given to each participant. The museographer mentioned that Raluca Ripan kept the work in her office, at the Chemistry University, without registering or declaring it. After Raluca Ripan deceased, Mr. Macrea donated the work to Hadrian Daicoviciu. The artifact did not become part of the museum's collection instantly. At first, the lithography decorated the Heritage Office without any official

\footnotetext{
${ }^{65}$ Goman 2011, 87-89.

${ }^{66}$ Comşa 2010, 6.

${ }^{67}$ Inventar ASSP, 5.
} 
registration document. The museographer decided to register the object in 1992, with the inventory number C 6502, to solve the ambiguous status of the work.

Following, I will try to see how much of the new version of the story fits reality, overlapping the information mentioned by the museographer thirty years later and what we know about the conferences, the promoting posters, and Raluca Ripan's international activity.

Raluca Ripan was a renowned chemist, a professor at Cluj's University, and the first woman accepted as a member of the Romanian Academy in $1948 .{ }^{68}$ Besides her academic and scientific career, she was a civic activist, constantly fighting for women's rights. In 1921 she was leading Cluj's Women associations, and from 1940 she was vice-president of The Association protecting the female students. She was also a member of The Group of Romanian Women (Gruparea Femeilor Române). ${ }^{69}$

In the book dedicated to her activity and published in 1966, an entire chapter discusses Raluca Ripan as a fighter for peace. The study mentions that Ripan attended numerous events dedicated to preserving peace. She participated in the World Peace Conferences, and the authors also name another participation in Vienna in 1952 and the one organized in Berlin in $1954 .^{70}$

Ripan, just like Fr. Joliot Curie, famous chemist and President of the World Council of Peace, publicly expressed her opinion against the war, affirming that scientific discoveries are not to be put into service of destruction. Unfortunately, the participation in the Congrès National du Mouvement de la Paix, held in Issy-Les-Moulineaux and dating 1962, is not mentioned in her resumé. The fact that the Blue Dove was made for the Paris Congress and was used in the promotion poster of the event only supports the indication of Mrs. Topârceanu. I find it most relevant that Mrs. Topârceanu dated Ripan's participation in the Congress in 1962, even if the work was signed in 1961, thus supporting the authenticity of the information she gives in the donation document.

Probably, Acad. Ripan attended the conference and, like other participants, received a copy especially printed for the event. The large number of copies specified in the donation document concurs with similar situations mentioned in the specialized literature about other lithographic series by Mourlot Studios after Picasso's drawings for similar events. I believe the lithography is not part of the limited edition or an artist proof, since the work has no additional signature nor a series number. Even if the donation document was drafted by Miss Topârceanu many years after the actual donation, I believe the information offered by the museographer is accurate and sustains the authenticity of the artifact and the story.

\section{Blue Dove - museum artifact}

The Blue Dove, part of the museum's collection, displays a dove, with a blue outline, represented in mid-flight, towards the right, with its wings outstretched, carrying a green olive branch in his beak. The Blue Dove is hand-signed in blue, directly on the plate, and dated lower right, 28 December 1961, next to Picasso's signature. The museum artifact

\footnotetext{
68 Drăgulescu 1966; Macarovici, Munteanu 1982; Clujeni 2000.

${ }^{69}$ Macarovici, Munteanu 1982, 81.

70 Omagiu 1966, 85.
} 
$(63 \times 48 \mathrm{~cm})$ is framed by a thin black wooden frame, without passe-partout, probably added in the sixties. A preliminary condition report shows that the artifact has never been restored, the paper displays the markings of improper storage and display before the work became a museum item: on the downside, there are some traces of previous water stains, and on the surface, there are some traces of discoloration, foxing, and darkening due to prolonged exposure to natural light.

I started the research presuming that the lithography is probably part of a series printed in March 1962 for the Congrès National du Mouvement de la Paix, held in Issy-Les-Moulineaux, organized close to Paris, and probably it was a gift for the participants attending the event. The same image of the Blue Dove, with additional text, was part of the poster advertising the event. ${ }^{71}$ Picasso created the entire concept for the poster, the image, and the text. Miguel Orozco's book, dedicated to Picasso's posters, a catalog raisonné, mentions the promoting materials, photolithography with the Blue Dove, a print-run of 4,000 or even 8,000 . At the same time, he discusses some impressions only with dove, i.e., the upper part of the poster, circulate on the art market, some of them signed in pencil above the stone signature and numbered out of 250 . The author also mentions that the originality of these posters is questionable. Also, he stated that the same plate was reprinted in large series in the 1990s and 2000s. ${ }^{72}$

This situation is not unique in the case of Picasso's lithographs. In some cases, Picasso's drawings were printed separately from the posters, in lower numbers, and sold as independent works. One of the examples is the crayon on zinc lithography Les Mains liées I, previously mentioned, dated 1952. The graphic work was submitted for the Viennese conference and rejected. Finally, Mourlot Freres printed it in just five artist proofs and 50 copies, numbered and signed, and sold as an independent work. ${ }^{73}$ The work Colombe volant (à l'Arc-en-Ciel), created in October 1952, was published in 200 copies as an independent work, with an additional signature, to raise funds. The same image was reused much later for the poster with the title Paix Désarmement pour le Succès de la Conférence au Sommet Paris, held in Paris, May $1960 .^{74}$

Picasso printed his works in the atelier of Fernand Mourlot, a master lithographer that also worked with Chagall, Miró, Braque, Dubuffet, Léger, Giacometti, and numerous other artists, being famous for the quality of his reproductions. Picasso met Mourlot in 1945 and, for many years, he used his studio for his printmaking. ${ }^{75}$ Before 1930 Picasso had few experiences with lithography, he created the first drawings with lithographic pencil directly on the stone around $1928 .{ }^{76} \mathrm{He}$ paused using the technique until 1945 when, at the urging of Fernand Mourlot, Picasso began to do his work directly on the stone. ${ }^{77}$ Between 1945 and 1969, Picasso worked with Mourlot Studios to create over 400 lithographic images. He experimented with lithography and other printmaking techniques, pushing the boundaries

\footnotetext{
${ }^{71}$ Orozco 2019, 55, catalog no.80.

72 Orozco 2019, 198.

73 Orozco 2019, 232, catalogue no. 503 A; Orozco 2018, 265.

${ }^{74}$ Orozco 2019, 165, cat. no. 333A, 334.

75 Walther 2001, 64.

76 Orozco 2018, 30-31.

77 Powel 1954, 22-24.
} 
of the medium, producing a large number of black and white, but also poly-chromatic, prints and posters for exhibitions and magazine illustrations. ${ }^{78}$

Lithography is a printing technique that consists of the artist drawing their design on a lithographic limestone or metal plate with fat pigment or wax. An acid and gum Arabic solution which 'etches' the non-greased part of the design applies to the stone. Then, an oil-based ink used directly to the stone allows only the greasy part to pick up the ink and then print it on the material. ${ }^{79}$ Picasso did most of his drawing on the stone and, only in some cases, on a zinc plate or lithographic paper. Most of the time, five artists' proofs and 50 more copies were printed, numbered, and signed by the author. Then, sometimes even 5,000 or 8,000 offset prints were published for commercial use.

The dove integrated into the poster entirely created by Picasso, associated with his handwriting announcing the place and the date for the event, but I presume that there were independent prints just with the image of the dove, probably printed to be sold or as gifts for the participants. A quick search over the internet reveals that lithographies, just with the Blue Dove, are selling in contemporary auction houses. Some of the sold copies are additionally signed in pencil, numbered from an edition of 200 copies, and dated 1962..$^{80}$ I also found auction houses that sell prints of the Blue Dove, signed and dated on the plate, and numbered in graphic pencil, as part of a printed edition of 1,000 copies, without a counter signature, and reproduced in $1983 .{ }^{81}$ The auction houses offer an authenticity certificate in both situations, thus supporting my assessment that there were prints with the upper part of the poster. None of the two cases match our museum artifact. The work hosted by the museum does not have the pencil signature nor a numbered printing edition.

Based on the material gathered up to this point, I argue that the information offered by the museographer in the donation deed supports Blue Dove's authenticity and the fact that it pertains to the series printed for the 1962 Peace Congress. Probably it was given as a gift for the participants, and Raluca Ripan attended the event, as she mentioned.

Picasso was a famous artist, and his artworks are and were appreciated worldwide and in Romania as well. The Peace Dove was an iconic symbol, universally accepted and recognized. I reason it is, and it was a matter of prestige to have a Picasso hanging on the wall, and I'm inclined to believe that the Blue Dove decorated Raluca Ripan's and later in H. Daicoviciu's office or the Office for National Cultural Heritage. The aspect and the conservation state of the work support this hypothesis.

Still, without analyzing the paper and the pigment to compare the data with other similar already dated works, I can't precisely establish the edition of this series. I also consulted the museum restoration department regarding the possibility of removing the frame and analyzing the paper. To preserve the artifact's integrity, due to the lack of a specialist in graphic restoration, we decided not to remove the frame for the time being. For a specialized opinion and evaluation, I consulted Cristian Opriș, Ph.D. Associated Professor at Art and Designed University in Cluj-Napoca in the graphic department. Considering his expertise, I was hoping he could find clues regarding the type of reproduction implied for

\footnotetext{
${ }^{78}$ Lieberman 1952, 3-17; Gilmour 1987, 81-90.

79 Dicţionar de Artă 1995, 256.

80 'Picasso, La colombe bleue, 1961'/MFA.

81 'Picasso, La colombe bleue, signed hand, numbered 704/1000'/Worth Point.
} 
the artifact. Unfortunately, without removing the glass protecting the work, he could only confirm that it is very high-quality lithography, but he could not establish whether the reproduction was offset, or not.

\section{The afterlife of the Blue Dove}

The contextualization and supplementary discovered information were extremely useful for the contemporary exhibition that initiated this research. Andrea Szöcs created a new artwork, The Red Dove, exhibited to face Picasso's Blue Dove, and mirror the original lithography. The original dove was blue, a symbolic color for peace, and carried a green olive branch, a symbol of hope and renewal. The new dove, created from a contemporary perspective, was red, a color generally associated with aggression-the opposite of peaceand, in this particular case, associated with communism. The red dove de-conspired the USSR propaganda behind the Peace Movement. The green olive branch became ashes, slowly crumbling while the work was exhibited, suggesting that this hope for peace was ephemeral and ideal.

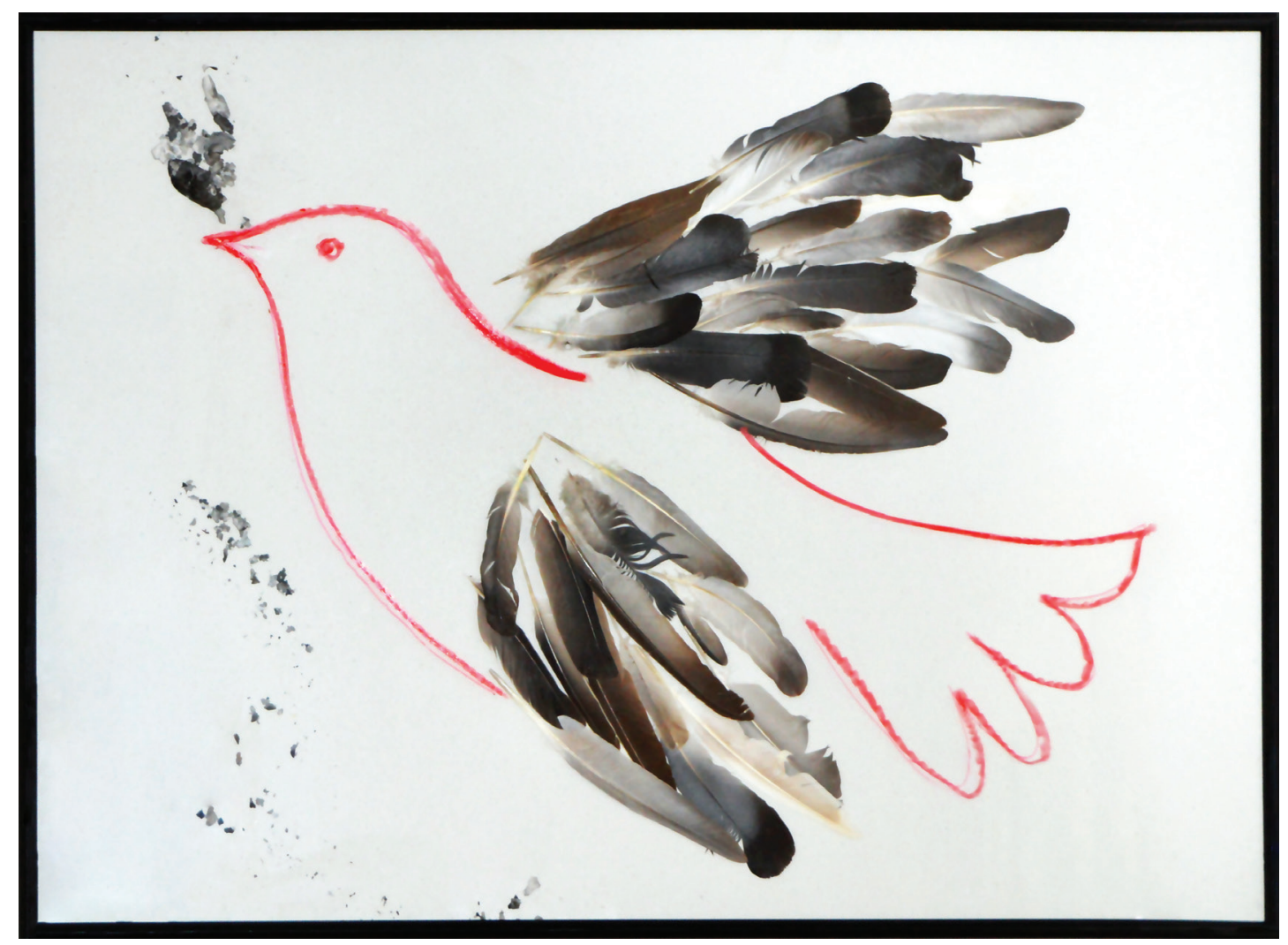

Fig. 2. Andrea Szőcs, Red Dove, red lipstick, pigeon feathers, paper, ash, $70 \times 50 \mathrm{~cm}$ (private collection of the artist; photo by Ioana Gruiţă, 2016).

Picasso's dove of peace was an abstraction, trying to encapsulate the wish for a peaceful world. Andrea Szöcs' dove had wings made of real feathers meant to remind of the reality behind this dove of peace, insinuating the actual nature of this symbol. Even if 
the feathers were genuine, they lost their purpose and are not facilitating the flight toward freedom. Blue Dove was a construct, the result of a long-lasting creative process, and became an enduring symbol; Andrea Szöcs drew her dove on the surface of the glass with red lipstick, thus unprotected, easy to remove, and somehow ephemeral. The use of lipstick gives another layer of interpretation-the lipstick is used on the lips, suggesting that the dove speaks, but some things remain unspoken.

Picasso's doves triggered controversy when first created, and they remained a subject of debate. Kaulbach mentions in his research paper that the Museum of Fine Art in Leipzig did not exhibit a single dove in the 1996 exhibition dedicated to Picasso's lithographies because the images played a significant role in the propaganda supported by the socialist states. ${ }^{82}$

\section{Conclusion}

Picasso's pigeons have been acknowledged as doves of peace for a long time during the Cold War, and they still are. Just as people tend to forget the atrocities and the consequences of war, probably a plausible reason why history has recorded a cyclical repetition of the events, so they tend to forget the symbolism behind once an iconic image. I exhibited Blue Dove at MNIT without much publicity. I wanted to initiate a small experiment, to test how many people recognize a Picasso and how many respond to a symbol that once provoked strong reactions. Without the guide's explanations, most of the visitors have not identified the artifact. Consequently, I assume that the subtle cultural reference, generated by the association of the two artworks, was even less frequently noticed by the public. It is up to art historians and museum curators to remind the audience through exhibitions, articles, and museum education programs how powerful these images are and how art can carry, willingly or not, a political, social, or civic message.
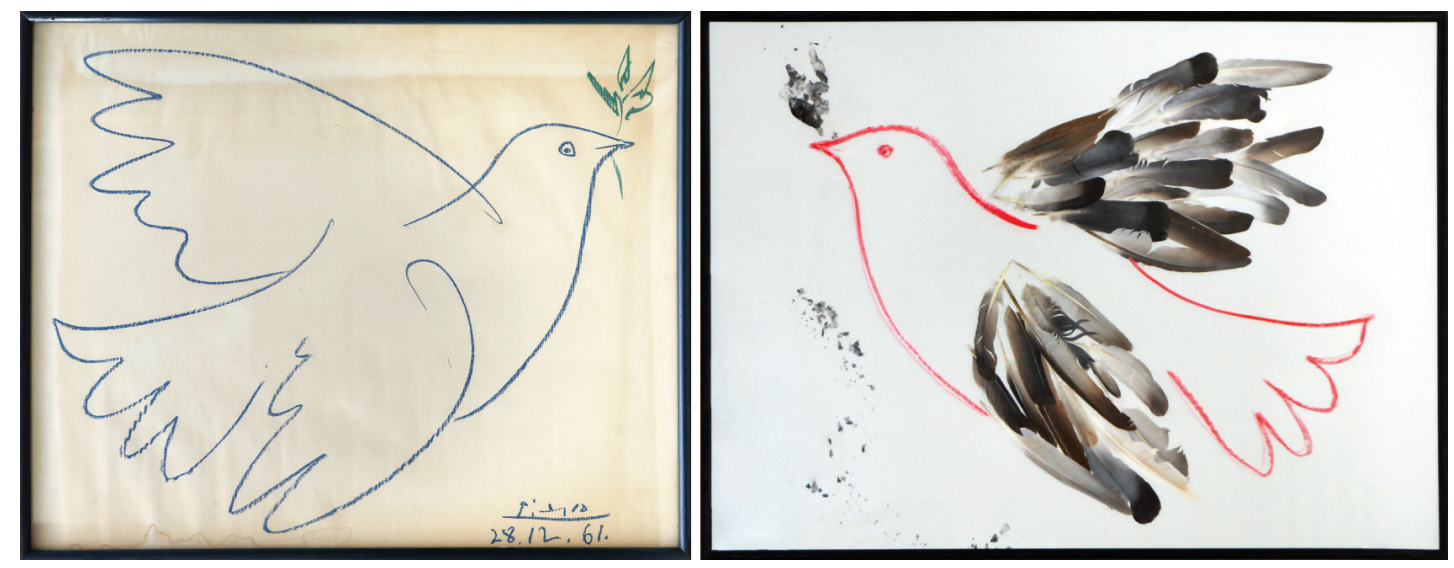

Fig. 3. Blue Dove, Red Dove, Between Black and White (photo by Ioana Gruiţă in the MNIT Archive, 2016).

I believe that my research managed to recover the narrative of the artifact, presenting the history, the evolution, and the reception of an iconic symbol. I consider I managed to reconstruct the line of owners of this artwork and its filiation. Now, I am more aware of

${ }^{82}$ Kaulbach 1997, 165. 
how the communist propaganda worked during Ceaușescu's regime, and I see differently the innocent drawings of all the peace doves that my generation drew during the art classes in the gymnasium. We didn't know we were giving a tribute to Picasso's peace doves. BEWARE, PICASSO!

\section{Bibliography}

\section{Catalogs}

Comşa 2010

D. Comşa, Constantin şi Hadrian Daicoviciu, Memoria Imaginilor, Cluj-Napoca 2010.

Orozco 2018

M. Orozco, Picasso lithographer and activist, Picasso Foundation, 2018, https://www.academia.edu/36544351/PICASSO_LITHOG RAPHER_AND_ACTIVIST, accessed 21 Jul. 2020.

Orozco 2019

M. Orozco, Catalog raisonné of Picasso Posters, 2019, https:// www.academia.edu/39165767/Catalogue_Raisonn\%C3\%A9_of_ Picasso_Posters, accessed 21 Jul. 2020.

Podoksik 2010

A. Podoksik, Pablo Picasso 1881-1973, Parkstone International 2010.

\section{Books}

Drăgulescu 1966

C. Drăgulescu, Omagiu Acad. Prof. Raluca Ripan, București 1966.

Galluzzi 2009

F. Galluzzi, Viața și Opera lui Picasso, București 2009.

Goman 2011

M. Goman, Activitatea didactică şi ştiinţifică a lui Constantin Daicoviciu, Oradea 2011.

Harris 2013

J. Harris, The Utopian Globalists, Artists of Worldwide Revolution 1919-2009, Oxford 2013.

Macarovici, Munteanu 1982

C-tin. Gh. Macarovici, G. Munteanu: Raluca Ripan, București 1982.

Penrose 1958

R. Penrose, Picasso His Life and Work, New York 1958.

Vallentin 1968

Walther 2001

A. Vallentin, Pablo Picasso, București 1968.

I. F. Walther, Picasso 1881-1973, Genius of the Century, New York 2001.

\section{Articles \& Studies}

Gilburd 2006

E. Gilburd, Picasso in Thaw Culture, Cahiers du Monde Russe, 47/1/2,(2006),65-108.https://doi.org/10.4000/monderusse.9592.

Gilmour 1987

P. Gilmour, Picasso and his printers, The Print Collector's Newsletter, 18/ 3 (1987), 81-90.

Deery 2002

$\mathrm{Ph}$. Deery, The Dove Flies East: Whitehall, Warsaw and the 1950 World Peace Congress, AJPH, 48/4 (2002), 449-468. https://doi. org/10.1111/1467-8497.00270.

Kaulbach 1997

H.-M. Kaulbach, Picasso und die Friedenstaube, Georges Bloch-Jahrbuch, 4 (1997), 165-197. 
Keene 2017

Lieberman 1952

Powel 1954

Reid 2015

Murawska-Muthesius 2008

\section{Archives and collections}

Inventar ASSP

Colecția MNIT + no.

\section{Dictionaries}

Clujeni 2000

Dicţionar de artă 1995

\section{Theses \& Disertations}

Dobrenko 2016

Feeser 1996

\section{Online resources}

Botinelli 2004

'Picasso, La colombe bleue,1961'/MFA
J. Keene, Framing Violence, Framing Victims: Picasso's Forgotten Painting of the Korean War, Cultural History 6/1 (2017), 80-101. https://doi: 10.3366/cult.2017.0136.

W. S. Lieberman, Picasso: His Graphic Art, The Bulletin of MoMa, 19 /2 (1952), 3-17. https://doi.org/10.2307/4058187.

M. Powell, Four Lithographs by Picasso, Bulletin of St. Louis, 39/4 (1954), 22-24.

S. E. Reid, Picasso, the Thaw and the 'New Realism' in Soviet Art. In: Colloque Revoir Picasso, Musée Picasso, Paris 2015, 1-4, http://revoirpicasso.fr/wp-content/uploads/2016/03/Revoir Picasso-2015_J2_S.E.Reid_.pdf, accessed 07 Jul. 2021.

K. Murawska-Muthesius, Modernism between Peace and Freedom: Picasso and Others at the Congress of Intellectuals in Wroclaw, 1948. In: D. Crowley, J. Pavitt (eds.), Cold War Modern: Design 1945-1970, London 2008, 33-41.

Inventar ASSP Fond Academia de Ştiinţe Sociale şi Politice, Secţia de Istorie şi Arheologie, Inventar. Anii: 1961; 1963-1972, http://arhivelenationale.ro/site/download/inventare/Academiade-Stiinte-Sociale-si-Politice.-Sectia-de-Istorie-si-Arheologie.1961-1963-1972.-Inv.-3325.pdf, accessed 07 Jul. 2020.

Colecția Muzeului Naţional de Istorie a Transilvaniei, Cluj-Napoca, Contemporană fond, C 6502.

Clujeni ai secolului 20. Dicţionar esenţial, Cluj-Napoca 2000.

Dicţionar de artă. Forme, tehnici, stiluri artistice, $A-M$, Bucureşti 1995.

V. Dobrenko, Conspiracy of peace: the cold war, the international peace movement, and the Soviet peace campaign, 1946-1956, Ph.D. thesis, The London School of Economics and Political Science (LSE), London 2016.

A. Feeser, The Recuperated Radical: Pablo Picasso and the Debate on art and Politics in France, 1942-1962, Ph.D. thesis, The City University of New-York, New York 1996.

G. Botinelli, 'Pablo Picasso, Dove, 1949', Tate (2004), https:// www.tate.org.uk/art/artworks/picasso-dove-p11366, accessed 27 Jun. 2020.

'Pablo Picasso, La colombe bleue (Blue Dove), 1961,' Masterworks. Fine Art Gallery, https://www.masterworks fineart.com/artists/ pablo-picasso/lithograph/la-colombe-bleue-blue-dove-1961-3/ id/w-5182, accessed 24 Aug. 2021. 
'Picasso, La colombe bleue 704/1000'/Worth Point

'Picasso: Peace and Freedom 2010'/Tate
'Pablo Picasso, La colombe bleue signed hand numbered 704/1000,' Worth Point, https://www.worthpoint.com/worthopedia/pablo-picasso-colombe-bleue-signed-1847662369, accessed 24 Aug. 2021.

'Picasso: Peace and Freedom 2010', Tate, https://www.tate.org.uk/ whats-on/tateliverpool/exhibition/picasso-peace-and-freedom, accessed 24 Aug. 2021. 


\title{
CULTURAL SURVEILLANCE IN COMMUNIST ROMANIA IN THE 1950S AND 1960S. REPRESSION, RE-EDUCATION, AND REINSERTION. THE CASE OF CONSTANTIN NOICA
}

\author{
ANDREI DĂLĂLĂU*
}

\begin{abstract}
The present study aims to analyze the relationship between the so-called 'bourgeois' intellectuals (socialized and educated in prestigious cultural groups in the interwar society) and the Romanian secret police, the Securitate, from three perspectives: repression, re-education, and social reinsertion. The main argument is that all three phases corresponded to Politburo's political approaches directly related to the evolution of internal or international political events of the late 1950s and early 1960s. The sources used are the Securitate files of the persons convicted in the 'Noica-Pillat trial' from 1960. The research method is qualitative analysis combining an institutional approach of the Securitate files with a case study. Consequently, the article focuses on the case of Constantin Noica, a prominent Romanian intellectual. He was sentenced to prison in 1960, pardoned in 1964, and later used by the regime in power service. The Securitate used Constantin Noica's friendship with Emil Cioran and Mircea Eliade to attract prestigious intellectuals back to Romania and enhance the nationalist orientation of the regime through philosophy.
\end{abstract}

Keywords: Constantin Noica, cultural surveillance, intellectuals, repression, show trials

Rezumat: Studiul de față își propune să analizeze relația dintre intelectualii „burghezi”, socializați și educați în grupuri culturale de prestigiu din perioada interbelică, și Securitatea, poliția politică din România comunistă. Studiul este realizat pe trei stadii de analiză: represiune, reeducare și reinserție socială. Argumentul principal susține că toate cele trei stadii corespund modalității prin care Biroul Politic a ales să acționeze în raport cu societatea, în legătură directă cu evoluțiile interne și externe de la sfârșitul anilor 1950 și începutul anilor 1960. Sursele utilizate sunt arhivele Securității, în special dosarele de urmărire informativă și cele din fondul penal ale persoanelor condamnate în procesul Noica-Pillat. Metoda de cercetare este cea a analizei calitative, combinând abordarea instituțională a dosarelor de arhivă cu studiul de caz. Studiul de caz tratează evoluția lui Constantin Noica, care a fost condamnat în 1960, grațiat în 1964 și ulterior folosit de regim în interesul puterii. Securitatea a instrumentalizat prietenia lui Constantin Noica cu Emil Cioran și Mircea Eliade pentru a-i atrage înapoi în România și pentru a susține orientarea naționalistă a regimului.

Cuvinte-cheie: Constantin Noica, intelectuali, procese-spectacol, represiune, supraveghere culturală

\section{Introduction}

With the establishment of the communist regime in Romania after 1945 and the founding of the Romanian secret police, the Securitate in 1948, communist authorities began the persecution of entire social categories: political opponents, resistance groups,

* Ph.D. Student, 'Babeș-Bolyai' University, Cluj-Napoca, Romania, email: andrei.dalalau@yahoo.com, D https://orcid.org/ 0000-0002-5741-6432. 
landowners, and chiaburi [kulaks], priests and intellectuals. The repression became part of the political, social, and economic system as the communist regime implemented the nationalization of industry and collectivization of agriculture. It also aimed to subordinate the whole political and cultural activity. The Communist Party placed literature, philosophy, history, art, theatre, music, and cinema under its ideological control to prevent the emergence of alternative group identities in a society that would eventually threaten the communist regime.

In the broader context of repression, the authorities targeted intellectuals for their uncertain position towards the newly established communist regime. Some of them supported the political transformation of the country, while others were thrown in prisons. The consensus among the researchers is that the communist regime in Romania was a deeply anti-intellectualist political order considering the frequent arrests based on fictitious 'hostile activities,' such as conspiring against the social order, reading a book, or attending literary meetings. ${ }^{1}$ Moreover, the communist authorities attributed imaginary blames to certain intellectuals for the simple fact of belonging to an undesirable social group with 'unhealthy origins.' By his/her very existence, the interwar or 'bourgeois' intellectual was a persona non grata in the new socialist order. The idea of a free thinker with the capacity for critical analysis was inherently subversive for the socialist order, as the new man was to be a submissive and obedient individual in the service of power. ${ }^{2}$

Considering their role in the legitimation of a political order, intellectuals were always 'symbolic instances of their social time." 3 Their support was motivated either by ideological sympathy or by material advantages, or both. These 'engaged' intellectuals supported the regime by writing according to the 'party line' and creating biased literature, philosophy, and art while posing as politically involved individuals. Highly prestigious intellectuals appeared on the lists of Grand National Assembly's deputies in March 1948, including Mihail Sadoveanu, Mihail Roller, Andrei Oțetea, Mihai Ralea, Traian Săvulescu, Ion Pas, Gala Galaction, Petre Constantinescu-Iași, and others. I.C. Parhon, professor of endocrinology, was appointed President of the Grand National Assembly Presidium. The position was, to some extent, the modern equivalent of the head of the state. In reality, the 'engaged' intellectuals had no real power as political control was exclusively in the hands of the Politburo's elites. ${ }^{4}$

While some intellectuals believed in the cause of communism or sought to obtain financial advantages by supporting the new political power, others had gradually shifted from hostility (or neutrality) to conformism to survive. They overcome marginalization by working in factories, earn low wages by performing unqualified work, or simply adapting their ideological message to the official 'party line.' Among them one can mention George Călinescu, Constantin Noica, Dinu Pillat, Ion Barbu, C. Rădulescu-Motru, Marietta Sadova, and others. The regime perceived with suspicion and distrust this particular category of intellectuals based on their past political sympathies. Thus, the Securitate kept them under surveillance due to their former compromising political allegiances.

\footnotetext{
1 Mareș 2009, 10.

2 Mareș 2005, 11.

3 Șandru 2015, 302.

${ }_{4}$ Boia 2021, 311.
} 
During the repression phase, the regime targeted some of these intellectuals through its political police. The Securitate put them under permanent surveillance while constantly receiving reports from its informers about their daily comments on various topics. During the surveillance process, the case officer would summarize all the reports obtained from the informers and reduce them to ideological clichés (spy, enemy, counter-revolutionary, saboteur) to obtain an incriminating conclusion. For this reason, any person targeted by the Securitate could easily be transformed into a class enemy.

The regime projected ideological representations on specific categories of people to justify its repressive actions against the 'undesirables' (the enemies of people). It later used ideology to 're-educate' and 'recover' intellectuals in the service of power. All these steps were taken under the permanent attention of the Securitate secret police and communist leaders.

The article aims to analyze three phases of cultural surveillance in communist Romania during the 1950s. The first phase is the repression of the 'bourgeois' intellectuals between 1958 and 1960. Its focus was on the so-called 'Noica-Pillat trial', when 23 persons were sentenced to prison for reading foreign literature. The second period is Constantin Noica's re-education process, a highly important cultural figure in Romania, during his imprisonment from 1960 to 1964 . Lastly, the third phase considers the social and cultural reinsertion of Noica after his release from political detention. This last part also deals with the subsequent attitude of the regime towards the cultural contribution that a 'bourgeois' intellectual could have had in the construction of the new national orientation of Nicolae Ceausescu's regime. On the one hand, we will focus our analysis on how the attitude of the communist regime towards a persecuted social group (in this case, the convicted intellectuals of 1960) gradually evolved during the 1950s and 1960s from repression to collaboration. On the other hand, the article addresses the social status of specific cultural figures, presenting both the need for survival and the need for 'collaborating' with the Securitate to be published and remunerated.

Moreover, the article does not aim to address the moral issue of collaborating with the Securitate. ${ }^{5}$ It also did not aim to establish whether Noica was a supporter or a dissident of the communist regime, nor to support one group or another in the 'battle for Noica' as a contest for representativeness.

The 'Noica problem' is far too vast and nuanced to be treated exhaustively in this study. The article aims to analyze the evolution of an intellectual's behavior and establish under what conditions his perception towards the communist regime shifted during a tumultuous political decade. In the 1960s, the communist authorities in Bucharest gradually changed their attitude towards different groups in society. The change created various forms of collaboration as the 'old guard' of intellectuals understood that communism would not collapse and that they had to integrate into the system. As a result, intellectuals responded by gradually taking steps to support the national policy adopted by the Communist Party after 1964, as compromise was part of cultural survival.

\footnotetext{
${ }^{5}$ The controversy surrounding Constantin Noica's collaboration with the Securitate was analyzed in Gabriel Andreescu 2013.

${ }^{6}$ Verdery 1991, 266.
} 
From a methodological point of view, the article uses qualitative analysis. It combines a case study approach with an institutional and social analysis coming from the interpretation of the Securitate archival documents. While the three phases (repression, re-education, and reinsertion) are not explicitly mentioned in the Securitate file, they can be distinguished by reading Constantin Noica's files through the lens of a repressive institution concerned with maintaining social and cultural control by all means. While physical repression was possible in the early 1960s, the communist regime eased its coercive methods in the mid and late 60 s as the result of political changes and international treaties. Considering that all three phases were variations of power-shifting relations inside the Politburo, the Securitate's main purpose was to control social groups either through repressive or persuasive means. ${ }^{7}$

The climate of suspicion, fear, and control created by the Securitate in the 1950s favored denouncement between friends, neighbors, or strangers. The Securitate developed networks of informers whose mission was to provide information about the so-called 'hostile' individuals. The informers were divided into qualified, unskilled ('collaborators' or 'support people') and residents ('hosts', who made their home available to the Security in certain situations). ${ }^{8}$ All categories of informants were used to monitor the suspected intellectuals. The present case study considers the Securitate archives and several works dealing with the Securitate as an agent of repression and surveillance in the service of the Communist Party. Through a close reading of the Securitate files, the analysis tries to find the answer to the purpose of the intellectuals' secret surveillance files. ${ }^{9}$ The files included information provided by institutions, agents, friends, informants, and testimonies of several witnesses or cellmates during the imprisonment.

In order to answer this, I chose the file of Constantin Noica as he is considered one of the most influential philosophers in recent Romanian history, and his ambiguous stance towards communism sparked intense debates in the public space. Also, I chose to analyze Noica's activity. He was the only intellectual from the 'Noica-Pillat trial' who gained popularity even during the communist regime, not only after its collapse in 1989. Consequently, his files reflected the perpetual reconstruction of his image in the eyes of the Securitate agents and high-ranking communist officials, alongside his role in accomplishing the purposes of the regime.

The first section presents an overview of the political context between 1956 and 1960. In this specific period, the 'remaining intellectuals' (who were not convicted in the first wave of repression between 1948-1953) were put under surveillance, persecuted, and sentenced to prison after being convicted in show trials. The case study reflects the repressive methods used for silencing an 'idealistic and reactionary' philosopher. The second section deals with the re-education used by the Securitate tried to introduce Marxist ideas in Constantin Noica's philosophical thought. The third section analyzes a former political prisoner's social and professional reintegration, including the conditions under which Noica could get a job and publish philosophy works following the 'party line.' This section also highlights how the communist regime tried to use Noica's symbolic capital to convince the exiled intellectuals in France that cultural freedom was granted in Romania after 1964.

\footnotetext{
7 Preda 2021, 7.

${ }^{8}$ Oprea 2008, 80.

9 Preda 2021, 3.
} 


\section{The political context of the late repression}

In 1956, the Romanian Communist Party (whose name was the Romanian Workers' Party between 1954 and 1965) went through a political shock during the Hungarian Revolution in November 1956. The uprising was perceived as a direct threat to the hegemonic power of the ruling Party in Romania ${ }^{10}$ and also a challenge to the Soviet dominance in Central-Eastern Europe. The initiators of the Hungarian uprising were the intellectuals, the students, and the journalists who met to discuss and examine the problems Hungary was facing. They managed to gather political and popular support and form an opposition party. The Romanian communists, led by first secretary Gheorghe Gheorghiu-Dej, feared that similar actions could occur in Romania and its internal and external competitors would endanger his political power. As Vladimir Tismăneanu observed, Gheorghiu-Dej learned that the hegemonic status of the Communist Party in the Romanian society was highly dependent on repression-starting from political rivals to intellectuals or other powerless social categories. As a result, Dej destroyed the credibility of the opposing faction in the Party and blocked any liberalization initiative. ${ }^{11}$ In 1956, Gheorghiu-Dej supported the Soviet military intervention in Hungary and remained devoted to Kremlin. Consequently, the Red Army withdrew from Romania in 1958, consolidating the political power of the Romanian communist leadership. Shortly after the Soviet army withdrawal, Dej began a persecution campaign against the intellectuals to strengthen the Party's leading role in society. ${ }^{12}$

The general repression of the opposition - real or imagined - translated itself into new abusive measures. In 1956, The Securitate forces were supplemented with 2,059 officers and 429 men, despite the lack of large-scale arrests that year. ${ }^{13}$ In 1958, Politburo launched a large-scale repression campaign. It aimed to punish those who allegedly have strayed from the 'party line.' In addition, those who, without actually opposing communism, did not appreciate its aims and methods became victims of the repression campaign. ${ }^{14}$ The weapons used for punishing the 'enemies of the regime' were the Securitate and the Judiciary power. In this context, during the pre-repression stage, Politburo changed some provisions of the Criminal Code, including article 209 that incriminated the 'conspiracy against the social order. ${ }^{15}$ Decree no. 469, adopted in 1958, changed article 209, replacing the delict with the crime. The punishment for 'the crime of initiation or participation in organizations that pursued the change of the existing social order in the state' was the sentence to forced labor from 15 to 25 years. $^{16}$

The wave of arrests began in June 1958. Intellectuals were the main targets of the Securitate, which sought to prevent any artistic, cultural, or economic activity that could lead to human interaction in a space that was not controlled or supervised by the state. ${ }^{17}$ Among the victims were 23 intellectuals tied together in a show-trial known as

\footnotetext{
10 Tănase 1997, 160.

11 Tismăneanu 2014, 188.

12 Deletant 2019, 222.

13 Deletant 2019, 218.

14 Raportul Final 2006, 190.

15 Bădescu et alii 2019, 2.

16 Crăcană 2014, 181.

17 Preda 2021, 17.
} 
the 'Noica-Pillat trial' or 'the trial of intellectuals' in February 1960. The Noica-Pillat trial included philosopher Constantin Noica, literary critic Vladimir Streinu, Nicolae Steinhardt, Alexandru Paleologu, writer Constantin (Dinu) Pillat, epigrammist Alexandru (Păstorel) Teodoreanu, actress Marietta Sadova, art historians Remus Niculescu and Theodor Enescu, and others. The trial consisted of two different groups, the 'Noica group' and the 'Pillat group', with few mutual interactions. The Securitate agents and investigators artificially linked the two groups in summer 1959 based on three joint meetings between Dinu Pillat and Constantin Noica. The Securitate's intervention resulted in the NoicaPillat group, where many defendants met each other for the first time in court under a common accusation.

The fictitious Noica-Pillat group was charged with 'conspiring against the social order' for reading and disseminating the books of Mircea Eliade and Emil Cioran, both of them living in the West at that time. Moreover, the brutal investigation conducted by Securitate agents sought to establish a 'conspiracy group' around Noica's book on Hegel's philosophy. ${ }^{18}$ The book was to be published in France, and it was edited by the philosopher Emil Cioran. The Securitate applied the same strategy to the 'Pillat group' by instrumentalizing his novel Waiting for the Afterlife. ${ }^{19}$ as a pro-fascist writing which urged 'subversive activity, praising and justifying crimes and instigating acts of terror. ${ }^{20}$ The conspiracy group was nothing but a Securitate's fictitious narrative designed to facilitate the conviction of the so-called socially undesirable individuals under a common charge. They were accused of illegally meeting each other in closed meetings, having hostile discussions about the regime, and writing counter-revolutionary works while propagating the 'change of social and state order in our country. ${ }^{21}$ Constantin Noica and Dinu Pillat were sentenced to 25 years hard labour, while Alexandru Paleologu received 14 years and Păstorel Teodoreanu seven.

\section{The repression phase (1958-1960)}

Constantin Noica was born in 1909. He studied at Spiru Haret High school in Bucharest and then attended the Faculty of Letters and Philosophy of the University of Bucharest, graduating in 1931. Between 1932 and 1934, he was a young member of the Criterion Association along with prominent intellectual elites including Mircea Eliade,

18 The book was initially entitled Povestiri din Hegel [Stories from Hegel], later published under the title Povestiri despre om [Stories about Man] in 1980.

${ }_{19}$ Dinu Pillat finished the novel Așteptând ceasul de apoi in 1948, but censorship prevented its publication. The novel's subject was the youth adherence to the fascist political party Iron Guard between 1933 and 1938. Pillat tried to understand the psychological motivation of one group of teenagers for supporting an aggressive and extreme political movement. He portrayed his characters as young individuals full of uncertainties and existential doubts who chose to embrace Fascism as an idealistic pathway for creating a new society. Dinu Pillat shared the novel with his ex-Guardist friends (such as Constantin Noica, Arșavir Acterian, Gheorghe Florian, Constantin Răileanu, Aurelian Vlad, Sandu Lăzărescu). He hoped to find out if he had managed to catch the inner political motivation of the Iron Guard's members. During the documentation process, Pillat read several books written by the fascist leader Corneliu Zelea Codreanu, such as For Legionaries and The Archangel's Envoy. Later on, these readings were considered incriminating evidence in the trial. The novel's manuscript was confiscated by the Securitate in 1959 and considered lost until 2010 when it was accidentally found in the Securitate archives. Waiting for the Afterlife was officially published in 2010 at Humanitas Publishing House.

${ }^{20}$ Giugariu 2010, 439.

${ }^{21}$ Giugariu 2010, 410. 
Emil Cioran, Haig and Arșavir Acterian, Marietta Sadova, Petru Comarnescu, Zaharia Stancu, Belu Zilber, Lucrețiu Pătrășcanu and others. ${ }^{22}$ His generation was influenced by the right-wing philosopher Nae Ionescu, a partnership for which Noica would later pay dearly. ${ }^{23}$ These young intellectuals, including Noica, Eliade, and Cioran, supported the fascist Iron Guard in the late 1930s. After the defeat of the Legionary Rebellion in 1941, some of them chose to leave the country. Others remained apolitical or shifted their political allegiances as the Communist Party seized political power in Romania after 1945. As expected, Constantin Noica's political background was unfavorable for a peaceful integration into the new socialist order: he supported the fascist Party Iron Guard; he was a landlord and a 'reactionary' philosopher. According to communist ideological criteria, Noica was an 'enemy of the people.'

In 1949, the communist authorities sentenced Noica to 10 years of forced residence in Câmpulung-Muscel, where he spent nine years in relative isolation and marginalization. Noica's social loneliness in a small mountain city favored the creation of small cultural circles around his ideas. These meetings were called 'literary circles' or 'cenacles', where people usually met to debate ideas forbidden by the authorities. ${ }^{24}$ The cenacle was a specific form of socialization inherited from the interwar 'bourgeois' society. These meetings were held in private homes, and they avoided the Party's ideological line. Thus, these meetings became a safe environment for anti-communist intellectuals. There was also an economic reason behind it. Private lessons were the only source of income for many intellectuals after the regime destroyed their traditional source of income. From the beginning, the authorities sought to destroy the cultural cenacles by sentencing various groups of writers to prison as they realized the potential threat of private meetings to strengthen and preserve alternative identities to the communist regime. Consequently, cenacles offered Securitate the possibility of detecting the so-called 'reactionary elements' that perpetuated an undesirable cultural habit. In a Securitate report from 1956, informant 'Ionescu Ioan' wrote that Noica was the organizer of a literary cenacle held in Radu Rosetti's house in Câmpulung Muscel. On the side of a document, the case officer requested additional information about these meetings. As a result, he instructed the informer to attend future cenacle meetings to determine 'the true meaning the reported individuals are meeting, how they educate their children, what they discuss, and other issues. ${ }^{25}$

Noica found refuge in studying philosophy, reading Goethe and Hegel, and keeping in touch with his friends outside of Câmpulung through correspondence, including with the exiled Emil Cioran. He wrote two philosophy books: Anti-Goethe between 1953 and 1955 and Stories from Hegel, between 1955 and 1957. The two books circulated as samizdat ${ }^{26}$

\footnotetext{
${ }^{22}$ For an overview of the cultural and political activity of the Criterion Association, see Bejan 2019.

${ }^{23}$ Verdery 1991, 258.

${ }^{24}$ Mareș 2005, 16.

${ }^{25}$ ACNSAS, Bucharest, Fond Informativ, file 3718/1, folio 122.

${ }^{26}$ Samizdat (from Russian sam, 'self', and izdatelstvo, 'publishing') was a secretly written, copied, and circulated literature in the former Soviet Union. Historians credit the poet Nikolay Glazkov with the first use of the word, and it refers to self-published texts and underground, self-publishing process (Arnold 2020, 56-57). Because of the government's strict monopoly on presses, photocopiers, and other printing devices, samizdat publications typically took the form of carbon copies of typewritten sheets. They were passed by hand from reader to reader' (Source: 'Samizdat'/ Encyclopaedia Britannica). Between 1956 and 1962, samizdat
} 
in small groups of persons interested in Noica's philosophical thinking after his failure to officially publish them.

Starting with 1957, theSecuritate began to intercept Constantin Noica's correspondence to detect his contact persons. Noica was a passionate writer. Writing long and thorough letters to his friends was the only way the philosopher could maintain contact with his former colleagues in Bucharest and Emil Cioran in France. Moreover, Noica tried to keep abreast of the cultural evolution in the country and with the Romanian exiled intellectuals through correspondence. The content of the letters was either cultural or philosophical. The Securitate agents began to make ideological hermeneutics of the letters. One example dates from 11 June 1957, when agent N. Panaitescu informed his superiors of the hostile ideas found in Noica's letters:

The content of this letter is very subtle and reactionary. It shows that the Romanian language and civilization will inevitably perish if some miracle does not save Romania from Russian influence. He believes that the only solution to save the Romanian people from the geometric civilization [communism, n.a.] would be a massacre. This is reproduced on the page II below in the form of a paraphrase: 'To undertake a night of St. Bartholomew among the elders of Romania... This is the substance of our wisdom now, it is the last chance, or our form of lucidity. The whole letter is full of this kind of hatred for 'utopian socialism.' For him, our socialism remained a utopia replaced by barbarism. For all these reasons, the letter should be confiscated. ${ }^{27}$

From the content of this short analysis, one can observe how the Securitate agents interpreted a philosophical letter signed by Noica. The philosopher was considered a 'spy' (agents highlighted his connections with Emil Cioran in France) and a hostile anti-Marxist intellectual. During the repression time, Noica was portrayed as an enemy of the people par excellence in the Securitate files, who was to be marginalized, censored, and silenced by all means.

Later that year, Noica attempted to mail the manuscript of Stories from Hegel to France for publication at Plon Publishing House, but the Securitate intercepted and confiscated the manuscript. While Securitate agents intercepted one manuscript transmitted through the mail, Noica sent another manuscript with the help of a doctor named Pavel Ion, attending a medical congress in Paris. He handed the manuscript to Emil Cioran. The Securitate agents noted that: 'It is clear that between Noica C-tin and E. Cioran in France, there is an illegal channel through which the suspects mentioned above could carry out their suspicious espionage activity. ${ }^{28}$ As a result, the Securitate's surveillance file on Constantin Noica was opened on 5 December 1957 on suspicion of 'espionage activity.' ${ }^{29}$

Throughout the year, the agents created five 'plans of measures' (plan de măsuri) to find evidence for Noica's so-called 'hostile' activity related to his cultural activity. The

in Romania primarily focused on literature and poetry, including Dinu Pillat's novels, Constantin Noica's philosophy works, Vasile Voiculescu's poems, and others.

27 ACNSAS, Bucharest, Fond Informativ, file 3718/2, folio 33.

28 ACNSAS, Bucharest, Fond Informativ, file 3718/3, folios 127-128.

${ }^{29}$ ACNSAS, Bucharest, Fond Informativ, file 3718/1, folio 6. 
main preoccupation of the Securitate was to block Noica's possibility to publish abroad: 'he is seriously concerned to write a book entitled Stories from Hegel, with the intention of publishing it in the country or abroad. ${ }^{30}$ After analyzing its content, the Securitate concluded that the book had a 'philosophical idealist-reactionary' character. According to the 'plans of measures' included in his file, the officers took several actions in terms of surveillance and influence: two informants ('Petrică Alexandrescu' and 'Mehedințeanu's1) were to infiltrate into Noica's entourage to determine who was the intermediary of the manuscript sent to France. Others were instructed to find how Noica managed to get a copy of Emil Cioran's new book La tentation d'exister. Despite being officially banned in Romania, the book circulated among small groups of people. On 4 September 1958, agents introduced an 'operative technique' in Noica's house to listen to his telephone conversations. ${ }^{32} \mathrm{After}$ failing to determine the 'illegal communication path' with France, the Securitate took notes from different informers to establish a track that would have allowed them to arrest Noica. One note belonged to Herbert (Belu) Zilber, a former communist speaker at Criterion conferences, where he met Constantin Noica and Emil Cioran back in 1933. Zilber was arrested and convicted as part of the 'Pătrășcanu trial' in 1954. Commenting on Noica's past cultural and political allegiances, Zilber emphasized that the philosopher supported the fascist political party Iron Guard in 1940 by publishing propaganda articles in Buna Vestire, an extreme-right newspaper. This information gave the Securitate the possibility to hasten his arrest.

Constantin Noica was arrested on 11 December 1958 for illegally sending the manuscript of his book Stories from Hegel in France using alternative channels such as persons traveling abroad or working at the French Embassy in Bucharest. The Securitate officers investigated him from December 1958 to February 1960. In parallel, the so-called Pillat 'group' was also under brutal investigation. In the late summer of 1959, the Securitate merged the two groups in the so-called 'Noica-Pillat group.'33 and convicted it for holding hostile discussions against the regime during cenacle meetings and reading legionary books.' Noica was accused of writing samizdat works that 'slandered Marxism and promoted

${ }^{30}$ ACNSAS, Bucharest, Fond Informativ, file 3718/1, folio 7.

${ }^{31}$ Mehedințeanu's real name was Emil Lăzărescu. The agent was instructed to request a delegation from the Pitești Regional Museum stating that he was a museum collaborator who carries excavations at the Mateiaș Mausoleum, the Dâmbovicioara Cave, and the Negru Vodă Monastery in Câmpulung, where Noica resided. On 15 July 1958, Noica wrote to his ex-wife Wendy Muston: 'I have Emil Lăzărescu here for a few days, who is digging to see the old Catholic church somewhere in the city. He is very passionate about what he is doing; otherwise, he is a bit depressed, tired as I see' (ACNSAS, Fond Informativ, file 3718/II, folio 375). Noica was pleasantly surprised by the reunion with his old friend, without suspecting that he was the Securitate agent whose purpose was to keep him under surveillance.

32 ACNSAS, Bucharest, Fond Informativ, file 3718/3, folio 9.

33 The trial group was the creation of Securitate officers around Constantin Noica's and Dinu Pillat's entourages, which were similar in terms of cultural affinities. The group consisted of 25 persons: philosopher Constantin Noica, writer Dinu Pillat, essayist Alexandru Paleologu, writer Păstorel Teodoreanu, orientalist Sergiu Al-George, literary critic Vladimir Streinu, director and actress Marietta Sadova, Beatrice Strelisker, Nicolae Radian, Constantin Ranetti, Sandu Lăzărescu, Gheorghe Florian, Arșavir Acterian, Constantin Răileanu, Ion Mitucă, Emanoil Vidrașcu, Barbu Slătineanu, Mihai Rădulescu, Teodor Enescu, Remus Niculescu, Iacob Noica, Anca-Maria Ionescu, and Sanda Simina Mironescu. Barbu Slătineanu and Mihai Rădulescu died during the investigation, and consequently only 23 intellectuals arrived in front of the military law court. 
reactionary fascist philosophy, taking part in hostile and defamatory discussions about the popular democratic regime in the RPR' and propagating 'the change of the social and state order in our country. ${ }^{34}$ As a leader of the 'Noica group,' he was sentenced to 25 years of forced labor and ten years of civic degradation.

Once sent to Jilava prison, the repression phase ended in March 1960, and the second phase began. The Noica-Pillat show-trial that led to the condemnation of the 23 intellectuals was also the last political process in communist Romania. The trial was hastened by the approach of the Romanian Worker's Party Congress on 20-26 June 1960, as trials were a part of the repression measures that usually preceded the organization of party congresses.

\section{The re-education phase between 1960 and 1964}

The second phase was the re-education that took place during the imprisonment. Between 1958 and 1964, Noica spent 6 of the 25 years he was sentenced to in prison. After being officially convicted in March 1960, Noica was sent to Jilava Prison, where he stayed until 1964. Before his conviction, Noica went through a brutal investigation at Pitești prison in the first half of $1959 . .^{35}$ After that, Noica was imprisoned in terrible conditions where he had to endure misery, food shortcomings, promiscuity, and the brutality of the guardians. Starting from 1962, he was in permanent contact with a Securitate officer, colonel Rusu Emanoil, who brought him communist books, newspapers, political treaties, and pencils to encourage Noica to adopt a Marxist cultural standpoint. One detail worth mentioning: few political prisoners, if not only Noica, received such items in jail. He was primarily subjected to an ideological re-education program, even if many other imprisoned intellectuals would be used in the regime's interest.

Despite its brutal beginnings, the relation between Constantin Noica and the Securitate changed after 1962. It evolved from hostility to agreement (or at least a form of mutual understanding). Andreescu argued that the regime chose to approach and use Noica $^{36}$ due to his celebrity abroad, especially among the Romanian emigration in Paris. A Marxist Noica would have shocked his Criterionist friends in Romania and his emigrant friends in France, which portrayed him as a victim of the communist terror. On 22 May 1962, colonel Rusu approached Noica to see what his position on Marxism was. Noica admitted his guilt and considered fair the punishment received. ${ }^{37} \mathrm{He}$ offered to write a book on the relation between Marx and Hegel, and for this, he requested bibliographic material and communist newspapers and publications.

\footnotetext{
${ }^{34}$ Giugariu 2010, 404.

35 According to his friends in prison, Constantin Noica was beaten and tortured by investigators during the interrogations in Pitești. The intensity and pace of these unorthodox methods are not well known. Noica's autobiography Pray for Brother Alexandru (Rugați-vă pentru fratele Alexandru) mentions the brutality of the Securitate agents. The testimonies of the former victims differ, but they share the idea of the use of violence against Noica. Alexandru Botez, Noica's cellmate, claimed that the philosopher was not beaten during the investigation in Bucharest, but 'he has been physically aggressed before we met' (Tănase 1997, 286). Simina Mezincescu recalled that Noica's weakness was also related to having only one kidney. She remembers that Noica was physically assaulted during the investigation in Pitesti: '[The girls from Argeș, arrested for armed resistance, n.a.] told me that the whole prison in Pitesti recognized Noica's screams' (Tănase 1997, 276).

36 Andreescu 2013, 64.

37 ACNSAS, Bucharest, Fond SIE, file 4862/I, folio 8.
} 
In June 1962, Noica constantly received books and newspapers, including the works of Vladimir Ilici Lenin (Materialism and empiro-criticism, April Theses, Imperialism, The Highest Stage of Capitalism), various editions of Contemporanul newspaper, a pair of glasses, cigarettes, and sheets of paper for writing. As part of the re-education (or invitation for collaboration) program, the officers talked to Noica about what he would have to do in the future for his proper rehabilitation..$^{38}$ On 18 July, Noica handed 79 pages of autobiography and four pages of the preface to a Marxist philosophy book he intended to write. Ten days later, Noica wrote another 80 pages of autobiography and requested 100 more sheets of paper. In September 1962, the Securitate report specified that Noica was willing to write more if only he knew if the three works submitted at that moment were 'useful to society', ${ }^{39}$ by which he meant that they were under the 'Party line.'

During his imprisonment time, the Securitate used agent 'Șerban' to review Noica's works' ideological content. 'Șerban' was also a philosopher, and he evaluated Noica's first work written in prison, The logical time, giving the following verdict:

This work is not only not Marxist, but it proves that its author does not even know Marxism. The work hints at some changes in Constantin Noica's position towards the problems of contemporaneity. He tries to justify an understanding attitude towards socialism, with arguments taken from Hegel's idealist philosophy. Precisely because of this, Noica's writing could arouse some interest abroad and could convince emigrant circles that people's consciences are not constrained in Romania.

Suppose there is any political reason for the paper to be published and used in our propaganda abroad. In that case, this text can be a basis for a new paper (considering its Hegelian speculative character, it cannot be simply revised as it is fundamentally wrong). The publication of the work in the country would be contraindicated because it would be a source of endless ideological and political confusion. ${ }^{40}$

As mentioned throughout the article, the topic of Romanian exile remained of great importance for the Securitate. Intellectuals who corresponded with people abroad were placed under surveillance, and once they were convicted, the regime tried to turn them against the Romanian dissidents in the West.

The consequences of Constantin Noica's re-education are analyzed from two different perspectives. The first one is Noica's perspective. Following the unfavorable evaluation from agent 'Șerban,' Noica was discouraged, and thus, his attempt to adopt a Marxist point of view was considered a failure. He added: 'Since I do not consider myself able to give my writings a satisfactory Marxist form, I offer them for reformulation to any philosopher interested in it, while I agree to sign the works and at most use a pseudonym. ${ }^{41}$ The philosopher considered himself unable to write from a Marxist perspective. The second viewpoint is based on the Securitate official reports, which recorded that Noica's re-education was a success:

\footnotetext{
38 ACNSAS, Bucharest, Fond SIE, file 4862/I, folio 10.

39 ACNSAS, Bucharest, Fond SIE, file 4862/I, folio 23.

40 ACNSAS, Bucharest, Fond SIE, file 4862/I, folio 26.

${ }^{41}$ ACNSAS, Bucharest, Fond SIE, file 4862/I, folio 41.
} 
In order to remove Noica Constantin from the influence of bourgeois ideology and to attract him into a useful activity for our state, starting with May 1962, with the approval of the MIA leadership, he was subjected to a special program through creating optimal conditions for detention and study. Various materials of Marxist-Leninist ideology and novels with socialist content were made available for him. As a result, Noica was able to acquire the conceptions of Marxist-Leninist ideology to some extent and appreciate more realistically our Party's policy. He also produced some important philosophical works. ${ }^{42}$

Even if the re-education could not have been completed in a two-year time, Noica was put in the 'right direction' that later allowed him to integrate into the cultural life of socialist Romania. He was pardoned by Decree no. 411 and released in August 1964 as part of Romania's political prisoners' general pardon.

\section{The reinsertion phase after 1964}

After 1964, Constantin Noica and his convicted friends were convinced that there was no other option for survival than to accept a form of collaboration with the regime. As former political prisoners, intellectuals needed to prove their political and cultural attachment to the communist ideology to get a job, be published, and be able to travel in the West.

Immediately after his release from prison, Noica was able to demonstrate his allegiance to the regime. Informer 'Marin Oltescu' (Alexandru Paleologu) noted that Noica was unwilling to leave Romania and considered himself a follower of the ideology and politics of the communist regime. Consequently, he wanted to prove his fidelity by writing and serving 'the Romanian culture. ${ }^{\text {'43 }}$ Moreover, Noica was concerned that one of his old manuscripts entitled Cercul metafizic [The Metaphysical Circle], ${ }^{44}$ written in 1949, was to be republished in France by his anti-communist friends. However, the ideas presented in that work no longer represent his new philosophical vision, which was now friendly to Marxism. He then blocked the publication not to give the communist authorities any more reasons for suspecting him. If the French publishing house had published the book, Noica was ready to notify the Department of Propaganda of the Party's Central Committee about this issue and even write an article to fight his past 'idealist positions. ${ }^{45}$

Noica wanted to improve his material and social condition by obtaining a research position at one of the Institutes of the Romanian Academy. He carefully prepared his integration into a research institute by publishing a study in the Contemporanul journal and lobbying academician C. Ionescu-Gulian and Minister Athanase Joja. To Joja he wrote: 'I came out of prison with a changed attitude and willing to contribute to the cultural

${ }^{42}$ ACNSAS, Bucharest, Fond SIE, file 4862/I, folios 51-52.

${ }^{43}$ ACNSAS, Bucharest, Fond SIE, file 4862/I, folios 55-56.

${ }^{44}$ There is no evidence for this manuscript other than Noica's claims from the informant note: 'Noica responded that it is a manuscript sent in 1949 at Montpellier in France, entitled Metaphysical Circle. He added that the Securitate had known the content of the manuscript since his investigation. The book is written from an idealistic standpoint, which he now denies' (CNSAS, Bucharest, Fond SIE, file 4862/I, folio 57).

${ }^{45}$ ACNSAS, Bucharest, Fond SIE, file 4862/I, folio 59. 
upliftment of my country. ${ }^{36}$ After several applications, he found a position as a scientific researcher at the Center for Logic Studies and Researches in 1965, which was the only regular post in his life. On 2 June 1965, the Minister of Internal Affairs, Alexandru Drăghici, approved Noica's request for a two-room apartment in Bucharest. ${ }^{47}$

Noica's main concern was to convince the regime of his fidelity to visit his family in Great Britain and overturn his son's decision to become a monk. He motivated his visit abroad by invoking the need to visit his family and by the possibility to visit the Romanian intellectuals in Paris and tell them that communism has changed:

Finding intellectuals who have gained a reputation today, like Mircea Eliade, Eugen Ionescu, Emil Cioran and others, or politicians like Fărcașanu and maybe others (except the legionaries, from whom everything separates me today) I think I could share them what is the attitude of old intellectuals like me towards the regime. [The intellectuals from Romania] could have asked for expatriation, but they chose to put their last years in the service of the new Romania. ${ }^{48}$

Despite his numerous attempts to get a visa, the Securitate remained suspicious of the philosopher's intentions and did not allow him to leave the country until $1972 .{ }^{49}$ In the meantime, he sparked controversy among the exiled intellectuals following the publication of a pro-regime article in Glasul Patriei on 20 April 1965, where Noica aimed to 'convince the fugitives that the conditions in Romania have changed.50 The Romanian emigration in Paris claimed that Noica was coerced to write that article by the Securitate, as Emil Cioran told Beatrice Strelisker (convicted alongside Noica in the 1960 trial, later a Securitate collaborator) in a note from October 1966 that 'the Romanian emigrants do not understand the evolution of C. Noica's thinking and attitude. Although no one questioned his good faith, the Romanians in France consider him a renegade and his attitude a form of capitulation. ${ }^{51}$ Agent 'Șerban' argued that the exile's assumptions were correct as long as the Noica was not published in Romania or allowed to leave the country. He claimed that Noica was particularly important for attracting the Romanian emigration from Paris to Romania, and his departure to France should be officially supported..$^{52}$

The Securitate agents were also interested in the psychology of the individuals they were surveiling. In Noica's file, he was characterized as a proud and reckless intellectual with complicated psychology and nervousness, which was to his detriment. However, he was considered a man of honor who never does anything against his beliefs and respects precisely what he has to do. ${ }^{53}$ For example, Noica was asked by a communist official to tell Mircea Eliade that there was cultural freedom in Romania. He firmly replied that there is no freedom in Romania, but progress had been made, and this little progress implied 'both happiness and culture':

\footnotetext{
46 ACNSAS, Bucharest, Fond SIE, file 4862/I, folio 60.

47 ACNSAS, Bucharest, Fond SIE, file 4862/I, folio 75.

48 ACNSAS, Bucharest, Fond SIE, file 4862/I, folios 97-98.

49 Andreescu 2013, 68.

50 ACNSAS, Bucharest, Fond SIE, file 4862/I, folio 74.

${ }^{51}$ ACNSAS, Bucharest, Fond SIE, file 4862/I, folio 129.

${ }^{52}$ ACNSAS, Bucharest, Fond SIE, file 4862/I, folio 140.

${ }^{53}$ ACNSAS, Bucharest, Fond SIE, file 4862/I, folio 141.
} 
I forgot that my interlocutor was neither an intellectual nor a revolutionary, but a simple bureaucrat. I do not even think he knew what Lenin said about the justified suspension of freedom during the period of revolutionary transformation. He only knew the letter of the book, he pricked up his ears, and when he heard offreedom, he got scared and left. ${ }^{54}$

At the end of the 1960s, Constantin Noica was satisfied with the evolution of Romania's cultural life, especially since he got permission to publish books and articles and receive copyrights. A note of 'Șerban' from 1966 described Noica as a person who was supporting the Party's new nationalist political orientation. He was convinced that he must stay in Romania and bring his contribution to Romanian philosophy. He believed that 'the regime wants to pursue a Romanian policy and thus must be helped. ${ }^{55}$ About Emil Cioran and Mircea Eliade, Noica claimed that they remain isolated from their country regardless of their fame in the West. Consequently, they 'cannot contribute in the direction of promoting românism [the nationalist orientation of the regime]. ${ }^{56}$ Moreover, he considered himself a 'recovered intellectual since 1964.' He was willing to further 'recover intellectuals from abroad, including Mircea Eliade. However, as Andreescu rightly observed, attracting Mircea Eliade or Emil Cioran was Noica's stake, not necessarily the Securitate's. ${ }^{57}$

Noica's social reinsertion was a form of compromise but not a drastic one. It was a compromise for survival to eliminate the social marginalization he was subjected to until 1964. His submissive and agreeable nature allowed him to create, write and think while the regime had always kept an eye on him. He was never as trusted by the regime as he would have wanted to. He became a famous cultural figure during the 1980s. After retiring from the Centre of Logic Studies, he settled in a cabin in Păltiniș and began to tutor a few disciples, forming the so-called 'Noica School.' The Securitate kept him under permanent surveillance until his death on 4 December 1987.

\section{Conclusions. A reckoning with Nae}

The article demonstrated that the three phases of cultural surveillance-repression, re-education, and reinsertion-were applied to certain intellectuals during the 1960s as part of the changing political attitude of the regime towards society. The contribution of a 'bourgeois' intellectual who was educated and socialized in elite cultural groups to the new communist order underwent profound transformations after the regime consolidated in the late 1950s. Stripped of their economic, cultural, or political power, the old intellectuals did not threaten the stability of the communist regime. Their only power was symbolic. In the mid-1960s, the communist authorities 'recovered' such intellectuals as the collaboration built political legitimacy for the new nationalist orientation of the Party's policy. As so, Noica's behavior transformed following the imperatives of political transformations.

Looking for a new life in a new political context, Noica verbally condemned his past mistakes, significantly his pro-Guardist articles in 1940: 'I was wrong not only about

\footnotetext{
${ }^{54}$ ACNSAS, Bucharest, Fond SIE, file 4862/I, folio 157.

${ }^{55}$ ACNSAS, Bucharest, Fond SIE, file 4862/I, folio 143.

${ }^{56}$ ACNSAS, Bucharest, Fond SIE, file 4862/I, folio 143.

57 Andreescu 2013, 79.
} 
history, but also about myself. I do have a reckoning with Nae [Ionescu]. ${ }^{58}$ The former philosophy professor and mentor of the 'Young Generation' of interwar intellectuals was the main culprit in attracting the youth to Fascism, including Constantin Noica, Mircea Eliade, and Emil Cioran. The 'Noica paradox' consists precisely in the moral condemnation of his former mentor while unconsciously promoting his nationalist ideas in the context of national-communism under Dictator Nicolae Ceaușescu. As Katherine Verdery describes it, Noica 'was directly continuous with the interwar arguments on the national essence, for he was a central figure in the cultural battles of the 1930s, and he pursued his work on the national essence even beyond his death in 1987.59

Noica remained faithful to his friends and professors. As the present study aimed to provide an inside on the re-education of one 'bourgeois' intellectual, there can be no better ending without considering Noica's thoughts on his nihilistic friend, Emil Cioran. In July 1964, Noica was asked to write an extended report on his relation with Cioran from the beginning to the present day ${ }^{60}$. He described their friendship as a brotherhood, where Cioran was the 'sick brother' that needed help in his professional and personal life due to his general pessimism. Noica's writing style is full of compassion and understanding for the fate of a 'suicide aspirant', who was always mocking himself, others, and philosophy in general. ${ }^{61}$ Reading between the lines, the text's message was that Cioran could not be considered a dangerous individual or an enemy of the people but rather a victim of his anarchist ideas. Noica ends his plea by moving the discussion towards a philosophical understanding of Cioran's status, contrary to the ideological approach of the regime: 'Cioran is the enemy of the regime. However, there is too little to only say 'of the regime.' He is also an enemy of man, of Europe, of culture, of progress, of the joy of living. He is a universal enemy. Such a man must be fought. Nevertheless, I am doubtful that he deserves to be fought with so much perseverance. I had chosen the path of fighting him by adopting him.... A Cioran returned to the country, tamed, humanized, could have done some services with his extraordinary culture.' ${ }^{62}$ This document was the expression of re-education, where Noica combined the formal condemnation of Emil Cioran's philosophy with the attempt to recover him in the eyes of the communist authorities as a precious and innocent intellectual.

As his friends fled the country after the end of the Second World War, Noica endured the consequences of his past fascist political commitment after establishing the communist regime. He was marginalized, isolated, censored, and convicted in 1960. After his release from prison in 1964, he slowly rebuilt his personal and professional life, even though compromises were part of survival. Noica paid the price for his cultural reinsertion in the communist society: the loss of credibility among the Romanian exile and his damaged reputation as a supporter of the regime. However, at the same time, he gained much internal popularity as an exotic philosophy mentor after the publication of Gabriel Liiceanu's Journal from Păltiniș in 1983.

Constantin Noica's involvement in the service of the communist regime was a complex process, which cannot be easily understood without multiple factors taken into

\footnotetext{
${ }^{58}$ ACNSAS, Bucharest, Fond SIE, file 4862/I, folio 144.

${ }^{59}$ Verdery 1991, 257.

${ }^{60}$ The report can be found in ACNSAS, Bucharest, Fond SIE, file 4862/II, folios 8-28.

${ }^{61}$ ACNSAS, Bucharest, Fond SIE, file 4862/II, folio 13.

${ }^{62}$ ACNSAS, Bucharest, Fond SIE, file 4862/II, folio 27.
} 
consideration. His attitude and behavior were that of a man deprived of wealth, divorced from his wife and far from his children, placed under forced domicile, sentenced to prison, and then permanently harassed by the Securitate agents after 1964. The economic and cultural shortcomings have never ended, as he struggled to be officially published for several years after release. He had to write compromising articles with Marxist content to simulate his support for the regime. After that, he made countless requests to the ministry to get a job at an institute and later visit his family abroad. Although he faced rejection and social marginalization, he continued to mentor young people and write philosophy studies. Some scholars argued that Noica gradually developed an emotional attachment for guards and agents, known as the Stockholm syndrome. ${ }^{63}$ Others believed that the philosopher developed a self-defense instinct through compassion for torturers to preserve his self-esteem. ${ }^{64}$ The transformation of Noica's attitude after his release from prison did not make him a follower of the communist regime but allowed him to continue unhindered his intellectual work. His docility and compassion for the Securitate agents were no signs of an evil character, but instead, they are related to how each individual seeks to survive a totalitarian regime. On the whole, the political context heavily influenced the individual fate of a promising intellectual whose career was compromised and altered by an abusive political order.

\section{Bibliography}

\section{Archives}

ACNSAS, Bucharest, Fond SIE

\section{Primary sources}

Giugariu 2010

Noica 1990

\section{Secondary sources}

Andreescu 2013

Arnold 2020

Bădescu et alii 2019

Bejan 2019

Arhiva Consiliulului Naţional pentru Studierea Arhivelor Securităţii, Bucharest, Fond Informativ, Fond SIE (Serviciul de Informații Externe).

M. Giugariu (ed.), Prigoana. Documente ale procesului C. Noica, C. Pillat, S. Lăzărescu și alții, Bucharest 2010.

C. Noica, Rugați-vă pentru fratele Alexandru, Bucharest, 1990.

G. Andreescu, Cărturari, opozanți și documente: manipularea arhivei Securităţii, Bucharest 2013.

J. R. Arnold, Whistleblowers, Leakers, and Their Networks. From Snowden to Samizdat, London 2020.

V. S. Bădescu, L. Done, Unele considerații privind dreptul penal românesc în perioada regimului comunist, Acta Universitatis George Bacovia. Juridica, 8/2 (2019), 287-348.

C. A. Bejan, Intellectuals and Fascism in Interwar Romania. The Criterion Association, Durham 2019. doi.org/10.1007 /978-3-030-20165-4.

\footnotetext{
${ }^{63}$ Andreescu 2013, 90.
}

${ }^{64}$ Petreu 2011, 477-505. 
Crăcană 2014

Deletant 2019

Mareș 2005

Mareș 2009

Mezdrea 2009

Oprea 2008

Petreu 2011

Preda 2021

Raportul Final 2007

Șandru 2014

Șandru 2015

Tănase 1997

Tismăneanu 2014

Verdery 1991
I. Crăcană, Stalinizarea și destalinizarea justiției în România comunistă. In: C. Budeancă, F. Olteanu (eds.), Stalinizare și destalinizare. Evoluții instituționale și impact social, Iași 2014.

D. Deletant, Romania under Communism: Paradox and Degeneration, London-New York 2019.

C. Mareș (Cosmineanu), S. B. Moldovan, Nicu Steinhardt în dosarele Securității, București 2005.

C. Mareș, Argument, Anuarul IICCMER, 4 (2009), 9-18.

D. Mezdrea, Noica și Securitatea, Bucharest 2009.

M. Oprea, Bastionul cruzimii. O istorie a Securităţii (1948-1964), Iași 2008.

M. Petreu, De la Junimea la Noica. Studii de cultură românească, Iași, 2011.

C. Preda, The Aesthetic Surveillance of Performance Art by the Romanian Securitate in the 1970s and 1980s, Third Text, 35/3 (2021), 355-372. doi.org/10.1080/09528822.2021.1916219.

Raportul Final al Comisiei Prezidențiale pentru Analiza Dictaturii Comuniste din România, București 2007.

D. Șandru, Ipostaze ale ideologiei în teoria politică, Iași 2014.

D. Șandru, Puterea cuvintelor: despre relația intelectualilor cu ideologia, de la comunism la postcomunism. In: M. Anton, B. Crețu, D. Șandru (eds.), Cuvintele puterii: literatură, intelectuali şi ideologie în România comunistă, Iași 2015, 299-320.

S. Tănase, Anatomia mistificării 1944-1989, Bucharest 1997.

V. Tismăneanu, Stalinism pentru eternitate. O istorie politică a comunismului românesc, București 2014.

K. Verdery, National Ideology Under Socialism. Identity and Cultural Politics in Ceaușescu's Romania, Berkeley 1991.

\section{Dictionaries and Encyclopedia}

'Samizdat'/Encyclopaedia

Britannica
'Samizdat,' Encyclopaedia Britannica https://www.britannica. com/technology/samizdat, accessed 27 Jun. 2021. 



\title{
NIHON NO SENSOU - THE JAPANESE WAR EXPERIENCE ILLUSTRATED THROUGH THE LENS OF NINGEN NO JOKEN (THE HUMAN CONDITION)
}

\author{
MIHAI CHIȘ
}

\begin{abstract}
Japan's military campaigns in Asia during the Second World War were taboo, especially during the 1950s and the 1960s in Japanese society. After the Second World War, Japan experienced a political and social transformation, which unfortunately could not 'eradicate all the elements of militarism' still present in the society of the time. Instead of repenting for their misdeeds, many conservative leaders and people who experienced the war chose to identify themselves as the actual victims of the war. Consequently, they ignored the suffering of the inhabitants of the Japanese-occupied territories during the Second World War. I will not dwell, however, into the reminiscences of the past present in the Japanese society of the time nor discuss the issue of war responsibility, but instead look into the case of a noteworthy attempt of coming to terms with the past, the case of Kobayashi Masaki's trilogy, Ningen no Joken. The trilogy was not the first attempt at reconciling with the past. However, it is one of the most ambitious and well-acclaimed attempts to acknowledge Imperial Japan's misdeeds. By using Kobayashi's movies, I will endeavor to sketch a portrait of the Japanese war experience and those who lived in the Japanese-occupied territories of the time.
\end{abstract}

Keywords: kokutai, Japan, war, humanism, pacifist, war experience.

Rezumat: Desfășurarea acțiunilor militare din Asia în timpul celui de-Al Doilea Război Mondial a reprezentat un subiect tabu pentru societatea japoneză, cu precădere în timpul anilor '50 și respectiv '60. Sfârșitul celei de-a doua conflagrație mondială a dat startul unui proces de schimbări de ordin politic și social, care însă nu a reușit să elimine în totalitate fostele elemente militariste din societatea japoneză a vremii. Astfel, o serie de lideri conservatori, precum și o parte a foștilor combatanți aleg să se identifice ca adevăratele victime ale războiului, alegând să plaseze în obscuritate consecințele acțiunilor liderilor militari de la Tokyo. În acest articol însă nu voi aborda problematica reminescențelor militarismului nipon, și nici chestiunea responsabilității asupra faptelor comise în timpul celui de-al Doilea Război Mondial, ci în schimb propun o incursiune în lumea cinematografică niponă. Astfel, voi dori să mă opresc asupra uneia dintre cele mai aclamate încercări de a recunoaște greșelile trecutului, și anume trilogia regizorului Kobayashi Masaki, Ningen no Joken (Condiția Umană). Prin intermediul filmelor lui Kobayashi voi schița o imagine a ceea ce a însemnat experiența războiului nu doar pentru japonezi ci și pentru populația din teritoriile aflate sub ocupația Armatei Imperiale Japoneze.

Cuvinte cheie: kokutai, Japonia, război, pacifist, experiență de război, umanism.

* M.A. Student, 'Babeş-Bolyai' University, Cluj-Napoca, email: chismihai513@yahoo.com, (D) https://orcid.org/0000-0001-6482-3856. 


\section{Introduction}

Japan has experienced a radical political and social transformation after the country was defeated in the Second World War. The image of a defeated nation, which was about to enter an era of radical changes, is sketched by Douglas MacArthur. In his memoirs, the American General stated that

Never in history had a nation and its people been more completely crushed than were the Japanese at the end of the war. They had suffered more than a military debacle, more than the destruction of their armed forces ... Their entire faith in the Japanese way of life, cherished as invincible for many centuries, perished in the agony of their total defeat. The impact of such a disaster was probably greater than had ever been experienced in modern history. ${ }^{1}$

The post-war development of Japan was influenced by the change of the post-war international system (the outbreak of the Cold War and its 'debut' in Asia during the Korean War). From the 50s, Japan has developed into an economically strong yet politically conservative state. The emerging conservative force came too early for the Japanese to have had a proper process of dealing thoroughly with the pre-1945 misdeeds of the militaristic rule period and acknowledging the past's mistakes. At that time, it was important for Japanese society to construct a demarcation between the interwar/World War Two and the post-war periods, as the Japanese state needed to separate the past from the present. As a result, a so-called 'victim mentality' emerged in post-war Japanese society. Consequently, the emphasis fell upon the suffering of the Japanese people, while the victims of the Japanese military campaigns in the Asia-Pacific region were cast into the shadows. ${ }^{2}$

Instead of opting for a total national self-criticism of the past, Japan chose a less drastic measure ${ }^{3}$, the self-victimization of the Japanese, which was used as a means of coming to terms with the past. The memory of the war had thus to be selective. It was to emphasize the suffering of the Japanese people, but at the same time ignore the fact that the Japanese state was the aggressor during the conflict. ${ }^{4}$ The majority of the Japanese did not identify with the objectives of pre-war and wartime militarism. Consequently, they did not feel responsible for the actions of the Japanese state during the war. They considered themselves to be the victims of pre-war and wartime militarism. They thus chose to blame the wrongdoings of the Japanese Imperial Army within the occupied territories of the Asia-Pacific region solely on the military leaders of the time. The main reason why such an attitude existed could be the emergence of the Cold War. The new political context meant that the Japanese state could use little time to acknowledge their wrongdoings fully and cleanse all the elements that contributed directly to the rise of militarism in the 1930s and 1940s. Ironically, many members of the pre-1945 apparatus were reinstated in their former positions because their experience was needed in rebuilding the country ${ }^{5}$ (such as the cases

\footnotetext{
${ }^{1}$ MacArthur 2012, 281.

2 Shimazu 2003, 101.

3 Shimazu 2003, 115.

${ }^{4}$ Shimazu 2003, 106.

5 Shimazu 115.
} 
of Okinori Kaya, the former Minister of Finances from 1941 to 1944 or Kishi Nobusuke a Class A war criminal, who didn't undergo trial and instead was released in 1948, eventually becoming the prime minister of Japan from 1957 and 1960).

The refusal to acknowledge their misdeeds could also be seen in how the Japanese officials and several influential conservative elites considered the Tokyo Trials a one-sided American justice and even denied launching a war of aggression against China. Many groups demanded the release of Japanese war prisoners. In some cases, the Japanese Diet even agreed to pay back their salaries and restore their pensions (they considered that the war prisoners should not be treated as standard criminals, as they were not judged under Japanese domestic law). Historian Yoshida Yutaka named these practices the 'double standard,' which on one hand consisted of an external acceptance of war responsibility. However, on the other hand, internal denial became means of dealing with those involved in the war. 6 Another element of this 'double standard' was the series of decisions from 19561958 and 1963 regarding the examination of textbooks. In the first interval, a procedure of examining textbooks was implemented, this procedure allowing the downplaying of the Japanese colonialism and expansionist wars. ${ }^{7}$ In 1963 a law on textbooks was passed, which aimed to 'normalize education.' Thus, a series of textbooks that overlooked Japan's culpability in starting a war of aggression against China and the United States were printed. ${ }^{8}$

However, this article aims not to dwell on the nationalist reminiscences that persisted in the post-war Japanese society nor discuss the issue of war guilt or responsibility of the Japanese state. It focuses on a noteworthy attempt of presenting the past in its true colors, the case of Kobayashi Masaki's trilogy, Ningen no Joken [The Human Condition]. I propose to offer an image of how the war experiences were perceived by a man who was not an advocate of the militaristic ideas promoted by the Japanese propaganda of the Second World War. These movies address the question of one's war experience and draw our attention to the repugnant behavior of Japanese forces in the occupied territories (in this case, Manchuria). The films are unique, as the main character, Kaji, is a pacifist with left-leaning sympathies. During that time, he could have been easily considered an outcast or representative of the decadent Western societies (according to the militaristic leaders of the time). The films give the perspective of a character that was not a fanatic or demon. This label was mostly used to portray Japan throughout the Second World War. The trilogy is even more genuine because Kobayashi Masaki served in the army during the Second World War. His experience during the war inspired many of the film scenes.

Before dwelling on the film analysis itself, I propose that to understand better the past that needed to be faced but was ignored by many, I will take a look at the Japanese propaganda during the Second World War. In this instance, I will use the manual Kokutai no Hongi to exemplify some of the ideas that served as a core for the imperialist ideals of Japan's military circles in the 1930s and the 1940s. After a general introduction to Japanese history during the war, I propose to sketch a portrait of the Japanese war experience using Kobayashi Masaki's films. My analysis will present how the war affected Japan and how Japan's actions affected the territories which at the time were occupied by its Imperial Army.

\footnotetext{
${ }^{6}$ Bix 2001, 652.

7 Bix 2001, 659.

8 Bix 2001, 668.
} 
In the analysis of the film, I will focus on several aspects: the behavior of the Imperial Japanese Army towards civilians; the life in the Imperial Japanese Army; the conflict of beliefs between the fanatical army officers and the soldiers; how the experience of the battlefield combat can affect a soldier (in this case, the main protagonist of the movie, Kaji). In the final parts of the article, I will endeavor to illustrate how Kobayashi's trilogy is different from previous attempts to condemn Japan's militaristic past. At the same time, I propose to look into aspects of the films that could be transposed into the post-war Japanese society, and use the idea of the so-called Rashomon Effect ${ }^{9}$ to illustrate such instances.

\section{A Portrait of Japanese Imperialism in the first half of the twentieth century}

The twentieth century found the once isolated Archipelago of Japan in a continuous and thriving road of development which made the Western powers worry for their position in the Far East. The accomplishments in the economy and international relations came to an end in the 20s. At that time, a wave of economic shortcomings and internal conflicts hit Japan. The political system found itself incapable of solving the on-going crisis. At the same time, the military gained the upper hand on the country's political scene (thanks to the extensive powers given to the military by the Meiji Constitution and because of the rebellious attitude of the military). ${ }^{10}$ The unavoidable rise of militaristic ideas and leaders would plunge Japan into its deadliest conflicts ever since the Sengoku Jidai ${ }^{11}$ or The Boshin War, ${ }^{12}$ which brought a tremendous amount of suffering not only to the Japanese Isles but also in the territories occupied by the Imperial Japanese Army.

The period of the twentieth century is one of ambiguity for the Japanese space, a feeling which is eloquently presented by Ōe Kenzaburōss 1994 Nobel Prize in Literature speech:

After one hundred and twenty years of modernization since the opening of the country, present-day Japan is split between two opposite poles of ambiguity. I too am living as a writer with this polarization imprinted on me like a deep scar. This ambiguity which is so powerful and penetrating that it splits both the state and its people is evident in various ways. The modernization of Japan has been orientated toward learning from and imitating the West. Yet Japan is situated in Asia and has firmly maintained its traditional culture. The ambiguous orientation of Japan drove the country into the position of an invader in Asia. On the other hand, the culture of modern Japan, which implied being thoroughly open to the West or at least that impeded understanding by the West. What was more; Japan was driven into isolation from other Asian countries, not only politically but also socially and culturally. ${ }^{13}$

\footnotetext{
9 The Rashomon Effect is a concept which reffers to a situation when the same event is described in different ways, which most likely will result in a contradiction, by people who were either involved or witnessed a specific event.

${ }^{10}$ Chiș 2019, 180.

${ }^{11}$ Known as the 'Warring States Period,' a historical period of Japan (1467-1615) known for its state of constant civil war.

12 The civil war which paved the road of the Meiji Restoration (1868-1869).

13 Ōe 1994.
} 
For many, throughout the 30 s and the 40 s, Japan represented a total enigma, the general opinion about the Japanese Isles being demonized, especially during the Second World War. In that period, Japan was portrayed as a militaristic and fanatical nation. Such views can be illustrated by the Japanese propaganda of the time. The propaganda praised Japan as a land blessed by the Gods and led by a God-like Emperor. Japan was portrayed as the defender of all Asian nations threatened by communism and Western imperialism. In the same vein, the Japanese mind, values, and customs were superior to Western ideals. Consequently, Japan's mission was to build a utopian Far East whose foundation stone was represented by the Japanese economic, political, and cultural practices. Japan was not an aggressor and had to resort to violence because of the unfair treatment imposed on the Japanese state throughout the first half of the twentieth century. Related to it, I can mention few events considered insulting by the Japanese: refusal to implement a Racial Equality Clause during the 1919 Paris Peace Conference, the 1921 Washington Naval Treaty, or the attitude of the League of Nations towards the Manchurian Incident.

These ideas contained one of the most important works of Japanese state propaganda of the time, respectively Kokutai ${ }^{14}$ no Hongi. ${ }^{15}$ Kokutai no Hongi materialized in a series of norms and values already present in the collective mind of the Japanese people of that time, which the military leaders could use in promoting their expansionist ideas. One of the first values is the 'land of the gods', known as shinkoku, which underlines the importance of myths in Japanese culture. In the opinion of many, Japan was a country created by Gods led by the successor of a goddess. This idea led to the emergence of a sentiment of superiority among the nation's elites. Another value was the veneration of the emperor, which had strong ties to the idea of a hereditary monarch of divine origins. In the eyes of many, this fact confirmed the idea of Japan's superiority as a nation. One last value worthy of mentioning is the idea of the 'Japanese spirit', the Yamato-damashii. The Yamato-damashii was the theory according to which the Japanese possessed bright and pure minds, and this helped to serve the emperor accordingly. ${ }^{16}$

The goals of Kokutai no Hongi can be best illustrated by the introduction present in its first pages that stated the following:

That is, it can be said that both in the Occident and in our country the deadlock of individualism has led alike to a season of ideological and social confusion and crisis. We shall leave aside for a while the question of finding a way out of the present deadlock, for, as far as it concerns our country, we must return to the Standpoint peculiar to our country, clarify our immortal national entity, sweep aside everything in the way of adulation, bring into being our original condition ... This means that the present conflict seen in our people's ideas, the unrest in their modes of life, the confused state of their civilization, can be put right only by a thorough investigation by us of the intrinsic nature of Occidental ideologies and by grasping the true meaning

${ }^{14}$ The term Kokutai originates in the classical Chinese language. It refers to form of government, though in the first half of the twentieth century, the Japanese authorities used it to describe the uniqueness of the Japanese Isles and people.

15 Translated as Cardinal Principles of the National Entity of Japan.

16 Susumu 2008, 56. 
of our national entity ... Herein lies our grave cosmopolitan mission. It is for this reason that we have compiled the Cardinal Principles of the National Entity of Japan, to trace clearly the genesis of the nation's foundation, to define its great spirit, to set forth clearly at the same time the features the national entity has manifested in history, and to provide the present generation with an elucidation of the matter, and thus to awaken the people's consciousness and their efforts. ${ }^{17}$

To sum up the content from above, Kokutai no Hongi represented a means of articulating an official ideology that could be used in promoting the political and military agendas of the militaristic leaders of Japan. At that time, the Japanese Isles were preparing for a future war, as the international community's opinion was not favorable towards Japan (due to the aggressive actions taken against their neighbors, like the 1931 invasion of Manchuria). Consequently, mobilizing the nation for the upcoming conflict was necessary to exist within the nation. To create unity within the nation, Japan had to abandon the Western ideals that threw the Japanese society into turmoil. In the eyes of the militaristic leaders, the Western ideals have 'plagued' Japan for too long, and 'a return to one's origins' was necessary to prepare the Archipelago for a prolonged conflict. For example, individualism was one of the most condemned characteristics as it represented a deterrent hindering Japan's sacred mission. Following one's ambitions could prevent one from fully dedicating oneself to a so-called ultimate goal, building a utopic Far East following the Japanese political and social model. Instead of promoting Western ideas, what made Japan truly unique had to be put on full display. For example, I mention the Shinto faith, the founding of the national myths, but most importantly, the Japanese monarchy and its emperor (which was portrayed as a descendant of the Gods). Embracing its unique characteristics and renouncing what the militaristic leaders deemed as 'threats' was thus the only way to awaken the nation's consciousness and mobilize it for what was to come.

The text of Kokutai no Hongi is marked by a powerful nationalistic message that could excite a strong feeling of pride in the hearts of the Japanese population of that time. At the same time, the pompous language leaves no place for interpretation for those who were forced to read it, thus facilitating the process of assimilating the expansionist ideas of the military leaders. Using this volume, the militaristic leaders sought to emphasize the uniqueness of the Japanese people, the so-called Yamato-damashii. A comparison can thus be made between the pure soul of the Japanese people and the tainted, decayed, and immoral soul of the Westerner who has no respect for their families, communities or leaders, and only thinks of themselves and their well-being. To increase its reception among the rural population, the text paid particular attention to specific elements, including the founding myths of the Japanese nation, the importance of family and filial piety, harmony between man and nature, unity of religious rites, and the state, loyalty and patriotism, etc. In order to mobilize the country for the upcoming conflict, the volume also mentioned the importance of Bushidō. The samurai's honor code was used to strengthen the bond between the emperor and its warriors (the people), so they could be convinced to accept the sacrifice to fulfill Japan's sacred duty. The emperor was thus clad in the mantle of the nation's supreme leader, and every loyal subject had to be obedient and fulfill all of his

17 Hall 1949, 54-55. 
decisions, even if that meant sacrificing one's life for the well-being of the state and the imperial will. Only by renouncing one's ego, personal interests and dedicating oneself to the emperor's will could someone be considered genuinely Japanese.

Kokutai no Hongi served as a means of encouraging the population of the Japanese Archipelago to contribute to the war effort of the period between 1937 and 1945. It helped to consolidate the idea of the uniqueness of the Japanese state and monarchy. However, as a result of Japan's defeat in the Second World War, the American authorities responsible for overseeing the democratization process of the Japanese state banned the volume and any ideas promoted by the military Japanese military leaders throughout the war.

\section{The Japanese War Experience - Kobayashi Masaki's Ningen no joken}

Before talking about the movie itself, one must look at the Japanese film industry during the 1950s. In October 1945, the Civilian Information and Education Division (CIE), a subsidiary organization of General Headquarters of the Supreme Commander for the Allied Powers, received the task of managing the entirety of the Japanese film industry. CIE had absolute authority over the films produced as well as all censorship tools. A list of elements banned from films appeared. It included the following: praising nationalism, patriotism, or fealty to feudal thought; revenge stories, stories praising suicide; any work that encouraged cruelty or immoral violence. The occupying authorities did not simply ban certain themes but also encouraged the production of 'idea films' as a means of promoting the American-style democracy. ${ }^{18}$

The censorship was in effect only until 1951, as in September, the San Francisco Peace Treaty was ratified, and in the following year, Japan regained its independence. The film censorship was eliminated, and Japan's filmmakers were not constrained into making idea films anymore. Unfortunately, the idea that a war based on militarism was evil was abandoned by some filmmakers, the war experience being portrayed sentimentally by some directors. Movies depicting the heroism of the Japanese soldiers and sailors, such as Battleship Yamato $(1953)^{19}$ or The Tower of the Lillies (1953) ${ }^{20}$ were typical. These films were not just movies; they were received as important events in Japanese society. They had one thing in common: the confirmation of the consciousness of the Japanese people of themselves as the actual victims of the war. ${ }^{21}$ Despite numerous contributions that dealt with war stories had been previously banned, the 1950s also saw one of the most acclaimed attempts in coming to terms with the past, which is Kobayashi Masaki's Ningen no joken.

The Human Condition is a nine-and-a-half-hour long trilogy which was released between 1959 and 1961. The films were directed by Masaki Kobayashi and used Jumpei Gomikawa's novels with the same title as the main source of inspiration for the plot. Kobayashi felt a deep connection to the story of Kaji, a fresh university graduate conscripted into the army in Manchuria who struggles to retain his humane principles in the whirl of

\footnotetext{
${ }^{18}$ Inuhiko 2014, 99-102.

19 The film portrayed the mission of the Japanese warship Yamato to defend Okinawa against the upcoming attack of the United States forces (see: Inuhiko, 2014, 112).

${ }^{20}$ The movie describes the deaths of many young girls on the battlefields of Okinawa as an act of heroism (see: Y. Inuhiko 2014, 112).

${ }^{21}$ Inuhiko 2014, 109-112.
} 
war. Both Kobayashi and Gomikawa shared the same experience during the Second World War, as they served in Manchuria during the conflict. They opposed the war, yet their resistance was passive and unspoken, which stirred a sentiment of guilt and regret in both of them..$^{22}$

Kobayashi thought that his experiences during the war granted him the necessary tools to make this film, and he felt that Kaji's experiences during the war were his own. Like the protagonist, Kobayashi despised the military, but both became good, obedient soldiers who led to the emergence of an internal sense of self-betrayal. The filmmaker resented the enrolment in the army, but he had to accept it as the only means for surviving. ${ }^{23}$

I chose Kobayashi's films for several reasons. The first is related to their generous runtime of nine hours and a half and that Kobayashi chose to portray the behavior of the Imperial Japanese Army without hiding its gruesome behavior. The director described the Red Army's brutal behaviour during the last months of the war against the Japanese. Another reason is the insight given on the life of the Japanese soldiers from a double perspective (as the oppressors in the first two films and the oppressed in the last film when the Soviets captured some Japanese soldiers). The movie also does not refrain from addressing issues considered taboo by many nationalists, such as the poor treatment of the prisoners of war or the question of comfort women. Lastly, the movie served as a suitable means of portraying the conflict between two parts: the fanatical leaders and their followers, and those who did not support the expansionist ideas but were constrained into joining the military under the threat of incarceration, on the other hand.

In this section, I will analyze how the war affected the main protagonist and how the unfolding of the conflict perverted his ideals. I will also try to present the behaviour of the Imperial Japanese Army, what the conditions were in the Japanese occupied territories and how the prisoners of war were treated. The conflict between what is considered to be moral and what is not will also be considered. Lastly, life in the Imperial Japanese Army and the conflict between the fanatical and indoctrinated leaders/soldiers and those who chose not to abandon reason and human values throughout the war will also be presented. In my analysis, I will use my observations on the movie (alongside movie quotes) and several contributions to the film series. ${ }^{24}$

\section{No Greater Love (1959) - A pacifist's attempt to remain humane}

The first installment, No Greater Love (1959), takes place in 1943 Manchuria (the region in the North-East part of China, which Japan occupied from 1931). In the first sequence, a mural depicting several soldiers and civilians is showed. The soldiers are most likely committing crimes as it looks like they are assaulting women and robbing civilians. This image can help us outline a general image of the military occupation for the countries occupied by the Imperial Japanese Army. Given that the movie's main character is a pacifist, the mural can also be interpreted as Kobayashi acknowledging the errors of the past, as he is not trying to deny that such acts never existed.

\footnotetext{
22 Prince 2017, 123.

23 Prince 2017, 124.

${ }^{24}$ See: Prince 2017, 123-177; Orr 2001, 116-129.
} 
The first scene when we meet the protagonist is symbolic, as Kaji and his lover, Michiko, are outside on a cold winter night. At the same time, their rendezvous is interrupted by a column of marching soldiers (who represent Kaji's fear of conscription in the army). The atmosphere is distressing, specific to the war period, best illustrated by the crumbling wall present in the background. Their first interaction also introduces us to one of the war dramas, the fear of leaving the loved one at home while being sent to the front. The fear is why Kaji decided not to marry Michiko yet, as he faced the perspective of being conscripted.

The nature of Kaji's character is revealed in the first minutes of the movie when his supervisor calls him to the South Manchuria Steel Company to discuss his report about the supervision of colonial labor. During this meeting, Kaji claimed that 'Men should be treated as men - I suppose that is the gist.' ${ }^{25}$ Despite the suspicions of leftist tendencies, his boss is intrigued by Kaji's report. Thus, to put his methods to use, Kaji is offered the chance to work as a work supervisor at the Loh Hu Liong mine in exchange for exemption from military service. After presenting this dilemma to his friend Kageyama, he encourages Kaji to accept the offer of his supervisor, and at the same time, marry Michiko. Despite the harsh conditions in that area, a small village with an ore mine and a labor camp, Michiko accepts Kaji's proposal of marrying him.

The journey to the mine is symbolic. Michiko and Kaji travelled to the labor camp in the back of a truck to shelter themselves from the winds driving clouds of dust across a barren landscape. The dust was similar to smoke as the landscape looked as if it was burnt. The scene reminded the viewer of the image of hell. The protagonist is thus journeying into hell. The trip underlines the idea to the labor camp and the suffering of the prisoners working in the mine. ${ }^{26}$

After arriving at the mine, Kaji hoped that he could be able to dwindle the excess of violence from within the labor camp administration. At the same time, he hoped to fulfill his desire for personal happiness. The first person he meets there, Okishima, will be his associate, and to Kajis surprise, they share a series of ideals. Though Okishima sympathizes with Kajis ideas and collaborates with him in implementing them, he doubts that Kaji's plans could be implemented within the 'rotten' administration of the camp where violence and inhuman treatments towards the prisoners were the predominant attitudes of the majority of supervisors. As Okishima implies, if they tried to show compassion for the Chinese, both would be buried with the prisoners. The only path for survival for the men thus lies in the act of compromise, the fact that Kaji is not yet ready to accept. ${ }^{27}$

Kaji's approach towards supervising work as the camp is as follows 'If labor conditions are improved, more men will show up to work. ${ }^{28}$ He proposes a radical change in the employment system, paying increased attention to the necessity of improving labor conditions for the workers within the mine, who, in his opinion, deserved to be treated with respect. If they were to be treated as fellow human beings, he believed that better results in the production quota could be achieved. Kaji is an idealist, and therefore his

\footnotetext{
${ }_{25}$ Kobayashi 1959, 00:08:04.

26 Prince 2017, 132.

27 Orr 2001, 118.

${ }^{28}$ Kobayashi 1959, 00:19:10.
} 
beliefs will soon clash with the conservative and militaristic beliefs of the 'gang' running the mine. They were only interested in meeting the quotas, and they did not care about the miners' well-being, but still were ineffective. When Kaji called out their incompetence, the 'old gang' resorted to favoritism from Kuroki, the head of the labor camp and Kaji's boss, in order to not get penalized, which for Kaji seemed inadmissible.

Thus, Kaji identifies the danger that the 'old gang' represented for the health and well-being of the miners, as he begins a battle for obtaining better food rations, medical care, and work conditions. One his statements best illustrates his attitude towards the miners: 'It's ridiculous to compare men with ore. Take care of your men and the ore will come out $^{29}$ in a dialogue between him and Okazaki, a supervisor who was constantly abusing his men. Despite constant quarrel between Kaji and people like Okazaki, it seemed that the old administration did not want to change the way of running the mine, as Okazaki said that 'Let me make it clear, that Okazaki of Loh Hu Liong won't be changed by any of your half-baked theories. I'll stick to my own ways. ${ }^{30}$

Although Kaji manages to improve the living conditions for the laborers and production does increase, he becomes more involved in the war effort when the Kenpeitai ${ }^{31}$ force him to introduce 600 prisoners of war (POW) laborers into the mine's workforce. ${ }^{32}$ Despite Kaji's principles, his initial attitude towards the Chinese POW is marked by an expectation that they should be grateful for his efforts and blindly trust his good intentions. In this instance, Kaji's mistake is that he regarded the Chinese as subjects of his work and failed to understand the situation from their perspective. This is best shown during the first meeting with the POWs. Their leader, Wang, tells Kaji that the Japanese came to their villages, raped the women, killed the men, and sent the rest to the labor camp, where they were hungry and dying. He then tells Kaji that they deserve to be free, to which Kaji replies that he has no authority to grant such a thing but instead promises them protection. Kaji's words are considered lies by Kao, a hot-headed Chinese patriot, who thinks that the Japanese never keep their promises. Kao's claim would soon be proved right, as Kaji's authority was undermined when Okazaki beat and murdered one of the workers and was not punished for his actions. ${ }^{33}$

Kaji's inability to understand the POWs situation is evident in his interactions with Chen, a Chinese assistant who tells Kaji that he would most likely get in trouble if any of the prisoners escaped. Surprised, Kaji couldn't think of why they would escape and asked Chen for his opinion. He then explains that the men used to work in their villages and were away from their homes, with no family, wives, or children. Kaji refuses to acknowledge the truth as he cannot accept the role of the antagonist in this story. ${ }^{34}$ His interactions with Chen will also be the first step in his dehumanization process. After an episode when Chen is caught stealing flour for his sick mother, Kaji resorts to violence and slaps Chen in the face. This behavior, according to Kobayashi, was an indoctrination practice of the Imperial Army. Using violence, Kaji becomes an accomplice of the system that he despises, and by

\footnotetext{
${ }^{29}$ Kobayashi 1959, 00:27:51.

${ }^{30}$ Kobayashi 1959, 00:28:02.

31 The Japanese military police.

32 Orr 2001, 118.

${ }^{33}$ Prince 2017, 140-141.

34 Prince 2017, 141.
} 
his failure to resist violence, he facilitated the system and its goals. For his cowardice, Kaji was rebuked by his wife, who tells him that 'I know why you struck Chen. You could have forgiven him for such a small matter. It's because you lost face in the front of the others. For a man who aspires to great things you have a small mind.' Thus, when Kaji struck Chen, he became the representation of a Japanese beast and devil known by the Chinese; he became what he detested the most, a violent actor of the occupation and a defender of Japanese imperialism. ${ }^{35}$

If Kaji overcame his hypocrisy and returned to its humanist principles, he had to embrace the POWs' position. This was his most difficult challenge in the first installment and is illustrated when Kao and the other six POWs were accused of attempting escape and were summarily sentenced to beheading. ${ }^{36}$ This episode was predicted by Okishima's departure from the mine (in order to solve some administrative matters). Before his leaving, he said that 'I'm boarding this run-down truck, but you're trying to catch the train of humanism before it's too late. I won't stop you. You seem willing to pay the fare, no matter how high. ${ }^{37}$ Okishima's words seem to illustrate the determination Kaji had in his attempt to reform the camp's operational policies, despite the hardships he encountered along the way. In a place of constant violence and suffering, this trace of humanity will, unfortunately, be the reason why Kaji will lose his exemption from military service and thus will experience the reality of war himself.

At the execution grounds, Kaji finds a new resolve. The seven prisoners kneel with their hands tied and plead for mercy while Watari, a Kenpeitai officer, wets his katana, as according to him, it helps prevent fat from sticking to the blade. Watari beheaded two men while Kaji was watching speechlessly. When Kao was brought in front, he watched Kaji with hatred and called him a hypocrite, saying, 'Inhuman wretch. This is your true form. The face of a man but the heart of a beast.' This was the moment that determined Kaji not to sit idly anymore and confront Watari, as the other Chinese POWs joined him in chanting the word 'Murderers.' Fearing a full-scale mutiny, the officers decide to halt the execution and arrest Kaji. ${ }^{38}$ After the Kenpeitai tortured him, he would return to the mine. As he entered Kuroki's office, he presented him the drafting papers, and this is the beginning of Kaji's real suffering.

\section{Road to Eternity (1959) - A pacifist in the army}

The first sequence of the second installment is a mural, too. It depicts several Japanese soldiers alongside, probably, prisoners of war. The action is set in the winter of the following year yet again in Manchuria. From the film's first minutes, one experienced the violence taken to a level of fanaticism specific for the Imperial Japanese Army. This time, violence is used against their recruits. The scene that sets the tone for the movie is when the new conscripts are beaten by their superior because some of the soldiers have thrown a cigarette in one of the water buckets that was supposed to be kept clean and sanitized. This scene also shows Kaji's vigilante character, as he thinks his superior's action is wrong, while at the same time, he tries to defend his colleagues.

\footnotetext{
35 Prince 2017, 141-142.

36 Orr 2001, 119.

${ }^{37}$ Kobayashi 1959, 2:32:08.

38 Prince 2017, 145-146.
} 
Japanese officers' behavior and contempt for those failing to complete their task are also shown during a scene when the soldiers are out for target practice. For his poor performance, Obara, one of the weaker soldiers, is constantly beaten and ridiculed by both his colleagues and his superiors, who in one instance told him that 'You're a disgrace to the whole Kwangtung ${ }^{39}$ Army. ${ }^{40} \mathrm{He}$ was constantly reminded that 'A sense of responsibility is a soldier's life. A grenade could wipe out your squad because of your missed shot. Show some responsibility and some shame. ${ }^{31}$ The constant verbal abuse of the officers did not encourage the young recruit but placed even more mental stress on his shoulders. Another scene that depicts the abuse of the army officers is when Obara was forced to rewrite a letter to his wife. He is forced to do so because in the original letter, he mentioned the mental and physical stress that was forced upon him by statements such as 'It's driving me crazy' or 'I am so worried that I could never face death. ${ }^{42} \mathrm{He}$ is labeled as unmanly, one of the officers saying, 'Coward, I've never seen a worse soldier in ten years of service. ${ }^{33}$ Another thinks that 'Such effeminate ideas are more harmful than Red propaganda."4

A change in Kaji's personality occurred during his final instruction test at the camp. Obara was doing poorly during the march, but Kaji decided to help him by carrying half of his equipment. Unfortunately, Kaji will ultimately give up on him because Obara refused to continue the march even though the distance left was relatively small. Kaji has an outburst and tells Obara, 'Then to hell with you.'45

This action again shows Kaji's limitations, as he cannot show empathy but instead choose to use the violent attitude of the army that was slowly starting to impregnate his character. Kaji's limitation is evident when he refuses to intervene, and Obara is again abused for failing to complete the march. Obara's humiliation reaches its peak this time, as he is forced to mimic a prostitute and ask favors from his fellow soldiers. The attitude of Kaji in these episodes underlines an antithesis to Kajis attitude in the first installment when despite all odds; he tried to do everything in order to help the Chinese prisoners. The attitude he shows in the second film is different, as he abandons Obara easily and results from the stress and abuse specific to the military instruction. The desire to survive and get back to his wife is also a factor that shaped this attitude. Kaji chose to do his best in military training to fulfill his desire, even though it meant 'walking over dead bodies.'

After the bullying episode, Obara committed suicide, and this episode affected Kaji profoundly. Obara's suicide shapes Kaji's future evolution as a character, leaving us with the impression that he was starting to get back to his older self slowly. Two of Kaji's actions illustrate this conclusion. Firstly, Kaji demands that Yoshida, the one who pushed Obara to suicide, be punished for his lack of camaraderie and compassion. In this instance, Kaji claimed that he was even willing to violate military regulations to serve justice. Kaji even chose to confront the superior officers claiming that Obara's death was not caused by his

${ }^{39}$ An army group of the Imperial Japanese Army, that existed from 1919 to 1945 and was stationed in the region of Manchiuria.

${ }^{40}$ Kobayashi 1959, 00:10:57.

${ }^{41}$ Kobayashi 1959, 00:11:05.

${ }^{42}$ Kobayashi 1959, 00:50:21.

${ }^{43}$ Kobayashi 1959, 00:50:33.

${ }^{44}$ Kobayashi 1959, 00:50:42.

${ }^{45}$ Kobayashi 1959, 00:56:23. 
weakness but by the military itself. Later on, he will claim that 'Our real enemy is the army.'46 Yoshida will not be punished but drown in a marsh while he and Kaji chased Shinjo, who decided to desert while a wildfire started near the compound. After this event, in which Kaji almost died as well, Kaji will be hospitalized.

Secondly, after being discharged from the hospital, Kaji meets his old friend Kageyama, who asks him to assist in training a group of recruits, claiming that under his guidance, 'You could spare those recruits a lot of grief. ${ }^{47}$ Kaji was reticent at first, but his implication in the training process could prevent fresh conscripts end up like Obara, which made him accept Kageyama's offer. He had one condition that the veterans should not interfere in the training process of his squad. Kaji claims that 'Training alone won't make men strong. I'll work them hard during training, but show them kindness in the barracks. I want to train men who'll be willing to die with me. ${ }^{38}$ Thus, one can observe a joint between humanistic and militaristic ideas in Kaji's reasoning. Nevertheless, Kaji received punishment from the veterans when they accused the recruits of misconduct, and in one instance, he chose to be punished alongside his squad.

The end of the second film presents the war situation in which Japan was at the time, Kaji's superiors receiving the news that Okinawa had fallen to the US forces. ${ }^{49}$ Kageyama was skeptical about Japan's chances of victory. However, by doing so, he quarreled with the other officers who could not grasp the reality Japan found herself in the last months of World War II. The generals claimed that 'Japan's not as feeble as you might think. A pessimist like you can't begin to grasp its strength. Yes, we've had to draw back our battle lines. We've lost Okinawa and face battle on our main land, but that's all part of our basic strategy. Look how the enemy doesn't yet dare to attack our main island.50 This is a prime example of the pride and underestimating the enemy's strength that Japanese military staff showed throughout the Second World War. This resulted in a series of catastrophic tactical decisions taken by the Imperial Japanese Army and Navy.

Meanwhile, the news about Okinawa does not discourage Kaji, who claims that 'Personally, I love my wife more than ultimate victory. ${ }^{51}$ Consequently, one can see that he continues to value human life more than an unrealistic goal set by some fanatical leaders. The last days of war will find Kaji and his squad digging a series of fortifications along the Soviet border. At first, their attitude is carefree. Soon they will experience the true horrors of wars first-hand, as a massive Soviet offensive, which devastated the Japanese lines, was launched upon Kaji's position. This is the moment when Kaji abandons everything related to humanism. The final scenes show how the actual combat can affect a man. In the final moments, Kaji claims that 'I'm a monster, but I'm going to stay alive,, ${ }^{52}$ as he is forced to kill one of his comrades. He went mad and started screaming so that his whereabouts were not to be revealed to the enemy. This moment marked the decadence of Kajis persona as the horrors of war seem to already take a toll on him.

\footnotetext{
${ }^{46}$ Kobayashi 1959, 2:14:18.

47 Kobayashi 1959, 1:46:21.

48 Kobayashi 1959, 1:47:40.

49 Okinawa fell in June 1945.

50 Kobayashi 1959, 2:02:36.

${ }^{51}$ Kobayashi 1959, 2:04:40.

${ }^{52}$ Kobayashi 1959, 2:56:58.
} 
One last aspect of the second installment mentioned is the conflict between Terada (the son of an army officer), a sympathizer of the idea of ultimate victory, and the squad members, as they did not share the same ideals. Terada claimed that 'They only think of themselves, not our country. ${ }^{53}$ His attitude was in opposition, for example, to the one of an older soldier that thought, 'Even if we lose, if I survive, my wife has a future. If parents survive, the kids have a chance to grow up, ${ }^{54}$ as well as with Kaji's humanist nature. He claimed that 'I can't approve of how your father raised you, ${ }^{55}$ thus referring to the wrong set of values promoted by the militaristic leaders.

\section{A Soldier's Prayer (1961) - Kaji's final punishment}

The final installment begins with Kaji's attempt to find any remaining survivors following the Soviet attack and try to regroup with the remaining forces of the Kwantung Army in South Manchuria. After the killing of a Russian soldier (this action corrupted Kaji's ideals and the pacifist values that he held dear ${ }^{56}$ ) and a flashback of the Soviet attack, Kaji got sick of the conflict and decided not to join the army ranks again. The toll of real combat on Kaji is best illustrated by a monologue of his addressed to Michiko (there will be other instances where such monologues occur). During the film, the monologue represents some kind of prayer that Kaji uses to justify his actions but also atone for his crimes: 'Michiko... I am a murder. These hands that once caressed you killed a man in cold blood. Just to cross the road to safety! Was it justified, or was it wanton murder. ${ }^{37}$

Rather than continuing to support a conflict he disapproved of, Kaji decided to lead the remaining survivors to safety, offering protection to several refugees he meets along the road, who consider that meeting Kaji was 'like meeting Buddha in hell. ${ }^{58}$ The journey was not easy, as civilians and soldiers were affected by the lack of food, water, or diseases. In one instance, some refugees even chose to eat poisonous mushrooms, ultimately leading to their death. Besides the suffering of civilians, the soldiers' pain is also illustrated, especially for those who felt dishonored because they were still alive.

For some of them, an honorable death on the battlefield would have been better. One of the soldiers claimed that 'I should have died a hero's death in action. I'd be in a fancy coffin at Yasukuni Shrine ${ }^{59}$ (being buried in the Yasukuni Shrine complex represented a great honor for the soldiers of the time, as it was proof that one has served his country and emperor accordingly). ${ }^{60}$ For Kaji, the experience of war and its uncertainty is illustrated when he marches alongside these soldiers 'Can I keep walking? Where I am headed anyway? All this walking, it is just a waste of time? Has South Manchuria become just another mass grave for the Japanese? Maybe there's nowhere left for the Japanese to go.' ${ }^{61}$

\footnotetext{
${ }^{53}$ Kobayashi 1959, 2:31:16.

${ }^{54}$ Kobayashi 1959, 2:31:00.

${ }^{55}$ Kobayashi 1959, 2:32:10.

56 Prince, 2017, 160.

57 Kobayashi 1961, 00:09:43.

58 Kobayashi 1961, 00:18:09.

59 Kobayashi 1961, 00:36:25.

60 The Yasukuni Shrine is a complex of Shinto shrines built by Emperor Meiji which is used as a resting place for the soldiers who fought in Japan's wars from 1868 to 1954.

${ }^{61}$ Kobayashi 1961, 00:39:13.
} 
One can notice that Kaji is slowly starting to lose hope, and a mantle of fatalism falls on his shoulders. The skepticism begins to settle in Kaji's mind as he is unsure whether he will be able to return home alive. Kaji starts to have a series of flashbacks related to the first film's events (the scene of execution), which makes him feel even more guilty than before. As a result, he thinks he does not deserve to return home as his decisions prevented the POWs return to theirs.

In one scene, Kaji's opinion about the militaristic leaders becomes clear as he claims, 'The country you were taught to know will be dead... and that's how it should be. Japan's full of helpless creatures like myself... or worse. ${ }^{62}$ This message illustrates Kaji's anti-war beliefs and his hostility towards the fanatical leaders of the country that pushed Japan into a vortex of constant suffering in the name of their misguided ideology. In Kajis opinion, the deviation from humanist ideals could be achieved through the 'destruction' of the country. Only this way, democratic society would emerge at the end of the war. Despite his beliefs, Kaji also acknowledges that he had an active role in the process that would ultimately destroy his country because 'the joys we shared at the cost of Chinese sacrifices, I am now paying dearly.' ${ }^{63} \mathrm{He}$ is also aware of the fact that 'I must kill and steal to fight my way back to you'64 (referring to Michiko) in order to fulfill his desires. This behavior opposes the humanist nature of the first film, in which Kaji considered that theft and murder could not represent means of fulfilling one's desire. Thus, one can notice the effect warfare has on changing one's way of thinking and ideas.

The movie pays special attention to the cruelty of the Red Army. A woman is thrown out of a truck after the Soviet soldiers have most likely abused her. Kaji is reluctant to accept the truth due to his socialist beliefs. He claims that 'The Red Army wouldn't mistreat civilians, ${ }^{3}$ but immediately received a glimpse of reality when one refugee woman tells him that the Red Army mistreats: 'Not any civilians - just Japanese women. And the Manchus squeal on us to the Russians. The prison convoys are a sickening sight. Nothing's more pitiful than the women of a defeated nation.' ${ }^{66}$

Despite the woman's testimony, Kaji refuses to abandon his ideational views on the Soviet Union. Consequently, he chose to compare the incident with the same wrong path Japan had taken during its history: 'Of course, there must be scoundrels in the Red Army too. A handful among the millions, a few dozen, or a few hundred like that. No, do not undermine the theory of the Red-no- the People's Army. ${ }^{67}$

In the later parts of the film, Kaji and his squad went to a village to meet women and an older man. During the encounter, the villagers complain that the remaining disorganized Japanese troops 'Brought nothing but trouble. They stagger in half-starved. We've used up all the supplies we brought, and our fields have been constantly plundered.' ${ }^{6}$ One woman from the village even claimed that 'they're better than our own men. They bring us bread.

\footnotetext{
62 Kobayashi 1961, 00:46:01.

63 Kobayashi 1961, 00:56:48.

${ }^{64}$ Kobayashi 1961, 00:57:00.

65 Kobayashi 1961, 1:15:37.

${ }^{66}$ Kobayashi 1961, 1:15:42.

${ }^{67}$ Kobayashi 1961, 1:16:14.

${ }^{68}$ Kobayashi 1961, 1:47:46.
} 
If we're nice to them, they leave peacefully. Not like our troops, who are just freeloaders.' ${ }^{69}$ This was a rare sight indeed, given the numerous acts of violence committed against the Japanese population of Manchuria. Moreover, the Soviet commanders even encouraged the Chinese population in the area to partake in such actions.

The end of the third film can be interpreted as Kajis ultimate punishment for the hypocrisy of participating in a war he did not approve of. He is transposed into the role of the Chinese prisoners of the first movie, as he and his brothers in arms were captured by the Soviet troops. One is yet again exposed to the cruel treatment shown by the Japanese authorities throughout the first movie. Kaji will thus experience the humiliation and acts of violence himself, just as the Chinese laborers did in the first movie. His first trial was the march to the labor camp, which resembles the episode when the POWs were brought to the mine (except that Kaji did not travel by a train), as the Japanese had to march in extreme conditions, with no rest, water or food.

His second trial is represented by the fact that Kaji did not escape the draconic work conditions of the Japanese, not even at the Soviet labor camp. The camp was led by former Imperial Japanese Army officers that decided to collaborate with the Soviets. He received the same harsh treatment as the Chinese in the first movie, alongside the other Japanese soldiers that the Soviets captured. Despite this, Kaji and Terada decided to undermine the authority of the Japanese collaborators. They started scavenging through the Russians' garbage, looking for food that could be added to the rations. He also decided to create new clothes out of the gunnysacks found in the labor camp. For their actions, he was labeled as a saboteur, judged, and sentenced to harsh labor.

The Soviet labor camp is also where his romantic ideas about socialism and the Soviets start to wane. This resulted from a corrupt interpreter and Soviet officers' attitude towards the inhumane treatment of their Japanese collaborators. Kaji claimed that: 'I survived the battle and tried to escape. I hoped to find proof here that I was wrong to run. But now I see that it was an idealistic miscalculation. Russia's needs and its historical mission lead it to destroy human lives and then justify doing so. ${ }^{70}$ The Soviet Union thus becomes an aggressor, like Japan, in the eyes of Kaji, who thought that the two countries followed the same wrong path during the war. Kaji confronts an authoritarian system, represented by the Soviet interrogators, whom a corrupt Japanese translator misleads. Unfortunately, the interrogators misinterpreted Kaji's humanitarian protests against the insufficient food and clothing for prisoners and Kaji was labeled as a 'fascist samurai.' ${ }^{\text {'1 }}$

While Kaji was sent out to harsh labor, one of the Japanese collaborationists, Kirihara, beat and worked Terada to death after he was caught looking for food in the garbage. Kaji decides that Kirihara needs to atone for his crimes and chooses to kill him then escape from the camp on his own. This is the final step of the dehumanization of Kaji. From a pacifist who would never consider murder to solve a problem, he resorted to such action with no remorse. After escaping, Kaji meets a group of Chinese peasants that ridicule and call him a 'Japanese devil' and then beat him when he asks for food. He is exhausted and continues to move and eventually succumbs to the cold, dying covered in snow in the wastelands.

\footnotetext{
${ }^{69}$ Kobayashi 1961, 1:48:44.

${ }^{70}$ Kobayashi 1961, 2:35:30.

71 Prince 2017, 169.
} 
This is the final punishment bestowed upon Kanji for not sticking to his beliefs and for contributing to a war that he despised from the beginning. Kajis death also represents the pain and grief of all families or individuals who experienced the horrors of the Second World War.

The choice of Kaji's clothing needs to be addressed before concluding, as it has a deep meaning. Kaji's final moments were influenced by the Christian elements, as his clothing would be called sackcloth, and wearing such attire. At the same time, fasting (represented by Kajis lack of food) represented a means of repentance and humility. Kaji's clothing, fasting, and a scene where he carries a heavy bag on his back, like Christ, until he falls to the ground suggest that Kaji is repenting not only for his crimes but also for the crimes committed by the nationalistic leaders of the time. When he covered by snow in the final images of the film, his death represented a sacral moment. ${ }^{72}$

\section{Conclusions}

Ultimately, The Human Condition carries a message of the individual's inability to change things in the face of war and institutions such as the military. Kaji ultimately becomes a tragic figure whose weakness and failure elicit sympathy from the public. In order to achieve the purity of manhood as a 'human being, he became a victim of the militaristic regime. His sacrifice could also serve as a means of emphasizing the importance of examining the problem of war responsibility and how one must not hide the errors of the past but try to learn from them and ultimately correct them. ${ }^{73}$

Kaji's idea of treating the workers as human beings can be interpreted as a means of maintaining humanistic principles in the face of an on-going conflagration. Kaji is hesitant to accept the offer of supervising a labor camp, making him an accomplice to the war effort. As he presents this side of the story to Kageyama, his draft-evader friend, Kageyama points out that they are already accomplices of the war, as both are opposed to the war. However, neither of them dares to face a jail sentence for blaming the war publicly. They chose an opportune, yet hypocritical, method of avoiding military service, emigrating from Japan to Manchuria, which could be considered a bastion of Japanese imperialism of the '30s. Kageyama claimed that 'It is odd for him to worry about selling out now', as both of them transformed from a 'young anti-war champion to a henchman of the merchants of death.' Thus, they decide to borrow Kaji's metaphor, telling him to make something good out of the proposed exemption and become a 'good sheepdog who leads the sheep to green pastures.' ${ }^{34}$

Despite his hatred for the war, Kaji ultimately becomes a war profiteer himself, given his privilege of draft exemption. In contrast to the village, the house where Kaji and his wife lived was spacious. It had multiple rooms, elegant furniture, a study filled with books for Kaji, and even electricity to power consumer goods like their radio. Compared with the living conditions of the Chinese, Kaji lives a comfortable life while he helps to administer Japan's colonies. Instead of offering a ready-made hero, Kobayashi systematically interrogates Kaji and his failure to light the errors of passive resistance Kaji has chosen. This could also be

\footnotetext{
72 Prince 2017, 170.

73 Orr 2001, 128.

${ }^{74}$ Orr 2001, 117.
} 
said about Kobayashi and Gomikawa, as they both found themselves in Kajis shoes when they enlisted. Consequently, the film could be considered a self-critique of the filmmaker for not acting accordingly to his beliefs during the war. ${ }^{75}$

By accepting the draft exemption and the job as mine labor supervisor, Kaji knew that he compromised his principles of justice and humanism in exchange for a safe and comfortable life with his wife. From the start, he hoped he could serve as a buffer against imperialist cruelty. However, the execution episode in the first installment forced him to confront his failure to save the Chinese prisoners. The episode also served as a warning meant to limit any further compromise of his ideals, but he became a victim of imperialism as well. ${ }^{76}$

Ultimately, the hero's death could represent the individual's helplessness to the unfolding of historical events. Kaji does not prevail over the circumstances he was forced to face. At the same time, he chose not to despair and instead fought to fulfill his desires. Though unsuccessful in achieving his objective (returning home to his wife), his death is symbolic. As Kobayashi admitted, there was hope that humans could overcome the evils of the war $^{77}$ and ultimately acknowledge their misdeeds. For the producer, the hero's death represents the condemnation of human evil and a symbol of hope for the film's viewers. According to Kobayashi, Kaji became a martyr for humanity. The humility and repentance illustrate this fact that he shows during the final sequences of the movie, where he does not blame his wrongdoings on others but instead chooses to accept its punishment. With his death, Kaji thus can live in the minds of people for eternity as a symbol of hope in eradicating the human tragedy of war $^{78}$ but at the same time serve as a warning on the importance of acknowledging the misdeeds of the past.

Kobayashi Masaki's Ningen no Joken was not the first artistic work that condemned the militaristic past of Japan. After the war, several autobiographical writings from the Japanese soldiers were published. One can mention Noma Hiroshi's The Zone of Emptiness (1947) and Ōoka Shōhei's A Prisoner's Record (1948). Both works promoted a powerful anti-militaristic message. The books recorded the authors' personal experiences who served in the army during the war. Thus, the violence, the repression, and even the bullying, which were constant in the Japanese Imperial Army were finally publicly exposed before the Japanese public. Ōoka's statements regarding the war were also self-explanatory. They represented a slap to the face of the militaristic leaders, as he claimed that 'I never felt that the position of a prisoner was as shameful as the military had taught me.' At the same time, he was one of the few writers that blamed the silent majority for the rise of militarism, claiming that 'I felt strong hatred towards the military that had drawn my home country into such a desperate war; but I also felt that I did not have any right to complain about the regime since I myself had not done anything to prevent it from coming into being in the first place. ${ }^{79}$

Another instance in which the militaristic past was brought to light took place in 1957. Determined to solve the lack of knowledge about Japan's campaign in China, some war

\footnotetext{
75 Prince 2017, 134-135.

76 Orr 2001, 121.

77 Prince 2017, 174.

78 Prince 2017, 173.

79 Shimazu 2003, 103-104.
} 
veterans who had just returned home from captivity decided to make public the immoral behavior of the Japanese Imperial Army during its military campaigns in China. Their confessions were published under the title of Sanko, ${ }^{80}$ which ultimately became a bestseller. The veterans were, however, labeled as communists or a disgrace to the entire nation. Under threat from right-wing sympathizers, such confessions were no longer published. Such images could not be shown to the Japanese public in a time when the government was aligning itself to supporting the US policy of containing China and commemorating the losses in the war. ${ }^{81}$

One last instance, before Kobayashi's trilogy aired, was the publication of Gomikawa Junpei's books. They have the same name and represented the source of inspiration for Kobayashi. Gomikawa's work is unique, even today, as the author opted to depict the Japanese as the aggressor, thus the Japanese people were not the only victims of the imperialist leaders. Emphasis was also given to the suffering of Chinese and Korean citizens, who were considered second-class citizens of Japan's Greater East Asia Co-Prosperity Sphere. ${ }^{82}$

The Human Condition differs significantly from other artistic works that tackle the subject of experience of the war, as it looks beyond Japan and the war's effect on the Japanese. Kobayashi shows and criticizes the military and economic imperialism that Japan directed at China alongside the specific cruelty of the Japanese authorities. The Imperial Japanese Army was also his target, as he shows its oppression of Chinese laborers and then of its conscript soldiers. The films also show the mistreatment of Chinese living under Japanese occupation in Manchuria, depicts Chinese characters in important roles, thus dramatizing their points of view toward the Japanese whom they considered devils. ${ }^{83}$ Kobayashi's work thus offers its viewers a 'logic of negation,' one's refusal to adapt to the world unconditionally just for the sake of survival and well-being. He revolts against the profane principles present in war and offers the alternative of an ethical and moral world based on universal principles. ${ }^{84}$

Another unique characteristic of the film is the glimpse of the criminal underworld that is most likely to appear in occupied territories. The leader of this criminal network was Furuya, who has the other supervisors at the mine working for him. The relationship between Furuya and the others is part of a web of underworld alliances that links numerous personnel that works at the mine. These even include the comfort women who live in the village as well, as their leader Jin, plots with Furuya to arrange small-scale escapes that were used to get revenge on Kaji. One must also mention that one of Kajis duties was also the supervision of the comfort women, which made him feel disgraced, comparing himself to a manager of whorehouse. This little detail also emphasizes one of Japan's biggest atrocities during the Second World War, which was enforced prostitution, a problem that many conservative or nationalistic leaders sought to bury or deny. This problem remains a new topic, but it is still a slap in the face for those who refuse to acknowledge past errors. ${ }^{85}$

\footnotetext{
80 Which translates as 'Burn All, Kill All, Steal All' See: Bix 2001, 657.

81 Bix 2001, 657.

82 Shimazu 2003, 104.

83 Prince 2017, 128.

84 Prince 2017, 129.

85 Prince 2017, 136.
} 
An element worthy of mentioning about Kobayashi's trilogy is the illustration of the hatred towards the left and pacifist ideas present in the barracks. This was materialized by insults addressed to Kaji (who is suspected to be a Red ${ }^{86}$ ) such as, 'You're a Red shit, just like him's7 (referring to Shinjo, one of Kaji's friends that was also suspected of leftist tendencies). The hatred towards communism was not specific to the military only, as it was present in the political and civil societies of interwar and wartime Japan. The militaristic leaders spread this sentiment with the help of the propaganda machine of the Empire. They claimed that the left-wing sympathizers wanted to overthrow the values and identity of the Japanese state by destroying the so-called Kokutai ${ }^{88}$ It is known that the left wanted the Japanese Monarchy abolished and even had a hostile attitude towards its members. In 1923 the Japanese emperor Hirohito, the crown prince, survived an assassination attempt carried out by a left-wing sympathizer). Because of the egalitarian beliefs and hostility towards the monarchy shown by the left sympathizers, the conservative leaders demonized anything related to the left movement, its members ending up in jail. A promulgated law (known as the Public Security Preservation Law of 1925) stated that belonging to any movement/ organization whose purpose was to disrupt the Kokutai was forbidden, death being the punishment for partaking in actions that could have affected the unity of the Japanese state.

One last aspect unique to the movie is what I consider a parable for the watcher. One such instance is the surprising development of Terada's character. In the second film, he was portrayed as a nationalist. Throughout the series' final installment, Terada has grown into a compassionate man instead of an arrogant right-wing nationalist like he was in the beginning. He thus models himself after Kaji's humanistic ideals and rethinks the correctness of ideas such as dying for the emperor, which by the end of the movie appears as utter nonsense. ${ }^{89}$ Terada's behavior in the last installment could serve as an example of the importance of acknowledging the past with all its flaws and acknowledging one's mistakes before it is too late to fix them. This could also be interpreted as a reminder for the young generation not to fall prey to extremism. For those following the path of extremism in the past or were currently in its footsteps, Terada's transformation served as a means of showing that it was never too late to repent for one's misdeeds and seek to go back on a path that values the human lives and liberties.

The Japanese society's ambiguity regarding the war experience in the Asia Pacific region could be illustrated by the so-called Rashomon effect. It is associated with Akira Kurosawa's 1950 movie Rashōmon. Instances of the Rashomon effect could be found in Kobayashi's film. They were also present in post-war Japanese society. The Rashomon effect represents a combination of a difference of perspective and equally plausible accounts, with the absence of evidence to elevate one above others, with the inability to disqualify any particular version of the truth, all surrounded by the social pressure for closure of a specific question. The Rashomon effect is present in our daily lives, as we are faced with a certain problem where a difference of perspective arises, but reaching a satisfactory conclusion is

\footnotetext{
${ }^{86}$ Communist.

${ }^{87}$ Kobayashi 1959, 00:21:11.

${ }^{88}$ Kokutai refers to a national body or state structure in the 1930s and 1940s Japan to justify the emperor's sovereignty in the Japanese state.

${ }^{89}$ Prince 2017, 167.
} 
hampered by the lack of sufficient evidence that could lead to the closure of the question at hand. The effect occurs where interests, culture, and power converge to fix our attention on closure, propel us to ask for explanations and expect to get them as soon as possible. Thus, the Rashomon effect is not just about differences of perspective. It occurs mainly where such differences arise in combination with the absence of evidence to elevate or disqualify any version of the truth, plus the social pressure for closure on the question. The convergence of these three ingredients is sufficient in all cases. However, there are more substantial and weaker cases of the effect. They are distinguished by the intensity of the interaction of the three ingredients. ${ }^{90}$

The first instance is the conflict between the humanistic beliefs of Kaji and the militaristic and inhumane approach of the mine supervisors in the first film. This represents the conflict between the younger generations exposed in one way or another to Western beliefs and values and the old conservative generation that refused to embrace change. The conservators remained faithful to the traditionalist values that they deemed the only correct way the Japanese society could have functioned (or were forced to think so by the society).

The second instance is Kajis failure to understand the Chinese POWs situation. By forcing his preconceived ideas (that they were lucky to have him as a guard) on them, he refused to accept the possibility of other solutions for the problems they were facing at the time. By doing so, he became an accomplice to the Empire's cruel policies, just like those who refused to understand the impact the war had on their neighbors in the post-war period.

A third instance is how the end of the war was perceived in the cases of Kageyama, Kaji, and the other Army officers. In the case of Kageyama, scepticism spoke the most as he was unsure of the idea of Japan's ultimate victory. For Kaji, the war's end meant nothing, as he valued life more than any twisted militaristic ideas. In the case of the Army officers, their attitude corresponds to those who refused to acknowledge the real implications Japan's war had in the Far East. For them, Japan's actions were justified. They were thought to be a sacred mission that could save the Far East from Western Imperialism (but ironically replace it with a local form of imperialism).

The last instance considers Kaji's decision not to grasp the realities of the violence in the occupied territories. The moment when he refused to acknowledge the errors of the Soviet Army can be compared to the attitude of the Japanese conservative leaders to acknowledge the horrific acts that the Imperial Japanese Army committed throughout the Far East.

One may wonder how much the ambiguity of perceiving the past events managed to persist in Japan. The 1970s represented the moment when a change in mentality finally occurred within Japanese society. Japan was transforming into an urbanized society, thus meeting the financial, technical, and social requirements needed to sustain such a society. The younger generations, who did not experience the wartime propaganda and the old Japanese values, started to stray from the lifestyle of their parents or grandparents. Because the new generation emerged into a capitalist society, they chose to identify with the big companies that played a crucial role in the post-war economic development. By doing so, they tended to be distrustful of the state and its politicians and promoted the values

${ }^{90}$ Anderson 2016, 71-81. 
of democracy ${ }^{91}$. This was also the first generation exposed directly to the consequences of the Japanese military campaigns in the Asia-Pacific regions. By visiting China, Korea, the South-East region of Asia, or the Pacific Islands, the Japanese tourists could learn about the cruel reality of the war, as the locals could have easily offered them a history lesson on what the Japanese occupation truly meant for those regions. The 'heroic war dead' view of the old generation is no longer shared by the members of the younger generations, as they are the first to take responsibility for errors of the past. ${ }^{92}$

\section{Bibliography}

\section{Filmography}

Kobayashi 1959

Kobayashi 1959

Kobayashi 1961

\section{Secondary sources}

Anderson 2016

Bix 2001

Chiș 2019

Hall 1949

Inuhiko 2014

Orr 2001

MacArthur 2012

Ōe 1994

Prince 2017

Shimazu 2003

Susumu 2008
M. Kobayashi, The Human Condition - No Greater Love, 1959, Ninjin Club.

M. Kobayashi, The Human Condition - Road to Eternity, 1959, Ninjin Club.

M. Kobayashi, The Human Condition - A Soldier's Prayer, 1961, Ninjin Club.

R. Anderson What is the Rashomon effect? In: B. Davis, R. Anderson, J. Walls (eds.) Rashomon Effects. Kurosawa, Rashomon and their Legacies, Abingdon 2016, 66-85.

H. P. Bix Hirohito and the Making of Modern Japan, New York, 2001.

M. Chiș, Insubordonarea armatei și expansionism în Extremul Orient. Statul japonez înainte de izbucnirea celui de-al Doilea Război Sino-Japonez, Revista Philohistoriss, V/7 (Summer 2019), 180-194.

R. K. Hall (ed.), Kokutai no Hongi. Cardinal Principles of the National Entity of Japan, tr. by J. O. Gauntlett, Cambridge, 1949.

Y. Inuhiko, What is Japanese Cinema? A History, tr. by P. Kaffen, New York, 2014.

J. J. Orr, The Victim as Hero: Ideologies of Peace and National Identity in Postwar Japan, Honolulu 2001.

D. MacArthur, Reminiscences, Annapolis, 2012.

K. Ōe, 'Japan, The Ambiguous, and Myself' (7 Dec. 1994), https:// www.nobelprize.org/prizes/literature/1994/oe/lecture/, accessed 29 Jun. 2021.

S. Prince, A Dream of Resistance: The Cinema of Kobayashi Masaki, New Brunswick 2017.

N. Shimazu, Popular Representations of the Past: The Case of Postwar Japan, JCH, 38/1 (Jan. 2003), 101-116.

S. Susumu, State Shinto and Emperor Veneration. In: Ben-Ami Shillony (ed.), The Emperors of Modern Japan, Boston 2008, 53-78.

\footnotetext{
${ }^{91}$ Bix 2001, 669.

92 Bix 2001, 674.
} 


\title{
UNWILLING OR INCAPABLE? UNDERSTANDING HOW PEOPLE REMEMBER INFORMAL EXCHANGES DURING COMMUNISM ${ }^{*}$
}

\author{
VLAD ONACIU ${ }^{* *}$
}

\begin{abstract}
The history of everyday life during the communist period continues to fascinate us. However, such research always poses methodological challenges. This is especially true when one tries to explore the issue of informal exchanges. In this paper, I aim at identifying several challenges with some proposed approaches which can aid research. Firstly, we presented the reactions of witnesses when interviewed and how we can analyze them. Secondly, I tried explaining the three aspects of memory that we consider essential: remembering, nostalgia, and taboo-ization. The goal is to introduce a psychological explanation into historical research to improve on existing methodology.
\end{abstract}

Key words: nostalgia, remembering, memory, history, psychology, 'pile, cunoștințe și relații'

Rezumat: Istoria vieții cotidiene în perioada comunistă continuă să exercite o fascinație asupra noastră. Totuși, astfel de cercetări ridică o serie de provocări metodologice. Acest fapt iese în evidență mai ales în explorarea fenomenului schimburilor informale. În acest articol voi încerca identificarea câtorva dintre provocări, precum și propunerea unor abordări care să faciliteze cercetarea. În primul rând, voi prezenta reacțiile martorilor în interviuri și cum le putem analiza. În al doilea rând, am încercat să explic cele trei aspecte ale memoriei pe care le-am considerat esențiale: rememorarea, nostalgia și tabu-izarea. Scopul este de a introduce o explicație psihologică în cercetarea istorică pentru a îmbunătăți metodologia existentă.

Cuvinte cheie: nostalgie, rememorare, memorie, istorie, psihologie, 'pile, cunoștințe și relații'

Three decades have passed since the fall of the communist regime in Romania. However, the subsequent transition to democracy has not erased, nor has it faded the experiences of that period. Be it abandoned factories or grey apartment buildings, also behaviors or strategies have carried on to the present. Writing about the history of everyday life can pose quite a challenge. While some documents from the archives offer bits of information, the best instrument might be oral history interviews. However, this approach also raises several methodological issues regarding memory, remembering, and autobiographical practices.

\footnotetext{
* Writing this paper was possible due to financial support provided by Entrepreneurial Education and Professional Counseling for Social and Human Sciences $\mathrm{PhD}$ and Postdoctoral Researchers to ensure knowledge transfer Project, co-financed from European Social Fund through Human Capital Programme (ATRiUM, POCU/380/6/13/1233/43).

"* Ph.D., Postdoctoral researcher, 'Babeș-Bolyai' University, Cluj-Napoca, email: onaciu.vlad@gmail.com, (D) https://orcid.org/0000-0001-8586-952X.
} 
This paper is the result of an attempt at using instruments borrowed from psychology and sociology to explain certain behaviors of witnesses. However, it remains a study into a history subject. I must underline the fact that the research focuses on the widespread yet informal practice of 'pile, cunoștințe și relații,' also known as 'P.C.R.,' also the acronym for the Romanian Communist Party. Humour was one strategy of passive resistance in the face of an oppressive regime. I argue here that the use of 'P.C.R.' in everyday life during communism was in itself a strategy of overcoming severe shortages. It was also a means of defiance to what was deemed by some as an unfair system.

The experience of interviewing witnesses on such a subject is interesting, as the historian may very often encounter a 'behavioral dichotomy.' Despite preliminary discussions and agreement to be recorded, their demeanor during the interview can change very much. Willingness to share their experiences with 'P.C.R.' decreases; they bottle up, saying very little or nothing at all, resorting to a strategy of avoidance. ${ }^{1}$ Based on an established mutual trust, previous social ties to the witnesses did not eliminate or diminish this reluctance. Some were relatives of varying closeness (aunts, uncles, a grandmother, mother, etc.). In several of the cases, they offered to share their experiences from the communist period. However, this willingness changed to a certain degree when they were being recorded. Familiarity did not seem to help ease their minds since they knew this was part of a study on not only an amicable conversation.

Further reading on the subject revealed there are underlying psycho-social reasons for the aforementioned phenomenon. This paper is a direct attempt at offering an interdisciplinary explanation. My focus is mainly on clarifications coming from cognitive psychology rather than the more classical behavioral approach. The aim is to look into the underlying mechanisms within the mind, where memory is formed, rather than on the experience of the interview itself.

\section{Historiography}

The history of everyday life during the communist period has gotten little attention in Romania. Aspects such as politics and ideology have constituted the focus of research. This development is explainable by the regime's nature, a mixture of European communism and Asian influences, which created a 'sultanistic' regime. ${ }^{2}$ A cult of personality was constructed around Nicoale Ceaușescu with an extreme form of patrimonialism. Most research has been focused on trying to explain this particular evolution. However, every such desert has its oases from where we can begin.

Firstly, we must refer to the contributions of Katherine Verdery, What Was Socialism... ${ }^{3}$ It offers several insights into how people related to the regime and its inadequacies, and I shall refer to it several times in the paper. Secondly, Gail Kligman's research on abortion when it was banned is another glimpse at an uncomfortable part

\footnotetext{
${ }^{1}$ Interviewed witnesses were asked for their oral agreement to be recorded and for the use of their names. Romanian legislation on the issue is unclear and incomplete. Recorded oral consent is sufficient. For this paper, I decided to use only the initials of the names to allow for a certain degree of anonymity.

${ }^{2}$ Chehabi, Linz 1998, 3-48.

${ }^{3}$ Verdery 1996.
} 
of everyday communism in Romania. ${ }^{4}$ In a sense, it illustrates another side of seeking alternatives to the official system, often with dire consequences.

Then, there are a few more attempts from the direction of social history or sociology. Cătălin Augustin Stoica has written several papers and a chapter on the phenomenon or practice of 'P.C.R.'5 However, he has focused chiefly on its macro-workings rather than on the individual experience. His contribution has thus been in the realm of creating a theoretical framework for such further research. Vlad Onaciu has attempted to move this analysis from a sociological approach to a more historical one. In Societatea Penuriei, ${ }^{6}$ he mixed documents from the archives with interviews, placing individual experiences within the overall economic failings of the regime. We will refer to his proposed concept of the alternative economic system when defining 'P.C.R.'

I must mention the volume coordinated by Adrian Neculau, Viața cotidiană în comunism. It gathers the contributions of a variety of authors on topics such as fear, shortage, private life, and abortions. ${ }^{7}$ Also, an interesting contribution is Ioana Pârvulescu's Și eu am trăit în communism, ${ }^{8}$ structured as a collection of short episodes of everyday life during the communist period.

The most success with interviews was that of the collective volumes by Zoltán Rostás and Antonio Momoc, Bisnițari, descurcăreți, supraviețuitori ${ }^{9}$ and Activiști mărunți: istorii de viață. ${ }^{10}$ Their contribution lay not only in gathering oral testimonies relating to 'P.C.R.' or other informal activities but also in creating a specific methodology. Simultaneously, they increased the interest in the subject through the inclusion of younger colleagues (students). Unfortunately, their efforts remain rather singular in Romanian historiography.

The memory of this period is in itself a challenge. It has been picked up by some Romanian researchers, each exploring specific aspects of the memory of this period. Interesting contributions were made in the two volumes edited by Maria Todorova and dedicated to remembering communism, with valuable contributions from Smaranda Vultur, Simina Bădică, Andi Mihalache, Virgiliu Țârău, Tamás Lönhárt.. ${ }^{11}$

One of the most interesting parts of the historiographical of Romanian communism, especially regarding aspects of everyday life, is the difference of perspectives between generations of historians. Recent years have brought more contributions from researchers born after the regime's fall, who did not experience it directly, but who grew up with the stories of their parents or grandparents. It is, especially for them, more challenging to navigate the trappings of memory and nostalgia when working the testimonies of others as they seek legitimacy for their interpretation of the past.

\section{Explaining 'pile, cunoștințe și relații'}

The communist regimes of Europe collapsed due to their inability to be economically competitive and satisfy the needs of citizens. The system itself was full of issues and was

\footnotetext{
4 Kligman 1998.

${ }^{5}$ Stoica 2018; Stoica 2012.

${ }^{6}$ Onaciu 2020.

7 Neculau 2004.

8 Pârvulescu 2015.

9 Rostás,, Momoc 2013.

10 Rostás, Momoc 2007.

11 Todorova, Gille 2010; Todorova 2014.
} 
wholly inefficient, incapable of reformation, and inadaptable. There was no scientific method to plan what people consumed. Insistence on overproduction merely encouraged the spread of official lies. This situation generated widespread shortages of consumer goods and services. Romania stands as an extreme example in Europe. The regime became more preoccupied with abstract macro-economic indicators than the state of its poverty-stricken population.

In this context, people adapted, and they tried to compensate where the regime was incapable of providing. This situation led to the birth of an alternative economic system in which people were involved in informal exchanges of goods and favors, a sort of barter economy. Such practices were anything but new or original, and we can identify them in other countries as well. Two of the best-known examples are the Russian 'blat' and the Chinese 'guanxi.' However, there are clear cultural distinctions between them, influencing social perceptions. Yet they both have in common the important role of trust between individuals. ${ }^{12}$

Alena Ledeneva has done impressive research on the Russian case of 'blat.' She underlined methodological issues and some regarding the concept itself, the meaning it carries, and the types of practices it includes. She has tried tackling the methodological issues I put forth in this paper and came up with solutions from anthropology. The researcher can use un-recorded accounts to collect general information of social practices involving 'blat.' ${ }^{3}$

The term itself was often used to refer to a broad set of informal exchanges of goods, services, or favors. Taking part in it could bring prestige to those adept at it and knew how to play the game (blatmeisters). However, it was often difficult to establish a price for such interactions, making it less like a mercantile exchange and more like one of reciprocity as well. ${ }^{14}$ This last aspect is also brought to light by Sheila Fitzpatrick, as this was a means of distinguishing 'blat' from relationships of patronage, which are inherently hierarchical, this is a horizontal experience. Individuals involved in informal exchanges are on the same level. One does not necessarily have power over the other. They enter this exchange willingly. ${ }^{15}$

In the Romanian case, the most often used expression for such activities is 'pile, cunoștințe și relații' ('P.C.R.'). While widely used, it does not always encompass a social spectrum as broad as 'blat.' It refers mainly to exchanges with people from the system with better access to goods and services. They were, as Stoica says, social connections, used to solve problems. ${ }^{16}$ 'P.C.R.' often involved manipulating official bureaucracy by those in favorable positions. Such practices were in an antagonistic relationship with the regime.

This system functioned outside the official channels. Thus the regime was anything but tolerant towards such practices. Documents from the archives of the former Securitate reveal the extent of actions taken to stop or discourage informal exchanges or other related criminal activities. The files are full of reports from the regular police indicating the running of sting and surveillance operations aimed at discouraging people. The alternative

\footnotetext{
12 Onaciu 2020,104-105.

13 Ledeneva 1998.

14 Ledeneva 2008, 122-123.

15 Fitzpatrick 2000, 63.

16 Stoica 2018, 140-141.
} 
economic system undermined the legitimacy of the regime on two levels. Firstly, it created different means of accessing goods or services, one not controlled by the authorities. Secondly, it illegally operated with goods stolen from the workplace or smuggled from abroad. This development further hindered the already struggling production process. ${ }^{17}$

The official stance against 'P.C.R.' is very important in my attempt at understanding people's reluctance in interviews. At the same time, it was a widespread social and economic phenomenon, the fact that it was a crime associated it with the potential of social stigma. This can, in part, explain the dichotomy of people's relation to it in their personal histories.

\section{The role of oral history in our research}

I consider it important to explain where oral history practices and interpretations come into play in the reconstruction everyday experience. As Alistair Thomson so very well put it, this shift during the 1970s introduced to history the practice of studying memory, which became both subject and source. ${ }^{18}$ In this regard, I refer to it as a source of information for everyday life, especially where the archives offered little insight. In this sense, I will avoid going into the debate of whether oral history is an instrument for researchers or a way in itself of writing and understanding the past.

However, I would like to add a few clarifications regarding interviews and the methodology used. Memory was at the core of this experiment. Consequently, it must be said that history deals with long-term memory and is thus tributary to how people perceive the past. They will remember what they deem as essential and not what the researcher believes to be most consequential. ${ }^{19}$ This relates to the fact that in the practice of oral history, one inevitably delves into autobiographical memory, where details fade or change and only the broad contours remain the same. ${ }^{20}$

Alessandro Portelli describes the interview as an exchange where both the observer and the observed are involved simultaneously. ${ }^{21}$ It is a dialogic process between the interviewer and the interviewee. ${ }^{22}$ The analysis of voice itself is important as one can read much from tonality or rhythm, maybe even understand more regarding the relationship between the witness and their personal history. ${ }^{23}$ This, of course, is part of the challenge faced by researchers, especially when talking about sensitive topics such as 'P.C.R.'

\section{How memory works}

The human mind is fascinating and still holds many secrets despite science's many attempts at deciphering it. Psychology has come a long way since the days of psychoanalysis and dream interpretation. One can offer more competent explanations now, primarily rooted in the findings of cognitive psychology. One of the experimental aims of this paper is to bring these new clarifications with the help of historical research.

\footnotetext{
17 Onaciu 2020, 205-206.

18 Thomson 2007, 54-55.

19 Ritchie 2015, 1, 16.

20 Abrams 2010, 86.

${ }^{21}$ Portelli 2018, 241.

22 Abrams 2010, 19.

23 Portelli 1981, 98-100.
} 
Firstly, one must understand how the process of remembering works. It is tempting to believe that this is an accurate and objective activity. People are so very often convinced of the truth of our depiction of past events and experiences. In all honesty, as individuals, it is, and if we were subjected to a polygraph test, we would pass it. However, remembering is anything but an accurate representation.

When our mind creates a memory, it stores an image, but it is only a partial one, containing some relevant information for the individual. When remembering, we bring out these images from their mental folders, but there are gaps between them. Creating a coherent story or narrative requires the mind to fill in these gaps with what seems logical or plausible information, which makes sense to the individual. ${ }^{24}$ The narrative, in turn, is determined by the present. The context influences the stories of the past that we tell. It is because of this reason why eye-witness accounts are no longer considered as a very reliable source of evidence for the police; they can so easily be influenced. ${ }^{25}$

I move into the realm of autobiographical memory (A.M.), which is considered distinct from memory in most research. A.M. is usually comprised of those episodes deemed personally significant in our everyday life. They are the basis for how we see and handle the present time of our existence ${ }^{26}$. Some researchers have identified up to eight reasons why people talk about their past: 1 . Problem-solving; 2 . Identity; 3. Conversation; 4. Boredom reduction; 5. Intimacy maintenance; 6 . Death preparation; 7. Teach/Inform; 8. Bitterness revival. ${ }^{27}$

As I have already mentioned, this is a process influenced by our current state and context. Evidence points to the fact that people reconstruct their past attitude or perspective regarding an issue or episode after first considering their present-day opinion and then evaluating whether or not they had a reason to suppose their views changed over time. ${ }^{28}$ People try to recall the past in a way that is consonant with current views, primarily if they are related to the self. ${ }^{29}$ Wilson and Ross have underlined two important functions carried by autobiographical memory. One is linked to maintaining a favorable view of the self. ${ }^{30}$ We use it to develop a sense of ourselves, our emotions, even plans and frame our relationships with others. We remember events from the past because our memories tell us about who we are. ${ }^{31}$ This makes discussing or remembering the past an internal mental exchange, where we negotiate our past self with our present self.

The other function is social, in which people attempt to convince others of their improved self. ${ }^{32}$ This is more complex, as sharing memories is often described as a means of creating connections and improving social bonds. It can go as far as shaping a group identity through common shared experiences. The past and how we remember it is

\footnotetext{
${ }^{24}$ Pinker 2015, 138; McDermott, Roediger 2021. Also see, Sutton 2009.

${ }_{25}$ Baddeley 2012, 74-75.

26 Webster 2003, 203.

27 Harris et alii 2014, 561.

${ }^{28}$ Wilson, Ross 2003, 138.

${ }^{29}$ Wilson, Ross 2003, 138. Also see, Albert 1977.

${ }^{30}$ Wilson, Ross 2003, 146.

${ }^{31}$ Harris et alii 2014, 559.

${ }^{32}$ Wilson, Ross 2003, 146.
} 
very relevant for how we see the present, how we interpret reality, and how we project the future. ${ }^{33}$

It is also essential to understand the relationship between A.M. and culture (which influences or represents the context). Changes happening at this level will ultimately influence how people talk about the past and perceive themselves. Further exploration of the issue reveals that we can encounter significant differences in A.M. when comparing individualistic and collectivist cultures, especially in defining 'the self.' ${ }^{34}$

\section{Nostalgia}

Another challenge in researching the recent past is the influence of nostalgia on remembering. The term has a history of its own and has gravitated between the realms of medical science and psychology. Initially, it was defined as grief or longing for one's native land, a form of homesickness. ${ }^{35}$ This interpretation owes to the physician Johannes Hofer, who was trying to diagnose the gloom of overcoming mercenaries fighting in foreign lands. ${ }^{36}$ The word itself is the pairing of 'nostos,' which means to return home, and 'algia,' longing for a place, a person, a period. ${ }^{37}$

Thus, nostalgia started with a negative connotation, perceived as a disease of the soul. In time, we have moved from a diagnosis to a more complex understanding, with psychologists and sociologists each focusing on different aspects. ${ }^{38}$ We now see it as more of a beneficial experience, as it elicits a positive affect. ${ }^{39}$ This shift was triggered by the assumption that the term should be restricted to the past experienced by the individual, ${ }^{40}$ giving it personal meaning.

Svetlana Boym has argued that nostalgia can also be seen as a defense mechanism when the individual feels overwhelmed by 'accelerated rhythms of life and historical upheavals. ${ }^{41}$ Thus, it becomes a longing for a more familiar past. In this interpretation, one can see nostalgia as a means through which one tries to seek refuge in a gone period. This period is associated with fond memories or which one has idealized. Batcho ties to dissatisfaction with the conditions of the present, which underlines the individual's preference for an earlier historical period to which they might feel more connected. ${ }^{42}$ It is often, especially in oral history interviews, that witnesses refer to the past as a time when they were young, the peak of their biological life. This situation influences their interpretation of those times.

Therefore, the negative or stressful conditions and negative feelings can bring about sentiments of nostalgia. Thus, it comes an as little surprise that it is less common for those whose context has changed very little. ${ }^{43}$ The differences between the present and the past

\footnotetext{
33 Albano 2016, 61.

${ }^{34}$ Conway et alii 2012, 59.

35 Batcho 1998, 411.

36 Osborn et alii 2020, 1.

37 Boym 2001, 8.

38 Batcho 2021, 228.

39 Osborn et alii 2020, 2.

40 Batcho 1998, 412.

${ }^{41}$ Boym 2001, 8.

${ }^{42}$ Batcho 2021, 228-229.

${ }^{43}$ Nikelly 2004, 185.
} 
self are not significant enough. However, one would argue that aging can create feelings of nostalgia, a yearning for the time of youth. Boym describes mass nostalgia in the context of yearning for the time of youth and childhood, 'projecting personal affective memories onto the larger historical picture and partaking collectively in a selective forgetting. ${ }^{34}$ Thus, negative aspects take a backseat, making room for those experiences deemed more positive (incomplete comparison!).

When discussing nostalgia, there is also an issue of comparison between past and present. People try to construct the memory of the past self in a manner that puts the present self in a positive light. ${ }^{45}$ In this sense, it can serve a social function as it aims at projecting a particular image of the self into the community, an adaptation to the values of our current times. This will tie into issues of taboo-ization, which I will discuss in the next segment.

It is by now evident that talking about the past involves a complex psycho-social process that invariably influences testimonies. Since they are recorded, witnesses are even more concerned about the image they project, about how others will know their 'self.' Simultaneously, longing for their time of youth might also influence their story. Our memory changes over time in a constant shuffling and re-shuffling. It aims at adapting the recollection of the past to the realities of the present. One such example is that of the interviews with the veterans of the First World War. As Dan Todman noted, their recollections underwent multiple phases, influenced by the general public discourse regarding the war. ${ }^{46}$ This conclusion is also true for the memory of communism in the minds of those who lived then.

\section{Taboo-ization}

The activities involving 'P.C.R.' are often left out of autobiographical memory not because they belong to every day but because they risk carrying social stigma. Denial or avoidance becomes a defense mechanism for the preservation of an image of honesty. ${ }^{47}$ However, Verdery's research seems to have proven that it was seen as a source of personal pride. It allowed the individual to differentiate the self 'in the face of relentless pressures to homogenize everyone's capacities and tastes into an undifferentiated collectivity. ${ }^{48}$ This feeling significantly increased, and the practice grew more popular during the severe shortages of the 1980s and over-emphasis on exports of consumer goods. Then why are people so reluctant during interviews?

The regime criminalized and discouraged involvement in the alternative economic system. While most of the population was involved in one way or another at a certain point, being caught still carried social stigma. Thus, it became a taboo, a widespread phenomenon of which they were not to speak.

The word taboo came into use after it was brought back to Europe by Captain Cook from Polynesia. It referred to foods, places, or activities that were prohibited or impermissible

\footnotetext{
${ }^{44}$ Boym 2001, 41.

${ }^{45}$ Osborn et alii 2020, 2.

46 Todman 2005.

${ }^{47}$ Ledeneva 1998, 60.

48 Verdery 1996, 29.
} 
within a community. ${ }^{49}$ The Longman Dictionary defines its primary meaning as something 'strongly forbidden by social custom, especially because it is offensive or likely to cause social discomfort.'50

Social taboos influence memories, leading to the selective recollection of autobiographical memories. ${ }^{51}$ Douglas Davies argued that we understand the world as clean and unclean. ${ }^{52}$ Thus, if the regime was hostile towards 'P.C.R.', and it became taboo, unclean, one's association to it could be seen as morally compromising in the eyes of their peers, lowering self-esteem. Fear of shame will lead to denial or avoidance of anything that could harm our psychological well-being. ${ }^{53}$

The refuge witnesses seek in avoidance through the use of euphemism reminds us of George Orwell's vision of a totalitarian regime. Through the introduction of 'doublethink' and 'doublespeak', he illustrated a halving underwent by individuals about actions carrying social stigma. People were forced to try and hide their involvement, despite its widespread use, as a means of self-preservation. ${ }^{54}$

We use euphemisms for various reasons, but they have in common a wish to protect or reduce harmful effects, be it on other individuals, a conversation, or one's self-image within the social network or community. According to Arif, the first euphemisms resulted from religious superstition with the scope of avoiding prejudice. There is also a cultural component to this practice. ${ }^{55} \mathrm{In}$ the case of former communist societies, the use of informal practices was and is hidden behind the cloak of euphemisms, a strategy of avoiding social stigma. Slovenko calls this a form of sanitization of the discourse through which we either conceal a crime or deflect guilt from it. ${ }^{56}$

In his analysis of the Soviet example, Stephen Kotkin proposed the thesis of the double life. He shows how it inevitably led to the development of something similar to Orwell's idea of 'doublethink.' Families would plan what they would say in public their general attitude would be. It went as far as keeping many secrets from their children so as they, intentionally or mistakenly, would not give them away. ${ }^{57}$

Gail Kligman argues that the dictatorial and controlling nature of the communist regime in Romania forced people to have something very much similar to playing a role for the public space while being a whole different person at home, in the privacy of one's safe home environment. ${ }^{58}$ Pavel Câmpeanu's view was grimmer as from his point of view, shortage and the implicit 'P.C.R.' generated a sort of competition in queues, making individuals less likely to trust others. ${ }^{59}$ This conclusion is frequently illustrated in my interviews. They remembered how they had managed to go over, under, or around

\footnotetext{
49 The Penguin Dictionary of Sociology, 391.

${ }^{50}$ Longman Dictionary of English Language and Culture, 1372.

51 Hirst et alii 2012, 153.

52 Dutton 2006, 42.

${ }^{53}$ Eviatar 2006, 5, 7-8.

54 Orwell 2003.

55 Arif 2015, 151-153.

56 Slovenko 2005, 537.

${ }^{57}$ Kotkin 1997, 195, 228-229.

${ }^{58}$ Kligman 1998, 14-15.

59 Câmpeanu 1994, 14, 26, 30-31.
} 
the system to get the required items. This was especially true for festive events, such as birthdays, weddings, or baptisms. As one witness revealed, she and her family each used their 'friends' and 'connections' to get meat, fruit, or vegetables for such special occasions. ${ }^{60}$

When referring to the idea of 'doublethink' and 'doublespeak' it becomes important that I also try and explain how identity would function in such a context. Dictionaries define identity as 'who or what a particular person or thing is ${ }^{31}$ or 'an ensemble of data through which a person can identify itself.' ${ }^{62}$ According to Kay Deaux, 'social identification is the process by which one defines themselves in terms and categories shared with other people. ${ }^{63}$ Identity becomes inherently tied to social context, to the community in which one develops as an individual. There, a series of values are enforced on the individual, and one constructs themselves starting from here. Thus, for those born and raised under communism, the official condemnation of 'P.C.R.' was essential in constructing their social identity. Yet, simultaneously, they were involved in such activities as a means of survival. ${ }^{64}$

Deaux further argues that we have to accept that an individual can often have different configurations of an identity. ${ }^{65}$ When applied to communist and post-communist realities, this interpretation fits well, in the sense that the second identity (the one involved in 'P.C.R.') is suppressed to ensure the survival of the first's moral integrity. Judith A. Howard adds two other dimensions along which individuals can define their identity. Firstly, there is 'the social,' membership to one or more social groups. Secondly, 'the personal,' what distinguishes one from others, ${ }^{66}$ this being somewhat linked to the concept of alterity. Thus, 'doublethink' is in the lines of the ability to create two co-existing interpretations of the world. In one interview, the witness talked about how life changed after collectivization. She would frequently say it was a horrible thing, that people suffered great tragedies, but simultaneously, she told me that life improved afterward. Here we can see how two realities co-exist in a paradox of some sort. ${ }^{67}$

\section{Method and findings}

The first step in my research was to establish the pool of witnesses who were to be interviewed. Our project followed urbanization and industrialization in the Romanian city of Cluj. The focus was on people who held jobs in factories or moved here from the countryside. I can make a first categorization, strangers, to which introductions were made through common acquaintances and those with which I had pre-existing social ties. The first group was made up of two men and a woman of differing social status and education levels. One of the witnesses was a Ph.D. holder in agricultural sciences and with quite an active civic life after the fall of communism. He proved to be very forthcoming with information regarding changes the city underwent during the 1950s and 1960s. However, very much like the others, his testimony stopped short when talking of 'P.C.R.' ${ }^{68}$

\footnotetext{
${ }^{60}$ Interview with O.M., February 2014.

${ }^{61}$ Longman Dictionary of English Language and Culture, 657.

${ }^{62}$ Dicționarul Explicativ al Limbii Române, 470.

${ }^{63}$ Deaux 2001, 1059.

${ }^{64}$ Câmpeanu 1994, 12, 97.

${ }^{65}$ Deaux 2001, 1062.

${ }^{66}$ Howard 2000, 369.

${ }^{67}$ Interview with D. N., Dec. 2012.

${ }^{68}$ Interview with S. I., Febr. 2014.
} 
The other man was an elderly person from the countryside who had worked in one of Cluj's new factories in his youth. He was willing to talk about most aspects of his life. However, he constantly expressed confusion about the relevance of his life story ${ }^{69}$ The woman was very open. What is interesting to mention is that she constantly stated that 'it was of no consequence to her as what could they do to her now, as she is old and sick.' At certain moments she seemed to avoid offering direct answers through the use of euphemisms. When asked how her relationship with the bosses was, she would say that 'it was good, they understood us, like people do,' and that if you requested a day off, they would give you permission. ${ }^{70}$

The second group was comprised of people with whom there were already established relationships. This decision was prompted by a lack of cooperation from the other category. The rationale was that the pre-existing social tie, trust already established, would be easier to convince them to share experiences with 'P.C.R.' Here, I include three women and two men. Of these, only one benefited from higher education, while two pursued the courses of trade schools.

Both men were eager to share many of their views of the world. However, they had certain points or barriers they were unwilling to cross when asked about 'P.C.R... One of them resorted to talking about present corruption and his discontent with the current political class. Yet, he did share one piece of interesting information, but it had little relevance for my research on 'P.C.R.': it was more aimed at highlighting his importance in the workplace. ${ }^{71}$ The other man, a more talkative personality, was more willing to share such stories, even some of the patronage and stealing from the workplace. He only stopped at the consequences of his actions, reverting to avoidance through the use of euphemisms, 'I even went where I shouldn't have ended up. ${ }^{72}$

The eldest of the women, nearing eighty years at the time of the interview (worth mentioning she is still in good health), was open to sharing information, especially regarding others. Her attitude towards collectivization illustrated a dichotomy of thought, it was both good, but she underlined the suffering it inflicted on people. ${ }^{73}$ Another one, though willing to speak, would change her tone when talking about 'P.C.R.' She resorted to a slight whisper as if to conceal what she was saying. This was despite the fact there was no one else in the room with us. ${ }^{74}$

Women seem more likely to speak of their experiences, although sometimes resorting to euphemisms to obscure or avoid certain aspects. It would seem that men put a higher emphasis on their self-worth regarding society's moral standards. I shall further explore this aspect of autobiographical memory and the construction of the self. There does not seem to be a clear correlation between age groups and the willingness to share.

Before I attempt to go into methodological and psycho-social explanations, I must discuss the three types of reactions from witnesses. Firstly, I notice a proclivity towards trivialization. In their testimonies, people tend to attribute less significance to the use of

\footnotetext{
${ }^{69}$ Interview with C. I., Nov. 2013.

${ }^{70}$ Interview with T. V., Nov. 2013.

${ }^{71}$ Interview with V. T., Apr. 2014.

72 Interview with O. I., Mar. 2014

${ }^{73}$ Interview with N. D., Dec. 2012.

${ }^{74}$ Interview with V. A., Apr. 2014.
} 
'P.C.R.' It was indeed a widespread phenomenon but criminalized and discouraged by the regime. This might be their attempt to make it less of a 'dirty deed', banalization through shared guilt. However, this issue is more complicated from a psycho-social perspective.

The second type of reaction involves avoidance through the use of euphemisms. Individuals speak of their experiences with 'P.C.R.', but resort to hinting at it rather than speaking directly of it. After being asked how he managed to get the accord to work in a factory from the collective farm, one witness simply resorted to answering that 'they had found a way' or that 'they did so as things to be well.' Throughout the rest of the interview, the same question was asked two more times under different forms or circumstances, but the replies remained the same. ${ }^{75}$ This can be linked to taboo-ization, 'a phenomenon of avoiding a word and replacing it with another out of superstition or shyness. ${ }^{76}$ Further analysis will reveal that this is also an issue of social identity and how people wish and hope to be seen within their community.

The third type of reaction is the one any historian wishes for, that of a free-speaking witness. Some individuals have no problem sharing their stories. This reaction could have two underlying explanations: they might have realized that there are no consequences as of now for their actions in the past, or they might be lying. While this can be verified to a certain extent, there are no certitudes, and it would violate professional ethics to make such accusations. The last witness on the list, born in 1961, at the height of the communist regime in Romania, was also the one I had the closest tie. This witness was the most willing to share, saying beforehand that there was nothing left to fear since everyday realities were different now. ${ }^{77}$

It is here that the existing literature has failed to underline the long-lasting effects of the regime's condemnation of 'P.C.R.' through propaganda. Alena Ledeneva touches on the subject in her analysis of 'blat,' but little has yet been written for the Romanian case. I previously mentioned that communist authorities took extensive policing measures to catch those involved in such practices, and penalties for the guilty were harsh. Probably, the Securitate's involvement best illustrates the importance of the matter to the regime, as it was not left to the responsibility of the local police forces.

Witnesses seemed willing to speak of their involvement in the alternative economic system activities, but they are usually more at ease in casual conversation. One can even detect a sense of pride from their accounts. When they are recorded, demeanor changes and more attention is paid to what words are used. There is an emphasis on euphemisms used to describe their involvement. These both mask the actual act of 'P.C.R.' and do not reveal any incriminating details. Witnesses, in fact, constantly express concern that their story will be preserved and that others might read about it. This is where they are faced with the new task of constructing an ad-hoc autobiography for others, for strangers.

While I can better understand why witnesses avoid certain subjects during interviews, I am still faced with the challenge of gathering information on 'P.C.R.' in communist Romania. Alena Ledeneva argues that there are two ways of doing this. Recorded interviews are one solution, being more productive because the researcher is free to focus strictly on

\footnotetext{
${ }^{75}$ Interview with C. I., Nov. 2013.

${ }^{76}$ Dicționarul Explicativ al Limbii Romane, 1066.

77 Interview with M. O., Febr. 2014.
} 
the interview itself. Also, it allows for later analysis of key moments of the session. The other approach involves talking to people and taking notes; this limits our focus and makes it impossible to listen once more to specific passages once the interview is over. ${ }^{78}$ There is one other issue with the second method; it is more challenging to justify statements and examples if one cannot rely on a transcript of the conversation, leaving credibility in the eyes of the beholder.

In past research, I tried to explain these phenomena by referring to taboo-ization of certain aspects of life, such as criminal activities. However, this explanation is insufficient for understanding how the representation of 'the self' in a community is constructed. It does not delve into the psychological or neurological explanations regarding the act of remembering, autobiographical memory, or even nostalgia.

\section{Conclusions}

For a long time, historiography thought of communist societies as being atomized, with individuals isolated. This was the initial depiction of life under totalitarian regimes. However, later research illustrated that the situation in this 'brave new world' was far more complex. Individuals did indeed wear 'public masks' and avoided certain topics in public, but they also interacted and became involved in informal exchanges based on trust. This form of networking was essential to the mechanism of the alternative economic system they created.

This paper tried to illustrate some of the challenges researchers face in using oral history to gather information on taboo subjects, such as the alternative economic system. To this end, I used explanations from the field of cognitive psychology paired with sociology and history. In this respect, this paper is an experiment at a multidisciplinary approach towards the research of everyday life under communism.

One must take into account the lasting effect of official discourse, propaganda, and policies. This result represents the influence of culture on autobiographical memory and what people choose to share with others. People have an innate predisposition to protect themselves and their image within the local community by avoiding public association with activities or behaviors which might bring social stigma.

I also consider it essential to have in mind the interesting manner in which remembering occurs. It is not a precise recounting of the past, but rather a reinterpretation through the lenses of the present. One holds to episodes and link them into a narrative by filling in the gaps with what might make sense. It is here that researchers need to pay attention to nostalgia and its subjective influence. It can easily lead to an idealization of the past, a further subjective distortion.

\footnotetext{
${ }^{78}$ Ledeneva 1998, 4-9, 218.
} 


\section{Bibliography}

\section{Interviews}

Interview with D. N., Dec. 2012. Interview with T. V., Nov. 2013. Interview with C. I., Nov. 2013. Interview with M. O., Febr. 2014. Interview with S. I., Febr. 2014. Interview with O. I., Mar. 2014. Interview with V. A., Apr. 2014. Interview with V. T., Apr. 2014.

\section{Books}

Abrams 2010

L. Abrams, Oral History Theory, London-New York 2010.

Albano 2016

C.Albano, Memory, Fotgetting and the Moving Image, London 2016.

Boym 2001

S. Boym, The Future of Nostalgia, New York 2001.

Câmpeanu 1994

P. Câmpeanu, România: Coada pentru hrană. Un mod de viață, București 1994.

Donald 2015

R. Donald, Doing Oral History, Oxford 2015.

Fitzpatrick 2000

S. Fitzpatrick, Everyday Stalinism: Ordinary Life in Extraordinary Times: Soviet Russia in the 1930s, Oxford-New York 2000.

Kligman

G. Kligman, The Politics of Duplicity: Controlling Reproduction in Ceaușescu’s Romania, Berkley-Los Angeles 1998.

Kotkin 1997

S. Kotkin, Magnetic Mountain: Stalinism as Civilization, BerkleyLos Angeles 1997.

Ledeneva 1998

A. Ledeneva, Russia's Economy of Favours: Blat, Networking and Informal Exchange, Cambridge 1998.

Neculau 2004

A. Neculau (ed.), Viața cotidiană în comunism, Iași 2004.

Onaciu 2020

Orwell 2003

V. Onaciu, Societatea Penuriei: Carențele din construcția regimului comunist din România. Studiu de caz: Cluj în anii 60 și 70, Cluj-Napoca 2020.

Pârvulescu 2015

G. Orwell, Nineteen Eighty-Four, London 2003.

Pinker 2015

I. Pârvulescu, Și eu am trăit în comunism, București 2015.

Rostáș, Momoc 2007

Rostáş, Momoc 2013

S. Pinker, How the Mind Works, London 2015.

Z. Rostáș, A. Momoc, Activiștii mărunți: istorii de viață, București 2007.

Z. Rostáș, A. Momoc, Bișnițari, descurcăreți, supraviețuitori, București 2013.

Stoica 2018

C.A. Stoica, România continuă: schimbare şi adaptare în comunism şi postcomunism, Bucuresti 2018.

Todman

D. Todman, The Great War: Myth and Memory, London 2005.

Todorova, Gille 2010

M. Todorova, Z. Gille, Post-Communist Nostalgia, New YorkOxford 2010. 
Todorova et alii 2014

Verdery 1996

Zerubavel 2006

\section{Articles and chapters}

Albert 1977

Arif 2015

Baddeley 2012

Batcho 1998

Batcho 2018

Chehabi, Linz 1998

Conway, Jobson 2012

Deaux 2001

Dutton 2006

Harris et alii 2014

Hirst et alii

Howard 2000

Ledeneva 2008
M. Todorova, A. Dimou, S. Troebst, Remembering Communism: Private and Public Recollections of Lived Experience in Southeast Europe, Budapest-New York 2014.

K. Verdery, What Was Socialism and What Comes Next?, New Jersey-Princeton 1996.

E. Zerubavel, The Elephant in the Room: Silence and Denial in Everyday Life, Oxford-New York 2006.

S. Albert, Temporal Comparison Theory, Psychological Review, 84/6 (1977), 485-503.

N. F. Arif, Social and Cognitive Implications of Using Euphemisms in English, IJEL, 5/6 (2015), 151-156.

A. Baddeley, Reflections on autobiographical memory In: D. Berntsen, D. C. (eds.), Understanding Autobiographical Memory: Theories and Approaches, Cambridge 2012, 70-88.

K. I. Batcho, Personal Nostalgia, World View, Memory, and Emotionality, Perceptual and Motor Skills, 87 (1998), 411-432.

K. I. Batcho, The role of nostalgia in resistance: A psychological perspective, Qualitative Research in Psychology, 18/2 (2021), 227-249.

H. E. Chehabi, J.J. Linz, A Theory of Sultanism 1 \& 2. In: H.E. Chehabi, J.J. Linz (eds.), Sultanistic Regimes, Baltimore-London (1998), 3-48.

M. A. Conway, L. Jobson, On the nature of autobiographical memory. In: D. Berntsen, D. C. Rubin (eds.), Understanding Autobiographical Memory: Theories and approaches, Cambridge (2012), 54-69.

K. Deaux, Social Identity. In: J. Worell (ed.), Encyclopedia of Women and Gender: Sex Similarities and Differences and the Impact of Society on Gender, San Diego-San Francisco-New York-Boston-London (2002), 1059-1068.

E. C. Dutton, Ritual, Taboo and Political Protest, Mankind Quarterly, 47/1/2 (2006), 41-59.

C. B. Harris, A. S. Rasmussen, D. Berntsen, The functions of autobiographical memory: An integrative approach, Memory, 22/5 (2014), 559-581.

W. Hirst, A. Cuc, D. Wohl, Of sins and virtues: memory and collective identity. In: D. Berntsen, D. C. Rubin (eds.), Understanding Autobiographical Memory: Theories and approaches, Cambridge 2012, 141-159.

J. A. Howard, Social Psychology of Identities, Anuu.Rev.Sociol, 26 (2000), 367-393.

A. Ledeneva, Blat and Guanxi: Informal Practices in Russia and China, CSSH, 50/1 (2008), 118-144. 
Nikelly 2004

Onaciu 2020

Osborn et alii 2020

Portelli 1981

Portelli 2018

Thomson 2007

Slovenko 2005

Stoica 2012

Sutton 2009

Webster 2003

Wilson, Ross 2003
A. G. Nikelly, The Anatomy of Nostalgia: From Pathology to Normality, IJAPS, 1/2 2004, 182-199.

V. Onaciu, The Alternative Economy: Informal Exchanges and Criminal Activities from the perspective of the Communist regime's institutional framework, SUBB Historia, 65/2 (Dec. 2020), 101-122.

H. Osborn, K. D. Markman, J. L. Howell, Nostalgia and temporal self-appraisal: Divergent evaluations of past and present selves, Self and Identity (2020).

A. Portelli, The Peculiarities of Oral History, HWJ, 12 (1981), 96-107.

A. Portelli, Living Voices: The Oral History Interview as Dialogue and Experience, The Oral History Review, 45/2 (2018), 239-248.

A. Thomson, Four Paradigm Transformations in Oral History, The Oral History Review, 34/1 (2000), 49-70.

R. Slovenko, Commentary: Euphemisms, The Journal of Psychiatry \& Law, 35 (2005), 533-548.

C. A. Stoica, Old Habits Die Hard? An Exploratory Analysis of Communist-Era Social Ties in Post-Communist Romania, EJST, 8/ Supplement 1 (2012), 171-193.

J. Sutton, Remembering. In: P. Robbins, M. Ayede (eds.), The Cambridge Handbook of Situated Cognition, Cambridge 2009, 217-235.

J. D. Webster, The reminiscence circumplex and autobiographical memory functions, Memory, 11/2 (2003), 203-215.

A. Wilson, M. Ross, The identity function of autobiographical memory: Time is on our side, Memory, 11/2 (2003), 137-149.

\section{Dictionaries and encyclopedias}

Dicționarul Explicativ al Limbii Române, București 1998.

Longman Dictionary of English Language and Culture, Harlow 2003.

The Penguin Dictionary of Sociology, London 2006.

\section{Online sources}

Deaux 2001

K.Deaux,'SocialIdentity',https://www.yumpu.com/en/document/ $\mathrm{read} / 6587262 /$ social-identity-the-university-of-texas-at-austin. pdf, accessed 5 Jun. 2015.

McDermott, Roediger $2021 \quad$ K. B. McDermott, H. L. Roediger, 'Memory (Encoding, Storage, Retrieval), NOBA Collection (2021), http://noba.to/bdc4uger, accessed 15 Jun. 2021. 


\title{
THE METAMORPHOSES OF THE UN PEACEKEEPING PRINCIPLES: HOW THE END OF THE COLD WAR RESHAPED THEM (1988-1992)
}

\author{
GABRIEL ZVÎNCĂ $\breve{A}^{*}$
}

\begin{abstract}
The end of the Cold War was for the international system, and particularly to the United Nations, an opportunity to make use of all the prerogatives found in the UN Charter to protect and secure international peace and security on the globe. The change of the international system also had an impact over the peacekeeping mechanism, created and developed by the UN during the Cold War, to watch over and protect the peace. The 90s were also seen as a great opportunity for the international organization to accomplish its purpose of preventing future generations from the scourge of war. During this period, peacekeeping and its principles suffered a series of modifications which would later have an important role in the operations authorized in the middle of 1990s.

The present paper's purpose is to analyze these metamorphoses and present how they evolved from 1988 to 1992, to understand why these years were important for the formulation of the new peacekeeping mechanism and present the basis on which the operations were authorized starting with 1993. The study is divided into four different chapters. The first will present the methodology used to address the problem. The second will offer a definition of peacekeeping and of its principles, whereas the third will examine the metamorphoses suffered because of the change of the international system. The final chapter will put forward the conclusions and will present prospects of analysis on the topic.
\end{abstract}

Keywords: United Nations Oragnization, peacekeeping, Cold War, international system.

Rezumat: Încheierea Războiului Rece a reprezentat pentru sistemul internaţional și pentru Organizația Națiunilor Unite o oportunitate de a face uz de toate prerogativele din Carta Naţiunilor Unite pentru menținerea păcii și securităţii internaționale. Schimbarea sistemului internațional a avut un impact și asupra mecanismului de menținere a păcii sau peacekeeping, creat și dezvoltat de ONU în timpul Războiului Rece pentru a veghea și proteja pacea. Anii 1990 au fost văzuți și ca o oportunitate pentru ca organizația internațională să își îndeplinească obiectivul de prevenire a viitoarelor generații de flăgelul războiului. În această perioadă, 1988-1992, peacekeeping și principiile sale au suferit o serie de mutații care mai târziu vor avea un rol important pentru operațiunile autorizate la mijlocul anilor ' 90.

Articolul de față își propune să analizeze aceste metamorfoze și să prezinte cum au evoluat principiile începând cu 1988 și până în 1992, pentru a înțelege importanța acestor ani pentru formularea unui nou mecanism de menținere a păcii și să prezinte pe ce baze au fost autorizate operațiunile începând cu 1993. Studiul este împărțit în patru capitole. Primul își propune să prezinte metodologia folosită pentru a analiza subiectul. Al doilea va oferi o definiție a peacekeeping și va prezenta principiile sale, în timp ce al treilea va analiza metamorfozele din perioada amintită. Ultimul capitol va analiza concluziile și va prezenta noi perspective de cercetare.

* M.A. Student, 'Babeș-Bolyai' University, Cluj-Napoca, email: gabriel.zvinca7@gmail.com,

https://orcid.org/0000-0002-3070-8515. 
Cuvinte cheie: Organizația Națiunilor Unite, peacekeeping, Război Rece, sistem internaţional.

\section{Introduction}

The end of the Cold War had profound implications for international relations. The end of the rivalry between the United States and the Soviet Union implied that the international system changed from a bipolar to a single or a multipolar one. ${ }^{1}$ The United Nations, the entity created by the Allies during World War II, was deeply influenced by the (bi)polarization of the international system. This influence also led to the blockage of the collective security mechanism, which was designed at the conferences in Dumbarton Oaks and San Francisco in 1944-1945. Despite these, during the forty years of bipolarism, one can notice that the UN developed tools to maintain international peace and security and even developed a new security mechanism: peacekeeping. With peacekeeping, the UN had the opportunity to intervene in several inter-state and intra-state conflicts to solve disputes and guard international peace and security. Despite having succeeded several times in favor of the pacification process, ${ }^{2}$ the UN remained, during the Cold War period, influenced by the bipolarization of the system and the rivalry between the two superpowers. However, the end of this conflict allowed the UN to use its instruments and contribute to peace between 1988 and 1992. It resulted in the authorization of operations in Kuwait, Somalia, and Yugoslavia. This was possible because the interests of the superpowers no longer played an important role in determining the nature of the missions to be authorized. The UN had the opportunity to intervene based on the UN Charter and seek solutions to the problems.

This paper aims to analyze the peacekeeping mechanism developed by the UN and its evolution during the 1988-1992 period when the international system underwent significant changes. More specifically, the study will focus on how changes in the international system also led to the metamorphosis of the peacekeeping principles and how peacekeeping adapted to the new conditions. Thus, the research question, from which the study starts, focuses on how the last years of the Cold War influenced UN peacekeeping principles and redesigned the role of the mechanism in the system. I propose a comparison between operations authorized during and at the end of the Cold War. One could assess to what extent the superpowers' rivalry influenced the peacekeeping mechanism, the evolution of the principles, and what role the organization assumed through the operations in question.

Besides, my paper aims to show how the principles of peacekeeping, formulated during the Cold War, changed at the end of the conflict. The historical sources include UN documents and resolutions found in the online archive of the organization, as well as secondary sources, namely, previous research about the end of the Cold War, and

\footnotetext{
${ }^{1}$ The perspective on the international system depends on each school of thought. In this paper, I will adopt the theory developed by the realist school. Therefore, according to the Realists, the international system is anarchic, the states are the most important actors of the system, and their interaction determines their behaviour. The system is in a constant state of antagonism, as was during the Cold War. For more on the Realist school of thought, see Elman 2008, 15-29 in Kennedy 2008.

${ }^{2}$ Illustrative examples were the operations authorized in Lebanon, the United Nations Observation Group in Lebanon (1958), and in New West Guinea, the United Nations Security Force in West New Guinea (1962-1963).
} 
peacekeeping. I structure my analysis on three levels. The first level will address the changes in the international system produced by the end of the Cold War. These changes impacted the peacekeeping mechanism and the United Nations at a broader level. The second level will focus on the peacekeeping principles and how these changed during 1988-1992. The third level examines and compares four operations, two authorized during the Cold War and two authorized at its end. This approach illustrates how the identified changes impacted the mechanism. It will also evaluate the impact the international actors had on UN-authorized missions.

The structure of my paper encompasses three parts. The first part will define the concept of peacekeeping. Firstly, the definition of peacekeeping, its periodization, and the main principles of this security mechanism will be considered. The second part of the study will focus on 1988-1992, by analyzing the peacekeeping principles, and two case studies. The third will focus on the research conclusions, limits, and future perspectives for analysis and research.

\section{Definition and periodization of the UN peacekeeping principles}

After the Second World War, following in the shoes of the League of Nations, the United Nations was created to maintain international peace and security and prevent a new global conflagration. To this end, the UN received a collective security mechanism mentioned in the Charter of the United Nations. Despite this, the Cold War international system prevented the UN from using the provisions of the Charter to respond to international crises. ${ }^{3}$ However, the organization avoided the deadlock caused by the Cold War $^{4}$ and developed the peacekeeping mechanism, thus acquiring the opportunity to solve international conflicts and disputes actively. Especially after 1956, the UN has established and incorporated the capacity to intervene in disputes through monitoring and peacekeeping operations. Through several specific features, these actions have bypassed the disputes of the Security Council and provided opportunities for the United Nations to intervene in existing disputes by monitoring armistices and borders, positioning themselves between combatants and other activities aimed at restoring and maintaining peace. Considering the limits imposed on the international organization, the UN intervened in several inter-state and intra-state conflicts during the Cold War to preserve international peace and prevent significant conflicts involving the two superpowers. Over the years, the impact of the Cold War on the UN peacekeeping mechanism has been evident. In this respect, the United Nations could authorize actions only after considering the confrontation and positions of the United States and the Soviet Union. Therefore, one could notice that at the end of the Cold War, the mechanism escaped the only after constraints of the bipolar system. Since 1989 the UN could authorize a series of missions that predicted the future of the security mechanism in the post-Cold War period.

The United Nations did not play an essential role in managing international crises in the first few years after its establishment. Starting with Dag Hammarskjöld's secretariat (1953-1961), the United Nations began to master the instruments of preventive diplomacy. Peacekeeping operations, the most important instrument, were developed in the early

\footnotetext{
${ }^{3}$ MacQueen 2006, 53-54.

4 Murphy 2007, 2.
} 
years of the Cold War and aimed at preventing local tensions from evolving into global conflicts between the two superpowers. With the success of the operation in the Suez Canal (1956), the United Nations intended to institutionalize and formalize the concept of peacekeeping and provide a set of rules as a model for future operations. From a legal point of view, peacekeeping was not part of the UN Charter, hence controversy over its legality. Hammarskjöld framed it in the so-called 'Chapter 61/2', which had characteristics from Chapter VI and Chapter VII. This ambiguity of the term, as well as the fact that it was not included in the UN Charter, caused uncertainty, Ray Murphy pointing out that the lack of definition created confusion about the components of peacekeeping. ${ }^{5}$ However, this confusion over peacekeeping allowed it to intervene in different complicated contexts.

Alan James formulated a conclusive definition of peacekeeping operations. The definition focuses more on four key elements of peacekeeping. ${ }^{6}$ Thus, applied for the traditional period of peacekeeping operations, 1947-1987, Alan James identified staff, values, conflict resolution, and the context of intervention as essential to understand the peacekeeping mechanism. Whether the personnel was made up of military or civilians, the values were the most important as they determined the character of the operations. In this respect, the operations had the right to use force only for self-defense purposes, and they had to be mandatory impartial to ensure the cooperation of both parties. Moreover, the functions were also important. The operations had the functions of de-escalating, observing armies, and withdrawing troops. They were meant to discourage a reescalation of tensions and stabilize tense situations. The central purpose of the operations was to deal with the causes of the conflict and protect international peace and security. It involved the interposition between the camps in conflict, administering the disputed territory, and ensuring the organization of plebiscites and elections. Finally, the last element identified by James was the context, being divided by the author into four distinct parts, as follows: the authority setting up the operation, the mandate, the principles on which the mission is based, the positions of the states involved in the conflict and their cooperation with the mission.

Peacekeeping missions were based on several rules and evolved based on the experiences gained, then operationalized and integrated by the peacekeeping mechanism. Each intervention takes account of the provisions of the Charter. The operations mandated during the Cold War adapted to the bipolar context and managed to comply with the provisions of the UN Charter. In this respect, following the intervention in the $1956 \mathrm{Suez}$ crisis, ${ }^{7}$ Secretary-General Dag Hammarskjöld used the success of the operation, United Nations Emergency Force, and integrated the experiences gained in the form of basic principles of the mechanism, which then had to be respected by all other authorized operations.

The main features that Hammarskjöld identified in 1958 were presented at the 13th Session of the General Assembly, considering them to be essential for the authorization

${ }^{5}$ Murphy 2007, 1.

6 James 1990, 2-8.

7 The UN intervention in the Suez Crisis of 1956 was based on United Nations General Assembly Resolution 1001 (ES-I). The organization authorized the United Nations Emergency Force operation to overview the withdrawal of France, the United Kingdom, and Israel's troops from Egypt and serve as a buffer zone between Egyptian and Israeli forces. 
and success of other peacekeeping operations that would have been authorized. ${ }^{8}$ Thus, the Secretary-General exposed three critical principles on which operations should be based if they were to be authorized. ${ }^{9}$ The first essential rule, intended to enable the organization to intervene on the territory of a state, was to obtain the consent of the host states, which would provide the legal basis for the UN to bypass Article 2, paragraph $7 .{ }^{10}$ The second principle was to prevent the organization's direct involvement in the conflict and ensure the cooperation of the parties concerned through impartiality. The operation was prohibited from favoring one side of the conflict. The third regards the use of force only for self-defense cases, resulting from the compromise reached with the superpowers. Operations, although they had military force, were to use it only if under attack. Thus, the role of the operations was limited to monitoring, observation, and mediation. ${ }^{11}$ Additionally, Hammarskjöld specified other principles to ensure the smooth running of operations. They included provisions on forbidding permanent members of the Council to send troops, to avoid the involvement of the two superpowers in the existing conflicts. The UN troops had to enjoy the freedom of movement on the territory where they were authorized. The operations were to be financed from the UN general budget, a principle abandoned in the following years. ${ }^{12}$ During the Cold War, operations closely followed these principles, a compromise that the UN managed to reach indirectly with the superpowers. However, this did not always work, and, in many cases, no peacekeeping operation was authorized to safeguard international peace and security. The failure of the mechanism was evident in the case of the 1967' Six Day War where the first element of peacekeeping, the consent of host states, was withdrawn a few weeks before the conflict began. ${ }^{13}$

The peacekeeping mechanism has been periodized over time. Wiseman gave a complex periodization of the operations authorized during the Cold War. He identified no more than five periods, 'the Nascent Period (1946-1956),' 'the Assertive Period (19561967),' 'the Dormant Period (1967-1973),' 'the Resurgent Period (1973-1978),' and 'the Maintenance Period (1978-1985'). ${ }^{14}$ Another research has identified four periods, or sections, of peacekeeping operations. These were divided into 'Early Experiences - 19481963, 'Cold War Peacekeeping - 1964-1987, 'Post-Cold War Peacekeeping - 1988-1998,' 'Peacekeeping in the Twenty-First Century - 1999-2013.'15 However, this paper will appeal to Gary Wilson's periodization, that identifies four generations of operations over time.

${ }^{8} \mathrm{~A} / 3943$, October 1958.

${ }^{9}$ Langholtz 2010, 41-49.

${ }^{10}$ The article did not allow any entity to intervene in the internal affairs of a state, unless the state agreed to the intervention, or the provisions of Chapter VII were appealed to.

${ }^{11}$ The rule was a direct consequence of the UN's involvement in the Korean War when Chapter VII authorized the United States' intervention in the peninsula. Since then, the USSR has opposed any resolution that allows the organization to intervene to resolve the dispute, using the right of veto.

${ }_{12}$ The costs of Operations de Nations Unies au Congo (1960-1964) are estimated to be raised somewhere to $\$ 400$ million and led to the 'Article 19 crisis' in 1963 when the Soviet Union and France threatened with the suspension of voting rights for the backlog of their contribution to the UN budget. For more details on the 'Article 19 crisis' see Luck 1999, 233-238.

${ }^{13}$ For an analysis of the 1967 conflict and the failure of the peacekeeping mechanism in preventing the 1967, 6 Day War, see Gagnon 1967, 812-836.

${ }^{14}$ Wiseman 1987, cited in Fetherstone 1994, 16.

${ }^{15}$ Koops et alii 2015. 
The first is the traditional period of 1956-1987, when the operations subscribed to the 1958 principles of Hammarskjöld. Consequently, the UN troops interposed between conflicting parties, oversaw armies and borders, supervised troops' withdrawal, and ensured disengagement of the involved sides. The next period, and the one that interests us, is that of operations authorized between 1987 and 1992. These did not have to follow the principles of 1958 closely and took on other functions, such as peacebuilding, by overseeing democratic elections or by administering post-conflict territories. ${ }^{16}$ As shown below, the principles of peacekeeping operations changed as the missions assumed more critical roles than surveillance and interposition. The end of the Cold War also enabled actors and missions to play roles other than traditional ones. The third period refers to the operations authorized after 1992, whose purpose was to intervene in internal wars, stop the conflict, and facilitate peace. The most notorious missions authorized in this period are those in Somalia and Yugoslavia. The last identified period by Wilson refers to the operations authorized after 1999. Their purpose was more of building peace than of keeping the peace by establishing democratic institutions in the fallen states. Such missions were authorized in Timor Leste and Kosovo. For the scope of this study, I will focus on the second generation of peacekeeping as identified by Wilson.

\section{The metamorphoses of the UN peacekeeping principles}

After the institutionalization of peacekeeping, after Hammarskjöld's speech in 1958, the mechanism had the opportunity to intervene in international disputes and solve the problems. During the Cold War, thirteen peacekeeping operations took place. Operations after 1956 were authorized based on the principles operationalized by Hammarskjöld in 1958. The superpowers influenced the operations at their initial stage but also during the deployment of troops on the ground.

However, the end of the Cold War was for the UN and peacekeeping, as Norrie MacQueen argued, an excellent opportunity for intervention, as bipolar interests disappeared and, theoretically, all conflicts could be addressed by the organization. Moreover, peacekeeping had the potential to evolve and become intensely involved in international crisis management and identify conclusive solutions without considering the interests of the two superpowers. ${ }^{17}$

\section{a) The principles' metamorphoses between 1988 and 1992}

The period of transition and evolution of the UN peacekeeping mechanism to the new form began before 1991 and the dissolution of the Soviet Union. Thus, since 1988 and with the authorization of operations in Afghanistan, Namibia, Angola, or Nicaragua, the operations have included provisions and tasks characteristic to traditional operations, such as interposition and fostering a climate of peace. The operations authorized during that period included other elements characteristic to peacebuilding, which determined the operations to be more complex. The process was not limited only to keeping the peace but also to building the peace. ${ }^{18}$ After 1988, the peacekeeping operations evolved as the

\footnotetext{
16 Wilson 2014, 116-152.

17 MacQueen 2013, 92-93

18 For more details on the concept of peacebuilding and how the United Nations made use of it, see Cavalcante 2019.
} 
international system changed, and the UN was called upon to deal with crisis management. The situation resulted in a shift in peacekeeping principles and rules as the peacekeeping mechanism that was 'revitalized' by including the emerging peacebuilding agenda and the need to intervene in intra-state wars. ${ }^{19}$ For example, the Namibia operation was in charge of supervising democratic elections and included an increased number of UN police patrols. ${ }^{20}$ They received complex roles as the operation performed activities related to state security and contributed decisively to the process of transition to democracy. ${ }^{21}$

Given that the paper aims to understand the changes of the peacekeeping mechanism during this period, I will focus on authorized operations that most accurately reflect the UN mechanism and their compliance with the essential rules. In this respect, operations authorized during this period followed the traditional missions' basic tasks and included other duties. Moreover, the mechanism has evolved further since 1992, and the UN has authorized operations based on the provisions of Chapter VII, as was the case for operations in Somalia and Yugoslavia. ${ }^{22}$ In the context of new authorized operations, the principles of peacekeeping have also changed. Compared to the classic rules identified by Hammarskjold, one could notice that the 'Holy Trinity' of peacekeeping has undergone specific mutations. ${ }^{23}$ First, peacekeeping operations continued to be authorized only with the agreement of the host states, but they began to go beyond the required impartiality and took on more complex functions. In the case of Namibia or Mozambique, peace troops supervised the democratic elections and provided humanitarian support. They were even involved in state administration during the transition period, as happened in Cambodia. ${ }^{24}$ Secondly, operations began to be more coercive, and some of them were authorized based on Chapter VII, including Somalia and Yugoslavia, which allowed them to overcome the rule of use of force only in self-defense cases. ${ }^{25}$ Thirdly, starting with the operation authorized in the wake of the First Gulf War, the five permanent members of the Security Council sent troops to the regular operations. As a result, they bypassed the provision that forbidden permanent members to contribute with troops for the UN peacekeeping operations, so that the missions would not serve the interests of one of the two superpowers.

The evolution or revitalization of the UN security mechanism surprised the international scene. Most of the authorized operations were successful, increasing the number of peacekeeping operations, troops, and budget. Thus, the UN authorized 22 missions in only six years, compared to only 13 missions in forty years of Cold War. ${ }^{26}$ The number of troops reached 78,000 in 1994 , compared to 11,000 in 1988 , and the UN budget for peacekeeping reached a maximum of 3.8 billion dollars, compared to

\footnotetext{
19 Koops et alii 2015, 261-262.

${ }^{20}$ UN police troops were also mandated in operations in Congo and Cyprus only that their role was limited and, mainly, they had to train local police services.

${ }^{21}$ MacQueen 2006, 187-191.

${ }^{22}$ For more details on these missions, see Murphy 2007.

${ }^{23}$ The 'Holy Third' of peacekeeping operations refers to the three basic principles. They are still considered essential in the authorization of missions. They refer to the host state's consent, impartiality, and force only for self-defense. Bellamy, Williams 2010, 174.

${ }^{24}$ MacQueen 2006, 187-201.

${ }^{25}$ For more details on the two operations see Tardy and Williams, in Koops et. alii 2015, 383-441.

26 The number of UN operations reflects the Cold War impact over the mechanism: eight from thirteen operations took place between 1956 and 1967 when the superpowers accepted the meditation of the UN.
} 
230 million in $1988 .{ }^{27}$ The importance of the UN peacekeeping mechanism was evident in the institutionalization of the mechanism. In March 1992, the Department of Peace Operations began to function. Its creation allowed operations to benefit from its direct supervision and coordination. Its workings were also a precedent for future peacekeeping missions. ${ }^{28}$ Moreover, Secretary-General Boutros-Boutros Ghali's 'An Agenda for Peace' of 1992 reflected the optimism of those years about the possibilities of the UN. In this respect, Ghali hoped that the organization, through peacekeeping, would be the guarantor of international peace and security for years to come. The document suggested a series of interesting proposals that were inconceivable during the Cold War, such as the revitalization of Article 47, concerning the formation of a Staff Committee composed of the Heads of State of the Five Permanent Members, or the use of the entire Article 43 to establish 'peace-enforcement units' from volunteers and to be better equipped than the traditional peacekeeping troops. ${ }^{29}$

Secretary-General Ghali's hopes, however, were shattered in the following years. In Somalia, Yugoslavia, or Rwanda, operations failed to fulfill the mandate. The situation triggered a pessimistic view on peacekeeping, which forced the international community to reconsider the possibilities created by the mechanism. In the following period, these failures made the UN and other international actors more skeptical about peacekeeping. Hence, the number of troops and the budget allocated to the peacekeeping mechanism fell considerably between 1995 and 1998. Moreover, Ghali's optimism diminished. In the 1995 Supplement 'Agenda for Peace', he presented a more cautious attitude, specifying that peacekeeping's 'Holy Trinity' remained the base of the UN authorization of mission. This development implied that the earlier bold proposals were abandoned. ${ }^{30}$ What followed was a period of stagnation. From 1998, after the operation in Timor Leste and the Secretary-General Kofi Annan's 'Brahimi Report' in 2000, peacekeeping entered a new phase of evolution. This new phase of multidimensional operations was a mix of traditional operations and innovative elements. Consequently, the peacekeeping operations combined observation and surveillance - with more complex tasks, including humanitarian support, supervising democratic elections, cooperation with states to lay the foundations for democratic institutions, police involvement in developing a police system in war-ground states. ${ }^{31}$

\section{b) Comparative perspectives: operations authorized during and after the Cold War}

In this latter part, the paper will briefly compare two peacekeeping operations authorized during and after the Cold War, which are similar in the objectives in the mandates assigned. The following comparison aims to analyze two types of authorized missions during and after the Cold War focusing on intervention and observation. Although they were authorized in different contexts, from comparing these missions, one could gain a meaningful understanding of the international system they operated, how the principles

\footnotetext{
${ }^{27}$ Koops et. alii 2015, 262.

${ }^{28}$ Findlay 2002, 164-165.

${ }^{29}$ Ghali (A/47/277), June 1992.

${ }^{30}$ Ghali (A/50/60), January 1995.

${ }^{31}$ For more details on the multidimensional missions and the use of Chapter VII, see Howard, Dayal 2017, 71-103.
} 
evolved, and their role in keeping the peace. The focus will be centered on presenting the mandate of operations, integrating the principles, and appreciating their success or failure. This comparative perspective underlines the role of principles in authorizing these missions and the factors contributing to their success or failure. The comparison criteria are the importance of the peacekeeping principles for the operations, to what extent they were observed. Also, I will consider in the comparison the impact the structure of the international system had on the development of peacekeeping operations.

The first comparison is between the operation authorized in New West Guinea in 19621963 and Namibia in 1989. ${ }^{32}$ Thus, the comparison is interesting because it can illustrate how the international system has influenced the rules of peacekeeping in the case of these operations. In terms of the mandate, the operation in New West Guinea had two parts. The first part aimed to oversee the transition from the Dutch to the Indonesian administration, acting as the governing authority through Operation United Nations Temporary Executive Authority (UNTAE). In the second phase, the mission focused on maintaining peace and security in the region through the United Nations Security Force (UNSF). ${ }^{33}$ The Namibia operation, although authorized in a more complicated context, sought to withdraw South African and Angolese troops from Namibia and to ensure the transition to democracy from civil wars and colonialism through the United Nations Transitional Assistance Group (UNTAG). ${ }^{34}$ Both operations were authorized under the agreement of the host states. They were impartial to the internal issues and aimed to use force only in self-defense cases. Two questions arise: how was the international system influenced by the peacekeeping mission, and how important were the superpowers in the case of these operations? Regarding the operation in New West Guinea, one can notice the favorable context of decolonization. The transition from the Dutch to the Indonesian authority was natural; it did not face the opposition of actors or superpowers whose attention and interests turned to the situation in Congo. Although the intervention plan was conceived in 1978, operation in Namibia was postponed due to the beginning of the Second Cold War. The confrontation between the superpowers delayed the management of Namibia's situation. However, in 1989, the UN authorized an operation in Namibia to ensure its transition to democratic institutions.

Both operations complied with the 'holy trinity' of authorization having the consent of host states, impartiality, and the use of force only for self-defense purposes. A similarity is evident in the contribution of the permanent members of the Security Council. In both cases, members with a veto contributed in one way or another to these operations. In the case of New West Guinea, several American specialists were sent, ${ }^{35}$ while in Namibia, no less than 51 states contributed, including France and Great Britain. ${ }^{36}$ Thus, comparing

${ }^{32}$ Although it is known that the Cold War ended officially in 1991 with the dissolution of the Soviet Union, we adopt Norrie MacQueen's view and argue that in 1989 the peacekeeping mechanism emerged from the bipolarisation of the system by authorising operations different from those authorized during the Cold War. Such a different operation was deployed in Namibia in April 1989. MacQueen 2013, 89-91.

33 The operation was based on the New York Agreement of August 1962 between Netherlands and Indonesia and on the UN Resolution A/RES/1752 (XVII) from October 1962.

34 The mission was authorized based on two UN resolutions: S/RES/435(1978), September 1978, S/ RES/632(1989), February 1989.

35 https://peacekeeping.un.org/sites/default/files/past/unsffacts.html.

${ }^{36}$ https://peacekeeping.un.org/sites/default/files/past/untagF.htm. 
the two operations shows us that the peacekeeping missions had all the chances to be successful when they enjoyed the favorable context. The superpowers agreed with the mandate of the transition, and the rules were observed accordingly. The mandates were easy to fulfill, with both UNTAG and UNTAE/UNSF successfully attaining their purposes.

Another comparison that leads to insightful perception on peacekeeping rules is the operation in Suez in 1956, the United Nations Emergency Force (UNEF), and the operation in Kuwait in 1991, the United Nations Iraq-Kuwait Observation Mission (UNIKOM). This second comparison underlines how the organization intervened with a military force in a post-conflict area and managed the situation. The reasons for selecting these operations consider the similarities between operations and the moment of their authorization. These operations received authorization in different periods. The analysis will indicate how the international system changed and how this development impacted the rules and the peacekeeping mechanism.

As for their mandate, both operations had to oversee the withdrawal of troops from the territory of the victim state and guard the border between the two to prevent a resurgence of conflicts. ${ }^{37}$ In terms of principles, the operations were authorized with the agreement of the host state, Egypt and Kuwait, used force only for self-defense, being impartial to the conflict. The main difference considers the context in which the operations were authorized. Thus, UNEF was authorized following a fragile truce based on the preventive diplomacy promoted by Dag Hammarskjold and enjoyed the goodwill of the superpowers for authorization. ${ }^{38}$ UNIKOM was ordered following the collective intervention of international actors against Saddam Hussein's aggression. ${ }^{39}$ However, the difference is given by the possibility for UNIKOM, based on Chapter VII and the unanimous support of the Security Council, to enjoy greater coercive power and thus prevent possible new aggression by Hussein. The UNEF had to withdraw in 1967, a month before the Six-Day War, when Gamal Abdel Nasser withdrew support for the operation, and Israel refused to accept the operation on its side of the border. Why did UNIKOM manage to prevent a resurgence of conflicts and UNEF did not? The answer is related to the possibility of making use of all provisions of the UN Charter. In this direction, when Saddam Hussein showed prospects for crossing the border between Iraq and Kuwait in 1993, the issue was immediately taken to the UN by the United States, which mobilized 3,000 troops to discourage this development. ${ }^{40}$ From this perspective, one notices that the principles were respected in both cases except for the provision of troop contributions, which, through Chapter VII intervention and unanimous support from the Security Council, ${ }^{41}$ gave the Kuwaiti operation a strong position compared to Suez.

${ }^{37}$ UNEF was authorized through the UN Resolution A/RES/1001(ES-I), November 1956, whilst UNIKOM was authorized on the UN Resolution S/RES/689(1991), February 1991.

38 For more details on the 1956 Suez operation and the importance of peacekeeping for the Middle East see Dombroski 2007.

39 See Bury 2003, 71-88.

${ }^{40}$ UNIKOM mandate was extended by the UN Resolution S/RES/806(1993), February 1993.

${ }^{41}$ Bury 2015, 314-315. 


\section{Conclusions}

The international system between 1988 and 1992 allowed the UN to use the peacekeeping mechanism at its disposal and solve several older international crises, as was the case in Namibia, or more recent ones. The principles and rules of peacekeeping evolved, which allowed them to be more complex when fulfilling the mandate. The context that emerged in 1988 was also favorable. Following the intervention in Kuwait in 1991, the United Nations' role on the international scene has changed, and the actors saw in the organization an entity that would protect international peace and security, high hopes surrounding the UN during that period. The failures of the missions in Somalia, Bosnia, and Rwanda caused the decline of initial optimism surrounding the UN interventions in those years to decline in intensity. The organization and international actors became more reluctant about the UN peacekeeping mechanism. In the light of the two comparisons, one notices the importance of the international context in which post-Cold War operations were authorized, underlining the UN's dependence on superpowers between 1947 and 1987.

The paper focused on the evolution of the peacekeeping principles between 1988 and 1992 and how this development influenced subsequently authorized operations. As shown above, the UN principles have been equally respected, but they have evolved to allow for more complex operations in the right context. Thus, in the case of the first type of operations compared, I showed that when the peacekeeping mechanism enjoys proper functioning, provided by the cooperation of all the actors involved, the operations are likely to be successful and principles of peacekeeping observed. Regarding the latter, the rules remained equally important. They evolved to the extent that the involvement of the Security Council's permanent members also meant that former combatants were more likely to cooperate in the peace-making process. These made an essential contribution to the UN's peacekeeping mechanism and predicted and illustrated the optimism about its success between 1992 and 1995.

The present paper managed to analyze how the international system evolved and how its metamorphoses had an impact over the UN peacekeeping mechanism. Focusing only on the period of 1988 and 1991, my paper leaves open for discussion other important aspects of peacekeeping ${ }^{42}$. Therefore, an analysis of the period after 1992 will allow us to understand how the development of the peacekeeping principles continued and what experiences they had that determined their further evolvement and understand how the mechanism developed in these years. Secondly, analyzing each operation after 1992 can explain the evolution of the principles and how they have been operationalized in each case. Thirdly, an in-depth analysis of the reports provided by the Secretaries-General between 1988 and 2000 will allow for an accurate analysis of the organisation's reference to peacekeeping and principles.

${ }^{42}$ The operations authorized from August 1988 to October 1991 are: United Nations Iran-Iraq Military Observer Group (UNIIMOG), United Nations Angola Verification Mission I (UNAVEM I), United Nations Transition Assistance Group (UNTAG), United Nations Observer Group in Central America (ONUCA), United Nations Iraq-Kuwait Observation Mission (UNIKOM), United Nations Mission for the Referendum in Western Sahara (MINURSO), United Nations Angola Verification Mission II (UNAVEM II), United Nations Observer Mission in El Salvador (ONUSAL), and United Nations Advance Mission in Cambodia (UNAMIC). 


\section{Bibliography}

\section{Primary sources: UN Archival Documents}

UN General Assembly, doc. A/RES/1001(ES-I) of 7 Nov. 1956,

https://undocs.org/en/A/RES/1001(ES-I), accessed 17 Febr. 2021.

UN General Assembly, doc. A/3943, of 9 Oct. 1958,

https://undocs.org/A/3943, accessed 15 Febr. 2021.

UN General Assembly, doc. A/RES/1752(XVII), 21 Sept. 1962,

https://undocs.org/en/A/RES/1752(XVII), accessed 17 Febr. 2021.

UN Security Council, doc. S/RES/435(1978), 29 Sept. 1978,

https://undocs.org/en/S/RES/435(1978), accessed 17 Febr. 2021.

UN Security Council, doc. S/RES/632(1989), 16 Febr. 1989,

https://undocs.org/en/S/RES/632(1989), accessed 17 Febr. 2021.

UN Security Council, doc. S/RES/689(1991), 9 Apr. 1991,

https://undocs.org/en/S/RES/689(1991), accessed 17 Febr. 2021.

UN General Assembly, doc. A/47/277, 17 Jun. 1992,

https://undocs.org/en/A/47/277, accessed 16 Febr. 2021.

UN Security Council, doc. S/RES/806(1993), 5 Febr. 1993,

https://undocs.org/en/S/RES/806(1993), accessed 18 Febr. 2021.

UN General Assembly, doc. A/50/60, 25 Jan. 1995,

https://undocs.org/en/A/50/60, accessed 16 Febr. 2021.

\section{Secondary Sources}

Bellamy, Williams 2004

Bellamy, Williams 2010

Bury 2003

Bury 2015

Cavalcante 2019

Dombroski 2007

Findlay 2002

Gagnon 1967

Howard, Dayal

James 2010

Langholtz 2010
A. Bellamy, P. Williams, Understanding Peacekeeping, First Edition, London 2004.

A. Bellamy, P. Williams, Understanding Peacekeeping, Second Edition, London 2010.

J. Bury, The UN Iraq-Kuwait Observation Mission, International Peacekeeping, 10/2, 2003, 71-88.

J. Bury, United Nations Iraq-Kuwait Observation Mission (UNIKOM). In: J.A. Koops, T. Tardy, N. MacQueen, P. D. Williams (eds.), The Oxford Handbook on United Nations Peacekeeping Missions, Oxford 2015, 314-315.

F. Cavalcante, Peacebuilding in the United Nations, Switzerland 2019.

K. R. Dombroski, Peacekeeping in the Middle East as an International Regime, New York, 2007.

T. Findlay, The Use of Force in UN Peace Operations, Oxford 2002.

M. Harrington, Peace Forces and the Veto: The Relevance of Consent, International Organization, 21/4, 1967, 812-836.

L. M. Howard, A. K. Dayal, The Use of Force in UN Peacekeeping, International Organization, 72/1, 2017, 71-103.

A. James, Peacekeeping in International Politics, New York 1990;

H. J. Langholtz (ed.), Principles and Guidelines for UN Peacekeeping Operations, Williamsburg 2010. 
Kennedy 2008

Koops 2015

Luck 1999

MacQueen 2006

MacQueen 2013

Murphy 2007

Wilson 2014
P. Kennedy (ed.), Security Studies: An Introduction, London 2008.

J. A. Koops, The Oxford Handbook of United Nations Peacekeeping Operations, Oxford 2015.

E. C. Luck, Mixed Messages: American Politics and International Organization, 1919-1999, Washington DC 1999.

N. MacQueen, Peacekeeping and the International System, London 2006.

N. MacQueen, The United Nations, Peace Operations and the Cold War, London 2013.

R. Murphy, Peacekeeping in Lebanon, Somalia and Kosovo, Cambridge 2007.

G. Wilson, The United Nations and Collective Security, New York 2014.

\section{Online Resources}

https://peacekeeping.un.org/sites/default/files/past/unsffacts.html, accessed 18 Febr. 2021.

https://peacekeeping.un.org/sites/default/files/past/untagF.htm, accessed 18 Febr. 2021. 



\title{
THE GAZA STRIP AND THE ISRAEL-HAMAS CONFLICT: FROM 2008 UNTIL NOWADAYS
}

\author{
LILIANA-MARIA TIVADAR
}

\begin{abstract}
The paper analyzes the relations between Hamas and Israel through a series of conflicts that occurred from 2008 until nowadays. Thus, the study aims at the chronological presentation of the Israeli military offensives from 2008 to 2014 (known as code: Cast Lead, 2008-09; Pillar of Defense, 2012; Protective Edge, 2014), supplemented by the assessment of the conflict situation after 2014 and taking into account of the escalation of current tensions (Operation Guardians of the Walls, May 2021).

The two Palestinian territories-the Gaza Strip (ruled by Hamas since June 2007) and the West Bank (divided into three zones - A, B, and C, following the 1995 interim peace agreement-over which the Palestinian Authority exercises partial control) - are areas of significant security interest (Fig. 1). Here, local tensions can erupt at any time and create a state of conflict that is difficult to manage. This situation was visible again in the Gaza Strip in May 2021, when Hamas launched missiles at major Israeli cities, and-in response, the Israeli army carried out a new military operation known as code name Guardian of the Walls. As such, this area continues to be of significant interest in local, regional, and international security and requires increased attention from specialists and analysts who assess the course of events in this area.
\end{abstract}

Keywords: Palestine, Gaza Strip, Israel, Hamas, conflict

Rezumat: Lucrarea analizează relațiile dintre Hamas și Israel prin prisma seriilor de conflicte care au avut loc din 2008 până în zilele noastre (2021). Astfel, studiul urmărește prezentarea cronologică a ofensivelor militare israeliene din 2008 până în 2014 (cunoscute sub numele de cod: Cast Lead, 2008-09; Pillar of Defense, 2012; Protective Edge, 2014), fiind completat de evaluarea situației conflictuale după 2014 și luând în considerare escaladarea tensiunilor actuale (Operation Guardians of the Walls, mai 2021).

Cele două teritorii palestiniene-Fâșia Gaza (condusă de Hamas din iunie 2007) și Cisiordania (împărțită în trei zone - A, B și C, în urma acordului interimar de pace din 1995 - asupra căreia Autoritatea Palestiniană exercită un control parțial) - sunt zone de interes semnificativ din punct de vedere al securității. Aici, tensiunile locale pot izbucni în orice moment și pot crea o stare de conflict dificil de gestionat. Această situație a fost vizibilă, din nou, în Fâșia Gaza, în mai 2021, când Hamas a lansat rachete către marile orașe israeliene și - ca răspuns-armata israeliană a efectuat o nouă operațiune militară cunoscută sub numele de cod Guardian of the Walls. Ca atare, această zonă continuă să fie de interes semnificativ pentru securitatea locală, regională și internațională, și necesită o atenție sporită din partea specialiștilor și analiștilor care evaluează cursul evenimentelor din această regiune.

Cuvinte cheie: Palestina, Fâșia Gaza, Israel, Hamas, conflict

`M.A. Student, 'Babeș-Bolyai’ University, Cluj-Napoca, e-mail: liliana.tivadar@stud.ubbcluj.ro,

https://orcid.org/0000-0003-1170-5420. 


\section{Introduction}

In May 2021, international attention turned again to the Palestinian territories. The world experienced clashes between Hamas and Israel in the Gaza Strip, about seven years after the last conflict (2014). The current security situation (May 2021) in the Gaza Strip has become increasingly fragile as tensions between Palestinians and Israeli security forces have increased in East Jerusalem. According to Al Jazeera, tensions have risen following clashes between Palestinians and Israeli settlers in 'the occupied East Jerusalem neighborhood of Sheikh Jarrah.' There have been protests and street fights between Palestinians, Israeli settlers, and Israeli police since April. Following a raid by Israeli security forces on the Al-Aqsa complex (10 May 2021), Hamas issued an ultimatum to Israel to withdraw its security forces from the Al-Aqsa complex and the Sheikh Jarrah neighborhood. ${ }^{1}$ All this eventually led to the escalation of violence between Hamas and Israel in the Gaza Strip. The firing of missiles by Hamas into Israeli cities resulted in harsh responses from the Israeli state. In this context, a new Israeli military offensive (known as Operation Guardian of the Walls) emerged in the Gaza Strip. This operation was similar in proportion to the previous three operations.

My paper's purpose is to make a historical analysis of the conflict situation between Israel and Hamas in the Gaza Strip, covering the period 2008 until nowadays. This study is important because it creates a comprehensive framework reflecting the dynamics of the Palestinian territories (particularly in the Gaza Strip). The Palestinian issue is still one of the significant unresolved issues on the Middle East's political agenda. Therefore, this study addresses a current concern both for regional security and international security. At the same time, it details how this small territory (Gaza Strip) has grown into an unstable security environment. Lastly, this paper also captures the complexity of the problems between Israelis and Palestinians in general. Following a diachronic perspective, I show how these conflicts manifested history, and their impact on the current situation in Gaza.

The Gaza Strip (which, along with the West Bank, forms the current Palestinian territories) is a small territory - comprising a portion of the land of about 360 square kilometers, $41 \mathrm{~km}$ long, and 6-12 kilometers wide. ${ }^{2}$ Contrary to expectations during the peace negotiations between the Palestine Liberation Organization (PLO) and Israel, the quasi-government of the Palestinian Authority has led to the fragmentation of the future Palestinian state. Since 2007, the Palestinian territories have been separated into two opposing governments - both geographically and politically. The Gaza Strip was and is still held captive in the middle of violence between its government (Hamas) and the state of Israel. It is controlled by Hamas (considered a terrorist organization by the US, Israel, the EU, and others) since June 2007, following its capture by military means. The Israeli government withdrew its armed forces and settlers from the area in August 2005, after 38 years of 'occupation.' This action did not contribute to a peaceful solution. Moreover, it has become a somewhat controversial issue, as future events have led to the imposition of an economic blockade on Israel on Gaza, which has resulted in maintaining control over land, sea, and air space over the Palestinian enclave. Thus, the international community considers Gaza to be a still occupied territory. ${ }^{3}$ On the contrary, in the years that followed, Hamas'

\footnotetext{
1 'What led to the most recent Israel-Palestine escalation?'/Al Jazeera.

${ }^{2}$ Efrat 2006, 167.

${ }^{3}$ For more details on this topic, see: Rynhold, Waxman 2008; Cuyckens 2016; Butt, Butt 2016.
} 
success in the Palestinian legislative elections and the seizure of control of the Gaza Strip led Israel to pursue a strict policy. Calling it a 'hostile entity, ${ }^{4}$ after the area came under the military control of Hamas (2007), Israel pledged to destroy Gaza's 'terrorist infrastructure.' The imposition of an economic blockade to encourage the Palestinian people to oppose the Hamas governance has not ended with the desired result: Hamas has remained in power in Gaza until nowadays (2021).

In general, the Palestinian issue is a matter of interest to specialists in the field. Consequently, there is a rich range of in-depth and varied studies on the subject in the literature. From the point of view of historical analysis, both Israeli historians, such as Benny Morris ${ }^{5}$ or Avi Shlaim, ${ }^{6}$ and Palestinian historians, such as Rashid Khalidi ${ }^{7}$ capture in their books the gradual evolution of the Israeli-Palestinian conflict. They also address the many problems that have arisen throughout history on this dispute.

Numerous books and articles deal with the topic of the Gaza Strip. One of these is the book by researcher Elisha Efrat, called The West Bank and Gaza Strip. A Geography of Occupation and Disengagement. ${ }^{8}$ The piece describes the events between 1967 and 2005 based on the geographical factor and their relation to the 'Israeli occupation.' The study of researcher Sara Roy (Failing Peace: Gaza and the Palestinian-Israeli Conflict ${ }^{9}$ and Hamas and Civil Society in Gaza. Engaging the Islamist Social Sector ${ }^{10}$ ) is also focused on both the evolution of the Gaza Strip and civil society in a conflict environment and Hamas-led domestic policy and on Israeli policy related to the Gaza Strip. In the recent book - known as Unsilencing Gaza ${ }^{11}$ - the author dedicates a section of the paper (Part II. The Marginalized Center: The Wars On Gaza And Their Aftermath ${ }^{12}$ ) to analyze the period of conflict in Gaza (from 2008 to 2014). It puts a major emphasis on relations between Israel and Hamas, respectively Hamas and Fatah. Also, she reviews the situation in Gaza Strip after the three conflicts (Israeli military operations) from the economic and social sector point of view. Consistent with the actual subject of this paper, in a chapter of his book, called Israel's Wars: A History Since 1947, ${ }^{13}$ Ahron Bregman ${ }^{14}$ makes an interesting but brief analysis of the three Israeli military offensives in Gaza. Given the author's background in the Israeli army and parliament, his political allegiances may influence the interpretation and presentation of events.

From a methodological point of view, my paper approaches the subject from a diachronically perspective. Thus, it aims to provide a short history of the Palestinian problem by identifying the leading causes of the conflict. Special attention will be paid to the actions of two actors: the state of Israel and Hamas. Their efforts and international

\footnotetext{
${ }^{4}$ Filiu 2014, 305.

5 Morris 2001.

6 Shlaim 2014.

7 Khalidi 2020.

${ }^{8}$ Efrat 2006.

9 Roy 2007.

${ }^{10}$ Roy 2011.

11 Roy 2021.

12 Roy 2021, 55-94.

${ }^{13}$ Bregman 2016, 309-329.

14 Ahron Bregman was a captain in the Israeli army during Israel's 1982 invasion of Lebanon and worked as a parliamentary assistant at Knesset (Israel's unicameral parliament).
} 
perceptions of their interventions differ greatly depending on the status of each. While the former is a state actor, the latter is a non-state actor. Israel has international recognition, a territory, a government, and a loyal population. By comparison, Hamas does not have international recognition: it is considered a terrorist organization and an illegal government in Gaza. However, the status of Hamas has evolved a lot since its inception. At present, Hamas can be perceived as both a political party and a resistance movement. Benedetta Berti makes a complex analysis of the Hamas case, following its evolution as a political party, government, and non-state armed group. ${ }^{15}$

The result involvement of the two actors (Israel and Hamas) in the conflict regarding Palestine resulted in a cyclical conflict. By cyclical conflict, I mean a state of confrontation that takes place periodically. In the Gaza Strip, the conflict between Hamas and Israel took place in four different time intervals (2008-2009, 2012, 2014, and May 2021). Thus, in my paper, I will analyze how this cyclical conflict had long-term repercussions in Gaza on both the economic ${ }^{16}$ and humanitarian ${ }^{17}$ situation. I will also employ a case study considering the historical, political, and military evolution of the Gaza Strip. My paper also contributes to regional studies since it deals with one of the most controversial issues in the Middle East, that of the creation of a Palestinian state. This issue influences both developments of the Israeli - Palestinian conflict and the attitude of the Arab states on the Palestinian question.

The sources of my paper cover the general framework of the Palestinian issue and the conflict in Gaza. Thus, the primary sources include official documents, such as UN resolutions (Resolution 181), official documents of Palestinian organizations (Palestinian National Charter, 1968; Hamas Charter, 1988), but also the interim peace agreements between Israel and the PLO (Declaration of Principles on Interim Self-Government Arrangements, 1993; The Interim Agreement on the West Bank and the Gaza Strip, 1995). The secondary sources consist of the books and specialized articles, which - among other things - describe and highlight the historical, political, and military evolution of the Palestinian question.

My paper has six parts. The first contains the introductory remarks and includes a review of the relevant literature, methodological considerations, and an analysis of the sources used. The second section provides a brief history of the Palestinian problem in general and the evolution of the Gaza Strip's status in particular. This creates a broad, historical framework that would ease the understanding of the current situation in Gaza nowadays. Moreover, a review of the events taking before 2008 will also be helpful to understand why the violent clashes between 2008 and 2014 took place. The conflicts in Gaza are important because, in addition to hindering the adoption of a peaceful solution to the Israeli-Palestinian conflict, they influence regional and international security. At the level of the Gaza Strip, these conflicts are presenting long-term repercussions for economic, political, or individual security. The third part of the paper draws attention to the results of the Palestinian legislative elections (2006) and the Palestinian civil conflict between Hamas and Fatah (2007). These two events were essential for the evolution of Hamas as a

\footnotetext{
15 Berti 2015.

${ }^{16}$ For more details on the economic situation, see: Rieger, Yashiv 2018.

17 For more details on the humanitarian situation, see: Salamanca 2011.
} 
political party, not just as a resistance movement. Hamas won 76 of the 132 seats available in the 2006 legislative elections. Under Palestinian law, it became eligible to form a new government. However, the situation changed radically. In June 2007, Hamas captured the Gaza Strip and became an illegal government following the Palestinian civil conflict. This moment is known for the political division of the two Palestinian territories. These actions have played an essential role in raising tensions in the Gaza Strip. Thus, the fourth and fifth parts evaluate and analyze the period 2008 until now to highlight the conflict's evolution between Hamas and Israel. The last subchapter of the paper contains conclusions.

\section{Palestinian Issue and the Gaza Strip: A General Historical Overview}

The Israeli-Palestinian conflict is one of the most complex and complicated conflicts in history. It dates from the middle of the last century (with the birth of the state of Israel in May 1948). The actions of the late nineteenth century (the emergence and development of the Zionist movement and mass immigration of Jews in Palestine) mark the early stages of the conflict. This conflict revolves around multiple issues, but the main one relates to the territory. The territory in question is called the Land of Israel (Eretz Yisrael, in Hebrew), while the Palestinians call it Palestine (Filastin, in Arabic). In this sense - as Dov Waxman well sums up in his book The Israeli-Palestinian Conflict - the narratives of both sides demand full rights over the same piece of land. ${ }^{18}$

Throughout history, Jewish aspirations have materialized through the Balfour Declaration (2 November 1917), which mentioned that the establishment 'of a national home for the Jewish people' in Palestine was considered favorable. ${ }^{19}$ Also, the events that led to war were materialized during the British mandate for Palestine (1920-1948) and complemented by the United Nations' involvement in the Palestinian question. Resolution 181 (II) - commonly known as the UN Partition Plan for Palestine - was proposed by the United Nations Special Committee on Palestine (UNSCOP) and adopted by the General Assembly on 29 November 1947. The document suggested the division of the territory of Palestine into two states: an Arab state and a Jewish state, with Jerusalem placed under international control. ${ }^{20}$ As a result of this situation-although there were multiple discontents on both sides (for Jews and Arabs) regarding the UN Resolution - David-Ben Gurion took the liberty to proclaim the independence of the State of Israel on 14 May $1948 .{ }^{21}$

The day after the birth of Israel, the neighboring Arab states (Egypt, Jordan, Syria, Lebanon, and Iraq) invaded the Jewish state. All these actions led to the outbreak of the first Arab-Israeli war (15 May 1948-10 March 1949). This stage remains known in Israel's memory as the 'War of Independence,' while the Palestinians call it 'Al-Nakba' (catastrophe). ${ }^{22}$ The war ended in 1949 with armistice agreements between Israel and the Arab states (Egypt, Lebanon, Jordan, and Syria). The outcome of this war highlighted, on the one hand, the survival of the Jewish state and its advancement far beyond the borders set out in the UN partition plan (comprising about '78 percent of Mandatory Palestine,

\footnotetext{
18 Waxman 2019, 36.

19 Morris 2001, 75.

20 'Resolution 181 (II). Future government of Palestine'/UNISPAL.

${ }^{21}$ Waxman 2019, 82-84.

22 Waxman 2019, 91-92.
} 
including the western part of Jerusalem, which the UN plan had put under international control $\left.{ }^{23}\right)$. On the other hand, for the Palestinians, the war results were a total failure because the idea of the Arab state proposed in the UN partition plan did not materialize (never, at least until now). The agreements signed with Egypt and Jordan led to the inclusion of the territories provided by the partition plan to an Arab state under their influence. The Gaza Strip - following the signing of the Israeli - Egyptian ceasefire agreement in Rhodes on 24 February 1949 - became a separate entity under Egyptian administration, while Jordan gained control of the West Bank and the eastern part of Jerusalem (as a result of the signing of the agreement on 3 April 1949). ${ }^{24}$ This formula lasted until June 1967, when - during the so-called 'Six-Day' War - the victory of the Israeli army resulted in the capture of the Palestinian territories (the Gaza Strip, the West Bank, even the East Jerusalem), the Golan Heights, and the Sinai Peninsula. ${ }^{25}$ This is how the 'Israeli occupation' of the Gaza Strip and the West Bank begins. ${ }^{26}$

After 1967, the emergence and growing visibility of Palestinian national liberation movements (The Palestine Liberation Organization, Fatah, The Popular Democratic Front for the Liberation of Palestine - to name a few) brought the Palestinian issue on the international agenda. The Palestine Liberation Organization (PLO), founded in 1964 - and led since 1969 by Yasser Arafat (founder and leader of Fatah) - under the auspices of the Arab League and the direct involvement of Egyptian President Gamal Abdel Nasser, has become an 'umbrella organization' that included most Palestinian nationalist groups. ${ }^{27}$ It was recognized as the 'only legitimate representative of the Palestinian people' at the Arab League Summit in Rabat in October 1974. It was admitted to the UN as an observer in November of the same year. ${ }^{28}$

PLO, which in Article 20 of the Palestinian National Charter adopted in 1968 declares that 'the Balfour Declaration, the Mandate for Palestine, and everything that has been based upon them, are deemed null and void, ${ }^{29}$ came to accept - during the $1990 \mathrm{~s}$ territorial compromises and sign peace agreements with the state of Israel. In the context of the outbreak of the First Intifada and the birth of Hamas, in December 1987, Yasser Arafat decided to adopt the Algiers Declaration on 15 November 1988. It proclaimed the 'State of Palestine' with 22 percent of the British Mandate for Palestine to counterbalance the rise of Hamas and to maintain the authority of the PLO in the Palestinian territories. ${ }^{30}$

The 1990s, despite many challenges, held an important key to the future of the Israeli-Palestinian conflict. On 13 September, Mahmoud Abbas and Shimon Peres signed the Declaration of Principles on Interim Self-Government Arrangements (shortly the Declaration of Principles - DoP). Negotiations between the PLO and Israel in Oslo,

\footnotetext{
${ }^{23}$ Waxman 2019, 92.

24 Waxman 2019, 91-92.

${ }_{25}$ Bunton 2013, 87.

${ }_{26}$ In the Gaza Strip, on August 2005, following the decision of Prime Minister Ariel Sharon, Israel withdraws its troops and settlers from the area; while in certain areas of the West Bank the Israeli occupation is still visible today, especially through the creation and expansion of Israeli settlements.

27 Blackwell 2008, 782.

${ }^{28}$ Filiu 2014, 156-157.

29 'Amended Palestinian National Charter (1968)'/Economic Cooperation Foundation.

30 Waxman 2019, 147.
} 
Norway, through a secret channel, emerged in this context. ${ }^{31}$ Also known as 'Oslo I', the agreement led to the mutual recognition of the two parties and Israel's withdrawal from Gaza and Jericho. The PLO pledged to renounce terrorism and recognized 'the right of the State of Israel to exist,' while Israel recognized his unique right as a representative of the Palestinian people, and as an official negotiation partner. The Palestinian Authority (PA) - as a quasi-governmental entity - would be created during a five-year transitional period (also, a final peace agreement was to be reached in the next five years). ${ }^{32}$

Following the 'Oslo negotiations,' Yasser Arafat and Yitzhak Rabin signed the interim agreement establishing Palestinian autonomy in Gaza and Jericho - known as the Cairo Agreement - on 4 May $1994 .^{33}$ This agreement was into 'Oslo II.' Thus, after all the ups and downs encountered during the implementation of the DoP, Yitzhak Rabin and Yasser Arafat - in the presence of Bill Clinton, Hosni Mubarak, and King Hussein of Jordan - had signed The Interim Israeli-Palestinian Agreement on the West Bank and Gaza Strip, on 28 September 1995, in Washington DC. ${ }^{34}$ This agreement provided for the division of the West Bank into three separate areas of jurisdiction: Zone A (under absolute Palestinian control), Zone B (under joint Israeli-Palestinian control), and Zone C (under Israeli control). ${ }^{35}$

Following the signing of the interim peace agreements ('Oslo I' and 'Oslo II'), the first elections for the Palestinian Legislative Council and the presidency of the newly established Palestinian Authority (PA) took place in 1996. Yasser Arafat was elected president of the PA, while Fatah (the majority party) got 55 of 88 seats available, plus seven more seats for independent candidates. Islamist groups (Hamas, Palestinian Islamic Jihad) and left-wing ideological groups boycotted the elections. ${ }^{36}$ Promoting, since 1994, a strategy based on suicide attacks targeting Israel, ${ }^{37}$ Hamas justified its decision to boycott the elections because they were a result of agreements signed with the state of Israel (which it does not recognize - nor the agreements peace, nor the state of Israel). From another point of view, there is a possibility that Hamas leaders feared that 'the movement would perform poorly should it decide to take part in the elections. ${ }^{38}$ This vision would fade over time, and in 10 years, in the 2006 legislative elections, Hamas decided to run in the elections and to the surprise of many - won them. However, the historical and political context of the moment (2006), plus the developments over the years, is the essential factors influencing the decisions of Hamas decision-makers.

\section{Hamas: Organization, Activity, and Political-Military Success (2006-2007)}

Hamas, an acronym for Harakat al-Muqawama al-Islamiyya (Islamic Resistance Movement), is one of the best-known Palestinian Islamist organizations. ${ }^{39}$ It appeared

\footnotetext{
31 'Agreement-Declaration of Principles on Interim Self-Government Arrangements (a.k.a. Oslo Accord)'/ UNISPAL.

32 Waxman 2019, 142.

${ }^{33}$ Filiu 2014, 225.

34 Shlaim 2014, 455.

35 'Israeli-Palestinian Interim Agreement on the West Bank and the Gaza Strip (Oslo II)'/United Nations Peacemaker.

${ }^{36}$ Bhasin, Hallward 2013, 79.

37 Hroub 2006, 51.

${ }^{38}$ Muslih 1999, 9.

${ }^{39}$ Levitt 2006, 8.
} 
in Gaza, in December 1987, amid the outbreak of the First Intifada. ${ }^{40}$ According to the Covenant of the Islamic Resistance Movement (made public in 1988), the organization declares itself as 'one of the wings of Muslim Brotherhood in Palestine' (Article One), with a strong emphasis on the Islamic faith, and considers 'that the land of Palestine is an "Islamic Waqf" consecrated for future Moslem generations until Judgement Day"41 (Article Eleven). At the same time, Hamas called for the liberation of Palestine from Israeli occupation and advocated for the establishment of an Islamic state in all Palestine. ${ }^{42}$

According to Levitt, Hamas is organized of 'three interrelated wings': (1) the social welfare and (2) political wings (represent 'the public faces of the group's social, administrative, political, and propaganda activities'), while (3) the military wing (Izz al-Din al-Qassam Brigades) is mainly engaged in covert activities (execution of collaborators, surveillance of possible targets, procuring weapons or carrying out terrorist attacks). The entire activity of Hamas is overseen by a Consultative Council (Majlis al-Shura), which is the group's political and decision-making body. It is based in Turkey and Qatar (before the conflict in Syria, it was in Damascus). It is also representative of local committees in the West Bank and Gaza Strip, and Israeli prisons. ${ }^{43}$

In the middle of the first decade of the current century, Hamas is still hostile to the 'historic compromise' made by the PLO through peace negotiations, considering Israel as the most important enemy, refusing to recognize its right to exist. Thus, until the Israeli disengagement from Gaza, Hamas created a favorable image in the Palestinian territories (especially in Gaza), which brought it success in the 2006 elections. Hamas - along with other resistance movements in Gaza-claimed to have played an essential role in influencing Israel's decision to withdraw from the area by promoting 'armed resistance' against the occupation. Following the 'disengagement plan' announced and implemented by Ariel Sharon (Israel's prime minister), Israel evacuated its 8,000 settlers from the twenty-one settlements that existed in the Gaza Strip (as well as from four isolated settlements in the West Bank). It also abandoned its presence in the Philadelphia Corridor (the border area between Gaza and Egypt). At the same time, the last Israeli soldiers left Gaza on 12 September, ending the 38 years of the Israeli occupation of the Gaza Strip. ${ }^{44}$ In this way, the status of 'occupied territory' of the Gaza Strip becomes 'null and void,' as the Israeli Prime Minister himself declares. ${ }^{45}$ However, despite this reality, the territory's status has become quite controversial following the Israeli withdrawal. This was especially because Israel (after Hamas won the election and conquered the area) declared the Gaza Strip a 'hostile entity' and imposed a blockade that controlled its land, sea, and airspace. ${ }^{46}$

Considered a terrorist organization by Israel, the United States of America, the European Union and banned by Jordan, Hamas ran in the Palestinian Legislative Council

\footnotetext{
${ }^{40}$ The First Intifada was one of two Palestinian uprisings, which constituted the struggle of the Palestinian population in Gaza and the West Bank against the Israeli occupation. For more details on this topic, see: Lesch 1990; Alimi 2007.

41 'Hamas Covenant 1988'/The Avalon Project.

42 'Hamas Covenant 1988'/The Avalon Project.

${ }^{43}$ Levitt 2006, 9-11.

44 Rynhold, Waxman 2008, 11.

45 Ghanem 2010, 30.

${ }^{46}$ Cuyckens 2016, 287.
} 
elections scheduled on 25 January 2006 - with the 'Change and Reform' political platform. ${ }^{47}$ The result was the claim of 76 seats out of 132 (74 under the auspices of Hamas, plus two independents), which gave it the right, according to Palestinian law, to form a coalition. Immediately after this event, growing tensions between Hamas and Fatah led to street fighting, which turned into a bloody episode (known as 'the Palestinian civil conflict'). ${ }^{48}$ After violent clashes on Palestinian streets, Hamas and Fatah reached an agreement known as the 'Mecca Agreement' signed on 8 February 2007, under the auspices of Saudi Arabia. Shortly, this agreement called for an end to the confrontations between the two fighters and the acceptance of dialogue as the sole basis for resolving political differences in the Palestinian arena. It also called for - among other things - the formation of a national unity government (a fact on which Hamas and Fatah agreed on 17 March 2007). ${ }^{49}$ However, the period of calm was short. By 13 June, Gaza was under Hamas's complete control: 'its forces controlled the streets and Palestinian Authority buildings, including the presidential compound of Mahmoud Abbas and the massive security compound known as al-Suraya. ${ }^{50}$

All these events, consumed relatively quickly, led to the fragmentation of the Palestinian territories (geographically and politically) and revealed the fragility of the Palestinian Authority's government. The Gaza Strip remains under Hamas's control, while Fatah and the Palestinian Authority restrict their rule over the West Bank. In the West Bank, PA President Mahmoud Abbas established a new government operating separately from Gaza. At the same time, Hamas Prime Minister Ismail Haniyeh tried to deal with restrictions imposed by the West and Israel. Following these significant changes, the state of Israel declared - on 19 September 2007 - the Gaza Strip as 'a hostile territory, against which military and anti-terrorist operations would be intensified. ${ }^{51}$ Subsequently, in collaboration with the Egyptian government, the Israeli state imposed a blockade that provided the maintenance of control over the land, sea, and air space of the Palestinian enclave. This blockade will lead to a severe humanitarian crisis. ${ }^{52}$ The blockade aimed to put pressure on the civilian population in the hope this would weaken the Gaza authorities, ${ }^{35}$ as Israeli leaders had declared on countless occasions. However, this did not happen; Hamas continued to rule in Gaza while the region plunged into a major crisis. The Gaza Strip continued to take an unfavorable course with a government unrecognized by the US or Israel and protracted conflicts. The three Israeli military operations during the years 20082014 came against the background of the actions taken by the Islamic resistance groups in Gaza. Their results led to serious long-term repercussions.

\section{The Violent Clashes between Hamas and Israel (2008-2014)}

The clashes between Hamas and Israel existed before the Hamas government came to power in Gaza. They escalated, especially after this event. Following Israel's withdrawal from

\footnotetext{
47 Turner 2009, 570.

48 Schanzer 2008, 95-98.

49 Schanzer 2008, 103.

${ }^{50}$ Schanzer 2008, 107.

${ }^{51}$ Filiu 2014, 313.

52 Butt, Butt 2016, 158.

${ }^{53}$ Butt, Butt 2016, 160-161.
} 
the Gaza Strip in 2005, Hamas (and other Islamist groups operating in Gaza) promoted a discourse that highlighted the vital role of armed resistance against Israel.

The next period was dynamic, marked by the outbreak of the Second Lebanon War (in the summer of 2006) and two minor operations by Israel against Hamas, following the abduction of Israeli soldier Gilad Shalit. ${ }^{54}$ These two operations - codenamed Summer Rains $^{55}$ (28 June-26 November) and Autumn Clouds ${ }^{56}$ (31 October-7 November) - were not as violent as the following ones (those during the period between 2008 and 2014). Their consequences contributed to the destabilization of the situation in the Gaza Strip. However, the Israeli military actions in the summer and autumn of 2006 did not receive attention from the international community. One can't say the same thing about the operations from 2008 to 2014 . The latter was much more violent and complex than the two mentioned above, causing long-term repercussions in Gaza.

Israel's military operations against Hamas in the Gaza Strip had their stated purposes and objectives. According to Shamir and Hecht, each of these operations 'has a short-term, a medium-term and long-term objective.' Therefore, the short-term goal was to achieve a de-escalation of hostile attacks. The medium-term aim was to degrade the enemy's capabilities to determine him from renewing hostilities for as long as possible. The long-term objective is to achieve a cumulative deterrence that will gradually lead to a cessation of attacks at an undetermined future date. ${ }^{57}$ The militant groups' actions in Gaza, such as the bombing of Israeli cities (mainly those in the Southern District), were not hindered by the events of 2006-2007. These led to large-scale clashes with its Israeli-neighbor.

One of these clashes in Gaza turned into a well-known Israeli operation called Cast Lead. It took place between 27 December 2008 and 18 January 2009. After three weeks of fighting, the results resulted in a victory for Hamas over Israel since the latter failed to eradicate the movement despite the overwhelming force used. The bombing aimed to Hamas' security offices and facilities and at the tunnels carrying smuggled goods into Palestinian territory. On 18 January, Israel declared a ceasefire, and the violence ended on 21 January, when the last Israeli troops left Gaza. The armed conflict resulted in many casualties among Palestinians, but this did not stop Hamas from continuing its rule in Gaza, let alone being severely affected by the Israeli offensive, although it lost about 150 fighters of the Qassam Brigades, ${ }^{58}$ according to statements made by the internal Hamas sources. ${ }^{59}$

In a study on the Palestinian enclave, Shlomo Hasson identifies the purpose of the operation as 'punishing Hamas for its indiscriminate missile attacks against civilian targets

${ }^{54}$ Gilad Shalit was an Israeli soldier when he was abducted by Palestinian militants, following a raid on the Kerem Shalon border crossing, in 2006. He was released in 2011. For more details, see: 'Gilad Shalit'/ Encyclopaedia Britannica.

55 Filiu 2014, 294-298.

${ }^{56}$ Filiu 2014, 298.

57 Shamir, Hecht 2015, 88-89.

58 The Izz al-Din al-Qassam Brigades (IQB) was founded in 1991 as the military wing of Hamas. It is the largest and best-equipped group operating in Gaza, and its primary goal is the liberation of 'all Palestine.' In the 1990s, the group engaged in suicide attacks, and by 2005 it was using missile attacks against the Israeli targets. After 2007 (Hamas' military success in Gaza), the IQB gained increasing freedom of movement within the Gaza Strip and evolved into a 'quasi-army'. For more details on this topic, see: Berti, Gutiérrez 2016.

${ }^{59}$ Filiu 2014, 316-317. 
in southern Israel and restoring deterrence. ${ }^{60}$ This statement is furthered developed by David E. Johnson, following his discussions with IDF officers. According to him, the overall objective of the operation was 'to create conditions for a better security in southern Israel' by causing 'major damage' to the Hamas organization. It led to a reduction in the number of terrorist attacks in Gaza and increased Israel's military deterrence by 'minimizing collateral damage and avoiding escalating conflict in other fronts. ${ }^{61}$

This conflict highlighted that Hamas had improved its military capabilities, despite the economic blockade imposed by the Israelis since 2007. This was largely due to the tunnels used to bring weapons into the area. As a result of this operation, Israel destroyed about 80 percent of the tunnels connecting Sinai and Gaza. ${ }^{62}$ Tensions between Hamas and Israel continued in the region until the next major military offensive, in Gaza, from 14 November to 21 November 2012.

Operation Pillar of Defense (2012) was the second-largest Israeli military offensive on Gaza Strip. Specifically, on 14 November, an Israeli Air Force airstrike targeted 'rocket launch pads, weapons depots, government facilities and apartment blocks where, claimed the Israelis, arms were hidden.' ${ }^{63}$ Hamas and the Palestinian Islamic Jihad ${ }^{64}$ were the main Palestinian groups fighting Israel's armed forces. The conflict continued until 21 November, when American and Egyptian mediators persuaded the warring parties to accept a truce. Under the agreement, Hamas and other Palestinian groups should have stopped all missile attacks on Israeli settlements. Israel should have engaged in peace talks to ease the economic blockade imposed on the area. ${ }^{65}$

Egypt played an essential role in this offensive, as it would have a new approach to the issue of the tunnels connecting Sinai and Gaza, the new regime of Abdel Fatah el-Sisi orders their closure. Former Egyptian President Mohamed Morsi (June 2012-July 2013), a supporter of the Egyptian Muslim Brotherhood, has been much more permissive with the transmission - through tunnels - of food and other goods to the Gaza Strip. Under the command of the new president (el-Sisi), Hamas was seen 'as an ally of the Muslim Brotherhood movement (the opposition in Egypt). ${ }^{66}$ Thus, hundreds of smuggling tunnels were closed: in 2014, more than 1,500 of the 1,800 tunnels were closed. ${ }^{67}$

The third Israeli military offensive against the Palestinian enclave was in 2014 unlike the previous ones, which lasted for 50 days, being much more violent and bloodier. ${ }^{68}$ Operation Protective Edge started on 7 July 2014. The trigger for the conflict was the disappearance of three Israeli teenagers on 12 June. Their bodies were found three weeks

${ }^{60}$ Hasson 2010, 395.

61 Johnson 2011, 111.

${ }^{62}$ Bregman 2016, 319-320.

${ }^{63}$ Bregman 2016, 321.

64 The Palestinian Islamic Jihad (Harakat al-Jihād al-Islämi fi Filastīn) was founded in 1981, in the Gaza Strip, by a group of Palestinian students. Compared to Hamas, the PIJ focuses on the armed struggle against the Israeli state, ignoring the need for an effective social assistance system. However, like Hamas, the PIJ denies the Jewish presence in Palestine and does not recognize the 'Oslo Accords.' Unlike Hamas, the PIJ did not engage in the Palestinian electoral process in either 1996 or 2006. For a comprehensive approach, see: Skare 2021.

${ }_{65}$ Bregman 2016, 321.

${ }^{66}$ Bregman 2016, 322.

67 Shamir, Hecht 2015, 83.

${ }^{68}$ Bregman 2016, 323. 
later in the southwestern city of Hebron, and Hamas eventually claimed responsibility for their killing. However, Hamas political leaders said they were unaware of the action. ${ }^{69}$ Ten days after the beginning of the conflict, the Israelis turned their attention to the identification and destruction of clandestine tunnels in Gaza. This mission (destruction of secret tunnels in Gaza) required a ground incursion by the Israeli army. Unlike the aerial bombardments used in the previous period, this direct mode of action proved much more dangerous and complicated for the armed forces. ${ }^{70}$

Operation Protective Edge can be divided into three stages. The first stage considers the Israeli airstrikes on the Gaza Strip, which ends on 14 July 2014 with a ceasefire proposal from the Egyptian government, which Israel accepts, while Hamas refuses. The second stage consists of the land invasion, which ended with an armistice on 16 July. The truce proposed by Hamas and the Palestinian Islamic Jihad included ten conditions. They included: the release of Palestinian prisoners, the opening of the Gaza-Israel borders for the passage of citizens and goods, the international surveillance of the Gaza seaport instead of the Israeli blockade. The Israeli state, however, did not accept the proposed conditions. The last stage was the withdrawal of Israeli troops, following numerous discussions on the ceasefire terms. On 3 August, IDF (Israel Defense Forces) left the area after destroying 32 tunnels used by Hamas and other groups. Fifty days after the launch of the operation, on 26 August 2014, Israel and Hamas reached a ceasefire agreement under the observation of the Cairo government. ${ }^{71}$

The political objectives of both sides were different during Operation Protective Edge. Hamas wanted to eliminate Israeli-Egyptian control over the Gaza Strip. In addition, it tried to build a seaport and an international airport and ensured free transition between Gaza-Israel and Gaza-Egypt. Israel's goal was to create a security zone at the border by 'containment.' Because Hamas was considered a group with growing authority in Gaza, Israel did not seek to remove Hamas from power, but only to discourage it enough to stop hostile acts against the Israeli state. ${ }^{72}$

The 2014 military offensive made more victims and provoked the damages than the previous army offensives against Hamas. The number of the victims recorded is debatable, each party stating its version. Hamas claimed that about '2,200 people were killed' and another '11,000 wounded in Gaza', of whom 'more than 75 percent of the dead were civilians.' Israel argued that about half of the dead were combatants, with many civilian deaths caused by the deliberate use of civilians as 'human shields.' According to the figures, the Israelis suffered losses of 14 civilians and 67 soldiers killed, about 400 civilians, and 705 wounded soldiers. ${ }^{73}$

\section{The State of the Conflict After 2014}

The cycle of violence between Hamas and Israel ended in 2014. From then until 2020, there was a so-called 'period of peace,' considering that no military offensives took place as in previous years.

\footnotetext{
${ }^{69}$ Ahmad et alii 2019, 516.

70 Slesinger 2018, 2.

${ }^{71}$ Ahmad et alii 2019, 517.

72 Shamir, Hecht 2015, 83.

${ }^{73}$ Shamir, Hecht 2015, 87.
} 
Although violent Israeli operations against Hamas did not take place in the Gaza Strip, border incidents and missile attacks (by various Palestinian groups in Gaza) upon Israel happened every year - so as the Israeli's responses. Major violent episodes took place during the year 2017 (after the changes made by US President Donald Trump: the recognition of Jerusalem as the capital of the state of Israel and the relocation of the US embassy from Tel Aviv to Jerusalem) and between 2018 and 2019 ('The Great March of Return $\left.{ }^{34}\right)$.

Even though tense situations marked the post-2014 period, the marches and riots by Palestinians did not result in conflicts similar to those prior to 2014. However, this atmosphere changed almost abruptly and began to become increasingly tense during May 2021. In the first phase, Hamas started launching missiles at Jerusalem and other major cities in Israel. In response, the IDF hit Hamas and Palestinian Islamic Jihad targets in Gaza, engaging in a new military confrontation with Islamist groups in the Gaza Strip, which - according to the IDF's website - received code name Operation Guardian of the Walls. ${ }^{75}$ As a result, the Palestinian enclave reached again on the top of the international agenda. The actions were similar - in terms of the degree of violence and impact - to the previous ones from 2014, 2012, and 2009-08.

Before these tensions were evident, the Palestinian elections (scheduled for May 2021) were postponed indefinitely by Palestinian Authority President Mahmoud Abbas on 29 April following Israeli refusal to allow Palestinians in East Jerusalem to vote. ${ }^{76}$ According to a report by Jim Zanotti and entitled Israel: May 2021 Violence, Other Background, and US Relations in Brief, it is considered that among the factors that have been the basis for the escalation of the conflict are the recent tensions that took place in East Jerusalem. This area - controversial and much disputed amid the Israeli-Palestinian conflict - is of particular interest to both sides, especially for religious reasons. ${ }^{77}$ International law has considered this territory under Israeli occupation since 1967 (as a result of the conquest of the Palestinian territories in the 'Six Day' War). The unrest around East Jerusalem was amplified by a decision of the Israeli Supreme Court, according to which several Palestinian families had to evacuate their residences in the Sheikh Jarrah neighborhood (a predominantly Arab area in the east of Jerusalem). ${ }^{78}$ Thus, since 10 May 2021, Hamas and the Palestinian Islamic Jihad - the main Palestinian actors in Gaza - have begun launching 'hundreds of missiles at Israel', killing civilians. The Israeli army's response also resulted in many deaths and victims among the Palestinian civilian population in Gaza. ${ }^{79}$

The United States, the European Union, Russia, and other countries expressed their concern over tensions between Hamas and Israel and called for talks to conclude a ceasefire

\footnotetext{
${ }^{74}$ For an overview of this topic, see: 'What is The Great Return March?'/American Friends Service Committee (AFSC).

75 'First Week Summary: Operation Guardian of the Walls'/IDF.

76 'Mapping Palestinian Politics, Elections 2021'/European Council on Foreign Relations.

77 Jerusalem holds deep religious significance for Jews, Muslims, and Christians. For Jews, Jerusalem includes the holiest land in Judaism, while for Muslims, it is the third most important place in Islam (after Mecca and Medina).

For more details on this topic, see: Abu-Amr 1995.

${ }^{78}$ Zanotti 2021, 3.

${ }^{79}$ Zanotti 2021, 2.
} 
agreement. The Biden administration sent Hady Amr (Deputy Assistant Secretary for Israeli and Palestinian Affairs in the Bureau of Near Eastern Affairs within the US Department of State) to the region to solve the conflict. At the same time, The Secretary of the State, Antony Blinken, called for an immediate end of the violence on 16 May. During a telephone conversation on 17 May with Prime Minister Netanyahu, President Biden also referred to the ceasefire, the protection of civilians, Israel's right to self-defense, and insisted on calming down the tensions. ${ }^{80}$

Despite numerous victims and destroyed infrastructure (especially among Palestinians), both sides consider themselves victorious in this conflict, according to statements made by Palestinian and Israeli officials. Finally, according to the media sources, after 11 days of fighting, the two sides - Hamas and Israel - reached an armistice agreement under the aegis of Egypt, which entered into force on 21 May 2021. The United States welcomed the new truce. President Biden said it would 'work with the UN providing humanitarian assistance in Gaza and in reconstruction efforts of the enclave' through a 'full partnership' with the Palestinian Authority. ${ }^{81}$

In a relatively short time, the conflict between Israel and Hamas has returned to the international agenda, drawing attention to the unresolved issues in the region. The current actions show that the periodic cycle of violence between Israel and Hamas did not end in 2014 and probably will not end in 2021 . The future dynamics will largely depend on the actions and compromises of all the actors involved in this conflict.

\section{Conclusions}

The Gaza Strip is still a security-precarious territory. The rising tensions in May 2021 between the two actors (Hamas and Israel) have escalated the armed conflict, which in 11 days has caused extensive damage to both sides, especially on the Palestinian side. Also, as can be seen above, in a relatively short time, the Gaza Strip (related to the conflict between Israel and Hamas) has once again become one of the issues of significant interest for regional and international security.

At the same time, after 28 years after the Oslo Accords (1993-1995), the Palestinians face the same problem: the establishment of the Palestinian state. For the first time in history, the Oslo Accords created an authentic and strong chance for peace. However, the Palestinians still aspire to create a full-fledged Palestinian state that will live in peace and security with its neighbors. In addition, the mutual attitudes of Hamas and Israel have not changed much since the Oslo period. From then until now, the statements of both sides (Israel and Hamas) reveal the same idea of mutual hostility. In this context, Hamas - the current Gaza Strip government (since June 2007) - is still considered illegal (Israeli and Palestinian authorities). Thus, Israel's attitude has not changed concerning the status of Hamas: Israel still considers Hamas to be a terrorist organization. This stripped the Gaza government of its legal rights that a proper government should have. Moreover, Hamas cannot be seen as a legitimate partner in peace negotiations in these conditions. At the same time, Hamas continues to promote the same hostile attitude towards the Israeli state:

\footnotetext{
${ }^{80}$ Zanotti 2021, 4-5.

${ }^{81}$ Bateman 2021.
} 
it refuses to recognize both the 'Oslo Accords' (peace negotiations between the PLO and Israel) and Israel's right to exist.

Simultaneously, the fact that there are still major internal problems on the Palestinian side may be one of the reasons why the enthusiasm of the 'Oslo period' has dissipated over time, thus contributing to the conflict situation in Gaza. Hamas continues to consider the Palestinian Authority led by Mahmoud Abbas overwhelmed by the current political situation. The political fragmentation of the Palestinian territories since 2007 and the inability of the Hamas and Fatah parties to create a national unity government up to nowadays postponed the resolution of internal and external animosities indefinitely. As long as these divergences exist, security and peace will be under threat in the Palestinian territories.

Becoming a closed area, controllable in all respects, this territory is often described as 'an open-air prison. ${ }^{82}$ The fact that the area frequently appears on the international agenda is primarily due to the influences and the rivalries that occur in the region (this article examines the rivalries between Israel and Hamas). Because its borders are closed and strictly controlled by Israel and Egypt, the Gaza Strip has collapsed into a severe economic and humanitarian crisis. In contrast, the four conflicts, which have taken place since 2008, profoundly contributed to the development of this territory in an unfavorable security environment. Current actions (tensions between Hamas and Israel - Operation Guardian of the Walls, 6-21 May 2021) show us that the Palestinian problem (and, implicitly, that of the Gaza Strip) is active and persistent even after so many years of conflict.

Finally, this study sought to capture and examine the conflicting relations between Hamas and Israel, focusing on the events that have taken place since 2008 in the Gaza Strip. Following the assessment of the violent clashes between the two sides, it can be seen that all the defining events that have existed throughout history have had repercussions over time and have certainly contributed to the gradual development of the current situation. The activity of the last years suggests that the tensions in the area decrease and increase without identifying a viable solution for both parties involved in the conflict. In other words, all this has a significant contribution in terms of influencing future dynamics.

\section{Bibliography}

\section{Primary sources}

'Agreement-Declaration of Principles on Interim Self-Government Arrangements (a.k.a. Oslo Accord), UNISPAL, https://www.un.org/unispal/document/ auto-insert-180015, accessed 16 Jul. 2021.

'Amended Palestinian National Charter (1968),' Economic Cooperation Foundation, https://ecf. org.il/media_items/677, accessed 16 Jul. 2021.

'Hamas Covenant 1988,' The Avalon Project, https://avalon.law.yale.edu/20th_century/hamas.asp, accessed 17 Jul. 2021.

'Israeli-Palestinian Interim Agreement on the West Bank and the GazaStrip (Oslo II),' United Nations Peacemaker, https://peacemaker.un.org/israelopt-osloII95, accessed 16 Jul. 2021.

${ }^{82}$ Filiu 2014, xi. 
'Resolution 181 (II). Future government of Palestine', UNISPAL, https://unispal.un.org/DPA/DPR/ unispal.nsf/0/7F0AF2BD897689B785256C330061D253, accessed 16 Jul. 2021.

\section{Dictionaries and Encyclopedia}

'Gilad Shalit'/Encyclopaedia 'Gilad Shalit,' Encyclopaedia Britannica, https://www.britannica. Britannica com/biography/Gilad-Shalit, accessed 11 Aug. 2021.

\section{Secondary sources}

Abu-Amr 1995

Z. Abu-Amr, The Significance of Jerusalem: A Muslim Perspective, PIJ, 2/2 (1995), https://pij.org/articles/646, accessed 12 Aug. 2021.

Alimi 2007

Ahmad et alii 2019

E. Y. Alimi, Israeli Politics and the First Palestinian Intifada. Political opportunities, framing processes and contentious politics, New York 2007.

A. A. Ahmad, A. M. H. B. Mohamed, S. M. B. Y. Nasir, A. B. Talib, N. S. B. M. Nor, The Israel-Gaza Crises of 2014: The Conduct of Hostility and Its Effect on Protected People, IJ-ARBSS, 9/12 (2019), 514-532. doi.org/10.6007/IJARBSS/v9-i12/6747.

Berti 2015

B. Berti, Non-State Actors as Providers of Governance: The Hamas Government in Gaza between Effective Sovereignty, Centralized Authority, and Resistance, MEJ, 69/1 (2015), 9-31. doi.org/10.3751/69.1.11.

Berti, Gutiérrez, 2016

B. Berti, B. Gutiérrez, Rebel-to-political and back? Hamas as a security provider in Gaza between rebellion, politics and governance, Democratization, 23/6 (2016), 1059-1076. doi.org/1 0.1080/13510347.2016.1170008.

Bhasin, Hallward 2013

T. Bhasin, M. C. Hallward, Hamas as a Political Party: Democratization in the Palestinian Territories, Terrorism and Political Violence, 25/1 (2013), 75-93. doi.org/10.1080/0954655 3.2013.733273.

Blackwell 2008

A. H. Blackwell, Palestine Liberation Organization. In: S. C. Tucker (ed.), The Encyclopedia of the Arab-Israeli conflict, California 2008.

Bregman 2016

A. Bregman, Israel's Wars, A history since 1947 (4th edn.), London-New York 2016.

Bunton 2013

M. Bunton, The Palestinian-Israeli Conflict: A Very Short Introduction, United Kingdom 2013.

Butt, Butt 2016

K. M. Butt, A. A. Butt, Blockade on Gaza Strip: A Living Hell on Earth, Journal of Political Studies, 32/1 (2016), 157-182.

Cyckens 2016

H. Cuyckens, Is Israel Still an Occupying Power in Gaza?, NILR, 63 (2016), 275-295. doi.org/10.1007/s40802-016-0070-1.

Efrat 2006

E. Efrat, The West Bank and Gaza Strip. A geography of occupation and disengagement, New York 2006.

Filiu 2014

Ghanem 2010

J. P. Filiu, Gaza, A History, tr. by J. King, New York 2014.

A. Ghanem, Palestinian Politics after Arafat, A Failed National Movement, Bloomington-Indianapolis 2010. 
Hasson 2010

Hroub 2006

Jensen 2009

Johnson 2011

Jospe 1995

Khalidi 2020

Lesch 1990

Levitt 2006

Muslih 1999

Morris 2001

Rieger, Yashiv 2018

Roy 2007

Roy 2011

Roy 2021

Rynhold, Waxman 2008

Salamanca 2011

Schanzer 2008

Schanzer 2013

Shamir, Hecht 2015

Shlaim 2014
S. Hasson, Gaza Enclave: Victim, Enemy, Rival, Geopolitics, 15/1 (2010), 385-405. doi.org/10.1080/14650040903486983.

K. Hroub, Hamas, A Beginner's Guide, London 2006.

M. I. Jensen, The Political Ideology of Hamas, A Grassroots Perspective, tr. Sally Laird, London 2009.

D. E. Johnson, Hard Fighting: Israel in Lebanon and Gaza, Santa Monica, CA-Arlington, VA-Pittsburgh 2011.

R. Jospe, The Significance of Jerusalem: A Jewish Perspective, PIJ 2/2 (1995), https://pij.org/articles/647/the-significanceof-jerusalem-a-jewish-perspective, accessed 12 Aug. 2021.

R. Khalidi, The Hundred Years' War On Palestine, A History of Settler Colonial Conquest and Resistance, London 2020.

A. M. Lesch, A. M., Prelude to the Uprising in the Gaza Strip, Journal of Palestine Studies, 20/1 (1990), 1-23. doi.org/10.2307/2537319.

M. Levitt, Hamas, Politics, Charity, and Terrorism in the Service of Jihad, New Haven-London 2006.

M. Muslih, The Foreign Policy of Hamas, New York 1999.

B. Morris, Righteous Victims, A History of the Zionist-Arab Conflict, 1881-2001, New York 2001.

A. Rieger, E. Yashiv, The Gaza Economy. In: A. Kurz, U. Dekel, B. Berti (eds.), The Crisis of the Gaza Strip: A way out, Tel Aviv 2018.

S. Roy, Failing Peace: Gaza and the Palestinian-Israeli Conflict, London 2007.

S. Roy, Hamas and Civil Society in Gaza. Engaging the Islamist Social Sector, New Jersey 2011.

S. Roy, Unsilencing Gaza, London 2021.

J. Rynhold, D. Waxman, Ideological Change and Israel's Disengagement from Gaza, PSQ, 123/1 (2008), 11-37. doi. org/10.2307/20202970.

O. J. Salamanca, Unplug and Play: Manufacturing collapse in Gaza, Human Geography, 4/1 (2011), 22-37. doi.org/10.1177/ 194277861100400103.

J. Schanzer, Hamas vs. Fatah, The Struggle For Palestine, New York 2008.

J. Schanzer, State of Failure, Yasser Arafat, Mahmoud Abbas, and the Unmaking of the Palestinian State, New York 2013.

E. Shamir, E. Hecht, Gaza 2014: Israel's Attrition vs Hamas' Exhaustion, Parameters, 44/4 (2015), https://press. armywarcollege.edu/parameters/vol44/iss4/10.

A. Shlaim, The Iron Wall, Israel and The Arab World, New YorkLondon 2014. 
Skare 2021

Slesinger 2018

Turner 2009

Waxman 2019

Yarchi, Ayalon 2020

Zanotti 2021

\section{Online sources}

Bateman 2021
E. Skare, A History of Palestinian Islamic Jihad: Faith, Awareness, and Revolution in the Middle East, Cambridge 2021.

I. Slesinger, A Cartography of the Unknowable: Technology, Territory and Subterranean Agencies in Israel's Management of the Gaza Tunnels, Geopolitics (2018, reprint 2020), 1-26. doi.org/10. 1080/14650045.2017.1399878.

M. Turner, The Power of Shock and Awe: The Palestinian Authority and the Road to Reform, International Peacekeeping, 16/4 (2009), 562-577. doi.org/10.1080/13533310903205997.

D. Waxman, The Israeli-Palestinian Conflict, What Everyone Needs To Know, New York 2019.

M. Yarchi, A. Ayalon, Fighting over the Image: The Israeli-Palestinian Conflict in the Gaza Strip 2018-19, Studies in Conflict \& Terrorism, 2020, 1-14. doi.org/10.1080/1057610X.2020.1751461.

J. Zanotti, 'Israel: May 2021 Violence, Other Background, and US Relations in Brief,' Congressional Research Service (18 May 2021), https://www.everycrsreport.com/files/2021-05-18_R44245_ 161183849f60624390e4a5e2856024019ec75f9a.pdf, accessed 22 May 2021.

T. Bateman, Israel-Gaza ceasefire holds despite Jerusalem clash, BBC News (23 May 2021), https://www.bbc.com/news/ world-middle-east-57195537, accessed 27 May 2021.

'First Week Summary: Operation Guardian of the Walls', IDF, https://www.idf.il/en/articles/ defense-and-security/israel-under-fire/, accessed 19 May 2021.

'Mapping Palestinian Politics, Elections 2021, European Council on Foreign Relations, https:// ecfr.eu/special/mapping_palestinian_politics/elections-2021/, accessed 19 May 2021.

'What led to the most recent Israel-Palestine escalation?', Al Jazeera, https://www.aljazeera. com/news/2021/5/12/what-lead-up-to-most-recent-israelpalestine-escalation, accessed 12 Aug. 2021.

'What is The Great Return March?', American Friends Service Committee (AFSC), https://www.afsc. org/blogs/news-and-commentary/what-is-great-return-march, accessed 12 Aug. 2021. 


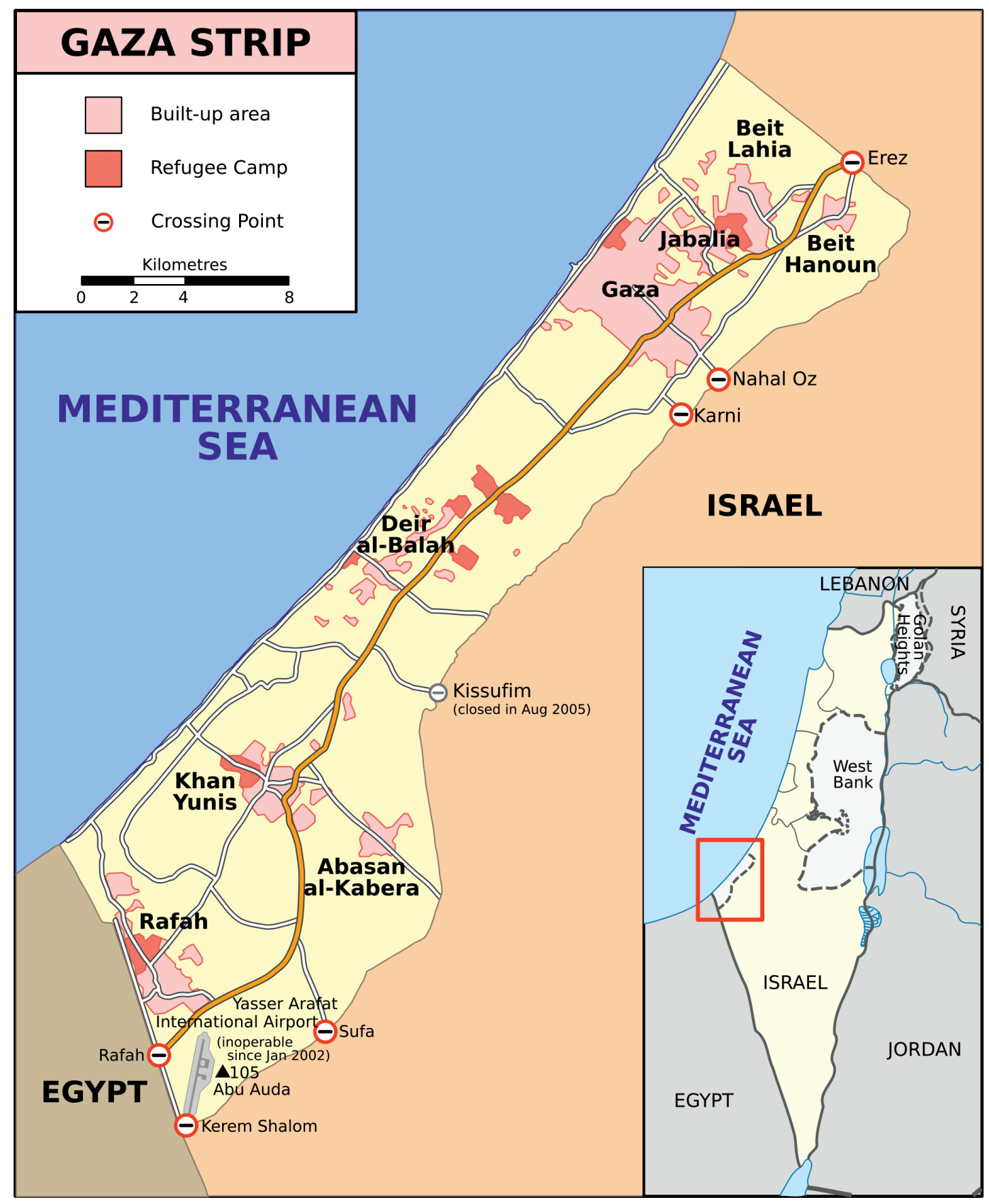

Fig. 1. Map of the 'Gaza Strip' (source: https://www.mapsof.net/gaza-strip/gaza-strip-map). 


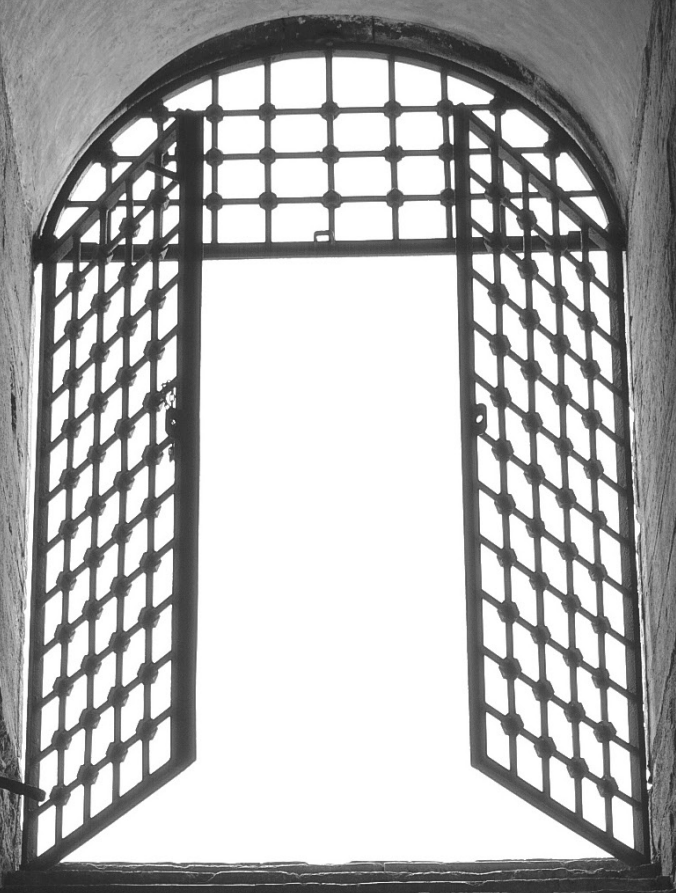

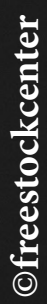




\section{REVIEWS}





\title{
Peter BURKE, Polimatul: o istorie culturală de la Leonardo da Vinci la Susan Sontag [The Polymath: a Cultural History from Leonardo da Vinci to Susan Sontag], Litera Press, Bucharest, 2021, pp. 384, ISBN 978-606-33-6921-6008.
}

\author{
Reviewed by TUDOR TURIAN ${ }^{*}$
}

Studies on cultural history and intellectuality abound nowadays in the field of liberal arts. They are rather appreciated by professors, students and the public that is not familiar with the topic. The book written by Peter Burke, which makes the subject of this review, is unusual and intriguing in the way it approaches the subject. In his work, Burke tries to offer an extensive image of the intellectuality in the West between the fifteenth and twenty-first centuries. He argues about intellectuals' different interests, abilities, and the impact they had on the development of knowledge. As he states from the beginning, the book 'offers an approach to cultural and social history' (p. 1). This is a broad study 'based for the most part on a prosopography, a collective biography of a group of five hundred individuals active in the West between the fifteenth century and the twenty-first' (p. 3). The book consists of introduction, eight chapters, conclusion, and an appendix of five hundred polymaths from the Western world.

In the introduction, the author tries to explain the method he used in his work, also defining polymath individual. By defining the polymath as 'someone who is interested in learning about many subjects' (p. 2), the author restrains his study to those who can manage various areas of human knowledge. Moreover, he defines the term 'discipline' as a particular branch in the field of knowledge, thus being easier to identify and classify polymaths. Burke distinguishes between different polymaths, such as passive, who know virtually everything but are not productive, limited, specialists in two or more related disciplines, or serial polymaths, who move from one field of knowledge to another.

The first chapter presents a series of intellectuals with an 'unusual breadth of knowledge' (p. 10). They came from East and West, from early Antiquity to the late Middle Ages. The author lists some of the greatest philosophers, such as Pythagora and Aristotle, the roman intellectuals (Pliny the Elder, Cicero), or the Chinese scholar Shen Gua. Then he shifts focus on the scholars of the Middle Ages, both Christians, and Muslims (Hugh of Saint-Victor, Albert the Great, Ibn Khaldun, Ibn Rushd, etc.).

The following four chapters discuss the different stages and the evolution of polymaths from the Renaissance to the twentieth century. The first chapter is dedicated to the Renaissance, analyzing the characteristics of the period and examining the broad spectrum of the intellectuals, from da Vinci and Brunelleschi to humanists as Nicolaus Cusanus or Pico della Mirandola. Later known as 'the man of the Renaissance,' virtually

B.A. Student, 'Babeș-Bolyai' University, Cluj-Napoca, email: tudor.turian@yahoo.com, (D) https://orcid.org/0000-0001-5779-4305. 
every polymath of this age is attracted by a universal idea of knowledge, making Faust the representative character of the period. The author does not forget to mention three famous women of the Rennaissance, namely Isotta Nogarola, Laura Cereta and Cassandra Fedele.

The next chapter describes what the author, citing a polymath named Hermann Boerhaave, called the era of 'monsters of erudition.' This period is seen as a golden age for intellectuals with multiple interests, concentrating mainly on Leibniz, the representative figure, among many others. A major problem addressed by Burke in this chapter is the so-called Leonardo syndrome, the impatience of the polymaths when it comes to focusing on only one project or subject. Christopher Wren, Robert Hooke, Athanasius Kircher, and even Leibniz himself, were a few of those who suffered from this syndrome. Nevertheless, the seventeenth century also marked a time of fragmentation and specialization in the academic field, which created a significant challenge for all intellectuals.

The period of 1700 and 1850, or the era of the 'man of letters', marked a decline in the scholars' work due to some criteria mentioned above. Nonetheless, some important figures also seemed to be interested in studying and specializing in various domains. However, most importantly, this age was the era of Enlightenment, a cultural movement that marked the whole of Europe. Among many of the intellectuals mentioned in this chapter are the French philosophes (Voltaire, Montesquieu, Condorcet, Diderot), Scottish Enlightenment representants (David Hume, Adam Smith, Adam Ferguson, Lord Kames) and English scholars (Samuel Johnson, Joseph Priestley). A separate part is dedicated to the system builders: positivism - Auguste Comte, social Darwinism - Herbert Spencer, and Marxism - Karl Marx.

The following two chapters are dedicated to intellectuals from the mid-nineteenth century to the twentieth century. In these, the author discusses the work of a wide range of polymaths, from 'monsters of erudition' such as Alexander von Humboldt to scholars as Aldous Huxley and scientists as John von Neumann. But the main idea of these chapters is that the specialization becomes a significant problem for all types of intellectuals.

In the last three chapters, the author explains the success of the polymaths and some characteristics most of them seemed to have in common. For example, all of them had unlimited curiosity, imagination, and physical energy. Also, most of them had an extraordinary memory, a relentless capacity of work, and a 'play element' (p. 184). Amongst them, only Neumann seems to have had all these talents. The author also stresses the importance of competition in motivating polymaths as in the cases of Humboldt and Polanyi brothers. In conclusion, Burke tries to uphold the idea of a third crisis that may affect the intellectual world in the twenty-first century. This crisis is caused by the unimaginable increase of information and the new behavior, related, mainly, to reading digital books.

Overall, the book is carefully documented and easy to read, thanks to the author's ability to address a large public, consisting of both, specialists and neophytes. He is also able to translate detailed knowledge into comprehensible ideas, making his work easier to understand. For these reasons, the volume is of relative high importance. 


\title{
Stefano BOTTONI, Lungul drum spre Occident. O istorie postbelică a Europei de Est [Long Awaited West. Eastern Europe since 1944], Mega Publishing, Cluj-Napoca, 2021,pp. 360, ISBN978-606-020-301-8.
}

\author{
Reviewed by ALEXANDRA COJOCARU
}

Political, economic, and social developments in Eastern Europe have experienced a difficult, violent and repressive path throughout the twentieth century. Even though the East European path has chosen a different trajectory with 'the end of history', it needs a historical update of the latest regional events.

The contemporary history of Eastern Europe has been extensively researched, especially in the last thirty years, which turns the intellectual approach of Stefano Bottoni into a challenging process. Besides dealing with seven decades of events, he critically analyzes the political and historical delimitation of the region. He further deals with the primary causes of the economic and social stagnation of Eastern Europe and the antithetical relationship between the logic of the nation-state and the region's multiethnic character.

The author's interest in Eastern Europe is part of broader academic interest, his previous research focusing on the social and political history of Eastern Europe during the socialist regimes. He also paid special attention to Romania's national policies towards the Hungarian minority during the 1950s-1960s.

The author's ambitious desire to write an Eastern Europe monograph is a real success, managing to cover in just 320 pages the defining historical aspects of the Eastern European region in both the Soviet and postcommunist worlds until 2017. The present study is based on extensive research. It integrates both the latest historiographical works and archival materials from the Hungarian, Romanian and American archives.

The concept of 'Eastern Europe' is questionable and cannot be comprehended objectively. According to the author, the concept often encompasses deeply rooted cultural and social prejudices. This is why Bottoni offers additional terminological clarifications in order to have 'a pragmatic definition of Eastern Europe as those territories that were exposed to the historical experiences of Soviet communism starting with the Molotov-Ribbentrop Pact and the subsequent outbreak of the Second World War. Following the collapse of the three multinational states (the Soviet Union, Yugoslavia, and Czechoslovakia), the region currently encompasses twenty countries with a total area of nearly 2 million square kilometers and a population of around 180 million people' (p. 18).

Based on chronological sequence, the book aims to analyze thematically the main events that shaped regional history, from the integration of Eastern Europe 'on Soviet Turf (1944-1948),' the period marked by 'Terror and Thaw (1949-1955),' 'Political Crises and Social Consolidation (1956-1972)', to 'The Decline and Fall of the Soviet Bloc (1973-1991).' The fifth chapter, suggestively titled 'Return to Europe? The Postcommunist

\footnotetext{
* Ph.D. Student, University of Bucharest, email: alexandra.cojocaru6@s.unibuc.ro, (D) https://orcid.org/0000-0002-0986-8186.
} 
Galaxy,' questions objectively how the collapse of the Soviet bloc has given rise to latent tensions in Eastern Europe. In the author's own words, the fall of communist regimes in Europe 'prompted an unexpected ethnic and national revival,' (p. 226) understood as an organic element of ethnic rivalry within the Eastern European region. Bottoni argues that the postcommunist period not only failed to close the gap between West and East, but it 'confirmed the status of Eastern Europe on the economic periphery' (p. 224).

Stefano Bottoni's scientific approach completes the historiographical spectrum of Eastern Europe. The last chapter of his paper addresses the region's current challenges, emphasizing how these onerous actions will have fundamental repercussions across the continent. Demographic instability, favored by the emigration of skilled labor, declining birth rates, and the inability of social integration of the Roma minority are the most urgent issues that require the attention of Eastern European states. The author suggests taking over the Western model in solving its demographic crisis, namely, 'the import of non-European immigrants.' (p. 291)

Bottoni argues that the Euro-Atlantic integration of postcommunist states did not significantly lower the gap between West and East but instead introduced the experience of Eastern Europe in the binomial relation between 'mimetic reception of foreign models versus ethno-protectionist national egoism' (p. 315). He draws attention to the dichotomy between nationalism and universalism, a paradoxical association identified in public discourses in the surveyed states. Once the two are related, Bottoni highlights the danger of transforming Eastern Europe into a buffer zone, disputed between the great powers. The author confronts current realities with the possibility of a bleak future, in which the West's failure to integrate Eastern Europe into the logic of pan-European evolution, already increasingly challenged at the regional level, will only produce 'a new era of catastrophe' (p. 318).

Stefano Bottoni's work is a necessary read for those interested in the history of communist states in Eastern Europe and the history of postcommunist states. Also, the developments of the last decades signal the future problems that the European continent could face. Nowadays, one of the major challenges is that the concept of 'Eastern Europe,' a Cold War invention, still finds its relevance in an era of interdependence, indicating a profound psychological rift between the citizens of the same Europe. 
Vlad PAȘCA-OPRIȘIU, Cincinalu-n patru ani și jumătate (1971-1975). Nicolae Ceaușescu și economia României socialiste, de la tentații tehnocratice la primatul politicului ['The Five-Year Plan in Four and a Half Years (1971-1975). Nicolae Ceaușescu and the Economy of Socialist Romania, from Technocratic Temptations to the Primacy of Politics], Mega Publishing, Cluj-Napoca, 2020, pp. 263, ISBN 978-606-020-215-8.

\author{
Reviewed by GABRIEL ZVÎNCÄ
}

As a totalitarian ideology, communism planned to reshape societies and states to create a world where everyone could live equally based on the principle 'from each according to his ability, to each according to his needs', thus, creating a new socio-economic order in which social classes and money were absent. Therefore, communism has tackled the modernization of the society and state in terms of economy, society, and politics. Regarding the economy, this ideology was against the socio-economic order based on capital. Accordingly, society was divided into the working class, the so-called proletariat, and the capitalist class, the bourgeoisie. Communism called for a social revolution against this order and planned to reshape it by instituting another one in which the proletariat were the owners of means of production and not the bourgeois. This view, however, suffered a modification in the form of Marxism-Leninism. After the experience of the Soviet Union, the economic restructuring envisaged by the communists, in the first phase, was to create a new model of economy. It was a centralized economy in which the state, or the Communist Party, decided the country's economic future, whereas the free market economy in which the state would hold little to no control. Heavy industrialization, the collectivization of agriculture, and the elimination of private commerce were ways the communists sought to create the utopic socio-economic order envisaged by them.

After the abdication of King Michael and the proclamation of the Romanian People's Republic on 30 December 1947, the Romanian Communist Party followed an economic strategy by which it wanted to modernize Romania in the view given by the communist ideology. Therefore, starting with 1948 and 1949, the Romanian Workers' Party, under the control of its Secretary General, Gheorghe Gheorghiu-Dej, have implemented a strategy by which it wanted to transform Romania from an agricultural state to a heavily industrialized one. This was to be done by following the Soviet model. Detailed plans conceived by the Party and its organisms would guide the economy for five years, the so-called 'five-year plans' (cincinale).

The historiography of the Romanian economy under the communist regime has been treated in various works ${ }^{1}$ but one which focuses on how a cincinal was drafted, adopted, and

* M.A. student, 'Babeș-Bolyai’ University, Cluj-Napoca, email: gabriel.zvinca7@gmail.com,

(D) https://orcid.org/0000-0002-3070-8515.

${ }^{1}$ See, for example, Postolache 1992; Ionete 1993; Grigorescu 1993; Murgescu 2010; Alexandrescu 2012; Ban 2014. 
implemented has not been thoroughly analyzed. Therefore, the work of Vlad Paşca-Oprișiu is of great importance because he approaches this issue in various ways. He details the way the Communist Party was organized under Nicolae Ceaușescu, how decisions regarding the future of the Romanian economy were adopted, who were the experts and the deciding actors, and so on. The author further argues that his work is important because he wants to give an 'honest and valid scientific view to the public on the economic past of Romania' (p. 12) in his effort to both present the qualities and the flaws of the Communist economy.

'The five-year plan in four and a half years' is a well-documented and written research on the problem of Communist Romania's economy in the so-called 'Golden Age' of Romanian communism (1965-1989) and, in particular, on the Decade of Prosperity (the 1970s). The volume has three parts. Vlad Pașca-Oprișiu wants to explore the Romanian Communist Party on the eve of Ceauşescu's takeover. He presents how the system was shaped and how decisions were taken inside the economy. He is particularly interested in analyzing the 1971-1975 cincinal from an economic performance angle. He has chosen this cincinal because the previous one, 1966-1970, was already drafted under the control of Gheorghe Gheorghiu-Dej and Ceaușescu's influence over it was null. He further argues that his choice can be supported in terms of research as 'the paradigm of the existing planned development in the socialist system offered autonomy to the cincinals' (p. 12).

In the first part, the author offers a complex perspective over the Romanian Communist Party, how Ceaușescu was elected as Secretary General by the Central Committee, the deciding structures in terms of economy, and how the newly elected Secretary placed his men on top of the decision pyramid. His research is interesting because it offers valuable information about the State Planning Committee, the persons responsible for drafting the plans and organizing the planned system.

In the second part, Vlad Pașca-Oprișiu went more profoundly into analyzing the economic system of Communist Romania in the 1960-1970s. He explains why the proclaimed economic reform of Romania in 1967 was not like the reforms in Central and Eastern Europe but was actually a need to reorganize the clientelistic system. He then further explains the international economic context and how the Détente period was beneficial for the Romanian economy. The country had the opportunity to import technologies from the West and raise its export, mainly to the Third World countries.

The most important and interesting part of the work is the third, in which the author examines the 1971-1975 cincinal. He explores the whole process of its adoption, how the Central Committee influenced it by reviewing it and suggesting modification, and how the plan was applied in the identified period. He further divides this chapter into four different parts, focusing on the socio-economic profile of Romania before the implementation of the plan, the stages of drafting the plan, its objectives and results, and what problems it faced in implementing it. Of particular interest is the 'Objectives and results' of the cincinal in which the author, in about 70 pages, examines the implementation of the plan in all economic areas, such as heavy industry, agriculture, energy, electricity, and the standard of living of the Romanian citizens. Here, using official documents of the Communist Party found in the Central Historical National Archives, he compares the numbers envisaged in the five-year plan with the ones in the yearly plans and the actual numbers obtained after the implementation. His results are interesting as they show that the cincinale offered no 
realistic numbers because they were drafted before their actual implementation. The actual implementation of the plan was done through the yearly ones.

Despite all the above results, the author falls short in certain areas. He fails to explain why the yearly plans were more important than the cincinale, why they were used to coordinate the economic activity, how each yearly plan was drafted considering the cincinal perspectives, and how it was implemented from year to year. Moreover, the research could be extended to the other five-year plans that followed to assess if the system suffered changes when Ceaușescu's reign was at its peak, and the political and economic relations flourished, what was Ceaușescu's influence over the economy through the deciding system of the cincinale as analyzed in this work, and how the system performed all around in the period that followed 1975 .

\section{Bibliography}

Alexandrescu 2012

Ban 2014

Grigorescu 1993

Ionete 1993

Murgescu 2010

Postolache 1992
I. Alexandrescu, România între Est și Vest: Aderarea la FMI și BIRD, Târgoviște 2012.

C. Ban, Dependență și dezvoltare. Economia politică a capitalismului românesc, Cluj-Napoca 2014.

C. Grigorescu (ed.), Nivelul dezvoltarii economico-sociale a României în context european, București 1993.

C-tin. Ionete, Criza de sistem a economiei de comandă și etapa sa explozivă, București 1993.

B. Murgescu, România și Europa. Acumularea decalajelor economice (1500-2010), Iași 2010.

T. Postolache (ed.), Economia României, secolul XX. Noua tranziție la economia de piață. Premise istorice și perspective, București 1992. 



\section{Zoltán GYÖRKE, Napoca, o istorie recentă a Clujului. Obsesia romanizării sub două regimuri politice 1974-2014 [Napoca, a Recent History of Cluj. The Obsession of Romanization under Two Political Regimes], Mega Publishing, 2017, pp. 334, ISBN 978-606-543-898-9}

Reviewed by MIHAI CHIȘ*

Zoltán Györke's book proposes a foray into the political and administrative history of Cluj during the period of National Communism of Nicolae Ceaușescu. According to the 1968 law regarding the territorial administration of the Socialist Republic of Romania (SRR), local historic traditions had to be considered when naming the counties. A so-called 'exception' to these traditions occurred in 1974, specifically on the 15 October, during a meeting of the Executive Political Committee of the Romanian Communist Party. Then Nicolae Ceaușescu decided that Napoca should be added to the city's existing name at the time, which was Cluj. The following day, manifestations took place on the streets of Cluj, celebrating the 1850th anniversary of granting the rank of municipium to the settlement of Napoca. At the same time, a decree sanctioned the city's renaming was issued on the same day and signed by the Romanian communist leader during his visit to Cluj. This event is the starting point of Zoltán Györke's research, which not only dwells into the history of Cluj during the National Communism period but also examines the local realities of the post-communist Cluj.

There have been similar instances when a settlement was forcibly renamed during the period of the communist regime (such as the cases of Onești, which was named Gheorghe Gheorghiu-Dej or Ștei, which was named Dr. Petru Groza). However, by 1996 the old names of settlements were brought back. However, this was not the case of Cluj, which still kept the name imposed in 1974. Attempts were made to bring the old designation of the city. However, these efforts met the opposition of local politicians, the population, and even the city's mayor. As the author claims, the indifference of authorities and resilience of a certain percent of the local population needed an explanation. Consequently, in Napoca o istorie recentă a Clujului [Napoca, a recent history of Cluj], Zoltán Györke focuses on finding an answer to why a selfish act of a dictator (Ceaușescu's decision to rename Cluj) is not yet condemned.

The book has three parts. The first part, $O$ denumire adăugată [An added name], is the starting point of the journey proposed by Zoltán. This chapter presents the context, the decision, and the public manifestations during the renaming of Cluj. Throughout the chapter, one could read about different points of view regarding the continuity of habitation between the Antiquity period of Napoca and the medieval attestation of the city of Cluj under the names of Clus, Clusa, or Clusium. The author pleads with the arguments of the

M.A. Student, 'BabeşBolyai' University, ClujNapoca, email: chismihai513@yahoo.com, (D) https://orcid.org/0000-0001-6482-3856. 
'younger generation of historians,' which contradicts the views of the official historians of the communist regime. As a result, by the end of the chapter, the suggestion that can be drawn is that it is no longer justifiable to keep the city's actual name (an exclusively political decision of the time). Instead, the return of the old name of Cluj was the only solution. The first chapter also dwells briefly on a similar case similar to that of Cluj. Turnu-Severin was renamed Drobeta Turnu Severin in 1972, due to the same reasons as in the case of Cluj (the distortion of historical dates and propaganda).

The second chapter of the book, Structuri de putere și putere simbolica în Clujul comunist [Structures of power and symbolic power in communist Cluj], describes the mechanisms and the instruments of power specific to the local and county leaders of the Romanian Communist Party in Cluj. Throughout the chapter, one can read about the role of political leaders in consolidating Nicolae Ceausescu's views about Nationalist Communism. National Communist was a means of strengthening the national identity of Socialist Romania and played an essential role in developing a veritable cult of personality of the Romanian communist dictator.

The third and last chapter, Memorie locală și discurs public în Clujul postcomunist [Local memory and public discourse in post-communism Cluj], deals with politicians and a part of the local population's resistance to renaming Cluj-Napoca back to Cluj, the consecrated name of the city in the medieval period. The chapter contains an overview of the arguments of several specialists in history and archeology. They all support the idea of returning to the name of Cluj. The arguments are met with hesitation by the local authorities.

Work with a solid, informative role, Zoltán Györke's book is addressed to those who refuse an incursion into the political and administrative history of the city of Cluj-Napoca and disregard any dialogues on why the old denomination of the city should be brought back.

The book also brings to light the ethnic tensions between the Romanian and Hungarian populations of the city. Unfortunately, these tensions were fueled during Ceaușescu's nationalist rule and after the 1989 Revolution by a series of clichés. They included 'the Daco-Roman settlement of Napoca was the predecessor of Cluj;' 'the Hungarians want to remove this denomination, as the existence of Napoca is a prime example for the primacy of habitation of these lands by the Romanians.' Zoltán's research serves to correct such false views. It helps its readers understand the importance of listening to different opinions regarding the subject at hand and when we face a dilemma. The book uses an extensive specialty bibliography and archival sources found during the author's extensive field research, which brought to light several unknown aspects from the communist and post1989 past of Cluj. It represents a noteworthy attempt to raise awareness of the importance of studying one's local history. 


\title{
Vlad ONACIU, Societatea penuriei. Carențele din construcția regimului comunist în România. Studiu de caz: Cluj în anii '60 și '70 [Society of Shortage. Deficiencies in the Construction of the Communist Regime in Romania. Case Study: Cluj in the '60s and '70s], Cluj-Napoca, Argonaut Publishing, pp. 377, ISBN 978-973-109-991-0
}

\author{
Reviewed by ANDREI-DUMITRU OLTEANU*
}

Analyzing communist societies in different decades represents a field of research open to multiple questions and fruitful answers for historians. When dealing with the analysis of the society in communist regimes, one can identify authors such as Hannah Arendt, Sheila Fitzpatrick, or Igal Halfin. Vlad Onaciu is one of the youngest researchers interested in the social history of communism. He wrote many interesting studies on this subject. Among them, we mention Constructing Socialism at 'Tehnofrig.' A social history case study into the ethnic structure of the Cluj workforce during the mid-1960s and Battle for hegemony in the contemporary world: Civilizational disputes in historiography published in Studia Universitatis Babeș-Bolyai - Series Historia.

This book, Societatea penuriei: Carențele din construcția regimului comunist în România. Studiu de caz: Cluj în anii '60 și '70 [The Society of Penury: The Deficiencies in the Construction of the Communist Regime in Romania. Case study: Cluj in the '60s and '70s] was published in 2020 by Argonaut Publishing House with a preface written by Professor Virgiliu Țârău from the Faculty of History and Philosophy, 'Babeș-Bolyai' University, Cluj-Napoca. The structure of this book contains four chapters and introduction, conclusion, and bibliography. The topics approached are evident from the title of the chapters: 'Patterns of Romania's modernization,' 'The distribution system, the story of a failure, 'P.C.R., Pile Cunoștințe, Relații,' and 'The New Worker.'

The volume's title provides a clear perspective on its content in terms of chronological, spatial approach, and the main objectives pursued by the author. The book's content matches clearly with its cover: it is a story of a society faced with the lack of essential goods. The subtitle indicates it focuses on the shortcomings of the communist regime in Romania with a case study on Cluj County during the ' 60 s and '70s. The introduction presents reflections on communist Romania and its endemic penury, a subject that will be approached in the following pages. The acknowledgment section raises high expectations given the names of the specialists mentioned there.

The introduction contains a historiographical overview in which the author names a plethora of historians and specialists in various fields connected to the subject of the book. Before presenting the sources used by the author, Vlad Onaciu introduces the reader to the realm of small stories where the Romanian Communist Party (RCP) influenced and

* M.A. Student, 'Babeș-Bolyai' University, Cluj-Napoca, email: andreidoru14@gmail.com, (iD) https://orcid.org/0000-0001-8487-8360. 
changed the destiny of millions of people. The author introduces his readers to the variety of meanings of the terms 'society' and 'scarcity using dictionaries and well-known authors, including Anthony Giddens, Michael Mann, Immanuel Wallerstein, Janos Kornai, and of course, Vlad Onaciu. An exemplary research work, the primary sources bring indisputable evidence of the artist (in our case, the historian). The archival documents created by local bodies (People's Council of Cluj County) and by the Securitate, the Romanian secret police, local press, and oral history interviews are worth mentioning. The presentation of historiography focuses on the analysis of social and economic policies within totalitarian regimes. The author uses national and international literature and approaches them critically. The conceptual framework inserted at the end of the introduction introduces the readers to highly technical concepts, including centralized planning, types of budget constraints, and paternalism.

The first chapter, 'Patterns of modernization in Romania,' deals with some temporal frameworks of the modernization process in twentieth-century Romania. The first topic addressed in this genre is entitled 'Interwar Romania.' Vlad Onaciu presents the effects of the First World War and the Great Depression both globally and nationally, managing to highlight the effects of economic protectionism. At the same time, the author describes the social and economic differences of the period between 1910 and 1930 in the Central-Eastern European context. Regarding the relationship between agriculture and industry, the author mentions that rural dominate the urban space demographically. Also, agriculture suffered from extreme fragmentation of the land parcels and lack of funding. The debate over modernization influenced industrialization. The two significant events (the First World War and the Economic Crisis of 1929) opened the discussion on the Western economic model, favoring conservative and isolationist ideas. At the end of the argument of this subchapter, the author puts forward Nicolae Manolescu's theory of economic protectionism.

A subchapter approaches the evolution of the Romanian economy during the communist period. It started with its nationalization of the entire economy and ended with the failure of all economic policies of the Romanian regime. In 'The first post-war years: reconstruction and nationalization,' Vlad Onaciu makes a thorough analysis of the period from 1945 to the mid-'50s. He identifies the main legislative measures that changed the entire administration and management of the state economy. The author presents the modernization policies during the communist period with the help of figures and percentages this time, the reader being explained the process that led to the bankruptcy of the communist economy (the last subchapter).

After creating a context as only a historian knows how to do, the author presents us in the third chapter entitled: 'Evolution of Cluj' with an overview of the county 'before the communism' and continues with 'the construction of socialism in Cluj.' Before entering the analysis of the communist era, Vlad Onaciu offers the reader a route through Cluj and other cities of the county. During this imaginary and informative trip, the reader gets familiar with the culture of the area. This industry developed in the interwar period, each factory having its specifics and story. Socialism in Cluj was built, as the author presents it, through expanding existing enterprises and building other new factories, which increased the need for workers. Cluj gradually changed during this period, as industrialization occupied a central role. As a result, the author engages in the pertinent analysis of the factories '16 
Februarie,' 'Remarul,' 'Bombardier,' 'Iris,' 'Clujeana,' 'Charm,' 'Technofrig,' and 'Carbochim.' The conclusions concretized the ideas stated in the previous pages and clearly outlined the author's intentions and historical evolution and characteristics of each period. Also, the Stalinist model of industrialization and the effects of collectivization set the context for the next part of the paper.

In the second chapter, the author greets us with a new conclusion: 'The distribution system, the story of a failure.' The first part of this story comprises the definition of 'food penury.' Vlad Onaciu focuses on the discursive construction of an illusion that emerges in the period 1970-1975 regarding people's living environments, which contradicts the incipient state of habit with flaws. Another feature of the research is the 'mythology of local communism,' as the author calls it. It refers to the so-called abundance of the ' 60 s and '70s and the realities of long queues for food and basic goods. Queues became the central topic of research. Using literature and archival documents, the author demonstrates the differences in quantities in the field and those in newsletters, focusing on the context and mentality that resulted in the emergence of queues. The 'non-food penury' occurred due to precarious distribution, redistribution, and poor supply. The author demonstrates the failure of these systems with examples taken from the national and local archives. The gaps in the construction of the distribution system in the Cluj region are well argued with the help of the minutes of the People's Council, which show supply problems that conclude in a systemic problem. The institutional relations between the People's Council and the Local Construction Trust in Cluj, the gaps between the high prices of buildings, plans, and materials are examples of the system's inefficiency. They are solid proof of the failure of transforming the centralized and planned economy into a sustainable one.

In the third chapter, 'P.C.R. Pile, Cunoștințe, Relații', the author seeks to define the alternative economy through an 'umbrella concept.' Vlad Onaciu tries to define four other closely related concepts. They include secondary economy, informal economy, black market, and the gray market. The author closely well articulates these four concepts through examples taken from Cluj and elsewhere. Consequently, the reader gains a clear idea about the causes of the economy's collapse during the late communist period.

Starting from Alena Ledenava and her conclusions regarding the communist economy, Vlad Oanciu focuses on defining the concept of Blat, correlating it with abuses of power of the traditional 'pile, cunoștințe, relații.' The author gives examples from different industries in Cluj. The archival documents recorded different cases of fraud involving people from the same workplace. In other two subchapters titled: 'Theft and embezzlement' and 'Trafficking in precious metals,' Vlad Onaciu underlines the differences between the concepts used and their application to the Romanian case.

The 'New Worker' is entitled the last chapter of this research. The author analyzes this concept and compares the 'social engineering project of communism' with the activity of society in urban space and urban environment. Thus, Vlad Onaciu defines 'traditional ethics and formal training' by analyzing both the importance of social mobility and the process by which knowledge and professional positions are acquired. Another aspect pursued by the author in this chapter is the case of 'old specialists in the communist world.' The author uses the case of Dezideriu Jena to highlight the process, tensions, and relations between specialists before their activity during the regime. The author concludes the first 
segment of the 'new man' portrait with the 'profile of the new man.' The last two elements of the portrait focus on 'policies of modernization', 'from Stakhanovism to socialist competitions.' The author observes various systemic irregularities in the motivation for increasing productivity. Vlad Onaciu finishes the portrait by mentioning work accidents and diseases caused by the work environment.

The end of the book reiterates the author's conclusions already highlighted at the end of the previous chapters. Two annexes contain tables showing productivity levels, prices for different products, and population numbers. The bibliography is divided according to the type of source. Vlad Onaciu's work is an example of research on society during the communist period. Attention to detail, the careful definition of each concept is matched with relevant examples taken from archival documents. Vlad Onaciu succeeds in demonstrating how the economic penury between scarcity and the communist system are dominant factors of its failure. 



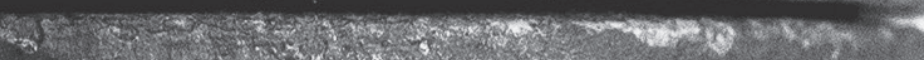

1

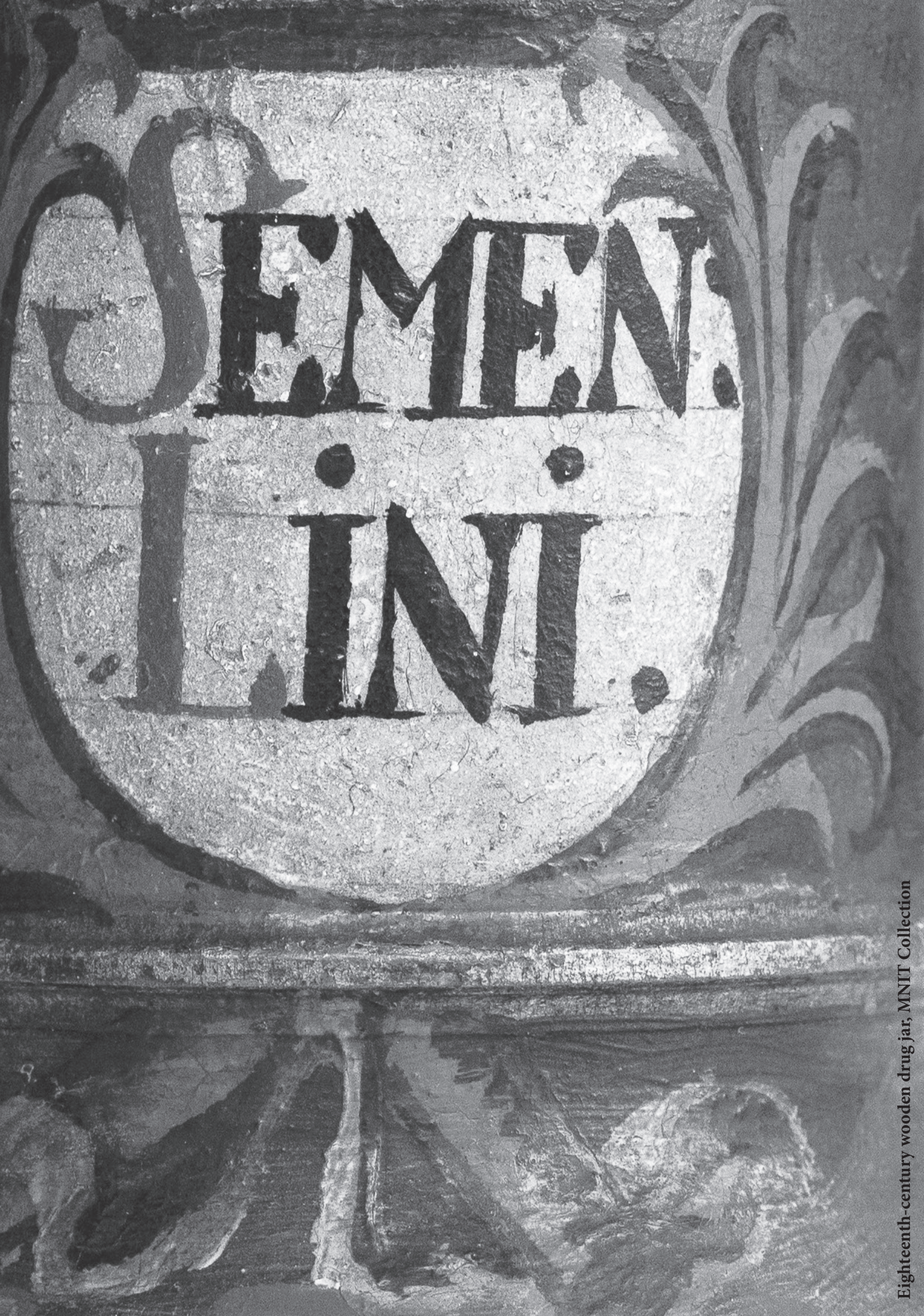

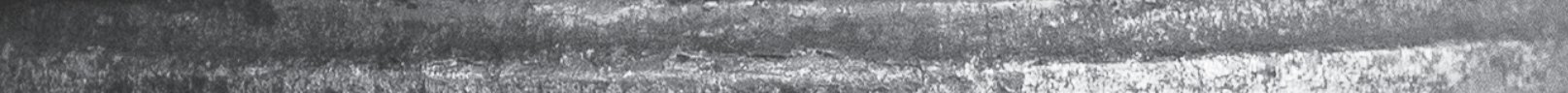

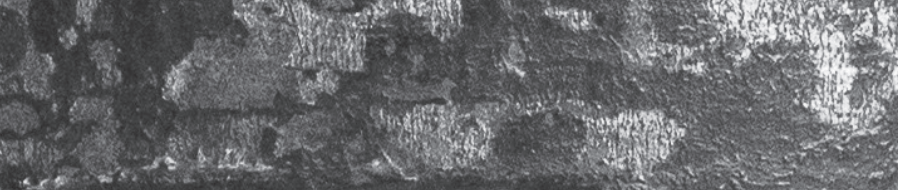




\section{PROJECT PRESENTATIONS}





\title{
PHARMATRANS. ALL THINGS APOTHECARY IN SIXTEENTH-TWENTIETH CENTURY TRANSYLVANIA. THE HISTORY OF PHARMACY COLLECTION IN CLUJ-NAPOCA*
}

\author{
ANA-MARIA GRUIA ${ }^{* *}$
}

In 2021 the National Museum of Transylvanian History (hereafter MNIT) began implementing a three-year exploratory research project supported by the Romanian Ministry of Education and Research (UEFISCDI), code PN-III-P4-ID-PCE-2020-1562, that focuses on its History of Pharmacy Collection. The project envisages the publication in English of a complete collection's catalog, as well as the conservation, and restoration of some of these cultural goods. It also involves research of the history of pharmacy in Transylvania during the eighteenth century based on the previously unpublished sources in the collection (manuscripts, jars, tools, printed materials). These will be analyzed through innovative methods. They include complex chemical analyses of preserved pharmaceutical preparations (mass spectrometry, chromatography) and new data obtained through the ongoing restoration work of the oldest pharmacy in Cluj (the Hintz House that houses the collection). This will be the first exhaustive catalog of the collection. We envisage the publication of six volumes in 2023, comprising all of the ca. 2500 artifacts from the sixteenth-twentieth centuries). The series will be a valuable source for future studies, made available online and sent to 150 libraries in Romania and abroad through the book exchange network of the MNIT and the network of specialists and museums created through the project. The catalog will be made available online (in pdf format) on a dedicated website.

The team consists of project leader Ph.D. Ana-Maria Gruia, a specialist in the history of pharmacy, researcher Ph.D. Mária Pakucs, a specialist in paleography and economic history who will focus on the manuscripts in the collection, researcher Ph.D. Ioana Gruiță, art historian and museographer, who will deal with the old books collection, Ph.D. candidate and conservation specialist Ioana Cova who will coordinate the manipulation and preservation of the items in the collection, and Ph.D. Alexandru Rădulescu will photograph the entire collection. The proposed activities and research are deeply interdisciplinary, at the intersection of fields of study such as entangled and global history, history of technology, social and economic history, cultural and museum studies (in which the project leader and the team members have studies and experience).

In connection to the project's main objective, i.e., the publication of its extensive catalog, the team has taken professional photographs of all 2416 artifacts, books, and manuscripts recorded under the 2362 inventory numbers during the first year. Ph.D. Alexandru Rădulescu has processed these photographs, and they have already

\footnotetext{
* This work was supported by a grant of the Romanian Ministry of Education and Research, CNCSUEFISCDI, project number PN-III-P4-ID-PCE-2020-1562, within PNCDI III.

${ }^{* *}$ Ph.D., Museum curator, National Museum of Transylvanian History, Cluj-Napoca, email: ana.gruia@ gmail.com, (D) https://orcid.org/0000-0003-4523-7346.
} 
revealed new data on many of the cultural goods in question. The History of Pharmacy Collection has been recently moved for the first time since its opening, in the 1950s, in the Hintz House that hosts it and which is currently undergoing major renovations. On this occasion, we have identified a significant number of previously unknown items that we decided to include both in the inventory ledger and the project and its final catalog: four boxes full of financial documents from the Hintz pharmacy in Cluj and the Engel pharmacy in Iassi (between the end of the nineteenth century and the end of the twentieth), documents about the history of the collection (Valeriu Bologa, previous museographers, blueprints of the museum), several education documents in the field of pharmacy, and several books. Another lot of druggist glass containers has just been uncovered during archaeological excavations in Cluj-Napoca (still ongoing), and we would like to add them to the collection as well. We estimate an extra 100 items (or small lots of similar items) in total, to be recorded and processed during the project's second year (with the pro bono continued cooperation of Ph.D. Alexandru Rădulescu).

One of the essential intermediate goals reached during this first year is identifying the intended structure of the catalog. There will be three types of records: one is typical to manuscripts (established by Ph.D. Mária Pakucs starting from the international standards of recording such goods), one typical to old books (established by Ph.D. Ioana Gruiță), and the third type to all other artifacts (mainly apothecary jars, established by Ph.D. Ana-Maria Gruia). For the third type, we created an Airtable database with the following inter-linked tables: inventory numbers, sub-collections, people, bibliography, pharmacies, and cities. The first table includes fields about the description of each item or lot (hence the structuring according to 'inventory number' taken as the unit of analysis): type, category, sub-category, dating, dimensions, material, photographs, contents, the context of use, history of reuse, description, signature, decoration, state of conservation, previous restorations, date of acquisition, bibliography, keywords, therapeutic indications, etc. The second table includes items with shared characteristics and similar contexts of use (apothecary jars were usually produced in sets). Other tables grouped data regarding known personalities connected to the items in the collection, primarily pharmacists, pharmacies where the items were used, and the cities with such pharmacies. The final table is the bibliography, structuring the data on books, articles, and catalogs where items in the collection have been published before. The database will allow team members to structure, store and access the data more easily and collaboratively. The final catalog will start from the exported database entries and include transcriptions, translations, and conservation files.

For the introductory volume of the catalog, Ph.D. Ana-Maria Gruia has secured the collaboration of several specialists: Ph.D. Melinda Mitu, museographer at the National Museum of Transylvanian History, will prepare an article on the biography of Hintz György; Ph.D. Kovács Zsolt, lecturer at the Babeș-Bolyai University in Cluj, intends to publish two papers, one dealing with the history of the Hintz House (the site of the oldest pharmacy in Cluj-Napoca that houses our collection, recently clarified during restoration works and wall-face researches) and the other focusing on the Jesuit pharmacy in town, along with one of its unpublished inventories; Ph.D. Cosmin Rusu, lecturer at the same university, will contribute with a paper on the history of sanitation and healthcare in Cluj. M.D. Robert Offner has offered to become a collaborator of the project (probably 
preparing a text on Tobias Maucksch, the privileged pharmacist of Cluj in the eighteenth century). For this initial volume, Ph.D. Ana-Maria Gruia will write the introduction, a detailed presentation of the history of the collection (including an interview with Ph.D. Eva Crișan, its first curator), and a thorough analysis of the item categories. Ph.D. Mária Pakucs and Ph.D. Ioana Gruiță will write the introductory studies of the volumes focusing on the manuscripts and old books in the collection.

The project has several intermediate objectives. The first secondary objective is to provide team members the opportunity to visit history of pharmacy museums in order to gain insight into their conservation, restoration, and display strategies, to acquire specialized secondary literature regarding such collections for analogies, and in-depth knowledge of the state of the art, and networking. Most of these visits took place in 2021, as team members visited a number of significant museums, in five countries: Romania, in Oradea (Muzeul Farmaciei - 'Apotheca Rodia'), Sibiu (Muzeul de Istorie a Farmaciei), and Sighișoara (Muzeul de Istorie); Hungary, in Budapest ('Arany Sas' Patikamúzeum), Székesfehérvár ('Fekete Sas' Patikamúzeum), Kőszeg ('Aranyi Egyszárvu' Patikaháza and 'Fekete Szerecseny' Patikaháza), and Kecskemet (Orvos- és Gyógyszerészettörténeti Gyüjtemény); the Czech Republic, in Český Krumlov (the Jesuit pharmacy collection part of the Regionální muzeum Český Krumlov), Klatovy (the Barokní Lékárna u Bílého Jednorožce), Kuks (the impressive Czech Pharmaceutical Museum, Hospital Kuks), and Prague (the Historical Museum and the Natural History Museum); Austria, in Graz (the pharmacy collection of the Graz Museum, currently closed to the general public) and Mauthausen (the history of pharmacy collection inside the Pragstein Castle); and Italy, in Venice (Ca Rezzonico, Farmacia ai do San Marchi, Palazzo Mocenigo, Muzeo d'Historia Naturale di Venezia). These visits have provided a general context for the research of the collection in Cluj. They have allowed team members to establish personal connections with specialists from Central and Eastern Europe.

The second intermediate objective is to clean, consolidate, and restore the artifacts that require such specialized interventions (ca. 500 artifacts). More than 200 artifacts of the collection have been or are still being cleaned, conserved, or restored by specialists of the MNIT in 2021. The selected items, made of paper, parchment, glass, ceramics, and metal, have been processed and documented by Ioana Cova (team member) and several colleagues from the conservation and restoration department that she coordinates: Cornelia Rotariu, an expert in the restoration of ceramic cultural goods, Tudor Tomescu, expert restorer of artifacts made of ceramic, glass, faience, and porcelain, Radu Cordoș, engineer, expert restorer of metal items, and Adriana Bulbuc, expert restorer of paper goods. The pharmaceutical collection is generally in a good state of preservation. Except for a few cases of actual restoration (broken containers), the interventions were focused on cleaning and consolidating the patrimony goods.

The third specific objective is to gain new knowledge on the artifacts in the collection through the latest methods: microscope investigation, micro-photographs, and especially chemical analyses of materia medica preserved in some of the old containers. In 2021 the team has identified the containers from which samples will be collected next year. They will be sent for analysis locally, in Cluj-Napoca, or at the Department of Chemistry and Industrial Chemistry of the University in Pisa. The exact list will be decided upon at 
the beginning of 2022. The laboratory in Pisa has specialized in such research through a national project entitled Colors and balms in Antiquity: from the chemical study to the knowledge of technologies in cosmetics, paintings, and medicine (2007) that involved analytical studies of pharmaceutical preparations from historical collections (seventeenthnineteenth centuries). The most important advantage of this department's experience is its expertise in performing and interpreting the results of such chromatographic and mass spectrometric analyses. The team led by Prof. Maria Perla Colombini has created a database of biomolecular markers by analyzing reference materials, replicas of old formulations, and artificial aging of both reference materials and replicas. The results are subsequently interpreted in the context of written historical sources to reconstruct the original recipes of the formulations and the processes involved, thus with the cooperation of the institution holding/commissioning the analyses. In the collection, analysis, and interpretation of the samples, we will benefit from the cooperation of Ph.D. Márta Guttmann, chemist and expert conservator, lecturer at the University of Sibiu. An interesting discussion has arisen around the opportunity and appropriate methods of collecting samples from tightly sealed eighteen century containers in the collection (in order not to damage them in any way). The matter will be decided during the second year of the project.

Taking digital micro-photographs of relevant details found on items from the History of Pharmacy Collection is a novel research method envisaged by the project. Ph.D. Magó Andrea Beatrix, working for the MNIT, is the specialist collaborator for this task. Her analyses will allow us to clarify faded inscriptions, production details (bookbinding decoration or painting layers on drug jars, for example), and identify some of the materials employed (parchment vs. paper), natural specimens preserved, and previous interventions. The use of ultraviolet and infrared light is sometimes very relevant for our research that focuses on different materials. She has already tested the Mic-Fi - VIS/IR/UV digital microscope and has performed an initial set of four in-depth analyses (compiling observation files).

The fourth objective is to transcribe, translate, and analyze all manuscripts in the collection, most of which have never been edited before. This lot mainly consists of handwritten pharmacy inventories, pharmaceutical taxes, study diplomas, manuscripts, labels, prescriptions, and book annotations. Ph.D. Mária Pakucs has become acquainted with the specific traits of many manuscripts dating from the seventeenth and the eighteenth century (chronology, languages, scripts, terminology) and has performed contextual research (such as the apothecary prescriptions of Baron Samuel von Brukenthal and his family kept at the County Branch of the National Archives in Sibiu, the Brukenthal Collection, inventory CD 1-51). She has transcribed and translated an eighteenth-century manuscript sheet (from the apothecary chest of Tereza Kemény) and some of the manuscript annotations of Giovanni Battista Gusetti on one of the old books in the collection. Mária Pakucs has also read and started transcribing the following manuscripts: Inventarium von der Maros Vasarhelyen Apotheken etc. 1790 ('The 1790 inventory of the apothecary shop in Târgu-Mureș') and Prothocollum ellaboratorum apothecae neo-erectae Armenopolitanae a prima Iunii 1788 ('The 1788 inventory of the apothecary shop in Gherla'). Ph.D. Ioana Gruiță, in charge of the manuscripts dated to the nineteenth and twentieth centuries, has already fully transcribed and translated Iosif T,iucra's Carte de mână pentru nedoctori ('Hand-written book for non-doctors,' 1878) and has processed about 60 old books. 
Due to the problematic reading of some of the manuscripts, their numerous pages, and the documents recently discovered in the Hintz House, we might have to select only the most important ones to transcribe and translate fully. Others, such as the financial documents, the prescriptions, and various lists, will only be accompanied by an abstract of their contents.

The fifth objective of the project is to research and present the most relevant discoveries made regarding the history of pharmacy during eighteenth-century Transylvania as reflected by the collection under discussion during international conferences and at least three articles in prestigious periodicals (ISI/ErihPlus). Though the research of the topic has already started, the most significant contributions will be obtained from combining the results of the chemical analyses with the new data from the manuscript collection and the context of the era's pharmaceutical practice and mentalities. During the first year of the project, team members have already delivered two presentations during international meetings. Ana-Maria Gruia took part in the international conference entitled Health, disease, and healing in old Cluj (The history of healthcare until the end of the nineteenth century), held online by the Association of the Erdélyi Múzeum-Egyesület on 1 and 2 October 2021. Her presentation was entitled From bezoar and cantharidis to deer antler. Medicines of animal origin in the History of Pharmacy Collection in Cluj-Napoca. Ioana Cova participated in the International Conference of Doctoral Candidates in History organized online on 12-13 November 2021 by the Doctoral School of the 'Babeș-Bolyai' University in Cluj. Her presentation was entitled How archaeological items become museum objects: a pharmaceutical archaeological glass collection.

The sixth objective is to promote the project, its activities, and results through a dedicated website, posts on social media platforms, press releases, and a book launch event in 2023. The logo and the bilingual website of the project have already been created. The website, https://pharmatrans.mnit.ro, in Romanian and English, is connected to the website of the National Museum of Transylvanian History in Cluj-Napoca. It has the role of promoting the project, the collection, and including, upon completion, the catalog in a free download format. In 2021 we have completed the website's information (project details, team, goals, results, contact). We have added more than 40 blog posts in Romanian and English, detailing some of the activities already performed. On the leading social media platforms (Facebook, Instagram), we have posted and promoted more than 50 posts (all marked with the hashtags \#pharmatrans \#mnit and \#uefiscdi, maximum individual reach $11.7 \mathrm{~K})$.

Through the completion of the project, we hope that the catalog will become a helpful tool for future researches in Romania and abroad, providing the basic data for study and comparative material for other collections. The project will also contribute to the conservation, restoration, and promotion of Transylvania/Romania's cultural (and technical) heritage. The research results of the current project can become a model of an inter-disciplinary approach applied to the eighteenth-century history of pharmacy in Transylvania. 


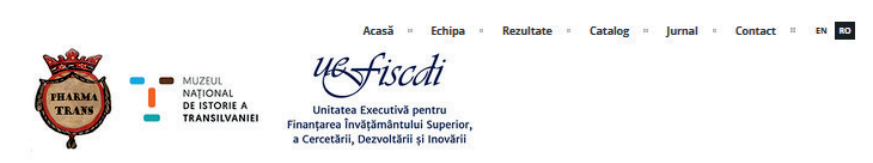

FARMACIILE SECOLELOR XVI-XX DIN TRANSILVANIA. COLECȚIA DE ISTORIE A FARMACIEI DIN CLUJ-NAPOCA

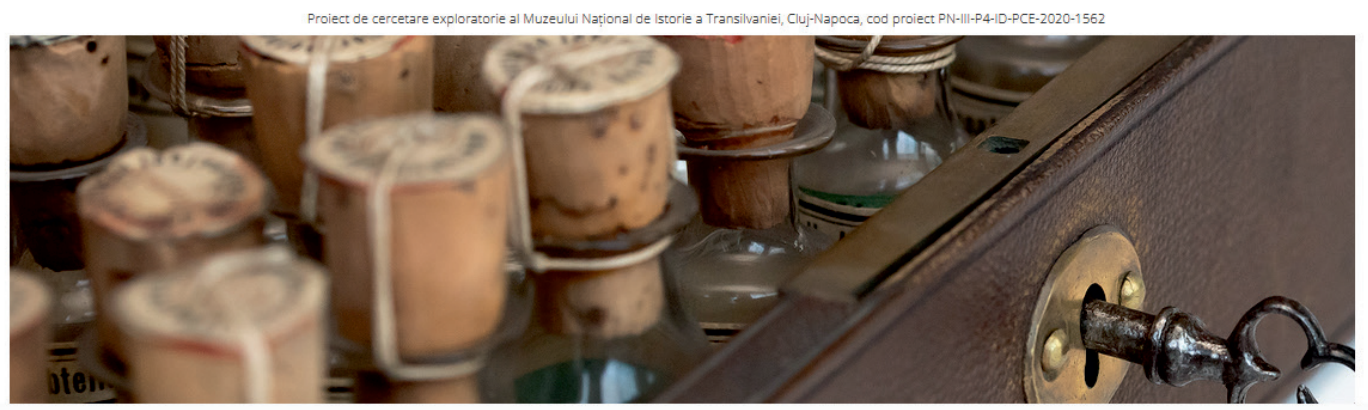

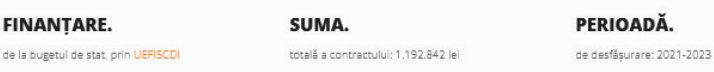

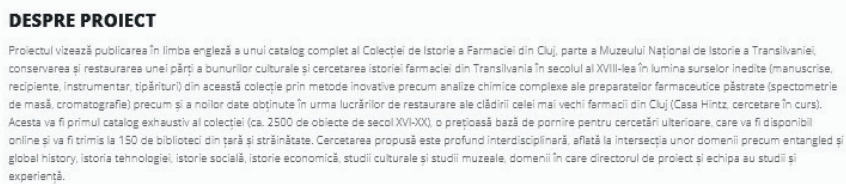

Fig. 1. Homepage of the dedicated website, affiliated to the website of the National Museum of Transylvanian History: pharmatrans.mnit.ro.

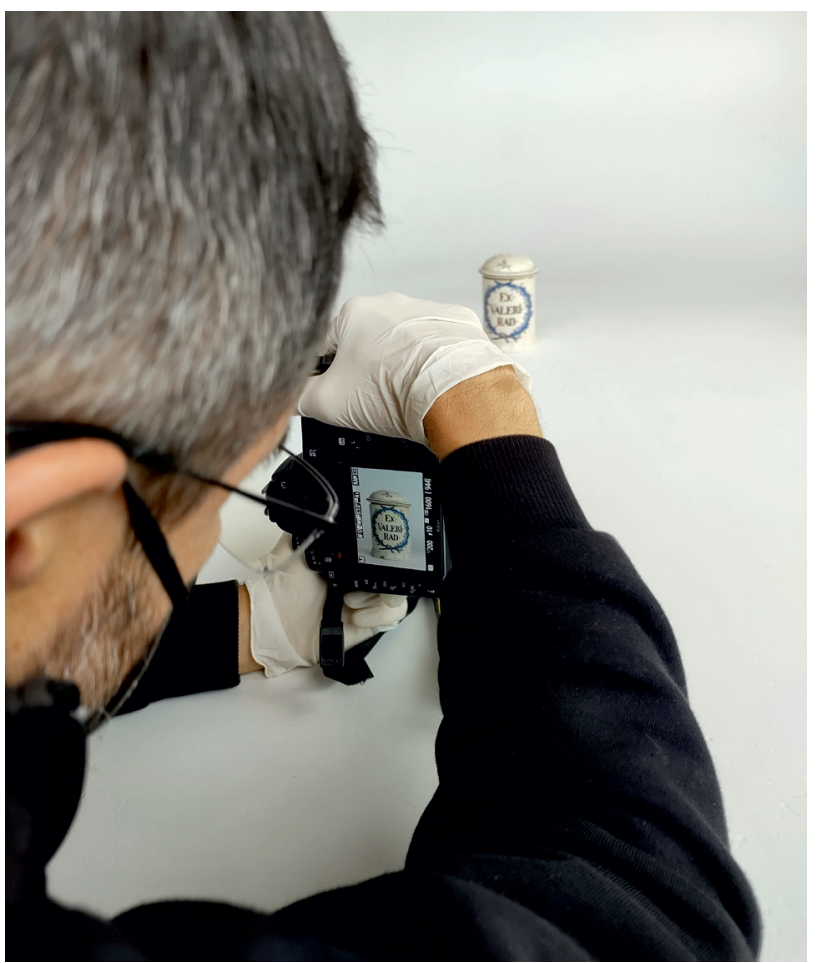

Fig. 2.

Ph.D. Alexandru Rădulescu photographing an apothecary jar. 


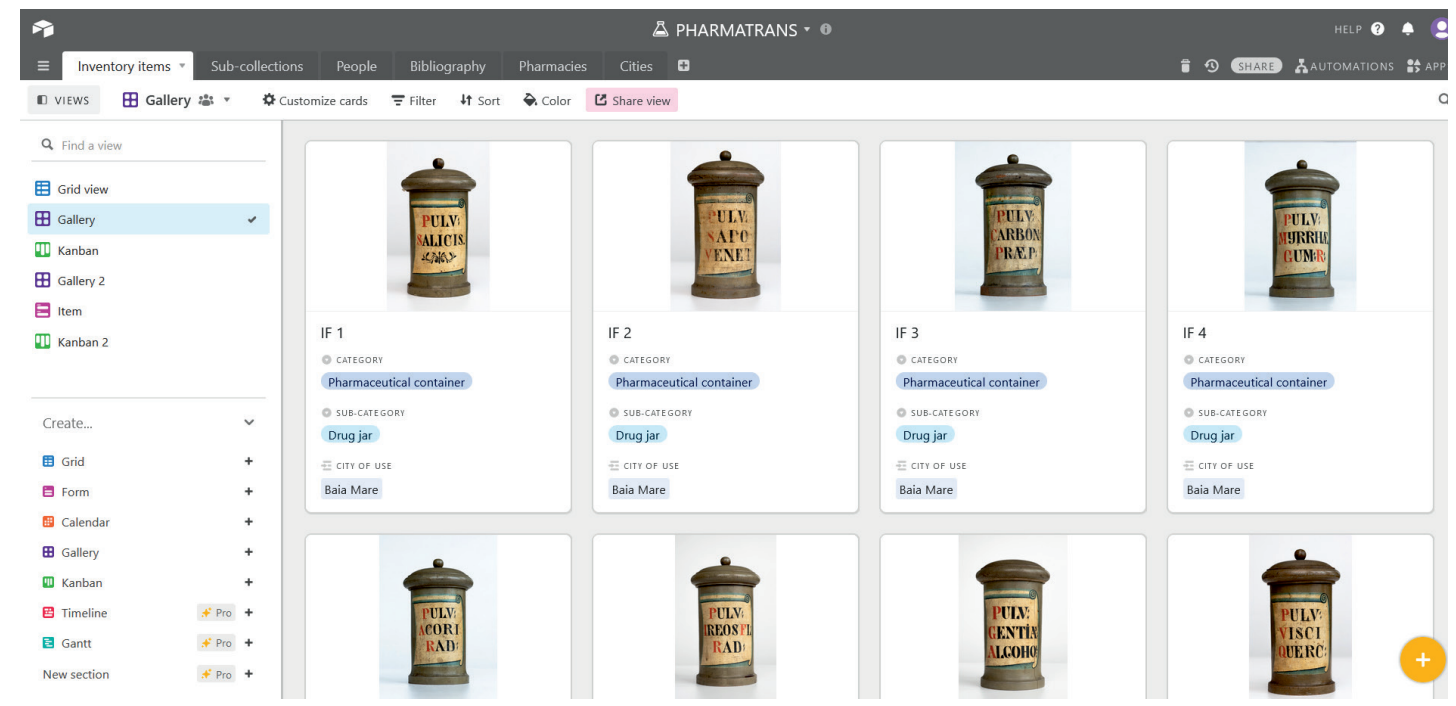

Fig. 3. The structure of the Airtable database employed for the structuring, collaborative access, and future export of data regarding the items in the History of Pharmacy Collection.

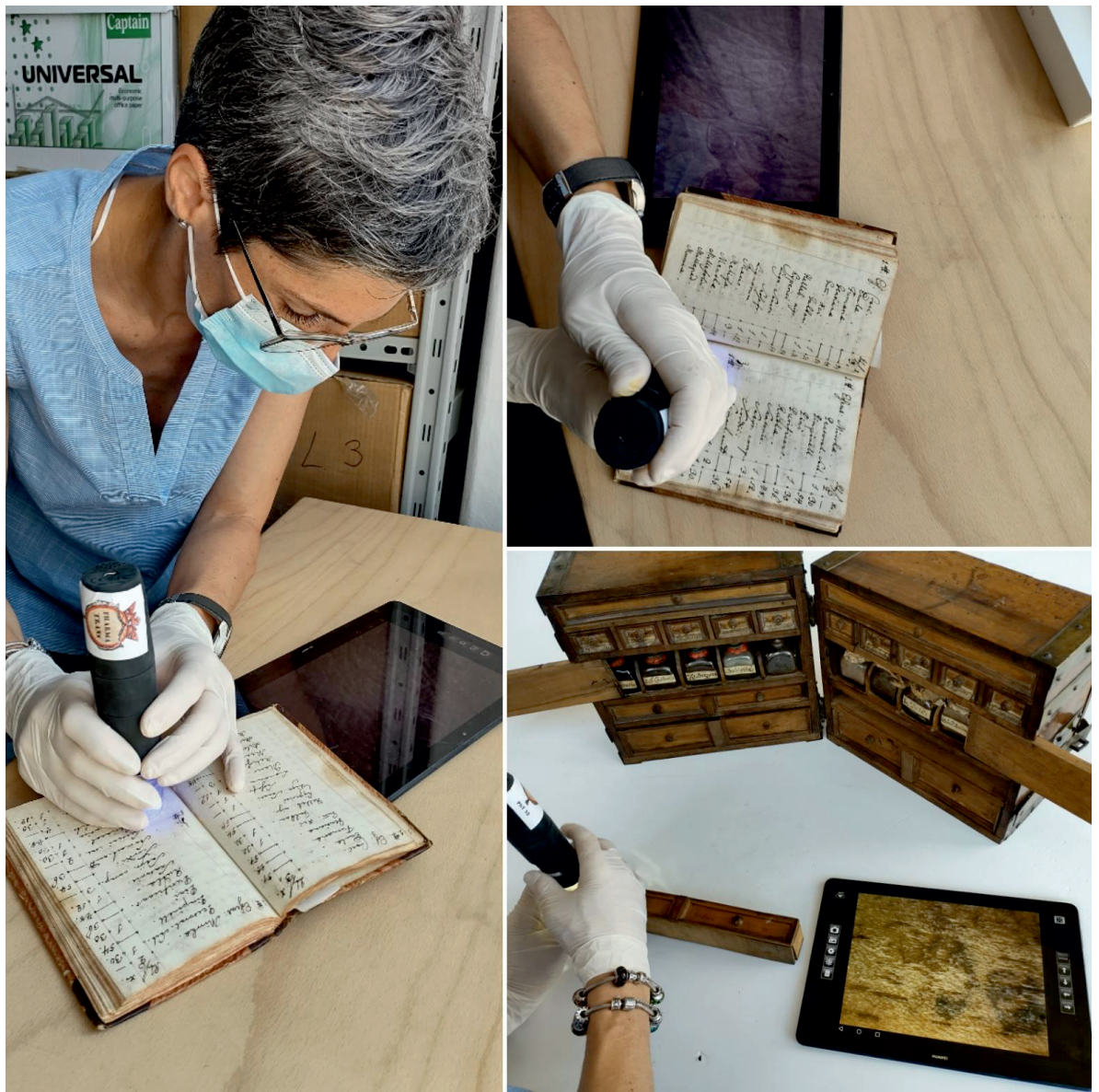

Fig. 4. Ph.D. Magó Andrea Beatrix taking micro-photographs. 


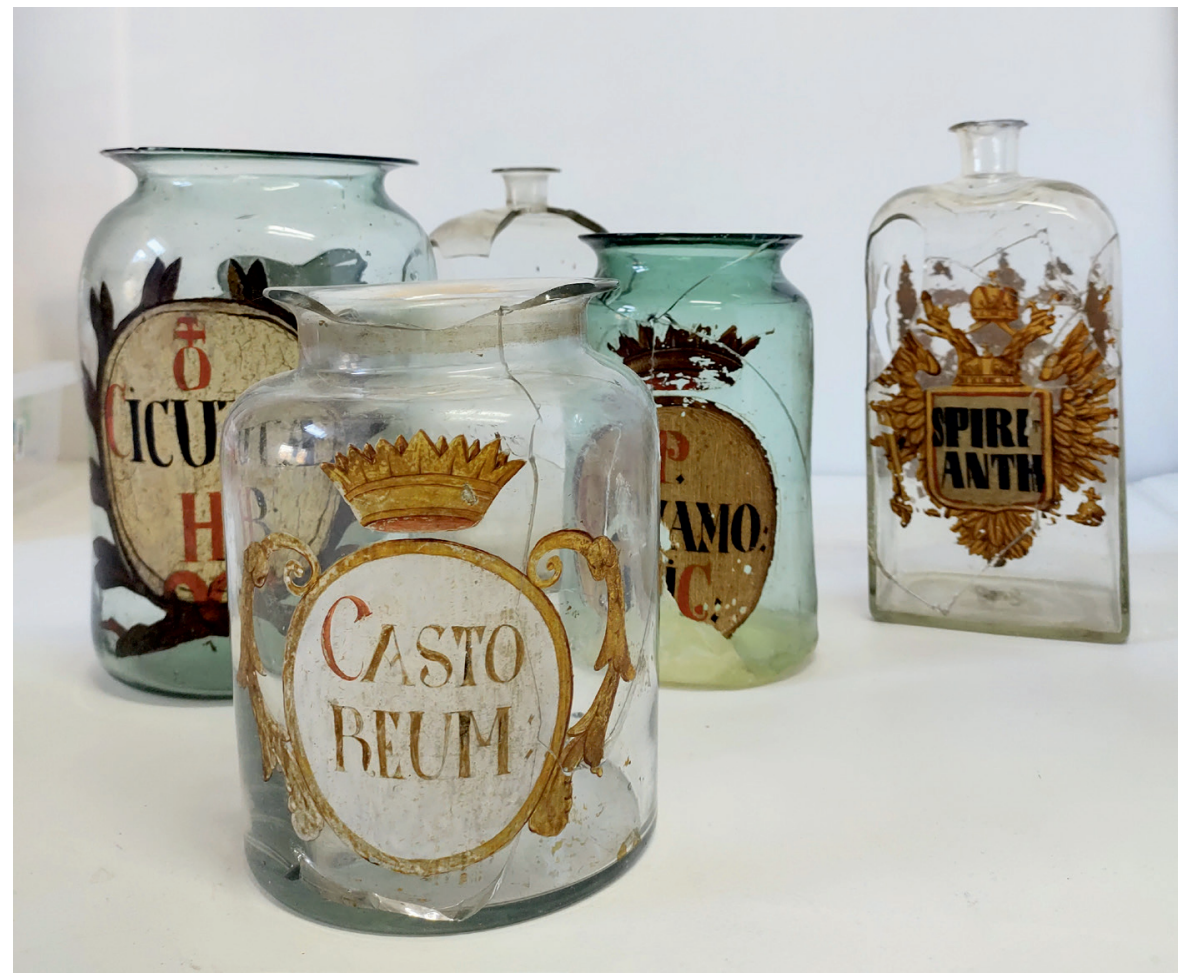

Fig. 5. Apothecary jars made of glass, with painted decoration, after restoration.

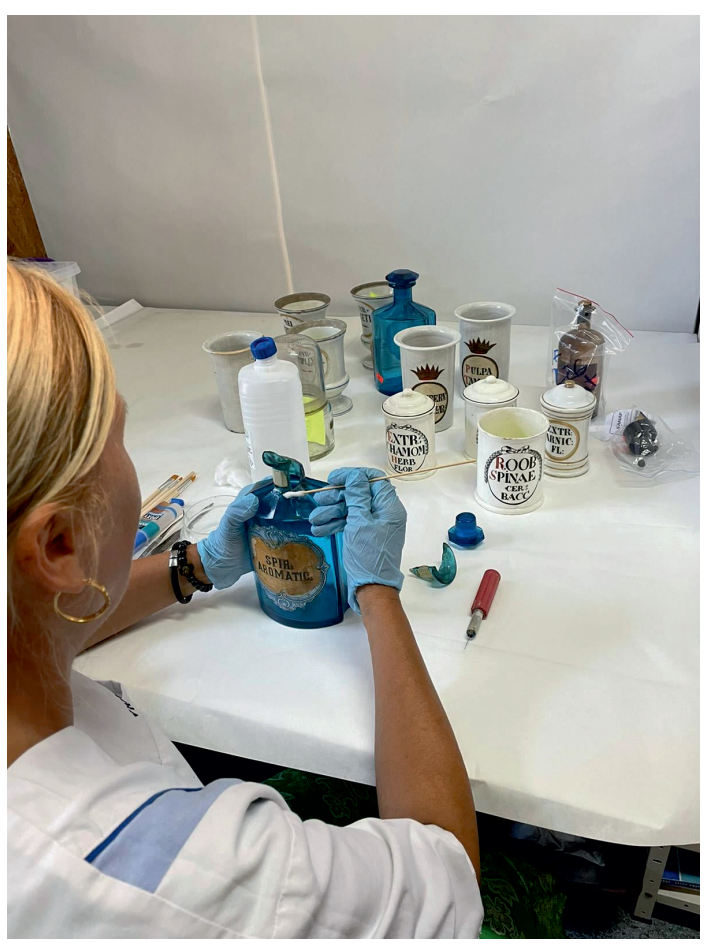

Fig. 7. Cornelia Rotariu restoring a lot of apothecary containers made of glass and pottery.

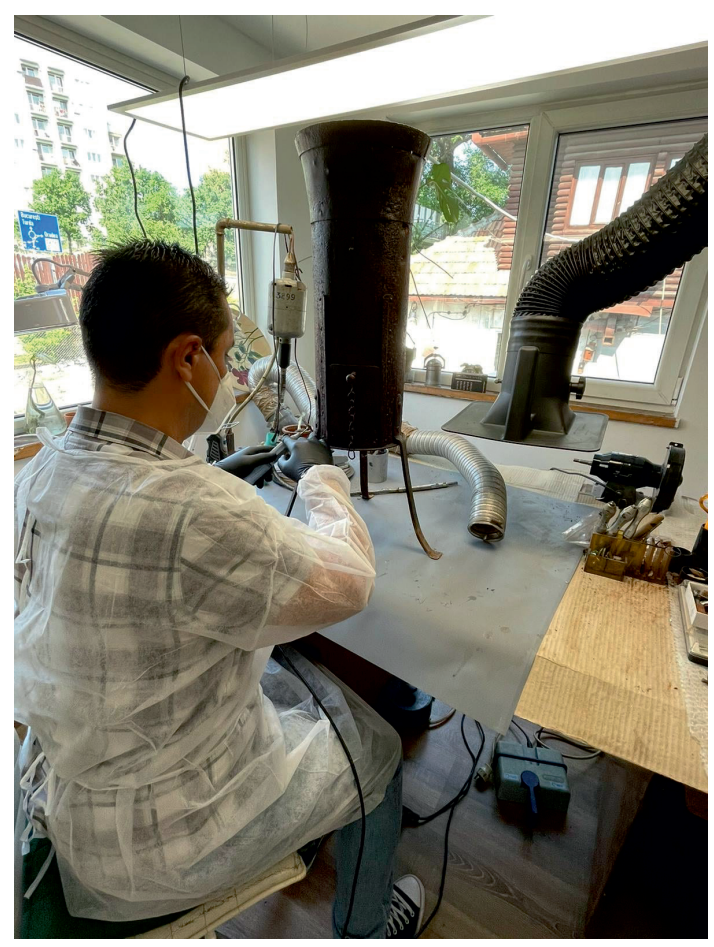

Fig. 6. Radu Cordoș conserving an apothecary laboratory vessel made of metal. 


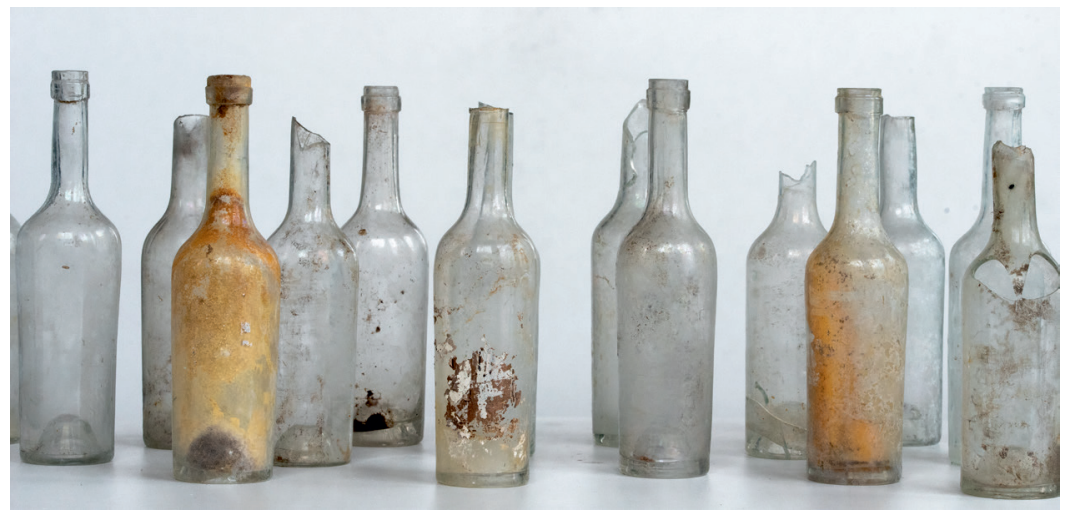

Fig. 8. Lot of druggist glass bottle recently uncovered on Iuliu Maniu Street in Cluj-Napoca (archaeological rescue excavation coordinated by Ph.D. Viorica Rusu-Bolindeț in 2020).

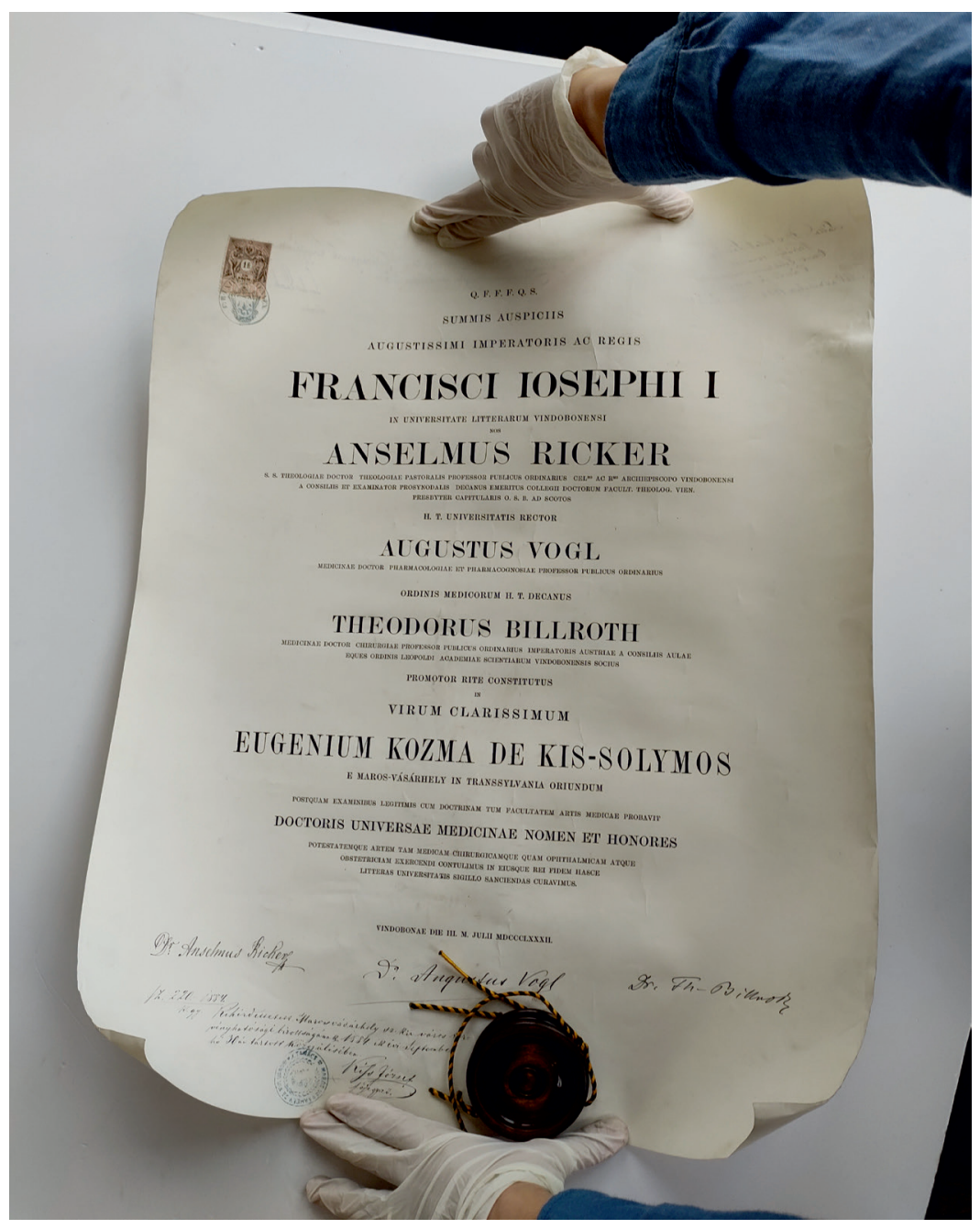

Fig. 9. Medicine doctor diploma issued by the University in Vienna in 1882, without an inventory number. 


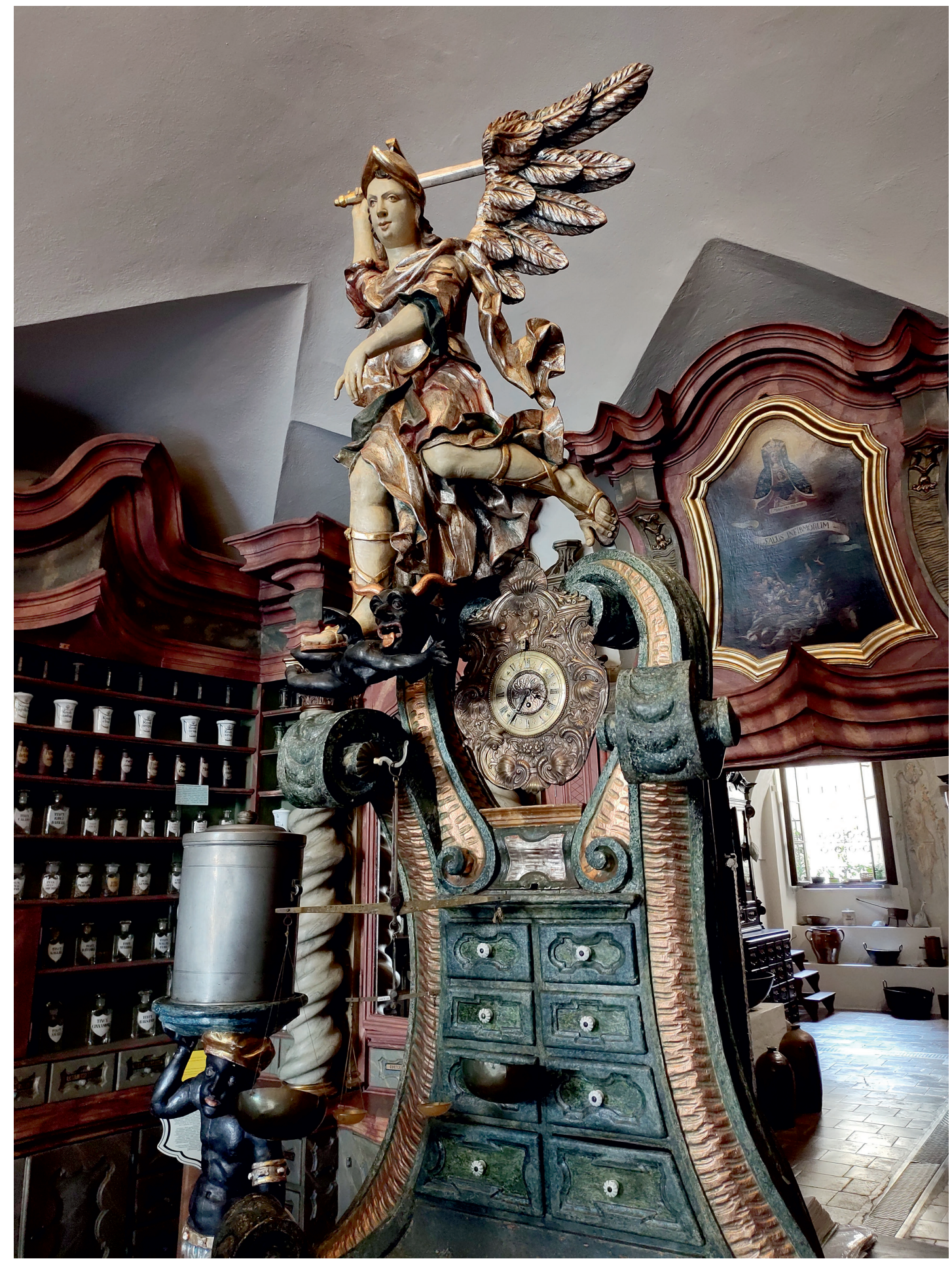

Fig. 10. Baroque apothecary furniture from the White Unicorn Pharmacy Museum in Klatovy, The Czech Republic (visited in July 2021). 


\title{
TOWARDS INCLUSIVE MNEMONIC COMMUNITIES: RE-VISITING VIOLENT PASTS THROUGH THE LENS OF ARTISTIC MEMORY IN EASTERN EUROPE*
}

\author{
MARIA ALINA ASAVEI ${ }^{* *}$
}

Eastern Europe experienced multifarious violent pasts and their deleterious legacies are still traceable on the symbolic map of the unescapable sets of concerns that this region has to face and deal with. These violent pasts comprise the Holocaust, the Nazi and communist-era atrocities, ethno-nationalistic wars and ethnic cleansing, forced labor, as well as various forms of racism like Romaphobia (among others). This interdisciplinary research project aims to flesh out the 'artistic memories' ${ }^{1}$ of violent pasts from an Eastern European historical and political perspective. We argue that the artistic memory projects produced after 1990 - and selected as case studies for this research project-can establish a new direction in the commemorative practices of the violent pasts. Artistic memory culture commemorates the violent past with an eye on the present concerns - because, unlike monumental sculpture memorializing both victims and heroes of violent pasts, the contemporary art projects have a more powerful/critical effect on viewers, triggering an active, engaged memory. Unlike the tradition of monuments, artistic memory works' effects on viewers/participants open the ground for a new direction in commemorative practices that fosters intersubjective remembering, rather than cast (and set) in stone memories about the past. We aim to demonstrate that artistic memory cultures can foster diverse but inclusive mnemonic communities that exceed the polarizing narratives about 'them,' and 'us' in light of memory activism for universal human rights.

The impetus for addressing the issue of commemorating violent pasts from a cultural and artistic memory perspective has been Tomas Sniegon's claims that the EU's initiative to foster a common European identity and memory of the dark pasts should work in changing the public's attitudes towards political violence 'from below. ${ }^{2}$ This is especially significant in the post-communist countries that attempt to discard centralized power over knowledge production. We claim that it is not enough to foster only cultural memories centralized initiatives - governed from above by the official institutions of remembrance - if the attitudes of the 'ordinary people' towards 'violent pasts' remembrance and commemoration are not considered too. While we acknowledge that enacting cultural policies is one of the most important instruments, in what regards the lasting prominence of the violent pasts remembrance and commemoration in light of the 'Never Again' political philosophy, this

This work was supported by a grant of the Romanian Ministry of Education and Research, CNCSUEFISCDI project number PN-III-P1-1.1-TE-2019-0025, within PNCD III.

** Ph.D., Assistant Professor, 'Charles’ University, Prague, email: maria.asavei@fsv.cuni.cz,

(D) https://orcid.org/0000-0002-4252-8044.

${ }^{1}$ Preda 2013.

2 Sniegon 2014. 
political - cultural process ought to be investigated also 'from below.' While artists and cultural workers are not the only grass-roots memory culture producers, their creative commemorations reshape the past in light of the present concerns and urgencies. Unlike collective memory traditionalist approaches - that address collective memory as heritage, tradition and national character ${ }^{3}$ - presentist approaches focus on re-visiting the past for the sake of the present. Although presentism and traditionalism are not mutually exclusive in memory studies, ${ }^{4}$ artistic memory culture produced in the former Eastern bloc after 1990, advances mnemonic discourses on The Holocaust and communism atrocities that also relate to other forms of injustice and structural violence - e.g., Romaphobia, hatred against refugees, homophobia - that are still pervasive in our times. Thus, we can speak of multidimensional and multidirectional ${ }^{5}$ content of artistic memory production. The discourses about human rights infringements are interconnected in the artistic collective memory.

Our geographical focus is Eastern Europe considering that the state of cultural memory research in Eastern Europe has different genealogies and routes than in Western Europe. It was not until recently (after 1990) that the cultural (artistic) memory projects dealing with 'violent pasts' have started to emerge in the former Eastern bloc (e.g., Olga Stefan's The Future of Memory project, Elana Katz's Spaced Memory in the Balkans). Body-sensual, performative, and conceptual re-enactments of the violent pasts are displayed through art practices, popular culture, museum initiatives, grass-roots enterprises and cultural/political entrepreneurs' online and offline platforms of engagement to various political ends. By the same token, only recently (since the collapse of the socialist regimes in the 1990s) have the historians of Eastern Europe started to write comprehensive accounts of the Holocaust and Eastern European Jewry.

European policies attempt to foster a European identity and common historical memory in order to advance European integration. In the wake of the European Commission actions from 2007 - which have focused on both Nazi and Stalinist crimes as common memory - European elites have come to the tasks of promoting an 'active European remembrance' of the dark past. Yet, as Markus Prutsch ${ }^{6}$ argues, what might appear at first glance to be a coherent European memory policy proves to be far from unchallenged. In this vein, it looks like there is a struggle between two at least partly competing memory frames: 'the uniqueness of the Holocaust" that has shaped Western European post-war cultures, and the National Socialism and Stalinism as equally evil that suits the needs of Eastern European countries to come to terms with their respective communist past. ${ }^{7}$ In addition to that, many studies emphasize that the Holocaust's uniqueness should not be understood as incomparability with other genocides, ${ }^{8}$ and that comparison (which deals with both similarities and differences) does not automatically entail moral justification or comparison of pain. At the same time, the diverging memory cultures of the Holocaust and communism, which separated like a fault line Eastern Europe from Western Europe since

\footnotetext{
3 Olick et alii 2011, 242.

4 Olick et alii 2011.

5 Rothberg 2009.

6 Prutsch 2015.

Prutsch 2015, 10, 30

8 Wulf 2011; Droit 2007; Rothberg 2009.
} 
1989, affect the identity of future Europe and its shared values. As many studies suggest, both the memory of the Holocaust and communism occasion tensions and divergences between Europe's post-communist countries' narratives and Western Europe's accounts about the past. ${ }^{9}$ On the one hand, some Eastern European sites of memory have started to exhibit the excruciating heritage of communism and state socialism (e.g., Romania, Hungary, Bulgaria), while the Holocaust is not as pervasive in the commemorative culture. In Poland, on the other hand, it is rather the opposite: there is much attention devoted to the history of the Holocaust (Auschwitz, Belzec camps, but also Polin museum, Schindler's factory and so on), but the commemoration of communism is still regarded as a very complex and difficult issue.

The following research questions will be considered by our team members: How can we understand these differences in the context of a common, European memory culture of the violent past? What kind of arguments can explain these competing or diverging memory cultures in the region? How can artistic memory disclose the differences in how people remember a traumatic event? To what extent and ends artistic memory re-visits the violent pasts in light of present concerns?

The project connects the theoretical perspectives from Memory Studies, Cultural History, Political Science, Transitional Justice, Cultural Studies and Human Rights Theory to highlight the artistic memory culture ability to deal with violent pasts, various forms of injustice and hegemonic patterns of domination from historical knowledge production about the past. Thus, the main objective of this research is to investigate how the 'official' politics of memory vis-à-vis violent pasts is apprehended, resisted/embraced, and worked out by artists and cultural producers and to what ends. We aim to demonstrate that the artistic memory cultures addressed in this research project have:

1. The ability to disclose the complexities of political violence, as well as the ambivalences of politics of memory imposed from above as the 'grand narrative' about the past.

2. The potential to foster mnemonic communities and discourses on the violent pasts, that also connect with other forms of mass violence and overlapping injustices (economic, social, epistemic) that took/take place in other spaces and time.

3. The ability to 'step back in time' with the aim of rendering 'history from above' permeable by the (his)stories of those who have not been the 'winners' or the 'heroes' of political history. Art can perform historical pasts in a democratic way allowing histories from below to contribute to the pervasive politics of memory.

The project Towards Inclusive Mnemonic Communities: Re-visiting Violent Pasts Through the Lens of Artistic Memory in Eastern Europe is funded by a UEFISCDI Young Researchers grant (TE 24/2020, PN-III-P1-1.1-TE-2019-0025). It is hosted by The Interdisciplinary Center for Research on Arts, Politics, Memory and Society (PolArt), Faculty of Political Sciences, University of Bucharest. The members of the project teams are: Maria Alina Asavei, Assistant Professor, Charles University, Prague and PolArt, University

\footnotetext{
9 Himka, Michlic 2013; Van der Laarse 2013; Droit 2007.
} 
of Bucharest as project director; Caterina Preda, Associate Professor, Department of Political Science and PolArt, University of Bucharest; Manuela Marin, Museum curator, National Museum of Transylvanian History, Cluj-Napoca and PolArt, University of Bucharest.

The team members organized two panels at The Association for Slavic, East European, and Eurasian Studies Annual Convention in 2020 and 2021 and one panel at the The Association for the Study of Nationalities (ASN) in 2021 in addition to several other individual conference participations. Maria Alina Asavei published several articles, including Indexical Realism during Socialism: Documenting and Remembering the Everyday Realities of Late Socialist Romania through Photographs, Photography and Culture, 2020 (Arts and Humanities Citation Index, ISI); The Artistic Memory of the Holocaust as a New Direction in Commemorative Practices in Central and South-East Europe. In: D. Letort, H. Lecossois, R. Bouchet, Résurgences conflictuelles:le travail de mémoire entre arts et histoire, Rennes, Rennes 2021, 325-343; On Tradition and Cultural Memory in Contemporary Art: Theoretical Considerations, Eidos. A Journal for Philosophy of Culture, 1 (2021), 126-139 (Erihplus, Scopus), https://doi.org/10.14394/eidos.jpc.2021.0008. Maria Alina Asavei co-edited with Jan Sir the Special Issue titled Troubled Pasts and Memory Politics: Contesting Hegemonic Narratives in North America Europe and Eurasia, Studia Territorialia, 20/2, 2021. Her paper on Engraving in the Skin: Vernacular Memorials for Ceausescu, Tito and Stalin is to be published in special issue edited by Maria-Alina Asavei and Katerina Kralova Troubled Past Representations in Central East and Southeastern Europe Beyond the National Museum Paradigm, in Nationalities Papers (Social Sciences Citation Index, ISI-IF 0.803). Caterina Preda published Representations of dissent against communism in Romania: anticommunist heroes, 'prison saints' and (extra)ordinary citizens in a special issue edited by Ferenc Laczo and Tamas Scheibner, Canonizing and Contesting Soviet-Era Dissent since 1989. Actors, Representations, Impacts, East European Politics and Societies (Social Sciences Citation Index). Also, her paper about 'Living Statues' and Monuments as 'Performative Monuments Events' in Post-Socialist South-Eastern Europe is accepted for publication in special issue edited by Maria-Alina Asavei and Katerina Kralova Troubled Past Representations in Central East and Southeastern Europe Beyond the National Museum Paradigm, in Nationalities Papers (Social Sciences Citation Index, ISI-IF 0.803). Manuela Marin published an article on The Politics of Memory and the Refashioning of Communism for Young People: The Illustrated Guide to Romanian Communism, Studia Territorialia, 21/1 (2021) (Erihplus and Scopus) and another one titled The Face of Resistance: the communist past as an exhibition project. The case of the 'Resisters' Exhibition was accepted for publication in Anuarul Institutului de Cercetări Socio-Umane Sibiu, 27 (2021) (Erihplus).

\section{Bibliography}

Droit 2007

Himka, Michlic 2013
E. Droit, Le Goulag contre la Shoah, Vingtième Siècle. Revue d'histoire, 2 (2007), 101-120. https://doi.org/10.3917/ving.094. 0101 .

J. P. Himka, J. B. Michlic (eds.), Bringing the Dark Past to Light: The Reception of the Holocaust in the Postcommunist Europe, Lincoln 2013. 
Olick et alii 2011

Preda 2013

Prutsch 2015

Rothberg 2009

Sniegon 2014

Van der Laarse 2013

Wulf 2011
J. K. Olick, V. Vinitzky-Seroussi, D. Levy, The Collective Memory Reader, New York 2011.

C. Preda, The Digital (Artistic) Memory of Nicolae Ceaușescu. In: E. Rutten, J. Fodor, V. Zvereva (eds.), Memory, Conflict and New Media: Web Wars in Post-Socialist States, New York 2013, 197-213.

M. Prutsch, European Historical Memory: Policies, Challenges and Perspectives (2nd edn.), European Parliament 2015, https://www. europarl.europa.eu/RegData/etudes/STUD/2015/540364/IPOL_ STU\%282015\%29540364_EN.pdf, accessed 15 Nov. 2021.

M. Rothberg, Multidirectional Memory Remembering the Holocaust in the Age of Decolonization, Stanford 2009.

T. Sniegon, Vanished History. The Holocaust in Czech and Slovak Historical Culture, New York-Oxford 2014.

R. Van der Laarse, Archeology of Memory: Europe Holocaust Dissonances between East and West. In: D. Callebaut, J. Mařík and J. Maříková-Kubková (eds.), Heritage Reinvents Europe, Namur 2013, 121-130.

M. Wulf, 'Changing Memory Regimes in a New Europe,' paper presented at the UACES Conference, Robinson College, September 2011, https://www.academia.edu/968404/Changing_ memory_regimes_in_a_new_Europe, 1-13, accessed 15 Nov. 2021. 



\section{ABBREVIATIONS}

ActaMN

ActaMP

Acta Universitatis George

Bacovia. Juridica

AIIC Humanistica

AJPH

Allgemeine Militär-Zeitung

Annales ÉSC

Annu.Rev.Sociol.

Anuarul IICCMER

$\operatorname{Archiv~(N.~F.)~}$

Arhiva Someșană

Akadémiai Értesítő

Cahiers du Monde russe

Continuity and Change

Crisia

$\mathrm{CSSH}$

Cultural History

Democratization

EJST

Erdélyi Helikon

Erdélyi Múzeum

Geopolitics

Georges Bloch - Jahrbuch
Acta Musei Napocensis (II. Historica), Muzeul Național de Istorie a Transilvaniei, Cluj-Napoca.

Acta Musei Porolissensis, Muzeul Județean de Istorie și Artă, Zalău.

Acta Universitatis George Bacovia. Juridica, 'George Bacovia' University in Bacău.

Anuarul Institutului de Istorie 'George Barițiu.' Series Humanistica, Cluj-Napoca.

Australian Journal of Politics and History, The University of Queensland and John Wiley \& Sons Australia, Ltd.

Allgemeine Militär-Zeitung. Jahresübersicht, Darmstadt.

Annales. Économies, Sociétés, Civilisations, École des hautes études en sciences sociales.

The Annual Review of Sociology, Annual Reviews.

Anuarul Institutului de Investigare a Crimelor Comunismului și Memoria Exilului Românesc, București.

Archiv des Vereins für Siebenbürgische Landeskunde (Neue Folge), Hermannstadt/Sibiu.

Arhiva Someșană, Năsăud.

Akadémiai Értesítő. Magyar Tudományos Akadémia, Budapest.

Cahiers du Monde russe, École des hautes études en sciences sociales, Paris.

Continuity and Change. A Journal of Social Structure, Law and Demography in Past Societies, Cambridge University Press.

Crisia, Muzeul Țării Crișurilor, Oradea.

Comparative Studies in Society and History, Society for Comparative Study of Society and History, Cambridge University Press.

Cultural History, Edinburgh University Press, Edinburgh.

Democratization, Taylor \& Francis.

European Journal of Science and Theology.

Erdélyi Helikon, Kolozsvár/Cluj-Napoca.

Erdélyi Múzeum. Az Erdélyi Múzeum-Egyesület Bölcsészet-, Nyelv-, Történettudományi, valamint Jog-, Közgazdaság- és Társadalomtudományi Szakosztályának közlönye, Kolozsvár/ Cluj-Napoca.

Geopolitics, Taylor \& Francis.

Georges Bloch-Jahrbuch der Kunstgeschichtlichen Seminars der Universität Zürich, Kunsthistorisches Institut, Zürich. 
Hiperboreea

Historical Methods

HSR

HU

Human Geography

HWJ

IJAPS

IJ-ARBSS

IJEL

International Organization

International Peacekeeping

$\mathrm{JCH}$

$\mathrm{JIH}$

Journal of Palestine Studies

Journal of Political Studies

JSH

Keresztény Magvető

Korall

Korunk

Magyar Családtörténeti Szemle

Magyar Történelmi Tár

Mankind Quarterly

MCU Journal

MEJ

Memory
Hiperboreea. Journal of the Balkan History Association, Penn State University Press.

Historical Methods. A Journal of Quantitative and Interdisciplinary History, Taylor \& Francis.

Historical Social Research/Historische Sozialforschung, Journal of the QUANTUM Association, GESIS - Leibniz Institute for the Social Sciences Köln.

Historia Urbana, Comisia de istorie a oraşelor din România, Sibiu-Bucureşti.

Human Geography, SAGE Journals.

History Workshop Journal.

International Journal of Applied Psychoanalytic Studies, Wiley-Blackwell.

International Journal of Academic Research in Business and Social Sciences, Human Resource Management Academic Research Society, Bahawalpur, Pakistan.

International Journal of English Linguistics, Canadian Center of Science and Education.

International Organization, International Organization Foundation, Cambridge University Press.

International Peacekeeping, Taylor \& Francis.

Journal of Contemporary History, SAGE Journals.

The Journal of Interdisciplinary History, MIT press.

Journal of Palestine Studies, Taylor \& Francis.

Journal of Political Studies, Department of Political Science, University of the Punjab, Lahore.

Journal of Social History, Oxford University Press.

Keresztény Magvetö, Magyar Unitárius Egyház, Kolozsvár/ Cluj-Napoca.

Korall. Társadalomtörténeti folyóirat, A Korall Társadalomtörténeti Egyesület, Budapest.

Korunk. Fórum-Kultúra-Tudomány, Kolozsvár/Cluj-Napoca.

Magyar Családtörténeti Szemle. Genealógiai és heraldikai szaklap, Budapest.

Magyar Történelmi Tár. Magyar Tudományos Akadémia. Történelmi Bizottmány, Budapest.

Mankind Quarterly, Ulster Institute for Social Research, London.

Marine Corps University Journal, Marine Corps University Press, Quantico, VA.

The Middle East Journal, Middle East Institute, Washington D.C. Memory, Taylor \& Francis. 
Militär und Gesellschaft in der frühen Neuzeit

MÖStA

Müvelődés

Nagybányai Hírlap

NILR

Perceptual and Motor Skills

Revista Philohistoriss

PIJ

Potaissa

PSQ

Psychological Review

Qualitative Research in

Psychology
Református Szemle

Militär und Gesellschaft in der frühen Neuzeit, Arbeitskreis Militär und Gesellschaft in der Frühen Neuzeit e.V, Potsdam.

Mitteilungen des Österreichischen Staatsarchivs Österreichischen Staatsarchivs, Wien.

Művelődés - közművelődési havilap, Kolozsvár/Cluj-Napoca.

Nagybányai Hírlap Társadalmi es szépirodalmi hetilap, Nagybánya/Baia Mare.

Netherlands International Law Review, T.M.C. Asser Press, and T.M.C. Asser Instituut.

Perceptual and Motor Skills, SAGE Journals.

Revista Philohistoriss, Asociația Philo-Historiss, Cluj-Napoca.

Palestine-Israel Journal of Politics, Economics, and Culture, Jerusalem.

Potaissa. Studii și comunicări, Muzeul de Istorie Turda.

Political Science Quarterly, Academy of Political Science, New York.

Psychological Review, American Psychological Association, Washington, D.C.

Qualitative Research in Psychology, Taylor \& Francis.

Református Szemle, Kolozsvári Protestáns Teológiai Intézet, Kolozsvár/Cluj-Napoca.

Research in Social Stratification Research in Social Stratification and Mobility. The Official Journal and Mobility

Revista de istorie/Revista istorică

Romanian Journal of

Population Studies

Saeculum of the ISA RC28, Elsevier.

Studii. Revistă de Istorie/Revista istorică, Academia Română, Institutul de Istorie 'Nicolae Iorga' (currently), București.

Romanian Journal of Population Studies, Centre for Population Studies, 'Babeș-Bolyai' University, Cluj-Napoca.

Saeculum. Jahrbuch für Universalgeschichte Lehrstuhl für Kulturgeschichte des Mittelalters und der Frühen Neuzeit, GeorgAugust-Universität, Göttingen.

Self and Identity Self and Identity. Taylor \& Francis Online.

Studies in Conflict \& Terrorism Studies in Conflict \& Terrorism, Taylor \& Francis.

SUBB Digitalia

Studia Universitatis Babeș-Bolyai. Digitalia, Centre for Digital Humanities Transylvania, 'Babeș-Bolyai' University, Cluj-Napoca.

SUBB Historia

Szabadság

Terrorism and Political

Violence

Textile History
Studia Universitatis Babeș-Bolyai. Historia, Facultatea de Istorie și Filosofie, Universitatea 'Babeș-Bolyai,' Cluj-Napoca.

Szabadság. Napilap, Kolozsvár/Cluj-Napoca.

Terrorism and Political Violence, Taylor \& Francis.

Textile History, Pasold Research Fund, Taylor \& Francis (currently). 
The Bulletin of MoMa The Bulletin of the Museum of Modern Art, The Museum, New York.

The Economic Journal The Economic Journal, Royal Economic Society, Oxford University Press.

The Journal of Psychiatry \& The Journal of Psychiatry \& Law, SAGE Journals.

Law

The Oral History Review The Oral History Review, Taylor \& Francis.

The Print Collector's Newsletter The Print Collector's Newsletter, New York.

Third Text

Third Text, Taylor \& Francis.

Țara Bârsei

Țara Bârsei. Revistă de cultură a Muzeului 'Casa Mureșenilor,' Brașov.

Unitárius Közlöny

Unitárius Közlöny. A vallásos és erkölcsös élet ébresztésére, Kolozsvár/Cluj-Napoca.

Utunk

Utunk, A romániai magyarság irodalmi, művészeti és kritikai hetilapjaként, Kolozsvár/Cluj-Napoca.

Vingtième Siècle. Revue Vingtième Siècle. Revue d'histoire, Presses de Sciences Po.

d'histoire

Virtus Romana Rediviva

Virtus Romana Rediviva. Almanah cultural-științific, Cluj-Napoca.

Zeitschrift für Historische

Zeitschrift für Historische Forschung. Vierteljahresschrift Forschung zur Erforschung des Spätmittelalters und der frühen Neuzeit, Duncker \& Humbolt, Berlin. 